[6.

13.) 

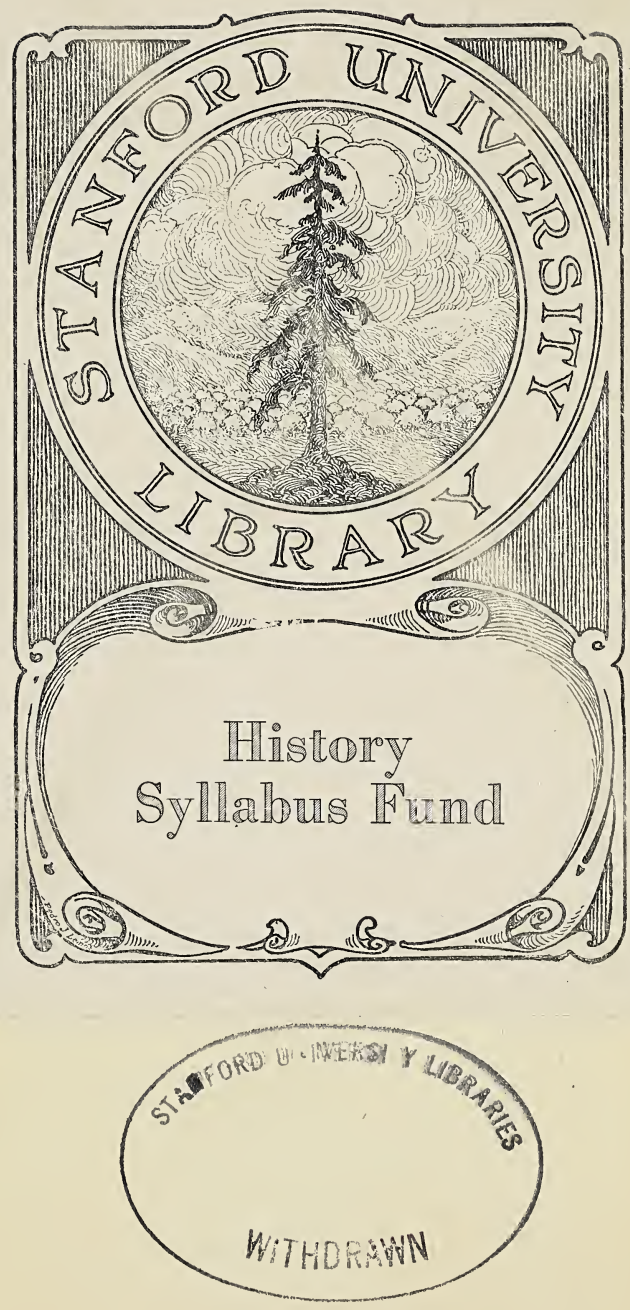


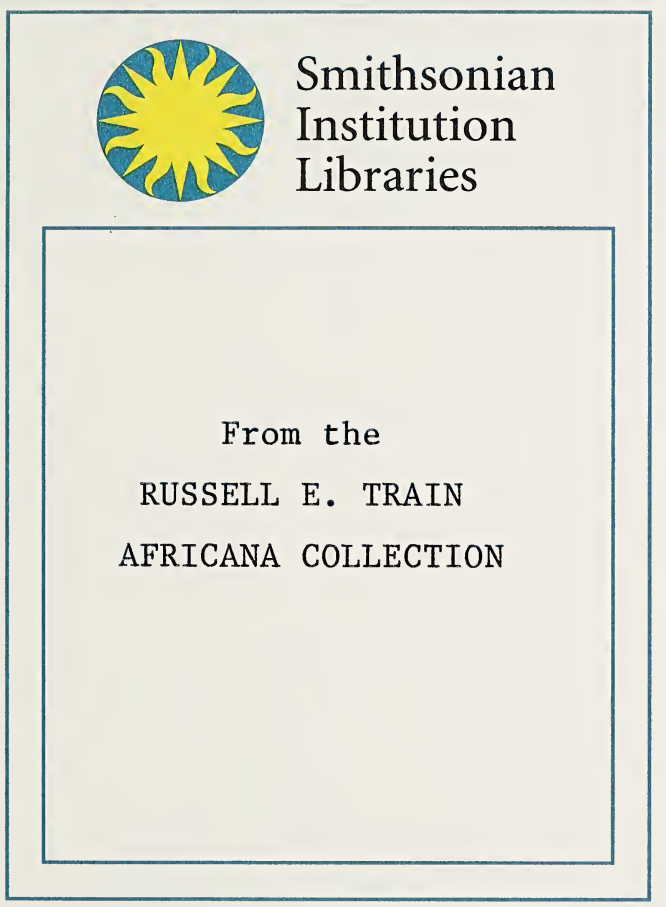





\section{Cambrioge $\$$ Isistorical Series}

Edited by G. W. PROTHERO, F.B.A., Litt.D.

HON. LL.D. OF EDINBURGH AND HARVARD, AND HONORARY FELLOW OF KING'S COLLEGE, CAMBRIDGE

\section{THE}

\section{COLONIZATION OF AFRICA}




\section{CAMBRIDGE UNIVERSITY PRESS}

ILondon: FETTER LANE, E.C.

C. F. CLAY, MANAGER

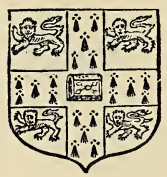

(EDinburgb: IOO, PRINCES STREET

Barlin: A. ASHER AND CO.

Ileipzíg: F. A. BROCKHAUS

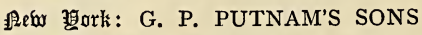

łombay and Calcutta: MACMILLAN AND CO., LTD. 


\title{
A HISTORY OF THE
}

\section{COLONIZATION OF AFRICA}

BY ALIEN RACES

\author{
BY
}

SIR HARRY H. JOHNSTON, G.C.M.G., K.C.B.,

Hon. Sc.D. Cantab.

WITH EIGHT MAPS

NEW EDITION, REVISED THROUGHOUT AND

CONSIDERABLY ENLARGED

Cambridge :

at the University Press

I 9 I 3 


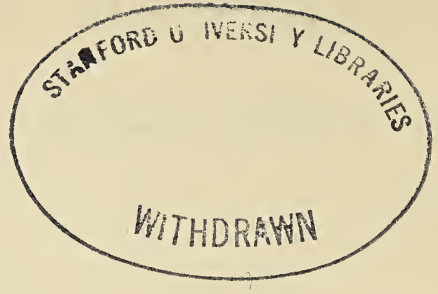

First Edition I899. Reprinted I899, 1905.

Second and enlarged Edition 19r3.

\section{4}


The aim of this series is to sketch the history of Modern Europe, with that of its chief colonies and conquests, from about the end of the fifteenth century down to the present time. In one or two cases the story commences at an earlier date: in the case of the colonies it generally begins later. The histories of the different countries are described, as a rule, separately; for it is believed that, except in epochs like that of the French Revolution and Napoleon I, the connection of events will thus be better understood and the continuity of historical development more clearly displayed.

The series is intended for the use of all persons anxious to understand the nature of existing political conditions. "The roots of the present lie deep in the past"; and the real significance of contemporary events cannot be grasped unless the historical causes which have led to them are known. The plan adopted makes it possible to treat the history of the last four centuries in considerable detail, and to embody the most important results of modern research. It is hoped therefore that the series will be useful not only to beginners but to students who have already acquired some general knowledge of European History. For those who wish to carry their studies further, the bibliography appended to each volume will act as a guide to original sources of information and works of a more special character.

Considerable attention is paid to political geography; and each volume is furnished with such maps and plans as may be requisite for the illustration of the text.

\section{G. W. PROTHERO.}




\section{ERRATA}

p. 69, for Motawakkiq read Motawakkil

p. 37I, for Boz read Bor 


\section{PREFATORY NOTE}

The Editor of this Historical series asked me in 1898 to compile this work on the History of African Colonization. Even at that date there existed a number of standard books on the history of African Exploration (Dr J. Scott Keltie and Dr Robert Brown), on the history of South Africa ( $\mathrm{M}^{\mathrm{c}} \mathrm{Call}$ Theal and Sir Charles Lucas), and on the Map of Africa by Treaty (Sir Edward Hertslet). But no attempt had yet been made to summarise and review in a single book the general history of the attempts of Asia and Europe to colonize Africa during the historical period. The original edition of this book published in 1898 was exhausted by the following year, and in the next reprint certain additions were made; while to the reprint of 1905 a new chapter was contributed giving the latest developments in the European colonization of Africa.

A further issue of the work having been contemplated seven years later, the Cambridge University Press agreed that I should rewrite the whole book from beginning to end and enlarge it considerably, so that it might be brought level with our more complete knowledge of African history in 1912, and at the same time continue the story down to the present year.

Much has happened since 1905 which forms an essential part of the history of the colonization and development of Africa by alien races. The old maps have been revised and new ones drawn. 
The first edition of this work contained the antique feature of a dedication. I hesitate to repeat this formally, yet I might mention that the names I associated in 1898 with my treatise on the Colonization of Africa were those of SIR GEORGE Taubman Goldie (Nigeria); Viscount Kitchener of Khartūm (Anglo-Egyptian Sudan); Monsieur René Millet (formerly Frénch Resident-General in Tunis), "who has shown how well a Frenchman can administer a great dependency when allowed liberty of action"; and MAJOR HERMANN voN Wissmann (formerly German Imperial Commissioner in Africa), "who founded the State of German East Africa, and who has done more than any living German to establish and uphold the prestige of that great nation in the darkest parts of the Dark Continent". I still think that under the guise of a dedication I chose notable instances of strong and wise men doing good work in Africa, not only for the colonizing nations, but equally for the subject peoples of backward race. Their work in its importance has stood the test of time. What Mons. Millet did in Tunis has been-or should bemade the model of an administration under which France may succeed in regenerating Morocco. It is tempting to add other great names to this list, but if, for example, one inserts that of Cecil Rhodes, then in common justice one must mention David Livingstone, John Kirk, H. M. Stanley, Joseph Thomson, Frederick Lugard, George Grenfell, E. N. Roume, and Franz Stuhlmann, and many others who have brought about the recent opening-up of Africa by the white man.

\section{H. H. JOHNSTON.}

POLING,

December, I9I 2. 


\title{
CONTENTS
}

\author{
CHAPTER I \\ Prehistoric Race Movements in Africa
}

The origin of African man-Principal Negro types-The BushmanNegroids (Fula, Songhai, Tibu, Hausa)-The Mystery of the Zimbabwe ruins of Rhodesia-Probable distribution of native races ten thousand years ago-The Dynastic Egyptians-The early SemitesThe Hamites-The Malay Colonization of Madagascar . I

\section{CHAPTER II}

\section{The Mediterranean Colonization of Africa}

The Phoenicians and their foundation of Sidonian and Tyrian cities along the north coast of Africa-Carthage-Hanno's voyage to West Africa -The Greeks in Cyrenaica-In Egypt, Abyssinia, East AfricaThe Romans in Egypt-In North Africa and the Sahara-Christian Abyssinia . . . . . . . . . . 32

\section{CHAPTER III}

\section{The Arab Conguest of Africa.}

The condition of North Africa in the 6th and 7 th centuries of the Christian era before the Arab invasion-Muhammad and MuhammadanismArabs invade Egypt-The Khariji sect-Arabs invade North AfricaSpain, Morocco, and the Berbers-The Jews and their relations with North Africa-The Fatimite Khalifs-The "Hilalian" invasion-The Almoravides-The Almohades-St Louis-The death of Dom Sebastião-The Sharifian dynasties of Morocco-The Turks in AfricaArab Egypt-Turkish Egypt-The Arabs of East Africa-Arab influence on Africa . . . . . . . . . $5^{2}$ 


\section{CHAPTER IV}

\section{The Portuguese in Africa}

Origin of the State of Portugal-Prince Henry the Navigator-Portuguese explorations of West African coast-Diogo Cam and the CongoRounding of Cape of Good Hope-East African conquests-Portuguese in Abysinia-in the Congo Kingdom-in Angola-Paulo Diaz - The benefits the Portuguese conferred on Africa-Their struggles with the Dutch-Progress of their rule in West Africa-in East Africa -Monomotapa-Dr Lacerda e Almeida-Livingstone's journeysPresent state of Moçambique-Delagoa Bay-Beira-Mouzinho de Albuquerque-Moçambique Company-The future of the Portuguese Colonies

\section{CHAPTER V}

\section{SPANISH AFrica}

The Canary Islands-Spain invades Morocco in I490-Algeria and Tunis nearly conquered in $\mathbf{I} 6$ th century-Spanish sphere in North MoroccoRio de Oro-Fernando Pô and Rio Muni . . • .

\section{CHAPTER VI}

\section{The Dutch in Africa}

Dutch traders on the Gold Coast-Dutch settle at the Cape of Good Hope - St Helena-Mauritius-The Netherland East India Co.-Huguenot colonists-Governor Tulbagh-extensions of Dutch influence-First hostile British expedition under Commodore Johnstone-First Dutch war with the Kafirs-First British occupation of the Cape of Good Hope-Interregnum of Dutch rule-British finally annex Cape Colony - Their rulers come into conflict with the sentiments of the Dutch colonists (Boers)-The Boer Treks-Origin of Transvaal and Orange Free State republics-Annexation and revolt of Transvaal-Sir Charles Warren's expedition-Gold in the Transvaal-Jews in South Africa-Johannesburg, the Outlanders, and Jameson's raid-The war of 1899-1902-Union of South Africa 


\section{Contents \\ CHAPTER. VII \\ The Slave Trade}

Negro predisposition for slavery-Slave trade in the Roman world, in Muhammadan countries and India-Great development consequent on the exploitation of America-English slave traders-English AntiSlavery movement-Author's own experiences of slave trade-Steps taken by various European countries to abolish Slave Trade-By Great Britain in particular-Rev. S. W. Koelle-Zanzibar slave trade -Wadai and Tripoli-Ethics of slavery-A word of warning to the Negro-The foundation and history of Liberia-Dr Blyden . I $5 \mathbf{I}$

\section{CHAPTER VIII}

The British in Africa, I

\section{(West Coast, Morocco, North-Central)}

The English in West Africa-The Gambia-Sierra Leone-Gold CoastAshanti-Northern Territories-Lagos-Niger Delta-BeecroftBenin-E. H. Hewett-H. H. Johnston-J. R. Phillips-Northern Nigeria-Dr Baikie-Sir G. Taubman Goldie-Lugard and Morland -Bornu-Fulas-Great Britain and Tripoli-and Morocco . $\quad$ I68

\section{CHAPTER IX}

\section{The French in West and North Africa}

The Dieppe adventurers-Jannequin de Rochefort and the Senegal-Briie and the foundation of the colony of Senegal-Campagnon-Progress of French rule over Senegambia-Seul Faidherbe-the Fula EmpiresAdvance to the Niger-Samori and Ahmadu-Timbuktu-Binger and the Ivory Coast-Samori-Timbuktu definitely occupied-Busa and the Anglo-French Convention-Administrative divisions of French W. Africa-France and Egypt-Algiers-Development of AlgeriaTunis-The Sahara-Voulet and Chanoine-Morocco ProtectorateAbyssinia-Marchand-Somaliland-French Congo-Gaboon-The Shari and Mubangi-Cessions to Germany-Bagirmi and WadaiSenussi-Trans-Sahara Railway . . . . . . ${ }_{196}$ 


\section{CHAPTER $\mathrm{X}$}

\section{Christian Missions}

Their work the antithesis to the slave trade-Portuguese missions to Congoland, to the Zambezi, to Abyssinia-First Protestant missions-Church Missionary Society-Dr Krapf-Wesleyans, Methodists, Society for Propagation of the Gospel-Roman Catholic missions to Algeria, Congoland, the Nile-Cardinal Lavigerie-The 'White Fathers'-The Jesuits on the Zambezi-in Madagascar-The London Missionary Society-Swiss and German Protestant Missions-French Evangelical Missions-Presbyterian (Scotch) Missions-Norwegian and American Missions-Linguistic work of latter-Universities' Mission-Plymouth Brethren-Baptists-North African MissionZambezi Industrial Mission-Abyssinian Christianity . . $\quad 239$

\section{CHAPTER XI}

\section{The British in AFricA, II .}

\section{(South and South-Central)}

Great Britain's seizure of the Cape of Good Hope-Permanent establishment there-Abolition of slavery-Dutch grievances-Kaffir WarsLord Glenelg and intervention of Downing Street-Boer TreksResponsible government in Cape Colony-Kaffir delusions as to expected resurrection of their forefathers and expulsion of EnglishSt Helena, Ascension and Tristan d'Acunha-Discovery of diamonds in Grikwaland-Notable Jewish pioneers in South Africa-History of Natal-Kuli labour and Indian immigration-Delagoa Bay arbitration-Damaraland-Origin of German entrance into South African sphere-Walfish Bay-Bechuanaland-Zambezia-Nyasaland-British Central Africa-The African Lakes Co.-African Trans-continental Telegraph-South African federation-The Transvaal-Sir Bartle Frere-Zululand and the Zulu War-Boer revolt-Rhodes and Rhodesia-Matebele Wars and Dr Jameson-Kruger and the DriftsJameson Raid-Viscount Milner-The War of I 899-r902-Peace and Chinese Labour-The Union of South Africa-The Basuto and Native Question-Mauritius and the Seychelles . . . . 254 


\section{CHAPTER XII}

Great Explorers

Old-time travellers-Herodotos-Strabo-Pliny-Ptolemy-The Arab geographers-The Portuguese explorers-Andrew Battel-British on the Gambia-French on the Senegal-James Bruce and the Blue Nile - Timbuktu-Mungo Park and the Niger-South African explorations -Portugal and Dr Lacerda-Captain Owen-Tuckey and the Congo -Major Laing-René Caillé-British Government expeditions in Tripoli,-Bornu, Lake Chad, and Sokoto-Lander and the Niger mouth-Barth and the Western Sudan-the Jewish explorer Mordokhai-Krapf, Rebmann, and the Snow Mountains-LivingstoneBurton and Speke, Speke and Grant-Samuel Baker-Livingstone and Kirk-French explorers in North-West Africa-Livingstone and Central Africa-Cameron-Rohlfs-Nachtigal-Alexandrine TinnePaul du Chaillu-Winwood Reade-Stanley and the Congo-Portuguese explorers-Schweinfurth and the Wele-Nile explorersNyasaland explorations-Pogge, Reichard, Boehm, and von BaryDr Felkin-Joseph Thomson-George Grenfell-von WissmannEmin Pasha-Cameroons explorers-Nigerian and Chad explorations - Tanganyika, Somaliland, and East African discoveries-Kilima-njaro -Morocco-Marchand-Madagascar-Remarkable 20 th century exploring work

297

\section{CHAPTER XIII}

\section{Belgian Africa}

The work of Cambier and Storms-Comité d'Études du Haut CongoH. M. Stanley founds the Congo Independent State-its subsequent history-Long struggle with the Arabs-Captain Hinde-Baron Dhanis-Rumoured atrocities-Katanga-Extension to the White Nile - Murder of Mr Stokes-Railway to Stanley Pool-Denunciation of King Leopold's maladministration by E. D. Morel-Congo Reform movement-Belgian annexation of Congo State . . . $34^{2}$

\section{CHAPTER XIV}

The British in Africa, III

(Egypt and Eastern Africa)

England wrests Egypt from the French-Rise of Muhammad Ali-Suez Canal-Arabi's rebellion-Tel-el-Kebir-Mahdi's revolt-Gordon's 
death-Lord Cromer-Lord Kitchener and the reconquest of the Sudan-Fashoda-Egypt in the 2oth century-Nationalism-Development of the Sudan-Sudd-cutting-Aden and Somaliland-The 'mad' Mullah-Zanzibar-Sir John Kirk-Kilima-njaro-British East African Company-Sir Frederick Lugard and Uganda-Sir Gerald PortalThe Sudanese mutiny in Uganda-The Special Commission-Sleeping Sickness-Zanzibar Government-Dissolution of British East Africa Company-Mubarak's rising-Ogadein Somalis-Big Game-'White' East Africa

\section{CHAPTER XV}

\section{The Italians in Africa}

Italian commercial intercourse with North Africa during Crusades and Renaissance-The Popes and geographical research-Italy in Tunis and Tripoli-Assab Bay-Abyssinia-Eritrea-Italian reverse at Adua-Italy in Somaliland-The Italian invasion and annexation of the Tripolitaine . . . . . . . . 390

\section{CHAPTER XVI}

\section{German Africa}

The Brandenburg traders and the West Coast-German aspirations after colonies in the forties and sixties of the I 9 th century-German missionaries in South-West Africa-Herr Lüderitz-Angra PequenaBritish indecision-German South-West Africa Protectorate foundedGermany in the Cameroons-in East Africa-Anglo-German partition of the Sultan of Zanzibar's dominions-Rising against German rule in East Africa-Germany in the Cameroons-Hottentot and Damara rebellions in South-West Africa-Prospects of German South-West Africa-Togoland . . . . . . . . . 403

\section{CHAPTER XVII}

\section{The French in MAdagascar}

First rumours of the existence of Madagascar-Confusion with Zanzibar and the Komoro Islands-Portuguese discovery-French Company of the East founded to colonize the Island-Fort Dauphin-Pronis, the immoral governor-Vacher de Rochelle, King-Consort of a Malagasy Queen-French East India Company founded. Île de Bourbon 
colonized-The Madagascar Pirates-French found settlement of St Marie de Madagascar-Send scientific expeditions to Madagascar which first make known its peculiar fauna-Benyowski, the Polish adventurer-The Malagasy-The Hovas-English capture Mauritius and Bourbon and turn the French out of Madagascar-French regain Bourbon and re-occupy St Marie de Madagascar-First missionaries of the London Missionary Society arrive in Madagascar ( 1818 )-Rise of Radama and the Hova power-French repulse in 1829-The shipwrecked sailor, Laborde-Queen Ranaválona and persecutions of the Christians-The Sakalavas-Prince Rakoto and Lambert's frustrated coup d'etat-Accession of Rakoto (Radama II)-Deposition and death-French concession repudiated and indemnity paid-The Laborde succession-Quarrel with France in I883-The Shaw incident-General Willoughby-England recognizes French protectorate over Madagascar-final invasion, conquest and annexation of the Island by the French-Réunion and Komoro Islands . $\quad 4_{423}$

\section{CHAPTER XVIII}

\section{Conclusions and Forecasts}

The European partition of Africa-Only Liberia and Abyssinia remain independent-Three classes into which Africa falls from colonization standpoint-Healthy Africa-Yellow Africa-Black Africa-Prognostications as to future race movements-Predominant European races in the future-The eight great languages of New AfricaPaganism will disappear-Muhammadan zeal will eventually decayThe Negro may become identified in national interests with his diverse European rulers, and not unite to form a universal Negro nation with the cry of 'Africa for the Africans,' if he is well treated-White nations may also arise in Africa-Yet future of Africa remains very uncertain

$44^{2}$

Appendix I. Notable events and dates in the history of African colonization

$45^{2}$

Appendix II. Bibliography . . . . . . . ${ }_{4} 67$

INDEX . 


\section{LIST OF MAPS}

I. Africa as known to the Ancients; showing distribution of native races and lines of Bantu invasion . . . To face p. 50

2. Muhammadan Africa . . . . . . To face p. 74

3. Portuguese Africa . . . . . . To face p. II4

4. French Africa . . . . . . . To face p. 238

5. British Africa . . . . . . . To face p. 388

6. German Africa . . . . . . . To face p. 422

7. Colonizable Africa . . . . . . At end

8. Political Africa, I9I2. . . . . . . At end

Note. The spelling of African names adopted throughout this book is the system sanctioned by the Royal Geographical Society, by which all consonants are pronounced as in English and all vowels as in Italian. $\tilde{\mathrm{N}}$, ñ represents the nasal sound of ' $\mathrm{ng}$ ' in 'ringing,' 'song,' as distinguished from the ' $n g$ ' in 'anger.' No consonants are doubled unless pronounced twice in succession: thus 'Massowah' is properly written Masawa. But where old established custom has sanctioned a spelling diverging from these rules the official spelling of the name is adopted. Thus: Moçambique instead of Msambiki; Quelimane instead of Kelimān; Uganda as well as the more correct Buganda; Bonny instead of Obani. 
ERRATUM

p. 3०6, last line, for Truster read Truter, and similarly in Index 



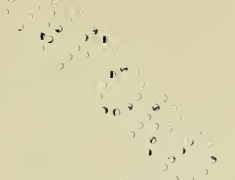

\section{CHAPTER I}

\section{PREHISTORIC RACE MOVEMENTS IN AFRICA}

THE theme of this book obviously deals rather with the invasion and settlement of Africa by foreign nations than with the movements of people indigenous in their present types to the African continent; nevertheless, it may be well to preface this sketch of the history of African colonization by a few remarks explaining the condition and inhabitants of the continent-so far as we can deduce them from indirect evidence-before it was subjected to invasion and conquest by races and peoples from Europe and Asia.

In all probability man first entered Africa from the direction of Syria. He penetrated into tropical Africa in the train of those large mammals which still form the most striking feature in the African fauna; many of which however were evolved not in tropical Africa but in southern Europe or western Asia as well as in Egypt and Cis-Saharan Africa. These great apes, elephants, giraffes, and antelopes sought a refuge in tropical Africa not only from the cold of the glacial pleistocene, but from the incessant attacks of carnivorous man. Later on, but still in most remote times, there were (no doubt) migrations of European man from the northern side of the Mediterranean. But it seems more likely that the bulk of African humanity as represented by its modern types passed from Syria and Persia into Arabia, and thence into northeastern Africa. 
Did the Neanderthal species of humanity-Homo primigenius, with his big hear, big brain, short neck, long trunk and arms, and shambling lezs, his ape-like jaws and possibly hairy body-ever populate any part of Africa? So far, no trace of him in an unmixed form has been found beyond the limits of Europe, eithere living or fossil. But no farther away from Africa than Gibråltar there has been obtained from the layers of deposit below the tloor of a cave the famous neanderthaloid Gibraltar skuil which in cranial capacity is lower than any other type of Homo primigenius as yet discovered. Yet there is nothing 'of the negro about this and other types of Homo primigenius. The nose was quite differently formed and was very large and prominent. The great brow ridges characteristic of Homo primiginius and of his collateral relation the modern Australoid are an un-negro-like feature, though occasionally they appear sporadically in the negroes of Equatorial Africa and even in the northern Bushmen. Some French anthropologists have thought that North Africa was first colonized by the Neanderthal species of man, and that this type has even left traces of its presence there in tribes like the Mogods of north-west Tunisia and certain peoples of the Atlas mountains.

The successor and supplanter of Homo primigenius in western Europe was a generalized type of Homo sapiens, represented by the Galley-Hill man inhabiting south-east England, France, and central Europe some I $_{5}$, 000 years ago - to judge by the approximate age of the strata in which his earliest remains have been discovered. This man of the Thames estuary (Galley-Hill is in north Kent, near Dartford) resembled somewhat closely in skull-form and skeleton the Tasmanian aborigines and like them possessed considerable negroid affinities. There is some slight evidence that the Galley-Hill type co-existed for ages with the more specialized and divergent Homo primigenius (perhaps mingling his blood and producing hybrid types), but gradually supplanted this big-brained though brutish being and spread over Africa and

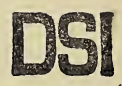


southern Asia, penetrating finally to remote Tasmania, where his last direct descendants were exterminated in the middle of the I 1 th century by the British settlers in that genial island. Certain "Strandlooper" skulls of unknown age found in southernmost Africa seem to suggest affinities with the Tasmanian or Galley-Hill type who may have been the first real man to colonize Africa.

The actual evolutionary area of the negro sub-species of Homo sapiens is unknown to us at present. At one time it was thought likely to have been India. There is a strong underlying negroid element in the mass of the Indian population; and in the southernmost part of the great peninsula there are forest tribes of dark skin and strikingly negro physiognomy, with frizzled or woolly hair. There is a negroid element in the gentle Burmese ; and in the Andaman Islandsgeologically little more than a depressed peninsula of Further India - the dwarfish people are absolute negroes of the Asiatic type. In the Malay Peninsula, here and there in Sumatra, above all in the Philippine archipelago, there are Negrito tribes or types akin to the Andaman islanders. In the more eastern among the Malay islands-especially in Buru, Jilolo, and Timor-the interior tribes are of obvious negro stock. Still more marked is this in the case of New Guinea, and most of all in the Bismarck archipelago and northern Solomon Islands. In these last the resemblance of the natives to the average negro of Africa is most striking, although the distance from Africa is something like 8000 miles. Negroid affinities extend east of the Solomon archipelago to Fiji and Hawai, and south to New Caledonia, Tasmania and even New Zealand. On the other hand, Africa for many thousand years has been obviously the chief domain of the negro. Did the negro sub-species originate in, say, North Africa, and thence spread eastwards to Persia (southern Persia has vestiges of an ancient negroid population-the Elamites of the Hebrew scriptures), India, Further India, Malaysia, and Oceania? Or was Europe- 


\section{Prehistoric Race Movements in Africa [CH.}

southern Europe-the region where the negro specialized from some basic type like the Tasmanian Galley-Hill man? Or Arabia $^{1}$, Syria, or India? The evidence as yet before us is too slight to justify any positive theory. The probability is that some region of western Asia such as Syria was the birthplace of the negro of a generalized type, who from this centre migrated into northern Africa, southern Europe, and southern Asia. The discoveries made by Dr Verneaux and others in southern and western France and in Italy would seem to show that from 30,000 to 40,000 years ago the population of these regions was of negroid aspect, and that they were succeeded by the tall Cro-Magnon race of totally different type, more recalling Caucasian man and the taller Mongoloids, such as the Amerindian. A glance however at the populations of Italy, France, Spain, Wales, and southern Ireland shows the observant anthropologist that both in nigrescence and in facial features the ancient negroid strain has never been completely eliminated in these lands.

1 A hundred thousand years ago the Red Sea may have been a long, isolated lake filling up a great Rift Valley, and the south-western extremity of Arabia have been joined across the narrow straits of Bab-al-Mandib to Somaliland. There is an Arab tradition that in the remote past these straits were formed by a series of earthquakes and land-slides. But if this were the case why is not the west of Arabia, in fertile, wellwatered regions, more "African" in its mammalian, bird, and insect fauna? Arabia is a great enigma still in these questions of geographical distribution. It would be convenient to regard it as the evolutionary area of the negro, if, for example, there were any evidence of a positive character-as there is in southern Persia - to show that it was ever the home of a negro race in ancient times. But there is no such evidence, and its present negro or negroid population only dates from the trade in negro slaves which began about the commencement of the Christian era, and flourished exceedingly after the eruption of Islam.

"Lemuria"- the hypothetical isthmus which once united Madagascar and East Africa with India and Ceylon-could not have been the negro's birth-place, as some have suggested, inasmuch as it ceased to exist in the early Tertiaries, long before Man had been evolved. 
There are certain anatomical differences between the existing negroes of Asia and Oceania on the one hand and the negroes of modern Africa on the other ${ }^{1}$. Whether the African negro was the first human colonizer of Africa, or was preceded by more brutish or more generalized types, such as the Galley-Hill man, is not yet known to us. But from the little we possess in the way of fossil human remains and other evidence it seems probable that every region of Africa, even Algeria and Egypt, once possessed a negro population. In Mauretania (Morocco to Tripoli) these ancient negroes were partly driven out by prehistoric Caucasian invaders and partly absorbed by intermarriage, the mixture resulting in the darkened complexions of so many of the North African peoples. In Egypt a dwarfish type of negro seems to have inhabited the Nile delta some 10,000 years ago; and big black negroes formed the population of upper Nubia and Dongola so late as about 4000 years ago.

Yet there are reasons for thinking that not all parts of Tropical Africa were colonized by negroes, or rather by the typical big black negro, until 2000 or 3000 years ago. Although the fringe of the Congo basin, for example, has been inhabited for a very considerable period (as is testified by the presence of stone implements somewhat deeply buried in the soil), the central part of that area would seem to have been invaded quite recently by man; while in South Africa beyond the Zambezi there have been periods in which the only human type was the Bushman, rather than the big black negro. The comparatively recent human colonization of the forests of the southern Cameroons and the inner Congo basin may have been due to the density of tree growth and the opposition of the gorilla; and (in Congoland) to the swamps

1 They can be gleaned-most of them-from the recent writings of Dr Arthur Keith, and Mr W. L. H. Duckworth, and are to some extent summarized in the preliminary chapter of the present writer's book on The Negro in the Nere World. 


\section{Prehistoric Race Movements in Africa [cH.}

and the presence of large shallow lakes now dried up into river-courses. Several French and German pioneers have described to the writer of this book the way in which, when attempting to explore the forests of South Cameroons, far back from the coast, their caravans of negro porters were attacked by the gorillas; and the utterly uninhabited character of considerable areas along the Congo-Cameroons water-parting is said to be due to the terror inspired in the native mind by these enormous, fierce, and resolute creatures. The same fact may have hindered at one time the populating of similar forest countries between the Mubangi and the main Congo. South of the main Congo there are no gorillas; but a good deal of this central Congo region has been under water until quite recent times, and even now its inhabitants are often compelled to live in pile dwellings raised above flood level.

The African negro is divisible into two main types, very distinct one from the other, the Negro proper and the Bushman. The former is of fairly tall stature (except in its few dwarf tribes), dark, almost black of skin, and long-headed, has abundant head-hair and an inclination to hairiness of face and body, is prognathous and large jawed, and has no marked tendency to fleshiness of the buttocks. His sweat glands emit a rank and most characteristic odour, absent-in this very marked form-from either the Asiatic negro or the Bushman. The Bushman on the other hand is yellow-skinned, short of stature (though of well-proportioned limbs), has a round head rather than a long one, is not markedly prognathous (in his southern types), has no hair on face or body-or at most a very scanty beard in the old men-has the hair arranged in segregated tufts on the head, and is especially distinguished by his marked steatopygy - the growth of fat and muscle on the buttocks. This steatopygy is much more marked in women than in men and is absent altogether in very young children. Both sexes amongst the Bushmen have 
peculiarities in their external genitalia absent from the true negro type ${ }^{1}$.

The average and typical Bushrnan is, as I have said, orthognathous rather than prognathous, and usually, like the negro, is noteworthy for the bulging forehead and the absence of strongly marked brow ridges. Yet there are types of Bush race still living, more especially in German south-west Africa, in which there is either a strongly marked brow ridge and much prognathism, or even a degree of prognathism more extreme and ape-like than is to be seen anywhere else in the world, unless it be here and there amongst the Congo pygmies. These exceptional Bushman types (which resemble somewhat similar sporadic "simian" individuals amongst the Berg-Damara negroes and the helot tribes along the northern Limpopo) have sometimes been identified with a certain class of "Strandlooper" skull found in caves on the South African coasts and exhibiting a low cranial capacity and much prognathism. But, again, among the Strandloopers ${ }^{2}$ there were other types of great antiquity which scarcely seem negro at all-they are of good cranial development and recall the skulls of a generalized Caucasian in form-so that South Africa may have been invaded by "white men," somewhat akin to the modern Hamite, many thousand years ago.

1 These will be found described in Mr W. L. H. Duckworth's Morphology and Anatomy, and also in studies of the Bushmen and Huttentots recently published by Dr Péringuey of the State Library and Museum, Capetown. It is true that the researches of German and Italian anthropologists have shown that the hypertrophy of the external genitalia characteristic of the Bushwoman, together with steatopygy, not only occur amongst the East African negroes, but even in Somaliland, Abyssinia and Egypt; but this is only an additional piece of evidence showing the previous existence of the Bushman in these regions, perhaps also in Southern Europe.

${ }^{2}$ The name is Dutch and means "shore-runners," there being a legend amongst the Boers derived from the Hottentots that the present race of Bushmen was preceded by a vanished type of humanity which derived its living from the shellfish on the sea-shore. 


\section{Prehistoric Race Movements in Africa [CH.}

The modern Bushman is singled out from other African races by his extraordinary gift for delineating and painting. $\mathrm{He}$ has painted or engraved many pictures on the rocks in past times, illustrating thus his customs, superstitions, battles, and above all the wild animals of which he has long been an adroit and fearless hunter. No existing tribe of true negro stock has possessed such a gift for drawing or such a desire to display it. To find some parallel to the artistic work of the Bushmen we must cross the Zambezi and travel northwards to the Sahara desert between Lake Chad and the northernmost Niger on the one hand and the coast regions of Algeria on the other. In all this vast region of desert or stony plateau there are many engravings and pictures on the rocks; but from such slight indications as we possess (some of them are so ancient that they depict extinct beasts) we are inclined to attribute them to a primitive white race, to some such people as covered the walls of caverns in France and Spain with splendid pictures of bison, horses, mammoths, reindeer, salmon, eels, lions, ibexes, and boars. So far no examples of Bushman paintings have been discovered in the far west of South Africa or to the north of the Zambezi. Yet there is some slight traditional and historical evidence to show that Bushmen still lingered in Nyasaland and in the interior of Moçambique down to a period of perhaps three hundred years ago.

Another distinguishing mark of the Bushman type is its peculiar language. This is almost unwritable, so much is it compounded of inarticulate and beast-like sounds-clicks with the tongue, gasps, and nasal grunts. There is very little discoverable syntax in Bushman speech. Its peculiar phonology is shared to some extent by the Hottentot; but, on the other hand, Hottentot has a well-marked syntax as clearly defined as that of any European language, and discriminates between the masculine, feminine and neuter genders. In short in its construction and grammar it recalls very markedly the Hamitic language family of north-east Africa; and there is-remarkable 
to relate-a language, the Sandawi of German East Africa, south of the Victoria Nyanza, which resembles Hottentot in possessing clicks and also in a few of its word-roots, and in its syntax. This speech is used by a semi-nomadic tribe of hunters, who, however, in physique seem to be negroid with some tinge of Hamitic blood.

So far as the slight indications of their legendary history go, the Hottentots of south-west Africa seem in their origin to have come from the same direction-Unyamwezi-to have wandered with cattle and sheep (both of a north-east African type) between Tanganyika and Nyasa, and across the Congo water-parting into Upper Zambezia, whence they made their way slowly, pushed on by other people, into eastern Damaraland. Here they settled for a time, and then again moved on to the Atlantic coast between Mossamedes and the Orange River. For hundreds or thousands of years, no doubt, they warred and yet mingled with the Bushmen, until at last they had acquired many of their physical characteristics and a large element of their language. At the present day they exhibit all the points of a cross between the true negro and the Bushman, with perhaps some attenuated element of the Caucasian, more in their minds and legends than in their bodies.

To return to the true negro. He again may be subdivided into three main types, and a fourth compounded of a mixing of the three others. The first three are (I) the Congo pygmy, (2) the Forest negro, and (3) the Nilotic negro. The Congo pygmy is a dwarfed form of the most ancient negro type, with some affinities to the Asiatic negro, distinguished by a very flat, large nose, much prognathism, long upper lips, turned-in toes, short legs, and a tendency to hairiness on the body. The Forest negro is a slightly improved pygmy, of taller stature, with exaggerated negro facial features, long arms, and legs that are disproportionately short. The Nilotic negro, on the other hand, is remarkable for his long, stilt-like legs, short arms, and a greater likeness to the Caucasian in his facial lineaments. 


\section{Io Prehistoric Race Movements in Africa [CH.}

The Nilotic negro in his finest developments (such as the Turkana of Lake Rudolf) is perhaps the tallest race in the world. A mixture of all these types one with the other, and no doubt with the vanished Bushmen of East and North Africa, has produced the "average" negro which is the commonest type to be met with in West, East, Central, and South Africa. The ordinary Kafir or Zulu, dressed appropriately, or the average Swahili or Munyamwezi of East Africa, or the Mubangi or Muluba of Congoland, would pass muster as a Mandingo, a Mosi, an Ashanti or a Nupe negro in West Africa, or even as a Hausa or a Senegalese.

From whatever direction the negro entered Africa-if he did not arise there-he seems to have settled most thickly to the north of the Equator, in that broad belt below the ${ }^{5} 5^{\text {th }}$ degree of north latitude which stretches across the continent from Senegal and Liberia to Abyssinia and the Victoria Nyanza. In the great western prolongation of Africa, above all, between Kordofan and Senegambia, especially in Nigeria, the negro must have been established for many thousand years to permit of the enormous variety and diversity of the languages therein spoken having arisen. In some parts of West Africa, such as Liberia and French Guinea, there are six or seven absolutely distinct language-families, some of which are confined in their use to an area no larger than Rutland or Bedfordshire.

On the other hand, over the great southern third of Africa, beyond the Equator, there are at most only eleven distinct language-families (as compared to the forty-two or forty-three farther north). Of these eleven, one, the Bantu, predominates vastly over the others; which others are the Bushman and Hottentot in the extreme south, three unclassified Sudanese language-families in Northern Congoland, three small patches of non-Bantu speech in Northern German East Africa, and in the same region and in British East Africa the intrusive Nilotic and Hamitic speech-groups.

At the present day nearly all Africa south of the Equator 
is the domain of but one language-family, the Bantu. The other negro languages are fast dying out. The Bantu conquest has all the appearance of having been a recent event, not beginning perhaps more than 2500 years ago. The Bantu language-family is distinguished by its use of distinctive prefixes, to which correspond a concord of pronouns and adjectival prefixes. Nouns are divided into a nummber of classes (say seventeen), and each class is marked by a special prefix and concord. But the classes do not correspond to the masculine and feminine of the sex-denoting languages, or masculine, feminine, and neuter. No discrimination in prefix or pronouns takes place to indicate sex; but nouns are allotted arbitrarily to classes which in most cases have lost any special meaning but originally undoubtedly corresponded with a division of objects into natural categories, each distinguished by some special feature. Thus there was the 'living' or ' human' class, the 'tree' class, the 'long' or 'river' class, the classes of diminutive objects, of 'gigantic,' of collective like 'water' and 'tribe,' of 'strong ' and 'weak.'

This principle of numerous classes not based on sex distinctions, but each class having its distinctive particle and concord, is by no means confined to Bantu in Africa, but is shared by an important group of West African languages in Senegambia and Sierra Leone (Timne, etc.), and by Fula. Except that the Fula speech (with some allied groups between the Niger bend, the northern Gold Coast and Dahomé) is governed by suffixes instead of prefixes, it offers much resemblance in structure to the Bantu. Other prefix-governed languages (but without a distinct concord) have been found recently in Southern Kordofan. From some such direction as this the Bantu language-family - which in vocabulary, though not in syntax, bears signs of relationship with some of the Lower Niger languages-must have taken its origin in a region between the basins of the Nile, Congo, and Shari. It may have been called into existence in the moulding of a number of 


\section{Prehistoric Race Movements in Africa [CH.}

negro tribes by some semi-Caucasian invader, of which the Hima of the Victoria Nyanza basin, the Mañbettu and the Nyamnyam of the Bahr-al-Ghazal and Wele-Mubangi are vestiges. After a special development in the Mountain Nile basin, this language-type was carried all over the southern projection of Africa by a series of strenuous invasions proceeding west to the Cameroons, east to the shore of the Indian Ocean, and south over the Great Lakes region, Zambezia, and Congoland.

Fula ${ }^{1}$, a form of speech of cognate origin, was the language of the mysterious light-complexioned Fül people who first came within the scope of world-history when they rose into power as a conquering Muhammadan nation of the Western Sudan (Senegambia and Upper Niger) in the eighteenth and nineteenth centuries. Before that they had wandered more or less as a cattle-keeping gypsy-like folk, scattered over Nigeria from the basin of the Gambia and the Senegal to the confines of Bornu and the Shari river; to the Benue, to Nupe, Borgu, and Dahomé. According to Arab tradition they came into Senegambia originally from the Adrar country, far south of Morocco. Some of their own traditions derive them from Fezzan, south of Tripoli. Other slight indications lead us to suppose that they formerly dwelt in Morocco and Algeria as-quite possiblythe predecessors of the Libyans or Berbers, who will be dealt with presently. The nearest affinities of the Fulde or Fula speech at the present day are with the group of Mosi-Gurunsi negro tongues spoken at the back of Ashanti and of Togoland. There are also faint resemblances to Wolof, the language of the handsome black-skinned Jolofs of Senegal, a mixed race with an ancient Caucasian strain in their blood. In any case the pure Fula is a handsome hybrid type, obviously an early cross (in North Africa most likely) between the

1 It is more convenient to refer to this speech family and racial type as "Fula," but the actual name applied by the "Ful-be" people to their language is "Fulful-de." 
invading Caucasian of Europe and some ancient negro stock of North Africa. The purer types of Fula have a skin no darker than the average Berber, the face-features of a European, and hair that is in curly ringlets. Their gradual invasion of the Western Sahara, Nigeria, and Senegambia -in the south they reached down to the Lower Niger and Yoruba-land, to Baghirmi, and across the Benue to within a few days' journey of the Cameroons coast-may have been caused by the peopling of North Africa some ten or more thousand years ago by the Libyans or Berbers, a Caucasian people related in speech and origin to the Gala and other Hamites of N.E. Africa, and to the ancient Egyptians.

Four other negroid peoples require to be considered in their effect on the colonization of Africa before we can deal with the more clearly alien races. These are the Songhai of Central Nigeria, the Mandingo of Western Nigeria, the Hausa, and the Tibus or Teda.

The Songhai (Sughai, Songhoi-the $g h$ is like the French $r$ grasséyé) are something like the Wolofs in appearance, in that, though black-skinned and woolly-haired, their features are often of Caucasian cast, and their characteristics generally those of negroids rather than negroes. Their language (the common speech of Timbuktu) is at present an unsolved mystery, its affinities are unguessed at. The Songhai seem to have dwelt first (where they still live under Tuareg influence) in the Oasis of Agades, a country on the southern verge of the Sahara, due east of the great Niger bend. Here they appear to have received immigrants from Ptolemaic or Roman Egypt, who brought with them Egyptian domestic animals and the Egyptian style of architecture. This last they applied to building in mud instead of stone. But, although much modified since by Berber or Arab (Saracenic) influence from the north, this massive Egyptian style of mud-built walls, palaces, and mosques still prevails throughout northern Nigeria from the Upper Niger to the vicinity of the Shari River. 


\section{I4 Prehistoric Race Movements in Africa [CH.}

While the Songhai were extending their influence to the northern bend of the Niger, the Mandingo peoples, from some unknown place of origin, were fighting their way westwards along the Upper Niger towards Senegambia. The Mandingos and the Songhai met somewhere about the junction of the Niger and the Bani, near the celebrated Jenné, which became a great Songhai city in the 8th century. The Mandingo negroids, who may have been connected with the ancient N.W. African Kingdom of Ghana, early attained wealth and power by opening up the salt and gold mines of the-arid country bordering on or within the Western Sahara. They possibly carried on a trade thence with Romanized North Africa. Southwards they got into touch with the gold-bearing country of Ashanti; and it was perhaps through them that Roman and Byzantine beads first found their way to Ashanti and the Gold Coast. Sometimes the Mandingo empire prevailed over the Songhai; latterly the Songhai dominated the northern Mandingos, until both were swamped by the Moorish invasion of the sixteenth century. Both alike showed themselves very ready to receive Arab traders and the Muhammadan religion.

The Hausa people are much more negro in their physical appearance than the Mandingos or Songhai. But their language, on the other hand, is imprinted with the white man's influence. Not only is it sex-denoting, but in pronouns and in the peculiarity of indicating the feminine gender by the consonant $t$ it offers so many indications of ancient Hamitic influence that we are entitled to assume that it arose through an early invasion of Eastern Nigeria by people speaking a Hamitic language. If there is any veracity in Hausa legends, these Hamitic civilisers of the regions between the Niger and Lake Chad came from Egypt ; apparently they likewise penetrated as far south as Baghirmi on the Shari and westward to the Logone, where they assisted to create the sex-denoting Musgu tongue. At one time it was thought that the evident 
"Libyan" element in Hausa came from the invasion of Central Nigeria by the Berbers or Tuaregs ${ }^{1}$; but it now seems much more probable that it was a Hamitic rather than a Berber influence, and more probably came from the regions of Nubia and Dongola where at one time a Hamitic language was spoken. The Hausa people were probably already in existence, and their "compromise" trading language had already been formed before the Tuaregs or desert Berbers of North Africa had found their way to the regions east of the Niger.

Indeed this region south of the Tripolitaine, from Fezzan across the Tibesti mountains and the eastern Sahara to Lake Chad, had become the domain of another remarkable negroid race which has had much to do with the opening up and the closing of negro Africa, the Tibu or Teda. Physically they are an exact hybrid between Hamite and negro, and resemble very much the more negro-like types of Somali; but their language, which is cognate with the Kanuri of Bornu, a kingdom first semi-civilized by the Tibu, offers no indications of affinity with other African forms of speech; like Songhai it is (so far as our existing knowledge goes) quite isolated. The Tibu had much to do with the introduction of iron weapons and implements and iron-working into negro Africa. They seem to have reproduced the boomerang or throwing-stick in iron, and thus to have originated those wonderful throwing-knives which attained their highest development in the north-central basin of the Congo. A notable stream of Tibu culture (no doubt largely derived from ancient Egypt) entered Congoland about I 500 to 2000 years ago, finding its way up the Shari from Lake Chad, across the Mubangi and

${ }^{1}$ It is more correct to spell this tribal name Tazvareq, the plural of Tarqi, "a raider." But the modern pronunciation of this Arab term (it is unknown to the Berbers themselves) is "Tuareg." Wherever in this book $q$ is used in transliterating African words it stands for the faucal " $\mathrm{k}$ " of the Arabs and other Semites, a guttural which is more commonly pronounced as a $g$ in North Africa, 


\section{I6 Prehistoric Race Movements in Africa [CH.}

main Congo, and so down into the Bushongo country of central Congoland. The old Bushongo language (now extinct) was not a Bantu speech, but an unclassified tongue with relationships to the forms of speech still current on the Upper Shari.

Other civilizing negroid immigrants, Tibu or Hamite in origin, appear to have drifted from the north-east into the Bahr-al-Ghazal region and thence into N.E. Congoland, where by mixture with the negroes they formed the remarkable Nyamnyam and Mañbettu peoples, or at any rate the aristocracies of those tribes. Farther east still we have the remarkable Hima aristocracies of cattle-keeping semi-nomads, very like the Fula in appearance and customs, but always speaking pure Bantu languages. They would seem to have been derived from an ancient Egyptian or Gala origin.

Putting together the slender evidence we have as to the prehistoric past of Africa at a period of, let us say, I0,000 years ago-evidence represented by stone implements, a few skulls of ancient date, rock engravings in Mauretania, the earliest archaeological remains in Lower Egypt-we may hazard the following conclusions. At that period the coastal fringe of North Africa from Morocco to Egypt was inhabited by Caucasian or semi-Caucasian races allied in the west, perhaps, to the Fula type, and in the east (Cyrenaica and Egypt) to the Libyan or Berber. There may even then have been the beginning of Semitic settlements on the Isthmus of Suez and the Suez coast of the Red Sea. These same Libyans or Hamites, at that period not strongly differentiated from the Proto-Semites in race and language, and emphatically "white men," had probably also penetrated to the highlands of Abyssinia, and by mixture with the precedent negroes and bushmen were forming the modern Hamitic races. Some of these white men (besides the more negroid Galas) had found their way down the more open, less densely-forested east coast of Africa 
to Zambezia and South Africa ${ }^{1}$. But beyond this white fringe of Northern and North-eastern Africa, the rest of the Dark continent was then the domain of the negro in his Bushman and black-skinned types. The Sahara desert was not such a rainless region then as now, but was more habitable and inhabited. On the other hand, much of Central and some of Southern Africa was still under water, covered with as yet undrained, unevaporated shallow lakes. The vast forests of the centre and parts of the west may have been uninhabited by man, afraid to encounter the chimpanzees and gorillas, the leopards, pythons, and elephants which tenanted them. Then, I0,000 years ago, more or less, there came into the Nile valley from the direction of Abyssinia the wonderful race of the Dynastic Egyptians ${ }^{2}$, whose original home seems to have been, first, South-West Arabia, and next, the Danákil country, the coast-line of Abyssinia. The Dynastic Egyptians were apparently a composite type, mainly of Hamitic stock, impregnated with an ancient negroid strain and tinged to some extent with Mongol blood from the early Mongolian invaders of Mesopotamia. Their language remains an unsolved problem to this day. It offers decided affinities with both Hamitic and Proto-Semitic, and yet contains puzzling elements of its own which may be due both to negro and to Mongolian influence. In the main it is an aberrant Hamitic tongue; but with no very close resemblance to Gala or Somali, or to the Bisharin dialects of Eastern Nubia. These (be it remarked) seem to have been spoken for an enormously long period of time; and possibly the Bisharin (Hamitic) natives of the Red Sea coast-lands-Rudyard Kipling's "Fuzzie-wuzzies"-were living

1 In which region they may have been preceded by Bushmen, and by a more generalized, Tasmanian-like type of man, similar to the Galley-Hill man who inhabited Kent and Central Europe approximately 100,000 years ago.

${ }^{2}$ So called by Professor W. F. Petrie and others because the type is illustrated in the many portraits of the Pharaohs of Egyptian dynasties. 


\section{I8 Prehistoric Race Movements in Africa [CH.}

where they now are when the dynastic Egyptians poured as a Neolithic conquering host into the Nile valley in Lower Nubia and made their way along the narrow ribbon of habitable Egypt on either side of the Desert Nile.

The dynastic Egyptians found the Delta occupied by a Libyan people, akin to the modern Berbers of North Africa. At that period the distinction already existed between the Libyan or Berber and the Ethiopian or Gala branches of the Hamitic family. Amongst these Berbers of the Nile Delta were still lingering Bushman or negro serfs. The dynastic Egyptians mingled much with these Libyans of North Egypt; indeed occasionally, in the eariy days of organized Egypt, the Libyan race from the Western Desert (which still lingers little altered in the Oasis of Siwah) invaded Egypt and gave dynasties to that country. The dynastic Egyptians ruled and populated the narrow valley of the Desert Nile as far south as the first cataract, and also its broad delta to the shores of the Mediterranean. South of the First Cataract there was a mixed population of Egyptians, Hamites and negroes of the Nubian race. Above the Second Cataract the country of the Nile valley was, whilst dynastic Egyptian rule lasted, entirely negro in population. It was not invaded and settled by Hamites of the Bisharin stock until about the period of Ptolemaic rule.

The dynastic Egyptians governed a small portion only of the Red Sea coast, between the Gulf of Suez and Ras Benās (Berenike). From ports at Kosseir and Berenike they sent their fleets of galleys down the Red Sea and out into the Gulf of Aden; and at a relatively late period of their long (perhaps 6000 years) rule over Egypt, in about 1500 B.C., they despatched the first of several expeditions to the Danákil coast and to Somaliland, in search of incense trees. Whether Egyptian influence in unrecorded voyages proceeded further down the east coast of Africa is doubtful ; at any rate it is not, so far, supported by any evidence. The Egyptians seem to 
have been somewhat timid navigators. Their sea-going galleys depended more on oarsmen than on lateen sails; and, although they may have found it comparatively safe to coast along the Red Sea, they would be perturbed by the much rougher, stormier waters of the Gulf of Aden; while the Indian Ocean, with its strong monsoon winds and big billows, would prove very unsafe for their unseaworthy ships. Their civilizing, "Caucasianizing" influence over negro Africa was however considerable, though probably not exercised with any effect until the real Egyptian dynasties were passing away and the land of Egypt was becoming a region doomed to be ruled by foreigners-Assyrians, Persians, Greeks, Romans, Byzantines ${ }^{1}$. Egyptian trade, even as far back as 3000 or 4000 years before the Christian era, was penetrating through Nubia to Kordofan and Darfur, Bornu, Tibesti, Agadés and the Niger; or down into the Bahr-al-ghazal and the countries of the Mountain Nile where the pygmies still dwelt. Hamitic peoples and Semitic colonists in Abyssinia and Northern Galaland were in touch with the Egypt of the last dynasties and the Egypt of the Ptolemies, and pushed a trade in Egyptian goods inland as far as Mt Elgon and the shores of the Victoria Nyanza. Their ancient, blue, Egyptian beads are dug up occasionally in the sub-soil of Kavirondo. Egyptian or Gala adventurers appeared (outcasts, criminals, or mutinous soldiers in origin, it may be) in the lands of savage negroes about the sources of the Nile. They were looked upon as demi-gods; and their descendants to this day (with a strikingly Pharaonic physiognomy) are often called by a name which means "spirits," "white men," or "gods." They, or traders whom they attracted, brought with them the domestic animals of Egypt and the cultivated plants, besides a knowledge of metal working.

Is it generally realized that the whole of negro Africa,

1 To be followed, with no return to sovereigns of real Egyptian race, by Arabs, Turks, Circassians, Albanians, Macedonians, Armenians, French, and British. 


\section{Prehistoric Race Movements in Africa [ $\mathrm{CH}$.}

south of the Northern Sahara, received its first and its principal domestic animals and cultivated plants from Egypt, and Egypt only? The ox, long-horned and straight-backed, or shorter-horned and humped, an Asiatic, and not a European or taurine ox; the hairy fat-tailed or maned sheep; the little Sudanese goat (not the long-eared, polled, fleecy Nubian goat of after-development); one or more breeds of dog; the domesticated Nubian ass; the domestic fowl-all came from Egypt. In vegetable food-stuffs there were the jowari or sorghum grain (Andropogon), the eleusine, the Pennisetum millets, the taro "yam" (Colocasia aroid), various peas and beans, and gourds and pumpkins. From Egypt came ideas as to boat-building which penetrated as far south and west as the Victoria Nyanza, Lake Chad, and the Northern Niger; also methods of hutbuilding and the ambitious mud-architecture of the Nigerian Sudan, a hint or reflection of which penetrated even to the Niger delta, the Northern Cameroons and Congo. Simple articles of furniture, such as carved stools, head-rest pillows, musical instruments (lyres, drums, harps, xylophones, zithers), games of the cat's-cradle and backgammon type, weapons (shields, improved bows, slings, lances and battle-axes), found their way into the heart of negroland; though many of these inventions got no farther south than Uganda and the central basin of the Congo, or south of the northern Niger.

Two other elements in the pre-historic colonization of Africa require mention at this stage-the Semitic and the Malay. "Semitic" and "Hamitic" are useful terms which apply exactly to two distinct types of sex-denoting languages; languages which conceivably had a common origin very far back in time-12,000 years ago or more?-somewhere in southwest Asia, perhaps not far from Caucasia or Armenia. But in a looser sense we apply Semitic and Hamitic to physical types, and speak of a Semitic profile and the dark Hamitic complexion and curly hair. "Hamite"-or, more correctly, Kushite-applies without much inconsistency to the physical 
type which speaks the Eastern Hamitic languages ${ }^{1}$-yellow or brown in skin colour, with the handsome features and straight, thin noses of the better-looking Caucasian, and bushy, black hair which betrays the ancient negro intermixture by its curliness. The Kushites are in fact descended from Libyans (Berbers) who have mingled in North-East Africa with negro races. The whiter Libyans passed on westwards to colonize the southern and north-western shores of the Mediterranean, while the Hamites populated Middle and Eastern Egypt, Abyssinia, and Galaland; from which direction their nomad wanderers as hunters and herdsmen permeated all Eastern Africa in ancient times. The Hamitic languages are akin to the Libyan, though the two groups are widely separated in affinities of vocabulary, and must have diverged from a common origin in North-Western Arabia ten or more thousand years ago.

It is far less easy in the case of the Semites to define a physical type associated with the speaking of Semitic languages; as difficult, indeed, as to postulate the corporeal form of the men who originated the Aryan tongues. The Aramaic type so familiar to us in the typical Jew is akin to the old Assyrian; and the Assyrian was probably a compound of Armenian and

1 Some writers reserve "Hamite" and "Hamitic" for the general name of the language family which includes the Libyan and the eastern Hamitic tongues, and employ Kushite as a special designation for the great eastern branch of Hamitic speech-forms which extends its range through Northeast Africa from Egypt to the Equator. The main groups of these eastern Hamitic or Kushite languages are the Beja or Bisharin of the Red Sea north-west coast and the country between the Nile and S'lakin; the Saho of the Abysinian coast-lands; the Afar-Danakil-Somali group; the Agau-Bilin of the Abyssinian highlands; the Gala, stretching from central Abyssinia to the Juba and Tana rivers; and the Kafa of southwest Galaland, reaching southward to near Lake Rudolf. In the south-west of the Ethiopian Empire there are many unclassified Hamitic dialects (as there are in northern German East Africa) which are much mixed with negro word-roots and syntax. These almost merge into the Masai and Nilotic. 


\section{Prehistoric Race Movements in Africa [CH.}

Mediterranean man mixed with the old negroid peoples of Southern Persia. The Arabs of Arabia are in the north very "Nordic" in appearance, and evidently exhibit the results of ancient invasions of Syria by peoples akin to the Teutonic or blond Aryan type ; others again show the hooked "Semitic" nose of the Armenian or the long nasal organ of the average Persian; while in the natives of Southern Arabia there is a Hamitic, Gala-like strain, besides the general underlying stratum of that hypothetical small-bodied, big-nosed white Neolithic race which is associated with stone-worship and megalithic stone-building, and is perhaps the basis of the Mediterranean type of man. Curiously enough, there is not any evidence as yet of an ancient negro peopling of Arabia, such as exists in regard to Algeria and Egypt, and Southern (Elamite) Persia.

These varying and composite races speaking Semitic tongues appear to have travelled south and west from Syria and Arabia on the heels of both Libyans (Amorites) and Hamites, and even to have settled on the Red Sea coast of Egypt at a very early period before the dynastic Egyptians had conquered the Nile valley. Much later they invaded Lower Egypt in force as the Haqshu (Hikushahu) or Shepherd kings-if these are rightfully identified as speaking a Semitic tongue. Still later they began to cross the Red Sea farther south and colonized Abyssinia and even Somaliland. In these regions (Abyssinia and Harrar) their Semitic tongues remain to this day. Perhaps as early as 1000 years before the time of Christ (at a guess) their ships, more seaworthy than those of the Egyptians, found their way from the ports of the Sabaean, Minaean and Himyarite kingdoms to India, to the Zanzibar coast of Africa, and to the north end of Madagascar and the Comoro Islands. Later, in all probability, than the first Minaean ventures along the East African coast was a more authentic voyage of the Phoenicians, which will be mentioned in the next chapter.

Attention should be given at this stage in our survey of the ancient colonization of Africa to the unsolved mystery of 
the Rhodesian ruins - the stone-built forts, the aqueducts, round towers, stone-embanked hill-terraces, stone-lined pits, rock-mines, and buildings which suggest the name of "temple." These ruins (in and under which have been found beautiful gold ornaments, ingot-moulds, strange, sculptured birds-eagles or vultures - at the ends of long soap-stone monoliths, and stone phalli) dot the surface of Southern Rhodesia somewhat thickly. They seem to radiate, as it were, from the head streams of the Sabi River, in fact from where the most wonderful of all these ruins, Great Zimbabwe, is situated. The northernmost of the clusters of ruins of stone buildings is to the north of Mt Hampden and the modern town of Salisbury; but none of these strange remains of an unexplained civilization are found anywhere near the Zambezi. It would seem that the unknown people to whom the really antique and skilfully built among these towers, temples, and labyrinthine fortifications (and not their more modern, negro-made clumsy imitations) are to be ascribed, entered south-east Africa at or near the old Arab port of Sofala and made their way up the Sabi river. The ruins are all situated on lofty tablelands or mountain ridges, in healthy, cool country. Their existence was noted by Arab writers so early as the roth century A.c.; and they were described as old and partly in decay when first seen by the Portuguese in the I6th century. The name "Zimbaoe," -like the modern Zimbabwe-applied to them in Portuguese writings is simply a local Bantu plural word meaning "stones"; but these Zimba or Zimbabwe came to be specially associated with the remarkable negro kingdom or empire of Monomotapa ${ }^{1}$ which existed in this part of south-east Africa from the time the Islamite Arabs settled anew at Sofala in the roth century A.C. down to the early rgth century, when it

1 This word is evidently derived from the Zambezi Bantu words Mwenemutapa $=$ Lord of the Mine. Another form "Bena mutapa" for the people might be translated "Brothers of the mine"-Bena (Baina) in Old Bantu = brothers, or "clan." 


\section{Prehistoric Race Movements in Africa [CH.}

was apparently finally extinguished by the invading Zulus from the south. From this region may have come the conquering hordes of the "Ba-zimba" who are thought to have crossed over into west Madagascar, and who passed ravaging and slaying up the east coast of Africa-very much after the style of the later Angoni-Zulu raids-in the late r6th century, temporarily effacing the Portuguese hold over Mombasa.

The Rhodesian stone buildings are obviously associated with gold-mining; but they must have been centres of somewhat elaborate agriculture, and of a phallic worship (the phallus being, together with the associated cylinder or lingam, a sacred symbol of a religious belief which prevailed once in Egypt, India, and ancient Arabia and Syria). Phallic worship, for example, was carried by the Phoenicians to southern Tunis-no doubt to Carthage and elsewhere; but its symbols happen to have survived in actual use in southern Tunis to the present day. The masonry of the Zimbabwe type of building (the real old kind, not the modern negro imitation) displays remarkable skill in the shaping and placing of stones in courses, all much of the same size. The masonry is without mortar, but the stones fit fairly closely in their horizontal, accurately-laid courses; and in the round buildings the symmetry is remarkable.

What race raised such monuments and was gifted with so much civilization at a period which is certainly antecedent (in the really ancient types of building) to the Ioth century A.c.? Was it the Arabs from southern Arabia, who were settled on the East African coast before the Christian era? This seems probable. The Zimbabwe ruins yield no ornament, no detail whatever of the Saracenic style, and (so far) no inscription of any kind in any language. There is nothing whatever about them to suggest their having been built by Islamic Arabs; everything to the contrary, as certainly these Arabs would not have carved either birds or phalli. There are suggestions here and there of Indian influence. The buildings of the true 
Zimbabwe style are certainly pre-Islamic or have been associated with a people which ignored Islam. They resemble most nearly the works of the Phoenicians and the southern Arabians, from any date between rooo B.c. and the early part of the Christian era. The round conical towers are like those of Sardinia and Ireland and other ancient haunts of the enterprising Phoenicians. Yet there is nowhere any inscription in the Phoenician, Hebrew, Sabaean or Kufic or other ancient eastern alphabets, though according to Portuguese traditions inscriptions in unknown characters did exist at Zimbabwe; and no skull has so far been dug up from beneath the ruins or in close association with them or the ancient gold-workings which is not of the ordinary Bantu negro type. No ancient coin has been found; all the pottery, porcelain, and glass fragments indicate comparatively modern oriental ware which might have been introduced at any date between the 15 th and the 17 th centuries. Yet most of these last discoveries, though made at a considerable depth below the surface under the oldest ruins, come from places where they might have been buried in recent times, and do not really militate against the theory that the finest masonry work of Zimbabwe and kindred establishments dates from a period of 2000 years ago or earlier.

No one who really knows the negro of Africa, south of the Sahara desert, can easily believe that the hundreds of stone-built towns, villages and forts of ancient appearance in southern Rhodesia were built, unaided and uninspired, by a pure negro race, or doubt even that these works (I am referring to those of perfect construction) were the outcome of some foreign invasion of south-east Africa at a period of unfixed history prior to the 7 th century of the Christian era. We know of no negro, scarcely any negroid, race of Africa which, left to itself and of its own inspiration, has taken to building in stone. The great metal-working tribes of the Congo basin which developed a really remarkable native art-the 


\section{Prehistoric Race Movements in Africa [CH.}

Bushongo, for example, a race more negroid than negronevertheless ignored stone as a building material or an object of worship. Between southern Congoland or Nyasaland on the north and Mashonaland on the south nothing has ever been discovered hitherto which indicates the existence in former times of a stone-building race of negroes or negroids, or of the path followed through the, until recently, barbarous regions of Zambezia and Moçambique by the possible ancestors of the people who built the Zimbabwe and similar monuments.

The resemblance between the round towers of Rhodesia and the primitive, conical, round minarets of the old mosques at Lamu, Malindi, Mombasa, and other places on the East African coast (dominated by Arabs for at least 2000 years) is very striking. Both may date from the pre-Islamic period. There are other analogies between the Rhodesian ruins and the ancient buildings of pre-Islamic Arabia which suggest, as the most probable explanation of this mystery in African colonization, that the ancient gold-miners, phallus- and sunworshippers, irrigators, terrace-cultivators of Matebele- and Mashonaland, were likewise Arabs from some part of western or southern Arabia who penetrated inland from Sofala attracted by the signs of gold. After a century or so of profitable gold-mining in a land which had only then a spare Bushman population, the Bantu hordes from the north descended on these Semitic colonies and eventually exterminated or drove away the Arabs, taking their place clumsily as gold-miners and builders. Although the Arabs never regained their position in the interior, they continued or resumed their occupancy of the south-east African coast-line down to the arrival of the Portuguese. Probably also the Tsetse fly, by its interference with the means of transport, was another deterrent factor in the history of this colonization which failed to spread. It is possible, nevertheless, that Madagascar and Bantu East Africa owe to these hypothetical, unnamed, prehistoric Arab colonizers not only the introduction (indirectly from India) of the edible 
banana or plantain, which afterwards spread right across the continent, but also the long-horned, straight-backed Egyptian ox, and the domestic fowl; hemp perhaps likewise, a "smoking mixture" which preceded tobacco by many centuries.

One of the greatest mysteries in the prehistoric past of Man is the Malayan colonization of the large island of Madagascar. Madagascar lies off the east coast of Africa at a minimum distance of 300 miles. Between the north-west corner of the island and the East African mainland lies the archipelago of the Comoro islands, which assist to some extent to bridge the interval. So far as our researches go, there is no evidence in Madagascar of ancient human inhabitants. The island was probably uninhabited by man until the arrival of the Malagasy from Sumatra or Java, though, more or less simultaneously, negroes from eastern Africa were arriving on the west coast of Madagascar, either in their own canoes, or more probably in the sailing vessels of the Arabs who were trading up and down the east coast of Africa from perhaps as early as 1000 B.C. But the unsolved problem is, How did the Malagasy tribes reach this island at different periods between an approximate 500 B.c. and 500 A.c.? Their language affinities ${ }^{1}$ show that they must have come from Sumatra or Java. Physically the Malagasy of pure racelike the Hova tribes-unmixed (as so many of them are along the eastern side of the central plateau) with negro, Indian, or Arab blood, resemble pretty closely the Malay types of Sumatra and Java. We can understand the Malay and Indonesian conquest of Oceania. In the relatively calm, island-studded Pacific Ocean it is not an impossible task for men to sail on

1 Although the people of west and south Madagascar are very negroid in appearance and those of the north are evidently mixed with Arab and Indian blood, the Malay-like Malagasy language is the one universal speech throughout the whole island. It contains, however, loan words from Himyaritic Arabic and from East African Bantu. 


\section{Prehistoric Race Movements in Afraca [CH.}

from island to island in large canoes with outriggers and decks, and with masts and sails, and thus to reach in their migrations to within 2000 or 3000 miles of North or South America, and 5000 or 6000 miles from their starting-point. But it is a different matter to cross in a direct line the whole breadth of the Indian Ocean from Java or Sumatra to Madagascar, with no convenient islands to halt at by the way. It is true that there is the little Chagos group, leading to the Mascarene archipelago of Mauritius, Réunion and Rodriguez; but on no one of these islands has there been found any trace of the former presence of human inhabitants before the arrival of the Portuguese, Dutch, and French. It seems more probable therefore that the excursions and adventures of the Sumatran and Javan Malays (inspired to some extent as they may have been by the mysterious Indonesians coming from Indo-China, who settled at some unknown date in Sumatra and the more eastern islands of the Malay archipelago, and were the progenitors of the Polynesians) first took a western direction in crossing the Bay of Bengal to Ceylon and southern India; thence passing on to the Maldiv archipelago, and so to the Seychelles and farther to the Almirante Islands and the north end of Madagascar. But there is very little evidence of a positive nature to support this theory, except it be the slightly "Malay" look about the people of the Maldiv group and the scanty remains of ancient human settlement which are undoubtedly to be found in the larger Seychelles Islands; though these had long been uninhabited when re discovered by the Portuguese and French. It seems, however, almost impossible, that repeated colonizations of Madagascar should have taken place by direct voyages from Sumatra or Java (at a period from 2500 to 1500 years ago) by adventurous Malays starting forth in outrigger canoes for an ocean journey of about 4000 miles. How did they know Madagascar awaited them on the other side of that tremendous interval? It is much more likely that they passed on by degrees from point to 
point in their western migrations; first to Ceylon, then to the Maldiv Islands (this name, like some other place and tribal names in South India, suggests affinity with "Malay," "Malagasy"), and so on to the Seychelles, Almirante, Aldabra and the Comoros. But, if so adventurous, why did not these Malagasy Malays also colonize the east coast of Africa? If they ever did so, there remains not the slightest trace of their presence in either the physique or the languages of the present inhabitants. There are, it is true, outrigger canoes in use at Zanzibar which may derive from some occupation of that island by Malagasies on their way to Madagascar; but Zanzibar, though only twenty miles from the mainland, is very distinct from East Africa. Its original inhabitants, when it was first examined by Europeans, belonged to only three types-negroes, Arabs, and Indians. There is evidence, however, of a scattered and varied character, that intercourse for trading purposes between China, India and Persia on the one hand, and South Arabia and Zanzibar on the other is as old as the beginning of the Christian era. Himyaritic-Arab intercourse with the Malagasy of north Madagascar must be at least as old as that ; to judge by a variety of indications, it is certainly pre-Islamic.

The west coast of Madagascar may have been already peopled by negroes from East Africa who had crossed over by the route of the Comoro archipelago'. But, if so, these last must have been assisted or compelled to make the attempt

${ }^{1}$ Some evidence, chiefly traditional, is adduced to show that Madagascar was once inhabited by a yellow-skinned dwarfish race of Bushman stock known as the "Kimo." But it is still more difficult to imagine a Bushman race possessing canoes sufficiently large and seaworthy for the crossing of the Moçambique channel; or to ascribe to the prehistoric Arabs, who may have traded with south-east Africa, the motiveless transportation of Bushmen to south-west Madagascar. The supposed negro aborigines, apart from the dwarfish Kimo, are known traditionally by the Malagasy as "Ba-zimba" or "Va-zimba," and their burial places are pointed out. The Ba-zimba may have been the mysterious race which built Zimbabwe. 


\section{Prehistoric Race Movements in Africa [CH.}

by some superior seafaring race coming from the north, Arab or Phoenician, because there is no evidence that the East African negroes have ever been great navigators or have possessed in earlier times any means of embarkation better than dug-out canoes propelled by paddles; and it is difficult to believe that in such unstable vessels they could cross a broad strait of rough sea between East Africa and the Comoro Islands. It is easier to suppose that the large negro element of Bantu origin which exists in north-west Madagascar was brought there within the last 2000 years by Arab ships, before and after the days of Islam. The negro colonization of this large island could not have been helped by the persistence of some land-bridge, some Comoro isthmus which has since broken down; for along such an isthmus would have come many African beasts, birds, and snakes, which are totally absent from Madagascar ${ }^{1}$. With only a narrow strait to cross, negroes or Bushmen might have passed over to Madagascar in canoes or on rafts. The Comoro Islands, when first discovered by Europeans, were (as now) inhabited by Arabs and a race of Bantu negroes, speaking dialects related to the Swahili of Zanzibar. But these may have been brought there centuries before by the Arab ships. It is probable that there was no Malagasy settlement of the Comoro archipelago until the igth century.

Another curious feature in this Malay colonization of Madagascar is that, once having reached this great island, the Malagasy immigrants appear to have completely renounced their seafaring life, to have maintained no sea-going vessels of any size (though they had and have still neatly made

1 Yet from two to ten thousand years ago, the Comoro island chain was probably larger and approached much nearer to the mainland, thus permitting Madagascar to be reached (by swimming) by two or three species of hippopotamus (now extinct) and by the bush-pig which still exists there. It is very improbable that either of these mammals could have swum the distance of 200 miles which now separates East Africa from the nearest Comoro Island. 
outrigger boats), and never to have voyaged anywhere from the coasts of their new home. Otherwise they could not have failed to discover and colonize Mauritius or Réunion. In many of its aspects the colonization of Madagascar in prehistoric times by a race coming obviously from Sumatra or Java and allied in physical type and language less to the Malays than to the Malayo-Polynesians and even to the darker Melanesians is perhaps the most puzzling of the unsolved enigmas to be found in the study of the peopling of Africa by foreign immigrants. Judging from local traditions, from time to time fleets of canoes containing Malays were blown right across the Indian Ocean to the east coast of Madagascar. Such was-it is said-the history of the Imérina or Hova tribes who originated mainly from the last accidental Malay colonization of Madagascar. These Hovas found the coast belt so unhealthy that they made their way inland to the high plateaus of Imérina. Here, after long isolation, they acquired strength from their invigorating climate and, obtaining arms from the Europeans in the $\mathbf{I} 7$ th and 18 th centuries, spread over Madagascar as conquerors and brought nearly the whole island under their rule. Yet the Sakalavas, the dark-skinned remnant of a far earlier Malaysian invasion, spoke a dialect nearer to the actual Malay than that of the Hova. It remains to be said that the strong negroid element of Madagascar is attributed by some authorities to Melanesian colonists from Malaysia of a relatively ancient date and not to negroes from Africa. There are numerous Melanesian words in the Malagasy language. 


\section{CHAPTER II}

\section{THE MEDITERRANEAN COLONIZATION OF AFRICA}

THE historical colonization of Africa by alien peoples (if we regard the dynastic Egyptians as autochthonous) commences with the exploits of the Phoenicians in Mauretania. This remarkable Semitic people, no doubt akin to the ancestors of the Jews in race and language, is believed to have originated on the S.W. shores of the Persian Gulf, and at a period of some remoteness-perhaps four thousand years ago--to have made its way up the Euphrates and across the Syrian Desert to the coast of the Mediterranean, where eventually the great trading cities of Tyre (Tsur or Șor), Akko, Saida or Sidon, Sarepta, Arvad or Ruad, Biruta or Biruna (Beirūt), etc., were established mostly on islets off the Syrian coast which eventually grew into peninsulas. From these strongholds their galleys ranged the Mediterranean and reached the North African coast, the Straits of Gibraltar, and the open Atlantic Ocean. By about the twelfth century before Christ the Phoenicians from Sidon had established trading stations at Utica (Atiqa) at the mouth of the Majerda River in North-East Tunisia, and at Lixus on the coast of Morocco (perhaps mouth of River Draa, opposite to the Canary Islands). At the same period-perhaps earliest of allGades (Cadiz) was founded as a Sidonian colony at the mouth of the Guadalquivir in Southern Spain. Carthage (Kart-hadshat or Kart-hadasht = the New City), afterwards the Phoenician metropolis in North Africa, did not come into existence till 
about 822 B.c. It was a settlement of the Tyrians on the west side of the Gulf of Tunis not far from Utica on the Majerda River, and was called the New City in contrast to Utica the "Ancient"(Atiqa). The Tyrians and perhaps the Phoenicians from other sea-cities also created trading depôts on the Cyrenaic and Tripolitan coast, thus coming into contact with the Egyptians. But from the seventeenth to the twelfth century before Christ the Phoenicians had been under the overlordship of Egypt; and it was only when the Egyptian power began to weaken that the great ships built at Sidon and at Tyre from the timber of Cyprus and the Lebanon dared to found African colonies immediately to the westward of Egypt.

Long afterwards, in the days when the strength of the Phoenicians was itself to decline in the grip of the Assyrian kings, these bold navigators hired themselves and their ships to the rulers of Egypt for naval transport and geographical discovery. In about 600 B.C., according to the story of Herodotos, the last but three of the native Egyptian Pharaohs, Niku (Necho) II, summoned a captain of the Phoenicians whose ships were stationed in the Gulf of Suez (perhaps conveyed thither from the Mediterranean through some canal between the Nile and the Bitter Lakes), and despatched him in command of an expedition of two or three vessels, with the order to attempt to sail round the peninsular continent of Africa and through the Straits of Gibraltar back to the Nile Delta. Very likely the ship-masters from South Arabia had already spread the news that the east coast of Africa trended steadily westwards beyond the equator, and had guessed that Africa was circumnavigable from the land of the negroes on the east back to that land of black men on the west of which the Carthaginians were beginning to spread some dim foreknowledge from their journeys southward along the Morocco and Sahara coasts.

This Phoenician expedition accordingly set out, and in about three years' time had circumnavigated Africa and reentered the Mediterranean through the strait which separates 


\section{Mediterranean Colonization of Africa [CH.}

Morocco from Spain. Somewhere off the southern coast of Africa they had landed, sown grain and waited in the southern summer (our winter) till it matured and ripened. Then they reaped their harvest and continued the voyage, not willingly losing sight of the coast, no doubt, yet landing as seldom as possible (we may imagine) in their justifiable terror of savage tribes and fierce wild beasts. The account given in Herodotos is very bare. Only one experience of these Phoenician pioneers is given, other than the corn-growing; they are said during the (northern) summer season to have had the sun on their right hand - that is to say, in the north of the sky at mid-day. This observation shows at any rate that these Phoenicians had sailed far enough south to have reached the south temperate zone wherein the sun would always be in the northern sky at mid-day; while the ship's general east-to-west course round the southern extremity of Africa would place the sun on the right hand of a spectator facing the west.

All the minor geographical discoveries of this expedition have been lost to us, if any were recorded. No mention is made of the gold of south-east Africa, of any Arab settlements along the east coast, of the negro inhabitants of these wild regions, or the means by which the Phoenician mariners supplied themselves with food to supplement the corn which they grew and reaped. It would not have been difficult for them, coming from the east, to reach the southern extremity of Africa, and still less difficult if there really were Arab stations at which they could recruit in the vicinity of Sofala and Inyambane. The story, by no means an incredible one, rests almost entirely on a statement of Herodotos, but was thought to have received fresh support from records of the events of the reign of Niku II which were said to have been discovered in the collection of a French Egyptologist. These inscribed scarabs are however now believed to be clear forgeries ${ }^{1}$. There is nothing

1 The alleged records on stone scarabs are discussed by Prof. Flinders Petrie in the Journal of the Royal Geographical Society, Nov. I9o8. 
improbable about this legend of the Phoenician east-to-west circumnavigation of Africa. The winds and currents, be it observed, would make it much easier for sailing ships to circumnavigate Africa from the east coast round to the west coast, and then north, than in the reverse direction; and it is curious to note, among other shreds of historical record, that a Persian nobleman of Egypt in the sixth century B.C. and the Carthaginians of the same period both tried to sail round Africa from Morocco past the West coast, and gave up the enterprise as too difficult and tedious.

There has been transmitted to us through the diligence of ancient Greek geographers the Greek version of what is supposed to be the original description in Punic of the voyage of Hanno the Carthaginian. This Punic explorer started from Carthage some time in the sixth century before Christ (perhaps about 520 B.c.) with a fleet of 60 ships, and a multitude of men and women (said to have been $3 \circ, 000$ in number), on a voyage of discovery mainly, but also for the purpose of replenishing with settlers the Carthaginian stations along the coast of Morocco. In the account given of the journey it is stated that, after passing the Straits of Hercules and stopping at the site of the modern Sebu, they rounded Cape Cantin and came to a marsh in which a large number of elephants were disporting themselves ${ }^{1}$.

1 This is an interesting observation. Not only does the statement repeatedly occur in the writings of ancient Greek and Roman geographers that the African elephant was found wild in Mauretania in these times, but this animal is pictured in the remarkable rock engravings in the Sus country in the extreme south of Morocco and in the central and south-eastern part of Algeria, besides being represented in the Roman mosaics of Tunisia, now exhibited at the Bardo Museum near Tunis. (See for this the travels of the Moroccan Jewish Rabbi, Mordokhai, the various works recently published by Mons. Gautier of the University of Algiers, and the researches of Professor A. Pomel.) The Phoenicians tamed the African elephant, found wild in the forests of Western Tunisia, which was a somewhat smaller breed than the Indian elephant or the elephant of tropical Africa, yet a typical African elephant in its large ears. It was 


\section{Mediterranean Colonization of Africa [CH.}

They then continued their journey along the coast till they came to the river Lixus, which has been identified with the river Draa. From here they coasted the desert till they reached what we now call the Rio de Oro, and on an islet at the head of this inlet they founded the commercial station of Kerne. From Kerne they made an expedition as far south as a river which has been identified as the river Senegal, having first visited the Lagoon of Teniahir. Once more setting out from Kerne, they passed Cape Verde, the river Gambia, and the Sierra Leone coast as far as the Sherboro inlet, which was the limit of their voyage of discovery. Here they encountered "wild men and women covered with hair"probably the chimpanzees, which are found there to this day, and not the gorilla, which is an ape, restricted in its westward range to the Cameroons. As Hanno's interpreter called these creatures "gorilla," that name was fancifully given in the nineteenth century to the huge anthropoid ape discovered by American missionaries in the Gaboon. When Hanno's expedition visited the neighbourhood of the Senegal river they were attacked by the natives, who were described as "wild men wearing the skins of beasts and defending themselves with stones." So far as we know, this was the first sight that civilized man had of his wild Palaeolithic brother since the two had parted company in Neolithic times, except for glimpses of the Troglodytes, whom the Carthaginians appear to have met with in the valley of the river Draa ${ }^{1}$.

more often figured on Roman medals and in Roman sculpture than the Indian type.

${ }^{1}$ It does not follow, however, that these Troglodytes were dwarfs or negroes, or palæolithic in culture, or greatly different in race from the Berbers. They may have been akin to the Troglodytes still to be seen in the Tunisian Sahara, a Berber people living in caves, which are either natural hollows in the limestone rock or have been artificially excavated. Other allusions and incidents connected with the story of Hanno and an analysis of that story are fully discussed in the first volume of the present writer's book on Liberia, published in 1906 . It is remarkable to note 
At Kerne and other trading stations on the coast to the south of Morocco, the Carthaginians did no doubt a little trade with the Berber natives in the produce of the Sudan, south of the Sahara, but after a time the weakening of the power of Carthage and the attacks of the natives must have destroyed most of these West African settlements; for the Romans in replacing the Carthaginians do not seem to have gone further south than the river Draa.

During the eighth century before the Christian era the Tyrian and Sidonian colonies in North Africa and Spain began to detach themselves from any political submission to the Phoenician State in Syria, a kingdom then much harassed by the Assyrians and henceforth doomed to lose its independence under the alternate sway of Egypt, Assyria, Chaldaea, Persia, and Macedonia. Carthage became the metropolis of Western Phoenicia, of the Canaanite ${ }^{1}$ settlements in Berberland and Iberia. The North African coast was dotted at frequent intervals, from Leptis (Lebda) in Tripoli to the mouth of the Draa on the Atlantic coast of Morocco, with Canaanite trading or governing cities. More especially was the Tunisian or African ${ }^{2}$

that the little islet at the head of the Rio de Oro Gulf is still called "Herne" by the Moors.

1 The national name for the Phoenicians was $\chi n \bar{a}$ (Khna, Kinah, Kinahni, 'Canaan'). The Greeks invented for them the name Phoinike, Phoinikes, which the Latins adopted as Punica, Poeni or Puni, from Phoinix = red; the Phoenicians appearing to the fair-skinned Greeks as "red" men. Very often they went by the name of Sidonoi (Sidonians), from the name of their oldest city Sidunnu (Sidon, Saida).

2 The Phoenicians may have first brought into vogue the word "Africa." This would seem to have been derived (see note on p. Io of Victor Piquet's Les Civilisations de l'Afrique du Nord: Paris, 1909) from a Berber tribe named Afarik, Awarigha-or latterly, Awuraghen-which occupied the north-east coast of Tunisia in pre-Roman times, but which with other Berber peoples retreated by degrees into the interior till at length it became a Tuareg or desert people. Under the name of Awuraghen, dwelling in Asjer, west of Ghat, this tribe, which has given its name to the whole continent, still exists. 


\section{Mediterranean Colonization of Africa [CH.}

coast under their domination, from the Island of MeninxJerba (the land of date-palms and Lotos-eaters) to what is now called Bona in Algeria; this last being one of the several towns anciently named Ubbo or Hippo. One such was the modern Benzert (Bizerta), the Hippo-Diarrhytos of the Greeks and the Hippon-Zaryt of late Roman and Byzantine times.

From Carthage, the metropolis, there ran a causeway, of which traces still remain, up the valley of the Majerda river (the Bagradas of old times) to the date-palm country, the fruitful land of the shallow salt-lakes and the hot springs-a region which is some day going to be of the greatest importance in North Africa for its medicinal waters, its never-failing springs of sweet water, its fertile soil and genial climate. The Carthaginians also held from time to time desert cities of commanding position in what is termed the Matmata country, between the land of the "Shatts" or lakes and the Tripolitan frontier. But it is doubtful even here if Carthaginian rule extended as much as 100 miles inland; and elsewhere in North Africa, away from Tunisia, the Carthaginians only held what they occupied. At the least weakening of their power the Berber tribes were ready to revolt and take part with their enemies. The Carthaginian troops were mainly recruited in Barbary, and were mercenaries. They frequently mutinied and turned against their Syrian employers. Yet occasionally Carthage produced a man like Hannibal who could win the confidence of these Berber soldiers and lead them to fight the battles of Carthage in Spain, Sicily, and Italy. But in the outlying districts of North Africa, especially in Morocco, tradition states that the Berbers occasionally rose as a nation and destroyed the Carthaginian settlements.

The Phoenicians introduced Syrian ideas of religion into North Africa, more especially the worship of Baal-hammana (the Lord Ammon) or Milk (Moloch, the "King"), to whom human sacrifices were offered; Tanit, the "Face of Baal," the 
virgin goddess of the moon, a variant of the Syrian Astarte; Ashmun, the God of Healing (Esculapius); Rashüf, the Flame, Fire, or Lightning God (=Apollo); Baal Milkkart, the "King of the City" identified with Hercules; Tammuz or Adonis (a beautiful young man); Pate $\chi$, a hideous dwarf god; Rabbat Amma, the "Lady Mother," a goddess like the Greek Cybele. These religious ideas became associated in southern Tunis and Tripoli with the worship of the phallus as a symbol of life-giving, creative power, and so powerfully tinged the mentality of the indigenes of this region that down to the present day there are schismatics in Islam (especially in the Island of Jerba) that erect small phallic temples and shrines, or crown with a phallic symbol every minaret. It is here, as well as in the fifth- and sixth-century buildings of south-eastern Syria, dating from the early days of Byzantine architecture, that one may trace the evolution of the mahrab (mihrab) or holy shrine of the Muhammadan mosque from the hollow phallus, into which the country people of Jerba enter to say their prayers. This cult once existed in western Arabia, and it is remarkable to find such distinct traces of it in the ruins of Zimbabwe in south-east Africa.

The Phoenicians being used to the tamed "Indian" elephant in Syria - a region in which there were wild Indian elephants down to about the time of the Phoenician settlement of the Syrian coast-brought about the taming of the smaller African elephant in North Africa. Probably they also introduced Syrian breeds of horses, cattle, and pigs, though the sheep and goats of Mauretania seem rather to have been derived from Spain. They brought thither the Syrian greyhound and perhaps some other breeds of dogs; but not the white, wolfish dog of the Berber nomads, which came from Europe. To these beauty-loving Tyrian mariner-merchants is due the early introduction of the peacock into North Africa. It is still a common domestic bird in Tunisia, and figures on old inscribed stones, even far away in the desert, which date, seemingly, back to 
Carthaginian times. The Phoenicians probably brought with them, likewise from Syria, the cultivated vine, olive, fig, and pomegranate.

Compared with the Romans, the Carthaginians did little to open up the interior of North Africa, except in what is now called Tunisia. Trade with the outer world was restricted by jealous monopolies ; but the Phoenician language was nevertheless much impressed on North Africa, and became the accepted means of intercommunication among the more civilized tribes between Tripoli and Western Morocco. Indeed the Phoenician tongue, closely akin to Hebrew and not very far removed from Arabic, is believed to have lingered all through the subsequent Roman occupation of Africa and only to have disappeared completely under the invasion of Arabic, the immediate consequence of the Arab conquest in the seventh century of our era. Even then it is considered that some Phoenician words remain incorporated in the Arabic dialects of Tripoli and Tunis and especially in Maltese; Malta having also been occupied by the Carthaginians. The Jews, who settled-so abundantly in North Africa both before and after the fall of Jerusalem, brought thither the influence of Hebrew and of Aramaic, and contributed to Semiticise North Africa in language and religion. So that Carthaginian rule paved the way for the Judaizing of certain tribes, before and after the Roman empire ousted Syria for a time as a colonizing agency; and the use of the Phoenician tongue down to the seventh century A.C. in the villages and smaller towns of the Tunisian coast-belt undoubtedly prepared the way for the rapid and wide-spread acceptance of Arabic a hundred years later. Amid all their wrangles, throughout all the recorded history of North Africa, Berber and Semite seem unconsciously to have recognized that by descent and language they had more kinship with each other than with the Aryan peoples.

The Jews, after the first century of the Christian era, settled numerously in North Africa from Cyrenaica to Western 
Morocco. They are believed to have preceded the Berbers in settling the oasis of Twat in mid-Sahara, and other oases of the desert also; though they probably found these habitable regions still retaining a negroid population.

The earliest historical connection between Aryan Europe and Africa was brought about by the Greeks, commencing some 600 years B.C. ${ }^{1}$, who settled in the country of Kurene (Cyrene), the modern province of Barka. After the repulse of the Persians there was a great expansion of Greece. Prior to the historical establishment of settlements in the Ionian Islands, in Sicily, at Marseilles and on the east coast of Spain, Greek seamen had no doubt ranged the coasts of the Mediterranean; and from their adventures were evolved the fascinating stories of the Argonauts and Ulysses. Prehistoric settlements of Greeks on the coast of Tunis are believed by modern French ethnologists to have taken place, on the strength of the well-marked Greek type to be found amongst the present population, for instance, in the Cape Bon peninsula; but these Greek types may also be descended from the Byzantine occupation of the country in the Christian era. The Island of Lotos-Eaters, of Greek mythology, would seem with likelihood to take its origin in the island of Jerba, where the date palm is indigenous ${ }^{2}$. But about 63 I B.c. an expedition of Dorians from the island of Thera ${ }^{3}$ founded the colony of Kurene on the north coast of Africa, where that continent approaches closest to the Greek Archipelago. The settlement of Kurene was situated about ten miles from the

1 The computation given by Eusebius would, according to the late Sir E. H. Bunbury, date the founding of the colony at 63 I B.c. In laying stress on the word historical $\mathbf{I}$ wish to impress on the reader that European immigration into Africa from Sicily and Spain stretches far back beyond the records of written history to ages quite remote in the existence of man.

2 The fruit of the date-palm was almost certainly the lotos of the ancients. It is much more likely to have made a profound impression on them by its honey-sweet pulp than the insipid berries of the Zizyphus.

3 The modern Santorin or Thira, the most southern of the Cyclades. 
sea at an altitude of nearly $1800 \mathrm{ft}$. on the forest-clad A $\chi$ dar mountains. Around Kurene (a name corrupted to Grenna by the Arabs) were grouped four other cities-Barke, Teu $\chi$ eira, Euesperides, and Apollonia. This Greek colony continued to exist with varying fortunes - threatened at times with dissolution through the civil wars of the colonists and the intermittent attacks of the Berbers-till it came under the control of Rome Ioo years before Christ. It was occasionally dominated by the Greek dynasty of the Ptolemies in Egypt. Though the civilization of the Cyrenaica was finally extinguished by the disastrous Arab invasion in the seventh century of the Christian era, it had nevertheless received a death-blow in II 7 A.c. by an uprising of the Jewish settlers, who attacked the GraecoRoman colonists with the help of the native Libyans and slew more than 200,000 of the descendants of the Greek and Italian invaders. The Jews in their turn were massacred, and after that most of the Cyrenaic cities fell into decay.

In the adjoining country of Egypt the Greeks began to appear as merchants and travellers in the seventh century B.c. A Pharaoh, Psammetik I, the father of the Niku who sent Phoenician ships to circumnavigate Africa, had employed Greek mercenaries to assist him in establishing his claims to the throne of Egypt. He rewarded their services by allowing their countrymen to trade with the ports of the Nile delta. The city of Naukratis was founded not far from the modern Rosetta, and became almost a Greek colony. Nearly 200 years later Herodotos, a native of Halikarnassos (a Greek settlement in Asia Minor), visited Egypt and Kurene. It is probable that he ascended the Nile as far as the First Cataract. $\mathrm{He}$ found his fellow-countrymen settled as merchants and mechanics and also as soldiers in the delta of the Nile, and he records that the whole coast of Cyrenaica between Dernah, near the borders of Egypt, and Benghazi (Euesperides) was wholly occupied by Greek settlements.

Through Herodotos and even earlier Greek writers, like 
Hekataios (who derived his information from the Phoenicians), vague rumours reached the Greek world of the Niger River, of ostriches $^{1}$, the dwarf races of Central Africa (then perhaps lingering about the Bahr-al-Ghazal and Nigeria), and baboons, described as "men with dogs' heads"."

The great development of the Persian Empire under Cyrus brought that power into eventual conflict with Egypt ; and under Kambujiya (Cambyses) the Persians conquered Egypt (in 525 B.c.), besides then and subsequently dominating the western and southern parts of Arabia, from which they occasionally meddled with Ethiopia. The Persians were followed more than two hundred years later by their great conqueror, Alexander of Macedonia, who added Egypt to his empire in 332 B.c., and founded in that year in the westernmost reach of the Nile delta the great city which bears his name, and which has been at times the capital of Egypt. Alexander's conquest was succeeded in 323 by the rule of his general, Ptolemaios Soter, who founded in 308 the famous Greek monarchy of the Ptolemies over Egypt, which lasted till near the commencement of the Christian era, when it was replaced by the domination of Rome.

Subsequently the sceptre passed from Rome to Byzantium, and Egypt again became subject to Greek influence. During the Ptolemies' rule Abyssinia was Egyptianized, and much Greek influence penetrated that country of Hamites ruled by Semites, resulting in the foundation of the semi-civilized kingdom of Axum in north-eastern Abyssinia with a port (Adulis) on Annesley Bay. This Hellenized and, later on, Christian State flourished for about six centuries from the commencement of the Christian era, and conquered in the 6th century the opposite Arab country of Yaman. Under the Roman and Byzantine Empire the Red Sea, the coast of

1 The 'cranes' with whom the pygmies fought.

2 Other evidence goes to show that baboons were found wild in the southern parts of Mauretania in ancient days. 


\section{Mediterranean Colonization of Africa [CH.}

Somaliland, and Equatorial East Africa were much more carefully explored and even charted; and it is said that the Greeks settled on the island of Sokotra. The extent of knowledge which the Roman world possessed at the beginning of the Christian era is displayed by the celebrated Periplus of the Red Sea, written by a Greek merchant of Alexandria about 80 A.c. This work shows that Greek commerce extended to Zanzibar and Dar-es-Salaam ; for by Rhapta is obviously indicated a port on the east coast of Africa which can only be Dar-es-Salaam, the modern capital of German East Africa. Opposite to this was the Island of Menouthias, intended (as described in the Periplus) for Zanzibar, and mentioned even then as being a region under the suzerainty of the Kings of Yaman, and much resorted to by Arab merchants from the port of Muza, no doubt the abandoned harbour of Uda, some distance north of Mokha. Beyond this the knowledge of the Greek writer of the Periplus did not extend; but further allusions to Menouthias or other islands near the east coast of Africa, to be found in later Greek and Latin writers on geography, seem to apply much more to Madagascar than to Zanzibar.

Among the Greek merchants of the first century trading with India was a certain Diogenes, who may have supplied the unknown Alexandrian author of the Periplus with some of his information. Diogenes, returning from a voyage to India in about 50 A.C., landed at Rhapta or Rhaptum. From some such point-Rhaptum in this instance may be distinct from Rhapta and equivalent to Pangani, a trading-post at the mouth of the Rufu River, opposite Pemba Island-Diogenes travelled inland for twenty-five days - so, at least, he stated-and arrived in the vicinity of two great lakes and a snowy range of mountains whence the Nile drew its twin sources. Twenty-five days' journey might have brought a Greek traveller easily within sight of Kilimanjaro, but certainly not of the Victoria Nyanza. It is more likely that Diogenes saw Kilimanjaro and added 
to his impressions of that mighty dome of snow and ice the statements of the Arab traders who may at that period have penetrated inland as far as the Victoria Nyanza and even ascertained the existence of Ruwenzori and the Albert Nyanza. If pre-historic Arab trade permeated these countries at that time, it was no doubt afterwards driven back to the coast by the tumultuous movements of the Bantu and Nilotic negroes.

Though the information of Diogenes may have reached the author of the Periplus, it was, so far as the semi-legendary history goes, told to a Syrian geographer, Marinus of Tyre, who published it at Alexandria about the same time that the Periplus was being written. The writings of Marinus disappeared with the dispersal of the Alexandrian Library. But that portion dealing with the sources of the Nile was quoted almost word for word by a later writer, Claudius Ptolemaeus, a latinized Egyptian-Greek who resided in Alexandria. Ptolemy (as he is commonly called in English) wrote his works about the year I 50 A.C.; and to him is commonly attributed the first clearly expressed theory as to the main origin of the White Nile. He believed that this mysterious river found its ultimate source in two great lakes, the waters of which were derived from a great snowy range called the Mountains of the Moon. It is, however, clear from the writings of Eratosthenes (an African Greek who published his geographical works about 200 B.C.) and Pliny the Elder (Caius Plinius Secundus, whose principal book was published in 77 A.c.) that before the Christian era a glimmering of the geography of the Upper Nile basin had already reached Greek Egypt. Perhaps earlier still it had come to the knowledge of the Persian rulers of Egypt, and may have been brought to them by Ethiopian slave and ivory traders, akin to the modern Abyssinians and Galas, who at that period seem to have freely penetrated through the lands of the negro savages.

Not long after the Romans had annexed Egypt to their Empire, they had begun to push their control of the Nile 


\section{Mediterranean Colonization of Africa [CH.}

beyond the First to the Second Cataract. Ahead of them went Greek explorers, mainly from Kurene or Asia Minor, who traced the Nile upstream about as far as Khartum, perhaps even beyond. All this region beyond the Second Cataract was known either as the Nubian Kingdom of Napata (which was then peopled by Ethiopians speaking Hamitic languages) or as Meroe (Merawi). The term Meroe applied not only to a city but also to the supposed island, a considerable tract of land nearly enclosed by the courses and tributaries of the Blue Nile, White Nile, and Atbara, a region formerly of great fertility which played a considerable part in the civilizing of Inner Africa, especially westwards towards Lake Chad. The Emperor Nero was temporarily interested in the mystery of the Nile sources and despatched an expedition under two centurions about the year 66 A.c., to discover the origin of the White Nile. This Roman expedition was organized in the principality of Meroe and furnished with boats and men by the Nubian or the Ethiopian chiefs. These boats were subsequently exchanged higher up the Nile for dug-out canoes; and in these the two centurions apparently travelled as far south as the confluence of the Bahr-el-Ghazal and the Kir or White Nile. Their further explorations seem to have been stopped by the accumulation of water vegetation called the sudd. Discouraged by the natural obstacles to their penetration of this desolate region, by the hostility of the naked Nile negroes, and no doubt also by the unendurable attacks of the mosquitoes, the two centurions returned to Egypt; and their discouraging reports apparently put an end to further Roman enterprise in this direction.

The wars with Carthage in the second century before the Christian era drew the Romans into the occupation of Tunisia. They were enabled finally to conquer and destroy Carthage by allying themselves with the Numidian and Mauretanian kings, who, in their desire to establish complete home rule in North Africa, were anxious to destroy the Carthaginian power. But 
after the destruction of Carthage in 146 B.C. Rome picked quarrels, first with the Kings of Numidia, and next with those farther west in what are now called Algeria and Morocco, with the result that between 104 and 50 B.C. the region equivalent to Tunisia and western Tripoli became the Roman province of Africa; while all the coast region of Algeria and Morocco was annexed to the Roman Empire in 46 B.C. and 42 A.C. respectively. Some time previous to this, in $9^{6}$ в.c., the Romans had annexed the old Greek colonies in Cyrenaica, to which-as a Roman province-was added Egypt in 30 B.C. ; while Roman armies established Roman influence in Fezzan by I9 B.c. Consequently, by the middle of the first century of the Christian era, the Roman power was predominant over the whole coast-belt of North Africa. Roman explorers even penetrated far into Morocco, examined the High Atlas range, and crossed it into the Sahara Desert near Figuig; in fact, a Roman general, Suetonius Paulinus, afterwards a conqueror of Britain, penetrated in 50 A.C. to the palm-fringed river valleys south of the Atlas range, which would seem to have been in Pliocene times the head-waters of streams flowing far south into the Niger basin. One such stream was called by Roman geographers the Ger, and is still known as Gir by the Berbers.

Even before the Christian era began-if we may place any reliance on the stories collected by Marinus Tyrius and cited in the works of Ptolemy the Alexandrian-the Romans had despatched in 19 B.c. an expedition from Fezzan (then a semi-civilized kingdom of the Tibus or Garamantes, far to the south of Tripoli) to reach the country of the Blacks, reports of which, together with some of its products, had come under Roman notice even before the conquest of Carthage. Setting out from Garama (Jerma, in Fezzan) and escorted by Tibu chieftains and their men, a Roman general named Septimus Flaccus is said to have reached the black man's country across the Desert in three months' marching. 
It is possible that camels were already employed on this expedition, but horses would also have been available; and even oxen seem to have been used as late as this period by the desert peoples to draw carts. It is very probable that I 800 years ago this portion of the Sahara was much less arid, and that there were more numerous wells and sources of water supply and a greater amount of forage. What happened to Septimus Flaccus, and whether he really reached the land of the negroes, afterwards to be known by an Arab name, Sudan, we are not told; but about the beginning of the Christian era another Roman explorer, Julius Maternus, also started from Garama and reached a land which he named Agisymba, after a march of four months. This was possibly Kanem, or even Bornu near Lake Chad, and is described as a country swarming with rhinoceroses-beasts still to be found there, though in much reduced numbers.

These are the only recorded attempts of the Romans to reach the Sudan across the Sahara Desert; but that intercourse had been going on for hundreds, if not thousands, of years between the Libyans and Hamites of Northern and North-Eastern Africa on the one hand, and the negroids and negroes of the Lake Chad and Benue regions and of the whole Niger basin on the other, there can be little doubt, from a variety of evidence ${ }^{1}$. Roman beads are dug up in Hausaland and are obtained even from the graves of Ashanti chiefs; and some of these differ but little from Roman beads found in the mud of the Thames or amidst the ashes of Pompeii. Even ideas of Roman and Greek Christianity filtered through the Libyan and Sahara Deserts and reached countries beyond the Niger.

1 This evidence has been fully discussed by the present writer in other works, such as, for example, The Nile Quest, London, 1904, The Openingup of Africa, 1911, Liberia, 1906, George Grenfell and the Congo, 1908, and Pioneers in West Africa, I9II, in which works references to the opinions and researches of other writers are also given. 
The Niger River had been vaguely known to classical geographers for two or three centuries before and two centuries after the commencement of the Christian era. These writers, as far back as the time of Herodotos, recorded legends of Libyan adventurers from southern Tunisia who penetrated through the Sahara Desert to lands of running rivers, open waters, and tropical vegetation. The Senegal River, under the name of Bambotus, is described by Polybius (about I 40 B.C.) as a great stream far beyond the Sahara Desert which contained crocodiles and hippopotami. To such a river, or even, it may be, to this dimly realized Niger, was applied a Berber name for a stream, Gir, or Ni-gir. I have already mentioned the Gir River which rises to the south of the Great Atlas range in Morocco, and which was discovered by the Roman general Suetonius Paulinus about the year 50 A.c. This was confused with the real Nigir or Niger, of which it may have been a million years ago one of the ultimate tributaries. Lamps of Roman design in metal penetrated as far into the interior of Africa as the Northern Cameroons, as did also imitations in clay architecture of Greek or Roman fortresses. But the remarkable clay architecture now associated with the Fulas and which is ascribed in its origins to the Songhai of Agades, would seem rather to have come from Egypt than across the Sahara Desert from Roman Africa.

Actual posts erected and even garrisoned by Roman soldiers may have extended as far south as Ghadames (Cydames) or Murzuk (Phazania). Direct Roman rule, however, was chiefly notable in what is now the Regency of Tunis and in Egypt. Tunisia and western Tripoli almost surpass Italy in the number and magnificence of their Roman remains. All along the actual coast of Algeria and Northern Morocco existing ruins testify to the great number of Roman cities which once flourished there. Eastern Algeria shared with Western Tunisia a most notable degree of Roman civilization. The present writer has been much impressed with the J. 


\section{Mediterranean Colonization of Africa [CH.}

fact that from Gafsa in the south of Tunis to Tebessa in Algeria the traveller can ride along about a hundred miles of ancient Roman road scarcely ever out of sight of the ruins of former cities, some of which must have been of great magnificence, though their culmination of splendour was not attained until the rule of Byzantium had replaced that of Rome.

Nevertheless, all through the period between I 46 B.c. and 4I 5 A.C., when the Vandals invaded Roman Africa ${ }^{1}$, the Romans were constantly warring with the Berbers, who no doubt to a great extent were pushed out of Tunisia by colonists more or less of Italian origin. The most prosperous and brilliant period of Roman rule was between $5 \circ$ A.C. and 297 A.c. In 297 A.c. began the establishment of definite Christianity. Between about 50 and 530 A.C., Latin replaced Punic as the tongue most commonly spoken in the Roman province of Africa and even in the coast-lands of Algeria and Morocco. Still the Berbers were there all the time. Only a few became Christianized, the bulk of the indigenous tribes showing disgust at the way in which the different Christian sects attacked and slew each other. The Jews, having settled numerously in North Africa, won over a number of Berber chieftains to the Jewish religion. Hatred of Roman rule and of Roman Christianity impelled the Berbers of Morocco and Algeria to

1 The Vandals were a Gothic people supposed to be not far from the Angles and Saxons in origin. After sweeping down on France and Italy and settling in Baetica or southern Spain-a region to which they are supposed to have given their name, Vandalusia, corrupted by the Arabs into Andalusia - they built ships. on the Spanish coast, crossed over with a host of Spanish camp followers into Morocco, and with the aid of the Berbers swept the Roman power before them till they conquered the whole country to the frontiers of Tripoli. They also acquired Sardinia. By degrees they concentrated their settlement on northern Tunisia, and here, mingling with the Roman colonists and the Berber indigenes, they gradually lost all their fighting spirit. But probably they added a not unimportant element of European (Aryan) blood to the mixed populations of North Africa, a region more or less ruled by their Teutonic kings for 116 years. 
AS KNOWN TO THE ANCIENTS

AMMADAN INVASION OF THE SEVENTH CENTURY, B C.

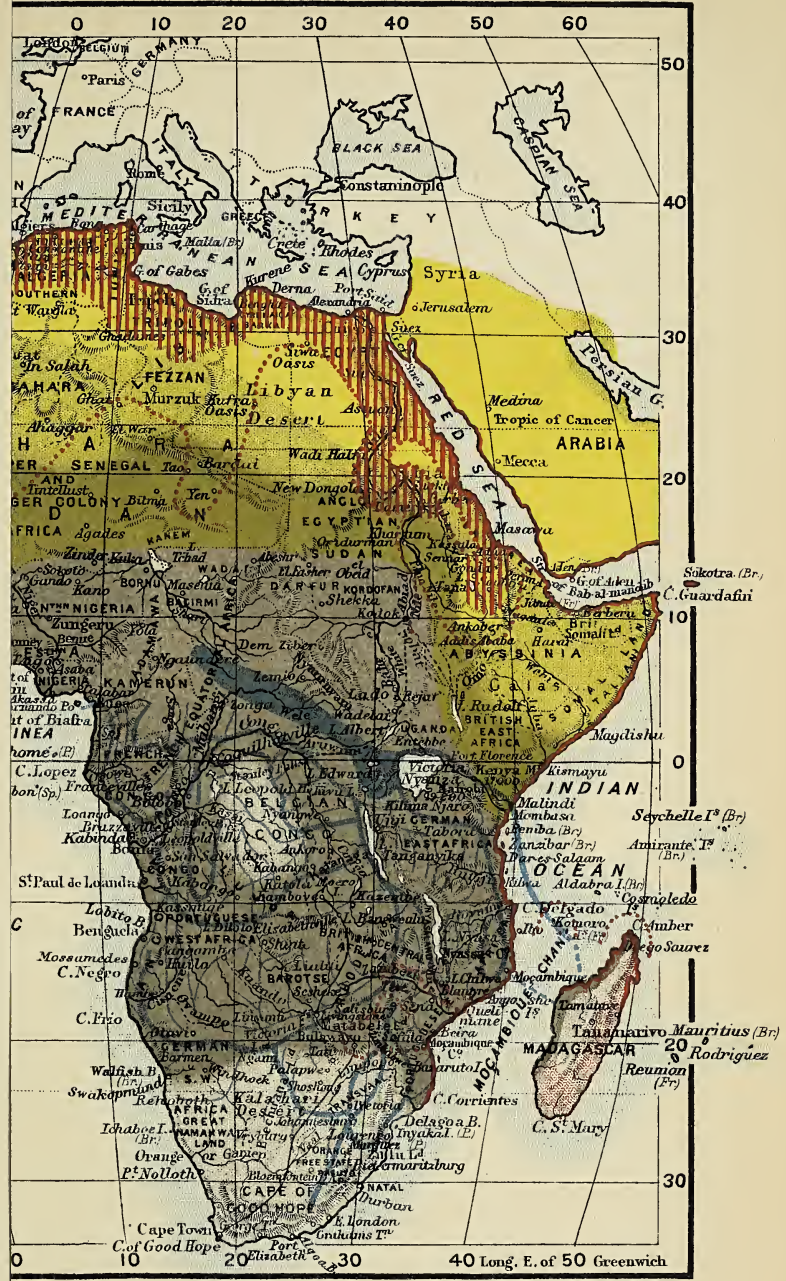

EXPLANATORY NOTE

Ble site of Bantu mother country

area of distribution of Black Negroes 2000 years ago

$$
\begin{array}{ll}
, & \text {, Pygmies, Bushmen, and Hottentots } \\
\text {, } & \text { " Hanites and Semites } \\
\text { ", } & \text { " Malay races }
\end{array}
$$

Le distribution of races about the commencement of the Christian Era on

of the principal. Bantu invasions

tes mixture of races

of more or less certainly known country; a red dotted line gives the ions. Red.shading indicates the approximate area of country well Asia 

AFRICA AS KNOWN TO THE ANCIENTS

BEFORE THE MUHAMMADAN INVASION OF THE SEVENTH CENTURY, B C.

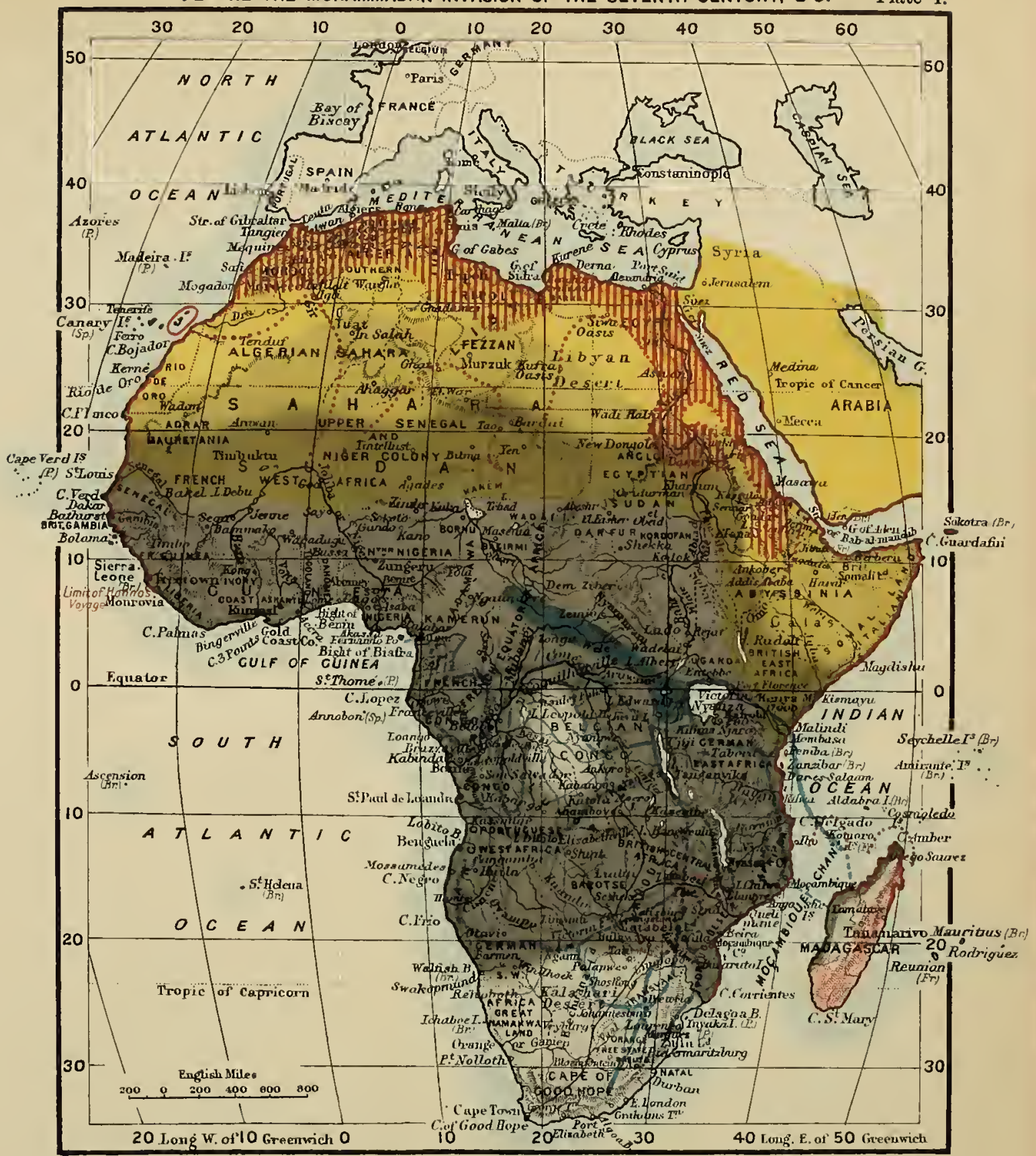

EXPLANATORY NOTE

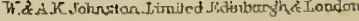
Probable site of Bantu mother country

" area of distribution of Black Negroes 2000 years ago

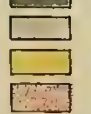

, ,

, Pygmies, Bushmen, and Hottentots

" " " Hamites and Semites

" ", Malay races

This map shows also the probable distribution of races about the commencement of the Christian Era and the lines of Bantu invasion

The Blie lines give the directions of the principal Bantu invasions

The mingling of race tints indicates mixtur of races

A Red line indicates the limits of more or less cirtainly known country; a red dotted line gives the limits of vaguely known regions. Red.shading indicates the approximate area of country well known to Europe or civilised Asia 

make common cause with the invading Vandals, and led to the rapid overthrow of Roman rule and Roman civilization. But in 53 I A.C. Byzantine generals from Constantinople conquered the Vandals and established the rule of the Eastern Empire over Roman North Africa from Tangier (Tingis) to Egypt. There was once again a revival of Mediterranean civilization throughout all this region, though the Berber tribes still remained recalcitrant.

Abyssinia between $35^{\circ}$ and 500 A.C. accepted Christianity from the teaching of Egyptian Greek missionaries, and developed a considerable degree of strength from the civilization which followed in the track of the Christian faith. Not only did Abyssinian kings rule over the opposite parts of Western Arabia, but their armies and slave raids penetrated far south from Galaland towards Equatorial Africa. A debased edition of the Christian faith was carried almost to the shores of Lake Rudolf; while the kingdom of Merawi, before the Arab invasions of this stronghold of the Ethiopian negroids, became a Christian state, which retained its Christianity well into the r 2 th century of our era. Through the Abyssinian traders, Graeco-Roman commerce began again to get indirectly into touch with the Upper Nile and East Africa. But the Christian-Abyssinian conquest of South-west Arabia seems to have arrested for a time the Arab trade with Madagascar and the East African coast, and may have contributed to the overthrow (by the invading hordes of Bantu negroes) of the Zimbabwe civilization of South-east Africa. It was however just as Graeco-Roman rule in northern Africa was coming to an end that its effects on Negro Africa became apparent. The great racial movements in the northern Sudan, which led to the creation of the Mandingo, Songhai, and Bornu kingdoms of the 8th century, were undoubtedly due to impulses coming across the desert from Greek or Roman Egypt, Tripoli, or Tunis. Christianized Berbers from North Africa even carried Jewish and Christian ideas of religion as far into the Dark Continent as Borgu, to the west of the Lower Niger. 


\section{CHAPTER III}

\section{THE ARAB CONQUEST OF AFRICA}

AT the beginning of the 7 th century of our era the condition of affairs in North Africa stood thus. In Egypt, which continued to be governed from Greek Alexandria, the semblance of Roman rule was wielded, in things temporal as well as spiritual, by the Greek Orthodox Patriarch, who was usually appointed by the Emperor at Byzantium to be Prefect as well. He occupied himself chiefly in persecuting non-orthodox Christian churches, such as the Monophysite or Jacobite Church, which, arising first in Syria, had become the national church of the Egyptians or Copts, as contrasted with the people of Greek race. The outposts of Upper Egypt were abandoned or left but feebly garrisoned; the Hamitic Blemmyes or Bisharin, the "Fuzzie-wuzzies" of the Red Sea coast-lands, and the negroid Nubians overwhelmed the $\mathrm{Na}$ batæan kingdom of Ethiopia and burst into Upper Egypt, and, although they were once or twice severely chastised, remained, and barbarized a land which at the beginning of the Roman empire over Egypt had attained a high degree of culture.

In 616 A.c. the Persian armies once more entered Egypt, assisted in their easy conquest by the disaffection of the Copts; at the same period they drove the Abyssinians out of western Arabia and even followed them up into eastern Abyssinia. 
Then the Persian power became paralysed in its turn. In 626 Heraclius sent an army into Egypt which drove out the Persians; and for a few years Egypt was fairly well governed by a Greek governor sent from Byzantium. Then once more the rule passed into ecclesiastical hands; and Kuros, the last Greek patriarch, ruled Egypt from 630 till the invasion of the Arabs, excepting for one short period of exile due to his fierce persecution of the Jacobite Copts. Cyrenaica had been practically abandoned to the Libyans after the terrible Jewish uprising and the massacre of Greek colonists in II 7 A.C. Along the rest of the littoral of North Africa there were still flourishing Roman colonies and cities under Byzantine rulers or Berber chiefs, from Leptis Magna and Tripolis (Oea) on the east to Tangis (Tangier) on the west; while other Roman or Byzantine towns still persisted far inland in Tunisia and Algeria, notably Gafsa, Thala, Tebessa, and Timgad. Elsewhere, beyond the walls of the Roman cities, the Berber tribes had regained their independence and ruled over Romans and Berbers alike.

At this period the great Libyan or Berber race of North Africa, which inhabited the whole region between the western frontiers of Egypt (Siwa) on the east and the Atlantic coast of Morocco on the west (practically but one language, the Libyan, being spoken throughout this vast breadth of Africa) were divided into three main branches: (I) the Berbers of the East or Libyans proper (Luata, Huara, Aurigha, Nefusa) occupying the Cyrenaica, Tripolitaine, Tunisia and a portion of eastern Algeria; (2) the Berbers of the West, or Sanhaga (Sanhaja), who peopled the Algerian coast-lands and western Algeria and all Morocco as far down as the limits of the Sahara; and (3) the Zeneta, a darker race, the descendants of the Getulians, perhaps in origin akin to the Fula, who in the $7^{\text {th }}$ century A.c. peopled the more or less desert regions at the back of eastern Algeria, southern Tunis and Tripoli. From these Zeneta are descended the modern Mzab Berbers, 
the Wargli people, and the Beni-Merin who founded one of the ruling dynasties of mediaeval Barbary. Several of these Zeneta dark-skinned Berber peoples pushed down to the Mediterranean coast in later times. On the other hand, many of the Eastern Berbers or Libyans were thrust back into the desert by the Arab invaders; and some of them have become the semi-nomad "Tuareg" (Tawareq) $)^{1}$ of to-day. Sections of the Western Berbers of the Sanhaga group also passed down into the Sahara from the 7 th century onwards (though no doubt Berber invasions of Negro Africa had occurred in previous times), and settled on or near the northern Niger and the northern Senegal coast. In fact from Sanhaga comes no doubt the Berber tribal name of "Zenaga" which the Portuguese corrupted into "Senegal."

In the 7 th century, also, the negroid Garamantes, who shared Phazania with the incoming Berbers and were no doubt identical with the modern Tibu or Teda (whose language is utterly unlike Libyan, and belongs to an unclassified negro speech-group), carried on a good deal of trading intercourse south and eastward across the Libyan Desert with Kanem and Lake Chad, Darfur and Kordofan, and no doubt in this way facilitated the subsequent Arab penetration of the Sudan and the Tripolitaine. The domesticated camel had been introduced into North Africa before this period, and greatly facilitated these race movements across the Desert.

In the year 623 A.c. an Arab of the Quraish Tribe of Western Arabia, probably born in Mecca (anciently known as Bakka and really called Makka at the present day), and named Muhammad or the Praiser, attracted attention by establishing himself at the Palm Oasis of Yathrib or Medina, not only as a bandit who led masterless men to the attack of trading caravans, but also as a mystic who was conceiving and promulgating a new form of religion, one which was largely based on Jewish teaching and the Jewish Scriptures and yet incorporated

1 Tawareq is the plural of an Arabic word, Tarqi, a raider. 
a few ideas from Christianity and perhaps even from the Zoroastrian faiths of Persia. Muhammad opposed the degraded beliefs in a variety of gods and goddesses which still lingered in Western Arabia and, above all, at Mecca itself, where a wonderful fetish stone - the remains of an immense meteoritewas exhibited for reverence, and where, together with the rude representations of old Semitic gods and a goddess named Allat ${ }^{1}$, existed-as in Coelo-Syria and Ancient Phoenicia-the idea of the Mahrab or Sacred Shrine. This last was a sexual symbol and a relic of the nature-worship of Phoenicia. It has also been the parent of the horseshoe arch. The Sacred Shrine is an essential feature in all Muhammadan mosques, though its original purport has long since been forgotten.

Muhammad prevailed partly by his successes in warfare and the rich booty they brought to his Arab adherents, partly by his sweetness of disposition, the magnetism of his appearance and manner, and his gift for pouring out conceptions of God and religion and garbled versions of the Jewish Scriptures and Christian beliefs in rhyming couplets easily committed to memory. He united gradually under his sceptre, as a religious teacher and legist, all the clans of fighting men in Western Arabia; and, in search of greater spoil than the povertystricken peninsula of that day could afford, he marched northwards to convert the Roman world and the great kingdom of Persia to his new faith. Almost like another Moses, he died on the threshold of the promised land; for within a few years of his death (632 A.c.) the Arab armies had not only smashed the Byzantine rule over Syria but were pouring into Byzantine Egypt and were rapidly conquering for the Muhammadan faith the states of South-west, South and East Arabia, and the whole kingdom of Persia, to the very heart of Asia.

In 640-2 Amr-bin-al-Aș (an early opponent and a later

1 The origin of the name Allah applied by Muhammadans to the Supreme God. Allah acquired a masculine sense although in its original form the word was feminine. 
convert of Muhammad) invaded Egypt from Arabia; and he or his lieutenants pushed thence into Tripoli, and even into Fezzan. A little later (647-8), under Abdallah-bin-Abu-Sarh and Abdallah-bin-Zubeir, the Arabs invaded Tripoli, and fought with a Byzantine governor known as Gregory the Patrician, who had just before rebelled from Byzantium, and proclaimed himself Emperor of Africa, with his seat of government in central Tunisia. The battle lasted for days, but Gregory was overmastered by a ruse and killed. The Arabs pursued his defeated army into the heart of Tunisia, and even into Algeria. For a payment of 300 quintals of gold they agreed to evacuate Tunisia, but they left behind an agent or representative at Suffetula (the modern Sbeitla), which had been Gregory's capital.

In $66_{\mathrm{I}}$ the first dissenting sect of Islam arose, the Khariji. These schismatics preached the equality of all good Muslimsa kind of communism-the need for a Puritan life and the cessation of the hereditary Khalifat (Caliphate) with the death of Ali. As they were much persecuted, some of the Khariji fled at this period to the coast of Tunis, and in the island of Jerba their descendants remain to this day; while their doctrines were adopted by the bulk of the Berber population of that island $^{1}$, and spread thence right across inner North Africa to the Atlantic coast of Morocco, becoming after 720 almost a national religion of the Berbers as contrasted with the orthodox Sunni Muhammadanism of the Arab governors or the Omaiyad dynasties of Spain, or the Shia faith of the Fatimites of Tunis and Egypt. The industrious Mzab Berbers of south central Algeria and the Nefusa tribes of western Tripoli are also Khariji still at the present day.

In 669 the Arab invasions of North Africa were resumed. Oqba-bin-Nafa overran Fezzan, and was appointed by the Omaiyad Khalif governor of "Ifriqiah" (modern Tunis). The

${ }^{1}$ Jerba, usually called Meninx by the ancients, is supposed to have been the Island of Lotos-Eaters of Greek mythology. 
Byzantines were defeated in several battles, and Kairwan ${ }^{1}$ was founded as a Muhammadan capital about 673. Oqba was replaced for a time by Dinar Bu'l-Muhajr, who pushed his conquests as far west as Tlemsan, on the borders of modern Morocco. Oqba resumed command in 68I, and advanced with his victorious army to the Sūs country and shore of the Atlantic Ocean, afterwards receiving a somewhat friendly reception from Count Julian at $\mathrm{Ceuta}^{2}$ (Septa).

But now the Berbers began to turn against the Arab invaders, finding them worse for rapacity than Roman or Greek. A quondam ally, the Berber prince Kuseila, united his forces with the Greek and Roman settlers, and inflicted such a severe defeat on Oqba near Biskra that he was enabled afterwards to rule in peace as king over Mauretania for five years, being accepted as ruler by the European settlers. Kuseila, however, was defeated and killed by other Arab invaders in 688, though the victors subsequently retired and suffered a defeat at the hands of the Byzantines in Barka. Queen Dahia-al-Kahina ${ }^{3}$ succeeded her relative Kuseila. The Arab general, Hassan-bin-Numan, was successful in taking Carthage (698), but afterwards was defeated and driven out of

1 The origin of the name Kairwan has been much disputed. The present writer, visiting this place some years ago, was told by a native that the word was the Arab name for a small bustard-like courser (a bird which the French call Poule de Kairouan), and that, seeing this bird in large numbers-where it is still to be found-in the marshy plain on which the city was built, the Arabs gave its name to the town. Kairwan was chosen as the site for the Muhammadan capital by the early Arab invaders because it was considered sufficiently far from the sea-coast to be beyond the reach of attack from a Byzantine fleet.

${ }^{2}$ Count Julian appears to have been a Byzantine governor on the coast of Morocco, who after the Byzantine downfall to some extent attached himself to the Romanized Gothic kingdom of Spain.

3 This is the Arab rendering of her name. Dahia meant "queen" and Al-Kahina "the wise woman" or "prophetess." This remarkable personage was from a Berber tribe, the Jorāwa, which had been converted to Judaism and was partly Jewish in blood. 
Tunisia by Queen Kahina. Unfortunately this brave woman ordered a terrible devastation of the fertile district or subprovince of Byzacene; so that the want of food supply might deter the Arabs from returning; and this action on her part was the beginning of the marked deterioration of this magnificent country, the southern half of Tunisia. Kahina was finally defeated and slain by the Arabs under Hassan-binNuman in 705 . Arab conquests then once more surged ahead under Musa-bin-Nusseir. The whole of Morocco was conquered except Ceuta, where the Arabs were repelled by Count Julian. To some extent also Morocco was Muhammadanized; and no doubt through all these invasions the Arabs experienced little difficulty in converting the Berbers to Islam, even though they might subsequently enrage them by their depredations. Before the arrival of the Arabs the Berbers in many districts had strong leanings towards Judaism ${ }^{1}$. Amongst the Berber chiefs converted to Muhammadanism by the invasion of Morocco was a man of great gallantry known as Tarik, who became a general in the Arab army. Tarik was left in charge of Tangiers by Musa, and entered into friendly relations with Count Julian at Ceuta. Count Julian, having quarrelled with the last Gothic king of Spain, urged Tarik to invade that country. After a reconnaissance near the modern Tarifa, Tarik invaded Spain at or near Gibraltar ${ }^{2}$ with 13,000 Berbers officered by 300 Arabs, and was shortly afterwards followed by Musa with reinforcements; and Spain was thus conquered.

For a few years longer all North Africa remained loosely connected with the Khalifs (Caliphs) of Baghdad; then Idris, a

${ }^{1}$ Jewish colonies began to settle in North Africa soon after the destruction of Jerusalem, or even as far back as the Ptolemaic rule over Egypt. The Jews were particularly attracted to Tunisia and Tripoli (the former Carthaginian coast) by their kinship in race and language with the Phoenicians.

${ }_{2}$ The rocky peninsula where Tarik landed was called by the Arabs Jibl-al-Tarik, a name which subsequently became corrupted by the Spaniards into Gibraltar. 
descendant of Ali, and consequently of Muhammad, established himself in Morocco as an independent sultan, afterwards asserting his claim to be Khalif and Imam, though he and his successors were of the Sunni, not the Shia faith. At his death he was succeeded by his son Idris II ; and his blood is supposed to have filtered down through many generations and devious ways to the present ruling family in Morocco. Until about 800 A.C. Eastern Barbary, at any rate, was ruled by an Arab governor from Baghdad; but soon after that date Harun-al-Rashid appointed a brave Berber-Arab soldier, Ibrahim-bin-Aghlab, to be his viceroy in Ifriqiah (as the Arabs called "Africa," i.e. Tunisia). Ibrahim-bin-Aghlab founded a dynasty which ruled over Tunis and Tripoli for a hundred and ten years. Concurrently with the Aghlabite viceroys or sultans in Roman "Africa," there was the independent Moorish kingdom of the Idrisites with its capital at Fez (near the Roman Volubilis); a Berber principality of the Beni-Midrar at Sigilmessa in Tafilalt (S.E. Morocco); and another of the Beni Rustam at Tiaret (Western Algeria). These two last were Khariji or heretic states.

Spain had remained from $7 I_{5}$ till about 760 an appanage of the Abbaside Khalif of Baghdad. But in $75^{8}$ there arrived in southern Spain a refugee prince of the rival house of Omar, Abd-ar-rahman bin Mūawiya, who after thirty years of almost incessant warfare wrested all Spain from the Baghdad Caliphate and founded the most splendid of the Arab dynasties in Spain, that of the Omaiyads, which lasted till about Iozo. The Omaiyad Amirs or Khalifs frequently invaded Morocco and derived thence numbers of negro slaves, who, together with Slav prisoners bought in Germany through the Jews, made up their powerful mercenary armies. As Mamluks or slavesoldiers, quite a number of Slavs from Germany and Austriamade prisoners and sold to the Moslems of Spain by Charlemagne and his successors-settled in North Africa from the 8 th to the Ioth century. 
In the ninth century numerous Shia Arabs, who were advocates of the caliphate of the descendants of Ali and Fatima (Muhammad's daughter), had converted to the Shia faith the powerful Berber tribe of the Ketama (of the Sanhaga group dwelling in Eastern Algeria) ; and an emissary of the "hidden" Khalif of the Alide family-Obeid-Allah-arrived in North Africa about 890 and preached the Shia faith and the coming of a Madhi or Divine messenger. Having by the aid of the Berbers overthrown the Aghlabite dynasty of Kairwan, this emissary, who was named Abu-AbdAllah, sent for the Mahdi, Obeid-Allah, the descendant of Ali and Fatima. Obeid-Allah came and founded the great Fatimite dynasty which played such a part in Tunisia, Sicily and Egypt; but ungratefully enough he caused Abu-AbdAllah to be slain and the Ketama tribe to be massacred. He then moved his capital from Kairwan to Mahdia, or Mehdia, on the coast of Tunisia, a city which he founded on the ruins of a Roman town. His son and successor, who nicknamed himself "The sustainer of God's orders" (Al-Kaïm bi Amr Allah), instituted the practice of never appearing in the open in public without a sunshade being held over his head-the Royal Umbrella which still figures in Moroccan court ceremonial. Under the third sovereign, Al Mu'izz, the dynasty of Fatimite Caliphs reigned over all North Africa, from Morocco to Egypt, and thence to Damascus. The Fatimite general commanding the army in Egypt, Jauharal-Kaid, founded the citadel and town of Cairo (Al Kahirah) in $969-7 \mathrm{I}^{1}$, more or less on the sites of the previous Arab capitals of Al-Masr, Al-Askar, and Al-Katai ; and here the

1 There has been a succession of great cities since prehistoric times ranging round about or situated on the site of Cairo-an "inevitable" city site, because it is at the head of the Nile Delta. Memphis was only I 2 miles away, and Heliopolis or On less than half that distance. Babel or Babylon was built by emigrants from old Babylon on the Euphrates on the actual site of Cairo in about 525 B.c. This became a Roman city and was succeeded by the Arab Al Fostat or Masr. 
Fatimite Caliph transferred his capital and his presence from Kairwan, giving up the rule over Tripoli, Tunis, Algeria and Morocco to Berber viceroys.

From the 7 th to the middle of the i ith century, the Arab element in North Africa was small and represented chiefly by a few thousand warriors, statesmen and religious teachers, who had in a marvellous manner, difficult to explain, forced their religion, and to some extent their language and rule, on several millions of Berbers, on some 300,000 Christians of Roman, Greek and Gothic origin, and ıoo, ,oo Jews. But in the IIth century took place those Arab invasions of North Africa which have been the main source of the Arab element in the northern part of the continent, and without which Muhammadanism might in time have faded away; and a series of independent Berber states have been formed once more under Christian rule.

About I045 two Arab tribes, the Beni-Hilal and the BeniSoleim (originally from Central Arabia, and deported thence to Upper Egypt), left the right bank of the Nile to invade Barbary. They had made themselves troublesome in Upper Egypt ; and the weakened rulers of that country, to get rid of them, had urged them to invade north-western Africa. About two or three hundred thousand crossed the desert and reached the frontiers of Tunis and Tripoli. They defeated the Berbers at the battle of Haiderān, and then settled in southern Tunis and western Tripoli. During their raids they destroyed the city of Kairwan, which never regained its former importance. Eventually some portion of them was unseated by the Berbers and driven westward into Morocco. They were succeeded by fresh drafts from Egypt and Arabia, but many of these later invaders settled in Barka and eastern Tripoli ${ }^{1}$. Later on other Arab tribes left the west coast of Arabia, and settled on

1 A little more than one-third of the modern population of Cyrenaica, Tripoli, and Mauretania is of Arab race; but seven-tenths of the North African population speak Arabic and not Berber. 
the central Nile, avoiding the Abyssinian highlands, where they were kept at bay by their Christianized relatives of far earlier immigrations; and on the Blue Nile (Sennār), where they founded the powerful Funj empire which lasted from the I 4 th to the early igth century. From the upper Nile they directed many and repeated invasions of Central and Western Africa. To this day tribes of more or less pure Arab descent are found in the districts round Lake Chad, in Darfur, Wadai, and in the western Sahara north of the Senegal and Niger rivers.

In the IIth century began the real revival of the Roman Empire from the onslaught of Arabia and the prior Teutonic invasions. The Normans recovered Sicily and Malta from the Berbers; earlier still, the Pisans drove the Berbers out of Sardinia and crushed them in Majorca. The cities of Italy, forming themselves into republics, were tempted by their extending commerce to interfere with North Africa. The Venetians, in spite of the hare-brained crusades and the damage that they did by reviving Muhammadan fanaticism, began to open up those commercial relations with Egypt, which for four and a half centuries gave them the monopoly of the Levant and Indian trade. The Normans, after founding the kingdom of Naples and Sicily, commenced a series of bold attacks on the coasts of Algeria, Tunis and Tripoli, which did not however lead to an occupation of more than forty years (about II 23 to II63). The Pisan and Genoese natives in the $\mathrm{I}$ Ith and $\mathrm{I} 2 \mathrm{th}$ centuries carried out a series of such sharp reprisals against the Moorish pirates, that they inspired some respect for Italy in the minds of Tunisians and Algerians. Afterwards they were enabled to open up commercial relations, especially with the north coast of Tunis; and these, to the advantage of both Italy and Barbary; continued, with fitful interruptions, until the I 6 th century.

In the IIth century another great Berber movement took place-the rise of the "Almoravides." The name of this sect of Muhammadan reformers is a Spanish corruption of 
Al-Murabitin, which is the plural of Marabut; and Marabut is derived from the place-name Ribat (a monastery or school), meaning "the people living at the Ribat," though the word has since come to mean in North Africa and elsewhere a Muhammadan saint. The Almoravides owed their origin to one of the early African Mahdis or Messiahs, of whom the tale has subsequently been repeated and repeated with such servile imitation of detail that one can only imagine the mass of African Muhammadans to have been without any philosophical reflections on history or any sense of humour; since Mahdi after Mahdi arises as an ascetic saint, and dies a licentious monarch, whose power passes into the hands of a lieutenant, who is the first in the line of a slowly crumbling dynasty. Far away across the Sahara Desert, and near the Upper Niger, was a tribe of Tawareq Berbers known as the Lamta or Lemtuna, who had been in the roth century converted to Muhammadanism. The chief of this tribe, returning from a pilgrimage to Mecca, met a Berber of South Morocco known as Ibn Yașin, who on his Meccan pilgrimage had acquired a great reputation for austere holiness. The chief of the Lemtuna invited Ibn Yașin to his court ; and the latter, after arriving in the Niger countries, established himself on an island named Ribat, on the upper Niger, where he collected adherents round him and promulgated his puritanical reforms. Gradually Ibn Yașin's influence extended over the whole Lamta or Lemtuna tribe, and he urged these Berbers towards the conversion of Senegambia. It was mainly through his influence that the Berbers were carried by their conquests into Senegambia and Nigeria. Then he led them (about I050) north-west across the Sahara Desert; and they conquered Morocco, and from thence invaded Muhammadan Spain. By this time Ibn Yașin, the teacher, was dead, but the warrior chief of the Lamta tribe-Yussuf-bin-Tashfin-had become sovereign of Morocco and Spain, and had assumed the title of Amir-al-Mumenin ${ }^{1}$.

1 Prince of the Faithful. 
A hundred years later another Berber Mahdi arose in the person of Ibn Tumert, who was "run" by Abd-al-Mumin of Tlemsan (West Algeria), and whose fighting force was the great Berber tribe of the Masmuda from the High Atlas Mountains. The programme was the same-to start with puritanical reform, afterwards degenerating rapidly into mere lust of conquest. This small sect known by us as the "Almohades" (from Al-Muāḥadim or Muahidūn, meaning "(Disciples of) the Unity of God") attacked the decaying power of the Almoravides. Ibn Tumert - an exact parallel of all the Mahdis - died early in the struggle, but was succeeded as "Khalifa" by his warlike lieutenant, Abd-al-Mumin, who pursued his conquests until he had brought under his power all North Africa and Muhammadan Spain, and had founded the greatest Berber empire that ever existed. Concurrently, however, with the sway of his overlordship, the Ziri and Hamadi dynasties of Berber sultans continued to exist at Tunis and in eastern Algeria. After ruling for a century the Almohade empire broke up, and was succeeded by independent Berber rulers in Tunis and Tripoli (the Hafsides), in Algeria (the Abd-alWadite or Zeyanite kings of Tlemsan), and in Morocco (the Marinide or Beni-Marin). Remarkable among these was the Hafs dynasty, which governed Tunis and part of Tripoli for 300 years, and proved the most beneficent of all Muhammadan rulers in North Africa. Abu Muhammad Hafsi was a Berber governor of Tunis under one of the last of the Almohade emperors, and eventually became the independent sovereign of Tunisia. The Almohade rulers, towards the end of the i 2 th century, had transported most of the turbulent Arabs of southern and central Tunisia to Morocco, where for the first time the Arabs began to form an appreciable element in the population. About this time Kurdish and Turkish mercenaries began to find employment in Tunisia and in Tripoli under chiefs who rebelled against the Almohade empire.

1 From the Arabic Wahad, "The One." 
During the period between 1250 and 1500 the Moorish civilization, art, architecture, letters, and industries reached their highest development: especially at Kairwan, Tlemsan, and Fas (Fez).

In 1270 that truly good but erratic monarch, St Louis of France, deflected a crusade intended for the Levant to Tunis as being a Muhammadan country much nearer at hand and more accessible. Moreover his brother, Charles of Anjou, claimed the sovereignty of Sicily and Naples, and thought the possession of Tunis would better establish his precarious kingdom. Louis IX landed at Carthage, but owing to failing health his imposing invasion was followed by military inaction. He died at Carthage, and a capitulation subsequently took place by which the Crusaders retired from Tunisia. After their departure the Muhammadans entirely destroyed all that remained of Roman Carthage, as the buildings had afforded to the invaders the protection of fortresses. Up till that time a good deal of Roman civilization had lingered in Tunisia, but now the country became more and more Arabized. Christian bishops probably ceased to exist in the $13^{\text {th }}$ century, but Christians were not persecuted for another two or three hundred years, until the attacks of the Spaniards and the intervention of the Turks roused Muhammadan fanaticism to a high degree which is only beginning to abate with the opening of the 2 oth century and the spread of education.

In the $13^{\text {th }}$ century the Spanish and Portuguese kings reduced the area of Muhammadan rule in the Iberian Peninsula to the kingdom of Granada in S.E. Spain; and early in the I $^{\text {th }}$ century the kingdom of Portugal felt itself sufficiently strong to carry the war into the enemy's country. In I4I 5 the Portuguese army, to which was attached Prince Henry, afterwards known as the Navigator, captured the Moorish citadel of Ceuta on the Moroccan coast ; and from this episode started the magnificent Portuguese discoveries initiated by Prince Henry which will be described in the next 
chapter. The Portuguese subsequently acquired Tangier, Tetwan, and most of the ports along the Atlantic coast of Morocco. Castile-Aragon, bursting out a little later, when her monarchs had conquered the last Moorish kingdom on Spanish soil (Granada), seized Melilla in $\mathrm{r} 490$, and, on one pretext or another, port after port along the coasts of Algeria and Tunis, until by 1540 the Spanish empire had established garrisons at Oran, Bugia, Bona, Hunein, and Goletta ${ }^{1}$. They also instigated the Knights of Malta-an outcome of the crusades - to hold for a time the town of Tripoli in Barbary, and the Tunisian island of Jerba. The Portuguese kings by the middle of the 16 th century were practically suzerains of Morocco. The penultimate ruler of the brilliant House of Avis-young Dom Sebastião-determined in ${ }^{5} 578$, soon after his accession to the throne of Portugal at the age of 23 , thoroughly to conquer Morocco. He landed with 100,000 men at Acila ${ }^{2}$, then marched inland and took up a position behind the Wadal-Makhazen on the fatal field of Kasr-al-Kabir. But he was utterly defeated by the Moors under Mulai Abd-al-Malek (who died during the battle) and Abu'l Abbas Ahmad-al-Mansur. The latter became Sultan of all Morocco after the defeat and death of the unfortunate Dom Sebastião. Al-Mansur belonged to a family of Sa'adi Sharifs ${ }^{3}$ (noblemen-descended from Fatima and Ali and therefore from Muhammad) from the upper valley of the river Draa in South Morocco. His ancestor, Muharnmad-al-Mahdi, had overturned the Marinide Sultan and founded the second Sharifian (Arab) or Saadian dynasty.

1 It also later on left traces of its temporary occupation on the island of Jerba, where a fine Spanish fortress remains intact to this day.

2 Arzila.

3 Sharif, plur. Shorfa, means in Arabic "nobly born." The first Sharifian Arab dynasty ruled Morocco from 788 to 970 . Then followed a long succession of Berber dynasties till I $5_{24}$, when the Sa'adi Sharifs from the upper Draa began to rule Morocco. The third Sharifian Arab dynasty -Filali, from Ta-filal-t-succeeded the Sa'adi Sultans in the $I 7$ th century and still occupies the Moroccan throne. 
Nevertheless, the Portuguese retained most of their fortified ports on the Atlantic coast of Morocco, and also Ceuta. During the 60 years of the abeyance of the Portuguese monarchy (r580-r640) these places became nominally Spanish, but returned to Portugal with the restoration of the House of Bragança, though Ceuta and Melilla were subsequently ceded to Spain, and Tangier to England. Thus ended what might very well have been, but for the battle of Kasr-al-Kabir, the Portuguese Empire of Morocco.

At the end of the rath century, other Sharifs of Yanbu, the coast port of the holy city of Medina in Arabia, following returning Moorish pilgrims, established themselves at Sijilmassa in Tafilalt, or Filal, a country of Southern Morocco. One of them, Hassan-bin-Kassim, increasing greatly in power, became in the ${ }^{1} 5_{\text {th }}$ century the founder of the present Sharifian dynasty of Morocco; though some centuries elapsed before these Filali chiefs succeeded in becoming supreme rulers over both $\mathrm{Fez}$ and Marrakesh. The Filali Sultans did not displace the Saadian Sharifs till ${ }_{6} 658$.

But during the reign of the sixth Saadian monarch-AlMansur, also surnamed "the Golden"-Morocco reached the acme of her power and acquired a vast Nigerian dominion. At the close of the 15 th century a Muhammadan negro dynasty had arisen on the upper Niger, and in the western Sudan. One of these negro kings, who made a pilgrimage to Mecca, obtained from the descendant of the Abbaside khalifs residing at Cairo the title of "Lieutenant of the Prince of Believers in the Sudan." He made Timbuktu ${ }^{1}$ his capital, and it became a place of great learning and flourishing commerce. His grandson, Ishak-bin-Sokya ${ }^{2}$, became rich and powerful, and attracted the rapacity of the Saadian Sharifian Khalif of Morocco (Abu'l Abbas al-Mansur, who had

1 Timbuktu had been founded by a Tawareq (Berber) tribe about I 100 A.C.

2 or Askia. 
distinguished himself by wiping out the Portuguese under Dom Sebastião at the battle of Kasr-al-Kabir), and had recently extended his rule across the Sahara to the oasis of Twat ${ }^{1}$. The Moorish emperor attempted to pick a quarrel by disputing this negro king's right to the title of Lieutenant of the Khalifs in the Sudan, demanded his vassalage, and a tax on the Sahara salt mines along the route to Timbuktu. Ishakbin-Sokya refused, whereupon a Moorish army under Juder Basha was despatched by Abu'l Abbas-al-Mansur in I590 to conquer the Sudan. This army crossed the Sahara, defeated Ishak-bin-Sokya, and captured Timbuktu, but raised the siege of Gaghu or Gao, lower down the Niger, whither Ishak had fled. A more vigorous commander, Mahmud Basha, completed the Moorish conquest of the Sudan, a conquest which extended in its effects to Bornu on the one hand and to Senegambia on the other, and only faded away in the I8th century, mainly owing to the uprise of the Fula and the attacks of the Tawareq. Gradually all Morocco was brought under Sharifian rule; all European hold over the country was eradicated ; and the reign of culminating glory was that of the Filali emperor Mulai Ismail, the "Bloodthirsty," who ruled for 57 years, and is said to have left living children to the number of 548 boys and 340 girls. Mulai Ismail died in 1727 . He had attained to and maintained himself in supreme power by the introduction of regiments of well-drilled Sudan Negroes; but the "nigrification" of Morocco-the importation on a large scale of negro slaves and soldiers-had begun much earlier in the conquest of North Africa by the Lamtuna Berbers from the northern Niger, the "Almoravides." But the civilization and the conquering power of Morocco were largely due to the "Ruma" or "Rumi" element, the Spanish Moors emigrating from Spain and bringing into North-West Africa a powerful "White Man" element-for they were often the descendants of the Roman-Iberian people of Gothic Spain. They were remarkable

1 Now in the hinterland of Algeria, and occupied by the French. 
for their knowledge of firearms and their skill as artisans; and their descendants are everywhere the "aristocracy" of Muhammadan North Africa.

Morocco might have conquered and ruled all North Africa in the 16 th century but for the arrival of the Turks. The Turks, who had replaced the Arabs of Mesopotamia, Syria, and Asia Minor as Muhammadan rulers, had captured Constantinople in 1453, had seized Egypt in 1517, and were becoming the backbone of the Muhammadan power. When the Algerians and Tunisians appealed to Turkish pirates for help against the attacks of the Christian Spaniards in the I6th century, the Sultan of Constantinople took advantage of their intervention to establish, through the Turkish Corsairs, Turkish regencies in Algeria ( $15 \mathrm{r} 9$ ), Tunis (1573), and Tripoli $(\mathrm{r} 55 \mathrm{I})^{1}$. Morocco, however, always remained independent; and indeed, after the extinction of the line of Abbasid Baghdad Khalifs at Cairo in $\mathbf{r} 538$, the great Sharifian sovereign, Al-Mansur, after his victory over the Portuguese, declared himself Khalif over the Muhammadan world in right of his descent from Fatima and Ali, and refused to recognize the claim of the Ottoman Emperor of Constantinople to have acquired the transfer of the Caliphate from Motawakkiq the

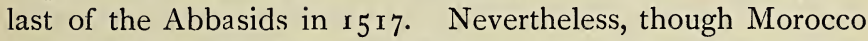
remained a great independent Muhammadan power, her princes borrowed many customs from Turkey, such as the Turkish style of clothing, the Turkish method of arranging troops in battle, and the title of Pasha (Basha).

Except in Morocco, Turkish control replaced Arab influence in northern Africa, and extended by degrees far into the

1 Algeria and Tunis were conquered by Turkish pirates, quite as much from the mild Berber dynasties possessing them as from the Spanish encroachments. Tripoli was taken from the Knights of Malta. Gradually all these three Regencies detached themselves from the Turkish Empire in everything but the mere acknowledgment of suzerainty; but, in 1835 , the Turks abruptly resumed the direct control of Tripoli and Barka, to which they added Fezzan in 1842 . 
old Garamantan kingdom of Fezzan, and across the Libyan Desert to the Red Sea. But no matter whether Turk, Circassian, Greek, Albanian, Slav, or Arabized Negro ruled in Berber North Africa, Muhammadan influence and Arab culture continued to spread over all the northern half of Africa. Somaliland, Sennār, Nubia, Kordofan, Darfur, Wadai, Bornu, Hausa-land and the Sahara, much of Senegambia, and most of the country within the bend of the Niger and along the banks of the upper Volta were converted to Muhammadanism, and became familiar with the Arab tongue as the religious language, and with some degree of Arab civilization.

Egypt after the Arab invasion of $640-2$ was governed from the Delta of the Nile to the First Cataract by Arab governors deputed by the Khalif of Baghdad. The Christian Copts and Greeks were not materially interfered with, provided they paid their taxes regularly. In 706 Arabic finally displaced Greek as the official language of the country, and never subsequently lost its hold over Egypt. Coptic (the degenerate form of Ancient Egyptian) gradually sank into the position of a ritual language only connected with religious exercises and literature; and Arabic since the 8th century has been the universal speech of all Egypt, except in the Oasis of Siwa, where a Berber dialect is still spoken, and among the tribes inhabiting the lands between the Cataract Nile and the Red Sea, who preserve their Hamitic (Gala-like) languages. A good deal of Arab colonization of Upper and Lower Egypt, and of Nubia and Dongola, took place between the 8th and the 12 th centuries. In 828-32 a serious rebellion of Copts and of malcontent Arabs was only suppressed by the Baghdad Khalif introducing an army of 2000 Turks; and from this time onwards the Turks had much to do with Egypt, as they had with Syria and Mesopotamia, because the Arabs were losing their energy and fighting capacity. After $85^{6}$ most of the functionaries in Egypt were Turks; and in 875 a Turkish governor, Ahmad bin Tulūn, turned his governorship into a 
hereditary sovereignty. The Tulunid dynasty of sultans governed Egypt till 905, when the direct rule of the Baghdad Khalifs was resumed. Then, once more, a Turkish governor was appointed to rule Egypt for the Khalif, in 935, to whom was granted the kingly title of Ikshid. The Ikshids governed until 969 , when they were supplanted by the establishment of the Fatimite Khalif Mu'izz-li-din-Allah already referred to, who left Tunisia in 973 to take up his residence first in Alexandria and then in newly-founded Cairo.

This revolution was really effected by a Jewish official, Yakub bin Killis, and a Slav or Greek general, Jauhar, both of them converts to Islam. The Fatimite Khalifs of Egypt rose for a short time to be the greatest power in Islam, their empire extending from Tangier to Aleppo, and nearly always including Syria. But the Khalifs soon became puppet sovereigns, the rule being carried on in their name by Jewish, Syrian, Negro, Turkish, or Kurd ministers. Between iा63 and II 70 the French and German crusaders invaded Egypt and for a short time garrisoned Cairo. They were driven out by a Kurdish prefect of Alexandria, Salah-ad-din Yusaf bin Ayub ("Joseph the son of Job"-the famous "Saladin"), who at last swept away the fiction of these Shia Khalifs, restored the Sunni form of Muhammadanism and proclaimed the Abbasid Khalifs of Baghdad as spiritual leaders. Egypt has remained Sunni ever since. Saladin however made himself "Malik" or King of Egypt and Syria. His descendants ruled Egypt, Western Arabia and such parts of Palestine as were not occupied by the Crusaders until I 260, when this Ayubite dynasty was replaced by that of the Turkish slave, Bibars. The Ayubite kings of Egypt purchased large numbers of boy slaves (Mamluk) and trained them as soldiers. They were European Slavs, Greeks and Italians, Asiatic Turks, Circassians, Kurds and Mongols. These dynasties of slave sultans recognized and kept in their midst a puppet Abbasid Khalif, who after the capture of Baghdad by the Mongols 
in 1260 resided in Cairo. The Mamluk Kings governed

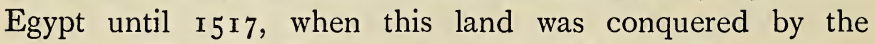
Ottoman Turks and the last of the Abbasid Khalifs was compelled to confer the Muhammadan Caliphate (most illegally) on the Ottoman Emperor of Rūm (Rome, i.e. Constantinople). But the Mamluk or slave soldiers, derived from the races above mentioned, continued to exist and to some extent to administer Egypt even under Turkish governors till the invasion of the French in 1798 ; they revived again after the French quitted Egypt (I80I), till the last of them were massacred by a Turkish (Macedonian-Albanian) major of artillery, Muhammad Ali, who became the almost independent Pasha of Egypt and founded the present dynasty of the Khedives.

During all this period of twelve hundred and twenty years (between, let us say, 690 and r9ro) while Northern Africa lay under Islamic control, enormous numbers of Asiatics and Europeans colonized Egypt and Mauretania-Arabs, Jews, Syrians; Turks, Kurds and some Persians ; Greeks, Slavs (sold by the conquering Germans to Jewish dealers who resold these Poles, Chekhs, Wends, Croats and Serbs to the Spanish Arabs, the Berbers, Egyptians and Turks); Italians, Spaniards, Germans ; French; and even English and Irish. One is also struck with the power wielded over the Muhammadan world of North Africa by the Jew, which was not displaced till the modern Christian European conquest of North Africa.

Arabs completely displaced the Hamitic tribes on the Desert Nile in Nubia, Dongola and Sennār after the IIth and $\mathrm{r}$ 2th centuries, and in the last-named country, Sennār, founded the Funj dynasty of kings which powerfully affected North-East Africa from the 13 th to the 18 th centuries. In the I 2 th century, Somaliland was converted to Islam and from that period onwards permeated by Arabs. From the middle of the 8th century, the pre-Islamic settlements of southern Arabs along the East coast of Africa were revived by fresh bands of militant traders and missionaries of Islam. 
Arabs established themselves once more at Sofala, at Sena and Quelimane on the lower Zambezi, at Moçambique, Kilwa, Zanzibar, Mombasa, and various ports on the Somali coast. A colony of Muhammadanized Persians joined them in the Ioth century at Lamu; and Persian as well as Muhammadan Indian influence began to be very apparent in architecture on the East coast of Africa. The powerful Sultanate of Kilwa was founded in the roth century, and exercised for some time a dominating influence over all the other Arab settlements on the East coast of Africa. Arabs, as already related, had discovered the island of Madagascar, which they first made clearly known to history. In Islamic times they again settled as traders on its north and north-west coasts, while the adjoining Comoro Islands or Islands of the "Full Moon" (Komr) became little Arab sultanates practically in the hands of Arabized Negroes. Until the coming of the Portuguese in the I6th century these Arab East African states were sparsely colonized by Himyaritic or South Arabian Arabs from the Hadhramaut, Yaman, and Aden. But a development of power and enterprise amongst the Arabs of Maskat, which led to their driving away the Portuguese from the Persian Gulf and subsequently attacking them on the East coast of Africa, caused the Maskat ${ }^{1}$ Arab to become the dominant type. The Maskat Arabs founded the modern Zanzibar sultanate, which quite late in the Igth century was separated by the intervention of the British Government from the parent state of 'Oman.

As the result of the Muhammadan invasion of Africa from Arabia-only brought to a close at the end of the I 9 th

1 or 'Oman. Maskat is the capital of the principality of 'Oman (a word which is really pronounced 'Uman) in East Arabia, ruled by an "Imam" or laicized descendant of a line of preacher-kings or "Prince Bishops," leaders of the Ibadite sect of Puritan Muhammadans, believing mostly that sin was worse than unbelief. The Ibadites were identical in origin with the $\mathrm{N}$. African Khariji already described, whose tenets, in the $\mathrm{I} 8 \mathrm{th}$ and $\mathrm{I} y \mathrm{th}$ centuries, were unconsciously repeated by the followers of Muhammad ibn Abd-al-Wahhab, the conquering "Wahhabis" of Nejd. 
century-it may be stated that Arabized Berbers ruled in North and North-West Africa; Arabized Turks ruled in North and North-East Africa; Arabized Negroes ruled on the Niger, and in the Central Sudan; Arabs ruled more directly on the Nile, and on the Nubian coast ; and the Arabs of south Arabia and of 'Oman governed the East African coast, and eventually carried their influence, and to some extent their rule, inland to the great Central African lakes, and even to the Upper Congo.

The Muhammadan colonization of Africa was the first event which brought that part of the continent beyond the Sahara and Upper Egypt within the cognizance of the world of civilization and history. The Arabs introduced from Syria and Mesopotamia an architecture-"Saracenic"-which was an offshoot of the Byzantine", with a dash of Persian or Indian influence. This architecture received at the hands of the Berbers and Egyptians an extraordinarily beautiful development, which penetrated northwards into Spain and Sicily and in a modified type into Italy, and southwards reached the Lower Niger, the Upper Nile, the vicinity of the Zambezi, and the north coast of Madagascar. They gave to all the northern third of Africa a lingua franca in Arabic, and besides spreading certain ideas of Greek medicine and philosophy, they taught the Koran, which admitted all those Berber and Negro populations into that circle of civilized nations which has founded so much of its hopes, philosophy and culture on the Semitic Scriptures. The Arabs, especially of Yaman and 'Oman, were the means, more or less direct (especially through their seafaring trade with India), of enlarging the food supply and

1 The architectural style known as Saracenic made its beginnings in Inner Syria and Mesopotamia a century or nearly" so before the Muhammadan invasion; and the "Horseshoe Arch" or the arch prolonged for more than half a circle was invented by Hellenized Syrians in the sixth century of this era. The "Mahrab" of the Mosque and some of the doming were added by the Arabs and actually descend from the symbols of phallic worship. 


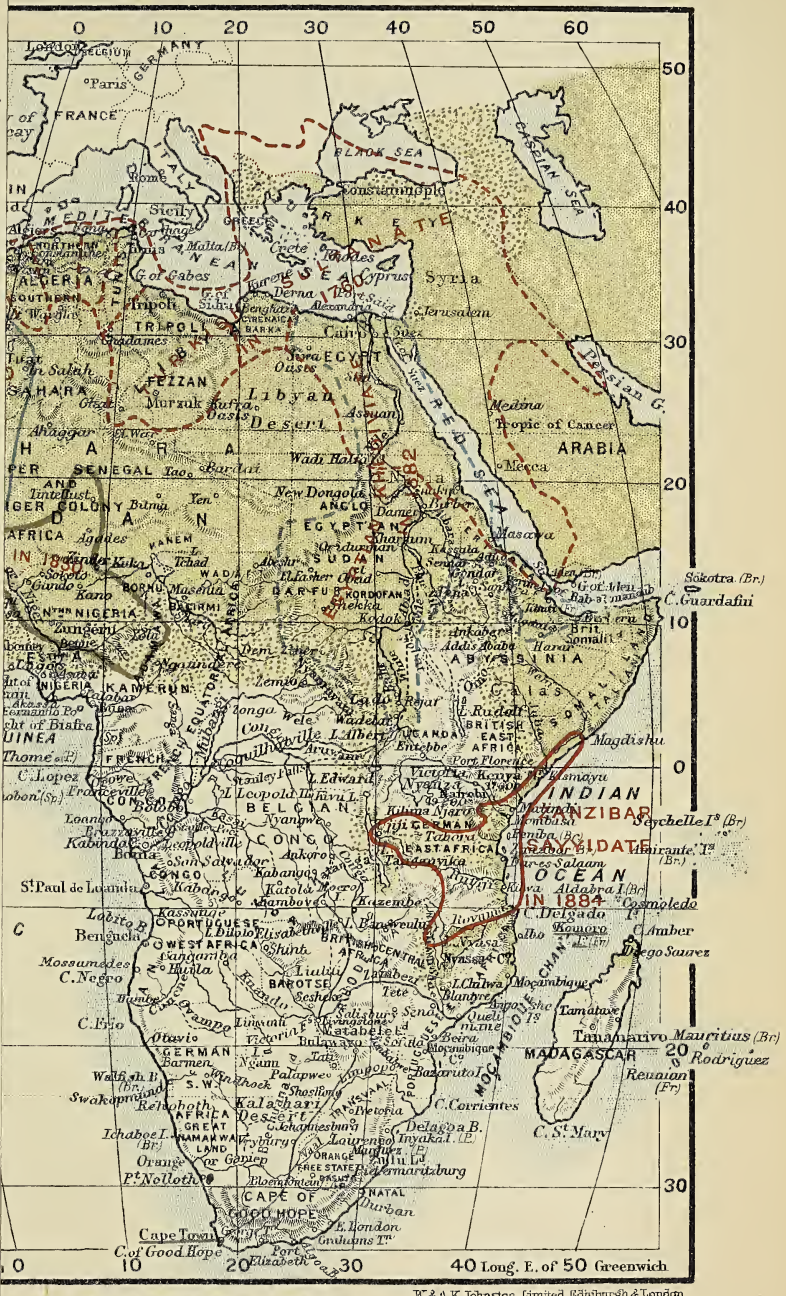

EXPLANATORY NOTE

Wids A K Johnston fimised Rabiburgh \&Ionion.

area over which Islam is the dominating religion at the present day present area is larger than it has ever been in the past) ur illustrate sporadic establishments of Michammadanism most important Muhammadan Empires when at their greatest $u n$ in coloured lines 

MUHAMMADAN AFRICA

Plate II.

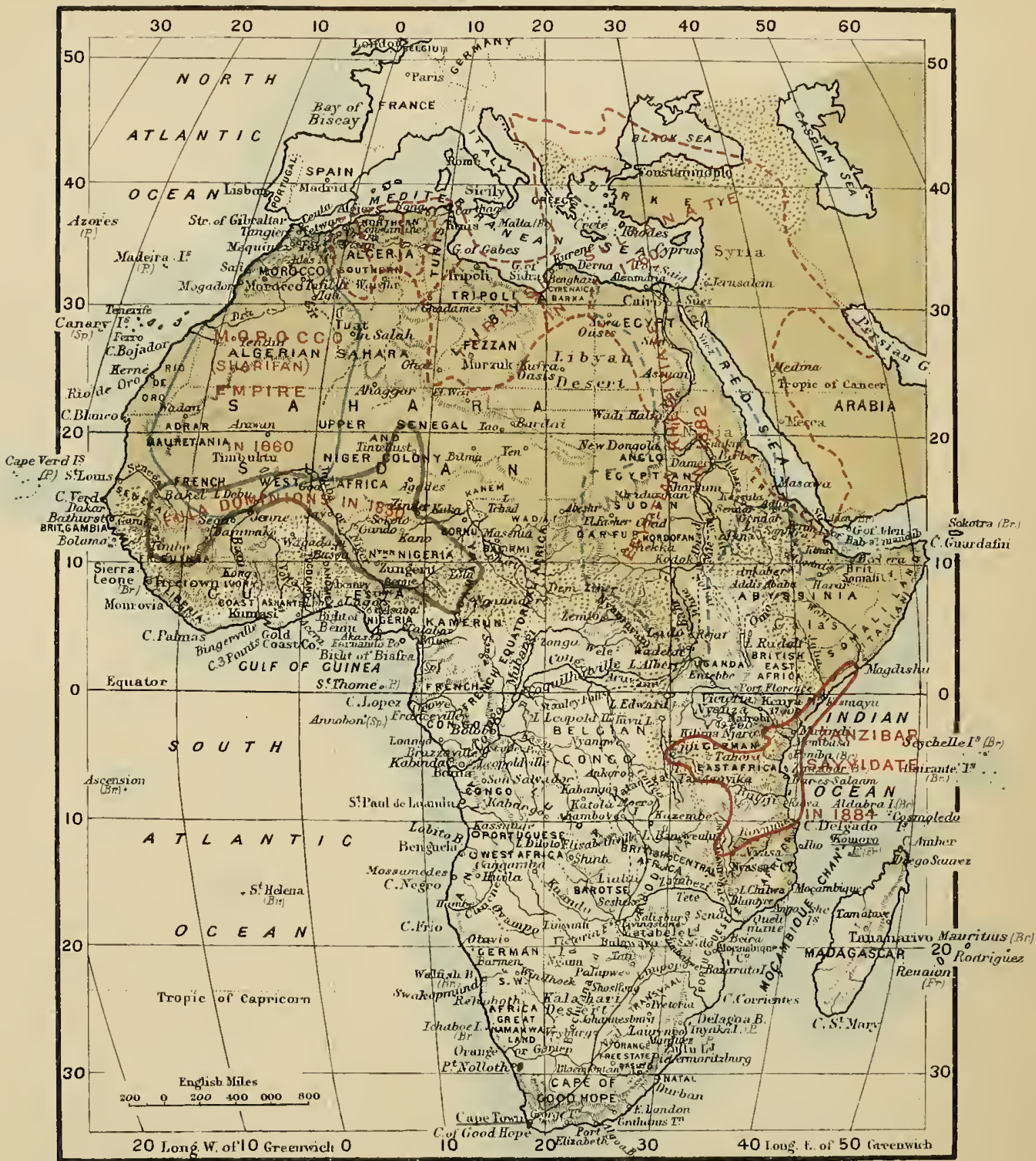

Sriff.Johnstan dol?

EXPLANATORY NOTE

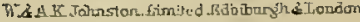

Indicates approximate area over which Islam is the dominating religion at the present day

(N.B.-The present area is larger than it has ever leen in the past)

Dotted spots of colour illustrate sporadic establishments of Mrohammatanism

The Boundaries of most important Muhammadan Empires when at their greatest extent are shown in coloured lines 

means of transport of the negro and negroid, and of conveying to Europe a few useful African products, such as coffee. They had much to do with the introduction of the Indian buffalo into Egypt, and the camel into the Sahara and Libyan deserts, Nigeria and Somaliland. Similarly they extended the range of the domestic horse and ass; of goats, and sheep and poultry in Negro Africa. They certainly introduced the lime and orange, and the sugar cane, and possibly the banana; though this last may date back to pre-Islamic times, like wheat and rice.

Through their contact with Europeans, Arabs and Arabized Berbers first sketched out with some approach to correctness the geography of Inner Africa, and of the African coasts and islands. The direct and immediate result of this Muhammadan conquest of Africa was the drawing into that continent of the Portuguese-themselves but recently emancipated from Muhammadan rule, and still retaining some conversance with Arabic, a language already used in African and Eastern commerce from Tangier and the Senegal to Ternate and the Spice Islands off the coasts of New Guinea. Thanks to this intimate acquaintance with Muhammadans, and their lingua franca, the Portuguese were now to advance considerably the colonization of Africa by the Caucasian race. 


\section{CHAPTER IV}

\section{THE POR'TUGUESE IN AFRICA}

The mother of Portugal was Galicia, that north-western province of the present Kingdom of Spain. It was here at any rate that the Portuguese language developed from a dialect of provincial Latin, and hence that the first expeditions started to drive the Moors out of that territory which subsequently became the Kingdom of Portugal. A large element in the populations of Galicia and of the northern parts of Portugal was Gothic. The Suevi settled here in considerable numbers ; and their descendants at the present day show the fine tall figures, flaxen or red hair, and blue eyes so characteristic of the northern Teuton. Central Portugal is mainly of Latinized Iberian stock, while southern Portugal retains to this day a large element of Moorish blood. The northern part of Portugal was first wrested from the Moors in the I Ith century by the bravery of Alfonso V, Ferdinand I and Alfonso VI, Kings of Leon. Alfonso VI placed it (as a tributary county) in charge of Henric of Besançon or Burgundy, a French prince of the Capetian house, who married the illegitimate daughter of Alfonso VI, and extended the conquered area nearly to the banks of the Tagus. He became known to the Moors as Errik; and his warrior son Alfonso I was styled in Moorish history "ibn Errik," the "son of Henry." Alfonso I became the first king of Portugal in Ir 43, though it is doubtful 
whether the kingly title was assumed or recognized till the reign of Henric's great-great grandson Alfonso III, by whom in $125^{\circ}$ the southernmost province of Algarve ${ }^{1}$ was conquered. By the middle of the $3^{\text {th }}$ century the Moors had ceased to rule in the Roman Lusitania. Lisbon, the capital, had been wrested from the Muhammadans in I I47, thanks to the cooperation of a crusading force of English, Dutch and Germans, who volunteered the aid of their ships and fighting men. Most of these Saxon crusaders settled in Portugal, which at that period even imported Anglo-Saxon or English architects and craftsmen; and not a few of the later conquistadores and bold sea-captains of the Lusitanian kingdom could trace their descent from Teutonic adventurers of the $\mathbf{I} 2$ th century.

In course of time the Portuguese, not content with ridding the western part of the Peninsula of the Moorish invaders, attempted to carry the war into the enemy's country, urged thereto by the irritating attacks of Moorish pirates. In I 4 I 5 , as already mentioned, a Portuguese army landed on the coast of Morocco, and captured the citadel of Ceuta, the Roman Septa. One by one the Portuguese captured the coast towns of north-west Morocco, till in the second half of the 16th century the king of Portugal was almost entitled to that claim over the Empire of Morocco which asserted itself down to I910 in the formal setting-forth of his dignities. Most of these posts were either abandoned some years before or just after the defeat of the young king "Sebastião o Desejado "-Sebastian the desired-who at the age of only 23 was defeated and slain by the founder of the Sharifian dynasty of Morocco on the fatal field of Al Kasr-al-Kabīr in $1578^{2}$. Ceuta was taken over by Spain in 1580 -was garrisoned, that is, by Spanish

1 From the Arabic Al-gharb the 'west,' the 'sunset.' The title of the Kings of Portugal was "King of Portugal and the Algarves, on this side and on the other side of the sea in Africa, etc."

2 This battlefield was on the banks of the river Lukkus, not very far from the coast port of Al-Araish, the Roman Lixus, 
soldiers $^{1}$; the two or three other Moroccan towns which remained in Portuguese hands after the battle of Kasr-al-Kabir, being garrisoned by Portuguese soldiers, reverted to the separated crown of Portugal in 1640. Of these Tangier was ceded to England in 1662 , Saffi was given up to the Moors in $\mathrm{I} 64 \mathrm{I}$, other points were snatched by the Moors in $\mathrm{I} 689$, and Mazagan was finally lost in 1770 .

The second son of the king Dom João I (who reigned from $\mathrm{r}_{3} 85$ to 1433 ) and Philippa, daughter of the English John of Gaunt, was named Henry (Henrique), and was subsequently known to all time as "Henry the Navigator" from the interest he took in maritime exploration. He was

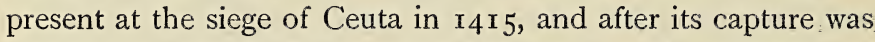
said to have inquired with much interest as to the condition of Morocco and of the unknown African interior, and to have heard from the Moors of Timbuktu.

On his return to Portugal he established himself on the rocky promontory of Sagres, and devoted himself to the encouragement of the exploration of the coasts of Africa. Under his direction expedition after expedition set out. First Cape Bojador to the south of the Moroccan coast was doubled by Gil Eannes in $1434^{2}$. In $144 \mathrm{I}-2$ Antonio Gonsalvez and Nuno Tristam passed Cape Blanco on the Sahara coast, and on the return journey called at the Rio d'Ouro or River of

1 It was finally ceded to Spain by Portugal in I668.

2 It had however been known to Italian and Norman navigators a century earlier. Indeed it is increasingly probable that the Portuguese as discoverers of West Africa had been preceded a hundred years earlier by the Genoese, the Catalans and Majorcans, and the Norman French of Dieppe. A remarkable map of the continent of Africa was painted in Italy, about $\mathbf{1 3 5} \mathrm{I}$, and is now in the Medicean Library at Florence. It is known as the Laurentian Portolano and gives the most correct general outline of the whole continent which had as yet been depicted. For the first time the great Bight of the Gulf of Guinea is shown, together with the tongue-like projection southwards of Central and Southern Africa. There is even the indication of a river where the Congo emerges into the South Atlantic. 
Gold $^{1}$, whence they brought back some gold dust and ten slaves. These slaves having been sent by Prince Henry to Pope Martin V, the latter conferred upon Portugal the right of possession and sovereignty over all countries that might be discovered between Cape Blanco and India. In I 445 a Portuguese named João Fernandez made the first over-land exploration, starting alone from the mouth of the Rio d'Ouro, and travelling over seven months in the interior. In the following year the river Senegal was reached, and Cape Verde was doubled by Diniz Diaz; and in 1448 the coast was explored as far as the Gambia river. In $1455^{-6} \mathrm{Ca}$ ' da Mosto (a Venetian in Portuguese service) and Uso di Mare (a Genoese) discovered the Cape Verde Islands, and visited the rivers Senegal and Gambia, bringing back much information in regard to Timbuktu, the trade in gold and ivory with the coast, and the over-land trade routes from the Niger to the Mediterranean. It is asserted by the Portuguese that some years later two Portuguese envoys actually reached Timbuktu; but the truth of this assertion is somewhat problematical, since, had they done so, they would probably have dissipated to some extent the excessive exaggerations regarding the wealth and importance of the Songhai capital. In 1460 Diego Gomes reached the river and mountain peninsula of Sierra Leone; the last named from the incessant rumble of thunderstorms making the mountain range roar like a lion. In 1462 , two years after the death of Prince Henry, Pedro de Sintra explored the coast as far as Cape Palmas in modern Liberia. By I47I the whole Guinea coast had been followed to the Gold Coast and on past the Niger delta, to the Cameroons and as far south as the Ogowe.

In I448, under Prince Henry's directions, a fort had been built on the Bay of Arguin, to the south of Cape Blanco; and

1 Only a long inlet in the Desert coast. At the head of this inlet was the little island of Kerné (still called Herné by the Moors) which was once a trading station of the Carthaginians. 
a few years later a Portuguese company was formed for carrying on a trade with the Guinea coast in slaves and gold. The first expedition sent out by this company resulted in the despatch of 200 Negro slaves to Portugal, and thenceforward the slave trade grew and prospered. It at first resulted in but little misery for the slaves, who exchanged a hunted, hand-to-mouth existence among savage tribes in Africa for relatively kind treatment and comfortable living in beautiful Portugal, where they were much in favour as house servants. In 148 I the Portuguese, who had been for some years examining the Gold Coast, decided to build a fort to protect their trade there. In $\mathrm{r}_{482}$ the fort was completed and the Portuguese flag raised in token of sovereignty. This strong place, for more than a hundred years in possession of the Portuguese, was called Saõ Jorge da Mina ${ }^{1}$. In the same year in which this first Portuguese post was established on the Gold Coast $^{2}$, exploration of the African coast was carried on beyond the mouth of the Ogowe by Diogo Cam, who discovered the mouth of the Congo in $\mathbf{r} 482$, and sailed up that river about as far as Boma. In 1485 Diogo Cam returned with a stronger expedition which sailed and rowed up the Congo to the mouth of the Mpozo river, just below the Yellala Falls ${ }^{3}$. Diogo Cam's discoveries were continued by Bartolomeu Diaz de Novaes, who, passing along the south-west coast of Africa, rounded the

1 Nowadays known as Elmina.

2 As will be seen in another chapter, there are traditions of Norman merchants from Dieppe having established forts or trading stations along the West African coast in the later years of the $14^{\text {th }}$ century, especially at "La Mine d'Or"-Elmina-where the Normans possibly preceded the Portuguese.

$3 \mathrm{Mr}$ E. G. Ravenstein deduces $\mathrm{I}_{4} 85$ as the date from the details shown in the coat of arms in the inscription. This inscription was only discovered on the high rock, near the Mpozo confluence, by a Swedish missionary in 1906. The inscription begins "Aqi chegaram os navios do esclarecido Rey Dom Joam ho sego de Portugall," and is followed by the names of Diogo Cam (Cão) and others. See the Geographical Journal for June, 1908. 
Cape of Good Hope in stormy weather without knowing it, and touched land on February 3, I488, at Mossel Bay, then again at Algoa Bay, Cape Padrone and the mouth of the Great Fish river. Here the timorous officers and crew insisted on a return westwards. On the homeward voyage Diaz beheld and named Cape Agulhas, and also "Cabo Tormentoso," the terminal point of South Africa, which was afterwards christened by Diaz, or by his monarch, King Joaõ II, "the Cape of Good Hope."

At this stage in the relation of the founding of the Portuguese dominion and influence over Africa some mention must be made of the part played during the I 5 th century by the Jews settled in Portugal. Badly as the Christians of Portugal treated the Jews, their existence in this western kingdom was not unbearable compared with the ferocious cruelty of the Spaniards ; consequently during the $15^{\text {th }}$ century the Jewish colonies in Portuguese cities increased considerably, and Jews even rose to a high position in the state. In return they established printing-presses, advanced education, and spread a knowledge of geography, astronomy, mathematics, classical history and medicine which was directly useful to the new school of Portuguese seamen-explorers, who mostly obtained their nautical instruments from the Jews. In short the Jews did much to create a Portuguese Empire beyond the seas ; but they were subsequently treated with the grossest ingratitude and expelled from Portugal in the early r6th century, thousands of them being deported to Saõ Thomé in the Gulf of Guinea where they died of malarial fever.

Before the rounding of the Cape of Good Hope by Diaz, the King of Portugal was convinced of the circumnavigability of Africa from the Atlantic into the Indian Ocean. Through enterprising Portuguese Jews (Abraham of Beja and Joseph of Lamego) who had travelled overland via Egypt and Syria to the Persian Gulf, he had heard that this was possible, and

${ }_{1}^{1}$ They described the Arab settlements on the South-East African coasts and alleged that certain Arab ships had been driven by stress of 
resolved to send two Portuguese officers, Pero de Covilham and Alfonso de Paiva, to travel to India by way of the Red Sea, and to find out all they could about the Christian King of Ethiopia and the Arab settlements on the East coast of Africa, and whether the King of Portugal might look for allies or friendly neutrals in this direction. Accordingly, in 1487 , de Covilham and Paiva reached Egypt; and the former journeyed by the Red Sea to India, while the latter made for Abyssinia, but was killed on the way, near Suakin. Pero de Covilham, on his return journey from Southern India, visited the north coast of Madagascar and the settlement of Sofala, near the modern Beira (S.E. Africa). Thence he proceeded northwards, calling at all the Arab ports of East Africa till he once more re-entered the Red Sea. Returning to Cairo he learnt that his companion, Paiva, had been killed, but he met the two Jews, Abraham and Joseph. By the last-named he sent back word of his discoveries to King John II, and then starting off with Abraham of Beja he visited Mecca and Medina and finally landed at Zeila (N. Somaliland) and travelled to Abys. sinia. The information sent back by de Covilham decided the despatch of an expedition under Vasco da Gama to pass round the Cape of Good Hope to the Arab colonies, and thence to India. Vasco da Gama set out in I497, and made his famous voyage round the Cape (calling at and naming Natal on the way) to Sofala, where he picked up an Arab pilot who took him to Malindi, and thence to India. On his return journey Vasco da Gama took cognizance of the island of Moçambique, and visited the Quelimane river near the mouth of the Zambezi. Numerous well-equipped expeditions sailed for India within the years following Vasco da Gama's discoveries. While India was the main goal before the eyes of their commanders, considerable attention was bestowed upon the founding of forts along the East coast of Africa, both to weather past the Cape of Good Hope, and had brought back word of the northward trend of the west coast. 
protect the Cape route to India, and to further Portuguese trade with the interior of Africa. In nearly every case the Portuguese merely supplanted the Muhammadan Arabs, whopossibly succeeding Phoenicians or Sabaeans-had established themselves at Sofala, Quelimane, Sena (on the Zambezi), Moçambique, Kilwa, Zanzibar, Mombasa, Malindi, Lamu, and Magdishu. Sofala was taken by Pedro de Anhaya in 1505 . Tristan d'Acunha hoisted the Portuguese flag on Sokotra Island and at Lamu in $15^{\circ} 7$, in which year also Duarte de Mello captured and fortified Moçambique. Kilwa and the surrounding Arab establishments were seized between I506 and 1508; and a little later the remaining places already mentioned on the East coast of Africa were in possession of the Portuguese, who had also Aden on the south coast of Arabia, the island of Ormuz on the Persian Gulf, and various places on the coast of 'Oman, including Maskat. Meantime, for thirty years, Pero de Covilham remained a prisoner at the Court of the Emperor of Abyssinia, though treated with the utmost distinction.

Before this period of the world's history, and from the time of the earlier crusades, a legend had grown up of the existence of Prester (priest) Johannes - some Christian monarch of the name of John, who ruled in the heart of Asia or of Africa, a bright spot in the midst of Heathenry and Islam. The court of Prester John was located anywhere between Senegambia and China; but the legend had its origin probably in the continued existence of Greek Christianity in Dongola and Abyssinia. Pero de Covilham having at last located Abyssinia, and an Abyssinian envoy having proceeded to Lisbon in 1507 to invite an alliance, a Portuguese embassy sailed round the Cape of Good Hope to the Red Sea and landed (apparently at Masawa) in I $^{20}$. With this embassy were two priests, one of whom (Alvarez) thirty years afterwards wrote an interesting account of Northern Abyssinia. The priest-missionaries remained for a long time in Ethiopia; but the lay-members of the mission 
returned after a residence of five years, bringing Covilham away with them. But he died on the way back.

The Turks meanwhile had taken possession of Egypt and Western Arabia, and became very jealous of Portuguese interference with Abyssinia and the Red Sea. They stirred up a Somali warrior, Muhammad Granye, furnished him with artillery, and urged him to conquer Abyssinia. This Muhammadan Somali from the Danákil country commenced invading and raiding Abyssinia from I 528. A Portuguese priest, Bermudez, was sent to Lisbon to beg for assistance. This was sent by way of India, whence came in I54 I a strong Portuguese fleet to Masawa. Six months afterwards the fleet landed at Masawa a force of 450 Portuguese soldiers under Christoforo da Gama. But after carrying all before them the Portuguese unwisely split their forces. Muhammad Granye, having received Turkish and Arab reinforcements, captured Christoforo da Gama's camp, and put that gallant Portuguese to death. Ultimately, however, with the help of the remaining Portuguese, the Abyssinian Emperor defeated Muhammad Granye, who was himself slain by da Gama's attendant, Pedro Leon (1542). Portuguese Jesuit missionaries remained in Abyssinia until I633 and penetrated into countries which have only been since revisited by Europeans within the last few decades. Father Pedro Paez discovered the source of the Blue Nile in I6r5; and Father Lobo visited the same region and much of S.W. Abyssinia in 1626 . Portuguese civilization distinctly left its mark on Abyssinia in architecture and in other ways. The very name which we apply to this Empire of Ethiopia is a Portuguese rendering of the Arab and Indian cant term for "negro"-Habesh - a word of uncertain origin.

From the beginning of the I6th century the Portuguese visited the coasts of Madagascar, as will be related in the chapter dealing with that island. They had also discovered in 1507 the Mascarene islands (named after a sea-captain, Mascarenhas) now known by the names of Réunion and 
Mauritius, though they made no permanent settlements on either. Madagascar, which was first sighted by Diogo Diaz in 1500 , was named the Island of St Laurence.

On the West coast of Africa geographical discovery was soon followed by something like colonization. The island of Madeira, which had been known to the Portuguese in the I 4 th century, was occupied by them in the I5th, and a hundred years afterwards was already producing a supply of that wine which has made it so justly famous ${ }^{1}$. The island of St Helena-afterwards to be seized by the Dutch and taken from them by the English East India Company-was discovered by the Portuguese in 1502 ; and this island also, at the end of a century of intermittent use by the Portuguese, possessed orange groves and fig trees which they had planted.

When Diogo Cam returned from the Congo in 1485 he brought back with him a few Congo natives, who were baptized, and who returned some years later to the Congo with Diogo Cam and a large number of proselytizing priests. This Portuguese expedition arrived at the mouth of the Congo in I $49 \mathrm{I}$ and there encountered a vassal chief of the king of Kongo $^{2}$ who ruled the riverain province of Sonyo. This chief received them with a respect due to demi-gods, and allowed himself to be at once converted to Christianity-a conversion

1 The Canary Islands, inhabited by a race of Berber origin, had been rediscovered (for Greek and Roman geographers knew of them) by Normans and Genoese in the 1 $^{\text {th }}$ century. Previous to that they had already been brought into touch with the Moors of the Moroccan coast, though they were never Islamized but remained in some respects in the primitive, stone-age condition which the Berbers of the mainland had quitted two thousand years before. The men often went naked; but the race in some respects exhibited a characteristic Neolithic civilization and was far removed from savagery. The archipelago was partially conquered by a Norman adventurer, Jean de Betancourt or Bethencourt; and his title after passing through many hands was finally claimed by Portugal. Portugal, however, transferred her rights to Castile in 1479 .

${ }^{2}$ It is necessary to discriminate in spelling between the river Congo and Congoland generally and the little kingdom of Kongo between Stanley 
which was sincere and durable. The Portuguese proceeded under his guidance to the king's capital about 200 miles from the coast, which they named São Salvador. Here the king and queen were baptized with the names of the then king and queen of Portugal, João and Leonora, while the Crown Prince was called Affonso. Christianity made surprising progress amongst these fetish worshippers, who readily transferred their adoration to the Virgin Mary and the saints, and discarded their indigenous male and female gods. Early in the $\mathrm{r} 6$ th century the Kongo kingdom was visited by the Bishop of São Thomé, an island off the Guinea coast, which, together with the adjoining Prince's Island, had been settled by the Portuguese soon after their discovery of the West coast of Africa. The Bishop of São Thomé, being unable to take up his residence in the kingdom of Kongo, procured the consecration of a native negro as Bishop of the Congo. This man, who was a member of the Kongo royal family, had been educated in Lisbon, and was, I believe, the first negro bishop known to history. But he was not a great success, nor was the next bishop, in whose reign in the middle of the $\mathrm{r} 6$ th century great dissensions arose in the Kongo church among the native priesthood, which led to a considerable lessening of Christian fervour. After the death of the King, Dom Diego, a civil war broke out; and one by one the males of the royal house were all killed except "Dom Henrique," the king's brother. This latter also died soon after succeeding to the throne, and left the state to his son, "Dom Alvares." During this civil war many of the Portuguese, whom the kings of Kongo had invited to settle in the country as teachers, mechanics and craftsmen, were killed or expelled as the cause of the troubles which European intervention had brought on the Kongo kingdom; but Dom Alvares, who was an

Pool and the Atlantic coast. This important native state, whose legendary founder was a mighty hunter armed with an iron spear (Kongo) gave its name to the great river, which was also styled Zaire by the Portuguese from the native term Nzadi. 
enlightened man, gathered together all that remained, and for a time Portuguese civilization continued to advance over the country. But a great stumbling-block had arisen in the way of Christianity being accepted by the bulk of the people-that stumbling-block which is still discussed at every Missionary conference, polygamy. A relation of the king Dom Alvares renounced Christianity and headed a reactionary party. Curiously enough he has been handed down to history as Bula Matadi, "the Breaker of Stones," the name which more than three hundred years afterwards was applied to the explorer Stanley by the Congo peoples, and has since become the native name for the whole of the government of the Belgian Congo.

In the middle of the 16 th century Portuguese influence over Kongo received a deadly blow. That kingdom, which must be taken to include the coast-lands on either side of the lower Congo, was invaded by a savage tribe from the interior known as the "Jagga" people, probably the same tribe as the Ba-Kioko or Ba-jok of Upper Kwango river ${ }^{1}$. The Jaga or Imbangola were powerful men and ferocious cannibals, and they carried all before them, the king and his court taking refuge on an island on the broad Congo, not far from Boma. The king of Kongo appealed to Portugal for help; and that ill-fated but brilliant young monarch, Dom Sebastião, sent him Franciso de Gova with 600 soldiers. With the aid of these Portuguese and their guns the Jaga were driven out. The king, who had hitherto led a very irregular life for a Christian, now formally married, but was not rewarded by a legal heir, and had to indicate as his successor a natural son by a concubine. About this time the king of Portugal pressed his brother

1 The original name of this tribe, which came from the southern Congo basin, was "Imbangola." Jaga was apparently like the Jinga of old Angola merely the title of their clan-chieftains. Jok or Kiokwe (as they are called in Lunda) was a nickname meaning "Hyena." Their descendants seem still to reside on the river Kwango behind Angola under the name of Imbangala. The Ba-yaka of the Northern Kwango are quite distinct. 
of Kongo to reveal the existence of mines of precious metals. Whether there are such in the Kongo country-except as regards copper-has not been made known even at the present day, but they were supposed to exist at that time; and certain Portuguese at the Kongo court dissuaded the prince whom they served from giving any information on the subject, no doubt desiring to keep such knowledge to themselves. The king of Kongo, Dom Alvares, when the Jaga had retired, made repeated appeals for more Portuguese priests, and sent several embassies to Portugal ; but Dom Sebastião had been killed in Morocco, and his uncle, the Cardinal Henrique, who had succeeded him and who was the last Portuguese king of the House of Avis, was too much occupied by the affairs of his tottering kingdom to reply to these appeals. But when Philip II of Spain had seized the throne of Portugal he despatched a Portuguese named Duarte Lopes to report on the countries of the Congo basin. After spending some time in Congoland, Duarte Lopes started to return to Portugal with a great amount of information about the country, and messages from the king of Kongo. Unfortunately he was driven by storms to Central America, and when he reached Spain the king was too busy preparing the Great Armada to listen to him. Therefore Lopes went on a pilgrimage to Rome to appeal to the Pope. Whilst staying in Italy, Lopes allowed a papal official named Filippo Pigafetta to take down and publish in I59 I his account of the Kongo kingdom, together with a recital of the Portuguese explorations and conquests in East Africa.

Although Portuguese priests-Jesuits probably-continued for a little while longer to visit the kingdom of Kongo, from the end of the I 6th century both Christian and Portuguese influence slowly faded, and the country relapsed into heathenism, in spite of the strenuous efforts made by the Popes of the $I 7$ th and 18 th centuries, who sent thither Italian, Flemish, and French missionaries. The Portuguese appear to have excited 
the animosity of a somewhat proud people by their overbearing demeanour and rapacity. They held intermittently Kabinda, on the coast to the north of the Congo estuary, and occasionally sent missions of investiture to São Salvador to represent the king of Portugal at the crowning of some new king of Kongo; and the king of Kongo was usually given a Portuguese name and occasionally an honorary rank in the Portuguese army. But it was not till after the middle of the r 9 th century that Portugal began to assert her dominion over the Congo countries. France and Britain during the $\mathrm{I} 8$ th and nearly all the rgth centuries steadily refused to recognize Portuguese rule anywhere north of the Loge river in Angola (south of the Congo Estuary); but Britain in 1884 proposed to do so under sufficient guarantees for freedom of trade set forth in a treaty which was rendered abortive by the opposition of the House of Commons. If this treaty had been ratified it would have brought under joint English and Portuguese influence the lower Congo, besides settling amicably Portuguese and British claims in Nyasaland. The opposition of a knot of unpractical philanthropists in the House of Commons wrecked the treaty, and gave to the other powers of Europe an opportunity for interfering in the affairs of the Congo. The result to Portugal, nevertheless, was that she secured the territory of Kabinda north of the Congo, and the ancient kingdom of Kongo south of that river.

Although the Portuguese discovered the coast of Angola in I490, they did not attempt to settle in that country until I.574, when, in answer to an appeal of the chief of Angola (a vassal of the king of Kongo), an expedition was sent thither under the command of Paulo Diaz ${ }^{1}$. This expedition landed at the mouth of the Kwanza river, and found that the chief of Angola who had appealed to the king of Portugal was dead. His successor received Diaz with politeness, but compelled him to assist the Angolese in local wars which had not much interest

\footnotetext{
${ }^{1}$ Grandson of the explorer, Bartolomeu.
} 
for the Portuguese. Diaz found in the interior of Angola many evidences of Christian worship, which showed that missionaries from the Congo had preceded his own expedition. When Diaz was at last allowed to return to Portugal, the king (Dom Sebastião) sent him back as "Conqueror, Colonizer, and Governor of Angola" with seven ships and 700 men. His passage out from Lisbon in the year I 574 occupied three and a half months-not a long time at that period for sailingvessels. Diaz took possession of a sandy island in front of the bay which is now known as the harbour of São Paulo de Loanda. Here he was joined by 40 Portuguese refugees from the Kongo kingdom. Eventually he built on the mainland of Loanda the fort of São Miguel, and founded the city of São Paulo, which became and remains the capital of the Portuguese possessions in South-west Africa.

For six years perfect peace subsisted between the Portuguese and the natives; then, afraid that the Portuguese would eventually seize the whole country, the king of Angola enticed 500 Portuguese soldiers into a war in the interior where he massacred them. But this massacre only served to show the splendid quality of Paulo Diaz, who was a magnificent representative of the old Portuguese type of Conquistador. Leaving Loanda with $\mathrm{I} 5 \mathrm{O}$ soldiers-nearly all that remained-he marched against the king's forces near the Kwanza river, and routed them with great loss, being of course greatly helped in securing this victory by the possession of muskets and cannon. The Angolese were defeated repeatedly before they gave up the struggle; but at length in $\mathbf{5 9 7}$ the Portuguese had established themselves strongly on both banks of the river Kwanza. In that year 200 Flemish colonists were sent out by the king of Spain and Portugal. In a very short time all were dead from fever. In spite of many reverses, however, the Portuguese slowly mastered the country south of the Kwanza nearly as far as Benguela. Portuguese traders and missionaries probably travelled inland up the Congo as far as the Bateke country or 
Stanley Pool. In I 606 an interesting but unsuccessful attempt was made to open up communication across south-central Africa between the Kwanza and the Zambezi settlements. But the explorer never got beyond the King of Kongo's capital, that potentate refusing him permission to proceed further into the interior. Nevertheless, from Portuguese annals it is clear that numerous venturesome priests and soldiers attempted at this period to penetrate Darkest Africa, and were never heard of again. What a subject for romance would be their experiences in these lands, at that time absolutely free from the influence of the European-a condition which no longer applied to the natives of Darkest Africa" when Stanley first made known the geography of those regions. For in the three and a half centuries which had elapsed, even those savages in the heart of Africa, who possibly knew nothing of the existence of white men, had nevertheless adopted many of the white man's products as necessities or luxuries of their lives, such as maize, tobacco, sweet potatoes, manioc, papaws, chillies, the pine-apple, and the sugar cane.

$\sqrt{W}$ e may here fitly consider the greatest and most beneficial results of the Portuguese colonization of Africa. These wonderful old Conquistadores may have been relentless and cruel in imposing their rule on the African and in enslaving him or in Christianizing him, but they added enormously to his food-supply and his comfort. So early in the history of their African and Indian explorations as about 15 Io they brought from China, India, and Malacca the orange tree, the lemon and the lime, which, besides introducing into Europe (and Europe had hitherto only known the sour wild orange and the lime, brought by the Arabs), they planted in every part of East and West Africa where they touched. They likewise brought the sugar cane from the Mediterranean and the East Indies and introduced it into various parts of Brazil and West Africa, especially into the Islands of São Thomé and Principe and the Congo and Angola countries. Madeira they had 
planted with vines in the $5_{5}$ th century; the Açores, the Cape Verde Islands and St Helena with orange trees in the I6th century. The cacao tree was introduced into São Thomé in I822. From their great possession of Brazil, overrun and organized with astounding rapidity, they brought to East and West Africa the Musk duck (which has penetrated far and wide into the interior of Africa), chili peppers, maize (now grown all over Africa, and cultivated by many tribes who have lost all tradition of its foreign origin), wheat (into Zambezia) ${ }^{1}$, tobacco, the tomato, pine-apple, sweet potato (a convolvulus tuber), manioc (from which tapioca is made), rice (into West Africa), haricot beans and lentils, onions, guavas, jackfruit, papaws, small bananas, ginger and other less widely known forms of vegetable food. The Portuguese also introduced the domestic pig into West Africa, and the domestic cat, possibly also certain breeds of dogs; in East tropical Africa the horse is known in the north by an Arab name, in the centre by the Portuguese word, and in the extreme south by a corruption of the English. Take away from the African's dietary of to-day the products that the Portuguese brought to him from the far East and far West, and he will remain very insufficiently provided with necessities and simple luxuries. I may add one or two dates concerning these introductions by the Portuguese:the sugar cane and ginger were first planted in the island of Principe, off the coast of Lower Guinea about I520; maize was introduced into the Congo (where it was called maza manputo) about $\mathbf{I}_{560^{2}}$.

1 Such wheat as is cultivated in Africa north of $15^{\circ}$ N. Latitude is similar to the European and Egyptian kinds; the wheat introduced by the Arabs and Portuguese into Zambezia is red wheat, apparently from India.

2 Duarte Lopes, who records this fact in his description of the Congo region at the end of the $\mathrm{s} 6$ th century, gives incidentally or directly other interesting scraps of information, such as, that the coco-nut palm was found by the Portuguese growing on the West coast of Africa. This palm, we know, originated in the Pacific Archipelagoes or on the Pacific coast of tropical America. It is possible to imagine that its nuts may have been 
In 162 I a chieftainess, apparently of the Kongo royal family, known as Jinga Bandi, came to Loanda, made friends with the Portuguese, was baptized, and then returned to the interior, where she poisoned her brother (the chief or king of Angola), and succeeded him. Having attained this object of her ambitions, she headed the national party, and attempted to drive the Portuguese out of Angola. For 30 years she warred against them without seriously shaking their power, though on the other hand they could do little more than hold their own. But a much more serious enemy now appeared on the scene. The Dutch, who took advantage of the union between the Spanish and Portuguese thrones in $15^{80^{1}}$ to include the Portuguese empire as a theatre for their reprisals against Spain, made several determined attempts during the first half of the 17 th century to wrest Angola from the Portuguese. They captured São Paulo de Loanda in I641, one year after Portugal had recovered her independence under the first Bragança king. The Portuguese concentrated on the Kwanza. The Dutch attempted by several treacherous actions to oust them from their fortresses on that river. At last, however, following on the reorganization of the Portuguese empire after $16_{40}$,

carried over the sea to Southern India and thence to Madagascar and the coast of East Africa, but, inasmuch as the coco-nut palm cannot grow further south than Delagoa Bay owing to the cooling of the climate it is not very clear how it reached the tropical West African coast, unless it was introduced by Europeans. Lopes mentions the banana for the first time under the name "banana," a name which seems to be derived from the Vai and other languages of the Sierra Leone-Liberia coast. Hitherto this fruit had only been known vaguely to Europe as the Indian fig or by its Arab name, which was latinized into Musa. The long banana or plantain was of ancient and widespread cultivation throughout tropical Africa, but the small banana with stubby fruit seems to have been a recent introduction from India which has penetrated into few parts of the interior.

1 Philip II of Spain had the best claim to the Portuguese throne after the death without heirs of the Cardinal-King Henrique. But the Portuguese disliked union with Spain and would have preferred to elect a Portuguese king. 
reinforcements were sent from Brazil to Angola, and a siege of São Miguel took place. The Portuguese imitated with advantage the Dutch game of bluff, and by deceiving the besieged as to the extent of their army they secured the surrender of I roo Dutch to under $75^{\circ}$ Portuguese. In the preliminary assault on the Dutch at São Paulo de Loanda the Portuguese lost I63 men. After the recapture of this place they proceeded methodically to destroy all the Dutch establishments on the Lower Guinea coast as far north as Loango. In the concluding years of the $\mathrm{I} 7$ th century nearly all the remaining Portuguese missionaries in the kingdom of $\mathrm{Kongo}^{1}$ migrated to the more settled and prosperous Angola. In I 694 Portugal introduced a copper coinage into her now flourishing West African colony -flourishing, thanks to the slave trade, which was mightily influencing the European settlement of West Africa.

In $175^{8}$ the Portuguese extended their rule northwards from São Paulo de Loanda into the Ambriz country, where however their authority continued very uncertain till about I885. About the same time Benguela was definitely occupied; and Portuguese influence continued extending slowly southward until, in 1840 , it reached its present limits by the establishment of a settlement (now very prosperous) called Mossamedes, almost exactly on the fifteenth parallel of south latitude ${ }^{2}$.

Between 1807 and 1810 attempts were made to open up intercourse with the Lunda kingdom of the Mwata Yanvo, and thence across to the colony of Moçambique, but they proved

${ }_{1}$ In 1621 Pope Paul V sent a mission to the King of Kongo at São

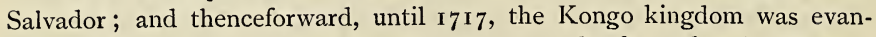
gelized by Italian and Belgian Capuchins, and after $16_{73}$ by Belgian Recollets friars. But in $17 \mathrm{I} 7$ the Capuchins were expelled by the king's people. In 1760 Catholic missions were resumed in Congoland (Loango and Kongo) by French, Italian and Portuguese missionaries; but these too came to an end by 1800 , and for some eighty years the Kongo kingdon relapsed into complete barbarism.

2 This place was named after the Baron de Mossamedes, a Portuguese Governor of Angola, afterwards Minister for the Colonies. 
only partially successful. In $\mathrm{I} 8 \mathrm{I} 3$ and in the succeeding years a renewed vigour of colonization began to make itself felt in the creation of public works in Angola. Amongst other I9th century improvements was the bringing of the waters of the Kwanza by canal to São Paulo de Loanda, which until then had no supply of good drinking water. The Dutch had attempted to carry out this, but were interrupted. The Portuguese efforts in the early part of the last century proved unsuccessful, but in $\mathrm{r} 887$ the canal was at last completed, and it made a great difference to the health of the town. Portuguese rule inland from Angola waxed and waned during the r 9 th century, but on the whole was greatly extended. Livingstone found Portuguese in I855 established to some extent on the upper Kwango, an affluent of the Congo, and for long the eastern boundary of Angola. From this, however, they had to retire owing to native insurrections; though now their power and their influence have been pushed far to the east, to the river Kasai.

In 1875 a party of recalcitrant Boers quitted the Transvaal owing to some quarrel with the local government, trekked over the desert in a north-westerly direction, and eventually blundered across the Kunene river (the southern limit of Portuguese West Africa) on to the healthy plateau behind the Shela Mountains. It was feared at one time that they would set the Portuguese at defiance and carve out a little Boer state in south-west Africa. About this time, also, Hottentots much under Boer influence and speaking Dutch invaded the district of Mossamedes from the coast region; but by liberal concessions and astute diplomacy, joined with the carrying out of several important works, like the waggon road (now the railway) across the Shela Mountains, the Portuguese won over the Boers to a recognition of their sovereignty, though they have since left the country and returned to German or British South Africa.

Slavery was not abolished in the Portuguese West African 
dominions until 1878 ; but the slave trade had been ostensibly forbidden in the first quarter of the r 9 th century. Prior to that time the slave trade had brought extraordinary prosperity to the islands of São Thomé and Principe, to the Portuguese fort on the coast of Dahomé, and to Angola, all of which countries were more or less under one government. The abolition of the slave trade however caused the absolute ruin of Principe (which has not yet recovered), the temporary ruin of São Thomé (the fortunes of this island have since revived owing to the cultivation of cinchona and the enormous extention of the planting of cacao), and the partial ruin of Angola, which began to be regarded as a possession scarcely worth maintaining. Brazil (though it had been severed from the crown of Portugal) did almost more than the Mother Country to revive trade in these dominions. Enterprising Brazilians such as Silva Americano came over to Angola in the sixties and seventies of the rgth century, started steam navigation on the river Kwanza, and developed many industries. Through Brazilian, United States, and British influence a railway was commenced in the eighties to connect São Paulo de Loanda with the rich interior, especially with the coffee districts on the water-shed of the Congo. Another railway of even greater importance has been begun by a British company in the Benguela district south of the Kwanza River. This line starts from Lobito Bay, near Benguela, and is destined to cross Angola at its broadest and ultimately reach the copper and gold mines of Katanga in the Belgian Congo. American and Swiss protestant missionaries have formed important settlements on the Bailundo uplands. The magnificent island of São Thomé, just under the Equator, possesses mountains which rise high into a temperate climate. On these, as already related, flourishing plantations of cacao, cinchona and coffee have been established. Public works in the shape of good roads and bridges have been carried out in many parts of Angola, and this country is certainly the most 
successful of the Portuguese attempts at the colonization of Africa. Unfortunately the "boom" in cacao (cocoa, chocolate) and the fact that it is a capricious tree, not easy to acclimatize and only growing to perfection in a few parts of tropical America and the west coast of Africa, notably São Thomé, induced the Portuguese government from I880 onwards to push the interests of São Thomé at the expense of Angola. A kind of slave trade under the guise of "apprenticeships" was revived in South and East Angola, which made its effects felt on the Congo populations as far inland as the Kasai and Lomami. These apprentices, once landed in São Thomé (they were regularly bought and sold) never, or hardly ever, obtained their liberty or received regular pay for their work. In all other respects they were kindly treated. But this policy led to native wars and insurrections in the Angola hinterland, and attracted attention and condemnation in Europe.

In the autumn of 1904 the Portuguese forces in Southern Angola sustained a disastrous defeat near the Kunene river from the Kuanyama (Cuanhama) people, a tribe connected linguistically with the Ovambo and the Ovaherero (Damara). Bantu negroes, speaking dialects of this Ondonga or Herero group and distantly allied in racial origin with the Zulu-Kafir stock, inhabit the south of Angola and are formidable warriors. These disturbances in Southern Angola have died down since the hinterland of Benguela was opened up to profitable commerce by the Anglo-Portuguese railway concessionaires who are building a line from Lobito Bay eastwards to Katanga.

Portuguese rule was extended in 1885 northwards to the southern shore of the Congo, and over the small territory of Kabinda, which is separated by a narrow strip of Belgian territory from the Congo estuary. On the other hand the Portuguese protectorate over Dahomé-a protectorate which never had any real existence-was abandoned to France together with its only foothold, São João d'Ajudá ${ }^{1}$ The

1 This fort, by the abortive Congo Treaty of $188_{4}$, was to have been J. 
Portuguese forts on the Gold Coast had not been held very long before they were captured by the Dutch at the beginning of the 17 th century. Portugal, in spite of discovering and naming Sierra Leone, never occupied it ; but in varying degree she continued to maintain certain fortified posts amid that extraordinary labyrinth of rivers and islands in Senegambia, between the Gambia and Sierra Leone. This is a district of some 14,000 square miles in extent, to-day carefully defined, and known as Portuguese Guinea. But in the seventies of the r 9 th century it was doubtful whether Portuguese sovereignty over this country had not been abandoned. England, which exercised exclusive influence in these waters, attempted to establish herself in the place of Portugal, but the Portuguese protested and proclaimed their sovereignty. The matter was submitted to arbitration, and the verdict was given against England. Consequently the Portuguese reorganized their colony of Guinea, which in time was separated from the governorship of the Cape Verde islands. There was a serious native rising in 1908, but it was suppressed. In the present condition of Portuguese Guinea, however, the native tribes are practically independent.

The Cape Verde Islands are a very important Portuguese asset three hundred miles off the north-west coast of Africa. They have been continuously occupied and administered since their discovery in the ${ }^{5} 5_{\text {th }}$ century. They possessed then no population, but are now peopled by a blackish race descended from Portuguese, Negroes and Moors. In one or two of the healthier islands are white settlers of Portuguese blood. Owing to the magnificent harbours which these islands offer to shipping,

made over to England. Although the Portuguese never in any sense ruled over or controlled Dahomé, their indirect influence and their language were prominent at the Dahomean court because certain Brazilians had during the first half of this century established themselves on the coast and in the interior as influential merchants and slave traders. Their descendants now form a Portuguese-speaking Brazilian caste in Dahomé. 
especially São Vicente, and their use as a coaling station, they may yet figure prominently in the world's history.

Both Ascension and St Helena were discovered and named by the Portuguese. The first-named was never continuously occupied until England took possession of it as an outpost of Napoleon's prison in $18 \mathbf{r}_{5}$. St Helena was taken in the early part of the 16 th century by the Dutch, and passed into the hands of the English in the middle of that century. Another Portuguese discovery was the most southern of those isolated oceanic islets, Tristan d'Acunha, which bears the name of its discoverer, but which, so far as occupation goes, has always been a British possession ${ }^{1}$.

On the East coast of Africa Portuguese colonization did not commence until the r6th century had begun, and Vasco da Gama, after rounding the Cape, had revealed the existence of old Arab trading settlements and sultanates between Sofala and Somaliland.

The need of ports of call on the long voyage to India caused the Portuguese to decide soon after Vasco da Gama's famous voyage to possess themselves of these Arab settlements, the more so because hostilities against the "Moors" were a never-ending vendetta on the part of Spaniard and Portuguese, while the conquest was at that date an easy one, as the Portuguese had artillery and the East African Arabs had none. By 1520 , the Portuguese had ousted the Arabs and had

1 Most prominent features, and some countries on the west and south coasts of Africa from the Senegal round to the Cape of Good Hope and Moçambique, bear Portuguese names: Cape Verde is "The Green Cape," Sierra Leone (Serra Leoa) is "The Lionlike Mountains," Cape Palmas "The Palm-trees Cape," Cape Coast is Cabo Corso "The cruising Cape," Lagos is "The Lakes," Calabar (Calabarra) is "The bar is silent," Cameroons is Camaroẽs "prawns," Gaboon is Gabão "The Hooded Cloak" (from the shape of the estuary), Corisco is "Lightning," Cape Frio is "The Cold Cape" and Angra Pequena is "The Little Cove," and so on. All the prominent points on the Liberian coast, and most of the Niger mouths, have Portuguese names. 
occupied in their stead Kilwa, Zanzibar, Pemba, Mombasa, Lamu, Malindi, Brava (Barawa), and Magdishu (Magadoxo), all north of the Ruvuma river. .South of that river they had taken Sofala and Moçambique. Here they had, it is said, established a trading station in ${ }^{1} 5^{\circ} 3$; but Moçambique island ${ }^{1}$ was not finally occupied by them till 1507 , when the existing fortress was commenced and built by Duarte de Mello. The fort was then and is still known as "the Praça de São Sebastião." It had been decided before this that Moçambique should be the principal place of call, after leaving the Cape of Good Hope, for Portuguese ships on their way to India ; but, when in ${ }^{5} 505$ the Portuguese deliberately sanctioned the idea of a Portuguese East African colony, they turned their attention rather to Sofala as its centre than to Moçambique. Sofala, which is near the modern Beira, was an old Arab port and sultanate, and had been for some 1500 years the principal port on the south-east coast of Africa, from which the gold obtained in the mines of Manika (Monomotapa, i.e. Southern Rhodesia) was shipped to the Red Sea and the Persian Gulf. Consequently the first proposed Portuguese settlement on the East coast of Africa was entitled "the Captaincy of Sofala." But later on Moçambique grew in importance, and eventually gave its name to the Portuguese possessions in East Africa.

The Quelimane river, taken to be the principal exit of the Zambezi by the Portuguese, was discovered and entered by Vasco da Gama in the early part of $\mathrm{r}_{49} 8$, and was by him called the "River of Good Indications." He stayed a month on this river, where there seems to have been, on the site of the

${ }^{1}$ This is a little coral islet about 2 miles long by $\frac{1}{4}$ of a mile broad, situated between 2 and 3 miles from the coast (a shallow bay), in 15 degrees south latitude, where the East African coast approaches nearest to Madagascar. It commands the Moçambique Channel. Its native name was probably originally Musambiki. By the neighbouring East African tribes it is now called Muhibidi, Msambiji, and Msambiki. It has sometimes been the only parcel of land remaining in Portuguese hands during the vicissitudes of their East African empire. 
present town of Quelimane, a tradiug station resorted to by the Arabs, who were even then settled Zambezia. The name Quelimane (pronounced in English Kelmane) is stated by the early Portuguese to have been the name of the friendly chief who acted as intermediary between them and the natives, but it would rather appear to have been a corraption of the Swahili-Arabic word "Kaliman," which means "interpreter."

The first "factory" or Portuguese trading starion at Quelimane was established about the year 1544 ; and by tris time the Portuguese had heard of the River of Sena (as they ealled the Zambezi) and of the large Arab settlement of Sena on- its banks. They had further heard both from Quelimane and from Sofala of the powerful empire of Monomotapa ${ }^{1}$, and especially of the province of Manika, which was reported to be full of gold. Having found it too difficult to reach Manika from Sofala, owing to the opposition of the natives, they resolved to enter the country from the north by way of Sena, on the Zambezi ; consequently, in 1569 , an exceptionally powerful expedition left Lisbon under the command of the Governor and Captain-General Francisco Barreto. After a preliminary tour up and down the East coast of Africa as far as Lamu, and a rapid journey to India and back, Francisco Barreto with his force, which included cavalry and camels, landed at Quelimane, and set out for Sena. The expedition was accompanied, and, to a certain extent, guided by a mischief-making Jesuit priest named Monclaros, who wished to avenge the assassination of his fellow-priest, Gonçalo de Silveira, martyred not long previously in the Monomotapa territories. Francisco Barreto found on arriving at Sena that there was already a small

1 A corruption of Mwene-mutapa. According to some authorities this title meant "Lord Hippopotamus," the hippopotamus on the Zambezi above Tete being looked upon as a Totem or sacred animal inclicative of the royal clan; but in my personal opinion Mwene-mutapa is really "Lord of the Mine, or gold mining," mutapo or mtapo being a shallow pit dug in clay or sand for mining, or washing gold. 
Portuguese settlement buil alongside an Arab town. These Arabs appear to have got: in very well with the first Portuguese traders, but they evidently took umbrage at Barreto's powerful expedition, and are accused of having poisoned the horses and camels. What realy took place, however, seems to have been that the horses and camels were exposed to the bite of the Tsetse fly, and died in consequence of the attacks of this venomprs insect. From Sena, Barreto sent an embassy to the Emperor of Monomotapa, whom he offered to help against a revoiled vassal, Mongase. After receiving an invitation to visit the emperor, a portion of the Portuguese force commenced to 'ascend the right bank of the river Zambezi, but apparently never reached its destination, because it was so repeatedly. attacked by the hostile natives that it was compelled to return to Sena. Shortly afterwards there arrived the news of a revolt at Moçambique, and consequently Barreto, together with the priest Monclaros, having handed over the command of the expedition to a lieutenant, entered a canoe, descended the Zambezi to the Luabo mouth, and from there took passage in a dau to Moçambique. He and Monclaros subsequently returned to Sena, but Barreto died soon after his arrival. The Portuguese chroniclers of this expedition write with considerable bitterness of the Jesuit Monclaros, to whose counsels most of the misfortunes and mistakes are attributed. The expedition after Barreto's death returned to Moçambique, and attempted later on to enter Monomotapa by way of Sofala, but was repulsed.

For some time to come further exploration of the Zambezi or of the interior of Moçambique was put a stop to by the struggle which ensued with the Turks. Towards the end of the I6th century (in 1584 ), following on the conquest of Egypt and at the instigation of Venice, the Turkish Sultan sent a powerful fleet out of the Red Sea, which descended the East coast of Africa as far as Mombasa, and prepared to dispute with Portugal the dominion of the Indian Ocean. The 
Turks, however, were defeated with considerable loss by the Adrniral Thomé de Sousa Coutinho; and Portuguese domination was not only strengthened at Zanzibar and along the Zanzibar coast, but was also affirmed along the south coast of Arabia and in the Persian Gulf.

At the end of the 16 th century the Portuguese had terrific struggles with the natives in the interior of Monomotapa, behind Kilwa, on the mainland of Moçambique ${ }^{1}$, and in the vicinity of Tete on the Zambezi; and shortly afterwards appeared the first Dutch pirates in East African waters, some of whom actually laid siege to Moçambique. In 1609 there arrived at Moçambique the first Portuguese Governor of the East coast of Africa, this province having been separated from the Portuguese possessions in India, and withdrawn at the same time from the spiritual jurisdiction of the Archbishop of Goa, and placed under the Prelate of Moçambique. Meantime the efforts to reach the gold-mines to the south of the Zambezi had been so far successful that a considerable quantity of gold was obtained not only by the officers, but even by the private soldiers of the different expeditions; but the expectations of the Portuguese as to the wealth of gold and silver (for they were in search of reported silver-mines on the Zambezi) were considerably disappointed; and later on, in the 17 th century, their interest in these East African possessions waned, largely on account of the poor results of their mining operations. The Dutch in 1604-7 twice attacked Moçambique, and again in 1662 sought to obtain possession of the little fortress island. In the middle of the I 7 th century, however, a new source of wealth was discovered-the Slave Trade-which

1 Where they have not yet brought under subjection the Muhammadan Makua and the Arab half-castes of Angoshe. The chief native foes of the Portuguese in East Africa at the close of the 16 th century were the Ba-zimba, one of those Zulu-like marauding tribes like the modern Angoni, which would range over hundreds of miles in a few months and commit devastations that left their effects for nearly a century. 
for two hundred years following gave a flickering prosperity to these costly establishments on the East coast of Africa. In 1645 the first slaves were exported from Moçambique to Brazil. This action was brought about by the fact that the province of Angola had fallen for a time into the hands of the Dutch, and, therefore, the supply of slaves to Brazil was temporarily stopped.

In consequence of this, Moçambique and the Zambezi for some years replaced West Africa as a slave market. In I649 the English first made their appearance on this coast; and two years afterwards the Portuguese were perturbed by the definite establishment of a Dutch colony at the Cape, and by the establishment of French factories on the coast of Madagascar - events which are prophetically described by a contemporary writer as "Quantos passos para a ruina de Moçambique!""So many steps towards the ruin of Moçambique!" At the same time the Arabs in the Persian Gulf drove the Portuguese out of Maskat, and towards the end of the 17 th century began to attack their possessions on the Zanzibar coast. By 1698 Portugal had lost every fortress north of Moçambique; and in that year this, their last stronghold, was besieged straitly by the Arabs and very nearly captured. In fact it was only saved by the friendly treachery of an Indian trader who warned the Portuguese of an intended night attack. All of these posts on the Zanzibar coast were finally abandoned ${ }^{1}$ by the Portuguese in the early part of the 18 th century by agreement with the Imam of Maskat, who founded the present dynasty of Zanzibar. In $175^{2}$ this fact was recognized by the formal delimitation of the Portuguese possessions in East Africa at the time when they were also again removed from any dependency on the Governor of Goa. In this decree of the r gth of April, I 752, the government of Moçambique was described as extending over "Moçambique, Sofala, Rio de Sena (Zambezi), and all the coast of Africa and its continent between Cape Delgado

1 Except Mombasa, which was retaken and held between 1728 and 1729 . 
and the Bay of Lourenço Marquez (Delagoa Bay)." Hitherto commerce in Portuguese East Africa had been singularly restricted, and after being first confined to the Governors and officials of the state, was then delegated to certain companies to whom monopolies were sold. In $\mathrm{I} 687$ there was a fresh arrival, after a considerable interval, of Indian traders, who established themselves on the Island of Moçambique ; and by degrees the whole of the commerce of Portuguese East Africa was thrown open freely to all Portuguese subjects, though it was absolutely forbidden to the subjects of any other European power, and considerable anger was displayed when French and Dutch endeavoured to trade on the islands or on the coast in the province of Moçambique. In the middle of the r8th century the practice of sending the worst stamp of Portuguese convicts to Moçambique was unhappily adopted in spite of the many protests of its governors. About this same time also there occurred a series of disasters attributable to the deplorable mismanagement of the Portuguese officials. The fortresses of the gold-mining country of Manika had to be abandoned, like $Z_{\text {umbo }}{ }^{1}$ on the upper Zambezi. The forts on the mainland opposite Moçambique were captured by an army of Makua; and the Island of Moçambique itself very nearly fell into the hands of the negroes of the mainland.

Towards the close of the I 8 th century, however, occurred a great revival. In fact, the period which then ensued was the only bright, and to some extent glorious phase of Portuguese dominion in South-east Africa. A remarkable man, Dr Francisco José Maria de Lacerda e Almeida (a Brazilian), was made Governor of Zambezia at his own request, and commenced the first scientific exploration of southern Central Africa. His journey resulted in the discovery of the Kazembe's division of the Lunda empire, a country on the Luapula and Lake Mweru. It is interesting to note that in 1796 , only one year after the

1 Zumbo was given up (though it was never much more than a Jesuit Mission Station) in 1740 . 
British had seized Cape Town, Dr Lacerda predicted that this action would lead to the creation of a great British Empire in Africa, which would stretch up northwards like a wedge between the Portuguese colonies of Angola and Moçambique. But Dr Lacerda in time fell a victim to the fatigues of his explorations ; and Portuguese interest in East Africa waned before the life-and-death struggle which was taking place with France in Portugal itself. Long prior to this also, in the middle of the I 8th century, the Jesuits had been expelled from all Portuguese East Africa; and with them had fallen what little civilization had been created on the upper Zambezi. In fact, it may be said that after Lacerda's journey the province of Moçambique fell into a state of inertia and decay, until Livingstone, by his marvellous journeys, not only discovered the true course of the Zambezi river, but drew the attention and interest of the whole world to the development of tropical Africa.

On all old Portuguese maps, indeed on all Portuguese maps issued prior to Livingstone's journeys, there was but scanty recognition of the Zambezi as a great river. It was usually referred to as the "rivers of Sena," the general impression being that it consisted of a series of parallel streams. No doubt this idea arose from its large delta; on one or two maps, however, the course of the Zambezi is laid down pretty correctly from its confluence with the Kafue to the sea; but the fact cannot be denied that its importance as a waterway was quite unknown to the Portuguese, who usually reached it overland from Quelimane and travelled by land along its banks in preference to navigating its uncertain waters. The Shire was literally unknown, except at its junction with the Zambezi. The name of this river was usually spelt Cherim, but its etymology lies in the Mañanja word chiri, which means "a steep bank." Admiral W.F. W. Owen, who conducted a most remarkable series of surveying cruises along the West and East coasts of Africa in the early part of the I gth century, was the first to make the fact clearly known that a ship of light 
draught might enter the mouth of the Zambezi from the sea and travel up as far as Sena.

Livingstone's great journey across the African continent in the earlier fifties attracted the attention of the British nation and Government to the possibilities of this region, so highly favoured by nature in its rich soil and valuable productions. Livingstone was appointed Consul at Quelimane, and placed at the head of a well-equipped expedition intended to explore the Zambezi river and its tributaries. Prior to this the Portuguese had abolished the slave trade by law, though slavery did not cease as a legal status till 1878, and had thrown open Portuguese East Africa to the commerce of all nations; and undoubtedly these two actions were an encouragement to the British Government to participate in the development of Southeast Africa, especially as Livingstone's journeys had shown conclusively that the rule of the Portuguese did not extend very far inland, nor to any great distance from the banks of the lower Zambezi. 'The second Livingstone expedition may, therefore, be regarded as the first indirect step towards the foundation of the present Protectorate over British Central Africa (Nyasaland and Northern Rhodesia), which dependencies follow to a great extent in their frontiers the delimitations suggested by Dr Livingstone at the close of his second expedition.

A jealous feeling, however, arose at the time of Livingstone's explorations between Portuguese and British; and considerable pressure was brought to bear on the British Government to abandon the results of Livingstone's discovery. These representations, together with other discouraging results of British enterprise in East and West Africa, induced the British Government during the later sixties and earlier seventies to hold aloof from any idea of British rule in the interior of the continent. Meantime the Portuguese were making praiseworthy efforts to develop these long-neglected possessions. Great improvements were effected, and a wholly 
modern aspect of neatness and order was given to the towns of Quelimane and Moçambique, which in many respects compared a few years ago favourably with other European settlements on the East coast of Africa. Large sums were spent on public works; indeed, in the year 1880 , not less than $£$ I57,000 was provided by the mother-country for the erection of public buildings in Portuguese East and West Africa; and at this period the handsome hospital in the town of Moçambique was erected, together with a good deal of substantial road and bridge making. A good many more military posts were founded; and Zumbo, on the central Zambezi, at the confluence with the Luangwa, was reoccupied. Nevertheless, Livingstone's work, and especially his death, inevitably drew the British to Zambezia. In 1875 the first pioneers of the present missionary societies travelled up the Zambezi and arrived in the Shire highlands. In 1876 the settlement of Blantyre was commenced, and the foundations of British Central Africa were laid. These actions impelled the Portuguese to greater and greater efforts to secure the dominion to which they aspired-a continuous belt of empire stretching across the continent from Angola to Moçambique; and an expenditure exhausting for the mother-country was laid out on costly expeditions productive not always of definite or satisfactory results. This policy culminated in the effort of Serpa Pinto to seize by force the Shire highlands, despite the resistance offered by the Makololo chiefs $^{1}$, who had declared themselves under British protection. Thence arose the intervention of the British Government and a long discussion between the two powers, which eventually bore results in a fair delimitation of the Portuguese and British spheres of influence, and the annulling of any inimical feeling between England and Portugal in their African enterprises. Moçambique proper

1 These Makololo chiefs were formerly headmen of Livingstone's second expedition, left behind by him on the Cataract Shire to stiffen the resistance of the timid natives against the Muhammadan slave raiders. 
(i.e. the provinces N.E. of the Zambezi) has proved a costly dependency to the mother-country. From the year 1508 to I893 there was always annually an excess of expenditure over revenue, sometimes as much as an annual deficit of $£ 50$, 000. In the year 1893 , for the first time since the creation of the colony, a small surplus was remitted to Lisbon. It is questionable whether this possession will ever prove profitable to Portugal. At the present day nearly two-thirds of the trade is in the hands of non-Portuguese (Indians and Europeans). The bulk of the wholesale commerce between Ibo and Quelimane is carried on by German, Dutch, and French firnıs; and the retail trade is conducted by British Indians, or by natives of Goa and other Portuguese Indian possessions.

The Chartered Company of "Nyassa" has a virtual monopoly of the hinterland trade between Lake Nyasa and the lbo coast, and administers the country between the Lurio river on the south and the Ruvuma on the north. In Portuguese Zambezia exists the Zambezia company with a number of minor concessionaires ; and most of these hold prazos or leases of prescribed areas, in which they have exclusive trading rights and a virtual mastery over the natives, who are consequently at times rebellious when exactions of labour in lieu of or in addition to taxes are levied on them. There is and has been very little real Portuguese colonization of the Moçambique and Zambezia provinces. The vicious spirit of the old slave trade days still taints the local administration. The Angoshe region between Moçambique Island and the northern vicinity of the Quelimane river is almost independent of Portuguese authority under powerful Arab-Negro Muhammadan "Sultans," who until quite recently shipped over many dau-loads of slaves to Madagascar.

The chief article of trade in the Moçambique province is ground-nuts-the oily seeds of the Arachis hypogaa, a species of leguminous plant, the seed-pods of which grow downwards into the soil. These ground-nuts produce an excellent and 
palatable oil which is hardly distinguishable in taste from olive oil, and indeed furnishes a considerable part of the socalled olive oil exported from France. This, perhaps, is the reason why the ground-nuts find their way finally to Marseilles. The india-rubber of Moçambique is of good quality and fetches a high price in the market. Other exports are oil-seeds derived from a species of sesamum, copra, wax, ivory and sugar. Some copper and malachite are exported from the Nyassa company's territories north of the Lurio. A few enterprising people started coffee plantations on the mainland near Moçambique some years ago; but the local Portuguese authorities immediately put on heavy duties and taxes, so that the coffeeplanting industry was soon killed. The same thing may be said about the coco-nut palm. At one time it was intended to plant-this useful tree in large numbers along a coast singularly adapted for its growth; but, owing to the fact that the local Portuguese Government imposed a yearly tax on each palm, the cultivation of the coco-nut was given up. The ivory comes chiefly from Ibo and Cape Delgado, and also from Quelimane, and is derived from elephants still existing in the Zambezi basin and in the eastern parts of Nyasaland. Nevertheless, most of the products above alluded to, with the exception of ivory, are only furnished by the fertile coast belt ; for beyond the twenty-mile strip of cultivated land which extends more or less down the whole coast of Moçambique, the interior of the country is dry and arid except in certain favoured river valleys, and in the splendid mountain region of Namuli, between Angoshe and the upper Shire river.

Portuguese influence, though not always Portuguese rule, was carried southward to the northern shore of Delagoa Bay at the end of the $I 7$ th century. Here the settlement of Lourenço Marquez was founded as a trading station. At the beginning of the r 8 th century this Portuguese station was abandoned; and the Cape Dutch came and built a factory there, which however was destroyed by the English in 1727 . Nevertheless Portugal 
continued to assert her claims to Lourenço Marquez; and when, in I 776, an Englishman named Bolts (formerly in the employ of the English East India Company), who had entered the service of Maria Theresa in order to found an Austrian Company to trade with the East Indies from Flanders, came thither with a large following composed of Austrian-Italian subjects, and made treaties with the chiefs of Delagoa Bay, the Portuguese protested and addressed representations to the Austrian Government. These protestations would have been of but little avail had not a terrible outbreak of fever carried off almost all the European settlers. The Austrian claim was therefore abandoned; and the Portuguese continued at intervals to make their presence felt there by a quasi-military commandant or a Government trading establishment. When Admiral Owen's expedition visited Delagoa Bay between I 822 and 1824 , they found a small Portuguese establishment on the site of the present town of Lourenço Marquez ${ }^{1}$. Realizing the importance of this harbour, and finding no evidence of Portuguese claims to its southern shore, Captain Owen concluded treaties with the King of Tembe by which the southern part of Delagoa Bay was ceded to Great Britain. The Portuguese made an indirect protest by removing the British flag during Captain Owen's absence, but the flag was rehoisted in I824. Owen's action, however, was not followed up by effective occupation, though on the other hand the Portuguese did nothing to reassert their authority over the south shore of the bay until, in the sixties, the growing importance of South Africa led the British to reassert their claims. The matter was submitted to arbitration, and Marshal MacMahon, the President of the French Republic, was chosen as arbitrator, His verdict-a notoriously biassed one-not only gave the Portuguese the south shore of Delagoa Bay, but even more

1 The modern and existing town of that name was not founded till I867. 
territory than they actually laid claim to. Britain had to some extent prepared herself for an unfavourable verdict by a prior agreement providing that whichever of the two disputing powers came to possess the whole or part of Delagoa Bay should give the other the right of pre-emption.

Reading the vast mass of evidence brought forward and preserved in Blue Books, it seems to the present writer that any dispassionate judge would arrive at these conclusions: That the Portuguese claim to the northern shore of Delagoa Bay was valid; but that over the southern shore of this important inlet they had exercised no occupation and raised no claim until the arrival of Admiral Owen and his treatymaking; and that even after the action taken by Admiral Owen, they did nothing beyond removing the flag he had raised, and effected nothing in the way of occupation or treaty-making on their own account. Owen's procedure was not repudiated by the British Government, who besides had other rights over the territory in question inherited from the Dutch. Owen's intervention was not, it is true, succeeded by immediate occupation; and the British case would have been a very weak one judged by the severe rules of the Berlin Convention of r 884. But then, if Portuguese territory in East Africa had been delimited by the same severe rules, it would have been reduced to a few fortified settlements. Great Britain had a fair claim to the south shore of Delagoa Bay; and the award of Marshal MacMahon was a prejudiced one, said to have been mainly due to the influence of his wife, who was ardently in favour of the Portuguese for a variety of reasons.

In $1887-9$ a railway was constructed under a concession by the Portuguese between Lourenço Marquez (Delagoa Bay) and the Transvaal border by a group of English and American capitalists, with results which are set forth in Chapter VII. This railway was seized and extended by the Portuguese in 1889 . 
Subsequently to the Delagoa Bay award, the Portuguese made determined efforts to explore and conquer the South-east coast of Africa and the countries along the lower Zambezi. To the extreme north of their Moçambique possessions they had a dispute with the Sultan of Zanzibar as to the possession of Tungi Bay and the south shore of the mouth of the river Ruvuma. After their disastrous struggle with the Arabs in the I 7 th and 18 th centuries, the Portuguese had defined the northern limit of their Fast African possessions as Cape Delgado ; and Cape Delgado would have given them the whole of Tungi Bay, though not the mouth of the Ruvuma. It is evident that the Sultan of Zanzibar was trespassing as a ruler when he claimed Tungi Bay, though not when he claimed the mouth of the Ruvuma. Portugal, losing patience at the time of the division of the Zanzibar Sultanate between England and Germany, made an armed descent on Tungi Bay in 1889 , and has since held it, though the Germans withdrew from her control the Ruvuma mouth, which they claimed as an inheritance of the Sultan of Zanzibar.

The establishment of the British South African Company in 1889 and the consequent development of Mashonaland and Matebeleland subjected the Portuguese territories south of the Zambezi to a searching scrutiny on the part of these merchant adventurers, who laid hands on behalf of Great Britain on all territory where the Portuguese could not prove claims supported by occupation or ruling influence. The strongest temptation existed to ignore Portuguese claims on the Pungwe river and to push a way down to the sea at Beira; but a spirit of justice prevailed, and no real transgression of Portuguese rights was sanctioned by the British Government, or indeed attempted by the Company. In June, I89x, after several unsuccessful attempts, a convention was arrived at between England and Portugal, which defined tolerably clearly the boundaries of British and Portuguese territories in Southeast, South-west, and South-central Africa. Rights of way were 
obtained under fair conditions both at Beira and at Chinde $\left(\right.$ Zambezi Delta $\left.{ }^{1}\right)$. Since 189 I a friendly feeling has been growing up between the British and the Portuguese.

The Portuguese have been making steady efforts to bring under control their richly endowed East African province. For some time after their settlement with Great Britain they were menaced in the south by the power of Gungunyama, a Zulu king who ruled over the Gaza country, and had been in the habit of raiding the interior behind the Portuguese settlements of Lourenço Marquez and Inhambane. The Portuguese warred against him for three years without satisfactory results, until Major Mouzinho de Albuquerque, by a bold stroke of much bravery, marched into Gungunyama's camp with a handful of Portuguese soldiers and took the king prisoner. For this gallant action he was eventually promoted to be GovernorGeneral of Portuguese East Africa, and then did something towards bringing under subjection the turbulent Makua tribes opposite Moçambique.

The greater portion of their trans-Zambezian possessions along the East coast and immediately south of the lower Zambezi and north of Inhambane and the Sabi River was in I 89 I handed over to the administration of a Chartered Company, - which although theoretically Portuguese derives its capital mainly from English, French and Belgian sources, and is mainly managed by Englishmen. This "Moçambique Company" since its institution has done much to open up the country; the railway construction however is chiefly due to the British South African Company, who have constructed a line of railway from the capital, Beira, to the eastern frontier of Southern Rhodesia. In addition, under the auspices of the Moçambique Company, a northern line is being constructed to the Zambezi and across that river to join the Shire Highlands

1 The use of the Chinde mouth of the Zambezi gives free water communication between the outer world and Nyasaland, by way of the Zambezi and Shire rivers. 


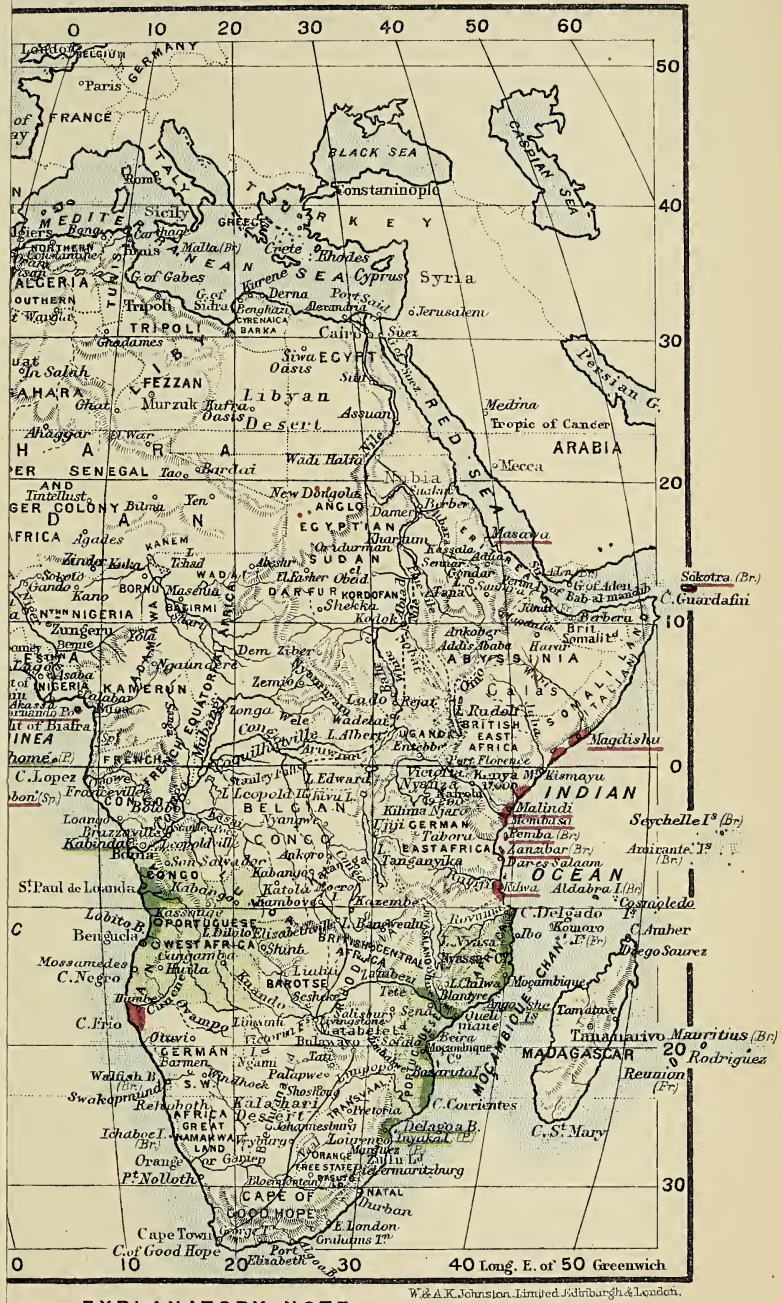

EXPLANATORY NOTE

Area of Portuguese Possessions in 1820

Possessions lost or exchanged

1912 

PORTUGUESE AFRICA

Plate III.

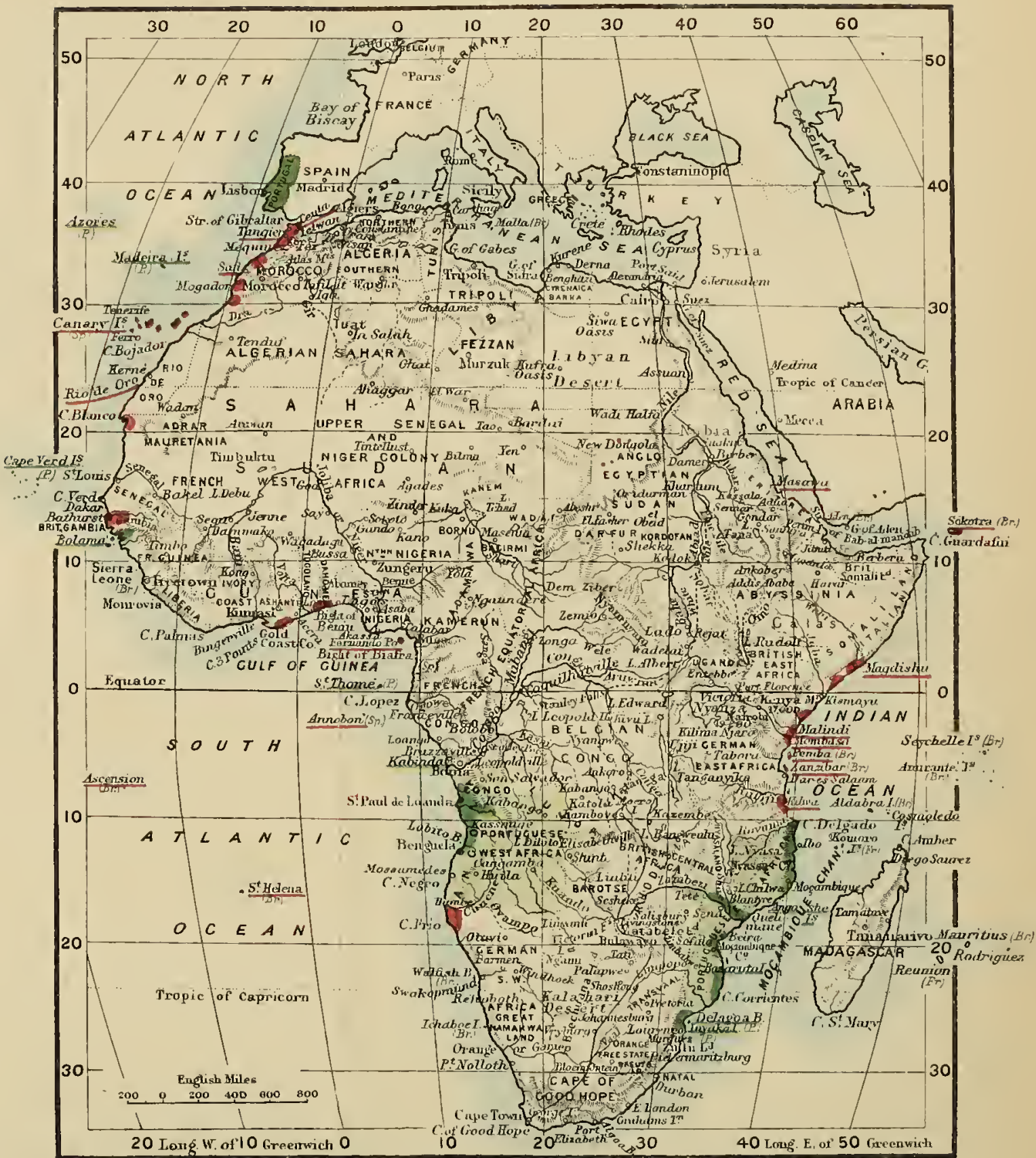



railway at Port Herald. When this is finished, Beira, instead of Chinde or Quelimane, will become the seaport of British Nyasaland.

South of the Sabi River and up to the frontiers of British South Africa the country is directly ruled by Portugal, the large town of Lourenço Marquez (Delagoa Bay) being now the supreme capital of the State of East Africa, as the Moçambique provinces are called. Here resides the Governor-General, with subordinate officials at Moçambique, Quelimane, Sena, Zumbo, Tete, Chinde and Inhambane.

The recent revolution in Portugal (1910), and the change from a monarchy to a republic, have slightly affected the Portuguese African possessions for the better. Long-standing abuses are being enquired into, and some remedies are being applied. Yet the resources of little Portugal are grievously strained in men and money to maintain rule, law, and order in these vast African possessions - possessions which stretch from North-west to South-east Africa and include an area of 794,000 square miles. In 1898 , when the unsettled state of Africa and the rivalry between Britain, Germany, and France made it advisable to forecast an allotment of the Portuguese colonies, should they slip from the grasp of Portugal or be offered for sale, an agreement was entered into between Britain and Germany partitioning the Portuguese African possessions into spheres of influence. But it is understood that at a later date Great Britain, on renewing her old alliance with Portugal, guaranteed her the undisturbed possession of her colonial dominions. 


\section{CHAPTER V}

\section{SPANISH AFRICA}

THE enterprise of Spain in Africa was relatively small, the greater part of Spanish energy being devoted to founding an empire in the New World, in the far East, in Italy and Flanders. It was also knit up politically at first with the Portuguese colonial empire. Nevertheless Spain has left very distinct marks of her influence on North-western Africa in both language and culture. This in past times arose from the Spanish Moors expelled from Spain, but bringing much Spanish valour, ingeniousness, art, and pride into the life of Morocco, Algeria, Tunis, and Timbuktu.

When Portugal was commencing to acquire oversea dominions in the Açores (I437-66), Madeira (1430), and on the coast of Morocco, Christian Spain was still divided into three kingdoms-Castile, Aragon and Navarre-and the two former were concentrating their energies on the destruction of the Moorish kingdom of Granada (not accomplished till I492). But the monarchs of Castile and Aragon became jealous of the oversea expansion of Portugal ; and that power deemed it wise to surrender to Castile in $\mathbf{1} 479$ the Portuguese claim to the Canary Islands.

The Canary Islands had been partially conquered by a Norman adventurer, Jean de Béthencourt, in $1402-6$, more or less under the suzerainty of Castile ; and the Canary kingdom passed into the hands of Ferdinand and Isabella in 1476 . Prior to the final occupation of the Spaniards the islands were 
inhabited by a Berber race of some antiquity known as the Guanches. These were partly exterminated and partly absorbed by the Spanish settlers, to whom they were so much akin in blood that complete race fusion was rendered easy, especially as the Guanches had not been reached by Muhammadanism. The Canary Islands were an invaluable steppingstone for the trans-Atlantic ventures of the Spanish ships during the first fifty years of American discoveryand colonization. Many Spanish and Guanche colonists - the Isleños or Islandersproceeded from this archipelago of seven islands to the greater Antilles; and there are plantations and villages to-day in Cuba and Porto Rico which possess Berber names derived from those of the Guanche prisoners or colonists who founded them. It took Spain however fifteen years to conquer the brave and warlike Guanches, a task not accomplished until I495. The wonderful scenery, genial climate, and fertile soil attracted the attention of the British in the I8th century; and one or two attempts were made to acquire this archipelago, but in face of the gallant resistance offered by the islanders (it was at Tenerife that Nelson lost his arm in an attempted landing) British cupidity was foiled. In I833 the archipelago was made a separate government-a province of Spain by itself; but in I902 a movement for home rule was severely repressed. The Canary Islands now form politically part of Spain. They are thoroughly civilized, well governed and prosperous. The two principal islands, Tenerife and Grand Canary, are favourite health resorts; and the whole group owes much to British capital, enterprise and shipping for its industrial and agricultural development.

At the close of the $5_{5}$ th century the Spaniards followed up their expulsion of the Moors from Spain by attacking them on the North coast of Africa. They established themselves at Melilla ${ }^{1}$, Oran, Algiers ${ }^{2}$, Bugia, Bona, Hunein, Susa, Monastir,

1 In 1490 .

2 Or the rock, or "Peñon," overlooking the town, seized and garrisoned 
Mehedia, Sfax, and Goletta ${ }^{1}$. The apogee of Spanish power in North Africa was reached about I535, at which time the Spaniards alternately with the Turks dominated the Barbary States. Then, owing to victory inclining to the Turkish corsairs $^{2}$, the Spaniards' hold over the country began to decline. A resolute attempt was made by Charles V in I $54 \mathbf{I}$ to take and hold the town of Algiers, the Spanish having lost Peñon, a rock fortress overlooking part of the town. This

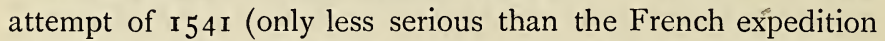
of I 880) would probably have succeeded but for a torrential downpour of rain, which made the surrounding country impassable to the Spanish guns and cavalry, and led to a terrible rout. Had Algiers fallen at this time, its capture might have resulted in a Spanish empire over North Africa. As it was, this twentyfour hours' downpour of rain changed the future of the northern part of the continent, or rather prevented a change which might have had very far-reaching results. Charles $\mathrm{V}$ had invaded Tunis in $\mathbf{I} 535$ at the appeal of the last sovereign but one of the House of Hafs, who had been dispossessed by the Turkish pirate, Khaireddin. Although his intervention was ultimately unsuccessful, and his protégé was killed and

by Cardinal Ximenez, in $\mathbf{5}$ 509. It was taken by Khaireddin, the Turkish corsair, in 1530 .

1 Held by Spain from 1535 to 1574 .

2 The following is a résumé of the history of the first intervention of Turkey in Barbary. In 1504 Uruj (Barbarossa I), a pirate of mixed TurcoGreek origin, attracted by the rumours of American treasure-ships in the western Mediterranean, captured Algiers ( 1516$)$ and Tlemsan ( 1517 ); but he was defeated and killed by the Spaniards coming from Oran. His younger brother Khaireddin (Barbarossa II) appealed to Turkey, which had just $\left(\mathrm{I}_{5} \mathrm{I} 8\right)^{-}$conquered Egypt, and received from Sultan Selim the title of Turkish Beglerbeg of Algiers and a reinforcement of 2000 Turks. $\mathrm{He}$ mastered almost all Algeria, was made Admiral of the Turkish fleet in I533, captured Tunis in 1534, was driven out by Charles V, and retired to Turkey in I535. His successors were sometimes Sardinian, Calabrian, Venetian, Hungarian renegades; but among the more celebrated was Dragut, a Turk of Karamania. 
succeeded by his son, who more or less intrigued with the Turkish corsairs, the Spaniards retained their hold on Goletta till $\mathbf{5 7 4}$, the Turks having then definitely intervened in the affairs of Tunis. The Spaniards surrendered Goletta to the renegade pirate, Ochiali ; and with it went all their influence over Tunis. An expedition which they had sent to the island of Jerba, under the Duke de Medina-Cœli and the younger Doria, ended in a great disaster-a defeat at the hands of the Moorish pirates who massacred, it is said, not less than r 8,000 Spaniards (May, I560). Their skulls were built into a tower, which remained visible near the town of Humt Suk till I840, when the kindly Maltese settlers on this island obtained permission from the Bey of Tunis to give Christian burial to the Spanish skulls, which now are interred in the Christian cemetery at Humt Suk. For brief intervals the Spaniards held other coast towns ${ }^{1}$ of Tunis, but in retiring from Goletta they withdrew from all further hold over the Regency.

They finally quitted Oran in I79I, after a terrible earthquake. They had been turned out of this place in 1708 , but recaptured it after a period of 24 years, and held it for 59 years longer. Spain only retained down to the present day on the north coast of Morocco the little island of Melilla ${ }^{2}$, the island of Alhucemas, the rock of Velez de la Gomera, and the rocky promontory of Ceuta. Ceuta (and Tetwan, which she once possessed) she inherited from Portugal after a separation had once more taken place between the two monarchies in $\mathrm{I} 640$.

Awakened from the torpor which followed the Napoleonic wars and the home struggles for constitutional government by the French activities in Algeria, Spain suddenly seized the Chafarinas Islands ${ }^{3}$ in 1849 so as to forestall the French. On

1 Susa, Sfax, and Monastir, which were lost to the Turks by 1550 .

2 The oldest of her continental African possessions, dating from 1490 .

${ }^{3}$ The Chafarinas Islands are off the mouth of the Muluya river, neal the Algerian frontier. 
the strength of some clause in a treaty concluded after the war with the Moors (1859-60), Spain secured from Morocco the town of Ifni, near Cape Nun on the Atlantic coast and nearly opposite the Canary Islands, but made no attempt to occupy it. From the middle of the I 9 th century onwards an increasing number of Spaniards, chiefly of the artisan and peasant class, emigrated from Andalucia to the Oran coast of Algeria, with the result that Western Algeria to-day contains a Spanishspeaking population of about 150,000 . Yet prior to the oth century, Spain, distracted by home affairs and troubles in Cuba, seemed willing to let Morocco drift beyond her control to that of England or Germany, until the revival of Spanish industries and trade and the loss of her colonies in America and the Pacific decided her to plead with Britain and France that a sphere of influence should be reserved for Spain on the North Morocco coast. In I9ro-I I the region between Melilla and the Muluya mouth was brought under Spanish control; and in I9I I Spanish troops occupied all the important towns on or near the coast between Melilla and Kasr al Kabīr on the Atlantic, except Tangier (which will probably be internationalized). Spain in fact will sooner or later annex all the Rif country of North Morocco. In the south she claims a very large area between Cape Jubi and the Anti-Atlas mountains.

Spain had allowed her influence over the coast opposite the Canary Islands ("Santa Cruz de Mar Pequena") to lapse between the end of the I6th century and the scramble for Africa which commenced in 1884 . At this period an English trading firm with agencies in the Canary Islands had been established at Cape Jubi, south of the Morocco border; and British influence for a time dominated the coast immediately opposite the Canary Islands, and arrested Spanish action in that neighbourhood. After the scramble for Africa commenced, however, the Spanish, who were greatly interested in the north-west coast (for its valuable fisheries in which the Canarian fishermen 
were employed), raised their flag in 1885 at an inlet called the Rio d'Ouro', and declared a Protectorate over the Sahara coast between Cape Blanco and Cape Bojador and for a varying distance inland. This Protectorate has since been extended farther to the north beyond Cape Bojador; but the Empire of Morocco theoretically extends to the south of Cape Jubi to meet the Spanish frontier, the Moorish Government having bought up the claims of the English company. The inland boundary of this Spanish Protectorate has recently been settled as between France and Spain, and comprises an approximate area of 73,000 square miles, mainly desert, but extending inland to the Adrar hills. The only establishment of any importance or size is on the Rio de Oro inlet, not far from the islet which the Carthaginians once frequented. No doubt before long the Rio de Oro Protectorate will be fused with the territory which Spain claims in South-west Morocco.

In 1778 Spain, which had become deeply interested in the slave trade on the West coast of Africa, on account of the need for a regular supply of slaves to her South American possessions, obtained from Portugal the cession of the island of Fernando Pô, and also took over the island of Anno Bom -the last of this series of equatorial volcanic islands and the smallest. About the same time the Spaniards made a settlement at Corisco Bay ${ }^{2}$. The Spanish claims extend some distance up the river Muni. The boundaries of Spanish Guinea (as it is called) were settled with the French in 1900-2 and resulted in a territory of 9800 square miles being allotted to Spain. This very interesting patch of Equatorial West African Coast is emphatically the home of the gorilla. It is

1 This Portuguese name becomes in Spanish Rio de Oro.

2 This also, like so many other places on the West coast of Africa, was named by the Portuguese; Corisco meaning "sheet lightning," a name applied to the place because it was first seen during a violent thunderstorm. 
populated by Bantu negroes, more especially belonging to the Fang group.

At the end of the r8th century the Spanish island of Fernando Pô was almost abandoned. When the British undertook to put down the slave trade off the West African Coast, Fernando Pô became their head-quarters (in I 829); and for a time they were allowed to administer it by the Spanish Government, the British representative or "Superintendent" being made at the same time a Governor with a Spanish commission. But in 1844 the Spanish decided to resume the direct administration, and refused to sell their rights to Great Britain, though overtures were made to that end. Until about I 890 nothing was done to develop the resources of this densely forested, very fertile, but unhealthy island. From that time onwards, however, some encouragement was given to negro and European planters. From the island having been for so long under British control, there is a large population of Englishspeaking negroes, and English is understood in Fernando Pô much better than Spanish. These negroes are descended from a number of freed slaves from Sierra Leone. The indigenous inhabitants are a Bantu tribe of short stature and very lowly culture known as the Bube ${ }^{1}$. This tribe is distantly related to the people of the northern part of the Cameroons, and speaks an isolated Bantu dialect. Much development of cacao planting has recently taken place in Fernando Pô, involving the importation of foreign negro labourers from Liberia; but the interests of the Bube natives have been well protected by Spanish Dominican and British Primitive Methodist missionaries.

1 Bube is said to be a cant term meaning "male" (from the Bantu root, -ume, -lume) and the real name of this race is perhaps Ediya. This subject is fully treated in the author's book, George Grenfell and the Congo, which gives a full account of Fernando Pô and the Bube indigenes. 


\section{CHAPTER VI}

\section{THE DUTCH IN AFRICA}

Although, as will be seen in a succeeding chapter, British seamen were the first adventurers of other nationalities to follow the Portuguese in the exploration of the African coasts, the Dutch, as settlers and colonists, are almost entitled to rank chronologically next to the Portuguese and Spanish. The Dutch made their first trading voyage to the Guinea Coast in I 595, I6 years after throwing off the yoke of Spain. On the plea of warring with the Spanish Empire, which then included Portugal, they displaced the latter power at various places along the West coast of Africa-at Arguin, at Goree (off Dakar, purchased from the natives $162 \mathrm{I}$ ), Elmina (1637), and at Saõ Paulo de Loanda about the same time; while they three times threatened Moçambique on the East coast (I604, I607, I662), and possessed themselves of the island of Mauritius ( ${ }_{598}$ ), which had been a place of call for Portuguese ships. Mauritius, discovered in 1505 by the Portuguese sea-captain, Mascarenhas (after whom the "Mascarene" Islands-the Mauritius-Réunion-Rodriguez groups-have been named), was uninhabited at the time and possessed enormous quantities of a large and monstrous ground fruit-pigeon, the Dodo, which the Dutch sailors and their imported herds of swine exterminated in the course of about a hundred years. On the West coast of Africa, besides supplanting the Portuguese, the Dutch 
established themselves strongly on the Gold Coast by means of 16 new forts of their own ${ }^{1}$, in most cases alongside British settlements, which were regarded by the Dutch with the keenest jealousy.

Dutch hold on the Gold Coast was responsible for an enormous increase of the Slave Trade between West Africa and America and is the reason why such a large proportion of the United States, West Indian, and Guiana negroes are of Ashanti (Coromanti, Kormantyn) and Fanti descent; as is evident from their folk-lore, legends and the linguistic evidence of their dialects. The Dutch were not loath to mingle their blood with that of the Gold Coast negroes; and their long occupancy of these forts produced an impression in the shape of a race of Dutch half-castes, which endures to this day, and furnishes useful employés to the British Government in many minor capacities. But after the abolition of the slave trade Dutch commerce with the Guinea Coast began to wane, and their political influence disappeared also; so that by $\mathbf{1} 872$ the last of the Dutch ports had been transferred to Great Britain in return for the cession on our part of rights we possessed over Sumatra. Meantime Dutch trade had begun to take firm hold over the Congo and Angola Coast; and it is

1 Their "capital" was at Elmina; they held-when in full vigourFort Nassau (built before they took Elmina from the Portuguese), Kormantin, Secondee, Takorari, Accra, Cape Coast Castle, Vredenburg, Chama, Batenstein, Dikjeschop (Insuma), Fort Elise Carthage (Ankobra), Apollonia, Dixcove, Axim, Prince's Fort near Cape Three-points, Fort Wibsen, and Pokquesoe. Before the abolition of the slave trade, Dutch Guinea was very prosperous. It was governed by a subsidized Chartered Company-the Dutch West India Co.-under the control of the States General ; and the local government consisted of a Governor-General at Elmina, a chief Factor (or trader), a chief Fiscal (or accountant-general), an under-fiscal (or auditor) and a large staff of factors, accountants, secretaries, clerks and assistant clerks. There was a chaplain; there were Dutch soldiers under Dutch officers who garrisoned the forts. After the wars of the French Revolution the Dutch Government took over the management of these establishments on the Gold Coast. 
possible that, had the cession of the Gold Coast forts been delayed a few years longer, it would never have been made, for Holland possesses a considerable trade with Africa, and there has been a strong feeling of regret in the Netherlands for some time past at the exclusion of that country's flag from the African continent.

But a far more important colonization than a foothold on the Slave-trade Coast was made indirectly for Holland in the middle of the I 7 th century; the Dutch East India Company, desirous of making the Cape of Good Hope something more than a port of call, which might fall into the hands of Portugal, France, England, or any other rival, decided to occupy that important station. The Dutch had taken possession of St Helena in 1645 ; but a Dutch ship having been wrecked at Table Bay in 1648 , the crew landed, and encamped where Cape Town now stands. Here they were obliged to live for five months, until picked up by other Dutch ships ; but during this period they sowed and reaped grain, and obtained plenty of meat from the natives, with whom they were on good terms. The favourable report they gave of this country on their return to Holland decided the Dutch Company, after years of hesitation, to take possession of Table Bay. An expedition was sent out under Jan van Riebeek, a ship's surgeon, who had already visited South Africa. The three ships of Van Riebeek's expedition reached Table Bay on the 6th of April, $165^{2}$.

At different periods in the early part of the 16 th century the Dutch had consolidated their sea-going ventures into two great chartered companies - the Dutch Company of the IVest Indies, and the Dutch Company of the East Indies. The West Indian Company took over all the settlements on the West Coast of Africa, and had the monopoly of trade or rule along all the Atlantic Coast of tropical America. The East

1 As Sir Charles Lucas points out in his Historical Geography of the British Colonies, "I $6+$ years after Bartolomeu Diaz had sighted the Cape of Good Hope." 
India Company was to possess the like monopoly from the Pacific Coast of South America across the Indian Ocean to the Cape of Good Hope. The head-quarters of the East India Company, where their Governor-General and Council were established, was at Batavia, in the island of Java. It was not at first intended to establish anything like a colony in South Africa-merely a secure place of call for the ships engaged in the East Indian trade. But circumstances proved too strong for this modest reserve. The inevitable quarrel arose between the Dutch garrison at Table Bay and the surrounding Hottentots. At the time of the Dutch settlement of the Cape all the south-west corner of Africa was inhabited only and sparsely by Hottentots and Bushmen; the prolific Bantu Negroes not coming nearer to the Dutch than the vicinity of Algoa Bay. A little war occurred with the Hottentots in 1659 , as a result of which the Dutch first won by fighting, and subsequently bought, a small coast strip of land from Saldanha Bay on the north to False Bay on the south, thus securing the peninsula which terminates at the Cape of Good Hope. French sailing vessels were in the habit of calling at Saldanha Bay; and in 1666 and 1670 desultory attempts were made by the French to establish a footing there. Holland also about this time was alternately at war with England or France or both powers. Therefore the Dutch resolved to build forts more capable of resisting European attack than those which were sufficient to defend the colony against Hottentots. Still, in spite of occasional unprovoked hostilities on the part of the Dutch, they were left in undisturbed possession of the Cape of Good Hope for more than a hundred years. The English had St Helena as a place of call (which they took from the Dutch in 1655); and the French had settlements in Madagascar and at Mauritius, where they succeeded a former Dutch occupation. On the other hand, the officials of the Dutch Company were instructed to show civility to all comers without undue generosity; they might 
supply them with water for their ships, but they were to give as little as possible in the way of provisions and ships' stores. It was to the interest of both France and England that some European settlement should exist at the Cape of Good Hope for the refreshment of vessels and the refuge of storm-driven ships. After several attempts, which continued down to 1673 , to dispossess the English of St Helena, the Dutch finally surrendered the island to them. They had also in 1598 taken the Island of Mauritius, and commenced a definite occupation in r640. But this island was abandoned in I7ro, and became soon afterwards a French possession. So that the French at Mauritius on the one hand (and also on the Island of Bourbon, now called Réunion) and the English on the other at St Helena, had places of call where they could break the long voyage to and from India, and were therefore content to leave the Dutch East India Company in full possession of South Africa.

The Government of the Netherlands East India Company was thoroughly despotic. It was administered by a Chamber of 17 directors at Amsterdam, with deputies at Batavia. The Commandant at the Cape, who was under the orders of Amsterdam and Batavia alternately and might be overruled by any officer of superior rank who called at his station in passing, was the slave of the Company and had to carry out its orders implicitly. He was advised in his local legislation by an executive council, consisting of a number of officers who assisted him in the administration, and legislating by means of proclamations and orders-in-council without any representation of popular opinion among the colonists, who, however, in time were allowed to elect members of the Council. of Justice or High Court.

After the first three years' hesitation, strenuous efforts were directed to the development of agriculture, especially the cultivation of grain. Wheat was sown in suitable localities, and vines and willows were planted by the banks of streams 
on the hillsides at the back of Cape Town. Nevertheless the colonists were terribly hampered by restrictions, which made them almost slaves to the Company. White labour proving expensive and somewhat rebellious, an attempt was made to introduce negro slaves from Angola and Moçambique, but they were not a success as field labourers. The Dutch therefore turned towards Madagascar, and above all, to the Malay Archipelago; and from the latter especially workers were introduced who have in time grown into a separate population of Muhammadan freemen of considerable prosperity ${ }^{1}$. As Dutch immigrants still held back from settling the Cape with an abundant population (owing to the greed and despotic meddlesomeness of the Company), it became more and more necessary to introduce black labour; and in the first half of the I 8th century many negro slaves were imported from the Gold Coast and from Moçambique. The Cape became a slaveworked colony, but on the whole the slaves were treated with kindness ; their children were sent to school, and some attempt was made to introduce Christianity amongst them. The people really to be pitied, however, were not the imported slaves, but the Hottentots, who had become a nation of serfs to the Dutch farmers, and whose numbers began greatly to diminish under the influence of drink and syphilis, and through their being driven away from the fertile, well-watered lands back into the inhospitable deserts. In $\mathrm{r} 682$, after the colony had been established 30 years, a census showed a total of 663 Dutch settlers, of whom 162 were under age or children. For about the same period few if any attempts were made to explore the country 100 miles from Cape Town; but the coast from Little Namakwaland on the west to Zululand on the east had been examined by the end of the 17 th century. Indeed the Bay of Natal was purchased by a representative of the Netherlands Company in r689; but the ship bringing back the purchase deed was lost, and no further attempt was made to push the claim. In 1684

$$
1 \text { The "Cape Malays." }
$$


the first export of grain to the Indies took place, and in 1688 some Cape wine was sent to Ceylon. In 1685 and in subsequent years representations were made to the directors in Amsterdam that the colony consisted mainly of bachelors, and that good marriageable girls should be sent out. The result of this appeal was that in 1687 many of the free Burghers (namely, persons more or less independent of the Company) had been furnished with wives; and they and their families amounted to nearly 600 , in addition to 439 other Europeans, who were mainly employés of the Company.

In 1685 , Louis XIV unwittingly dealt a fearful blow to France in the revocation of the Edict of Nantes, which resulted in thousands of French Protestants emigrating to other countries where they might enjoy freedom of religion. The Protestant Dutch sympathized with the homeless Huguenots; and the Netherlands Company decided to give free passages and grants of land to a number of these refugees. By 1689 nearly 200 French emigrants had been landed at the Cape and settled in the mountain country behind Cape Town. Here, however, they were not allowed to form a separate community. They were scattered amongst the Dutch settlers, their children were taught Dutch, and in a few years they were thoroughly absorbed in the Dutch community; though they have left ineffaceable traces of their presence in the many French surnames to be met with amongst the South African Dutch at the present day (always pronounced however in the Dutch way), and in the dark eyes, dark hair, and handsome features so often seen in the best-looking type of Boer. Handsomer men and women than are some of the Afrikanders it would be impossible to meet with; but this personal beauty is usually traceable to Huguenot ancestry. The French settlers taught the Dutch improved methods of growing corn and wine, and altogether more scientific agriculture. Towards the latter end of the $\mathrm{I} 7$ th century the Dutch introduced the oak tree into the Cape Peninsula and the suburbs of Cape Town, where it is 
now such a handsome and prominent feature. All this time the Hottentots gave almost no trouble. They were employed here and there as servants ; but they attempted no insurrection against the European settlers, though they quarrelled very much amongst themselves. In I $_{7} \mathrm{I}_{3}$ large numbers of them were exterminated by an epidemic of smallpox. The Dutch had not yet come into contact with the so-called Kaffirs ${ }^{1}$.

Towards the middle of the 18 th century the Dutch Company ceased to prosper, suffering from French and English competition. Already, at the beginning of the I8th century, its oppressive rule, and the abuse of power on the part of its governors, who used its authority and its servants to enrich themselves, resulted in an uprising amongst the settlers; and although some of these were arrested, imprisoned, and exiled, the Company gave some redress to their grievances by forbidding its officials in future to own land or to trade. Even before this the Company had found it necessary to place a special official, answering to an Auditor-General and an independent judge combined, alongside the Commandant or Governor, directly responsible to the Directors and independent of the Governor's authority; but this institution only led to quarrels and divided loyalty. Amongst the governors there were some able and upright men; and special mention may be made of Governor Tulbagh, who ruled without reproach and with great ability for twenty years $(\mathrm{I} 75 \mathrm{I}-7 \mathrm{I})^{2}$.

In spite of licences and monopolies, tithes, taxes, and rents, the Company could not pay its way in Cape Colony. In I779, it was more closely associated with the State in Holland by the appointment of the Stadhouder (or Head of

1 It will be no doubt remembered that this word is derived from the Arab word "unbeliever." The Arabs of south-east Africa applied this term to the Negroes around their settlements. The Portuguese took it up from the Arabs, and the Dutch and English from the Portuguese.

2 Tulbagh deserves special remembrance not only from his geographical explorations, but from the fact that he was the first person to send specimens of the giraffe to Europe. 
the State) as perpetual Chief Director. With this change, the Company, partly supported by the State, managed to continue the direction of its affairs ; and there was possibly some lessening of restrictions, which enabled settlers to live further afield. Until the beginning of the 18 th century a standing order had forbidden trading between the settlers and the natives; but this order being abolished, the farmers commenced to buy cattle from the Hottentots, and the population became more scattered. In leasing land to the farmers the Company laid down the rule that clear spaces of three miles should intervene between one homestead and the next; and this rule brought about a wider distribution of European settlers than was contemplated in the Company's policy.

By the beginning of the I8th century the Dutch settlers had begun to cross the mountains which lie behind the narrow belt of coast land that forms a projection into the ocean on either side of the Cape of Good Hope. Seventy years later the boundaries of Cape Colony on the north and west were the Berg River and the Zwartebergen Mountains, and on the east the Gamtoos River. A few years later the pioneers of colonization had crossed the Berg River, and had established themselves as far north as the Olifants River, so named because earlier explorers had seen on its banks herds of hundreds of elephants. The Orange River was first discovered in 1760 ; and in 1779 Captain Gordon, a Scotchman in the service of the Dutch Company, had traced it for some distance down to its mouth, and had named it after the head of the Dutch State. Hitherto, the Dutch Government was confined to a narrow coast strip; but in $\mathrm{I}_{7} 85$ the district of Graaf Reinet ${ }^{1}$ was formed, and the same name was given to the village which formed its capital. Then the Dutch boundary crept up to the Great Fish

1 Named after Van de Graaf, who was Governor at the time. "Reinet" means in Dutch " a goat's beard," but I have not been able to discover why this term should have been added to the name of the Governor. 
River, which rises far away to the north, near the course of the Orange River. This Great Fish River remained the easternmost boundary of the Colony in Dutch times. To the north its limits were vague, and in one direction reached nearly to the Orange River, beyond the second great range of South African mountains-the Sneeubergen. But beyond the immediate limits of Cape Colony the Dutch displayed some interest in the fate of South-East Africa. They opened up a furtive and occasional trade with the Portuguese coast of East Africa, which at first began for slaves (numbers of Makua were brought from Moçambique to Cape Town), was continued for tropical products, and, with many interruptions, resulted in the establishment at the present day of important Dutch commercial firms along the Moçambique coast. In 1720 , after the evacuation of Mauritius, an expedition was sent from Cape Colony to Delagoa Bay, which, though claimed by the Portuguese, had been abandoned by them at the beginning of the 18 th century, so far as actual occupation was concerned (see p. rio). A fort was built by the Dutch which was named Lydzaamheid; and tentative explorations were made in the direction of the Zambezi, from which gold dust was procured. During ten years of occupation, however, the deaths from fever were so numerous that the settlement was given up in 1730 .

In 1770 the total European population in Cape Colony was nearly 10,000 , of whom more than 8000 were free colonists, and the remainder "servants" and employés of the Company. All this time, although the prosperity of the Cape increased and its export of wheat, wine, and live-stock progressed satisfactorily, the revenue invariably failed to meet the expenditure; and, if other events had not occurred, the Dutch Company must soon have been compelled by bankruptcy to transfer the administration of the Cape to other hands. But towards the close of the I 8th century, the Dutch, too weak to resist the influence of France and Russia, were showing veiled hostility towards England, with the result that England-which on the other 
hand was secretly longing to possess the Cape, owing to the development of the British Empire in India-declared war against the Netherlands at the end of 1780 . In $178 \mathrm{I}$ a British fleet under Commodore Johnstone left England for the Cape of Good Hope with 3000 troops on board. Johnstone, however, from storms and other reasons not so apparent, but possibly due to a certain indecision of mind, delayed his fleet at Porto Praya, in the Cape Verde Islands; and news of the expedition having been treacherously imparted to France by persons in England who were in her pay, Admiral Suffrenone of the greatest of sea-fighters-surprised the British fleet at the Cape Verde Islands with a squadron of inferior strength, and gave it such a sound drubbing that Johnstone was delayed for several months in reaching Cape Town, where the French had preceded him, and had landed sufficient men to make a British attack on Cape Town of doubtful success. Johnstone therefore contented himself in a not very creditable way with destroying the unarmed Dutch shipping in the port, and then left Cape Town without effecting a landing. The result was the garrisoning of Cape Town by a French regiment for two more years, during which time however another attempt was made by the British to seize the Cape, which was nearly successful. In the course of this war, however, England apparently made up her mind that the possession of the Cape of Good Hope and of Trinkomali in Ceylon was necessary to the welfare of her Indian possessions, and did not lose sight of this policy when the next legitimate opportunity presented itself to make war upon Holland. On the other hand, the French, though they withdrew their troops in 1783 , were equally alive to the importance of the Cape; and in the great duel which was to take place between the two nations it is tolerably certain that South Africa would never have remained in the hands of the Dutch; if it had not become English it would have been taken and kept by the French.

About this time the Dutch came into conflict with the 
Kafirs. This vanguard of the great Bantu race had been invading southern Africa almost concurrently with the white people. Coming from the north-east and north they had-we may guess-crossed the Zambezi about the 6th century of the Christian Era; and their invasion had brought about the partial destruction and abandonment of the Sabaean and Arab settlements in the gold-mining districts of south-east Africa. The Semitic inhabitants of Zimbabwe and other mining centres had been driven back to the coast at Sofala. The progress of the black Bantu against the now more concentrated Hottentots and Bushmen was then somewhat slower, delayed no doubt by natural obstacles, by the desperate defence of the Hottentots, the tracts of waterless country on the west, and internecine warfare amongst themselves. Overlying the first three divisions of Bantu invaders there came down across the Zambezi from the districts of Tanganyika the great Zulu race, akin to the Bechuana-Basuto people who had preceded them, but less mixed with Hottentot blood, and speaking a peculiar Bantu language ${ }^{1}$. By the beginning of the 18 th century this seventh wave-as one may call it-of Bantu invasion had swept as far south as the Great Kei River, and some years later had pushed the Hottentots back to the Great Fish River. In I 778 they came into direct contact with the Dutch; and the Governor of the Cape entered into an agreement with the Kafir chiefs that the Great Fish River should be the boundary between Dutch rule and Kafir settlement. Nevertheless, this agreement was

1 Nevertheless, by their final and more complete contact with the Hottentots and Bushmen the Zulu-Kafirs adopted three of the Hottentot clicks; whereas earlier invaders-Karanga, Bechuana, and Herero-though adopting a few Iiottentot terms, kept clear of Hottentot phonetics, and use no clicks to this day. The Zulu-Kafir language, divided into four dialects-X́osa-Kafir, Zulu and Swazi (all three closely related), and Tonga or Ronga of the Delagoa Bay district, is on the whole most nearly related to the East African Bantu groups, with some affinities with Central African Bantu. But it has no near relations and has developed a very peculiar vocabulary, as though it had been isolated for centuries. 
soon transgressed by the Kafirs, who commenced raiding the Dutch settlers. In I 78 I the first Kafir war ended disastrously for the Bantu invaders, who were driven back for a time to the Kei River. Eight years later they again invaded Cape Colony. A policy of conciliation was adopted, which ended by the Kafirs being allowed to settle on the Dutch side of the Great Fish River in 1789 .

In 1790 the Netherlands East India Company was practically bankrupt; and in the following year (when it was computed that the European population of the Cape numbered I 4,600 persons, owning I 7,000 slaves) the Dutch Governor was recalled to Europe, and the country was for a year left in a state of administrative chaos, until two Commissioners, sent out by the States General, arrived and took over the government. But the next year these Commissioners went on to Batavia; and the Burghers of the interior districts became so dissatisfied with the mismanagement of affairs that they expelled their magistrates and took the administration of their district into their own hands, calling themselves "Nationals," and becoming to some degree infected with the spirit of the French Revolution. Meantime, in the same year, I793, the Dutch Government had joined England and Prussia in making war upon France. Two years afterwards, in $\mathrm{r} 795$, the French troops occupied Holland, and turned it into the Batavian Republic, a state in alliance with France. The Prince of Orange, hereditary Stadhouder of the Netherlands, fled to England; and in the spring of 1795 he authorized the British Government to occupy Cape Colony on behalf of the States General in order to obviate its seizure by the French. In Iune I795 a British fleet carrying troops commanded by General Craig arrived at False Bay. The Dutch were not very willing to surrender Cape Town at the first demand, even though the interior of the country was in revolt against the Company. Both the officer administering the Company's Government and the dissatisfied Burghers sank their differences in opposition to 
the landing of the British. The latter were anxious to avoid hostilities, and therefore spent a month in negotiations; but on the I 4 th of July the British forcibly occupied Simons Town, and three weeks later drove the Dutch from a position they had taken up near Cape Town. In September 3000 more troops arrived under General Clarke, and in the middle of that month marched on Cape Town from the south-east. A capitulation was finally arranged after an attack and a defence which had been half-hearted. Thenceforth for eight years the English occupied Cape Town and administered the adjoining colony. At first their rule was military, just, and satisfactory; afterwards, when a civilian governor was sent out, a system of corruption and favouritism was introduced which caused much dissatisfaction. The British also had made it known that they only held the colony in trust for the Stadhouder; and this made the Dutch settlers uncertain as to their allegiance. Meantime, however, the British administration gave some satisfaction to the settlers by its policy of free trade and open markets, and by certain reliefs in taxation; also by the institution of a Burgher Senate of six members. But the Boers of the interior remained for some time recalcitrant. The Dutch, moreover, made an attempt to regain possession of the Cape by dispatching a fleet of nine ships with 2000 men on board, which, however, was made to surrender at Saldanha Bay by Admiral Elphinstone and General Craig without firing a shot. Kafir raids recommenced; and the British having organized a Hottentot corps of police, the other Hottentots who were serfs to the Dutch rose in insurrection against their former masters. When in 1803 the British evacuated Cape Town, they did not leave the colony in a sufficiently satisfactory condition to encourage the Dutch settlers to opt for British rule. From 1803 to 1806 the Dutch Government ruled Cape Colony as a colony, and not as the appendage of a Chartered company, which had now disappeared. The Cape ceased to be subordinate to Batavia, and possessed a Governor and 
Council of its own. A check was placed on the importation of slaves, and European immigration was encouraged. Postal communication and the administration of justice were organized or improved. In fact, the Commissioner-General De Mist and Governor Janssens, in the two years and nine months of their rule, laid the foundations of an excellent system of colonial government. But the march of events was too strong for them. The great minister Pitt, in the summer of 1805 , secretly organized an expedition which should carry nearly 7000 troops to seize the Cape. In spite of delays and storms, this fleet reached Table Bay at the beginning of January, 1806. Six British regiments were landed 18 miles north of Cape Town. Governor Janssens went out to meet them with such poor forces as he could gather together-2000 in all against 4000 British. The result of course was disastrous to the Dutch, whose soldiers mainly consisted of half-hearted German mercenaries. On the I6th of January, Cape Town surrendered; and after some futile resistance by Janssens in the interior, a capitulation was signed on January $\mathrm{I} 8$, and Janssens and the Dutch soldiers were sent back to the Netherlands by the British Government.

By a Convention dated August I3, r8r4, the Dutch Government with the Prince of Orange at its head ceded Cape Colony and the American possession of Demerara to Great Britain against the payment of $£ 6,000,000$, which was made either by the actual tendering of money to the Dutch Government, or the wiping off of Dutch debts.

On the other hand, the surrender of the Cape to Great Britain induced the latter power to give back to Holland most of the Dutch possessions in the East Indies, which we had seized and administered during the Napoleonic wars. If Holland lost South Africa - which she had only directly ruled for three years-she was enabled by the British attitude of selfdenial to build up an empire in the East only second in wealth and population to the Asiatic dominions of Great Britain. 
Yet, in an indirect fashion, Dutch Africa exists still, though the flag of Holland no longer waves over any portion of African soil as a ruling power. The old rivalry between the English and the Dutch, which had begun almost as soon as the Dutch were a free people, and competitors with us for the trade of the East and West Indies, had created a feeling of enmity between the two races, which ought never to have existed, seeing how nearly they are of the same stock, and how closely allied in language, religion, and to some extent in history-also how nearly matched they are in physical and mental worth. Curiously enough, there is far greater affinity in thought and character between the Scotch and the Dutch than between the Dutch and the English. The same thriftiness, bordering at times on parsimony, oddly combined with the largest-hearted hospitality, the same tendency to strike a hard bargain, even to overreach in matters of business, and the same dogged perseverance, characterize both Dutch and Scotch; while in matters of religion, almost precisely the same form of Protestant Christianity appeals to both; so much so, that there is practically a fusion between the Dutch Reformed Church and the Presbyterians. Had Scotchmen been sent out to administer Cape Colony in its early days, it is probable that something like a fusion of races might have taken place, and there would have been no Dutch question to cause dissension in South African politics in the rgth century. The Scotch would have understood the Boer settlers and their idiosyncracies, and would not have made fun of them or been so deliberately unsympathetic as were some of the earlier English governors. Slavery would have been abolished all the same, but it would have been abolished more cautiously, in a way that would not have left behind the sting of a grievance. But after Cape Colony had been definitely ceded to Great Britain, its governors in the early days were mostly Englishmen, who, though often able and just men, were at little pains to understand the peculiarities of the Boer character, and to 
conciliate these suspicious, uneducated farmers. Another source of trouble was the influx of British missionaries, who found much to condemn in the Dutch treatment of the natives, which resembled that in vogue amongst Britons of the previous century, before the spirit of philanthropy was abroad. Some of these missionaries, it is true, were Scotchmen, though belonging to Protestant sects of more distinctly English character. At any rate, the missionaries no doubt had so much right on their side in condemning the Boers for their conduct towards the natives, that their feelings in this respect overcame their national affinity for the Dutch. The Boer settler at no time showed that fiendish cruelty to the natives he was dispossessing which was, and is, so terribly characteristic of the Spanish colonization of Mexico or northern South America, or of some of the English, French, and Portuguese adventurers on the West coast of Africa in the $I 7$ th century; but he was determined to make of the native a serf, and denied him the rights of a man like unto himself. If the native revolted against this attitude he was exterminated in a businesslike fashion; but if he submitted, as did most of the Hottentots, he was treated with patriarchal kindness and leniency. The Dutch settlers appear from the first to have dissociated their dealings with the Hottentots from their ordinary code of morals. It was not thought dishonest to cheat them, not thought illegal to rob them, not thought immoral to use their women as concubines. So entirely without scruples were the Dutch on this last point, that whole races arose, and have since become nations likely to survive and prosper, whose origin was "the illicit union of Dutch men and Hottentot women. These "bastards," as they were frankly called, were well treated by the Dutch; they were not disowned, were usually converted to Christianity, and were taught to lead a more or less civilized life and to talk the Dutch language, which they speak in a corrupt form at the present day. In short, the morals of the South African Dutch were the morals of the Old Testament, as were 
those of Cromwell's soldiers; and in this and many other modes of thought the Dutch Afrikanders lived still in the I 7 th century, whereas the British missionaries were of the early $\mathrm{I}$ th, in the red-hot glow of its as yet disillusioned and somewhat frothy philanthropy. The Dutch settlers were denounced at Exeter Hall and on every missionary platform; and the fact that many of the accusations were true in great measure did not make them more palatable to the accused.

As the Government policy at the Cape was for the first half of the century greatly influenced by the missionary societies, the Dutch with some justice regarded these attacks and recriminations as directly emanating from the British Government, and hence withdrew from or rebelled against our rule. The dissentient, dissatisfied Boers began to trek away from the settled portion of Cape Colony into the wilderness behind, where they might still lead the pleasant, unfettered, patriarchal life they had grown to love. They travelled beyond the Orange River, which had come to be the northern limit of British influence, and, avoiding the deserts of Bechuanaland, passed north-eastwards into the better-watered territories now known as the Orange Free State and the Transvaal. They also sought a way out towards the sea in what is now the colony of Natal. Here they came into conflict first with the Kafirs and Basuto on the west, and then with the Zulus on the east. The former were to some extent under British protection; therefore the British Government was ready to espouse their cause if they were unjustly dealt with. 'The Zulus, on the other hand, were strong enough and numerous enough to prevent a Boer settlement on their land. Nevertheless, the Boer invasion of Natal from the north was at that time a transgression into territory recently conquered and depopulated by one of the most abominable shedders of blood that ever arose amongst Negro tyrants-Chaka, the second ${ }^{1}$ king of the Zulus. This latter

1 If Dingiswayo, his master, can be regarded as the first. Dingiswayo 
saw the danger, and lured the pioneers of the Boers into a position where he was able to massacre them at his ease. With splendid gallantry-one's blood tingles with admiration as one reads the record of it--the few remaining Boers mustered their forces and avenged this dastardly murder by a drastic defeat of the Zulus. But this was in the early forties, when British adventurers, more or less discouraged or unencouraged by the Home Government, had founded a coast settlement in Natal, on the site of what is now the town of Durban. The usual shilly-shally on the part of the British Government misled the Boers into thinking that they could maintain themselves in Natal against our wishes. As they had further broken an agreement with us by attacking the Basuto and the Kafirs, a British force was despatched against them in I 842, which, after a brief struggle, induced them to capitulate. Natal was then secured as a British colony, and the Boers with bitter disappointment had to seek their independent state to the north of the Orange River. But here also they were followed up; and, had the Governor of the Cape-Sir George Grey-been supported from Downing Street, the Orange River sovereignty would never have become the Orange Free State, and it is probable that even the territory beyond the Vaal River might in like manner have been subjected to British control.

But Downing Street for eighty years after the cession of the Cape of Good Hope persistently mismanaged South African affairs, now blowing hot with undue heat, now blowing cold, and nipping wise enterprise in the bud. The action of the Governor was repudiated, and the Sand River Convention unratified. In the most formal manner the Boers north of the Orange River

was rather the paramount chief of a Kafir confederation, of which the Zulu tribe was a member. Chaka was the younger son of a Zulu chief, but was eventually elected chief in his father's place and then succeeded to the paramount sway of Dingiswayo. Racially and linguistically there is very little difference between Zulus and Kafirs. 
were accorded absolute independence, subject to certain provisions about slavery; and the like privilege had been previously accorded to those who had further trekked across the Vaal River at a time when the Orange River State was likely to become a British Colony. So, from $185^{2}$ and 1854 respectively ${ }^{1}$, the South African Dutch formed two states entirely independent of British rule in their internal affairs, and very slightly in their external relations. The Orange Free State, which contained a considerable British element dating from the period of British sovereignty, had latterly an uneventful career of steady prosperity ${ }^{2}$, due in large measure to the wisdom of its chief magistrates. When the diamond fields were discovered on its borders towards the end of the "sixties" it had some cause for complaint against the British Government, since, taking advantage of the undefined rights of a Grikwa (Bastard Hottentot) chief, the British extended their rule over this arid territory north of the Orange River, which was suddenly found to be worth untold millions of pounds. But the amount of territory under dispute was relatively small; and, if the British had transgressed their rightful borderland to some slight degree, they atoned for it by paying the Orange State an indemnity of $£ 90,000$. Great Britain also intervened several times to prevent the warlike Basuto (who dwell in that little African Switzerland between the Orange Free State and Natal) either from raiding the Orange Free State, or from being themselves raided and conquered by Boer reprisals. Eventually (r882) Basutoland,

1 The Sand River Convention, recognizing the independence of the Transvaal, was signed in January, $185_{2}$; the Bloemfontein Convention, which loosed the Orange Free State from British control, was signed in February, 1854 . In 1858 , Sir George Grey laid before the Cape Parliament proposals from the Orange Free State for reunion in a South African Federation, and was recalled by the Home Government for advocating this policy.

${ }^{2}$ For the first few years of its existence it had much fighting with the Basuto. 
whose affairs had been somewhat mismanaged by the Cape Parliament, was taken under direct imperial control; and ever since there has been a complete cessation of trouble in that quarter with the Orange Free State.

The career of the Transvaal Republic was much less successful in its early days. The territory was vaster, in many places not so healthy; and the native population, especially in the eastern districts ${ }^{1}$, was turbulent, and strongly averse to accepting Boer rule. The existence of gold, though occasionally hinted at by unheeded pioneers, was unknown to the world at large, and absolutely ignored by the Boers; there was little or no trade, and the European population was scanty. By r 877 the condition of this state had become so hopeless, with a bankrupt treasury and the menace of a Zulu invasion, that it was annexed, somewhat abruptly, by the Imperial representative, Sir Theophilus Shepstone. No doubt this step was consonant with the enlightened policy then favoured by the Imperial Government and subsequently by Sir Bartle Frere, who was to become Governor of the Cape during the latter part of the late Earl Carnarvon's tenancy of the Colonial Office. Lord Carnarvon himself was resolutely intent on carrying out in Africa south of the Zambezi a scheme of federation similar to that which had in 1866 consolidated the Dominion of Canada. But the actual method by which the Transvaal was taken over was not a well considered one; and unhappily it was followed by the appointment of an officer to rule over that country whose demeanour was wholly unsympathetic to the Boer nature. At the end of 1880 the Boers revolted. After a short military campaign, conspicuous for its utter lack of generalship on the part of the English, and for the disastrous defeats inflicted on our forces by the Boers at Lang's Nek and Majuba Hill, the British Government of the day (which a few months before had absolutely refused the

${ }^{1}$ Zulus under Msilikazi and Swazis in the east; Bechuana tribes in the west and north. 
Boers' appeal for the reversal of the annexation) concluded a hurried armistice, and gave back (I88I) its independence to the Transvaal, subject to a vague suzerainty on the part of the British Crown, and later on to a British veto which might be exercised on treaties with foreign powers. The best plea that can be urged on behalf of this surrender, which subsequent British Governments have had such cause to regret, was the belief that a stern prosecution of the war, and the eventual Boer defeat, would lead to the uprising of the Dutch settlers in Cape Colony and the intervention of the Orange Free State. It is doubtful whether there was much foundation for this fear, or whether it would not have been much easier at that time to settle British supremacy once and for all over all Africa south of the Zambezi, even if it led to some degree of internecine fighting; the more so as there would have been no danger of European intervention at that date. But the chance was let slip, and the Boers acquired an independence the more justly won and the less easily disturbed since it was the result of their sturdy valour.

The restraining conditions of the $\mathrm{I} 88 \mathrm{I}$ Convention were still further attenuated by the London Convention of February $27, \mathbf{1 8 8 4}$, in which with further fatuity the Government of the day accorded unnecessarily to the Transvaal state the extravagant title of "The South African Republic." Perhaps this is the most remarkable act of abnegation which has ever occurred in the history of the British Empire; and it must have seemed to the inhabitants of British South Africa like the admission of a rival ruling power into the British sphere south of the Zambezi. By this I 884 Convention (worthless for that purpose, as are all treaties and conventions when the force to maintain them is not apparent) the geographical limits of the Transvaal state were clearly defined, and the Boers engaged to keep within them.

Encouraged by this diplomatic success, and the feeble manner in which the Imperial Government had permitted them 
to carve out a fresh state in the heart of Zululand, the Boers of the Transvaal now determined to add Bechuanaland to their dominions ; thus possibly to cut off British expansion towards the Zambezi, and to make their western frontier coincident with the natural limits of that Protectorate which Germany had just established, north of the Orange River. But public opinion in Great Britain was becoming intolerant of any further sacrifices of British aspirations in South Africa or of breaches of faith on the part of the Boers, and forced the Government of the day to assert itself. A strong expedition was sent out under Sir Charles Warren at the end of 1884, which finally secured for Great Britain the Protectorate of Bechuanaland, and the restraining of the Transvaal within its proper limits. Nevertheless, in 1894 a fresh concession was made to that state by the withdrawal of British opposition to its absorption of a little enclave of Zulu country known as Swaziland. In excuse for the British Government it must be pointed out that the Swazi chiefs had previously made over to Transvaal subjects so many rights and concessions that any other solution than the further cession of the administration was rendered difficult under the existing conditions. [The detachment of Swaziland as a small native state, administered by Imperial officials, was effected in 1902.]

Soon after the conclusion of the London Convention of I 884, the vast wealth in gold, which for more than ten years back had been asserted by uneducated pioneers, and denied by mining experts, began to be made known. The development of the marvellous Witwatersrand brought about the foundation of Johannesburg, and directed to the Transvaal an enormous influx of outsiders, mainly English, at any rate mainly British subjects, though many of them were Jews from England, or from France and Germany, who had become naturalized British subjects ${ }^{1}$. Mines were also opened in the

1 The part played by the Jews in the development of South Africa has been as remarkable as their share in the settlement and civilizing of North Africa, of the West Indies and the Guianas, of Australia and New Zealand. 
east and in the north of the Transvaal. On the other hand, to counteract the influence of this British element, the Transvaal Government had almost ever since its establishment in I88 I been strengthening the Dutch element by inviting the settlement of Hollanders from the Netherlands, who were employed in its Government offices, in its schools, its churches, and on the construction of its railways. These natives of

Between $\mathrm{I} 84^{\circ}$ and $\mathrm{I} 85^{\circ}$ a number of Jewish business houses were founded or became prominent in Cape Colony and Natal. They started the guano collecting off the S.W. coast, the mohair, wool, hides, sealskin and whale oil industries, and sugar-planting. Notable among such were the De Pass and Mosenthal firms. The De Passes came (I believe) from Gibraltar, and followed to the Cape of Good Hope the first consignments of British troops. The protection given by the British Government to Spanishspeaking Jews at Gibraltar from the early part of the 18 th century onwards was well rewarded by a great increase of British commerce and political power in the Mediterranean. The Mosenthals were attracted to South Africa by the importation of German troops and German colonists. Already in the early sixties members of the firm of Lilienfeld were established in the Orange Free State and hastened to develop the diamond mining industry of the future Kimberley district. The part played by Alfred Beit (of a Hamburg Christian-Jewish family), by the Lipperts, the Honourable Simeon Jacobs, Sir Sigismund Neumann, Sir Lionel Phillips, Sir George Albu, Sir David Harris, Senator Samuel Marks, Professor Alfred Mosely, by the Mendelssohns, Rabinowitzes, and Rapaports, in South African finance, politics, industry, education, law, and philanthropic work has been a considerable one; and recent South African history, either in the Boer states or in the British colonies and protectorates, cannot be written in detail without an allusion to their names, their achievements, their intentions, influence, mistakes, and dogged, persevering belief in the resources and splendid future of Cis- or TransZambezian Africa. This was a region in earlier days so unpromising to the eye and on the surface that it needed the Semitic fair for gold and precious stones - the same mysterious divination which led the Sabaeans (I am sure) to Zimbabwe, the Phoenicians to Spain, and the Arabs to the Ashanti hinterland-to induce that persistent opening-up of Grikwaland, Orangia, inner Cape Colony, the Transvaal and Rhodesia, which has by the first decade of the 2 oth century laid the foundations of another United States in the southern quarter of Africa. 
Holland showed themselves very hostile to British influence; and through their efforts a great deal of sympathy with the South African Dutch was aroused in Holland and Germany. On the other hand, the Outlanders, who settled round Johannesburg and other mining centres and who soon came to outnumber the Boer element in the Transvaal population to the extent of five to one, became dissatisfied with their position under the Boer Government, who ruled them autocratically, without giving them any voice in the administration or in the spending of the heavy taxes levied on their industries. It should be noted that the Boer Government had attempted to wall itself in from contact with the surrounding British and Portuguese states by an exceedingly high tariff of import duties, which rendered many articles of necessity or luxury extremely expensive, and made civilized life five times dearer than in the adjoining Cape Colony. It was again the contrast between the very end of the rigth century and the manners, customs, language, and puritanical religion of the $\mathrm{I} 7$ th century.

To some extent this recalcitrant attitude of the Boers was condemned and deprecated by their much more enlightened brethren, the Cape Dutch. In time, probably, these latter might have encouraged and supported the intervention of the Imperial Government in securing fair terms to the Outlanders ; and as these fair terms must have given the Outlanders a preponderating voice in the Government, the Transvaal might have been brought within the South African Federation under the British ægis. But the Right Hon. Cecil John Rhodes, then Prime Minister of the Cape and Managing Director of the British South Africa Chartered Company, saw in this discontent at Johannesburg the means and excuse for his personal intervention in the Transvaal. He hurried on the movement, and even carried it beyond the limits indicated by the more disinterested Reformers. The administrator of the Chartered Company's territories, Dr Jameson, invaded the Transvaal (Dec. 29, 1895) with a small force of between 500 and 600 
mounted police, and endeavoured to reach Johannesburg, the centre of unrest, with a half-avowed intention of subsequently marching on Pretoria, and upsetting the Boer Government. But the Boer forces intercepted Dr Jameson at Doornkop before he could reach Johannesburg; and after an engagement in which a few of his men were killed, and when further progress would have meant annihilation, he surrendered. The High Commissioner of South Africa hurried to Johannesburg ; Dr Jameson and his officers were handed over to the British Government to be dealt with, and afterwards underwent a short term of imprisonment. On the other hand, the reformers of Johannesburg were treated by the Pretoria Courts with inexcusable harshness, seeing that they had not taken an active part in Dr Jameson's inroad, and had surrendered their city to the Boer Government. Enormous fines, amounting eventually to nearly half a million sterling, were inflicted on them, after a somewhat burlesque trial in which they were condemned to death, only to be subsequently imprisoned or expelled. For the time being this wanton aggression on the part of Mr Rhodes alienated all sympathy with the grievances of the Outlanders, and provoked strong expressions of opinion in certain European states, who, until they were assured that the British Government was dissociated with Mr Rhodes' scheme, were not unnaturally prone to imagine that their own territories in Africa might some day be exposed to a British raid. The immediate outcome, therefore, of this ill-advised action on the part of the Cape Premier (though that official was admittedly actuated by the same desire which has inspired some British statesmen, to bring about the Britannicizing of all Africa south of the Zambezi) was the strengthening and intensifying of the separatist character of the two Dutch republics still existing in South Africa. The Orange Free State concluded (1896) an offensive and defensive alliance with the South African Republic (Transvaal); and enormous quantities of arms, ammunition, and modern artillery were imported into Dutch South Africa 
via Lourenço Marquez (Delagoa Bay) and the new railway'. It was believed that eventually war must break out with Great Britain, but that probably one or more European powers would intervene and attack Great Britain, thus paralysing her striking force in South Africa; that the Cape Dutch would rise and contribute a quota of 30,000 men to the 80,000 to 90,000 of the Boer States; in short that the future of South Africa lay with the Dutch element. War was declared on Great Britain on October I I, I899. Amazing victories at first fell to the Boer generals, but Europe did not intervene, nor did more than 8000 Cape Dutch join their Boer brothers. The tide of victory having turned in favour of the British, Bloemfontein, Pretoria and Komatipoort (the frontier station of the Delagoa Bay railway) were occupied between May and September 1900. President Kruger fled to Holland, and the two republics were annexed to British South Africa. Though the war did not end till the peace of Vereeniging in May, 1902, the last year of the nineteenth century saw the extinction of any independent Dutch State in Africa. Yet soon after the conclusion of this peace responsible government was once more granted to the reconstituted states of the Orange River and the Transvaal in r 906-7. The last-named, however, was deprived of Swaziland and of its province of northern Zululand, which last was added to Natal. The Union of South Africa (Cape Colony, Orange Free State, Transvaal and Natal) followed in r9ro; and the

1 This Delagoa Bay railway was made by a group of British and American concessionaires, headed by Colonel Edward $\mathrm{M}^{\mathrm{c}} \mathrm{Murdo}$, an American, between 1887 and 1889 . In the following year it was arbitrarily seized by the Portuguese Government on an unfair quibble. The Portuguese then completed the line farther inland until it joined the Netherlands Railway Co.'s line to Pretoria, thus giving the South African Republic a means of access to the sea independent of British control. The wrong inflicted on the Delagoa Bay Railway Company went to arbitration in Switzerland, I889; and the case was decided after I I years' deliberations in favour of the Company, to whom the Portuguese paid $£ 978$,000 in compensation. 
first Prime Minister of Dutch and English-speaking South Africa was General Louis Botha, a leading general of the disbanded Boer army. These brave, sturdy Boers have played a great part in Africa, a part of which, Holland-the country which first colonized South Africa-may well be proud. The South African Dutch are so near to our own blood and tongue, and history, that we may, without any more sting of bitterness than that with which we recall the revolt of the American Colonies, take pride in their achievements and smile grimly at the stout blows they have dealt us in their own defence. 


\section{CHAPTER VII}

\section{THE SLAVE TRADE}

MAN had not long attained full humanity before he conceived the idea of enslaving instead of, or as well as, eating his enemies or his inferiors. Slavery and the slave trade, however-mere servitude-need not excite great horror or pity when it occurs among people of the same race or the same religion, or in countries which are not far from the home of the enslaved. It is where the state of servitude exists between widely divergent races that it gives rise to abuses, which are obvious even to those who are not sensitive philanthropists.

The Negro, more than any other human type, has been marked out by his mental and physical characteristics as the servant of other races. There are, of course, exceptions to the general rule. There are tribes like the Kruboys of the West African coast, the Mandingo, the Wolof, and the Zulu, who have always shown themselves so recalcitrant to slavery that they have generally been let alone; while the least divergence from the negro stock in an upward direction-such as in the case of the Fula, Gala and Somali-appears to produce an unconquerable love of freedom. But the Negro in a primitive state is a born slave. He is possessed of great physical strength, docility, cheerfulness of disposition, a short memory for sorrows and cruelties, and an easily aroused gratitude for kindness and just dealing. He does not suffer from home-sickness to the over-bearing extent that afflicts other peoples torn from their 
homes, and, provided he is well fed, he is easily made happy. Above all, he can toil hard under the hot sun and in the unhealthy climates of the torrid zone. He has little or no race-fellowships - that is to say, he has no sympathy for other negroes; he recognizes, follows and imitates his master independently of any race affinities, and, as he is usually a strong man and a good fighter, he has come into request not only as a labourer but as a soldier.

Negro slaves were imported into Lower Egypt as servants in the earliest dynastic times. A few reached Carthage from time to time and many were brought to Imperial Rome; but the determined exploitation of the black races did not begin on a large scale till the Muhammadan conquest of Africa. The Arabs had swept across Northern Africa, and become directly acquainted with the Sudan ${ }^{1}$. Before the promulgation of Islam they traded with the East coast of Africa, and after the Islamic outburst they ruled there as sultans. The secluding of women in harims guarded by eunuchs had come into vogue during the Byzantine Empire; but it was probably a custom of Syrian, Mesopotamian, or Egyptian origin. It was adopted with emphasis among the civilized Mussulmans, and the negro eunuch proved the most efficient and faithful guardian of the gynæceum. So the slave trade developed mightily in the Muhammadan world. Household slaves and eunuchs were imported into North Africa, Arabia, Turkey, and Persia from the Sudan; while in a later century the Emperors of Morocco established their power firmly by importing fighting negroes from Nigeria. Arabia, Persia, and India obtained negroes from the Egyptian Sudan, Abyssinia, and the Zanzibar coast. Into the West coast of India negro slaves were imported from East Africa to become the guards of palaces and the fighting seamen of navies. In the Bombay Presidency these negroes became so useful or powerful that they carved out states for themselves, one or more of which, still ruled by negro princes, are in 1 Sudan means in Arabic "Black men" or the "Land of the Blacks." 
existence at the present day as dependencies of the Government of India ${ }^{1}$.

The final impetus was given to this traffic by the European. When the Spanish, Portuguese and English discovered and settled America they found the native races too few in numbers, too fierce, or too weakly to be suited for compulsory agricultural work; and so early as $15 \circ 3$ African slaves were working in the mines of Hispaniola, brought thither by the Spaniards ${ }^{2}$. A few years later they were being imported into Mexico, Panama and

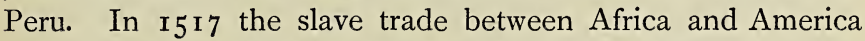
was regularly established, Charles V of Spain having granted to a Flemish merchant the exclusive privilege of importing into America 4000 slaves a year. This monopoly was subsequently sold by the concessionaire to a company of Genoese merchants, who struck a bargain with the Portuguese government to supply the slaves from Guinea.

English adventurers, who had first found their way out in Portuguese ships to investigate the spice trade, soon determined to take up the traffic in negro labourers for the plantations in America as being more profitable. John Hawkins, one of the famous seamen of the Elizabethan era, in $\mathrm{I}_{5} 62$ took over to the West Indies the first cargo of slaves transported under the British flag. Afterwards made Sir John Hawkins (and adopting a "demi-Moor in his proper colour, bound with a cord" as his crest) he made two other voyages $\left({ }_{5} 6_{4},{ }_{15}{ }^{67}\right)$ to the West coast of Africa, conveying some eight hundred kidnapped or purchased negroes to the West

${ }_{1}$ As for example, Janjira in Konkan, which has an area of 325 sq. m., and Jafarabad in Kathiawar, 42 sq. $\mathrm{m}$. in extent.

2 Three hundred negro porters and soldiers accompanied Cortes on his march to Mexico in 15I9; negroes carried the loads of Balboa when he discovered the Pacific Ocean in $\mathrm{I}_{5} \mathrm{I} 3$, and accompanied Hernandez to Peru in 1530 . Negro workmen assisted the Spaniards to found the city of St Augustine in Florida in ${ }^{1565}$; and negroes, rising high in the Spanish service, in the first half of the 16 th century explored for Spain the lands of New Mexico and Arizona. 
Indies. England did not engage largely in the slave trade on her own account until in the I 7 th century she commenced to possess Jamaica and other West Indian islands, and to develop the tobacco plantations of Virginia. Then she almost outdid rival nations. The late Dr Robert Brown, in his interesting work, "The Story of Africa," computed that in a little more than a century, from I680 to I $786,2,130,000$ negro slaves were imported into the British-American colonies, Jamaica in the course of 80 years absorbing 610,000. Towards the latter end of the $\mathrm{I} 8$ th century the various European powers interested in America imported on an average over 70,000 slaves a year, the British bringing more than one half, and sometimes a still greater proportion. At first the slaves came chiefly from the Gambia and the other rivers southward to Sierra Leone, and from the Gold Coast, where they were supplied to the Dutch through the incessant wars of the Ashanti people. Later they were brought from Dahomé and Benin, and from the Portuguese possessions of Angola and the Zambezi. Then, as the demand grew, a rich field was tapped in the I8th century in that network of swampy rivers, which we now know as the delta of the Niger river. But slowly there grew up in England, in Denmark, and in the United States a feeling that there was something wrong in this system which imposed so much misery on beings, who, though in some degree inferior to white men, were yet of the same species, since they could interbreed with us and learn to talk our language. That such feelings must have existed at all times was evident from the desire of good men when dying to grant freedom to their slaves. But the feeling as a national one remained dormant, and was not general in England until the close of the I8th century. Here and there cases of a negro prince being sold into slavery attracted attention and sympathy and caused a searching of consciences among enlightened men.

In I 768-72 a great-minded Englishman, Granville Sharp, succeeded by pushing a test case in getting a judicial decision 
that slavery could not exist in England, and that therefore any slave landing in England became free, and could not be taken back into slavery. In I 787 Wilberforce, Clarkson, and other philanthropists formed themselves into an association to secure the abolition of slavery, and by their exertions in Great Britain a bill was passed in 1807 which did not go to the lengths they desired, but which subjected the slave trade under the British flag to severe disabilities. In I 8 I $\mathrm{I}$ this measure was completed and enforced by another bill declaring the Slave Trade to be a felony punishable by penal servitude. Yet it is doubtful whether, before these acts were passed, the hardships of the slaves transported by sea were so terrible as they became after the restrictions placed on the trade rendered it necessary to carry large numbers of human beings on a single voyage more or less concealed from sight in the hold of the vessel with an utter disregard for sanitary conditions ${ }^{1}$. In these later days, when it was necessary to evade tiresome regulations or to carry on the trade in the face of direct prohibition, the sufferings of the slaves were so appalling that they almost transcend belief. It would seem as though the inhuman traffic had created in Arabs, Negroes and white men a deliberate love of cruelty, amounting often to a neglect of commercial interest; for it would obviously have been more to the interest of the slave raider and the slave trader and transporter that the slaves should be landed at their ultimate destination in good condition - certainly with the least possible loss of life. Yet, as the present writer can testify from what he has himself seen in the eighties and nineties of the last century, a slave gang on its march to the coast was loaded with unnecessarily heavy collars or slave-sticks, with chains and irons that chafed and cut into the flesh, and caused virulent ulcers. The slaves were half starved, over-driven, insufficiently provided with drinking water, and recklessly exposed to death from sunstroke. If

1 For particulars on this subject consult my book on the Negro in the New World (1910). 
they threw themselves down for a brief rest or collapsed from exhaustion they were shot or speared or had their throats cut with fiendish brutality. I have seen at Taveita (now a civilized settlement in British East Africa) boys and youths left in the bush to die by degrees from mortification and protrusion of the intestines owing to the unskilful way in which they had been castrated by the Arabs, who had attempted to make eunuchs of them for sale to Turkish and Arab harims. Children whom their mothers could not carry, and who could not keep up with the caravan, had their brains dashed out. Many slaves (I again write from personal knowledge) committed suicide because they could not bear to be separated from their homes and children. They were branded and flogged, and, needless to say, received not the slightest medical treatment for the injuries resulting from this usage.

So much for the overland journey which brought them to the depôt or factory of the European slave trader on the coast ; then began the horrors of the sea passage, the description of which, it must be admitted, refers almost entirely to the ships of civilized nations, like the English, Dutch, Spanish, Portuguese, and Americans, and not to the Arabs and Indians, who carried slaves across from the East coast of Africa to Arabia or India. In the latter case the sailing vessels were not often overcrowded, and the slaves were allowed a fair degree of liberty. In the slave trade with America, especially when it was placed under restrictions and finally penalized, it was the aim of the masters to pack as many slaves as possible on board the vessel, the peril of making one run being only half of what was entailed in making two. Very often the slaves were sent on board stark naked. They were packed like herrings in the hold or on the middle deck, and in times of bad weather, or for reasons of security, were kept under hatches. The stench they produced then was appalling, and many died asphyxiated. On some ships, and where the captain was a humane man, the slaves were occasionally 
allowed to go on deck, and were watered with a hose; and where the skipper's commission made it profitable to him to land the slaves in good condition, they received better food, and occasional luxuries like tobacco; but if the slaver were chased by a British cruiser, no scruple was shown in throwing the slaves overboard to drown.

Denmark has the credit of being the first European power to forbid the slave trade to her subjects (I792). Two years later the United States of America forbade their subjects to "participate in the exportation of negroes to foreign countries"; and in 1804 an act (first promulgated in 1794) was revived, which prohibited the introduction of any more slaves into the United States. A long struggle had taken place in Great Britain (many of the Liverpool and Bristol merchants being deeply interested in the slave trade) before, in 1807 , an act of Parliament was passed (intensified in $\mathrm{I} 8 \mathrm{I} \mathrm{I}$ ) abolishing the slave trade so far as British subjects were concerned. At the Congress of Vienna (r8I4) France agreed in principle that the slave trade should be done away with, and even signed a treaty providing that whilst the slave trade continued with French colonies it should only be carried on by French subjects. During Napoleon's hundred days of rule in I8 55 a decree was issued ending the slave trade for good and all. In the same year Portugal subjected the slave trade to certain restrictions, but did not finally abolish it till $\mathrm{I}_{3} \mathrm{O}$. In $183_{3} 6$ Britain paid Portugal the sum of $£_{300,000}$ in order to get the export of slaves from any Portuguese possession prohibited. Great Britain had also in 1820 paid $£ 400,000$ to Spain to purchase a promise from the Spaniards that they would cease to buy negroes in Africa. Both contracts, though ostensibly agreed to by the Governments concerned, were frequently violated by individuals. In I 8 I 4 and I8I 5 the Dutch and Swedes respectively prohibited the slave trade to their subjects, and a few years later most of the Spanish South American states abolished the slave-trade on attaining their independence. Slavery was abolished as 
a legal condition in all parts of the British dominions by 1840; in Jamaica and the West Indies in 1833 , in South Africa 1834-1840, and in India about the same time ${ }^{1}$. Besides the sums mentioned which Britain paid to Spain and Portugal to induce them to give up the traffic in slaves, she distributed twenty millions of pounds amongst slave owners of the West Indies as compensation for the abolition of slavery, and $\mathcal{E}_{\mathrm{r}, 250,000}$ to those who possessed slaves in Cape Colony when they were emancipated. Add to these sums the millions of money she has spent in founding Sierra Leone as a slave settlement, in helping Liberia ${ }^{2}$ (from the same motive), in patrolling the East and West coasts of Africa and the Persian Gulf, and it will be admitted that we have here a rare case of a nation doing penance for its sins, and making that real reparation which is evidenced by a monetary sacrifice.

By 1848 the French had abolished slavery in all their possessions. The Dutch did not do so till $\mathrm{r} 86_{3}$; in which year also the status of slavery ceased in the United States. Slavery lingered in some of the South American states until I840-5. In the Portuguese African possessions slavery was abolished in 1878 and in Spanish Cuba and Porto Rico in I 886 ; while Brazil remained a slave-holding country until I 888 , the final and somewhat abrupt abolition of slavery being one of the causes which led to the downfall of the Emperor. However, long after British or French possessions had ceased to offer inducements to the slave trader to run illegal cargoes, there were sufficient countries in the Western Hemisphere to provide an excellent market for negroes, while the

1 Natives of British India, however, continued to hold slaves on the East coast of Africa until it was made a criminal offence in 1873 .

${ }^{2}$ Liberia commenced with an attempt made by philanthropic Americans (the American Colonization Society) in $\mathrm{I}_{22}$ o to repatriate free negroes from the United States. It was formally recognized as an independent state by the British Government in 1847 and occasionally assisted to maintain its authority by British war vessels. Liberia did not enter into diplomatic relations with the United States till I 862 . 
Muhammadan world in the East continued to make greater demands than ever on the Central African slave preserves ${ }^{1}$.

To counteract the attempts to evade the law a powerful British squadron swept the West coast of Africa ; but in spite of British efforts to intercept slave-trading vessels, these latter continued to run cargoes across to the United States, Cuba and Brazil, and it was not possible for this traffic to be wholly vanquished until the abolition of slavery in those countries closed the last markets to the slave trader. A most interesting light is thrown on the vastness of the area covered by these slave-trading operations in a work by the Rev. S. W. Koelle (a missionary of the Church Missionary Society) published in I 854, entitled "Polyglotta Africana." Mr Koelle established himself at Sierra Leone for some years and busied himself in collecting from the slaves who were landed there from British cruisers vocabularies of the languages they spoke in their own homes. In this way he took down over 200 languages, which represented most of the tongues of the West coast of Africa, of the upper Niger, of Senegal, of Lake Chad, the South-west African coast as far as Benguela, Nyasaland, the Zambezi delta and the South-east coast of Africa, and even Wadai.

When, at the close of the I8th century, British philanthropists were desirous of repatriating loyalist negroes in North America who wished to return to Africa, the Sierra Leone Company was started, which purchased from native chiefs the nucleus of the present colony of Sierra Leone. Here, for three-quarters of a century, British cruisers landed and set free the slaves that were captured off the West coast of Africa. Zanzibar, on the other side of the continent, became about twenty years ago the eastern analogue of Sierra Leone. Since the British occupation of Egypt, slavery has practically ceased

1 Slavery was abolished in the Turkish dominions after the Crimean War, but the slave trade exists still to some degree on account of the harims, which demand a supply of eunuchs. Slavery of a mild kind also continues in force in the states of Arabia, in Persia, and in Morocco. 
to exist in that country; and owing to the French occupation of Algeria and Tunis, and the influence brought to bear by Britain on Turkey in regard to Tripoli, there is not much traffic in slaves across the Sahara Desert to those countries; though anybody visiting the south of Tunis will be surprised at the large number of negroes in all the villages, showing that quite recently constant supplies must have been received from Bornu and the Hausa states. The devastating slave raids of the Matebele Zulus have been abolished by the British South Africa Company; and similar raids of the Angoni have been put an end to by the British and German Governments in East and Central Africa.

The Arabs of Zanzibar had acquired an evil fame for their gigantic slave raids in East-central Africa. Great Britain, who had assisted to separate Zanzibar from Maskat as an independent state in 1862 , began to concern herself a few years later with the slave trade which flourished in those dominions. By 1873 the Sultan of Zanzibar had, after considerable pressure, been induced to make the slave trade illegal in his Sultanate, though it continued to flourish in an illegal manner until the administration of his territories by the British and Germans.

Arabs from 'Oman in South-west Arabia and from Zanzibar pushed ever farther and farther into Central Africa from the East coast until they reached the Upper Congo, where they established themselves as sultans amongst the negroes, and enslaved millions. Here and there they Muhammadanized a tribe like the Wa-yao, Manyema, or Wa-nyamwezi, whom they provided with muskets and made worse slave raiders than themselves. These slave raids in the districts of Lakes Nyasa and Tanganyika, revealed to the world by Livingstone, greatly concentrated the attention of Great Britain on these regions; and one of the intentions of the British Government in establishing a protectorate in South-central Africa was the abolition of the slave trade, which was brought about in 1896 , after 
six years' campaigns with a small force of Indian soldiers ${ }^{1}$, and the placing of two gunboats on Lake Nyasa. At the same time the Belgian officers of the Congo State had attacked and broken up the Arabs, the principal slave-hunters amongst whom were slain or expelled from the Congo. The Germans under the brilliant Major von Wissmann hanged several Arab slave-raiders in East-central Africa, and had completely abolished the traffic of the others. The slave-raiding states of Dahomé and Ashanti, of the Mandingo conqueror Samori, and of the Fula and Nupe Sultans and Vicegerents in Eastern Nigeria had been conquered by France or Britain between r893 and 1903. Finally between 1904 and 19rI, France conquered and occupied Wadai, the most powerful Muhammadan state of the Central Sudan and thus put an end to the slave-raiding of the Maba power which was fast depopulating the heart of Africa; while this action was fortified by the Italian occupation of Tripoli and Cyrenaica (IgIr). So long as any Muhammadan power held under its direct and uncontrolled sway any part of the African coast, there was bound to be slave-raiding and slave-trading in the interior.

In short, though slavery still exists, avowed or disguised, in many parts of Africa, the slave trade is almost at an end, and slave raids are confined to such parts of Nigeria, S.W. Congoland and Abyssinian Galaland as are not under complete European control.

Abominable as the slave trade has been in filling Tropical Africa with incessant warfare and rapine, it has added much to our knowledge of that continent, and has furnished the excuse or cause of European intervention in many cases, resulting sometimes in a vastly improved condition of the natives when European rule has taken the place of that of Negro or Arab sultans. Its ravages will soon be repaired by a few decades of

1 Sikhs from the Indian Army. These campaigns have been described in the present writer's work on British Central Africa; and by Mr Alfred Swann in Fighting the Slave-Hunters in Central Africa. 
peace and security during which this prolific, unextinguishable negro race will rapidly increase its numbers. Yet about the African slave trade, as with most other instinctive human procedure, and the movements of one race against another, there is an underlying sense of justice. The White and Yellow peoples have been the unconscious agents of the Power behind Nature in punishing the negro for his lazy backwardness. In this world Natural Law ordains that all mankind must work to a reasonable extent, must wrest from its environment sustenance for body and mind, and a bit over to start the children from a higher level than the parents. The races that will not work persistently and doggedly are trampled on, and in time displaced, by those who do. Let the Negro take this to heart; let him devote his fine muscular development in the first place to the setting of his own rank, untidy continent in order. If he will not work of his own free will, now that freedom of action is temporarily restored to him; if he will not till and manure and drain and irrigate the soil of his country in a steady, laborious way as do the Oriental and the European; if he will not apply himself zealously under European tuition to the development of the vast resources of Tropical Africa, where hitherto he has in many of his tribes led a wasteful unproductive life; then force of circumstances, the pressure of eager, hungry, impatient, outside humanity, the converging energies of Europe and Asia will once more relegate the Negro to a servitude which will be the alternative-in the continued struggle for existence-to extinction. The Negro in some parts of Africa has been given back his freedom that he may use it with a man's sense of responsibility for the waste of time and opportunities. In not a few European "colonies" or protectorates in Africa the over-ruling white man, or more often the irresponsible trader, planter, prospector and labour recruiter, stills looks upon the Negro race as a people doomed to perpetual serfage. But this mental outlook is fast being modified-under British influence, mainly- 
into an honest appreciation of native rights to land and produce.

An episode in the history of African colonization which may be most fitly mentioned here, in relation to the effects of the slave trade on West Africa, is the foundation of the negro Republic of Liberia by private agencies in the United States.

When the Napoleonic wars were over and the great western expansion of the United States was beginning, the question-not yet wholly solved-arose : what was to be done with the Negro or Mulatto as citizen, as a free man with every right to a vote? There were already many manumitted negroes in North America and in the West Indies, and their position in the first half of the I 9 th century was an indeterminate one. As it commenced to be irksome, from the social and ethical problems it involved, an attempt was made (1816-20) by certain benevolent and political societies to solve it by deporting all discontented free negroes and negroids back to Africa, where they might make a new home for themselves and even enjoy the privileged position that the one-eyed man occupies amongst the blind. Great Britain, as we have already seen, had much the same problem to face at an earlier date and answered it by the foundation of Sierra Leone. At first it seemed simplest for the various missionary and philanthropic societies to dump their free negroes on the coast of Sierra Leone (in 1820 ); but the Governor of that colony seems to have received the proposal rather coldly. The fact was that at Sierra Leone (almost a failure from the "repatriation" point of view) we were beginning to find that it is scarcely easier to plant a Black colony in any part of inhabited Africa than to found a White one; you have to displace some other people, and such indigenes, if asked to choose, would rather make way for an intrusive white element than a band of foreign negroes. And when such negroes or negroids come from America or Asia they resist the African climate, or rather its germ diseases, 
not much better than Europeans. Probably the Sierra Leone Government had begun by 1820 to think more of the interests of the really indigenous, native tribes of that "colony," than of the woes and welfare of American ex-slaves.

Being thus rebuffed, the promoters of the expatriation of American free negroes made a hasty compact with the chiefs of the Dē tribe at Cape Mesurado, on the Grain Coast, just beyond the Sierra Leone influence; and in I82 I sent out a large batch of negro and mulatto colonists under the tutelage of American white men. The white men all died of fever or abandoned the enterprise in severe ill-health; but amongst the future colonists was a courageous negro, Elijah Johnson, who by his indomitable courage and resourcefulness kept the infant colony from perishing at the hands of the natives, who had not really understood the transaction by which they were supposed to have sold for a few pounds' worth of trade goods a considerable tract of coast land. In 1823 however there came out a white man of high character and great abilities, the Rev. Jehudi Ashmun; and he it was who practically founded "Liberia" (as the new settlements were called by the Rev. Robert Gurley of the American Colonization Society, in 1824).

The town which American negroes built on Cape Mesurado was named "Monrovia," after the President of the United States who formulated the "Monroe" doctrine. Other settlements were made on Cape Mount (Robertsport), at Cape Palmas (Maryland), at Sinô (Greenville), and at Grand Basa. In course of time these grew into two separate republics, "Liberia" and "Maryland." The existence of the former as a sovereign and independent State was first recognized by Great Britain in 1847 ; indeed the British Government had not only been very benevolent all through to the struggling Liberian communities, and several times come to their assistance when they were attacked by native forces, but had urged on the American negroes the advisability of their forming a State that European Powers could recognize as a valid government on 
the Grain Coast. Britain was the first Power to recognize Liberia as a sovereign State. The first President of Liberia, an octoroon American named Joseph Jenkins Roberts, went to England in 1847, was very kindly received by Queen Victoria, and made a treaty with Lord Palmerston and the Colonial Office. He afterwards visited the principal countries of western Europe. In I 857 Maryland was united with Liberia; and this negro republic then (in the eyes of Europe) ruled the West African coast from near Sherbro on the west to the river San Pedro on the east-about 400 miles, an extent of littoral since reduced by about 90 miles.

Yet this State has not so far been a success. American immigration on any large scale ceased with the outbreak of the American Civil War and the emancipation of American slaves. The natives of the Kru coast and of the Muhammadan interior spurned any idea of being governed or taxed by foreign Europeanized negroes; and the Americo-Liberians lacked either the courage or the monetary means to effect a conquest of the regions outside the portions of the coast belt on which they had built their towns and established their plantations. As the more vigorous among the American negroes and mulattoes, who had started the settlement, died out, the younger generation failed to bring a similar degree of energy into the development of their native country. All had their faces far too much turned towards either America or England. English, of course, was and remained the official language of Liberia, its adoption being facilitated by the close connection between the Kru population and British West Coast trade (many Krumen also served, and serve still, in the British Navy); the constitution of the Republic was closely, too closely, modelled on that of the United States; very little interest was taken in the languages, history, manners and customs of the million and a half of Liberian aborigines, or in the wonderful native flora and fauna ${ }^{1}$. With the exception

1 Though Liberia is quite a small country-some 40,000 square miles- 
of the journeys of Benjamin Anderson in the sixties of the last century, there arose no Liberian explorer of any note who revealed anything about the geography or natural history of the hinterland. This indeed remained (geographically) a closed book down to 1903 , when a series of explorations by British, French, Swiss, German and Dutch explorers at last brought to light by I910 the main features of Liberian geography and ethnology. British and German traders and pioneers (not Americo-Liberians) alone discovered and worked the gold and diamonds of western Liberia and the rubber forests of the centre and east.

Meantime, from the beginning of the seventies onwards Liberia got into financial difficulties. Attempts to open up the interior were costly in a country of dense forests and unnavigable rivers. A loan was contracted in England in $\mathrm{r} 87 \mathrm{I}$, the proceeds of which were vaguely squandered without results. Another loan in 1906 enabled the Liberian Government to pay off some of its German, Dutch and British creditors; but, although this loan brought about the installation of a British official as head of the Liberian customs, and consequently a vast improvement in the revenue, the disorder in the country's finances continued. France took occasion to press for a settlement of the inland frontier on terms not favourable to Liberia, though as favourable perhaps as the circumstances warranted. Great Britain had greater vested interests in the country than any other foreign nation, but forbore to press them out of regard for American feelings and a wish not to seem to impinge too much on the French sphere. Germany had trading interests in the country scarcely inferior to those of Great Britain, and but for the American factor

and is not clearly demarcated by natural features from the surrounding lands of the West African coast, it is found to possess a peculiar mammalia of great interest and a rich flora which also has its regional peculiarities. Amongst singular Liberian mammals may be noted the pigmy Hippopotamus, the Zebra antelope and Jentinck's duiker. 
would probably have pressed for a German protectorate, an intervention which might have been displeasing to Britain and France, the two limitrophe Powers. In these circumstances the Liberians were encouraged to appeal to their mothercountry, the United States; and, after considerable deliberation, an American proposal was made for taking over the control of Liberian finances and a general supervision of Liberian affairs on somewhat the same lines as have been followed by American intervention in Santo Domingo. This was accomplished in the year I9I2. What the results will be it is difficult to say.

But for international jealousies, the preferable solution or the Liberian problem would have been fusion with the adjoining colony of Sierra Leone, the coast settlements of which had an origin very similar to that of Liberia, while the use of the English language, laws, forms of Christianity, were common to both. Not a few among the Sierra Leone citizens have attained local eminence in administrative capacities; one or two even have become "world-citizens"; and several have received marks of distinction from British sovereigns. Liberia has produced her noteworthy personalities, men like Dr Edward Wilmot Blyden (a great writer on Africa), and Arthur Barclay, President of Liberia from 1904 to I9II ; but they have been men of a European culture and class of mind, and have contributed little to the solution of African problems. 


\section{CHAPTER VIII}

THE BRITISH IN AFRICA, I

\section{(West Coast, Morocco, North-Central.)}

From very early days in the history of the Portuguese monarchy close and friendly relations had been established between England and Portugal. A large body of English (together with German and Flemish) troops on their way out to the Crusades had assisted the first king of Portugal to capture Lisbon from the Moors in the $\mathbf{r}$ th century. A later king of Portugal married a daughter of John of Gaunt, Duke of Lancaster; and his sons, among them the great Prince Henry the Navigator, were half English in blood. These friendly relations were no doubt partly to be accounted for by the French origin of both ruling houses.

Therefore, when the effect of Portuguese discoveries in West Africa began to be felt in England by the extension of the spice trade (hitherto a monopoly of Venice), and the dawning idea that negro slaves from Africa would be an excellent commodity for American plantations, British seamen-adventurers were prompt to follow in the path of the Portuguese. The trade in spices seems to have been the first inducement, more powerful than gold or slaves. Englishmen had previously shipped on board Portuguese vessels before they ventured to sail to West Africa in craft of their own. Quite early in the 16 th century several Englishmen thus found their 
way to Benin in company with the Portuguese. But their proceedings were looked upon with suspicion, and friendly relations between the two nationalities soon cooled under the influence of rivalry in what the Portuguese would have liked to make their monopoly of West African trade. At the end of the reign of Edward VI (1553), and during that of Mary (1554-5), English ships ventured to cruise to the Gambia, the Grain Coast, and even the Gold Coast and Benin river, bringing back gold, ivory, Guinea pepper" and "grains of Paradise $^{2}$ " for spice making. In ${ }^{5} 5^{62-4}-7$ Captain (Sir) John Hawkins visited the West African coast with a ship of his own, and later one or more ships of Queen Elizabeth. $\mathrm{He}$ piratically attacked the Portuguese ships and robbed them of their negro slaves; he bought and kidnapped slaves on his own account and conveyed them to the West Indies. But actual trading ventures of a peaceful or honest nature were rendered very hazardous by the hostility of the Portuguese. When, however, in the latter part of the I6th century, Portugal was absorbed by Spain and Spain went to war with England, Queen Elizabeth had no hesitation in granting charters to two companies of merchant adventurers to trade with the West coast of Africa. In $\mathrm{I}_{5} 85$ the first charter was granted to a body of London adventurers for the carrying on of commerce with Morocco and the Barbary States ; in 1588 another charter was given to Devonshire merchants, who had been for some time previously endeavouring to trade on the Senegambia coast. Thus in 1588 were laid the foundations of the British settlement of the Gambia. This river, which was at first, and probably more accurately, known as the "Gambra," is remarkable among African rivers in that it has a mouth with a deep

1 Made from various aromatic seeds, such as those of true pepper vines (Piper subpeltatum, Piper guineense), and of the fruits of Xylopia athiopica).

2 The seeds of the Aframomum, a zingiberaceous plant, of the same order as cannas, bananas, etc. These early English voyages are described in detail in my book on Liberia (2 vols, 1906). 
bar, which can be crossed by big ships at any time of the tide. Next to the Congo, it is probably the safest river to enter on all the West African coast ; and as its navigability extends for over 200 miles into the interior of Senegambia, it is a very valuable means of access to the heart of the fertile regions of North-west Africa. When the British arrived on the Gambia, and for two centuries afterwards, the banks of the river were thickly studded with Portuguese trading settlements. The Portuguese, however, never seem to have raised any difficulties about its passing under British control. It was the French from Senegal who made the most determined attempts to oust the British from the Gambia.

In 1592 Queen Elizabeth chartered a further association for trading on the coast between the Gambia and Sierra Leone. As regards the subsequent history of the Gambia, it may be mentioned that the first consolidated company formed to work the trade and administer the British settlements was incorporated in $16 \mathbf{r} 8$, but it was not successful and the association following it also failed ${ }^{1}$. In $\mathrm{I}^{6} 64$ a fort, subsequently called Fort James, was built on the island of St Mary, off the south bank of the mouth of the Gambia. This was the nucleus of the present capital of Bathurst, named a century and a half afterwards from the same Colonial Secretary whose name was given to the Australian town. In the $\mathbf{I} 7$ th century the French made determined attacks on the Gambia, and in 1696 succeeded in destroying the British settlement, which however was reoccupied and restored four or five years later. In spite of

${ }^{1}$ It was this company that sent out in 1618 George Thompson in charge of a trading expedition. Thompson was killed in some quarrel with his men at Tenda on the Upper Gambia. In $1620-21$, his companions were rescued, and his explorations continued by Captain Richard Jobson, who ascended the Gambia as far as it was navigable from the sea, came into contact with the Fula and Mandingo peoples, and on his return wrote an account of his experiences in a book called The Golden Trade. This work-recently republished in the unabridged form of the MS.-is one of the most vivid pen-pictures of Negro Africa ever penned. 
the dissipation of the rumours of gold in the country of the Upper Gambia (the result of the mission of enquiry conducted in 1723 by Captain Bartholomew Stibbs), the Gambia settlement became rich and prosperous in the 18 th century owing to the slave trade. The Gambia River became the starting place of the first serious British explorations in Western Africa and Nigeria. In 1783 the intermittent struggle with France was concluded by the French recognition of exclusive British trading rights on the Gambia, with the exception of the French factory at Albreda, in return for a similar concession to themselves of the commercial monopoly of the river Senegal; but as a set-off against the French factory on the Gambia the British retained the exclusive right to trade with the Moors of Portendik (near Cape Blanco) for gum. In 1857 these two rights were exchanged. During the Napoleonic wars England seized the French settlements at the mouth of the river Senegal, and British merchants went thither to trade. Upon the surrender of Senegal to France in $18 \mathrm{I} 7$ these British merchants left the Senegal and founded the town of Bathurst, now the capital of the Gambia colony. In 1807 , the tiny Gambia colony, now much impoverished by the abolition of the slave trade, had been subjected to the newly-founded government of Sierra Leone. In 1843 , its prosperity having somewhat revived owing to the growing trade in ground-nuts, and its area having been increased by various additions of territory along the banks of the river, it was rendered independent of Sierra Leone; but again in 1866 was attached to that colony until once more it was given a separate administration in 1888 . In the early seventies attempts had been made to assert British claims to the coast separating the Gambia and Sierra Leone, where Portuguese rule had lapsed; but Portugal having succeeded in asserting her claims (p. 98), the project was dropped, and during the period of discouragement which followed France was allowed to extend her sway over all the country on either side of the lower Gambia. Several times during the r 9 th century 
the project was mooted of exchanging the Gambia with France, first for her possessions on the Gaboon coast, and later on for Porto Novo, and Grand Bassam. The first project, which would have ultimately given us French Congo, was opposed and defeated by the British merchants on the Gambia; and the second, which would have eventually led to a continuous British coast line from Sierra Leone to the Niger, was upset by the opposition of Marseilles trading houses at Porto Novo. In $189 \mathrm{I}$ the best was made of a bad position, and a delimitation agreement was come to with France, which at any rate secured to Great Britain both banks of the river Gambia to the limits of its seaward navigability. After this settlement with the French there was a certain amount of friction amongst the Muhammadan (Mandingo and Fula) natives due to interference with their slave-raiding. A chief named Fodi Kabba had to be expelled for this reason from British territory. Two years afterwards another slave-raider, Fodi Silah, inflicted severe losses on a punitive expedition sent against him, but eventually was driven into French territory where he died. Meantime Fodi Kabba, having fixed his residence in French Senegambia at Medina, the celebrated town in Wuli associated with Mungo Park, directed thence an insurgent movement against the British which resulted in the death of two British officials. But the French forces cooperated in I.90 I with those of Great Britain; Medina was captured and occupied; and Fodi Kabba was killed. Since then the Gambia region-once a great recruiting ground for slaves - has been peaceful and prosperous. A hut tax has increased its revenues since 1894. In 1906 domestic slavery was extinguished by an ordinance, the slave trade having been extirpated by joint British and French occupation of the trade routes a few years previously.

The words "Sierra Leone" are a kind of compromise between Spanish and Portuguese due to the dull hearing and careless spelling of foreign names so characteristic of the English until the present generation. Projecting into the sea 
on this part of the coast (a coast otherwise flat and swampy) is a mountainous peninsula with bold hills facing the sea front. If these mountains are not sufficiently high" to be the "Theion Oxema" of the Greek translators of Hanno's journal, they were at any rate sufficiently striking to make an impression on the early Portuguese explorers, who dubbed them "Serra Leoa" or the "Lion-like Mountain Range" because the reverberating thunder from the frequent storms booms and echoes between these forested peaks and valleys exactly like the roar of many lions. (The Spanish form would be Sierra Leona, and it was apparently the Spanish name that the English navigators adopted.) The British first frequented this coast in 1562 when (Sir) John Hawkins came to the Sierra Leone (Rokel) river to get slaves. From that time onwards British ships called at Sierra Leone whenever they could elude the warships of the angry Portuguese. A British trading station was established here in the latter part of the $I$ th century and did not wholly disappear (though usually tenanted as the slave depôt of some English-speaking mulatto) till it was merged in the definite occupation of 1787 . Towards the end of the 18 th century the fine harbour--the best harbour on the West coast of Africa-attracted the attention of Dr Henry Smeathman; and inspired by his writings the British Government obtained the cession of the Sierra Leone peninsula in 1788 . Four years later a charter was granted and the territory was transferred to a philanthropic association known as the "St George's Bay Company," which decided to establish in that part of West Africa a settlement for freed negro slaves from the West Indies and Canada.

Upon the granting of the charter the name was changed to the "Sierra Leone Company." To Sierra Leone had been brought in $\mathrm{r}_{7} 87$ loyal free negroes, who had fought on the British side during the American War of Independence, and were therefore given their liberty, but whom it was thought

1 They rise at the highest to 2000 feet. 
better to deport to a climate more suitable to Africans than that of Nova Scotia, where they were at first disbanded. Then were sent out about 400 masterless negroes picked up in England after the judicial decision obtained by Granville Sharp as to the illegality of slavery in England. These were known as the "Granvilles." To them were added later the "Maroons" "-Jamaica negroes mixed in a slight degree with the blood of the extinct West Indian natives, who had taken to the bush in Jamaica, and were making themselves troublesome. Further, as soon as Sierra Leone was adopted as the dumping ground of the slaves set free from the captured slavetrading ships, there were added to these ex-slaves of America and England the heterogeneous sweepings of West, Central, and South-east Africa, generally known as "Willyfoss Niggers," because their freedom was originally due to the exertions of $\mathrm{Mr}$ Wilberforce. Then of course there were the original Timne, Bullom, Mendi, and Susu inhabitants; so that altogether the negro population of modern Sierra Leone is an extraordinarily mixed stock, to which a large colony of Kruboys from the Liberian coast has since been added.

The philanthropic company which started this settlement in 1787 had some quaint notions in its inception. Sixty London prostitutes were sent out to Sierra Leone to marry with the negroes and become honest women, while numbers of English, Dutch, and Swedes were invited to go there as free settlers, under the belief that West Africa was as suited for European colonization as Cape Colony. The result was of course that nearly all these European immigrants died a few years after their arrival, though not before they had left their impression upon the strangely mixed population of Sierra Leone. The whole settlement had to be begun over again in $179 \mathrm{r}$.

In 1807 the rule of the colony was transferred to the

1. Maroon' was a corruption of the Spanish "Cimarron," an outlaw frequenting the summits (Cimas) of the mountains. 
Crown; and in $182 \mathrm{r}$ Sierra Leone was for the first time joined with the Gold Coast and the Gambia into the "Colony of the West African Settlements." In I843 the Gambia was detached, in 1866 joined again; and in 1874 the Gold Coast and Lagos were separated from the supreme control of Sierra Leone. Finally in 1888, the Gambia having been made a separate administration, Sierra Leone became an isolated colony. Between 1862 and 1864 its territory was considerably extended along the coast; and a treaty of delimitation with France in 1894, though it cut off the access of Sierra Leone to the Niger, still extended the influence of the colony a considerable distance inland. During the eighties of the I 9 th century there were considerable difficulties with turbulent tribes, especially the 'Yonnis,' who were subdued by an expedition under Sir Francis de Winton. In 1898 an uprising of the natives of the interior in opposition to the suppression of the slave trade and the levying of a hut tax seriously disturbed the colony, and led to some months' obstinate bush fighting mainly against the Timne, Kisi, and Mendi peoples, and a massacre of American missionaries. But this little war produced excellent results. The turbulent, slave-trading, andin the south-east-fetish-governed, cannibalistic natives were for the first time effectively conquered by the white man. A resettlement of the territory of 30,000 square miles took place. The old colonial nucleus of Sierra Leone was limited to the peninsula of that name and the coast strip. All the interior was declared a protectorate and divided into districts wherein the rule of the native chiefs was maintained or revived, under the control of British resident commissioners. The hut tax was firmly instituted, but the natives' exclusive rights to the land were carefully respected. Finally a railway was built for some 230 miles across the south-east half of the Protectorate to the Liberian frontier. Other railways or tramways are being constructed to the French frontier on the north. A short but very important mountain railway now carries passengers to the 
healthy summit of the beautiful mountain range above the hot and unhealthy capital (Freetown). Here the European residents can reside, can pass the night in a comparatively cool climate. Sierra Leone has ceased to be the white man's grave. From many points of view it has become the model West African colony.

Although British traders in gold and in slaves came to the Gold Coast in the wake of the Portuguese in the r6th century, they established no form of administration there until 1672, when Charles II gave a charter to the Royal African Company and the monopoly of trade between Morocco and Cape Colony. The Royal African Company built forts at various places on the Gold Coast, and at Whyda $^{1}$ on the coast of Dahomé. It was succeeded in I $75^{\circ}$ by the African Company of merchants, a company subsidized by the Government, which continued to exist until I $82 \mathrm{I}$, at which date the British forts on the Gold Coast were placed under the Sierra Leone government of the West African settlements, and the fort at Whyda was abandoned. In I807, the powerful Ashanti tribe thrust itself anew on the attention of European nations (already acquainted with it as a great provider of slaves and a diligent worker of the alluvial gold deposits) by forcing its way to the coast, and attacking and destroying the British fort of Anamabu and the Dutch fort of Kormantyn. 'They even besieged Cape Coast Castle. In I8I 7 a mission, eventually under the charge of Thomas Edward Bowdich, was sent to Ashanti to bring about more friendly relations with the King of Kumasi. It succeeded, but the terms of the treaty then made were not carried into effect by the British Government, out of pity for the harassed Fanti coast tribe; consequently the relations between Cape Coast Castle (then the head-quarters of British administration in the Gold Coast) and Ashanti once more became strained ${ }^{2}$. In I824,

1 Properly 'Hwida.'

2 All this period in the history of the Gold Coast, including Bowdich's 
while on a tour of inspection, the Governor of Sierra Leone, Sir Charles Macarthy, landed at Cape Coast Castle, and unfortunately embarked on a war with the Ashanti without properly organized forces. He was defeated and killed. The Imperial Government carried on the war for three years, finally inflicting a defeat on the Ashanti near Accra, which led three years later to a peace. But this lengthy campaign had disgusted the Imperial Government with rule on the Gold Coast, and as soon as peace was concluded with the Ashanti they handed over these settlements to a committee of London merchants. This committee selected and sent out an excellent man as Governor-Mr Charles Maclean. This administrator contrived with a yearly subsidy of $£ 4000$ and a force of roo police to extend British influence over an area nearly coincident with the present Gold Coast Colony. But in 1843 the rule of the merchants was replaced once more by that of the Crown, though Maclean was taken into the service of the new Imperial administration.

The Danes and Swedes on account of the slave trade had established forts on the Gold Coast in the $I 7$ th and I 8th centuries, respectively, to supply the West Indian islands with slaves. The Swedes soon abandoned their trading forts, but Denmark still retained four down to the middle of the I $9^{\text {th }}$ century, all of which she then sold to England in $185^{\circ}$ for $f_{1} \mathrm{r}, 000$. For the same modest payment Denmark transferred to England the protectorate over a considerable area to the east of the Gold Coast Colony, along the river Volta. The Dutch during the $I 7$ th and 18 th centuries had planted forts on the Gold Coast in rivalry with the English, and in most cases alongside of them. After the abolition of the slave trade Holland lost interest in her West African possessions. Their existence was very awkward to the English, as it prevented the collection of customs duties. In mission, is described in detail in my book, Pioneers in West Africa (Blackie, I9II). 
I 868 a partition of the coast was negotiated between England and Holland, the Dutch taking over all the forts west of a certain line, and the English those which lay to the east of this boundary. In this manner the English acquired at last the whole of the town of Accra, which is now the capital of the Gold Coast. In $187 \mathrm{I}-2$ the Dutch agreed to abandon to the English all their remaining possessions on the Gold Coast in return for the cession of certain British claims over Sumatra. Unfortunately, the transfer of territory from the Dutch entailed a quarrel with the powerful negro kingdom of Ashanti, situated behind the coast tribes of this region but striving always to reach the sea. The Ashanti kingdom was rather a confederacy of small negro states, with the King of Kumasi at its head, than a homogeneous monarchy. In 1872 this paramount King of Kumasi despatched an army of 40,000 men to invade the British Protectorate and assert his claim to domination over the Fanti tribes of the colony. A large force of Fantis was to some extent armed and organized by the British Government, but the Ashantis defeated them twice with great slaughter, and then attacked the British fort of Elmina, where the Ashanti army sustained such a serious repulse that it avoided any further attacks on British fortified settlements. A year afterwards, Sir John Glover (as he subsequently became) marched with Hausa levies to attack the Ashanti from the east, while Sir Garnet Wolseley ${ }^{1}$, arriving in the winter of $\mathbf{1} 873$ with a strong expedition composed of British soldiers, contingents of the West Indian regiments, British seamen, and marines, drove the enemy back into their country, reached the capital, Kumasi, and captured and burned that place. A somewhat dubious peace was arrived at, the king never afterwards fulfilling the terms of the treaty, which he was supposed to have signed with a pencil cross; and for the following twenty-one years British relations with Ashanti (which was also devastated by civil war) were unsatisfactory.

1 Afterwards Viscount Wolseley. 
At last, in 1895, another strong expedition marched on the capital without firing a shot, and took the king prisoner. But the Ashanti people bided their time; and when, in I9oo, the British forces seemed fully occupied with the South African trouble, three tribes of the Ashanti confederation (40,000 fighting men) rose in rebellion just at the time when the Governor of the Gold Coast and his wife were visiting Kumasi Fort. The rebellion broke out on April I, and the Governor and his wife remained shut up till June 23 , only a slender relief of negro soldiers and British officers arriving. On June 23 the Governor and his wife (Sir F. Hodgson and Lady Hodgson) left Kumasi with an escort of 600 Hausa soldiers, cut their way through the Ashanti besiegers (with the loss of two British officers killed), and safely reached the Gold Coast Colony. A slender garrison of too Hausa soldiers and three white officers was left to defend Kumasi. Colonel (Sir) James Willcocks arriving from Nigeria with a few hundred Yoruba and Hausa troops marched through incredible difficulties of flooded lands, impenetrable forest and lack of transport to the relief of Kumasi. In the course of a few weeks he was reinforced by negro and Indian troops from British Central Africa and a number of British officers and non-commissioned officers, till at length he had a force of 3500 officers and men, besides the allied friendly tribes of Ashanti. Kumasi was effectually relieved on July I5 (the garrison was too weak to stand); and by the end of the year the whole of Ashanti had been effectually conquered and annexed. A railway from Kumasi to Sekondi on the coast, completed in I903, sealed the pacification of the country. Ashanti now forms a large province (some 23,000 square miles) of the government of the Gold Coast. Beyond the forests of Ashanti, to the north, is the considerable area $(33,000$ square miles) known as the Northern Territories. This is separated from Ashanti mainly by the course of the Volta and of its great tributary the Black Volta. Unlike Ashanti, it contains no great area of dense forest, but is a grassy park-like 
country, dry and even treeless in the south-east. The negro population belongs mainly to the Dagomba-Moshi group, and is largely Muhammadan in religion. These northern territories were practically part of unknown Africa until the eighties of the last century. They were revealed to us by the journey of English, French, and educated negro explorers, and became a British protectorate between 1892 and 1899 . The principal products are cattle and shea-butter (a vegetable oil).

The oldest possession in this region and the southernmost of the three great provinces of this important British territory is the Gold Coast Colony proper, which lies between Ashanti and the sea and covers an area of 24,200 square miles. Celebrated for its alluvial gold from prehistoric times onwards, it has of late become more remarkable for its rock gold from reefs of quartz and auriferous conglomerates. To work these more efficiently a railway was constructed from Sekondi to the interior by 1908 , with a branch line. The average value of the gold exported annually since 1907 is about one million sterling. Since the beginning of the 2 oth century there has been a great development of cacao planting amongst the natives, on their own land; and the importance of this movement and its profitable results has quite changed the European conception of African colonization. It is now realized that the native proprietor works far harder on his own land if there is a market for his produce than he does as a paid servant on a European-owned estate.

Although the Gold Coast is perhaps the most unhealthy of the British West African possessions, it is prosperous in its finances, and has made great progress in trade. In the last ten years the total value of its trade has quadrupled, and stands now at $£ 6,000,000$ in approximate yearly value.

The colony of Lagos came into existence in $1863^{1}$. It was afterwards added to the government of the West African Settlements, then attached to the Gold Coast ; and finally in

1 The territory was ceded by its king to Great Britain in $186 \mathrm{r}$. 
I 886 made an independent colony. Lagos, as its name shows, was originally a discovery of the Portuguese, who so named it from the large lagoon, which until recently was a harbour of very doubtful value, even on this harbourless coast, but is now by a vast expenditure of money rendered safe for the exit and entrance of steamers at high tide. In the days of the early Portuguese adventurers the modern territory of Lagos was partly under the influence of Dahomé, partly under the rule of Benin; and the Portuguese and subsequently the British came there to buy slaves which native warfare rendered so abundant. In prosecuting the crusade against the slave trade in the middle of the last century the British Government came into contact with the king of Lagos, who had become one of the most truculent slave traders on the coast. This king, Kosoko, was expelled by a British naval expedition in $185 \mathrm{I}$, and his cousin was placed on the throne, after having made a treaty with the British binding himself to put down the slave trade. A British consul was appointed to superintend the execution of this treaty, but neither the king who signed it nor the son who succeeded him kept faithfully to its provisions. At length, in 186r, the king of Lagos ceded his state to the British Government in return for a pension of $£$ rooo a year, which he drew until his death twenty-four years later. Under British rule Lagos attained remarkable prosperity, though unhappily its extremely unhealthy climate caused great loss of life amongst the officials appointed to administer the colony. Owing to the great commercial movement in its port (the adaptation of which to ocean-going steamers proved very difficult and very expensive) it was called, with some justice, the "Liverpool of West Africa."

At any time between the annexation of Lagos and, say, I880, the small strip of coast which separates Lagos from the Gold Coast might easily have been taken under British protection, the only power with any intervening rights being Portugal with one fort on the coast of Dahomé; but the 
Home Government would never agree to this procedure until it was too late and France and Germany had intervened. Subsequently, until about 1898 , there was growing trouble with France owing to her extending her protection or colonization over the little kingdom of Porto Novo, the large negro state of Dahomé, and the adjoining country of Borgu. These disputes as to delimitation of the frontier were settled in 1889 as far north as the 9th parallel. Then ensued in 1897 and 1898 a strenuous attempt on the part of the French to cut across the Lagos hinterland up to the Niger, but this difference was again happily solved by the Convention signed between the two countries in the summer of 1898 .

Beyond Lagos, and indeed connected with it by half choked-up creeks, begins the great delta of the Niger, which extends along an elbow of the coast about 200 miles to the eastward, and ends-so far as direct connection with the Niger is concerned - at the mouth of the river Kwo-ibo, though there are probably creeks inside the coast-line which would carry on the connection of the delta to the Old Calabar estuary. These innumerable branches of the Niger stream were taken to be independent rivers (which indeed they are to some extent, receiving as they do many streams rising independently of the main Niger) until well into the present century, when it was at last made clear that they constituted the outlets of the third greatest river of Africa. Together with the adjoining rivers of Old Calabar and the Cameroons, they became known as the "Oil Rivers," because they produced the greater part and the best quality of the palm oil sent to the European market. The Portuguese first came here in the 17 th and 18 th centuries (after falling out with the king of Benin) to trade in slaves; and the English followed them at the end of the r8th century and displaced them altogether. Evidence of former Portuguese interest in the Niger Delta is sufficiently shown by the fact that some of these rivers have Portuguese names, or Portuguese corruptions of native names. The remaining names 
are chiefly those of naval officers or ships that surveyed them, or occasionally a native designation more or less corrupted.

By the time the slave trade was rendered illegal, the wonderful virtues of palm oil had been discovered, chiefly in connection with its value as a lubricant for machinery (especially locomotives) and as a material for making candles and soap. Therefore the development of railways in Britain and other European countries, the new cleanliness, which coincidently was preached as a British gospel, and the spread of education and love of reading made the fortune of the Oil Rivers and those merchants who settled there at imminent risk of death from fever. Already in the forties of the last century British trading interests had become so important in the Niger Delta that a consul was appointed. The first consul, Captain John Beecroft, was a most notable personality, as an explorer and peacemaker. To him Great Britain owes the definite establishment of her influence on the Cross River and at Old Calabar. The British Government, for the purpose of putting down the slave trade, had, with the consent of Spain, occupied during the first half of the I 9 th century the Spanish island of Fernando Pô; and the administration of this island was for some time connected with the consular post for the Bights of Biafra and Benin ${ }^{1}$. Afterwards, when Spain resumed the possession of Fernando Pô, the British consul for the Bights was also consul for the Spanish island; but little by little his duties obliged him to reside more on the "Oil Rivers" than on the adjoining island. With the exception of the brilliant Richard Burton, who for four years was consul for the Bights of Biafra and Benin, the post was usually held by a gentleman

1 The powerful kingdom of Benin-remarkable for its development of the arts of sculpture, ivory carving, and of bronze-casting-extended its power seaward to the mouth of the Benin branch of the Niger Delta, and gave its name to this great bay or bight of the low-lying coast. Biafra was a native name given by the Portuguese to the opposite (eastern) bight between the Niger Delta and the Cameroons. 
who had been to some extent previously connected with African trade, and whose purview was not much extended politically; but in $\mathrm{I} 880 \mathrm{Mr}$ E. H. Hewett, formerly ViceConsul in Angola, and a man of some distinction, was appointed to the post. He took up his residence at Old Calabar, and his reports aroused great interest in the Government of that period, which was disposed to accede to the petitions of the chiefs and to take all the coast under British protection from Lagos to the Gaboon. But the plans of the Ministry were not fully settled until the end of $\mathrm{I} 883$; and when Mr Hewett returned to the coast with full powers he was delayed by ill-health and still more so by the beginning of the Niger Question, and the importance of securing a hold over the lower Niger. Consequently he left the Cameroons region to a later visit; and the German representative at Duala, the celebrated traveller, Dr Nachtigal, taking advantage of this omission, suddenly concluded a treaty with a chief at the mouth of the Cameroons estuary. The British flag was erected over all the remaining territories in South Nigeria, the Cross River district and the north-west Cameroons. But Germany was determined to have a fair slice of West Africa, and the British Government thought it wiser to deal with German aspirations liberally. The British flag was therefore withdrawn from the vicinity of the Cameroons river and mountain. The last patch of Cameroons territory which was given up to Germany was the interesting little settlement of Ambas Bay, on the flanks of the mighty Cameroons mountain, founded in $185^{8}$ by the English Baptist Mission when expelled from Fernando Pô. Mr Hewett annexed this territory in $\mathrm{r} 884$, and (Sir) H. H. Johnston administered it from 1885 until the time of its surrender to Germany in 1887 .

The limits of the "Oil Rivers Protectorate" were then drawn at the Rio del Rey on the east, and the boundary of Lagos Colony on the west. The eastern boundary was subsequently extended by agreement with Germany to the upper 
waters of the river Benue. This acquisition-now known as the Protectorate of Southern Nigeria and merged into the one great government, almost an Empire, of British Nigeriawas at first administered by consular authority, amongst others by the author of this book; and these consular administrators were obliged to face a serious difficulty in the determined opposition of certain coast chiefs to the carrying on of direct trade with the interior. These were the "middle men," who had for several centuries prevented the penetration of Africa from the West coast by Europeans, in the dread that they would lose their lucrative commission on the products of the interior which they retailed on the coast. Some of these chiefs were of long established ruling families; others again had commenced life as slaves and had risen to be wealthy merchant-kings with incomes of $£ 10,000$ to $£_{20,000}$ a year, derived from their profits on the goods from the interior which passed through their hands. Foremost among these obstructive individuals was Jaja, a slave from the Ibo country, who as servant, trader and counsellor to chiefs of Bonny had risen to such a position of wealth and influence that he had armed a large force of fighting men and a flotilla of war canoes, and made himself the most powerful chief in the Niger Delta. He resided on the river Opobo, and was very jealous of his independence, only signing a qualified treaty of protection with the British Government, from the well-grounded fear that, if he did not do so, the French would take his country as an access to the Niger. As Jaja at last went to the length of forcibly opposing trade between the British merchants and the natives of the interior, $\mathrm{Mr} \mathrm{H}$. H. Johnston, then acting consul for the Oil Rivers, removed him to the Gold Coast to be tried before a commissioner. As a result of the trial he was deposed and sentenced to five years' banishment in the West Indies. With the exile of Jaja the principal resistance of the middle-men was broken, though at Benin and 
behind Old Calabar similar action had to be taken to secure free trade.

In I893, under Sir Claude Macdonald, a regular administration was established over Southern Nigeria (the Niger Coast Protectorate, as it was called until 1906). In I 896-7 a peaceful mission to the King of Benin in the western part of the Protectorate was attacked by the soldiers of that chieftain and the leader (J. R. Phillips) and seven other British officials were slain, together with many of the native porters.

Benin had been in relations with British traders since 1553 . The Dutch traded there in the $\mathrm{I} 7$ th and $\mathrm{I} 8$ th centuries for slaves, but were ousted by the French, and the French (in I 792) by the British. In I823, Giovanni Belzoni, the Italian Egyptologist, died near Benin city when starting from this part of the Niger Delta to reach Timbuktu. In I 863 (Sir) Richard Burton came to Benin as British consul to try (in vain) to persuade the king to renounce his devastating human sacrifices, performed once a year for the king's "customs" of ancestor worship. (Sir) H. H. Johnston, after making an agreement with the king's viceroy, Nana, on the coast, explored the Benin river in a gun-boat, but was refused permission to proceed to the capital. This was accorded to (Sir) H. L. Gallwey in $\mathbf{I} 892$; and a treaty was then made.

After the massacre of $\mathrm{Mr} \mathrm{J}$. R. Phillips and his companions on January I, I 897 (only two Englishmen escaped) a British punitive expedition was rapidly organized by Admiral Sir Harry Rawson; and a month afterwards the city of Benin was taken, its king was exiled, and the worst offenders among his chiefs were executed. A second punitive expedition ranged through the Benin country in 1899 , since when this ancient kingdom has been peaceful. The Benin expedition revealed to us, in a far more extensive degree than had hitherto been realized, the marvellous art which had sprung up in that bloodguilty city, an art chiefly manifested by bronze castings in the cire perdue process. A splendid series of examples of this 


\section{vIII]_Benin and the Niger Coast Protectorate I 87}

work has since been exhibited at the British Museum. In all probability this art of working brass and bronze reached the Lower Niger and parts of the Niger Delta, such as Benin on the one hand and Old Calabar on the other, from the central Sudan, where it was introduced by Arab craftsmen, teachers and traders from Egypt and Tripoli; though some writers of late have argued an even earlier introduction of copper, bronze, and brass work emanating from Egypt prior to the Arab conquest, and extending from east to west across the central Sudan to the Upper Niger. In any case, this art had taken root in Benin, where it had acquired a special and national development. Concurrently with this had arisen an exquisite taste in the carving of ivory, almost oriental in its grace and finish.

In 1906 the Niger Coast Protectorate which had come under the Colonial Office in I900, was fused with the contiguous colony of Lagos under the name of Southern Nigeria. It had previously (1900) united its east and west halves by acquiring the whole deltaic course of the Niger from Idda to the sea, after the Royal Niger Companies' territories had been taken over by the British Govermment. Several small native wars were necessary between 1900 and I9ro for the subdual of the Arõ tribe (whose cruel fetish rites-the "long juju"-demanded constant victims) in the north-eastern part of the delta, and the Ibo people in the north; but the prosperity of Southern Nigeria has been notable. Its total trade averages in the year a value of $E_{\mathrm{I}} \mathbf{1}, 000,000$. A railway now proceeds inland from Lagos to the Niger and from the Niger to Kano, about $85^{\circ}$ miles. In $19 \mathrm{r} 2$, the government of Southern and Northern Nigeria were united under a joint Governor-General.

Lagos, the delta of the Niger and the lands of the Cross river (Old Calabar), have thus been united at last in peaceful and prosperous development under the British flag. But strong as were the British claims to control the lands along the main stream of the Niger, they were vigorously contested 
by France in the second half of the I 9 th century. The Niger had been discovered from its source to the last rapid at the head of its seaward navigability by Mungo Park, one of the greatest of British explorers, and by later travellers from Sierra Leone. The rest of the exploration from Busa to the sea had been completed by other British adventurers and officials; from the point of view of discovery the whole Niger was British from source to mouth. The navigation of the river from the sea to above its confluence with the Benue was first organized in $\mathrm{I}_{32}$ by a Scotchman, MacGregor Laird, who has been rightly called "the father of British trade on the Niger." Laird between 1832 and 1859 spent about $£ 60,000$ vainly in developing Nigerian commerce. In I841, I854 and I857 the British Government despatched or supported various expeditions to explore and make treaties; they also established a consulate at Lokoja, where the Benue meets the Niger, but the loss of life from the effects of the climate was so great in those days that the British Government became discouraged. The most distinguished of their consuls at Lokoja was Dr W. B. Baikie, who between I 854 and I864 established the beginnings of British Nigeria ${ }^{1}$. But the consulate at Lokoja was abolished in I868; and in another direction no attempt whatever was made to attach to the interior of Sierra Leone the rich countries lying beyond the sources of the Niger. But for independent action on the part of British traders the Niger would have become either entirely French, or in the main a French river with a German estuary. During the eighties the French Government of Senegal pushed forward

1 British Nigeria and the exploration of Africa generally-its botany, anthropology, and languages-owe much to the work of William Balfour Baikie, a native of the Orkney Islands, who between 1854 and 1864 served the British Government on the Niger and succeeded the equally remarkable John Beecroft as Consul. Baikie founded Lokoja in 1860. Lander, Laird, Beecroft, Baikie, and the black Bishop Samuel Crowther were the principal creators of British Nigeria. 
to the Upper Niger. Earlier still, by the influence of Gambetta, two powerful French politico-commercial companies were formed to establish trading houses all along the Lower Niger. In spite of much discouragement, however, the numerous British firms that traded with the Niger had stuck to the river; but although they were doing a great deal of trade their profits were reduced by excessive competition. From the British point of view, the hour had come to strike for the Niger; but where was the man? Captain George Goldie-Taubman ${ }^{1}$ (a Royal Engineers' officer) had been left several thousand pounds' worth of shares in one of these small Niger Companies. Having spent some time in Egypt, he resolved to go to the Niger (1877) and see whether his shares were worth retaining. Like an analogous great man in South Africa, he decided on working for amalgamation. With untiring energy and great tact he brought about the consolidation of all the British companies trading on the Niger. Then he bought out the French company, discouraged as they were by Gambetta's death, and boldly applied to the Imperial Government for a charter, being able to show them that no other trading firm but his own existed on the Niger. Britain was just about to take part at that time in the Conference of Berlin. She lost the Congo but won the eastern Niger. When the British claim to a protectorate was acceded to in principle at the Berlin Conference, a charter was granted to the National African Company founded by Captain Goldie-Taubman, who changed the name of his association to that of the Royal Niger Company. The main course of the river Niger down to the sea was placed under the administration of this chartered company, but the Benin district to the west, and the Brass, Bonny, Opobo, and Old Calabar districts to the east were, as already related, eventually organized as the Niger Coast Protectorate under direct Imperial administration, because in these countries the Niger Company had no predominating interests.

1 Afterwards the Right Hon. Sir George Taubman Goldie, P.C. 
When Sir George Goldie's Company had expended nearly all its available capital in buying out the French and purchasing governing rights from the native chiefs, a fresh obstacle had to be overcome: German rivalry came into play. The Germans had just taken the Cameroons but had failed to secure the Oil Rivers, on which in $\mathbf{1} 884-5$ they made several attempts. Herr Flegel was sent to obtain concessions beyond the limits of the Royal Niger Company's immediate jurisdiction in the Nigerian Sudan. But Flegel was forestalled in his principal object by the explorer Joseph Thomson, who most ably conducted a mission to the court of Fula Sultan or the Emperor of Sokoto, and secured a treaty with that important potentate which brought his territories under British influence. In 1890 the British claims to a vast Niger empire were recognized by France and Germany. But the French recognition was allowed to remain too vague in regard to the northern, western, and eastern boundaries of British Nigeria; thus rendering it possible for France in the ensuing eight years to strive to cut into the British sphere from two directions, if not three. On the north it was sought to push back the boundary of the empire of Sokoto, so as to bring the French sphere as far as possible to the south, though this assertion went little beyond map-making. On the south, the Benue basin, Lieutenant Mizon made the most persistent, and, as it would seem, unpractical attempts to secure for France a large sphere of influence on the river Benue, which could hardly be approached from French territory because the German sphere would stand in the way. Finally as the delimitation in the Anglo-French agreement of 1890 merely carried the British boundary from Lake Chad to Say on the middle Niger, and did not provide a western boundary, the French (though unofficially according the British in 1890 a straight line drawn from Say due south to the boundary between Lagos and Dahomé) gradually pushed their acquisitions eastward from Senegambia until they had secured all the right bank of the Middle and Lower Niger as far as Busa, which is at the 
end of the Niger cataracts and at the commencement of its navigability seawards. A British protectorate over Busa having been announced to France in 1894 , this act on the part of the French was considered a distinct trespass on British rights and caused considerable excitement at the time; but, as may be seen by the 1898 convention, the French finally yielded to British claims. They had some time before tacitly disowned the enterprise of Lieutenant Mizon, which had been rendered the more hopeless, firstly by the agreement between England and Germany in 1893 (which provided for a continuous AngloGerman boundary from the Rio del Rey on the coast to the southern shores of Lake Chad), and secondly by the subsequent Franco-German agreement of $\mathrm{I} 894$ by which a wedge of German territory was interposed between the French claims in Congoland and on the river Shari, and the British sphere on the Benue ; though nevertheless the Germans admitted the French to a point on the extreme upper waters of the Benue in return for German access to the Sanga, one of the Congo tributaries.

Besides being hampered by the conflicting ambitions of other European powers, the Niger Company had to conduct a difficult campaign against the Amir of Nupe. Like most great Muhammadan empires, Sokoto consisted of a bundle of vassal states owing a varying degree of allegiance to the dominant power. British Nigeria then contained four important civilized negro peoples, and an indefinite number of savage tribes who were politically of no account whatever. These four great peoples are the Songhai on the north-west, the Hausa occupying all the centre, the Bornu or Kanuri on the north-east, and the Nupe on the south-west. Over three of these (excepting the Kanuri) the Fula conquests of a century ago had established Fula rule with its head-quarters in the Hausa States. But the kingdom of Nupe, though ruled by a Fula dynasty, held its allegiance to the court of Sokoto but cheaply, and requested at the hands of the Niger Company a recognition of its complete independence, which for political 
reasons the Company could not give. This powerful kingdom, however, stood in the way of all access to Sokoto, and in its defiance of the Niger Company raided for slaves far down on the Lower Niger. Unless a way was to be opened for successful foreign intrigue by allowing Nupe to assert its independence of Sokoto and the Royal Niger Company, it was necessary to subdue its pretensions. Therefore Sir George Goldie, with the aid of a staff of British officers, of Hausa troops and machine guns, inflicted a crushing defeat on the forces of Nupe (mainly Fula), captured their capital, and successfully asserted the sovereign rights of the Company as conferred on them by the Sultan of Sokoto. Subsequently other turbulent and slave-raiding tribes were dealt with, and the Company gradually rendered itself master of a great riverain dominion in west-central Africa.

But the whole position was a false one so far as Great Britain was concerned. The British Government at the Berlin Conference on the affairs of Africa had pleaded everywhere the cause of Free Trade; yet here, in the British Nigerian sphere, a chartered company had secured the virtual monopoly of trade. Above Abo on the deltaic Niger it was practically impossible for anyone to carry on commerce except the natives and the Royal Niger Company. Yet the British Government was already called upon to protest against King Leopold's monopoly of trade in the interior of the Congo State and the French exclusion of British merchants from French Congo. So the step was taken in 1899 of buying out the administrative rights of the Royal Niger Company; and on January $\mathbf{r}$, I 900 , the British Government commenced the direct rule of "Northern Nigeria," a territory of approximately 256,400 square miles (as delimited by the r89o-r898-r9o2 conventions with France and Germany-338,000 square miles with Southern Nigeria) which stretched from the confines of the Sahara Desert and Lake Chad to the Upper Benue, the Central Niger, Borgu, and the Cameroons frontier. In three 
and a half years' time (1900-04) practically the whole of this enormous area had been brought under effective British control-thanks to the courage and indomitable energy of its first Governor, Sir Frederick Lugard (who had won Borgu and Illórin for the Niger Company in 1897-99). Colonel T. L. N. Morland commanded a force of 800 negro soldiers with British officers and non-commissioned officers, which with its light pieces of artillery and maxim guns defeated the large forces of cavalry brought against it by the Fula princes. In a campaign which lasted from the autumn of 1902 to the early summer of 1903 Colonel Thomas Morland marched from Nupe to Bornu, and Bornu to Sokoto, capturing the great Hausa city of Kano by the way. The inimical Fula Sultan of Sokoto was deposed, and a relative raised to the throne, who could be more depended on to work loyally with the British in suppressing the slave-trade and in discouraging those slave raids which were fast depopulating Northern Nigeria. It is pleasant to record that in the course of these operations the dynasty of the Kanemi Sheikhs of Bornu (the founder of which had been so good to the trans-Saharan expeditions sent out from England in the first half of the igth century) was restored to the headship of that country. They had been driven out of Bornu in an extraordinary invasion of the Central Sudan by Rabah, a former slave of Zobeir Pasha in the Egyptian Sudan. Rabah, deserting the crumbling Dervish power of Omdurman, had marched to the west and entered Bornu in $\mathbf{1} 895$ at the head of a large army. Rapidly he made himself master of the regions between Hausaland and the Congo basin. Ultimately he and his son, FadlAllah, fell in battle with the French; and the British, when they took over Bornu as the result of Colonel Morland's victories, replaced as Sheikh or native ruler of that ancient kingdom the great-grandson of Muhammad-alAmin-al-Kanemi, the man who so befriended Denham and Clapperton in 1822-4. 
The Fula power ${ }^{1}$ is not extinct in Nigeria. Far from it. The more intelligent Fula princes and aristocracy now assist the British as great chiefs, and in minor administrative posts. The trade of Hausaland is reviving, and a considerable mining development (mainly tin) is going on in the hilly country of Bauchi. A railway now links up Kano with Lagos on the Gulf of Guinea, and a branch of this great trunk line turns southward into Bauchi and may some day reach the upper Benue; just as the Kano line will in the future, far or near, join the French Trans-Saharan line and carry passengers from the Central Sudan and the eastern Niger to the Mediterranean ports of French North Africa.

An interest in the trading possibilities of the Central Sudan was evinced by the British Government early in the I 9 th century, quite apart from the Niger problem; and it was at the expense of Great Britain that expeditions set out from Tripoli across the Sahara Desert in 1818 and 1822 to discover Lake Chad. This move was partly occasioned by the successes of a remarkable man, Muhammad-al-Amin-al-Kanemi ${ }^{2}$, who had become the virtual ruler of Bornu and had opened up relations with Tripoli. Clapperton, a member of the $1822-25$

- 1 The Fulas, as already stated, are a semi-white race, who originally came from the Western Sahara, and colonised much of Senegambia and the Upper Niger basin, penetrating as far south as Borgu, and south-east to Adamawa, Mandara, Bagirmi, and Darfur. In the early igth century, under a great leader, Othman Dan Fodio, they conquered Sokoto and much of Eastern Nigeria, stopping short of Bornu, where they were arrested by the power of the Kanemi Sheikh of Bornu. A succinct account of the different Fula kingdoms and conquests is given in a footnote on p. 201 .

2 This man was no doubt a negroid Arab religious teacher from the country of Kanem, north-east of Lake Chad. He settled in Bornu early in the rith century and became the adviser of the king of that country, a phlegmatic descendant of a great and ancient dynasty of Berber or Hamitic origin. Muhammad-al-Amin-al-Kanemi assisted the Bornu sovereign and people to beat off the Fula invasion and became the virtual ruler of Bornu. He bore the title of Sheikh of Bornu. 


\section{viII] The British in Tripoli and Morocco 195}

expedition, traversed Hausaland and reached the court of the Fula Emperor at Sokoto. Denham nearly lost his life in joining a Bornu army which went to attack the Fulas of Mandara. Another expedition sent out from Tripoli in 1849 under Consul Richardson was mainly carried through to its ultimate purposes by one of its members, a German, Dr Heinrich Barth, who reached Timbuktu on the west and the Upper Benue on the south-east. So that Great Britain laid the foundations of her future Nigerian Empire both from the direction of the Mediterranean and by ascending the Niger and Benue from the Gulf of Guinea.

At one time British influence was so strong with the semiindependent Basha of Tripoli, that it seemed possible British protection might be accorded to this Barbary state, seeing that France in a similar manner had ignored equally valid Turkish claims to the suzerainty of Algiers. But the uprising of Muhammad Ali in Egypt awakened the Turks to the necessity of reinforcing their claims to Tripoli, and British projects in that direction were abandoned.

As regards Morocco, the Portuguese fortress of Tangier had been ceded to England in I662, the British having desired it as giving them a port of call close to the Straits of Gibraltar. It was found difficult however to maintain it against the continual attacks of the Moors, and it was therefore surrendered to the Emperor of Morocco in I684. It is not impossible that it may return one day to British keeping. 


\section{CHAPTER IX}

\section{THE FRENCH IN WEST AND NORTH AFRICA}

IT has been asserted with some degree of probability that certain seamen-adventurers of Dieppe found their way along the West coast of Africa as far as the Gold Coast in the I4th century, a hundred years before the Portuguese; and that they established themselves on the Senegal river, built two or more settlements (Little Paris, and Little Dieppe) on the Liberian coast, and established trading stations at "La Mine d'Or" (Elmina), at Accra, and at Kormantin, on the Gold Coast. The Dieppois station at Elmina was said to have been founded in 1382 ; and the legend runs that forty years later, owing to the wars in France having distracted Norman commerce from over-sea enterprise, these settlements were abandoned. There may have been some truth in these accounts of Norman discoveries on the West coast of Africa set forth in the second half of the $\mathbf{I} 7$ th century. A Norman adventurer undoubtedly rediscovered the Canary Islands in the I 4 th century; and it is probable that the Rio d'Ouro and even the whole coast of West Africa as far as the Gulf of Guinea were known to Italian seamen before these features were placed on the map by the Portuguese. When, three centuries later, the French founded a settlement at the mouth of the Senegal, they are said to have discovered the remains of a Norman fort (built by adventurers from Dieppe) and to have made it the nucleus of the modern town of St Louis. 
At any rate, soon after the Portuguese had laid bare the coast of Guinea, ships began to sail from the Norman ports to resume or to commence the West African trade, though no attempt was made to establish any political settlements ; for in the matter of founding colonies in Africa, France was considerably behind Portugal, Holland, and England. However, in $\mathbf{I}_{637}$, a young Frenchman named Claude Jannequin de Rochefort was pacing the quays at Dieppe with vague aspirations to be "another Cortes." Happening to ask where a certain ship was going, and being told in reply that she was bound for the "Senaga" river in Africa, near Cape de Verde, he instantly resolved to go, and before many hours were over was entered on the ship's book as a soldier; he afterwards performed the duties of clerk to the captain. It would seem that this vessel, which had not only soldiers but monks on board, must have been despatched by some far-seeing authority, since before the Sieur de Rochefort joined its company it had been determined to stop on the West African coast north of the Senegal river, cut down trees, build a small boat, and use it to explore the Senegal. This plan had been formulated in complete ignorance of the fact that the coast north of the Senegal and south of Morocco contains no timber for boatbuilding. Finding this to be the case, the Dieppe expedition, under the command of Captain Lambert, with the Sieur de Rochefort among its soldiers, went on to the Senegal and put together a small boat out of timber which had been brought from France. Into this small vessel was transferred a portion of the crew, including De Rochefort ; and the Senegal river was explored for I Io miles from its mouth. Although the Dieppe adventurers were said to have built a fort on the site of St Louis in $\mathrm{I} 360$, and the Portuguese had a few trading posts on its lower reaches in the ${ }^{5}$ th century, there were no Europeans on the river when it was visited by De Rochefort, though the Dutch had established stations on the coast not far off. After obtaining concessions from the natives, Captain Lambert's 


\section{I98 The French in West and North Africa [CH.}

expedition returned to France, experiencing many delays and adventures on the way; and six years after he had started from Dieppe De Rochefort published an interesting account of their adventures.

But this pioneer expedition was not soon followed up, owing to the hostility of the Dutch. The Norman Company sold its rights to the French West India Company, and the latter again transferred them to a subsidiary association afterwards called the "Royal Senegal Company." In 1677 , the French navy (France being at war with Holland) captured the Dutch ports on the Senegal coast-Rufisque, Portudal, Joal, and Goree Island-this last, famous in the history of West Africa, being named after a little island on the Dutch coast, and commanding the now important harbour and capital of Senegal, Dakar. In I 7 7, Portendik, south of Cape Blanco, and in 1724, Arguin, an islet north of Cape Blanco, were also taken from the Dutch, who had earlier still acquired them from the Portuguese.

The Royal Senegal Company sent out in r697 a very able man to attend to its affairs-André de Brüe-who made his head-quarters at Fort St Louis, which had been founded by De Rochefort's party. This remarkable person, Brüe, combined the qualities of a man of science and a far-sighted trader, and may be said to have really laid the foundations of the French empire in West Africa. Brüe made two important journeys up the Senegal and into the interior. He remained eighteen years on the coast of Senegal, and visited the Gambia in I 700, finding English, Portuguese, and Spanish there, the first-named trading at the mouth of the river, and the two last settled some distance up its course as flourishing slave-traders. According to Brüe, the Portuguese slave-trading settlements exhibited some degree of civilization, but also of rowdiness among the European element, not unlike the proceedings of the "Mohocks" in the streets of London. In his writings Brüe expresses his amazement at the enormous number of bees 
inhabiting the mangrove swamps and coast-lands of Guinea. In I7 16 Brüe sent out agents to extend French influence up the Senegal and towards the "Gold" country of Bambuk, the mountainous region on the upper Senegal. Brüe finally returned to France in I $_{7}$ I5 and lived quietly for a long time afterwards on the large fortune he had accumulated. His is a name to be well remembered in the annals of the French Empire. He was a far-sighted, cultivated man, who had also the gift of choosing and employing good associates. Among these may be mentioned the Sieur Campagnon, the beauidéal of a good-tempered, good-looking, supple, kind-hearted, valorous Frenchman. Only the charm of Campagnon's winning ways enabled him to penetrate the recesses of Bambuk, whose secrets as a gold-bearing country were jealously guarded by the natives. One little incident of Campagnon's life on the Senegal depicts his disposition. Walking round the outskirts of St Louis he came across an unfortunate lioness that had belonged to an inhabitant of the town, but had been thrown out on the rubbish heaps to die. The unfortunate beast had been suffering from some malady of the jaw which would not permit mastication, and was therefore nearly dead from hunger. When Campagnon saw the lioness, her eyes were glazing and her mouth was full of ants and dirt. He took pity on the unfortunate creature, washed her mouth and throat clean, and fed her with milk. This saved her life, and the grateful animal conceived a warm affection for him, and would afterwards follow him about like a dog and take food from no one else. Dr Robert Brown, who unearthed this charming anecdote, further informs us that after his romantic career in Africa Campagnon returned to France, and died, after a long and prosperous life, a master-mason and undertaker in Paris.

The French continued to develop their Senegal settlements with some prosperity until $\mathbf{I} 75^{8}$, when they were captured by the British, who held them until 1778 , and acquired them again for a time by the peace of 1783 ; after this they were in 
British hands a few years longer, but were French again by I790. In 1800 the British took the island of Goree, which the French had acquired from the Dutch in 1677 . By the peace of 1783 the English had secured from the French the exclusive right to trade with the Arabs or Moors of Portendik for gum. Portendik was a place on the Sahara coast about I 20 miles north of St Louis. All the French possessions in Senegal which were held by the British from time to time during the Napoleonic wars were given back to France two years after the peace of 18 I $_{5}$, though at that time the British hold over the Gambia was more clearly defined, the French only retaining one post on that river, given up in 1857 in return for the British trade monopoly with Portendik. The French had already resumed their explorations of Senegambia at the end of the 18 th century; and after the final recovery of the Senegal river in $18 \mathrm{I} 7$ these researches were pushed with some degree of ardour. In I8I8 Mollien discovered the sources of the Gambia, and De Beaufort explored the country of Kaarta. In 1827 René Caillié started from the river Nunez with help derived from the colony of Sierra Leone (for which he was subsequently ungrateful) and descended the Niger to Timbuktu, thence making his way across the desert to Morocco. His journey, however, did not do much to lure the French Nigerwards at that time, especially as a great Fula conqueror had arisen, Al Hajji 'Omaru, whose conquests not only blocked the way to the Niger, but later on threatened the very existence of the French settlements on the Senegal. But after a long period of inaction and lack of interest, the French colony of the Senegal was to receive great extension. General Faidherbe, who for political reasons was rather distrusted by the newlyformed Second Empire, was exiled to Senegal in I854 in the guise of an appointment as Governor-General. He was a man of great enterprise and intelligence, and immediately began to study the resources and extension of the Senegal colony. He first punished severely the Moorish tribes to the north of the 
river Senegal, who had again and again raided the settled country. Before he had been a year in Senegambia, Faidherbe had annexed the Wuli country, and had built the fort of Medina to oppose the progress of Al Hajji 'Omaru. 'Omaru sent an army of 20,000 men against Medina, but they were repulsed by the officer in command, and finally had to retreat before Faidherbe's advance. Following on the repulse of the Fulas came the annexation of many countries along the Upper Senegal, and in the direction of the Gambia. A year later the country between St Louis and the mouth of the Gambia, past Cape Verde, had been annexed. Then the Casamanse river, between the Gambia and Portuguese Guinea, was taken; then, in the sixties, the coast between Portuguese Guinea and Sierra Leone was added to the French possessions, under the name of "Rivières du Sud." In 1864, a French expedition under the gifted Lieutenant E. Mage (who was drowned off Brest in I869) reached Segu on the Upper Niger and was detained there for two years by the suspicious Fula Sultan-Tidiani, nephew of the Emperor Al Hajji 'Omaru'.

1 It might be advisable at this juncture to explain clearly about the Fula power in French Nigeria and Senegambia. The Ful or Fulbe people appeared first in the I 3 th century in West African history as peaceful cattlekeepers on the lower Senegal ; but as a matter of fact they had probably reached the Upper Niger and Senegal many centuries before. The Western Fulbe had become Muhammadans at quite an early datebetween the $I_{2}$ th and $I_{5}$ th centuries. Those in the more eastern part of Nigeria remained pagan in some settlements down to the I 9 th century, and are pagan even still. About the 16th century those of the Senegal began to emigrate as cattle-keepers into the cooler highlands of Futa Jallon, and became the ruling power on this upland two hundred years later. At the same period-the beginning or middle of the i 8 th centurythey likewise founded dynasties of Muhammadan kings in Futa Toro and Bondu (south of the Upper Senegal). In 1802, a Fula religious mystic and imam or religious preacher, Othman Dan Fodio, arose like a Mahdi in Eastern Nigeria (Sokoto), called on the Muhammadan Fulas of the central Sudan to join with him in a holy war, and in a few years conquered a vast Fula Empire, which was almost conterminous 
A suspension of French activity occurred after the disastrous Franco-German war, but it was resumed again in 1880 . Captain Galliéni surveyed the route for a railway to connect the navigable Senegal with the Upper Niger, which he reached in that year at Bamaku. By 1883 the post of Bamaku on the Upper Niger had been definitely founded and fortified. But General Borgnis-Desbordes, Galliéni, and other French officers had to contend with the imposing forces of king Ahmadu bin Tidiani, the grand-nephew and successor of Al Hajji 'Omaru, who ruled over the country between the upper Senegal and Jenné on the Niger. However Ahmadu was constrained by General Borgnis-Desbordes to make a treaty in 1887 which placed his territory under French protection. Nevertheless war with the Toucouleur (Takrur) Fulas followed in I890 (and

with the British (Northern) Nigeria of to-day. Fired no doubt by this example another Fula 'sheikh' or holy man-Ahmadu Lobo, in the country of Masina, between Timbuktu and Jenné-about 1813 attacked with his followers the vestiges of Moorish power on the Upper Niger, the "Roumas" (as they were called, from their having come originally from Andalusia- "Rome") and took all power from them, creating in Central Nigeria between Jenné and Gao the powerful Fula kingdom of Masina, which lasted until about $\mathrm{I} 86 \mathrm{r}$, when Ahmadu Ahmadu, the last Fula Emperor of Masina, was attacked and killed by a rival Fula Mahdi from the west.

This personage was 'Omaru bin Saidi, a Fula of Futa Toro, who had spent some years in Mekka and Medina, and had acquired the reputation of a holy man and a doctor of religion. On his return to West Africa he was received with great respect by the Fula princes of Futa Jallon, and with their support he rallied to the cause of Islam the Fula-negro peoples of Futa Toro and Bondu-the Takrur, Torobe, or "Toucouleurs" as they came to be called. Al Hajji 'Omaru (as he was called), after his return from the pilgrimage (Al Hajj) to Mekka was unsuccessful in his attack on the French (1857), and so turned his army against his fellow Moslems of the Upper Niger. Two years after the defeat and death of Ahmadu Ahmadu, the Fula Sultan of Masina, 'Omaru himself perished at Bandiagara, in the Masina kingdom. The Toucouleur power was, however, maintained by his sons and successors till it finally fell in 1892 with the capture of Segu on the Niger by a French force. 
also with a vestige of the Masina Fulas under Ahmadu Abdulei); and the French occupied the great country of Kaarta (where Mungo Park suffered so greatly) in $189 \mathrm{r}$, Segu on the Niger (also associated with Mungo Park) in $\mathbf{1 8 9 2}$, Jenné and Timbuktu in $\mathrm{I} 893$. The French as early as $\mathrm{I} 88 \mathrm{I}$ had taken under their protection the ancient Fula kingdom of Timbo or Futa Jallon. Their activities in this direction brought them into conflict with the forces of Samori, a negro (probably Mandingo) king who had risen from a very humble position to that of conqueror and ruler of the countries about the source of the Niger. Samori, like Al Hajji 'Omaru, commanded hordes of Mandingo negroes, whose conquests were often undertaken from propagandist motives, and who were to some extent in sympathy with the Muhammadan tribes of the Upper Niger. Samori's forces were mainly recruited from among the Mandingo tribes between the Upper Niger and the hinterland of Sierra Leone, Liberia and the Ivory Coast. In r 885-6 a campaign had been undertaken by Colonel Frey against Samori, which did something to check the power of that raiding chief; but after the destruction of the Fula power in 1892 the attacks of Samori on the French outposts redoubled and nearly embroiled France with Britain over the affair of Waima. By 1888 , a railway had been constructed which facilitated access to the Niger; and a small armed steamer having been put on that river at Bamaku, the Niger was for the first time since the last voyage of Mungo Park navigated beyond Segu. In I 887 this gunboat (named Le Niger) actually reached Kabara, the port of Timbuktu, but the hostility of the natives prevented its commander, Lieutenant Caron, from visiting the city. The gunboat returned without effecting more than an ominous reconnaissance.

In 1888 Captain Louis G. Binger commenced an exploring journey for France which had the most remarkable results. He was the first to enter the unknown country included within the great northern bend of the Niger. He secured by treaty 


\section{The French in West and North Africa [CH.}

for French influence Tieba, Kong, and other countries lying between the Niger and the Ivory Coast. Colonel Archinard, by his brilliantly conducted campaigns against Ahmadu bin Tidiani, added to the French West African dominions Kaarta, Bakhunu, Segu and Jenné, and thus freed from obstruction the road to Timbuktu. Later on Colonel Archinard defeated the raider-king Samori and occupied his capital, Bisandugu, near the frontiers of Liberia. An attempt was made in 1894-5 to attack him in the new kingdom which he soon conquered in the lands between the main Upper Niger and the Black Volta ; and Colonel P. L. Monteil (who had previously, I891-2, journeyed from Senegal to the Niger, and from the Niger to Bornu, and thence overland to Tripoli) led a military expedition against him from the Ivory Coast. Colonel Monteil was very unsuccessful, and was recalled by the French Government. Samori then attempted to advance northwards to the central Niger, as the last hope of breaking through the ring of French power with which he was being surrounded. Colonel Bonnier cut him off from that direction, however, in 1895 ; and Captain Marchand (of Fashoda fame) wrested from him the important town of Kong. In 1897 Samori had pushed eastwards, so that he was hovering about the northern boundary of the British Protectorate of Ashanti; and here his force attacked a small British surveying party, killed the native escort, and carried off the officer, Lieutenant Henderson. After a compulsory visit to Samori, Lieutenant Henderson was released ; and the chief relieved himself from all responsibility for the wanton attack on the British party by saying, "It was the will of God."

At length, in October 1898 , the French military authorities on the Upper Niger made a determined attempt to abolish the power of this bandit king, who had begun his career as a religious mystic and who ended by organizing his disciples"Sofas" or Sufis - into a tremendous slave-raiding army. They also determined to break the fighting strength of the Mandingos, as they had previously crushed that of the Fula and the 
Tawareq. By a brilliant feat of arms Samori was brought to bay and his forces routed by Lieutenant Woelfel. The Mandingo king was taken prisoner by Lieutenant Jacquin and Sergeant Bratières, and was exiled to the Gaboon.

During the reign of Louis Philippe a somewhat feeble revival of colonial enterprise had taken place, in which France made half-hearted attempts to establish herself in New Zealand, and secured New Caledonia and Tahiti in the Pacific. At this time also she thought of extending her possessions in unoccupied districts along the West Coast of Africa, and had acquired rights over Grand Bassam and Assini to the west of the British Gold Coast. During the sixties some efforts were rnade by Napoleon III to develop French trading and political influence in the Bight of Benin in Africa; and Porto Novo, near Lagos, was accorded French protection in 1868. These claims, however, had been allowed to lapse to some degree; and the places acquired would at one time have been willingly handed over to England for a small compensation. But in the scramble for Africa that commenced in I 884 they suddenly acquired immense value in the eyes of the French as footholds upon which to commence an expansion northwards from the Gulf of Guinea to the Niger empire of which France had begun to dream. In 1884 therefore Grand Bassam and Assini, on the Gold Coast, and Porto Novo, a tiny vassal kingdom of Dahomé, were effectively occupied. The journeys of Colonel Binger between the Niger and the Gold Coast in I888-9 I gave Grand Bassam a hinterland; and the consequence was that the Ivory Coast between Grand Bassam and Liberia (including the Rio Pedro district of Liberia) was annexed by France in 189r. Hitherto this coast, the interior of which was then and till the close of the rgth century one of the least known parts of Africa, had been of great importance to British trade, which was carried on chiefly by Bristol sailing. ships. Moreover, from the Ivory Coast came the bulk of the celebrated Kruboys, who are the best labour-force 


\section{The French in West and North Africa [CH.}

obtainable along the West Coast of Africa from the Gambia to the Orange River. Nevertheless, although the petty chiefs of the Ivory Coast had often offered their friendship and vassalage to Great Britain, no steps were taken on the part of the British Government, and therefore no protest was offered when France annexed the Ivory Coast and became next neighbour to Liberia. In $\mathrm{I} 892$ a somewhat stringent treaty was concluded between France and Liberia, by which, in the event of the latter coming under the influence or protection of any other power, France would have the reversion of much of her hinterland. The occupation of Porto Novo soon led to a quarrel with Dahomé, a kingdom of singular bloodthirstiness, which had defied both England and Portugal at different times, and had laughed at our futile blockades of its coast. After a preliminary occupation of the Dahomean coast towns and the imposition of a somewhat doubtful French suzerainty, the king, Behanzin, compelled the French to make their action more effective. A well-equipped expedition was sent out in I893 under General Dodds, who had conducted the first operations in r89r. For the first time Dahomé was invaded by a well-organized European force ; and after a fierce struggle the entire kingdom was overrun and conquered, and the king was captured and sent to the West Indies.

In the meantime, the French forces marching step by step along the upper Niger had captured the important town of Jenné in 1893-Jenné, the focus of Nigerian civilization, and the mother of Timbuktu. From Jenné at the close of r 893 Colonel Archinard directed a march to be made to Timbuktu - it is said, without or contrary to orders from the Governor of Senegal. Two squadrons marched overland, and a river flotilla of gunboats under Commandant Boiteux steamed to the port of Timbuktu, Kabara. The flotilla of gunboats and lighters arrived at Kabara in advance of the military forces, and caused considerable perturbation in Timbuktu. The civilized inhabitants of the town were willing to surrender it to the 
French, only fearing their hated masters-the 'Tawareq. The Tawareq, hearing of the coming of the land expedition, left the town to meet it; but the Niger being remarkably high, Lieutenant Boiteux was actually able to take two lighters armed with machine guns up the back-water, which in seasons of flood reaches the walls of Timbuktu. After a little deliberation the town surrendered to the French. Shortly afterwards the Tawareq attacked the naval station formed at Kabara on the Niger, killing a midshipman. Lieutenant Boiteux, hearing that firing was going on, rode out of Timbuktu with one other European, accompanied by his little garrison on foot, arrived at Kabara and routed the Tawareq. This was a truly gallant action, worthy to be recorded. After standing a short siege in Timbuktu and making a successful sortie, the little naval expedition was relieved from the anxiety of its position by the arrival of the first column under Colonel Bonnier on the I 4 th of January, I894. Timbuktu was thus captured by the French with nineteen men, seven of whom were French, and the remainder Senegalese negroes. But a slight reverse was to follow. Over-rash, Colonel Bonnier started with a small force to reconnoitre the country round Timbuktu and rid the neighbourhood of the Tawareq. Too confident, they marched into a trap. Their camp was surprised by the Tawareq at early dawn, and almost all the French troops were massacred, only three French officers and a handful of men escaping to tell the tale. Twenty-five days afterwards, a second column under Colonel Jouffre arrived on the scene, and collected the remains of the unfortunate Frenchmen for interment at Timbuktu. It then set out to follow up the Tawareq, whom the French surprised in turn at night in their encampment, and of whom Colonel Jouffre believed his soldiers to have slain many. From that time the French have had no serious fighting near Timbuktu. French merchants are established there already and French missionaries-the White Fathersfrom Algeria. A curious episode in the French conquest was 


\section{The French in West and North Africa [CH.}

an appeal, when hearing of the French approach, by the notables of Timbuktu to the Emperor of Morocco to intervene. After a year's delay the Moroccan Sultan replied that upon receiving proofs of the vassalage of Timbuktu he would march upon the French and drive them away.

Subsequently the French patrolled the Niger far to the south of Timbuktu, and found it much more navigable than was at first believed. They established a post at Say, and Lieutenant Hourst explored that small portion of the river between Say and Gomba which till then had remained marked by dotted lines on the map. Numerous expeditions came across the bend of the Niger from its upper waters to its middle course, incessantly making treaties and extending the rule of France. Again, following on the conquest of Dahomé, the French marched northwards across the 9 th parallel, which had hitherto marked the limitation between the French and British possessions, and occupied the country of Nikki, which had previously been acquired for the Royal Niger Company by Major, now Colonel Sir Frederick, Lugard. A bolder step still was taken by the occupation of Busa (already declared to be in the British protectorate), at a time when Sir George Goldie and his little army were winning victories over the forces of Nupe in the vicinity. This step however roused such a strong expression of popular feeling in England that a conference was formed in Paris to negotiate a settlement between England and France; and eventually France gave way on the point of Busa, though she kept Nikki, and was able to extend her control of the west bank of the Niger to Ilo, a considerable distance below Say. She thus united her Dahomean conquest to the rest of her Nigerian dominions. There is now no great native monarch or independent people existing in the vast area of French West Africa, though there are many kings and chiefs ruling their people peaceably and humanely under the eyes of French resident officers. There has been no serious breach of the peace in the Senegambian and Nigerian 
territories since 1900 , with the exception of the fighting in the region to the north of the Senegal which is rather ineptly styled "Mauretania." Here France had concluded treaties of protection with the chiefs of the Moorish and Arab tribes in I903-5; but in 1905 the French Commissioner, Coppolani, was murdered in the far interior. Between 1908 and 1909 a force under Colonel Gouraud conquered all Mauretania and especially the hilly country of Adrar Temmur. The oasis of Air and Asben (which contains the old Songhai town of Agades) came under French control in r905-6, and Bilma-farther east, in the Tibu country-at the same time.

In I902-4 an administrative reorganisation of French West Africa took place, in which (and in the additional acts of r909) the following divisions were recognised: Mauretania $(344,967$ sq. miles), bounded on the north by the Spanish protectorate of Rio de Oro and the $22^{\circ} \mathrm{N}$. latitude and on the south by the river Senegal; Senegal colony and protectorate $(74,000$ sq. miles), bounded by the Senegal and Faleme rivers and Portuguese Guinea ; French Guinea (95,000 sq. miles), bounded by Portuguese Guinea, Sierra Leone, and Liberia; the Ivory Coast (130,000 sq. miles), between Liberia and the British Gold Coast ; Dahomé (about 40,000 sq. miles), a narrow strip between Borgu, the Niger, and the Gulf of Guinea; and lastly the enormous "Colony of Upper Senegal and Niger," which, with its military territories, has an area of something like $1,268,400$ sq. miles. It is bounded on the west and south by the other divisions and by foreign possessions, and on the north by the Algerian and Moroccan protectorates. This last division of French West Africa stretches eastwards from the Faleme branch of the Senegal River to Lake Chad.

In Senegal and French Guinea, the ports of Dakar and Konakri have received a remarkable development, and are admitted to be the most splendid and civilized towns on the West Coast of Africa, far superior in sanitary arrangements and outward aspect to anything which as yet exists in the 
somewhat sluggish British West African possessions. From Konakri a railway has been constructed on to the healthy uplands of Futa Jallon and to the Upper Niger at Kankan. Nearly in front of Konakri is the little archipelago of the Isles de Los ${ }^{1}$. These islands until the beginning of 1904 belonged to Great Britain, but under the Anglo-French Convention of 1904 they were very properly ceded to France, as they no longer commanded a coast which could become British.

The development of Senegal since the commencement of the 2 oth century has not been limited to the making of Dakar (now the residence of the Governor-General and the metropolis of French West Africa) a first-class port, but a great advance has also been made in railway construction. Landing at Dakar, which is only eight days' steam from Bordeaux or Marseilles, the traveller journeys ${ }_{1} 65$ miles by rail to St Louis (the old capital), there embarks in a river steamer on the Senegal and journeys to Kayès, enters the train again at Kayès and travels on 344 miles to Kulikoro on the Niger, whence he can proceed by river steamer to Timbuktu, the whole journey from Timbuktu to Paris being reduced to a possible nineteen days. Timbuktu the inaccessible, twenty to thirty years ago, is now only a ten days' journey from an Atlantic seaport. Timbuktu is connected with Algeria (as well as with Dakar) by overland telegraph.

Dahomé and the Ivory Coast Colony have both shared in the development of French Africa. Dahomé is contented, peaceful, and prosperous under French rule. A railway due north from Kotonu to the Niger, beyond Borgu, is under construction, about half the line (200 miles) having been finished in rgro. On the Ivory Coast there has been a certain amount of financial depression owing to the failure to discover gold or other minerals in profitable quantities. A number of

${ }^{1}$ It is averred that this name is a contraction of Idolos. The islands would appear to have been named by the early Portuguese navigators Ilhas dos Idolos from the idols or fetishes which were very prominently in use. 
companies, mostly British, had been formed for developing the mineral resources of the Ivory Coast; but, in spite of the vigorous work of the French in opening up communications with the interior, no great degree of commercial prosperity has as yet come to that portion of French Africa. A serious native rising had to be suppressed in I9ro. In I9ro-I I the contiguous frontiers of Liberia and the French possessions in Guinea and on the Ivory Coast were settled, greatly to the advantage of the French possessions.

The total area of French West Africa to-day (I9I2) is approximately $1,95^{2,000}$ square miles, with a negro and negroid population of about I2,000,000, and some 8000 whites. It

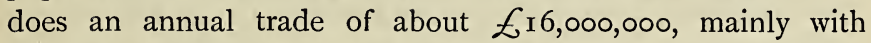
France; for France in her colonial policy still pursues the selfish policy of protection. But unlike what has happened in French Congo, the territories of Senegal, Guinea, Nigeria, the Sahara and Dahomé have enormously benefited from the imposition of French rule at the close of the r 9 th century. For the first time in their long, blood-stained history the industrious negro and Fula agriculturists and herdsmen of these tropical regions, and the semi-nomads of the Great Desert, know what it is to experience continual tranquillity, safety and commercial prosperity.

During the three centuries following the Turkish conquest of Algiers, Tunis, and Tripoli, France, like most other Christian nations in the Mediterranean, suffered greatly at the hands of Moorish corsairs-suffered so much that, not being able to defend her own coasts sufficiently, it probably never entered into her head to conquer and possess the corsairs' country; though under Francis I she tried, in rivalry with the Genoese, to obtain a trading and fishing station off the east Algerian coast, "Bastion de France," near La Calle (about I 544). So far as political aspirations went, her eyes were turned fitfully towards Egypt. At the end of the I 7 th century Louis XIV 


\section{The French in West and North Africa [CH.}

not only attempted to enter into political relations with Abyssinia (his envoy was murdered in Sennar, 1704), but was advised by Leibnitz to make a descent on Egypt, and to hold it as a station on the way to India. The idea was not adopted, yet it lay dormant in the French archives, and was probably discovered there by the ministers of the Directory after the French Revolution. Either it was communicated to Napoleon Bonaparte with the idea of sending him off on a fool's errand, or the notion had occurred to him independently as a means of striking a blow at the English. At any rate, with a suddenness that startled incredulous Europe, the Corsican General, fresh from the triumphs of his first Italian campaign, eluded the British fleet, and landed in Alexandria in 1798 with a force of 40,000 men. He met and defeated the Mamluk Beys, who ruled Egypt under Turkish suzerainty, and eventually chased them into Upper Egypt. He then established himself at Cairo, and sought to win over the Muhammadan population by professing more or less Muhammadan views of religion. But Nelson destroyed his fleet at Abukir Bay. A Turkish army landed in Egypt, but was cut to pieces and driven into the sea by the infuriated Napoleon, who then endeavoured to conquer Syria, with the stupendous idea that he might carry his arms to Constantinople, and possibly proclaim a revival in his own person of the Eastern Empire. He was foiled again by the British, who assisted the Turks to hold Acre. Napoleon, though victorious elsewhere in Syria, eventually drew back shattered by the unsuccessful siege of this fortress. He then abandoned his eastern conquests with disgust, and sailed for France. His able lieutenant, Kleber, was assassinated. A British and Turkish army settled the fate of the remaining French forces in Egypt, which after a capitulation were sent back to France. But this daring inroad on the East by Napoleon had far-reaching effects. It brought Egypt violently into contact with European civilization, and prepared the way for its detachment from the Turkish Empire. Moreover, it 
caused France to take henceforth an acute interest in the valley of the Nile, an interest which on several occasions brought her dangerously near rupture with a Power even more earnestly concerned with the Egyptian Question.

In 1827 the Dey of Algiers (a country which remained under nominal Turkish suzerainty), insolent beyond measure in his treatment of Europeans, because hitherto all European states had failed to subdue his pretensions, signalised some difference of opinion with the French Consul by striking him in the face with a fly-whisk. France brooded over the insult for three years, when the tottering government of Charles $\mathrm{X}$ sought to prop up the Bourbon dynasty by a successful military expedition, and in June 1830 landed 37,000 infantry, and a force of cavalry and artillery at Sidi Ferruj, near Algiers. Considering their renown as fierce fighters, the Algerians do not seem to have made a very sturdy resistance; though perhaps in the lapse of time since their last war with a European power the superiority of European artillery began to be felt. At any rate, three weeks after the French landed they had taken the town of Algiers and the Dey had surrendered. A week afterwards the Dey was banished to Naples. Great Britain then asked for information as to French projects, and was assured that within a very short time the French forces would be withdrawn when reparation had been made. But these assurances were as well meant and as valueless as Russian assurances in Central Asia, and our own repeated and unsolicited declarations that we hoped to be able to leave Egypt in six months. The government of Charles $\mathrm{X}$ fell, and the new Orleanist dynasty could hardly draw down on itself the odium of a withdrawal. But an unwise policy nevertheless was pursued towards the Arabs, a policy dictated by ignorance. The inhabitants of Algeria had not taken a very strong part in the defence of the Dey, who in their eyes was a Turk and a foreigner; but when they began to realize that their country was about to be taken possession of by Christians, and 
Christians who at that time did nothing to soothe their religious susceptibilities, they found a leader in a princely man, Abd al Kader ${ }^{1}$. From 1835 to 1837 the French sustained defeat after defeat at his hands. In 1837 however a truce was made, by which Abd al Kader was recognized by the French as Sultan over a large part of western and central Algeria. Two years after war broke out again between the French and Abd al Kader. An army under Marshal Bugeaud attacked Abd al Kader with unwavering energy-perhaps with some cruelty. In I $84 \mathrm{I}$ the national hero had lost nearly every point of his kingdom, and fled into Morocco, from which country he afterwards returned with a large army, only to be again and again defeated, though he occasionally inflicted great losses on the French. Finally, to save his own special district from ruin, he came to terms with the French GovernorGeneral, who gave him permission to retire to Alexandria or Naples. But the French Government repudiated the terms granted to Abd al Kader, and kept him a close prisoner for some years in a French fortress. When Louis Napoleon became Emperor he released him and allowed him to live at Damascus, where he died in 1883 .

At the time when the French invaded Algeria that country was by no means under a homogeneous government. There were the Dey of Algiers, the Dey of Oran, and on the east the Bey of Constantine (who ruled over much of eastern Algeria); whilst the Berber tribes in the mountains and on the verge of the desert were practically independent. Constantine was an extremely strong place, and in their first wars with its Bey the French failed to take it. It was not finally captured till 1847 . By this time France had warred against Morocco, and had crushed any attempt on the part of the "Emperor of the West" to interfere in the affairs of Algeria. They had overrun and to some degree conquered all Algeria north of the Sahara desert. Therefore, in 1848 , the Government felt justified in declaring

${ }^{1}$ Of Arab descent, born near Maskara in Western Algeria. 
the new African acquisition to be French territory, divided into three departments, to be ruled as part of France, and to possess the right of representation in the French parliament. Under the Second Empire this constitutional government, which was quite unsuited to what Napoleon III fitly termed ' an Arab kingdom,' was set aside in favour of military government. But this was not organized on suitable lines, and proved a failure. In 1858 an attempt was made to imitate the change then taking place in the government of British India. An Algerian ministry was formed in Paris with Prince Napoleon as Minister; but this form of administration also was a failure, and was abolished by the Emperor when he returned from his visit to Algeria in 1863 . The country was then governed by a military governor, generally with absolute powers, and attempts were made to conciliate the Kabail or Hill Berbers, whom utter mismanagement had driven into revolt. The country nevertheless continued to be afficted with unrest; and in 1870 , as the Empire was dying, a commission sat to enquire into the state of the colony, and to suggest remedies which might be applied to its misgovernment. By a vote of the Chamber military government was again abolished in favour of civil rule, but owing to an insurrection in Eastern Algeria which followed on the Franco-German War, the recommendations of this commission were not fully carried out till 1879 , when the first civil governor was appointed. One of the first acts of the new French Republic at the end of 1870 was to bestow the franchise on the Jews of Algeria, an action, which by discriminating between the Jews and Arabs has since caused a great deal of trouble.

From 1848 to 1880 numerous attempts were made to induce French people to settle in Algeria, nor were the colonists of other nations discouraged. At one time young soldiers would be selected from the army, would be married to poor girls dowered by the State, and sent off to settle in Algeria, where they were given grants of land; but often as 
soon as the dowry was spent the newly-wedded wife was deserted by her husband, who made the best of his way back to France. In I87 I nearly I I,000 natives of Alsace and Lorraine were granted land in Algeria, and subsequently some 25,000 other French colonists were settled in the country at a cost of $\mathrm{r}_{5}, 000,000$ francs. But despite failures, frauds and fickleness, the French settlers in Algeria increased in numbers by immigration and births, so that by the beginning of the 2oth century there was a French element in the European population of Algeria of more than a quarter of a million (298,000 in I910). Meantime, the peace and security of trade introduced by the French had attracted large numbers of Italians and Maltese to the eastern part of Algeria, and still larger numbers of Spaniards to the western department of Oran-so much so, that even at the present day Spanish is the common language of Oran, and Italian is as often heard as French at Bona, Constantine, and even inland as far as Tebessa. Several thousands of Maltese also settled in eastern Algeria, and became naturalized as French subjects. It is probable that in this way Algeria will be eventually colonized by Europe, not by the nations of the north, but by those Mediterranean peoples who are so nearly akin in blood to the Berber races of North Africa. The French type that prospers most is that drawn from the south of France; yet the fair-haired Alsatians are doing very well ${ }^{1}$. There has been a certain intermixture between the French and the native races, and between these again and other European settlers. It is the present writer's opinion, based on recent visits to Algeria,

1 In 1861 , there were I I 2,229 French settlers in Algeria, and 80,517 Italians, Spaniards, Maltese, Germans, and Swiss; in all, 192,746 European colonists, as against about 650,000 in 1910. It is a common mistake among British writers on political economy to assert that the French are not good colonizers, though they have Eastern Canada, Louisiana, Algeria and Tunis before their eyes. There are now some 340,000 thriving French inhabitants of Northern Africa between Morocco and Tripoli, who will play a considerable part yet in Mediterranean politics. 
that a remarkable degree of fusion between these elements is being brought about. The Arabs and Berbers in the settled parts of the country are approximating more and more in their costume and their mode of life to the Europeans, while the latter are becoming to some extent Arabised. There is scarcely an Algerian in any town who cannot talk French, and there is scarcely a French settler in Algeria who cannot talk Arabic, while among the lower classes an ugly jargon is springing up, in which both languages are represented, mixed with Italian and Spanish words.

In 1863 the Emperor Napoleon brought about the passing of a law which exchanged for a tribal holding of land the recognition of the indigenes as individual proprietors of the soil. This law has to some extent broken up the tribal system, has corrected nomad tendencies, and has done much to settle the Berbers on the soil with loyalty to the existing government. Of course, outside the relatively well-watered, fertile districts the nature of the country induces a wandering, pastoral life amongst the sparse population; and here a warlike spirit still shows itself from time to time in revolts of ever diminishing extent. During the eighties of the igth century the French were obliged to bring large forces into the field to suppress a serious insurrection under $\mathrm{Bu}$ Amama, a leader who represented the more-or-less Arab tribes inhabiting the steppe country, far to the south of Oran, on the borders of Morocco. Their turbulence was only finally subdued by the building of a railway into the heart of their country-a railway now reaching to south-eastern Morocco and destined to be prolonged across the Sahara to Timbuktu.

At the close of the r 9 th century the Jewish question gave rise to disturbances. The Jews, equally with the Christians in Algeria, are electors, while this privilege is granted to only a few Arab proprietors. As in Tunis, the Jews are greatly given to usury, and they were formerly disliked in Algeria with an intensity which is but little understood in England, 


\section{I 8 The French in West and North Africa [CH.}

where the Jews are scarcely to be distinguished from other subjects of the Crown in their demeanour or practices. But the fact is that parliamentary government, so far as Algeria and its connection with France are concerned is somewhat of a farce. Algeria will demand in future fuller measures of self-government, and less dependence on the selfish policy of French manufacturers and distillers. But the country nevertheless owes an immense debt of gratitude to France for its noble public works, its security, tranquillity and its successful battles against the forces of nature-drought, locusts and desert sands.

An example of a successful retention of native forms of government is to be seen in the adjoining country of Tunis, which under the ægis of a Turkish prince is governed despotically, ably, wisely, and well by a single Frenchman. Tunis, which, like Algeria and Tripoli, had since the close of the r6th century been more or less a Turkish dependency-that is to say, a country governed at first by Turkish officers, who finally became quasi-independent rulers, with a recognized hereditary descent-soon began to feel the results of the conquest of Algeria in an increase of interest felt by the French regarding its condition. At first the relations between France and Tunis were flattering to the latter country. The relatively enlightened character of the Husseinite Beys ${ }^{1}$ was recognized, and when France was in difficulties with Abd al Kader and the Bey of Constantine, proposals were even made to Tunis to supply from its ruling family two or three princes who should be made Beys of Constantine and Oran under French protection; but the idea was not carried out. In I 863 the Bey of 'Tunis went in state to visit the Emperor Napoleon at Algiers. Nevertheless, during the '50's and '6o's Great Britain firmly maintained the independence of Tunis, at whose court she was

1 This title arose of course from the Bey (Beg) or Colonel commanding the Turkish army of occupation. The present dynasty was founded in 1706 by the Bey, Hussein bin 'Ali, who was really a renegade Cretan Greek. 
represented for many years by a sage diplomatist, Sir Richard Wood. The disenchantment which Algeria caused in the early sixties diminished the interest which France felt in Tunis; and during this time, under the fostering care of Sir Richard Wood, British enterprise had acquired so large a hold over the Regency, that at the beginning of the seventies it would have been reasonable to have extended British protection to the Bey. But another factor had come into play-the newly-formed Power of United Italy. The finances of Tunis had from the time of the Crimean War onwards got into a disarray resembling in a minor degree the condition of Egypt under Ismail. Not only was the Bey extravagant, but still worse, his ministers, mostly of servile origin, robbed the country shamelessly, and loans were obtained over and over again merely to swell their ill-gotten gains. At last the Powers had to intervene, and in 1869 the finances of Tunis were brought under the control of a tripartite commission with representatives of England, France, and Italy. During the early ' 70 's, however, British commercial interest waned, and the enterprise of France increased, with the result that France obtained permission to erect telegraphs, and took over an important railway concession which had been accepted and then abandoned by a British firm. It was becoming obvious that the native government of Tunis could not continue much longer without a definite European protector. Whatever right England may have had to assume such a position, she quietly surrendered it to France through her official representatives at the Congress of Berlin. The only other rival then was Italy; and Italy, though she would have dearly liked to resume control in the name of Rome over the Roman province of Africa, shrank from the danger of thus defying France. A small British railway which had been made from the town of Tunis to the port of Goletta was sold to an Italian company in I88 ${ }^{1}{ }^{1}$. At the same time, a British subject, really acting as a

1 This now forgotten bone of contention was, in the autumn of 1898 , 
representative of the Tunisian Government, attempted on a point of law to prevent a very large estate in the interior of Tunis from falling into French hands. The French Government determined to delay action no longer. Taking advantage of the very insufficient plea, that a Tunisian tribe (the Khmirs or "Kroumirs") had committed small robberies across the Algerian frontier, a strong force invaded Tunis, and wrung from the Bey in his suburban palace the treaty of Kasr-es-Said, by which he placed his territories under French protection. When the news spread into outlying districts there were uprisings against the French or against the Bey's government which had placed the country under French control. The French troops had practically to conquer much of the south of Tunis, but in a year's time tranquillity had been restored. In 1883 the treaty of Kasr-es-Said was replaced by another agreement which brought the Tunisian Government under complete French control. In this year the other Powers surrendered their consular jurisdiction, and recognized that of the French courts. By 1897 all former commercial treaties with the Bey were abandoned in favour of fresh conventions made with France. From the commencement of 1898 , Tunis became emphatically an integral portion of the French Empire.

Through accident or design-let us hope the latter-a succession of able men was appointed to direct the affairs of France in Tunis. Several of these had a relatively long tenure of power, and were therefore able to carry out a continuous policy. Ablest amongst these French residents have been M. Jules Cambon, and M. René Millet. Tunis has been an example of almost unqualified success in French colonial administration. Of late, however, the protectionist policy which finds favour with the French Government has to some extent striven to secure the commerce of the Regency for sold by the Italian Company to the French Railway Company of BôneGuelma-et-Tunisie. 
France, a policy which may tend to qualify the praise which otherwise would be bestowed on a remarkable development of the country under French direction.

The extension of Senegal under General Faidherbe, and the occupation by the French of oases in the Sahara, such as Wargla and Golea, early suggested an overland connection between the two French possessions, and the "Chemin de fer Trans-Saharien" was hinted at, half in joke, during the sixties and became a subject of serious consideration in the seventies. But in $188 \mathrm{r}$ the massacre of the Flatters expedition in the Sahara Desert, and the obvious hostility of the Tawareq to any further advance of the French across the desert temporarily discouraged the idea; though the main discouragement no doubt arose from the thought of the enormous cost of such a railway, and the unfruitful character of the country it would traverse. Still France, when the word "hinterland" was creeping into political terminology, began to feel anxious that no other European Power should intervene between her North African possessions and her empire on the Niger; and in 1890 she secured from the British Government a recognition of this important point, the British recognition carrying the French sphere of influence to the north-western coast of Lake Chad as well as to the Niger. In $\mathbf{r} 898$ it was resolved to take effective possession of all this portion of the north-central Sudan, and three great expeditions converged on it; one from Algeria under Commandant Lamy with Mons. F. Foureau as political officer, one from French Congo (as to which more will be written when that region is considered), and the third from Senegal, under Captains Voulet and Chanoine. Unfortunately these last-named officers belonged to a type which in the closing years of the igth century came into prominent notice in the French and Belgian operations in Central Africa, while it was not entirely unknown in the British and German records of that period, as colonial and "Congo Atrocity" 
scandals testified-a type which became recklessly cruel and immoral through the possession of unlimited power and the belief that its doings would never be heard of in Europe. But the mistreatment of the natives in the Niger Bend did come to the knowledge of the French authorities in Senegal, and Lieut.-Colonel Klobb was sent eastward to catch up with the Voulet-Chanoine column and take command. Klobb overtook these officers in the Sokoto country. Voulet ordered his men to fire on the officer sent to supersede him. Klobb fell dead. Then Voulet and Chanoine marched away with most of their troops to found an independent state in the heart of Africa, leaving their junior officers and the remnant of the negro soldiers to do as they pleased. But their own Senegalese troops, on reflection, objected to outlawry and permanent banishment from their homes. They held a rough court martial, sentenced Voulet and Chanoine to die, shot them, and then returned to the command of Lieut. Pallier, who had succeeded Klobb in command of this mis-managed expedition. Pallier bravely and adroitly (for the tragedy took place nominally on British territory and the natives were arming to punish these marauders) led the reorganized expedition to Zinder in northern Hausaland (July, I899) where four months afterwards Foureau and Lamy arrived. From this time onwards the Sahara desert was occupied and pacified and is now traversed by several lines of telegraph wires. The Tawareq and Tibu have ceased to raid and devastate peaceful agriculturists in the oases, or the long caravans of traders. Between I899 and I903 French forces (chiefly native cavalry under French officers, and the Foreign Legion) had occupied all the prominent oases and centres of population in the Moroccan Sahara, from Figig and Beshar on the north to Tuāt, Tidikelt, Gurara and Insalah in the south.

The work of the $\mathrm{I} 890$ and $\mathrm{I} 898$ conventions between Britain and France was completed by the Agreement of 1904, 
in which the British Government acknowledged Morocco to be a sphere of exclusively French political influence, with the exception of Tangier and the portions which might be claimed by Spain on the Riff coast. But in 1905 the German Government showed its displeasure at this agreement by an ostentatious recognition of Moroccan independence. European diplomacy arranged the compromise of the Algeciras Conference in the spring of I 906, at which the thirteen assembled delegates drew up some regulations of a stop-gap nature for the policing of the Moroccan Atlantic ports, the re-establishment of Moroccan finances, the position of foreigners, etc. In 1907 however the disorder in Morocco became acute and French and English officials were captured or killed by the natives. To mark her displeasure, France occupied Ujda (Oudjda), a border town of north-east Morocco and advanced her troops to the Muluya river (which will probably be fixed as the theoretical boundary of "Morocco" in the north-east). Soon afterwards the tribesmen round Casablanca (Dar-al-baida) attacked and slew some European masons engaged on the harbour works. France (after the plunder of the town by the Shawia tribesmen) finally landed a force of r 5,000 men and forcibly occupied the Shawia country all round Casablanca. More fighting took place in South Morocco (1907-8) and French expeditions traversed and occupied the regions south of the High Atlas. In r9o8 occurred the civil war between the Sultans Abd-al-aziz and Mulai Hafid, which resulted in the defeat of the former, in spite of his English military advisers and non-commissioned officers $^{1}$. Germany seemed rather to espouse the cause of Mulai Hafid, but in any case the complication was unravelled by the abdication of Abd-al-aziz and the recognition of Mulai Hafid by France and the other signatory powers of the Algeciras conference.

But in 1909 the temporary peace in Morocco was again

1 Some of the latter performed really gallant services, and afterwards passed into the military and police forces organized by the French. 
rudely broken by Spanish activity round Melilla-the building of a railway to secure a new post, La Mar Chica, and to reach and work mineral deposits. The Riff tribes attacked the Spaniards with results already described in Chapter V. The ferment among the Moors against European intervention next took the shape of attacking the Sultan Mulai Hafid at $\mathrm{Fez}$ (I9ro). To save the Sultan and the Sultan's Government (the "Makhzen") and the European residents from possible destruction, the French Government sent an expeditionary force from the Shawia coast region to reach and relieve Fez. This was accomplished after some difficulty in the spring of I9I I, and a small army or government guard was organized for the Sultan under French officers.

This and other actions once more aroused German resentment and intervention on the grounds that France was creating a virtual protectorate over Morocco without Germany's consent, and without compensation to Germany for the possible loss of a profitable field of commercial development. So the German war vessel, the Panther, was sent to Agadir in the Bay of Sūs to "protect German interests"; these interests being the mineralogical researches and acquisition of concessions of the firm of Mannesmann. If we brush aside diplomatic fictions, the kernel of the matter was this. Germany had long fixed her desires on the Bay of Sūs or Agadir, that semi-circular bight of the Moroccan coast south of the Atlas range and opposite the River and Country of Sūs which is the nearest approach on the whole Atlantic coast of Morocco to a large and good harbour protected from the north wind. It was believed in Germany that Great Britain was too much involved in domestic agitation to be prepared to go to war over Morocco ; and that France would be willing to stave off trouble with Germany and obtain her consent to the acquisition of nearly all Morocco by agreeing to a German protectorate over the Sūs country and Anti-Atlas, thus admitting Germany as a territorial power in North Africa. 
Spain gave Germany some encouragement in this intervention, having already found the French very grudging in their allotment of Spanish spheres of influence in the north of Morocco and opposite the Canary Islands. But had Germany succeeded in her demand for the Sūs country Spain would have been the first to suffer. The Cape-Jubi-Bojador region and the Canary Islands might ere long have become German also.

An attempt was made in Germany to enlist European sympathy on her side by advancing the plea that this intervention at Agadir stood for free trade in Morocco. But this important principle had already been secured by the AngloFrench Convention of 1904 and the Algeciras Act of 1906; moreover the whole of the bargaining between France and Germany, since I 906 , bore reference to the selfish advantages which German concessionaires and traders were to obtain in Morocco to the detriment of (let us say) British, American, or Belgian competitors. Of course France, in the use she has made of North, West, and Central Africa and of Madagascar, has been inexcusably protectionist. She has adopted the thoroughly selfish policy of colonial exploitation characteristic of Spain and Portugal in the 16th-18th centuries and of Britain in the 17 th to early 19 th centuries. Nevertheless she has spent blood and treasure without stint in the redemption of North Africa; and in spite of her protectionist tariff the nonFrench, European trade with Algeria and Tunis is very considerable. But a question of even greater importance than a selfish French use of Morocco rose before Great Britain in I9I I. Not to support France in this diplomatic struggle meant the establishment of Germany on the Atlantic coast of Morocco, meant that the Emperor Wilhelm's half jesting description of himself at that period as "Admiral of the Atlantic" would become a reality, with all the consequences which might flow from such a position.

Germany realizing her false position shifted her ground, asked for reasonable "compensations in Central Africa," got 
them, and in return recognized definitely a French Protectorate over Morocco. With the exception of the Riff Coast, of Tangier, and of the region opposite the Canary Islands (which with the exception of Tangier will become Spanish) France will soon be mistress of Morocco in name, but probably not in actuality and entirety till many years have passed. No sensible person need regret this. The condition of Algeria and Tunis under French direction are a sufficient guarantee for the future prosperity and happiness of the most interesting country in Africa-Morocco-under French guidance,

As already related, France, or rather-the State being then but the king-Louis XIV, had become interested in the affairs of Abyssinia early in the $\mathrm{I} 8$ th century. This interest was reawakened in the middle of the next century by the remarkable researches of the brothers Antoine and Arnaud d'Abbadie, who though of partly Irish origin were French subjects. The elder brother had explored Brazil, the younger, Algeria; but both were attracted by the little-known civilization of Ethiopia and started together in 1838 for Abyssinia. Between 1838 and 1853 their researches were carried on from Masawa in the north to the little-known country of Kaffa in the far south; and, though the results were not entirely published until $\mathrm{x} 890$ (the publication began in I860), they gave to France a legitimate claim (together with the subsidized travels of Borelli in 1890 ) to an interest in the affairs and the future of Abyssinia.

In 1857 , jealous of the British establishment at Aden, France had intended to seize the island of Perim, at the mouth of the Red Sea, but was forestalled by the British. She therefore turned her attention to the coast opposite Aden, and there purchased from a native chief (in 1862) the Bay of Obok. This place was not effectively occupied till 1883 , after the break-up of the Egyptian Sudan empire. France then rapidly pushed her possessions southward to curtail as much as possible similar British operations in Somaliland. She thus secured the 
important bay of Tajurra. French territory now stretches inland to the vicinity of Harrar. On the north it is bounded by the Italian colony of Eritrea and in the interior by Abysinia and British Somaliland. French Somaliland, as this possession is called, is about 5,790 sq. miles in extent and is chiefly important for the comparatively good harbour of Jibuti and for the fact that it controls the easiest access to Abyssinia. Indeed the only existing railway which enters Abyssinia and connects that country with the sea coast starts from Jibuti and is constructed to the Abyssinian capital, Adis Ababa (275 miles), with a branch to the old Semitic city of Harrar (altogether about 192 miles of rail on French territory). It was an unfulfilled aspiration of France in the last decade of the 19 th century that a French Empire should extend across broadest Africa from Senegal to Abyssinia and the Red Sea or the Gulf of Aden. This project was to be essayed in a tentative manner by an expedition organized in the French Congo in 1894-5 (despite warnings from Great Britain that such action would be regarded as unfriendly) and led by an officer who had been very successful in the wars of Upper Nigeria, the brave Major J. B. Marchand, who advanced (mainly along the course of the Djur River) with a force of about 150 Senegalese and nine French officers to Fashoda, on the White Nile. Here they were saved from possible destruction at the hands of a large force of Dervishes by Lord Kitchener's victory at Omdurman. In consequence of the protests of the British Government, Major Marchand in November 1898 was instructed to leave Fashoda and retire through Abyssinia to French Somaliland. This journey up the valley of the Sobat River was successfully accomplished; and at the end of May I 899 Marchand and his officers reached Paris, where they received a great ovation.

French interest in the Congo region began in the 18 th century, mainly because of the importance of the servile labour of Congoland to the French West Indies and the desirability of preventing the Portuguese from regaining their 


\section{The French in West and North Africa [CH.}

monopolist hold over the Kongo kingdom and its commerce. The French Government contrived moreover to have French Catholic missionaries sent to the Congo and Loango in place of the Italian Capuchins. The Napoleonic Wars and the abolition of the slave trade suspended further action; but the idea of a French control over "Lower Guinea" revived in 1839 , at the time when the government of Louis Philippe was making half-hearted efforts to found French settlements on the West Coast of Africa. At this date King 'Denis' of the Gaboon, who had shown favour to Roman Catholic missionaries and to French traders, was induced to transfer his kingdom to France. The Gaboon, or country of the Mpongwe tribes, lies to the south of the Cameroon region. Effective possession was not however taken till 1844 , and Libreville, the present capital, was not founded till $\mathbf{1} 848$, when a cargo of slaves was landed there from a captured slaving vessel and set free to commence the population of the new town. Attention was drawn to this French settlement by the remarkable journeys of a French-American, Paul du Chaillu, and his making definitely known the characteristics of the largest known anthropoid ape, the gorilla. The existence of this ape had been to some extent established by the American naturalist, Dr Savage, from skulls sent home by American missionaries settled on the Gaboon estuary; but the gorilla was scarcely made familiar to the general public, until Du Chaillu came to England with his specimens ${ }^{1}$. In the early sixties French explorers established the lower half of the course of the important river Ogowé ; and in the seventies these explorations were extended by other travellers, who carried the knowledge of the Ogowé to the limits of its watershed, and passed beyond-unknowingly - to affluents of the Congo. Among these explorers was the celebrated Savorgnan de Brazza, of Dalmatian origin but born on a French ship off the coast of Brazil.

1 Now in the British Museum of Natural History. 
Political interest in the Gaboon languished so much on the part of France that the country was once or twice offered to England in exchange for the Gambia. However in I880, the awakening desire to found a great colonial empire urged France to extend her Gaboon possessions up the coast, towards the Cameroons, and southward in the direction of the mouth of that great river, the Congo, the course of which the explorer H. M. Stanley had just succeeded in tracing. Even before Stanley's return, the King of the Belgians had summoned a number of geographers to Brussels to discuss the possibility of civilizing Africa by an International African association. This conference brought about the creation of national committees, which were to undertake on behalf of each participating nation a section of African exploration. The French committee sent De Brazza to explore the hinterland of the Gaboon. While Stanley was commencing his second Congo expedition for the King of the Belgians and slowly working his way up the lower river, De Brazza had made a rapid journey overland to Stanley Pool and the upper Congo, making treaties for France and planting the French flag wherever he went. Soon afterwards an English missionary, George Grenfell, discovered the lower course of the great Mubangi, and French explorers promptly directed their steps thither. For some years there was keen and even bitter rivalry between Stanley's expedition, which gradually became a Belgian enterprise, and the French explorers under De Brazza; and when, at the Conference of Berlin in $\mathbf{1} 884-5$, it was sought to create the Congo Independent State under the sovereignty of the King of the Belgians, the adhesion of France to this scheme could only be obtained by handing over to her much of the western and northern watershed of the Congo, besides giving her a promise that, if the Congo State were ever to be transferred from the Belgian sovereign to another Power, France should have the right of preemption. Before the French had been many years on the Mubangi River (which is one of the few means of 
communication between the southern, Bantu part of Africa, and the northern regions, the "Sudan," populated by non-Bantu Negroes, Negroids, Hamites, and Semites ${ }^{1}$ ), they had very naturally conceived the idea of pushing northwards to the Shari river and Lake Chad. In I 890 Paul Crampel was the first European to cross this mysterious Bantu boundary, to leave the forest regions of the Congo and lower Mubangi, and enter the more open park-lands of the central Sudan. But he was attacked and killed (r89r) by suspicious Muhammadan raiders on the river Shari. Another Frenchman, of Polish descent, M. Dybowski, succeeded in chastising the murderers of Crampel, and further exploring the Shari. A further mission under Lieutenant Maistre continued the work of Dybowski, and was in turn followed by a well-equipped expedition under the command of the explorer Emile Gentil ; which last succeeded in placing a small armed steamer on the river Shari, and thence reached the waters of Lake Chad.

By an agreement with Germany in 1892 , France secured German recognition of her sphere of influence over the river Shari, over the Bagirmi country, and the southern shores of Lake Chad; while, by a treaty made with the King of the Belgians in 1894 , the Belgian boundary line was drawn at the Mubangi, the Mbomu, and the Nile watershed. Lastly, by the Anglo-French convention of June 1898 , Great Britain recognized the French sphere to the south and east of Lake Chad. Thus France obtained European recognition for a continuous empire stretching from Algiers to the Congo Coast, and Oran to Dakar - a remarkable outcome of the landing of 37,000 troops at the Bay of Sidi Ferruj, near Algiers, in the summer of 1830 .

In the last decade of the I 9 th century, the French method of administering the territories of the Gaboon, Loango and

1 The Mubangi is the name given to the western and southern course of the river which is known as the Wele in its upper waters, and was discovered by Schweinfurth in $187 \mathrm{I}$. 
Congo-Mubangi (grouped since 1888 in one government as "French Congo") was infected by the "concessionaire" spirit, which had unhappily inspired King Leopold II about the same time in his attitude towards the development of the Congo Independent State. These monopolist, protectionist ideas were a heritage from the older style of colonization in the I 6 th, I 7 th and I8th centuries. The great Berlin Conference of 1884 on the Congo question was supposed to have vetoed them and rendered their recurrence impossible. But no sooner was this conference over than this monopolist policy was revived by the Royal Niger Company on the Niger-Benue, by the infant Congo State on the Congo above Stanley Pool, by the French in Loango, and (though much more faintly) by the British South Africa Company in Rhodesia. But it was mainly in the case of the Royal Niger Company that the monopoly was one which completely crushed out other trade. That association did not theoretically forbid the natives to trade with any foreign merchants but itself; it merely said to outside traders: "Sorry! but this place is ours, and so is that-in fact the whole river-bank-and we cannot have you trading on our private land." The King of the Belgians copied this policy pretty faithfully on the Congo, and so did the French. The whole of French Congo, except two or three old-established towns on the coast, was divided up into concessions, varying from 20 square miles in extent to 54,000 square miles. The villages and plantations actually occupied by the natives at the time were recognized as native property, but this recognition did not necessarily confer on the natives the right to trade with whom they pleased.

All the coast ports of the Gaboon and Loango had long been frequented by British merchants doing a big trade with Liverpool; and great was the indignation when they found their commerce with the interior cut off by French concessionaires who, it may be, had done nothing to develop the trade of the country. In spirit, of course, this policy was 
in flagrant contradiction with the commercial stipulations of the Berlin and Brussels Acts which followed the Congo Conference of $1884-5$. But the French government, in reply to remonstrances, pointed to the monopoly of the Royal Niger Company ${ }^{1}$; and the French courts of law gave decisions adverse to British appellants.

It is only fair to quote the justification for this policy of concessions, charters, and other documents conferring special privileges. It is desired-in the interests of the native as well as of the overruling European government-to attract capital to the opening-up and the exploiting of the natural riches of Africa, riches of which the native has remained in utter ignorance for millenniums of years. To invite investments of capital some security must be given that the immediate fruits of the investors' labours and expenditure will not be unfairly garnered by others who have not run the like risks. No one questions the right of the native, in a varying degree, to a fair proportion of the land; the area being determined by his numbers, degree of civilization, energy, intellectual capacity, and the extent to which he has already developed its resources. It would be, for example, a ridiculous proposition that the $322,45^{\circ}$ square miles of German South-West Africa should be the exclusive heritage of a few thousand nomad Hottentot and Bushman hunters, or even of sixty thousand Bantu cattlekeepers; that some Congo forest of ten thousand to thirty thousand square miles should be assigned in perpetuity to a few thousand wandering pygmies prowling over it in search of game and wild bees' nests; or that the whole of the Sahara with its phosphates and salt-mines be allotted to the raiding Tawareq and Tibu. On the other hand, to say in connection with a well-populated, fairly well-known region like the Niger banks, the Gaboon and Loango coasts, or the lower

1 The invidious analogy of the Royal Niger Company was soon after-

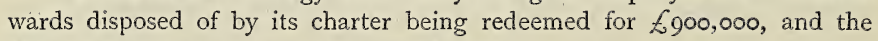
Niger being thrown open to general trade. 
Ogowe river, that the natives shall only trade with concessionaires or with the Government itself, or that one nation shall be specially favoured in its commerce or trading relations, is to impose a tyranny which the world at large and the subject races will no longer tolerate quietly. It does not follow from this that there is to be no interference with "native" rights, that "freedom should be free to slay herself," as has often been the case in wild countries; where the unthinking inhabitants destroy the resources of the country without thought for the morrow. It is quite permissible ethically for the French, the British or any other government to take possession of some thoroughly backward or very sparsely populated country in a more or less savage condition, and rule that country impartially for its own benefit and for its general usefulness to humanity at large. Under such conditions they certainly are not obliged by any moral law to attribute to the nearest native community of savages some large area of uninhabited forest or metalliferous rock. Such a source of future wealth they are entitled to administer as a trustee might deal with an estate for the benefit of a minor or of an imbecile; but only on the condition of putting the profits derived therefrom into the treasury of the state or country thus administered, not into the funds, private or public, of a distant European nation. King Leopold II or the French Republic were quite justified in declaring the uninhabited, unexploited, uncultivated forests of French and Belgian Congo to be "State domains"; but not with the sole purpose in the one case of swelling the revenues of his own privy purse, and in the other of enriching political partisans or public servants. The wealth of these regions need not have gone to some native chief or tribe dwelling in the vicinity who had had nothing whatever to do with the getting of the wealth, but should have been attributed to the whole community of the state or colony in which these forest or mining areas were situated.

Another grave defect in the earlier administration of French 


\section{The French in West and North Africa [CH.}

Congo was the handing over of thousands of natives as veritable serfs of the glebe to these European concessionaires. This was a wicked return for the trust they had placed in envoys of France like De Brazza, who had obtained their adherence to French dominion by treaty. The result of this policy was that gross abuses ensued, followed by native risings. At length the French Government was constrained by European opinion (largely awakened by $\mathrm{Mr}$ E. D. Morel) to look into the affairs of French Congo; and in 1905 the virtual creator of this dominion, De Brazza, was sent out as a commissioner to investigate the charges brought against the officials and the concessionaires. It is believed that De Brazza was horrified at much of the devastation and depopulation which he saw, as were some other high-minded French officials who had the courage to publish their impressions. But De Brazza died at Dakar on his way home, and his report was never published, though the French Government made afterwards some changes in matters of administration.

In r9i I Germany, in return for acknowledging a French Protectorate over Morocco, obtained from France important territorial advantages in French Congo-about 107,000 square miles-giving Germany (I) a strip on the south of Corisco Bay and a large piece of the Osheba country, which permits her to surround the Spanish possession of Rio Muni (she also acquired from France rights of pre-emption over the Rio Muni); (2) a long strip down the valley of the river Sanga to the main Congo River opposite Lukolela; (3) the Laka and Baya countries east of the Cameroons watershed; and (4) a strip of land communicating with the Mubangi river. In return, Germany ceded to France a piece of land (6450 sq. miles) along the left bank of the lower Shari. It was generally rumoured that Germany had asked for the whole left bank of the Mubangi from Libenge down to the Congo, and the whole of French Congo between the Mubangi, the Congo and the Atlantic coast. If she did so, other circumstances caused 
her to modify her demands. In any case she has succeeded in cutting off French Congo from the Mubangi-Shari-Chad territories, so far as uninterrupted land communication is concerned. She has ringed the tree in the hope that it may some day fall to her. But if it does, it will only be in-return for an equivalent in some other direction, perhaps a rectification of the Lorraine frontier.

Even with the loss of her Gaboon-West Congo territory, France would still possess a magnificent and compact African Empire exceeding in extent that of any other European Power, or at any rate superior in continuous area-an empire of something like $3,100,000$ square miles, stretching from Senegal and Morocco to the frontiers of Egypt and the Egyptian Sudan, from Algiers and Carthage to the Belgian Congo and the vicinity of Uganda; besides her valuable foothold on the Gulf of Aden, and the possession of Madagascar (presently to be described), which compensates her for the want of colonies in South and East Africa. In the regions north of the MubangiWele-a river which Germans, Englishmen and Belgians were the first to discover, but the whole of the north bank of which from the Mbomu confluence to the Congo confluence is now owned by France-Frenchmen have reason to be proud of their country's record. As already related, it was French explorers who first solved the mystery of the passage from the Congo watershed to that of the ShariChad; and several French explorers paid with their lives for their temerity. To enquire into and avenge the death of Paul Crampel, a French commissioner, Emile Gentil (subsequently, until 1908, Governor of French Congo) had penetrated down the Shari River, from the Congo basin, till he had reached the far-famed country of Bagirmi. Here he induced the muchharried native sultan to accept French protection, and placed a French resident at his court. Bagirmi was then invaded by Rabah Zobeir, who had made himself Sultan of Bornu. The Bagirmi sultan and the French resident had to flee before the 


\section{The French in West and North Africa [CH.}

army of Rabah; but after two years' fighting, in which at first the French met with several reverses, Rabah was defeated and slain in a great battle in which the Foureau-Lamy ${ }^{1}$ expedition, which had come from Algiers, were joined by the remnant of the Voulet-Chanoine column from Senegal, and a river flotilla from the Mubangi-Congo. For two years more, however, the French forces in Bagirmi had to fight Rabah's sons and successors; but the last of these was defeated and slain (on the borders of Bornu) in the early part of 1902 .

The next enemy to be grappled with and overcome-the last, so far as one can foresee, of the strong Mussulman states of Central Africa - was the country of Wadai, situated to the north-east of Bagirmi and a region which had been for a century or more the chief focus of slave-raiding and trading in Central Africa, besides being singular in that region for its secular hatred and distrust of the white man, in whom the Arabized ruling classes of Wadai saw not only the hated Christian infidel but the eventual opponent of the slave trade, out of which Wadai had amassed wealth since the seventeenth century. The French entered into relations with Wadai in 1900, and interfered in its civil wars. But incited by the agents of the Senussi sheikh ${ }^{2}$, the Wadai ruler attacked the French outposts

1 Major Lamy was killed in the battle which also cost Rabah his life.

2 At the end of the 18 th century there was born at Mostaganem in West Algeria from an Arab family in that place, Muhammad-bin-Ali, further named As-Sanusi (Senussi), after a celebrated saint of Tlemsan. He went as a young man to Mekka, and there achieved a reputation for holiness and learning. Here also he made the acquaintance of Muhammad Sharif, a negro prince from Wadai, who afterwards became Sultan of that country. In the middle of the rgth century As-Sanusi returned to $\mathrm{N}$. Africa and settled in the Cyrenaica, but finding the Turks suspicious he changed his head-quarters to Jaghbub in 1860 , just inside the Egyptian borders, thirty miles from Siwa. Here he died soon after his arrival, and as a religious leader he was succeeded by his second son, Al-Mahdi. Al-Mahdi Senussi II renewed the relations with Wadai, where his father's sect numbered many adherents, and in the last 
on the Shari in 1904 and carried off many negro prisoners. Another motive for their hostility was that France had given refuge to a claimant for the Wadai throne-Asil, subsequently Sultan of Wadai. Between I904 and I9 I fighting between the French and a section of the Wadaian peoples-mostly the Maba negroids and the Massalit Arabs-continued until the French had conquered the whole country and installed Asil on the throne of Wadai under the guidance of a French resident who has since (I912) deposed him for cruelty. They themselves took over the direct government of the southern provinces, the negro countries of Dar Runga and Dar Sila, so long the hunting-grounds for the slave-raiders; so much so, that their once abundant negro population was reduced to a few thousand miserable savages. In this long warfare against the strongest and most fanatical of Muhammadan negro states, the French lost numerous officers of note and displayed qualities of resource and heroism that promise well for a nation which can produce at the present day such officers and non-commissioned officers. As in the case of the British, the rank and file of their armies on these campaigns were Africans, mainly Senegalese.

The conquest of Bagirmi and Wadai naturally secured to the French the more sparsely populated country of Kanem, inhabited mainly by those Tibu negroids whose race extends

quarter of the I 9 th century removed his head-quarters to Al Jof in the Kufra oasis, midway between Cyrenaica and the Sudan. Senussi refused to countenance the revolt of the Mahdi in the Egyptian Sudan, but between 1899-1902 interfered strenuously in the Central Sudan to prevent the advance of the French, especially towards Kanem and Wadai. But his efforts were fruitless, and he died in or near Wadai in 1902. His nephew and successor, Senussi III, wandered about for some time in the borderland between Wadai and Kordofan, and finally betook himself to the Kufra oasis in the Libyan desert, where he now resides. The Senussiites profess a purified form of the Muhammadan faith, are rigid abstainers from alcohol and tobacco, but are above all an honest, industrious folk, who have done much of late years to improve the conditions of life in the Saharan and Libyan oases. 
right across the Sahara to the hinterland of Tripoli. Now that Italy is in occupation of Cyrenaica, and Turkey can no longer supply arms and ammunition to Wadai for the campaign against the interfering white man, it is unlikely that French rule will be seriously contested any more in the heart of the Central Sudan; so long, that is, as Britain rules to the eastward. Quite possibly a great strategic future may lie before Kanem and Wadai, and the lands of the French Mubangi province; for through these regions may pass the trunk line of Trans-African railways, the route which will connect South Africa with Tangier and with Alexandria. The conquest of Wadai by the French has been the final and the most crushing blow directed at the African slave trade of Islam, and it has been carried out with a lavish expenditure of money and bravery at a distance of something like $\mathbf{r}, 500$ miles from the nearest civilized base, a feat almost without parallel in African history. It may well serve as a pendant and an effacement to that brief lapse from the policy of a civilized Power during which something. like a new form of slavery was established by France in Western Congoland. 


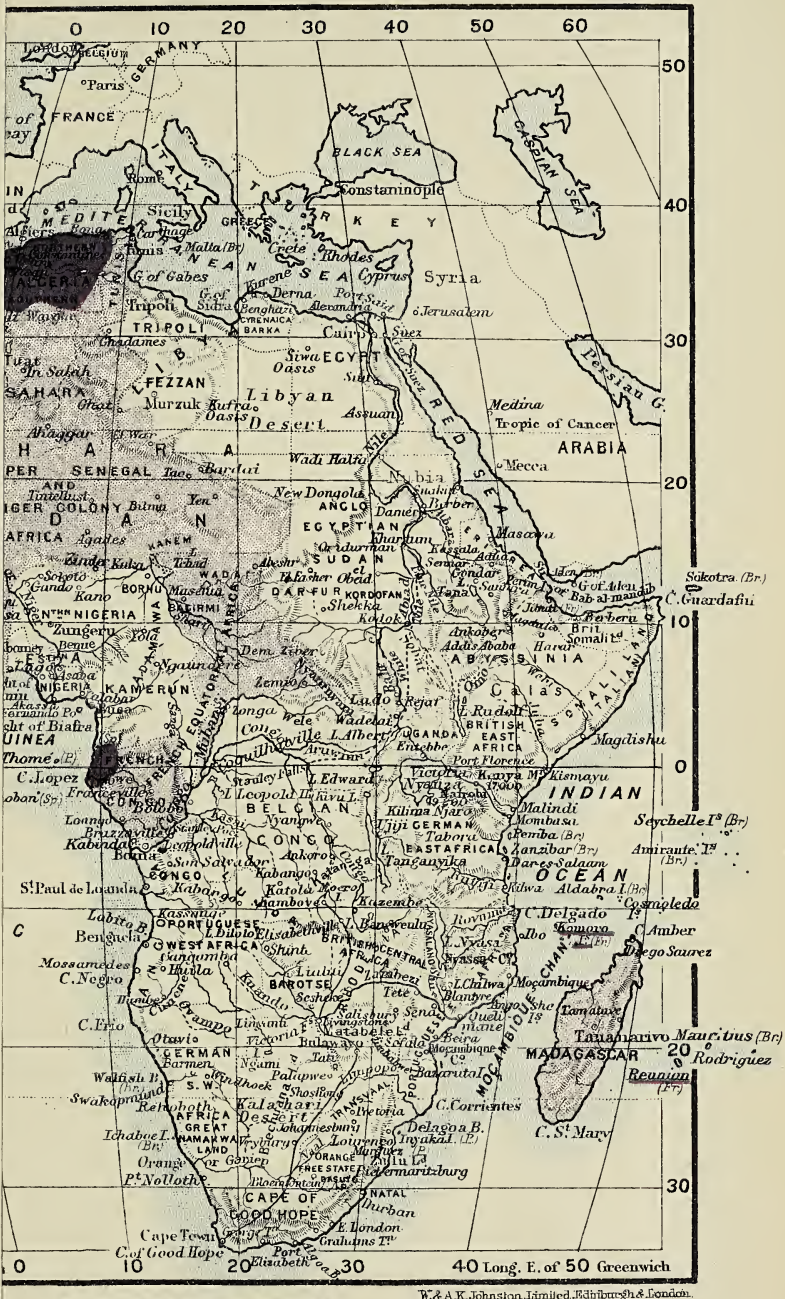

EXPLANATORY NOTE

Irea of French Possessions in 1880

" , Colonies and Protectorates in rora 

FRENCH AFRICA

Plate IV.

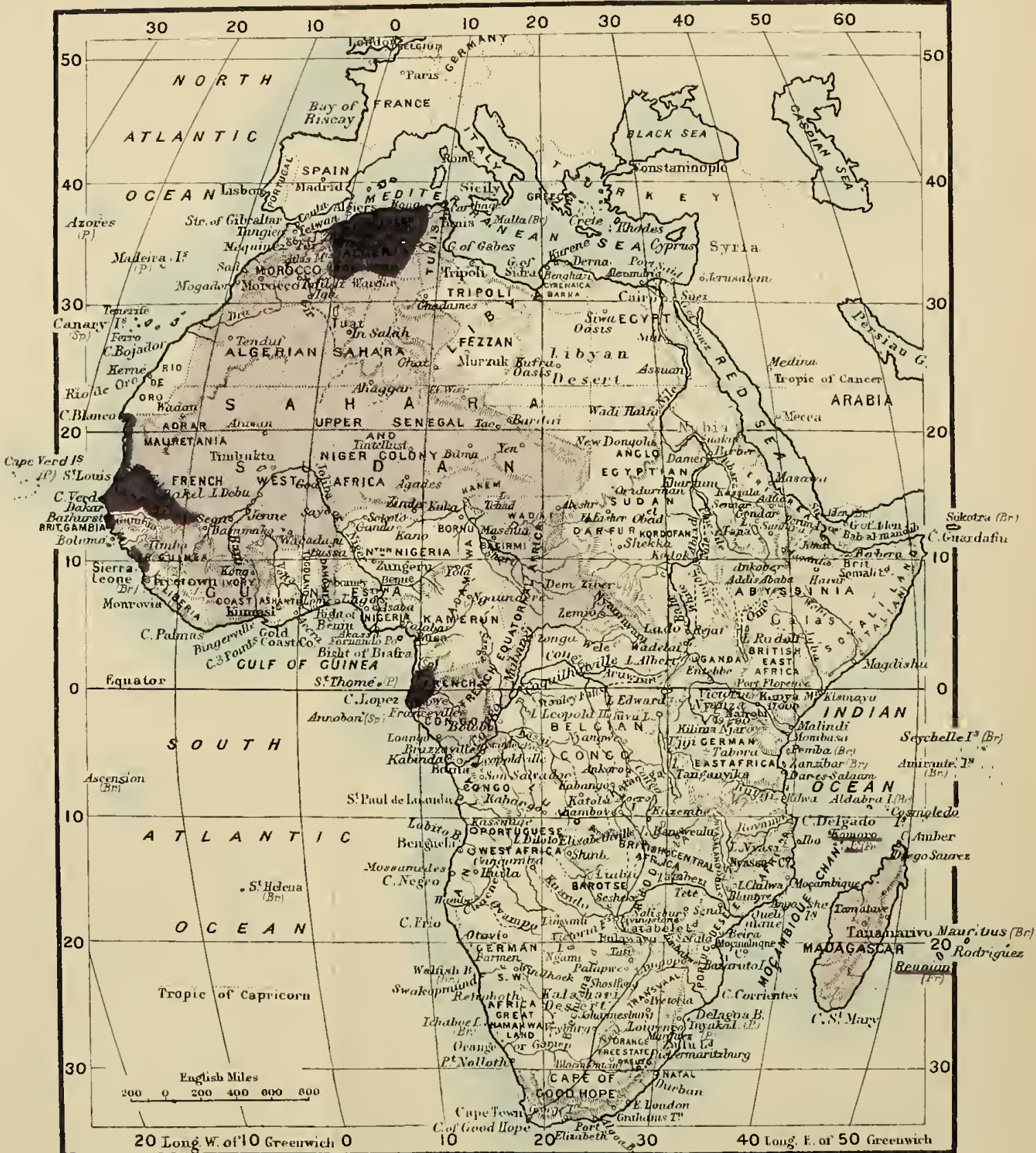





\section{CHAPTER X}

\section{CHRISTIAN MISSIONS}

IF I were writing this book for dramatic effect and less with a view to historical sequence, I should have been disposed to put this chapter next to the one dealing with the slave trade, as an effective pendant; for if Europe has dealt wickedly in enslaving Africa, she has sent thither a high-minded army of men and women, who, acting nearly always from noble and unselfish motives, have raised the African from a callous ignorance to a distinctly higher stage of civilization. And whether or not Britain was a greater sinner than other white peoples in the thoroughness with which she prosecuted the slave trade, she at any rate deserves credit for a degree of missionary effort far surpassing that attributable to any other nation.

The Portuguese were the first European nation to send missionaries to Africa. Their zeal was great, and, with one or two exceptions, wholly praiseworthy. Portuguese priests and Jesuit fathers accompanied most of the early expeditions to Africa ; in fact hardly any explorer or conquistador sailed without chaplains in his company, who raised the cross and preached Christianity as soon as they set foot on shore. In the chapter on the Portuguese in Africa I have touched upon the introduction of Christianity into Congoland in r $49 \mathrm{r} .$. But any race of purely negro blood accepts and loses Christianity with great facility. The Negro (unless he be Muhammadanized) 
is easily converted, and as easily relapses into gross superstition or a negation of all religion, including his former simple but sound ideas of right and wrong. In order that Christianity may become permanently rooted in a negro race it is necessary for it to be maintained by a European power for a long period as the religion of the State. If the negro kingdoms which remained independent retained their Christianity it was in an unrecognizable form. It is not so with Muhammadanism, the explanation being that Muhammadanism as taught to the Negro demands no sacrifice of his bodily lusts, whereas Christianity with its restrictions ends by boring him, unless and until his general mental condition, by individual genius or generations of transmitted culture, reaches the average level of the European. As instances of the former, one might mention some ten or a dozen individuals living at the present time, who are priests and deacons of Christianity in Africa; while for examples of permanently rooted Christianity as the result of inheritance it is only necessary to point to the two or three millions of really good negro men and women to be found in the United States, the West Indies and Cape Colony. Portugal, however, never attempted to rule the Kingdom of the Congo till the last quarter of the I 9 th century; so after more than three centuries of propaganda ${ }^{1}$ the Ba-kongo fell away from Christianity, and in less than a hundred years had absolutely relapsed into Heathenism, when once more, against their wishes, missionaries returned to Western Congoland.

Jesuit priests also accompanied Portuguese conquerors to the Zambezi and the south-east of Africa. Here they met with relatively little success, though they left their traces on Zambezia in the most marked manner by founding a settlement at Zumbo high up the Zambezi and even establishing stations beyond in the little known Batoka country, where their presence

1 For the detailed history of the Portuguese, Italian, Flemish, and French Catholic missionaries in the Kongo kingdom see my book, George Grenfell and the Congo. 
is attested to this day by the groves of fruit trees descended from those they introduced. Tete, the modern capital of Portuguese Zambezi, also began as a missionary station. Elsewhere, in Portuguese East Africa, the priests had very little success, as Muhammadanism had already got a hold. Indeed the first missionary explorer of Zambezia, who visited the court of the King of Monomotapa, was martyred there at the instigation of the Arabs ${ }^{1}$.

Portuguese priests also travelled over Abyssinia during two centuries after the Portuguese discovery of that country at the end of the I $^{\text {th }}$ century. Christian Abyssinia-the most probable origin of the myth of the Kingdom of Prester Johnattracted a good deal of attention from Portugal since she commenced her exploration of the outer world. But the Portuguese priests were quite unsuccessful in converting the Abyssinians from their debased form of Greek Christianity to the Roman Catholic Church; and after bitter quarrels with the native clergy these missionaries had been either killed or expelled from the country by $\mathbf{I} 633$.

The French traders who frequented the Senegal coast between $155^{\circ}$ and $165^{\circ}$ nearly always took a missionary chaplain with them.

Spanish, Portuguese, and Italian priests vainly attempted at different times to convert the Moors of North Africa. Finding this a hopeless task, they directed their efforts towards relieving the sufferings of the unfortunate Christian captives of the Barbary pirates, and practically continued this work down to the French occupation of Algeria.

The Protestant peoples did little in the way of missionary work in Africa till quite the end of the r8th century; though the good Huguenots, who went out to South Africa, endeavoured, somewhat to the surprise of the Dutch, to treat the Hottentots as fellow men fitted for baptism; and the

1 Gonçalo de Silveira; killed somewhere to the. south-west of Tete about $I_{5} 65$. 
Moravians, attracted by the Hottentots, began evangelizing work at the Cape of Good Hope in 1732, but were soon checked in their efforts by the Dutch Company.

Wesleyan missionary work was begun at Sierra Leone coincidently with the establishment of that place as a settlement for freed slaves in 1787 . The London Missionary Society was founded in 1795 , and the Edinburgh Missionary Society in I $79^{6}$; the Glasgow Missionary Society soon afterwards. By the end of the r8th century these three bodies had sent out missionaries to Sierra Leone and the adjoining Susu country. In 182 I the Glasgow Missionary Society sent the first Presbyterian missionaries to South Africa. The Church Missionary Society was founded in $\mathbf{I} 799$. It furnished missionaries for Sierra Leone, and after a long interval extended its operations to Lagos and the Niger Delta, where it is still the leading Christian mission. In 1830 this mission sent its first agents to teach Protestant Christianity in Abyssinia, and began to consider the possibility of evangelizing East Africa. In common with other English missionary societies at that time, and for reasons not altogether clear, it preferred to employ German evangelists, though from the results achieved few can find fault with the choice made. The Church Missionary Society introduced to us men of the stamp of Krapf and Rebmann. Dr Ludwig Krapf is justly a great name in African exploration, African philology, and African Christianity. Despatched by the Church Missionary Society to prospect Abyssinia in 1834, he was obliged to decide in 1842 (in Shoa), after disappointing experiences, that there was no field there for Protestant Christianity, and therefore directed his steps to the Zanzibar coast. Being a tactful man, and meeting with kindness at the hands of Sayyid Sa'id, the 'Sultan' of Zanzibar', he established himself at Rabai, near Mombasa, and there founded the work of the Church Missionary Society, which endures and

1 At that time the Arab viceroy of Zanzibar was only known as 'Sayyid' (Lord); not as Sultan. 
prospers to this day. Dr Krapf will also be referred to in the chapter on explorers. The Church Missionary Society educated the first Protestant negro bishop ${ }^{1}$ in the person of Samuel Crowther of the Niger. Its work met with some success on the West Coast of Africa as regards the number of adherents; but, like most Christian missions, it has not achieved rapid progress in more or less Muhammadanized East Africa. This mission stands out conspicuous for the magnificent philological work done by its agents in Africa; especially notable among whom have been Dr S. W. Koelle, Mr Reichardt, the Rev. James Frederic Schön, Bishop Crowther, Krapf, Rebmann, and J. T. Last.

The Wesleyan Methodist Missionary Society was founded in 1813 , and devoted its first efforts to South Africa, Namakwaland, and Kaffraria. The Primitive Methodist Society was started in 1843 , and continued the evangelization of Fernando Pô, which had been carried on by the (British) Baptist mission from I 844 to I 859 . They also went at the same time to South Africa. The prospects of this mission in Fernando Pô were affected by the resumption of the administration of that island by the Spanish Government, which at that time discountenanced Protestant missions in its territory. Some arrangement was come to, however, and the mission still continues to work there, and to work at the present time without any very marked restriction.

The Society for the Propagation of the Gospel became a distinctly missionary body in $182 \mathrm{I}$, and worked chiefly in South Africa.

1 The Portuguese Church had produced the first Roman Catholic negro bishop, in the 16th century. He was Bishop of the Congo, was a member of the royal family of Kongo, and was educated at Lisbon and Rome. Samuel Crowther was an Egba slave-boy from Lagos, who by education acquired the intellect and outlook of a European. He was an upright, sensible man who wrote valuable works on African philology, and did much towards founding British Nigeria and exploring the Niger and the Benue. 
The British Baptists organized a missionary society early in the 19 th century, and sent out missionaries as far back as 1840 to Fernando Pô. Owing to their expulsion from the island by the Spanish Government, they moved across to the Cameroons, where they established the flourishing settlement of Ambas Bay, and made English almost the second language of the Cameroons people.: The splendid work of this mission in the Cameroons was chiefly done under the late Edward Saker, whose name is still venerated on the Cameroons river for the great good that he did to the country by spreading the knowledge of many useful arts and industries and educating the Duala people to a remarkable degree. From the Cameroons the mission, under the guidance of the Rev. Thomas Comber and the Rev. Holman Bentley, moved on to the Congo ${ }^{1}$, where this Baptist mission now has numerous stations. One of its missionaries, the Rev. George Grenfell, made himself famous by discovering the great Mubangi river, the most important of the Congo tributaries, and known in its upper waters as the Wele, besides making a remarkable survey of the main Congo and several of its leading tributaries, thus earning the Gold Medal of the Royal Geographical Society and a number of other distinctions. Though several times offered posts of responsibility under the Congo Government he preferred remaining a missionary till his death in 1906 . The linguistic work done by this Baptist mission was important, and included an illustration of the language of Fernando Pô by Mr John Clarke, a like service rendered to the Duala language of the Cameroons by $\mathrm{Mr}$ Saker, a valuable Congo dictionary and grammar by the Rev. Dr H. Bentley, and work of far-reaching interest and importance by the Rev. W. H. Stapleton.

Roman Catholic missions entered North Africa soon after the conquest of Algeria. Lyons, in France, became a great

1 It quitted the Cameroons altogether soon after the establishment of the German colony, the German Government having expropriated most of its establishments. 
centre of missionary activity. It is the head-quarters at the present day of a powerful French Roman Catholic Missionary Society - that of the Holy Ghost and of the Sacred Heart of Mary-which of recent years has been doing a good work in Portuguese Angola and on the coast region of the Congo, and also in Senegambia and German East Africa. In i 846 missionary enterprise in Roman Catholic Austria decided to take advantage of Muhammad Ali's conquest of the Sudan to push its way into the heart of Africa through Egypt. In 1846 these Austrian Catholic missionaries chose Cairo as their starting point, and this mission continued to work in the Egyptian Sudan until the uprising of the Mahdists. Most of the readers of this book have heard of the adventures of Father Ohrwalder and the nuns who escaped from the clutches of the Khalifa in $\mathbf{r} 896$. This mission, amongst other philological studies, illustrated the interesting Bari language of the upper White Nile, and did excellent work in countries so remote as Kordofan and Sennār. Italian priests-before the disisters which befell the colonial enterprise of Italy in 1896-worked amongst the Galas of Abyssinia. Roman Catholic missions (French) had been begun in Tigré ( $\mathrm{N}$. Abyssinia) about 1830 . In 1847 , at the request of the Prince of Shoa, Pope Pius IX sent a Roman bishop-missionary, Monsignor Massaia, to Shoa, who remained there some years, and may be said to have started Italian mission work in that field.

In 1878 the late Cardinal Lavigerie having created the Mission of the White Fathers, which was to convert the Sudan and all Congoland to Christianity, Pope Leo XIII gave them a rescript directing them to evangelize all Central Africa. They had settled in Tunis (as well as in Algeria), on the Congo, on Tanganyika, and in West Africa (Senegambia), and finally they directed their energies towards Uganda: shortly after the Church Missionary Society had established itself in that country. Cardinal Lavigerie was a type of prelate somewhat 
characteristic of the last quarter of the i gth century, given to sonorous declamation, who posed as the denunciator of slavery and the slave trade without ever making personal acquaintance with its horrors. He endeavoured to obtain in the Roman Catholic world the glory of a Livingstone without going through Livingstone's hardships. Moreover, hand in hand with his desire to spread religion amongst Arabs, Berbers and Negroes was an equally ardent desire to make them at the same time French or French-protected subjects. His strong political bias has somewhat discoloured his strenuous efforts for the evangelization of Africa, since his work is now seen to have been by no means disinterested. No doubtas foreign critics point out-British missionaries often come as precursors to British rule; but they do so unconsciously, and indeed frequently prove inconvenient champions of native independence. But the missionaries of Cardinal Lavigerie's order aimed in earlier days at advancing the political interests of France almost before they had secured the conversion of their pupils; and this somewhat detracted from their value as missionaries of Christianity. The determined hostility shown by these men to the British protectorate over Uganda provoked a terrible civil war; though since 1898 (when a section of their work was taken up by a British Roman Catholic mission) this political aspect of their work has entirely ceased and they have won hearty commendation from British, German and Belgian administrators. The White Fathers wear an Arab costume - a red feż and a long white cassock tied round the waist with a girdle. Their churches and schools were formerly built in a Moorish style of architecture. It was Cardinal Lavigerie's idea that an approximation in dress and architecture to the Arabs might induce that people to give a hearing to his propagandists.

About eighteen years ago the Jesuits decided to resume their work on the Zambezi, which had been interrupted for more than a century by native troubles and by the 
expulsion of the Jesuits from the Portuguese dominions by the orders of the Marquez de Pombal. At first the efforts of the Jesuits resulted in utter disaster. They established themselves on the upper Zambezi, in the Batoka country, near the Victoria Falls, and all those who did not die of fever were massacred by the Batoka. Then they restricted their efforts to the vicinity of the Portuguese settlements at Zumbo and Tete and at Boroma. Near the last-named place they have a most prosperous and well-conducted establishment where a good technical education is given to the negroes of the Zambezi. At the invitation of the Portuguese Government they directed their attention to Nyasaland, but their establishment there being sacked and burned by Muhammadan Yaos, they retired from work in that direction. They have subsequently established mission stations in Mashonaland, besides resuming work in Madagascar.

Roman Catholic missionaries met with but poor success in Madagascar until French influence became dominant there a few years ago. The priests who attempted repeatedly to establish themselves on the coast of Madagascar in the early days of French colonial experiments either died from fever or were killed by the natives. The Jesuits who proceeded to the Hova Plateau during the sixties of the I 9 th century, and who were maintained there by subsidies granted by the French Imperial Government, met with so little success that they almost abandoned their work. At the present time, however, being strongly supported by the government of this French colony, they are obtaining an ascendancy over the Protestants.

Protestant missionary work, chiefly conducted by the London Missionary Society, and subsequently by the Quakers and the Norwegians, began in Madagascar in 1818 . The missionaries of the London Missionary Society met with great success in converting the natives of Madagascar to an undenominational form of Protestant Christianity; but their efforts were suddenly checked by the reactionary policy of Queen Ranavalona I, 
who persecuted and killed the native Christians, and compelled the missionaries to leave the island in 1836. After various attempts - which proved futile-to come to an understanding with the old heathen queen, the Protestant missionaries returned in full force at her death, and since that time until the French annexation of the island they may be said to have converted the mass of the Hovas to Christianity, and to have established a strong Protestant native Church in friendly co-operation with the Anglicans, who, under a Bishop of Madagascar, became established in the island from 1863 onwards.

The London Missionary Society, which has done such striking work in Madagascar, and was indeed the pioneer missionary society in South Africa, was attracted to the open field of Tanganyika at the time when the Church Missionary Society, stirred up by Stanley's appeal, sent its emissaries to Uganda. The first missionaries of the London Missionary Society, crossing Tanganyika from east to west, made their first establishment on the Kavala islet on the west coast. By means of the African Lakes Company of Nyasa, they conveyed a steamer in sections to the waters of Tanganyika, a steamer which has plied successfully on the lake since it was launched in $\mathbf{1} 885$. Subsequently, however, the London Missionary Society retired from those parts of Tanganyika which were under foreign flags, and directed their attention to the south shore of the lake, which was placed under British protection by the author of this book in 1889 .

A Swiss Protestant mission was founded at Basel in $\mathbf{1} 8 \mathbf{1} 5$, and soon afterwards commenced work on the Gold Coast, a work which produced the most remarkable and beneficial results in the industrial training of thousands of Gold Coast natives, enabling them thus to earn good wages and to fulfil many of the tasks hitherto assigned to Europeans. The Basel mission is now also established in the adjoining German territories of Togoland. The Moravian Protestant Missionary 
Society was founded as far back as 1732 , and sent out the first trained Christian missionaries to South Africa. At the present day this mission has flourishing establishments in that part of the continent. The Berlin Missionary Society was founded in 1823 , the Rhenish Missionary Society in 1829 , and the North German (Bremen) Society in $18_{3} 6$. The two firstnamed German Protestant missions directed their attentions to Damaraland, and to the Hottentot country in South-West Africa; the Bremen Mission sent its agents chiefly to West Africa. Several of these societies, together with the Moravians, have established mission stations in German Nyasaland, to the north of Lake Nyasa. A Bavarian Roman Catholic mission has commenced work in the coast regions of German East Africa.

The French Evangelical Church began its important missionary work in Africa as far back as 1829 . Its agentsnoted almost universally for their single-minded earnestness and dissociation from all attempts to procure political influence-have made remarkable progress in Christianizing Basutoland and the adjoining Bechuana peoples in South Africa. Following the Bechuana race movements, they were gradually directed to the Upper Zambezi, and to the Barotse Kingdom. Here, under the distinguished leadership of M. Coillard, they have carried out a work of civilization amongst the Barotse deserving of the highest praise, though they have suffered severe losses among their agents by ill-health. Sweden, not to be behind other Protestant states, founded a missionary society in the early part of this century, which devoted itself to the still unoccupied field of Galaland, attacking this country both from the Abyssinian side and from British territory on the East Coast of Africa, whence it is easier penetrated at the present day. Though the work of this society has resulted in important additions to our philological knowledge, its efforts to propagate Christianity amongst the Galas -who were either obstinate Muhammadans or equally obstinate Pagans-have been unsuccessful. The Swiss Calvinist Church 
has sent missionaries among the Basuto in South Africa, and at a later date into Angola. The Dutch Reformed Church has done a good deal of missionary work in South Africa, and of late in Nyasaland. The American Presbyterian Church started an African missionary society in $183 \mathrm{I}$ and sent its emissaries to Liberia, where it has many adherents.

British Presbyterians have established several important missionary bodies. The earliest (among existing societies) to commence work was the United Presbyterian Church of Scotland, which established a mission at Old Calabar, on the West Coast of Africa, in 1846 , and has since made great progress in converting the natives of Old Calabar and the Cross River to Christianity and a certain degree of civilization. It is mainly owing to the work of this mission that Old Calabar has become an important centre for European enterprise, and the capital of the eastern half of Southern Nigeria. The Edinburgh and Glasgow Missionary Societies of the early part of this century, which sent out missionaries to South Africa, were dissolved, and took shape in other forms as the foreign missions of the Free Church of Scotland and the Established Church of Scotland. The former, which was organized in the fifties, established strong missions in South Africa, and there founded the educational establishment of Lovedale, whence many hundreds of South African negroes have gone out into the world with a practical education. When Livingstone had directed attention to the Zambezi, the Free Church of Scotland thought of establishing a mission there, but after the report of its commissioner decided that the time was not come for such an enterprise. But in 1875 , after Livingstone's death, the Free Kirk sent out an expedition to Nyasaland for the establishment of a mission, which now has stations all along the west coast of that lake'. The Established Church of Scotland

1 The same body also established an industrial mission (initiated by Dr James Stewart, the founder of Lovedale) in British East Africa, halfway to Uganda. 
followed suit in 1876 , when a settlement was made on the Shiré Highlands, to the south of Lake Nyasa; and the headquarters of the mission was styled "Blantyre" after the little town in Lanarkshire were Livingstone was born. Blantyre is now in many respects the principal town in the Nyasaland Protectorate. The Norwegian Church sent out missionaries to Zululand (i842) and to Madagascar in later years.

Besides the American Presbyterian mission in Liberia, other American missionaries (Baptists, Episcopal Methodists, and undenominational) settled in the Gaboon and on the coast between the Cameroons and the French colony, on the Congo, in Angola, and, above all, on the highlands of Bihé, behind Benguela. Among the agents of these American missions, remarkable for the linguistic work they have done in African languages, were the Rev. J. L. Wilson, who, together with Preston and Best, wrote on the languages of the Gaboon coast ; Dr Sims, who compiled valuable vocabularies of Congo languages; Mr Héli Chatelain, whose work in connection with the Angola language was of exceptional value; and lastly, the Rev. W. M. Stover, who ably illustrated the Bihé language.

Besides the Church Missionary Society, the Anglican Church has been represented in Africa by the well-known "Universities' Mission," founded in $185^{6}$ as the result of an appeal by Livingstone to the universities of Oxford and Cambridge. While the Church Missionary Society is mainly supported by the Evangelical side of the English Church, the Universities' Mission is the outcome of the missionary enterprise of the High Church party. Its first establishment in Nyasaland under Iivingstone was unfortunate, and resulted in the death of Bishop Mackenzie (the first missionary bishop of Central Africa) and most of the missionaries with him. His successor, Bishop Tozer, resolved to suspend work in Nyasaland, and concentrate the efforts of the mission upon Zanzibar, which thenceforward became its principal seat in Africa; but later on, when he was succeeded by Bishop Steere, 
another and a successful effort was made to reach Nyasa. From the beginning of the eighties to the present day, though at times much harassed by the Muhammadan Yaos, this mission has taken a firm hold in Nyasaland, besides establishing and maintaining a number of mission stations in German East Africa. In Nyasaland it occupies chiefly the east coast of the Lake, and has one station on the west coast, having chosen to work mainly among those populations which have been to some degree under Arab or Yao influence. To this mission is due the erection of a fine cathedral at Zanzibar; and much valuable linguistic work has been done by the late Bishop Steere, Mr Madan, and the late Bishop of Likoma (better known as Archdeacon Chauncey Maples ${ }^{1}$ ).

The Plymouth Brethren have established a mission in South-Central Africa, across the Zambezi-Congo water-parting.

The Scotch Baptists began a mission to S.W. Nyasaland and also on the Zambezi in 1895. There, also, is the Zambezi Industrial Mission (undenominational), which was founded in 1893, and endeavours to be self-supporting by its industrial work. A few American missionaries, mostly under Bishop Hartzell of the American Episcopal Church, have attempted settlement in the Portuguese possessions on the West and the South-east coasts of Africa ; and there are also unattached American missionaries in the Congo basin carrying on work on their own account, without being connected with any special society: Finally, Plymouth Brethren and other English Protestants of different denominations organized a Protestant missionary enterprise in North Africa as the "North African Mission," established in 1886. This mission has numerous representatives in Morocco, Algeria, Tunis, Tripoli, and Egypt. As it devotes itself mainly to the conversion of Muhammadans, it has had but slight success at present from the propagandist's point of view, but it has

1 Who worked for many years in Nyasaland and in East Africa, and was drowned in Láke Nyasa in 1895 . 
achieved more than any other a preparation of the Moslem mind for the consideration of Christian ethics, and its educational work of late has been warmly appreciated by the French authorities. This mission has numerous women members who visit the harims for educational and for medical purposes. Its agents have been remarkable for their thorough acquaintance with Arabic and even with the Berber dialects of Morocco and Algeria.

The only Christian state which existed in Africa before the beginning of European colonization was Abyssinia, which is to some degree dependent on the Coptic Church in Egypt, and is in communion with the Greek Church. Christianity is said to have been introduced here in the 4 th century. The Abyssinians have usually resented the arrival of Roman Catholic missionaries, and have not shown much greater encouragement to emissaries from Protestant Churches. Abyssinian Christianity is, as might be imagined, so degraded and mixed up with fetishism that it is difficult to recognise it as a branch of the Christian faith which is the religion of so much of Europe and America. Russia in the latter part of the Igth century was much concerned at the spiritual darkness prevailing in Abyssinia, and endeavoured to send thither missionaries from the Greek Church, the domain of which she identifies with her own empire. But these have been propagandists of a singularly military type-wolves in sheep's clothing, if one may commit oneself to rather a strong metaphor-and hardly to be classed with the unarmed emissaries of Christianity, who, on behalf of the Roman Catholic and Protestant Churches of Europe and America, have striven usually with single-minded motives, almost always with deep personal unselfishness, ever with zeal, sometimes with indiscretion, and not unfrequently with bitter disappointments and cruel sufferings to evangelize Africa. The ultimate effect of their work on the history of Africa will prove to be far-reaching, important, and (I believe) highly beneficial. 


\section{CHAPTER XI}

\section{THE BRITISH IN AFRICA, II}

\section{(South and South-Central.)}

Towards the close of the 18 th century Great Britain cast longing eyes at the Cape of Good Hope, as a victualling station for her ships on the way to India which could not remain much longer in the weak grasp of a Dutch company and must not fall into the hands of France. In I795 the British Government despatched a strong expedition with the authority of the Prince of Orange and took possession of Cape Town, after a brief struggle with the local authorities. Free trade, with some preference for British goods, at once took the place of the grinding monopoly and vexatious restrictions of the old Dutch company; and various other liberal measures were enacted, which would have done much to reconcile the Dutch colonists to British rule were it not that, when England at the Peace of Amiens in 1803 restored the Cape of Good Hope to the Dutch Republic, there followed three years of direct Dutch rule under two most enlightened men, De Mist and Janssens, who did much to efface from the settlers' remembrance the justly hated selfishness of the old Dutch East India Company. Therefore, when Great Britain resumed, in a manner intended to be permanent, the administration of Cape Colony in 1805 , a still more decided opposition was shown to her forces than before; and even after the cession of this colony by Holland in 1814 there remained among the Dutch settlers a certain 
lukewarmness, and a disposition to find fault with the actions and motives of the Colonial Government and of the British people. In $\mathbf{1} 806$, when Cape Colony passed definitely under British control, it had an area of about 125,000 square miles ${ }^{1}$. The boundary on the East was the Great Fish river, and thence a curving line which ended at Plettenberg's Beacon, about fifty miles south of the Orange river. The boundary on the north was an irregular line from Plettenberg's Beacon (dipping far south in the middle) to the mouth of the Buffalo river (Little Namakwaland) on the Atlantic Ocean. The population of the colony (not counting the military forces) was about 26,000 Europeans (of whom 6,000 lived in Cape Town), about 30,000 Malay and negro slaves, some hundred thousand Hottentots and half-breeds, perhaps another hundred thousand Kafirs and a few thousand Bushmen. The industries and pursuits of the European settlers were limited to vine-growing, the raising of grain, and the care of large herds of cattle and sheep. The cattle were mostly the long-horned native cattle of the Hottentots, and the sheep the hairy, fat-tailed, domestic sheep of Africa. Ostrich farming was unknown, and although the Dutch commissioners, De Mist and Janssens, had begun to introduce merino sheep just before the expiration of their administration, wool had not yet figured amongst the exports.

The first beneficial effect of British rule was felt in the stemming of the tide of Kafir invasion. This race of Bantu negroes had during the previous century been pressing closer and closer on the extremity of South Africa from the northeast. The earliest branch of the Bantu to reach South Africa were the Herero, who invaded what is now known as Damaraland. But the desert and the Hottentots kept them from either reaching the Atlantic coast or penetrating any further south. Then came the Bechuana, who barely crossed the

1 As against an area for all British South Africa up to the Congo boundary of $1,152,619$ square miles in 1912 ; all of which has grown from the Cape Colony of 125,000 square miles annexed in 1806 . 
Orange river; and then, overriding these latter, latest of all in the field, the Zulu-Kafirs, who attempted to enter Cape Colony from the coast region bordering on the Indian Ocean. The first British-Kafir war took place in $181 \mathrm{I}-\mathrm{I}_{2}$, and ended in the Kafirs being driven eastward of the Sunday River, and further led to their expulsion from the Zuurveld (the modern district of Albany), to the west of the Great Fish river, which was then fixed as the Kafir boundary. In 1817 Lord Charles Somerset, the Governor of the Cape, visited the Zuurveld, and decided that the best obstacle in the way of repeated Kafir invasions would be to settle that district with a stout race of colonists. He therefore obtained a grant from the British Government of $£ 5,000$ to promote emigration to the Cape; and in 1820-21, 5,000 British emigrants landed in South Africa, 4,000 of whom were settled in the eastern districts, principally in the county of Albany. This settlement was at first a failure. Few if any of the settlers were skilled agriculturists; they were without any experience of life in a semi-tropical country; the cost of land transport pressed heavily on them; and the grants of land made to each individual were too small. The first few years Nature played her usual tricks; for Nature seems to hate the movement of species and the upsetting of her arrangements. Therefore she sent blight during three years, then floods for another season. The settlers fell into great distress, but in time things righted themselves. Some immigrants moved to the towns of the colony and obtained high wages as artisans; and others who held on to the Zuurveld at last attained prosperity by extending the area of land they occupied, and going in for sheep and cattle runs in preference to corn-growing. The Kafirs however had poured over the frontier in hordes under the leadership of Makana in 1817-18. They raided the Boer flocks and herds and attacked Grahamstown; and the second Kafir war which ensued ended in these warlike negroes being driven back to the east of the Chumi or Keiskamma river. 


\section{XI] British Colonization of Cape Colony 257}

The immigrants of 1820 and $182 \mathrm{I}$ created for the first time a strong British element in the population of Cape Colony. They were principally English in origin, but also included Scotch, Irish, and Welsh, though the Irish immigrants, who had settled in the western part of Cape Colony, did not prosper. Gradually, owing to the distribution of the new settlers, the eastern part of Cape Colony became English in race and language, as compared to the western and central parts, which remained principally Dutch. The Xंosa ${ }^{1}$ Kafir boundary having been shifted to the Keiskamma, the frontier district between that stream and the Great Fish river was at first regarded as a neutral land to be possessed by neither Kafir nor white man. Gradually, however, this system became impossible, and at last, in 1831 , the Colonial Office gave its assent to grants of land being made in the ceded territory to respectable settlers. Unfortunately in this despatch a distinction was drawn between Englishmen and Hottentots on the one hand and the Dutch Boers on the other, and the latter were not permitted to obtain land in the new frontier district. This tactless and unjustified announcement, together with the attacks made on the Boers by the British missionaries, and the knowledge that the abolition of slavery was near at hand, made many of the Dutch settlers profoundly dissatisfied with the British Government and anxious to move beyond its control.

An unhappy incident had occurred sixteen years previously which left bitter memories behind. The British Governor had enrolled about I8I a regiment of Hottentot soldiers under British officers. The Hottentots had many grievances to avenge, dating from the former rule of the Dutchmen; and these soldiers comported themselves with arrogance towards their former masters. Most unwisely they were used as policemen and sent now and again to arrest Dutch settlers

1 Xosa is pronounced with a preliminary click of the tongue like a cluck to encourage horses. 
who had broken the law. From one such incident arose in I8I5 the riot over the arrest and death of the Bezuidenhout brothers in northern Albany, and the hanging at "Slagter's Nek" of five of the rioters-an excessively severe punishment for which some writers have condemned Lord Charles Somerset as the originator of a race quarrel which lasted nearly a hundred years.

Till 1825 the Cape had been governed despotically by the Governor, but in that year an executive council of six members, all Government officials, was appointed to advise the Governor in his legislation. In 1828 two colonists were introduced into this council in place of two official members. But in 1833 the Cape received a regular constitution as a Crown colony with a legislative council in which the unofficial element was fairly represented. In 1827 the English language had been substituted for Dutch in courts of law (an additional cause of dissatisfaction to the Boers); but the administration of justice in that year was greatly improved by the appointment of a supreme court with judges appointed directly by the Crown, while the lower courts were entirely remodelled, and civil commissioners and resident magistrates were appointed. In I 822 the number of Europeans settled in South Africa was about 60,000 . In 1828 , owing to the growing importance of the Albany settlement, Cape Colony was divided into two provinces, the western and the eastern; and the latter was for a time governed with some degree of independence. By 1824 Cape Colony had taken what is now the southern limit of the Orange Free State as its northern boundary.

At this time there was a slave population in British South Africa of about 60,000 , of whom less than half were Hottentots (who were rather serfs than slaves), and the remainder Malays introduced by the Dutch, and black negroes brought from Moçambique and from Angola. The British Government having abolished the slave trade in 1807 , the further importation of slaves ceased; but there came into the colony a 
certain number of free negroes, who were rescued from the slave ships by cruisers, and landed in South Africa. In I 833 slavery was abolished. It was however enacted that, although the emancipation should come into effect on December ist, I $834^{1}$, complete freedom should not be given to the slaves till December Ist, 1838 ; further, that the Imperial Government should pay compensation to the extent of $1 \frac{1}{4}$ million pounds, As this compensation was saddled with various deductions and drawbacks, the slave-owners-chiefly Dutchmen-did not get fair value for their slaves, and therefore had further cause for grumbling.

At the end of 1834 , shortly after one of the most distinguished of South African Governors, Sir Benjamin d'Urban, had arrived to take up his appointment, I 2,000 armed Kafirs crossed the eastern border into the colony with a determined resolve to oust the Europeans, from the newly settled districts. For nearly a fortnight the Xosa clans under Makoma and Chali had it all their own way from Somerset East to Algoa Bay, killing many of the white men, burning their houses, destroying or carrying off their property, and turning a beautiful province into a desert. This raid was absolutely unprovoked, except in so far that for years the Kafirs had been nursing a grievance on account of their expulsion from the country west of the Keiskamma, which they themselves had not long before taken from the Hottentots. Prompt measures (the third Kafir war) were taken to repel this invasion and punish the X́osa tribe. Colonel Smithafterwards Governor Sir Harry Smith-mustered what forces were available, and drove the Xंosa Kafirs beyond the Keiskamma. Early in 1835 the British forces had reached the Kei river on a counter invasion of Kafirland. Sir Benjamin D'Urban dealt mercifully with the conquered Kafirs; very few even of the enemy were dispossessed of their homes,

1 The Negro and Malay slaves then numbered in all about 39,000. 
while those natives who had remained friendly were rewarded by grants of land. Beyond the Kei river Kareli the son and heir of Hintsa, chief of the Galeka clan (who had been killed while attempting to escape from imprisonment), was recognized as ruler over a section of the X́osas; while in the new province, afterwards to be known as British Kaffraria, British residents were placed with the Kafir chiefs to advise them, and missionaries were encouraged to return to their work. Yet this settlement (statesmanlike and far-sighted in its details-which there is not space to give-as in its general outlines) was upset, and the prosperity of South Africa seriously damaged by the Secretary of War and the Colonies, Lord Glenelg ${ }^{1}$; a sentimental doctrinaire, who had evolved from his inner consciousness an unreal South Africa in which Kafir raiders of oxen were noble-minded black kings, whom a harsh pro-consul was dispossessing from their ancestral territories. He not only upset all that was new in Sir Benjamin D'Urban's arrangement, but even compelled the retrocession to the Kafirs of land which had long been occupied by white settlers, and further damaged the authority of the popular Governor of the Cape by erecting the eastern province into a separate governorship, over which he placed a Boer named Andries Stockenstrom. The immediate result of this reversal of Sir Benjamin D'Urban's policy was ten years of intermittent war with the Kafirs (who took generosity of treatment for weakness), and grave dissatisfaction among those colonists of Dutch origin who had suffered from the Kafir raids. In fact, Lord Glenelg's blunder proved the last straw that broke the back of

1 He was at that time Sir Charles Grant, and a member of the great Reform ministry. His action in the matter was prompted by a mischievous personality, a Dr Philip, representative of a missionary society in South Africa, who conceived a great and unjust hatred of the Boers, and an affection for the negro invaders of Cape Colony, which was exaggerated and unreasonable. Much may be learnt of his attitude towards public questions in my Life of Livingstone (189r). 
Dutch tolerance of British rule ; and in 1836 a number of the Dutch colonists (who had come to be known as the "Boers," or farmers) trekked away from the limits of Cape Colony across the Orange river and the Vaal river, and south-eastwards into Natal. So far back as 1815 the Dutch farmers, as already related, had risen against the government of Lord Charles Somerset because it interfered with their summary treatment of the natives, and their rising had ended in the hanging of five of the rioters at Slagter's Nek; but in modern historical works dealing with Cape Colony it is reiterated that the main cause of the shaking-off of British citizenship by so many Boer farmers was not the resentment over the Slagter's Nek execution so much as Lord Glenelg's reversal of D'Urban's frontier settlement. The adventures of these Boers after leaving British territory I have dealt with in the chapter on Dutch Africa.

In 1823 a small enterprise under the leadership of Farewell and King, officers in the Royal Navy, started from Cape Town to explore the coast of Natal. They landed at Port Natal (now Durban), visited the Zulu king Chaka, and obtained from him in 1824 a grant of the port of Natal with 100 square miles of territory inland, and a coast-line of 35 miles. Other territories in what is now the modern colony of Natal were also obtained later on from the Zulu chief. The purchasers of these lands proclaimed them to be British territory. Although these adventurers were occasionally driven away by the violent wars and disturbances going on amongst the Zulus and Kafirs, they held on to their possessions; and in June $1834 \mathrm{Sir}$ Benjamin D'Urban forwarded to the Colonial Office a petition from Cape Colony for the establishment of a definite government in Natal. This petition the fatuous Lord Glenelg declined on the score of expense. In I 835 the white element in Natal was increased by missionaries from America, and by Captain Allen Gardiner, a pioneer of missionary enterprise on behalf of the Church of England. These settlers drew up the 
plans of a regular township, built a church, christened their territory Victoria (in honour of the heir to the British throne), and proposed to call the town they were laying out Durban, after the energetic Governor of Cape Colony. In 1835 they petitioned that their territory might be made a colony, but again the Imperial Government refused, then, as for many years afterwards, preferring to postpone action until it was costly and fraught with bloodshed. The Dutch immigrants were allowed to form a republic in the interior of Natal. In July 1838 General Napier, acting no doubt on instructions from home, invited the British settlers in Natal to return to Cape Colony; but a few months afterwards he sent a small detachment of troops to keep order at the port, and again pressed the Home Government to declare Natal a British colony, though the following year the soldiers were withdrawn. This was taken by the Boers to be a tacit consent to the establishment of a vassal republic under British suzerainty. They would probably have had their way but for imprudent dealings on their part with natives placed under British protection. At the same time, a feeling began to grow that the United States of America were going to have political dealings with the territory of Natal (as another "Liberia"); while a vessel had come out from Holland, sent, it is true, by private persons, but seeming to convey a promise of Dutch alliance to the Burghers of Natal. British troops had again occupied Durban. In 1842 they were attacked by the Boers, who were eventually repulsed, and afterwards tendered their submission to the Queen's authority. At length, in I843, a Conservative ministry being in power, it was intimated that the settlers on the coast of Natal might be taken under British protection, with the eventual object of constituting Natal a self-governing colony, in which the Boers were to have a share proportionate to their numbers. After much negotiation, Natal became a British colony with a legislative council in 1843 . The fighting Boers left the country and retired beyond the Orange river 
under a somewhat indefinite assurance that British rule would not follow them. The king of the Zulus received a recognition of his independence, and in return recognized the Tugela as the boundary of the British colony on the north-east. To the south, the territory of Natal was somewhat restricted, and the portion cut off from it became known as Pondoland, which remained an independent $\mathrm{Kafir}$ state till $\mathrm{x} 884$; it was finally annexed to Cape Colony in 1894 . In 1847 the mistake of Lord Glenelg was to some extent repaired under Governor Sir Harry Smith; and the eastern boundary of Cape Colony was once more advanced to the Kei river. This step was taken after a very serious Kafir war (the fourth, or "War of the Axe") which broke out in 1846 . In 1850 , however, a war began again (the fifth, or "Sandile" war) with the restless X'osa Kafirs. It extended far and wide, and was marked by not a few disasters; one being the loss at sea off Simon's Bay of the troopship Birkenhead, which foundered with large reinforcements of troops on board, 400 soldiers and seamen being drowned. At length, in $\mathrm{r} 853$, General Cathcart, who had succeeded Sir Harry Smith, captured all the strongholds of the Kafirs in the Amatola Mountains, and deported the Kafirs from that district, which subsequently became (from its settlement by Hottentot half-breeds) Grikwaland East ${ }^{1}$. In this native uprising the Kafirs had been joined by over a thousand pure-blood Hottentots, dissatisfied with British treatment and wanting to create a "Hottentot republic."

In 1852 the Sand River Convention was concluded, by which the independence of the Transvaal Boers was recognized; but the Orange River Sovereignty still remained under British control, and its difficulties with the Basuto compelled an intervention of the British forces. The invasion of mountainous Basutoland began with a drawn battle in which the

1 "Grikwa" was the cant name (Gri-kwa) given to the half-castes between Boers and Hottentots. 
Basuto held their own. They afterwards secured favourable terms of peace by sending in their submission. This incident discouraged the British Government, who decided to abandon the Orange River Sovereignty rather than be under any responsibility for its defence. Accordingly, independence was forced on the settlers, many of whom were Englishmen. Basutoland, after having frequently engaged in wars with the Orange Free State, and having to cede a portion of its territory to them, was finally taken under British protection in 1868 . In $187 \mathrm{I}$ it was annexed to the Cape, but, owing to the turbulence of its people and the mismanagement of the Colonial Government, it was transferred to direct Imperial administration in 1883 .

During several years prior to 1849 the Imperial Government had been endeavouring to arrange for the despatch of British convicts to South Africa, as it was becoming inconvenient to maintain the penal establishments in Australia. Whenever the question came up the Cape Colonists protested against the idea. Nevertheless, in September 1849, a ship brought over from Bermuda a number of ticket-of-leave men to be landed at the Cape. The ship anchored in Simon's Bay, but the colonists took strong measures to prevent the landing of the convicts. All were united to this end. The Governor met the dangerous situation with great wisdom. He kept the convicts on board ship until the order could be reconsidered in England. The Home Government, for a wonder, did not push the point to the raising of rebellion; the convicts were sent on to Van Diemen's Land, while an Order-in-Council authorizing transportation to the Cape was revoked. By $185^{\circ}$ the prosperity of Cape Colony had become established. Its population, white and coloured, at that time reached a total of 220,000 . The revenue at the same period stood at about $£ 220,000$ per annum, while the value of the colonial produce exported during that year was approximately $£ 800,000$. Wine was no longer the principal export, and even the export 
of grain had diminished; wool had taken the first place. In I $85^{\circ}$ it represented 53 per cent. of the total exports. Hair from Angora goats, which had been introduced during the thirties, was beginning to take an important place in the list of exported products; and ostrich feathers (chiefly derived from the wild bird, however) were also an important item. Ostrich farming, which has now placed the ostrich-happily-on the list of inextinguishable domestic birds, did not come into vogue till the sixties, though the emigrant Boers at a much earlier date had been accustomed to hatch and rear young ostriches about their farms.

On the 23rd of May, I 850, the Government and Council of Cape Colony were authorized to prepare for the establishment of a representative government; and three years later this was established, a Colonial legislature being formed; but the ministry was to be responsible only to the Governor. Responsible government, similar in many respects to that which obtains in the daughter nations of Canada and Australasia,was brought into force in 1872 .

In 1854 the great Sir George Grey became Governor of the Cape. He, even more than his predecessors, was anxious to build up against Kafir invasion on the East a wall of military colonists, who should be able to defend their flocks from raids without continually calling on the Colonial Government for intervention. After the Crimean War a means presented itself in the disbanding of the Foreign Legion, which Great Britain had recruited, and which consisted of German, Swiss, and Italian soldiers. After the conclusion of peace it was necessary to disband this force, and they were invited to volunteer for African colonization. The result was that 2300 Germans accepted the terms offered, and started for South Africa. They were settled in the Eastern Province. But trouble then began to arise from their being unmarried men, and Sir George Grey sought to remedy the defect by importing a large number of German women. The Imperial 
Government, however, thought that this would not be a politic step to take, to create a little Germany in British Africa. Finally the Cape Government sent on rooo of the German bachelors to India, and the 1300 who remained behind found wives in the colony, and merged their own nationality in that of British subjects. Nevertheless, the introduction of these German settlers led to the going out of many emigrants from Germany for some years afterwards, and these settled in such numbers in independent Kaffraria that there seemed a danger at one time of their invoking German intervention.

In 1856 a terrible delusion took hold on the X́osa Kafirs. They had endured a good deal of misery from the destruction of much of their cattle by an epidemic of rinderpest, and were in a mood to be influenced by the wild sayings of their witch doctors. One of these wizards, Umhlakazi, who had received a smattering of education at a mission school, arose and proclaimed a strange gospel. He announced that the dead and gone Kafir chiefs would return to earth with their followers, and bring with them a new race of cattle exempt from disease, and that following on this resurrection would come the triumph of the black man over the white. The prophet had heard of the Crimean War, and announced that the dead Kafir chiefs would bring with them many Russian soldiers and attack the British. But one thing was necessary to secure this millennium-the existing cattle and crops must be destroyed. A portion of the Kafir tribes believed this rubbish. Some of the chiefs even who knew better, and who smiled at the imposture, encouraged it, thinking that after taking these desperate measures their men would stick at nothing, and would really break down the British power. Therefore, most of the X'osa Kafirs of the Galeka and Gaika clans, set to work to slaughter their oxen and cut down their corn; and all looked forward eagerly to the dawning of February 18, I857, on which date the resurrection was to take place. Nothing happened, however; and the consequences of this hateful 
imposture were terrible. It is stated that 25,000 Kafirs died of starvation, and nearly I00,000 others left British Kaffraria and the territories beyond the Kei to seek another home. Some 40,000 of these Kafirs settled in Cape Colony, being taken into service there through the intervention of the Government; and from them, mixed with Hottentots and emancipated slaves, are descended the "Cape Boys," who have since attracted attention by their value as soldiers in suppressing the Matebele revolt. Sir George Grey in I858 was obliged to send a military force (the sixth Kafir war) against some of the Kafir tribes rendered desperate by destitution, and they were driven for a time into Pondoland; British Kaffraria being annexed to Cape Colony, and the Transkei being taken under British protection. This Transkei territory was subsequently repeopled, partly with Fingo ${ }^{1}$ Kafirs, and partly by the descendants of the Kafir tribes who were ruined by the teaching of the false prophets. In 1877 the Galeka, a clan of the X'osa tribe, commenced fighting the Fingos. They were joined later by the Gaika, another X́osa people, who had long been dwelling peaceably in the Eastern province, and during 1877 and 1878 the seventh and last Kafir war raged, ending inevitably in conquest and submission.

The British had taken from the Dutch in $165^{\mathrm{I}}$ the little island of St Helena ${ }^{2}$ (in the Atlantic Ocean), the Dutch having previously occupied it in 1645 . This island became of some value as a place of call for ships passing to and from India round the Cape. In I $\mathrm{I}_{5}$ it was selected as the

1 The Fingo-properly Amamfengu-Kafirs, were mostly fugitives into Cape Colony from Natal, sent flying westward from the Zulu slaughterraids of Chaka and others.

${ }^{2}$ Discovered by the Portuguese in $\mathrm{I}_{502}$, its existence was kept secret by them until ${ }_{15} 88$, when Captain Cavendish returning from a cruise round the world suddenly lighted on it. The Dutch twice seized it and held it each time for a few months in $166_{5}$ and $16_{73}$. In this last year it was definitely allotted to the East India Company. 
place of banishment for the deposed Napoleon Bonaparte; and to make security doubly sure, the islands of Ascension, to the north, and Tristan d'Acunha, to the extreme south ${ }^{1}$, were occupied also about the same time, and have remained British ever since. Whereas Ascension has always been managed directly by the British Admiralty, St Helena was from 1673 until 18 I 5 , and from I 82 I to 1834 , governed by the East India Company. In 1834 it became a Crown Colony. Tristan d'Acunha was occupied by a British garrison from 18I5 to I821, of which three men remained behind voluntarily and with some shipwrecked sailors started the existing colony, which is a self-governing community.

St Helena was profoundly affected by the opening of the Suez Canal in 1869 . She lost nearly all the shipping which formerly sought her harbour, and three-quarters of her trade; but she is now beginning to recover prosperity to some degree as a valuable health resort, especially for the ships of the West African Squadron, and as a possible coaling station in time of war.

Cape Colony might also have suffered from the opening of the Suez Canal but that she was already beginning to build up an importance of her own, due to her exports of wool, hides, wine, and ostrich feathers. Moreover a happy discovery intervened which effectually guarded against any waning of interest in South Africa. In I867 the first diamond was discovered near the Orange river, but it was not until $\mathbf{r} 870$ that a large find of these precious stones was made near the site of modern Kimberley. This discovery of diamonds to the north of the Orange river, and in country of doubtful ownership, but claimed by the Orange Free State, drove the now awakened British Government to rather sharp practice. The diamond-

1 The largest of a little group of islets in the South Atlantic, about I 260 miles west of the Cape of Good Hope. Tristan D'Acunha has an area of about 45 square miles, and is extremely mountainous, rising to $826_{4}$ feet. 
bearing land was claimed by a Grikwa (Hottentot half-caste) chief named Waterboer. On the other hand, the Orange Free State asserted that it had acquired the greater part of the country from the original Grikwa owners; and the northern part of Diamondland was claimed by the Transvaal. This last claim was submitted to the arbitration of the Lieutenant-Governor of Natal, who awarded most of the diamond country to the Grikwa and Bechuana chiefs. These latter had really become the men of straw hiding the hand of the British Government. Finally, in $187 \mathrm{I}$ Waterboer and other Grikwa chiefs ceded their rights to the British Government, who promptly erected the diamond country into a province under the name of Grikwaland West. The Orange Free State protested, and no doubt the action of the British Government was rather high-handed, and in rare contrast to the abnegatory policy usually pursued. Finally, the claims of the Orange Free State were settled by Lord Carnarvon, who in 1876 awarded to its government the sum of $£ 90,000$ in consideration of the abandonment of their contention.

In 1845 Natal had been annexed to Cape Colony, but later on in the same year it was given a separate administration, consisting of a Lieutenant-Governor and an executive Council; though in legal matters it still remained dependent on Cape Town. In I 848 a local Legislative Council was created, and finally in $185^{6}$ the colony was entirely severed from the Cape, and was endowed with a partially representative government. Some years previously the Governor of Cape Colony had been also created H.M. High Commissioner in South Africa, so that he might have power to represent the British Government outside the limits of Cape Colony. In this capacity therefore he continued to retain some authority over the government of Natal and its relations with the adjoining states. (The influence of the High Commissioner now extends over all South and Central Africa under the British flag, except, at present, the Protectorate of Nyasaland; in other words, over 
Rhodesia, the South African Union, Bechuanaland, Basutoland, and Swaziland.) The territory of Natal was not capable for some time of any great extension, being girt about with Boer states and negro tribes whose independence was to some extent guaranteed by the Imperial Government. But in $\mathrm{r} 866$ it received back a small territory on the south (the county of Alfred), which was within the original limits claimed by the founders of Natal, but had been for a time handed over to a Pondo chief. The settled government of Natal and the kindly attitude of the British Colonial Government brought about the repeopling of that fertile country by Kafir tribes.

This "Garden of South Africa" had been almost depopulated by the Zulu kings, who had slaughtered something like $\mathrm{r}, 000,000$ natives from first to last. Before the rise of the Zulu tribe, Natal or "Embo" " had been a thickly populated country. Under white rule the native immigration and population increased so rapidly that when the colony was only nine years old it contained II 3,000 Kafirs. The white colonists were of mixed origin, about one-third being the original Dutch settlers, while the remainder were either emigrants from Great Britain, Cape Colonials, or Germans. The German families mainly came from Bremen. At first the principal article of export was ivory, obtained from Zululand, where elephants still rioted in great numbers; but this was not to last long, for what with British sportsmen and Dutch hunters and the introduction of firearms amongst the natives, big game was rapidly exterminated. Then, during the fifties, the sugar cane and the cotton plant were introduced ${ }^{2}$, the export of sugar rising in I 872 to an annual value of $£_{154,000}$. These semi-tropical plantations brought about a fresh want-that of patient, cheap,

1 Or "Land of the Abambo," the name of one of the original Bantu tribes of the country. The root $-m b o$ is very common as a tribal name among the Bantu, and occurs repeatedly in Central Africa.

2 To which were added in later years tea (a great success) and coffeethe latter subsequently destroyed by the Ceylon coffee disease. 
agricultural labourers. Unhappily, the black man, though so strong in body and so unaspiring in ideals, has as a rule a strong objection to continuous agricultural labour. His own needs are amply supplied by a few weeks' tillage scattered throughout the year; and even this is generally performed by the women of the tribe, the men being free to fight, hunt, fish, tend cattle, and loaf. Therefore, the roo, o०o odd black men of Natal ${ }^{1}$, though they made useful domestic servants and police, were of but little use in the plantations. As sugar cultivation was introduced from Mauritius, so with this introduction came naturally the idea of employing Indian kulis, already taking the place in the Mascarene Islands which was formerly occupied by negro slaves. In $\mathbf{I} 860$ the first indentured kulis reached Natal from India, and by the end of 1875 I 2,000 natives of British India were established in Natal. A number of these had passed out of their indentures, and had become free settlers and petty traders. Nowadays the Indian population of Natal has risen to something like 142,000 . From Natal these British Indians have crept into the Transvaal, into the Orange Free State, and even into Bechuanaland and Rhodesia. Many of them are employed on the Natal railways, and in the towns they form a thriving class of petty traders. Here and there they have mingled with the Kafirs, producing a rather finelooking hybrid, similar in appearance to the black Portuguese on the Zambezi, who are descended from a cross between natives of Goa, in Portuguese India, and Zambezi Negroes. Added to the ordinary Kuli class are traders who belong partly to Tamul and other Dravidian races of South India and partly to coast tribes from Western India, mostly professing the Khoja faith. The Khojas are in a far-off way Muhammadans. The inhabitants of Natal have with great inaccuracy taken to calling these West Coast Indians "Arabs."

This Indian element--already about 150,000 in numberis likely to have its effect on the history of Natal. It is

1 Nov, 191 2, nearly I, 000, 000. 
strongly unpopular amongst the white colonists for selfish reasons. On the whole, it is not unpopular among the blacks, but the idea of an eventual fusion between Negro and Indian is not an agreeable one to contemplate from the colonist's point of view, as it would create a race strong both mentally and physically, far outnumbering the whites, and likely to make a dangerous struggle for supremacy. On the other hand, from the Imperial point of view,-from what may be called the policy of the Black, White, and Yellow-it seems unjust that the King-Emperor's Indian subjects should not be allowed to circulate as freely as those of his lieges who can claim European descent. Perhaps on the whole the solution which has been initiated in the British protectorates north of the Zambezi is the best-namely, that Indian immigration should be drawn rather to those countries which are administered on the same lines as India, than to the temperate regions south of the Zambezi, where the white man might be allowed to expand without let or hindrance.

The first railway worked in South Africa is said to have been a line connecting the town of Durban with the landingplace of its harbour, which was opened in 1860 . But soon afterwards a railway began to start northwards from Cape Town to Paarl; and this was directed, with many zigzags and with a seeming aimlessness, towards the Karoo. The discovery of the diamond fields gave railway extension an objective, and Kimberley became the goal which was finally reached in $1885^{1}$. In 1872 the Cape Government by Act of Parliament took over the existing railways in Cape Colony, which then only consisted of a total length of 64 miles. Soon afterwards an expenditure on railway extension of $£ 5,000,000$ was authorized. In Natal a Government railway was commenced in 1876 connecting Durban with the capital, Pietermaritzburg. This line now

1 Twelve years later the northern railway line had traversed British Bechuanaland and had reached Buluwayo. It attained the Zambezi in 1903 , and now enters the Belgian Congo in Katanga. 
traverses the Colony to the Transvaal border and in another direction enters the Orange Free State.

The history of Natal has been comparatively peaceful and prosperous, as compared with the weary Kafir warfare of the Eastern Province of Cape Colony. But in $\mathrm{x} 873$ the natives of Natal required a lesson. On its north-western frontier the Hlubi refugees from Zululand had been allowed to establish themselves under a chief of great importance, Langalibalele. His young men had gone to work in the Diamond fields of Kimberley, and had returned with guns, the introduction of which into the colony without registration was prohibited. Langalibalele, taking no notice of a summons to answer for this breach of the law, fled into Basutoland. Fortunately the Basuto gave him no support, and he was eventually captured and exiled for a time to Cape Colony. But this outbreak called attention to the great increase of the native population of Natal, and the unwisdom of allowing it any longer to remain under the government of irresponsible Kafir chiefs. Accordingly in 1875 Sir Garnet, afterwards Viscount, Wolseley was sent to Natal to report on the native question, and initiated changes which had the effect of bringing the natives more completely under the control of the Executive, and approximating them more towards the position of citizens of the colony.

All this time diamonds had been attracting many emigrants to South Africa, chiefly from Great Britain, but also from France and Germany. Among these emigrants were numerous Jews $^{1}$ belonging to all three nationalities, who were naturally

1 The Jews, as we have seen, played a considerable part in the development of North Africa since the Ist century of the Christian era. They have similarly had much to do with the progress of South Africa. Between I 840 and I 860 important Jewish houses of business were established in Cape Town and Port Elizabeth. Noteworthy amongst these firms was that of the De Pass brothers. The De Pass family specially concerned itself with the acquisition and development of the guano islets off what is now the coast of German South-West Africa. They developed the copper mining industry of Port Nolloth, were the first to 
attracted to the diamond trade. The growing interest taken in South Africa owing to the discovery of diamonds had not only tended to make the British Government very particular as to the exact rights it possessed in the vicinity of the Dutch republics, but also led it to revive its claims to the south shore of Delagoa Bay. The Portuguese Government, foreseeing this, had commenced to reassert its right to that harbour in its boundary treaty with the Transvaal in 1869 . In $1870-7 \mathbf{I}$ the British Government raised its claim in the manner I have already described in the chapter on Portuguese Africa. In I 872 Great Britain agreed to submit the question at issue to the arbitration of Marshal MacMahon, whose award, delivered in $\mathbf{1 8 7 5}$, was wholly in favour of the Portuguese. But Great Britain had already secured from Portugal a promise, confirmed by a more recent convention, that she should be allowed the right of pre-emption over Delagoa Bay ${ }^{1}$. During the fifties and sixties missionaries and traders had pushed due north across the Orange river, through Bechuanaland, to the Zambezi, and westward to Lake Ngami and Damaraland. In the sixties a good deal of trade was done in the last-mentioned country in ostrich feathers and ivory; and the Damara, who should more properly be known as the Ova-herero ${ }^{2}$, came under

manufacture ice in South Africa, and started the sugar planting in Natal. The firm of Mosenthal, of the Eastern province of Cape Colony, did much to promote agriculture and stock-rearing, the introduction of the Angora Mohair goat, ostrich farming, sheep and cattle breeding. Other South African Jews who have taken a prominent part in science, in the legal profession, in political, philanthropic, industrial, and mining affairs have been the Hon. Simeon Jacobs (a Judge of the Supreme Court), the Mendelssohns, Rapaports, Rabinowitzes, Solomons, Lilienfelds, Kisches, Neumanns, Moselys; Alfred Beit, Sir David Harris, Sir Lionel Phillips, and Sir George Albu.

1 To which was added later, over all Portuguese Africa south of the Zambezi.

2 Damara is the Hottentot name applied to these black Bantu negroes, who call themselves Ova-herero, Ova-mbo, etc. 
European influence. Wars arising between the Damara and the Hottentot Namakwa, and the complaints of the German missionaries at work in these countries, brought about the despatch of a commissioner ( $\mathrm{Mr}$ W. C. Palgrave) to Damaraland by the Cape Government. He reported in 1876 in favour of extending British protection over Damaraland; but all that Downing Street would concede was the annexation of Walfish Bay. (Twelve little islets off the S.W. coast had been annexed in $\mathrm{r} 867$, because they were leased to a guano-collecting company.) A little later another commissioner was despatched from the Cape to settle the intertribal quarrels north of the Orange river, and a further recommendation was sent home by the Governor ; but Lord Kimberley, the new Colonial Secretary, definitely forbade the extension of any British influence over Namakwaland or Damaraland. In $188_{3}$ Germany directly questioned England as to whether she laid claim to territory north of the Orange river. An evasive reply was sent, in which delay was asked for so that the Cape Government could be consulted. Eventually the Germans were told that England laid claim to Walfish Bay and the Guano Islands only, but that the intervention of another Power between the Portuguese frontier and the Orange river would infringe legitimate British rights. The inaction of the British Government on this occasion seems in the present day, and by our modern lights, inconceivable. Literally the only reason they had in not politely declaring that South-West Africa was under British protection was the remote dread that they would have to protect German missionaries and traders.

Yet not only Downing Street in the greater degree but the Cape Government in the lesser was to blame for this inactivity. The Cape Government at that time was directed by ministers who were much under purely colonial influence, and who, discouraged by their failure to administer Basutoland, had no very strong desire to spend the money of the colony in annexing and administering a vast territory mainly desert. 
Besides, the idea of Germany becoming a colonial power was laughed at in those days in Government circles as an impossibility. At length all doubts were ended by the declaration of a German protectorate over South-West Africa in 1884 .

In 1882 measures were passed in the Cape Parliament which gave equal rights throughout Cape Colony to the Dutch language. In the same year the "Afrikander Bond" was established, an institution with the avowed object of building up an Afrikander Dutch-speaking nation which should eventually be independent of the British flag. Its principal creators and supporters were Mr J. H. Hofmeyr of Cape Town, Mr Borckenhager of the Orange State, and Mr Reitz of the Transvaal. Measures for bringing about a federation of the British and Dutch states had failed (as will be subsequently narrated), and an annexation of the Transvaal had been reversed. British influence in South Africa seemed on the wane and the Dutch element in the ascendant.

British missionaries during the thirties and forties had crossed the Orange river and settled in Bechuanaland, a sterile plateau between the Namakwa and Kalahari deserts on the one hand, and the relatively well-watered regions of the Transvaal and Matebeleland on the other. By $185 \mathrm{I}$, British sportsmen, roving afield after big game, and the great missionaryexplorer Livingstone had reached the Zambezi, which till then was only known from the sea upwards for about 500 miles inland. Livingstone's exploration of the Zambezi attracted the attention of the British Government, which at that time was more interested (from philanthropic motives) in acquiring territories in Tropical Africa than in extending its influence over more valuable regions enjoying a temperate climate. Livingstone was sent back as a consul to the mouth of the Zambezi in $185^{8}$ with a well-equipped expedition to explore Zambezia and discover the reported Lake Nyasa, then known as Lake Maravi. For five years his expedition traversed these countries, adding immensely to our geographical knowledge ; but its 
members suffered terribly from ill-health. Although the Portuguese treated them with kindness and put no obstacle in their way, still Portuguese political susceptibilities were aroused. For this and other reasons, Livingstone was recalled, and his proposals in regard to Lake Nyasa quashed. Nevertheless, the seed had been sown, and produced a sparse crop of adventurers, elephant hunters, missionaries and traders, who found their way to Nyasaland. Livingstone himself resumed his explorations there (in 1866); and an expedition, under Lieutenant Edward Young, R.N., which was sent to obtain news of him (1868), kept the British in favourable remembrance amongst the natives. Finally, Livingstone's death revived missionary enthusiasm; and two strong Scotch missions in I 875-6 occupied the Shire Highlands and the west coast of Lake Nyasa, putting a steamer on that lake. Two years later the African Lakes Trading Company sprang from missionary loins, and the Universities' Mission in $188 \mathrm{r}$ advanced overland from Zanzibar to the east shore of Lake Nyasa.

In consequence of the increase of British interests in this quarter the British Government decided to establish a consulate for Lake Nyasa in 1883 . Portuguese susceptibilities again became ruffled. Although no attempt had ever been made by Portugal to establish herself anywhere near Lake Nyasa, or even on the river Shiré, which connects that lake with the Zambezi and the sea, it was felt in Portugal that the growing British settlements in Nyasaland should be made to contribute to the revenue of Portuguese East Africa; and that, since through further extension they might force a way to the coast, it would be better that they should be brought under Portuguese control. Although the British Government was absolutely determined if possible not to assume direct responsibilities in Nyasaland, it was equally anxious that its subjects should be left a free hand, and not be fettered by Portuguese control. Therefore an attempt was made by Lord Granville (in the projected Congo Treaty of $188_{4}$ ) to define 
the sphere of Portuguese influence on the Shiré, so as to leave the greater part of that river and all Nyasaland outside the Portuguese dominions. Had that Congo Treaty been ratified, there would probably never have arisen the Nyasa Question with the Portuguese. But it was not ratified, and therefore Portugal was equally free with Great Britain to make the best use of her opportunities, which she did by means of several expeditions in the manner already described in Chapter IV. But nevertheless Nyasaland, including the Shiré Highlands, was declared to be a British Protectorate, based on treaties with native chiefs concluded by two consuls, (Sir) H. H. Johnston and John Buchanan; and the former, assisted by (Sir) Alfred Sharpe, further brought within the British sphere of influence the rest of "British Central Africa" from the central Zambezi to Lakes Tanganyika and Mweru and the frontier of the Congo Independent State. To this sphere of influence was shortly afterwards added the Barotse Kingdom, made known to us by Dr Livingstone and by the French Protestant missionaries. Treaties with Germany (1890) and Portugal (I89r) having sanctioned these acquisitions north of the Zambezi, the administration of the new territory was divided between the Imperial Government-which decided to control the more organized territories round Lake Nyasa-and the newly-founded British South Africa Chartered Company. After 1895 the Chartered Company assumed the direct administration of its North Zambezian territories which are now known as Northern Rhodesia.

Since 1890 much has been effected in developing and making known these territories of British Central Africa, which are perhaps not sufficiently healthy in all parts or void of an indigenous population to permit of more than a restricted European colonization, though they are already becoming of great value as tropical "plantation" colonies and as mining districts, and will support an abundant native population. During the seven years of the existence of this British sphere north of 
the Zambezi the slave trade had to be met and conquered. Numerous Arabs from Zanzibar had established themselves in Nyasaland as sultans, and had Muhammadanized some of the tribes and infused into them a dislike to European domination. The countries west of Lake Nyasa were ravaged by the Angoni, a people of more or less Zulu descent, the remains of former Zulu invasions of Central Zambezia. In seven years, however, these enemies were all subdued by means of Sikh soldiers lent by the Indian Government, by the native levies that were drilled by the Sikhs, and by five gunboats, which were placed on the Zambezi, the Shiré, and on Lake Nyasa. The Right Hon. Cecil Rhodes began in 1893 his great scheme of connecting Cape Town with Cairo by a telegraph line. In five years he had at any rate connected Cape Town with Tanganyika through British Central Africa. The Shiré Highlands and much else of Nyasaland and Eastern Northern Rhodesia proved moderately favourable to the cultivation of coffee (which was originally introduced by Scottish missionaries and planters); but the product which will probably make the fortune of this part of Africa is cotton-as Livingstone predicted more than half a century ago. These countries possess other valuable resources in tobacco, maize, and timber, in minerals, and in ivory; and are well adapted for the growth of certain kinds of rubber. Through the middle of Northern Rhodesia the "Cape to Cairo" railway is now built with several branch lines; and regions unmapped and unknown when the first edition of this work was published are now familiar to many a sightseer and tourist, brought within a few days' railway journey (across the Victoria Falls of the Zambezi) of Cape Town. The Shiré Highlands are connected by a railway with the Lower Zambezi, a line which will before long terminate at the port of Beira in SouthEast Africa and be extended northwards to Lake Nyasa. Large towns have sprung into existence in Nyasaland and Northern Rhodesia; the native population has nearly doubled in numbers since 1890 ; and "British Central Africa" is well 
on the way to becoming one of the most prosperous portions of the British Empire.

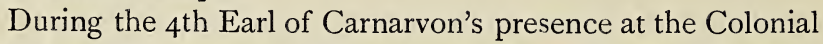
Office between 1874 and 1878 that statesman endeavoured to repeat in South Africa the success which had attended his consolidation of the North American colonies into one confederated Dominion. $\mathrm{He}$ sent out the historian Froude to represent him at the proposed conference of South African states. Already, Sir George Grey had tried hard to bring about this unification of South Africa under the British flag during the fifties; and in $185^{8}$ had pressed strongly upon the Imperial Parliament a scheme which would have well effected this desired end. For his pains he was recalled and sharply reprimanded, but, mainly owing to the influence of Queen Victoria, he was sent back to his governorship, though he was not allowed to carry out the far-reaching policy he had formulated. In Cape Colony the Federation Commission was appointed in 1872 . But the always present, more or less bitter divergence of sympathies between the English and the Dutchspeaking settlers - a discord constantly discernible in the debates of the Cape Parliament-prevented any ripening of the federation idea; and Lord Carnarvon's commissioner, Mr J. A. Froude, was snubbed for his pains by the Cape Dutch. Foiled in one direction, Lord Carnarvon sought to effect his end in another way. He sent out Sir Bartle Frere to be Governor and High Commissioner at the Cape. He had been chosen by Lord Carnarvon six months before as the statesman most capable of consolidating the South African Empire; "within two years it was hoped that he would be the first Governor-General of the South African Dominion." The second step in what seemed to Lord Carnarvon to be the right direction was the annexation of the Transvaal. With this territory of about $\mathrm{I} 20,000$ square miles in extent, in British hands, there would only remain the Orange Free State as an obstacle to the unification of South Africa. The Transvaal as an independent 
state had between $\mathrm{I} 853$ and 1877 come to grief. It was bankrupt, and it was powerless to subdue the powerful native tribes within its borders, some of whom had real wrongs to avenge. Moreover, it was threatened by $\mathrm{Zulu}$ invasion. It was therefore annexed by the British Commissioner, Sir Theophilus Shepstone, in the beginning of 1877 .

Unfortunately, Sir Bartle Frere's administration, after two and a half years of excellent work, was clouded by unmerited misfortune. The Zulu power to the east of Natal had been growing threateningly strong. At the beginning of the igth century an obscure tribe of Kafirs known as the Ama-zulu rose into prominence under a chief named Chaka, who became a kind of negro Napoleon, and a bloodthirsty slaughterer of all who stood in his way ${ }^{1}$ He and his chiefs included in their conquests all modern Natal and Zululand, much of the Transvaal and the Orange Free State, and Amatongaland up to Delagoa Bay ${ }^{2}$. Chaka's son, Dingane, though he most treacherously attacked the Boers, was fairly friendly in his relations with the British, and tolerated their establishment in Natal. In fact he seems to have allowed them to reorganize the territory of Natal which his father had almost depopulated. Owing to the founding of the Transvaal Republic and the Orange River Sovereignty in addition to the colony of Natal, the Zulus were henceforth shut up in a relatively small tract of South-east Africa represented by modern Zululand and Amatongaland; though the Amatonga were practically

1 Dingiswayo (the "Wanderer"), a Zulu of the Abatetwa clan, may perhaps be regarded as the founder of Zulu power. All this portion of South African history is described in some detail in my History and Description of the British Empire in Africa.

2 Driven out of the Orange Free State and the Transvaal by the action of Boers, British, and Basuto, a section of the Zulus conquered much of Portuguese South-East Africa, with nearly all modern Rhodesia, and carried their raids past Nyasa and Tanganyika to the vicinity of the Victoria Nyanza. 
another people. Dingane was succeeded by Panda, and Panda by Cechwayo (Cetewayo). The last-named chief perfected the system of a standing army of well-drilled bachelors. Anxious to find an outlet for his energies, he openly menaced the Transvaal, and was one of the causes of British intervention in the affairs of that republic. Shut off from this outlet, he seemed becoming dangerous; and, thinking it best to prick the boil before it burst, Sir Bartle Frere forced war on him by an ultimatum. The invasion of Zululand at the outset was not very wisely conducted, and led to a terrible disaster in which 800 British and over 400 native soldiers were cut to pieces at Isandhlwana ; and subsequently, through mismanagement, the Prince Imperial of France, who had come out as a volunteer, was allowed to stray into danger, and be killed by the Zulus. After a time, however, Lord Chelmsford succeeded in completely conquering the country, and Cechwayo was taken prisoner. Although Sir Bartle Frere was in no way answerable for these mistakes in a campaign which was eventually successful, his prestige was dimmed; and as the Liberal Government of $\mathrm{I} 880$ was inclined to pursue a reactionary policy in Africa, Sir Bartle Frere was recalled.

The Boers, taking advantage of British discouragement and the change of government in England, rose and demanded their independence. It was refused by Mr Gladstone's Administration, and troops were hastily sent out to subdue them, with the results detailed in Chapter VI. As to the afterhistory of Zululand, it may be briefly summarized as follows. The Boers were allowed to add a large slice of the country ("Vryheid" or the New Republic) to their reorganized State. Cechwayo was reinstated as king, but soon died. The country was then divided into various native principalities; but Dinizulu, Ćechwayo's son, fomented an insurrection and was exiled to St Helena. The country was then governed more or less as a British protectorate by Sir Marshall Clarke and in connection with the colony of Natal, the Governor of which was also 
made Governor of Zululand. In 1897 Zululand was incorporated with the colony of Natal. In $\mathrm{r} 887$ British protection was extended over Amatongaland up to the Portuguese boundary, and in 1895 this strip of coast territory was taken under more direct administration. In 1902 the Vryheid territory of northern Zululand was withdrawn from the Transvaal and united once more with Zululand.

As was related in Chapter VI, the Dutch South African Republic, soon after recovering its independence, sought to invade and absorb Bechuanaland; but the expedition under Sir Charles Warren (1884-5) put an end to their hopes in that direction, and a clear path was made for the British northwards to the Zambezi. In the early seventies, explorations of men like Thomas Baines and Karl Mauch (a German explorer) had revealed the existence of gold in the countries between the Limpopo and the Zambezi, countries which had come under the sway of a Zulu king, Lobengula, son of Umsilikazi ${ }^{1}$. Mr Cecil John Rhodes, an Englishman who had brought about the consolidation of the mines of Kimberley and had acquired great wealth and a position of political importance at the Cape, had interested himself firstly in the settlement of the Bechuana question with the Boers; and when Bechuanaland had been declared a British protectorate, his thoughts turned to the possibility of gold beyond; for the gold discoveries in the Transvaal were beginning to make a golden South Africa dawn on men's imaginations. He despatched envoys to Lobengula, and secured from him the right to mine. Other individuals or syndicates had secured mining rights in that direction, but Mr Rhodes with patience and fair dealing bought up or absorbed these rights, and in 1888 began to think of obtaining a charter from the Imperial Government which would enable the Company he intended forming to govern

1 A rebellious general of Chaka's, often known by his Sesuto name, "Moselekatse." 
South-Central Africa. At one time he seems to have thought that the De Beers diamond mining company should receive this charter and perform these functions; for, when he had framed the articles of association of the De Beers shareholders, he had inserted clauses enabling the Company to take up such an enterprise. But there were many reasons why this would not have worked well ; and it was resolved to constitute an independent company to work Lobengula's concession first, and to create another South African state afterwards. Already in 1888 the High Commissioner, Sir Hercules Robinson, had somewhat reluctantly extended a vague form of protection over Lobengula's country; and it had been made clear to Germany that Great Britain would not submit to be cut off from the Zambezi. In the early summer of 1889 a charter was granted to the British South Africa Company, of which Mr Rhodes became and remained the practical administrator. Mr Rhodes' ambitions then crossed the Zambezi, and he co-operated with Sir Harry Johnston in establishing British influence up to Tanganyika. For several years his Company afforded a subsidy to the administration of the British Central Africa Protectorate as well as to the territories under the Chartered Company's own control. The African Lakes Trading Company ${ }^{1}$ was given financial support, and enabled to extend its operations to Tanganyika.

1 The African Lakes Trading Corporation (as it is now called) was founded mainly by the energies of the brothers John and Frederick Moir (sons of an Edinburgh doctor) about $\mathbf{i} 878$, as an adjunct to the missionary enterprise in the Shiré Highlands. In course of time they established trading stations on Lake Nyasa, and cut a track or rough road over mountains and forest from the north-west corner of Lake Nyasa to the south end of Tanganyika, conveying over this "Stevenson Road" (so called because a Mr James Stevenson, a director of the Company, provided the cost of this undertaking) a little steamer in sections for the London Missionary Society. This steamer, the Good Neres, was the first to navigate the waters of Tanganyika. The African Lakes Company, being established at the north end of Lake Nyasa, inevitably came into contact 
In I89 I Mr Rhodes commenced the organization of the East coast route from Mashonaland to the sea, and he and his friends practically subscribed the capital for the Beira Railway. Fort Salisbury and other settlements in Mashonaland and on the east of Matebeleland were founded between I 89I and I893. In the last-named year the Matebele made an entirely unprovoked attack on the Company's forces, but a counter-invasion, most ably directed by Dr (afterwards Sir Starr) Jameson, achieved a complete victory over the Matebele. King Lobengula fled, and died soon after he had crossed the Zambezi. His capital, Buluwayo, became the administrative capital of the Company's possessions, to which the inclusive name of Rhodesia (Northern and Southern) was subsequently given. The development of Rhodesia proceeded apace. Mr Rhodes had since 1890 been Premier of Cape Colony; he was high in favour with the Dutch Party in South Africa; and he was fast becoming the actual, if not nominal Dictator of Africa, south of the Zambezi, when he made the fatal mistake of organizing a raid into the Transvaal (see page 287 ).

In the general disturbance which followed, the government of Southern Rhodesia became disorganized by a revolt of the Matebele in the spring of 1896 . They were soon joined by their former slaves, the Mashona. 'The revolt was suppressed partly by hard fighting, and partly by direct negotiation between Mr Rhodes and the Matebele chiefs, Rhodes and a few companions going unarmed to meet the induna in the Matopo hills. But the Mashona continued fighting until I 897. Rhodes

with the slave-trading Arabs who had settled there about ten years before. In 1887 the agents of the Company intervened to protect natives from being raided by the Arabs. The Arabs retorted by attacking the white men. Volunteers hastened to their relief from several quarters. Amongst these were two men afterwards to become famous as African governorsSir Frederick Lugard and Sir Alfred Sharpe. But the Arab question was not definitely settled until the Protectorate had been established for four years (1895). The African Lakes Corporation certainly did the pioneer work of British trade in South Central Africa. 
did much to atone for his one mistake by the enormous pecuniary sacrifices he made in pushing on the railways from Southern Rhodesia to Beira and the Lambezi, and in constructing the telegraph line from Mafeking to Tanganyika. There were signs that he was recovering to a considerable extent his influence in Cape Colony, and that he might yet play a great part in South Africa; but the terrible events of the great South African War of 1899-1902 interrupted the great work of development on which he had set his heart and ultimately caused his death.

In British South Africa momentous events took place after the summer of r899. The trouble engendered between the British and Boers in South Africa by the policy of Paul Kruger and the Jameson Raid culminated in the great South African War of $\mathrm{r} 899-1902$. As these episodes recede into history it has become clear to most seekers after truth that the Jameson Raid was brought about by the following trend of circumstances. Ever since $\mathrm{I} 884$ there had been a revulsion of feeling on the part of even Liberal and liberal-minded politicians in Great Britain against the Boers of South Africa. $\mathrm{Mr}$ Gladstone's restoration of their independence after the brief struggle of I88 I was esteemed a generous act. It gave the Boers of the Transvaal an opportunity to show what they could do in wise self-government under but the slightest control of their foreign relations by Great Britain. Three years afterwards the Boers of the Transvaal, in spite of treaty and other obligations, were invading Bechuanaland and attempting to cut off the British colonies to the south from any advance towards the Zambezi. It then began to be realized by the British public that the Boers, besides fighting very legitimately for their own independence in the Transvaal territory as well as in the Orange Free State, were aiming at something much greater-a domination over the whole of Africa south of the Zambezi. Both Liberal and Conservative administrations set themselves to resist this movement. At 
the close of the eighties Cecil Rhodes arose as an advocate for union between Boer and Briton in the common interests of the white man in South Africa. For a time he secured the suffrages of both; but the gold-mining industry became more and more powerful in the Transvaal and found the rule of a Boer Government irksome and obstructive. The mining industry set itself to influence public opinion in Britain and to organize in South Africa a movement against Boer independence. President Kruger played into the hands of the mining magnates by occasional breaches of his agreements with Britain. Among these was the famous "Drifts" question, by which Kruger in the summer of 1895 attempted to close access to the Transvaal from the rest of South Africa by any other routes than those of the Netherlands Railway, which was a privileged corporation. Mr Joseph Chamberlain, who had become Secretary of State for the Colonies in 1895 , took up this question with vigour and found himself fully supported by the Dutch colonists in Cape Colony and Natal. It seemed as though there was to be war with the Transvaal, in which case, on this question of the Drifts, Great Britain would have been thoroughly supported by her Dutch-speaking subjects in South Africa. As part of the plan of campaign conceived in the case of war, was a movement from the British South Africa Company's territory through Bechuanaland into the western and northern parts of the Transvaal; this in fact was the germ of the Jameson Raid.

Kruger gave way on the subject of the Drifts when he saw how united was the rest of South Africa against him; and it seemed to persons in authority in Great Britain as well as in South Africa that the great opportunity for solving the Boer question in South Africa had gone by. Insufficient measures were taken, or no measures at all were taken, to restrain the preparations of Dr Jameson (the Administrator of Rhodesia) for a descent on the Transvaal. Consequently the Jameson Raid took place-a most unfortunate occurrence, since it put Great Britain entirely in the wrong on a question 
where otherwise she could plead legitimate griefs and annoyances.

Sir Alfred (afterwards Viscount) Milner had been appointed in 1897 to succeed Lord Rosmead (Sir Hercules Robinson) as Governor of Cape Colony and High Commissioner of South Africa. Attempts were made between 1897 and the spring of r 899 to solve the South African problem peacefully by inducing the Boer Government of the South African Republic to grant the franchise to the "Outlanders" (foreigners) after a term of residence of a few years' duration; but Kruger would accept no sufficiently short term to enfranchise those most agitating for a voice in the Transvaal administration. But the war that broke out in October I899 was due immediately to an ultimatum from the Transvaal Government requiring Great Britain to cease any preparations for offence or defence on the Transvaal frontiers. The Orange Free State immediately made common cause with the Boers of the South African Republic, and a Boer invasion of Natal took place, to be followed by similar invasions of the eastern part of Cape Colony. The British were taken unprepared. Disaster followed disaster. Had the Boer leaders been wider in their knowledge and more daring, they might have taken possession of Natal and have gone far to wreck the British Empire in South Africa. But they delayed over the siege of Ladysmith, ably defended by Sir George White. British reinforcements on a large scale were sent to South Africa under the leadership of Lord (afterwards Earl) Roberts and Lord Kitchener. The British marched through the Orange Free State to Bloemfontein and Pretoria, and the Boers were finally expelled from Natal and Bechuanaland. It seemed as though, by the summer of I900, the war was at an end; but after the flight of President Kruger, Boer activities revived in such a marvellous way that the world wondered at the tenacity of the struggle, and for nearly two years longer the Boer forces held out against the British, and made an effective occupation of the Orange Free State 
and the Transvaal impossible. The Boers in their turn, however, were worn out by the persistency of Viscount Kitchener and his 'sweeping' movements. In the summer of I902 the Boer leaders asked for peace, and obtained it on terms highly honourable to themselves.

Cecil John Rhodes, the promoter of so much that was adventurous and history-making in British South Africa, died in March, I902, the immediate cause of his death being, not political heart-break (though that was the cause of his weakened constitution), but vexation resulting from a law-suit affecting his private affairs. Dr Jameson, however, recovered from the check to his career which followed his unsuccessful raid. He set himself in a spirit of moderation and tolerance to grapple with the local questions and general interests of Cape Colony, of which country he became Premier in 1904, remaining for four years afterwards at the head of the Cape Ministry. In 1908-9 he was one of the representatives who discussed and settled the conditions of the South African Union. In 19I I he was knighted as Sir Starr Jameson, and in I9I2 he retired from South African politics. President Kruger died in Holland in July I904. In the same year his political opponent, Lord Milner-whose seven years' work in South Africa, though it inspired many fierce contentions, yet cut through several Gordian knots-retired from the control of South African affairs to enter political life at home.

But the prosperity of South Africa did not at once revive with the conclusion of peace in I902. It was found that the devastations of the three years' war had reduced much of the Orange Free State, the eastern parts of Cape Colony, and above all, of the Transvaal to a desert, and time was required to repair the ravages to crops and agriculture and bring about the re-establishment of homes. So many of the inhabitantsBoers and Britons alike-had drifted towards the towns and there found it hard to maintain themselves under the extravagant cost of living; which seems to be at present an 
irremediable evil in South Africa, due to unwise fiscal laws, shipping combines, and railway rates. It was hoped that prosperity would return so soon as mining operations on the Rand could be resumed. But the local supply of unskilled labour proved to be insufficient for the enormous development of mining enterprise projected by individuals and companies. The labour problem is not yet completely solved. Some propose to meet it by drafts on the abundant negro population north of the Zambezi, these labourers being conveyed to and from South Africa under proper guarantees Others urge the throwing open of the land and the mines to white labour, so as to increase the European population of temperate South Africa. Many reasons have been put forward to combat the practicability of each scheme, either the increase of the black labour supply or the introduction of the white man in considerable numbers. Those in power in the period $1904-6$ preferred to redress the balance by the importation under special restrictions of the Chinaman. This step was adversely criticized by the Liberal party in Great Britain, not because that party was inclined to deny that a share of African development might be allowed to the Asiatic, but on the ground that the conditions under which the indentured Chinamen were to serve in the South African mines were not only opposed to British ideas of freedom but were detrimental to health and morality. Their anticipations of the bad results which might accrue from the employment of Chinese labourers in compounds were fulfilled; and in 1906-8 the Chinese were gradually repatriated from the Rand (as the mining area of the Southern Transvaal is called). The great question of the participation of the Asiatic in the development of South Africa and East Africa depends on the determination of the white man and the black man to be self-sufficing for the development respectively of the tropical and temperate districts of that continent. The black man must be less lazy and the white man likewise, as well as less proud, if both together are to be 


\section{XI] Elements in South African Population $29 \mathrm{I}$}

justified in denying to the yellow man a share of the Dark Continent, either as a settler or a merchant. It is interesting, however, to note that the white population of Cape Colony showed a considerable increase between 1891 and 1904. In I89 I the population of European descent numbered 366,608 . In 1904 it was stated at 579,74I. In the Transvaal the white population rose to 300,225 ; in Natal to 97,109 ; in the Orange Free State to 143,419 ; in Rhodesia to 12,623 ; and in Basutoand Bechuanaland to 1899 . In British South Africa the coloured (mainly negro) population was nearly 5,500,000. In I9 I 2, the total white population in British Africa, south of the Zambezi, was about 1, 306,400, and the negro and negroid about 5,800,000. There were also about 192,000 Asiatics; chiefly in Natal ; and these Asiatics consisted mainly of natives of Southern India (some I 72,000), together with I 5,000 Malays in Cape Colony, a few Chinese, Japanese, Arabs, and Syrians. North of the Zambezi, in Northern Rhodesia and Nyasaland, there are about 2200 whites, roo0 Asiatics and nearly 2,000,000 negroes: a total population of about 9,300,000. The area of all British South and South Central Africa (including Walfish Bay and the islets off the south-west coast) is r, I48,6 I9 square miles, extending from the frontiers of Angola and the Belgian Congo, Tanganyika and German East Africa to the coasts of Cape Colony and Natal-an Empire which is barely 100 years old, and which began in $1814^{1}$ with an area of I 25,000 square miles, with a population of about 150,000 , of whom some 26,000 were whites and the remainder Negroes, Hottentots, half-breeds, and Malays.

On May 3I, I902, the Peace of Vereeniging had brought the fratricidal South African war to a conclusion. Only four years afterwards the Liberal administration in Great Britain tried the bold experiment of granting responsible government to the Transvaal State by passing an act to that effect which

1 The cession of Cape Colony from Holland to Britain took place on August ${ }^{1} 3,1_{1} i_{4}$. 
came into force on January ist, I907. In the following year similar powers of self-government were bestowed on the Orange Free State (as it was eventually re-named). These concessions to the sturdy nationalism of the Boers were intended to pave the way for that long desired Union of South Africa. Negotiations were conducted between the statesmen of Cape Colony, Natal, the Orange Free State, and the Transvaal, which resulted in 1909 in an agreement and an Act of Union. This Act was ratified by the British Parliament and received the sanction of King Edward VII (who ever since his coming to the throne had striven earnestly to bring about peace in South Africa) on September 2 I, 1909. The Union of South Africa includes under one, central, South African Parliament at Pretoria, and one Governor-General, the states of Cape Colony (with British Bechuanaland and Walfish Bay), Natal, the Orange Free State, and the Transvaal. The native states of Basutoland, Swaziland, and Bechuanaland, and the territories of Southern and Northern Rhodesia and the Nyasaland Protectorate remain outside the Union for a variety of reasons most of which may not have a permanent value. But one of these reasons is the distrust which is felt in Great Britain as to the ability and fairmindedness of the white population to act as the governors of the states above mentioned in which the negro population very greatly preponderates over the white, or which, as in Basutoland, Bechuanaland and Swaziland, have been more or less reserved for negro colonization and expansion. Cape Colony, it is true, has a negro population of nearly $1,700,000$, contented and admirably governed for the most part, possessing a large proportion of the good land, and holding the franchise to the Cape Legislature on the same terms as white men. But the liberal-minded Cape Colony, in which one scarcely ever hears of native troubles or "Black perils," is only one of the states composing the Union; and the others, notably the Transvaal, have shown themselves-the Transvaal still keeps up this evil reputation-unfair and harsh in their 
treatment of the black man. When the provisions of the Act of Union were laid before the British Parliament they were found to exclude any man of colour from the franchise ${ }^{1}$. British ministers expressed regret at this illiberality, but passed the measure to end strife in other directions. Nevertheless the "Native question" will long continue to bar the way to a Greater South Africa, a vast confederation which shall extend from the Belgian Congo to the Southern Ocean. It is a question that is very complex, and one from which sentimentality, rash legislation, arbitrary pronouncements, and race prejudice must be carefully excluded. Had it been dealt with by far-sighted men like Sir George Grey in earlier times when the foundations of British South Africa were being laid, many causes of future trouble might have been eliminated. For instance some other solution of the Basuto claims might have been found than the handing over (fifty years ago) to the Basuto negroes I I, 000 square miles of the finest mountain country of South Africa, a region intended by nature to have been the Empire state of that region. Basutoland is a beautiful mountain country, well watered, with fertile valleys and snowcrowned peaks. Owing to its cold climate it was rather shunned by the South African negroes until the ancestors of the Basuto were driven thither in the early igth century to take refuge from the raiding Zulus. Had we offered the original ten to twenty thousand Basutos good locations on fertile land at lower levels when we first intervened to save them from Boer attacks (the Boers having intervened earlier still to save them from the Zulu hordes) they would have accepted. Now they are a well-armed people of nearly half-a-million, no longer

1 The franchise is limited to men of European race and descent only; while women are not granted the parliamentary vote, as is the case in Australia ; New Zealand; California, Colorado, Wyoming, and three other states of the American Union; the Isle of Man; Finland; and Norway. In these points, the framers of the Act of Union have shown the unprogressive spirit characteristic of the S. African Dutch. 
grateful to the white man, but the possible nucleus of a Black confederation. Their influence can only be stayed by the fair treatment of the Black man outside Basutoland, by the policy of Cape Town and not that of Johannesburg. The contentment of and the hold which education is getting over the million and a half of Kafirs in Cape Colony are valuable counteragents to Basuto presumption and ambition, and a proof that our oldest colony in South Africa possesses statecraft.

After dealing with such striking events, such potent personages and vast territories, it is rather an anti-climax to have to treat of the little island of Mauritius, which is not as large as the county of Surrey, and which, except under its first Governor, Sir Robert Farquhar (who tried from this vantage ground to annex Madagascar), has had no stirring connection with events of great importance. Mauritius was taken by the British from the French in 18 ro. The French had known it by the name of Île de France, but the British revived the older Dutch name of Mauritius. The French had introduced the sugar cane and other valuable plants; and these plantations were half-heartedly cultivated by means of slave labour until the slave trade was abolished. Then, in the fifties, Indian kuli labour was introduced with great success; and now the inhabitants of Indian descent in the colony number nearly 40,000, while Indian half-breeds are also numerous. The total population in 1912 was about 370,500 . The negro, negroid and Malagasy element was important-over 50,000. Deducting the Asiatics $(20,000$, mainly Indian, a few Chinese and Arabs) there remain about I 20,000 white and I60,000 halfcastes and Eurasians. The European population is almost entirely of French descent; and the marked French sympathies of the white inhabitants have sometimes caused a dissonance between the Governor and the governed, though ample concessions have been made to the Mauritians by the equal recognition afforded to French laws and the French language. 
Nevertheless, in spite of these political questions, and the occasional hurricanes which visit the island with disaster, it is a prosperous colony in ordinary years (doing a trade with an annual value of about $\mathcal{E} 5,000,000$ ), and only has to appeal to the Treasury of Great Britain for assistance on such rare occasions as when unusually great damage has been done by cyclones.

Numerous small islands in the Indian Ocean are dependent on the Government of Mauritius. All had much the same history-discovered by Portugal, they were eventually utilized by France, and finally captured and annexed by England. The most important among these Mauritian dependencies are the Island of Rodriguez, and the Oil Islands Group (Diego Garcia). The Seychelles were formerly associated with Mauritius, but since 1897 have been an independent colony under a full Governor. They consist of 90 small islands in the Seychelles group, the Almirante, Aldabra, Cosmoledo, and other tiny archipelagoes; the total land area being only i 60 square miles, with a population white and coloured of 26,000 . The Seychelles were taken possession of by the French in 1743 . Prior to that date they were uninhabited, though there are on them the traces of ancient habitation which may represent the halting places of Malagasy sea-wanderers on their way from Sumatra to Madagascar. Their name of Seychelles is a misspelling of "de Séchelles," the surname of a French minister of finance in 1756. The British fleet captured the principal island (Mahé) in $r 794$, but allowed the French Governor to continue to rule the islands until $\mathrm{r} 8 \mathrm{ro}$, when they were taken possession of definitely; partly for the reason that the French in Mauritius and Réunion had abused the tolerance shown to them, by directing constant privateering attacks on British shipping. It was in Mauritius that one of the noblest heroes of British colonial pioneering--Matthew Flinders, of the Royal Navywas imprisoned for six years, eating his heart out, losing all the advantages he might have gained from his truly wonderful 
circumnavigating survey of the Australian coasts ${ }^{1}$. To remove from the French all possible base of operations in the Indian Ocean, Bourbon (Réunion), an island slightly larger than Mauritius, and the most southern member of the Mascarene group, was also occupied by the British, who on this occupation and that of Mauritius, of Tamatave and other points on the coast of Madagascar, founded claims to a protectorate over the large island of Madagascar, as will be related in greater detail in a later chapter. Bourbon, however, was restored to the French in 1816 and renamed at a later date Réunion.

1 He reached England in $181 \mathrm{I}$ but was treated there with a neglect and ingratitude by the British Government which will long remain a scandal in our Imperial History, and for which as yet no public reparation has been made. His only descendant is Prof. Flinders-Petrie, the Egyptologist. 


\section{CHAPTER XII}

\section{GREAT EXPLORERS}

THE colonization of Africa in all its earlier stages is so closely akin to exploration, that in several of the preceding chapters I have seemed to deal rather with geographical discoveries than with political settlement. But as there is much exploring work which has not been directly connected with colonization (just as all missionary work has not resulted in the foundation of European states in Africa, nor have measures for the suppression of the slave trade invariably been followed by annexation) I think it better to devote a chapter to the enumeration of great explorers whose work has proved to be an indirect cause of the ultimate European control now established over nearly all Africa.

The first explorers known to history, though not, unfortunately, mentioned by name, were those Phoenicians despatched by the Egyptian Pharaoh, Niku II (son of Psammetik), about 600 (603-599) B.c. to circumnavigate Africa. We receive our knowledge of them through Herodotos, who derived his information from Egypt; but the account given of the voyage bears the stamp of veracity and probability, and seemed to be confirmed by some remarkable inscriptions on scarabs discovered by French explorers of Egyptian monuments. These, however, have been declared to be forgeries ${ }^{1}$.

${ }^{1}$ See the article of Professor Flinders-Petrie in the Geographical Journal, November, 1908 . 
Cambyses, the Persian king who invaded Egypt in 525 B.c., is said to have lost his life in endeavouring to trace the course of the Nile, he and his army having disappeared in the deserts of Upper Nubia. About 520 B.c. Hanno the Carthaginian, as already related in Chapter II, conducted an expedition round the West coast of Africa, which penetrated about as far south as the confines of Liberia.

The Greek Herodotos journeyed in Egypt and in the Cyrenaica about $45^{\circ}$ B.c. Eratosthenes, a Greek, born at Kurene in 276 в.с., became the librarian of one of the Ptolemies at Alexandria, and, although he derived much of his information about the valley of the Nile from other travellers, still he conducted a certain amount of exploration himself. Polybius, a Greek, born in 204 B.C., explored much of the North coast of Africa in the service of the Romans about 140 years before the Christian Era.

The celebrated Strabo flourished during the reign of Augustus Cæsar, and wrote a great work on geography about the year I9 A.c. He accompanied the Roman governor Elius Gallus on a journey up the Nile as far as Philæ, though his knowledge of the Cyrenaica was limited to a voyage along the coast. Nero sent two centurions (according to Pliny) with orders to ascend the Nile and discover its course. Thanks to recommendations from the king of Ethiopia, they were passed on from tribe to tribe, and apparently ascended the Nile as far as its junction with the Sobat, where they were stopped by immense masses of floating vegetation (the sudd).

Though Pliny the Elder ${ }^{1}$ does not appear to have visited Africa, or at any rate to have carried his explorations farther than a trip to Alexandria and visits to the ports along the Barbary coast, he nevertheless did much to collect and edit the geographical knowledge of the day; and has thus

${ }^{1}$ Caius Plinius Secundus: born at Verona or Como 23 A.c. His geographical publication or Natural History was published (according to Sir E. Bunbury) in 77 A.c. 
transmitted to our knowledge the slender information which the Romans possessed of interior Africa during the early years of the Empire. Pliny is remarkable for having handed down to us the first mention of the Niger, which he calls Nigir or Nigris and somewhat confounds with the humbler river Draa to the south of Morocco.

About the middle of the second century of the Christian Era there flourished in Egypt the famous geographer called Claudius Ptolemæus, better known to us as 'Ptolemy.' Though he also was mainly a compiler and owed much of his information to the works on geography published by his predecessor or contemporary, Marinus of Tyre, yet it seems probable that he travelled up the Nile for a certain distance, and visited the African coasts along the Red Sea and the Mediterranean. At any rate he published the most extended account of African geography given by any classical writer. His accounts of the Nile lakes, of the East African coast and of the Sahara Desert are the nearest approach to actuality of any geographer before the Muhammadan epoch.

With the decline of the Roman Empire came a cessation of geographical exploration, and there was no revival until the Muhammadan invaders of Africa had attained sufficient civilization to record their journeys and observations. Masudi and Ibn Haukal in the Ioth century, and other Arab travellers whose wanderings have not been recorded, furnished from their journeys information embodied in the map of Idris or Edrisi drawn up by a Sicilian Muhammadan geographer for Count Robert of Sicily in the I 2 th century. By these journeys the first definite and reliable information about the geography of Africa south of the Sahara, and along the East coast to Zanzibar and Sofala was brought to European knowledge. Ibn Batuta, a native of Morocco, in the I4th century ${ }^{1}$, and Leo Africanus (a Spanish Moor who afterwards turned Christian), in the I6th century, reached the Niger and the regions round Lake

${ }^{1}$ He visited the Upper Niger in $135^{2}$. 
Chad. The geographical enterprise of the Moors communicated itself to their conquerors, the Portuguese. Besides their great navigators, the Portuguese sent out overland explorers, the first, named João Fernandez, having in 1445 explored the Sahara Desert inland from the Rio d'Ouro. It is stated that Pero d'Evora and Gonçalvez Eannes actually travelled overland in 1487 from Senegambia to Timbuktu; but doubt has been thrown on their having reached this distant city; they may possibly have got as far as Jenné. Much more real and important were the explorations of Pero de Covilhão, who travelled in Sofala and reached Abyssinia in 1490 on his return from India, and remained in that country for the rest of his life. Passing over Francisco Barreto, who explored Zambezia more for immediate political purposes in 1569 and subsequent years, we may next note the exploration of a Portuguese gentleman named Jaspar Bocarro, who in I616 made a journey overland from the central Zambezi, across the river Shiré, near Lake Nyasa and the Ruvuma river, and thence to the east coast at Mikindani. From Mikindani he continued his journey to Malindi by sea. In 16 ז $3-18$ two Portuguese Jesuit missionaries, Pedro Paez and Jeronimo Lobo, explored Abyssinia, even far to the south. Paez visited the source of the Blue Nile, and Lobo directed his travels to the quasi-Christian states to the south of Abyssinia. In 1622, Lobo and other Portuguese missionaries attempted to enter Abyssinia by way of Zeila (Somaliland). They met with great misfortunes and much cruelty at the hands of the Somalis and the Egyptian Turks. Six missionaries died or were murdered. Lobo found his way from Mombasa to India, and, nothing daunted, returned to the Danákil coast in 1625 and landed at Bailul, opposite Mokha. His clothes tattered and his feet bleeding, he passed through the rough Danákil country, climbed the Abyssinian mountains, and reached the Jesuit mission centre at Fremona, near Axum. He then made a really remarkable exploration of Abysinia, and visited the source of the Blue Nile; but the jealous 
Abyssinians expelled him and the other Jesuits from Abysinia in 1633 by handing them over as prisoners to the Turks at Masawa ${ }^{1}$. It was thanks to the travels of Paez and Lobo that Abyssinian geography became so well known in Europe when all the rest of interior Africa was a blank. Numbers of unnamed, unremembered Portuguese soldiers and missionaries must have plunged into the interior of Africa between I 445 and the end of the $\mathrm{I} 7$ th century, bringing back jumbled information of lakes and rivers and negro states; but their information has perished-except in an indirect form-and their names are lost to history.

In 1588 Andrew Battel, a fisherman of Leigh in Essex, was wrecked on the coast of Brazil, seized by the Indians as a "pirate," and handed over to the Portuguese at Rio de Janeiro. The Portuguese decided to deport him to Angola. The vessel in which he travelled reached Benguela at a time when it was being ravaged by the predatory "Jagas.". The Portuguese being obliged to leave a hostage with the Jagas, left Battel behind; and in the company of these wild people he seems to have traversed much of the Congo country behind Angola and Loango before he eventually reached the coast again (north of the Congo) near a Portuguese fort, where he was allowed by the Jagas to leave them and whence the Portuguese permitted him to return to England in 1607. He appears to have roamed over South-West Africa for nearly i 8 years, and he brought back with him fairly truthful accounts of the pygmy races, the anthropoid apes, and some of the big game which penetrates the interior of Benguela from the south.

At the commencement of the I 7 th century, William Lithgow, a Scottish traveller, visited Tunis and Algeria. In I6 18 the London Company of Adventurers despatched George

1 The subsequent adventures of this heroic man, Lobo, are summarized in my book, The Nile Quest, 1903 .

2 Probably identical with the Ba-jok or Va-kioko between the rivers Kwango and Kasai. 
Thompson, who had already travelled in Barbary, to explore the river Gambia. During his absence up the river the ship by which he had come from England was seized and the crew murdered by Portuguese and half-caste slave traders, who resented this invasion of their special domain. Thompson managed to send back word of his difficulties, and the Company of Adventurers despatched another small ship. After sending her back with letters, Thompson continued his journeys for a distance of about 80 miles above the mouth of the Gambia. Thompson, however, lost his head, became fantastic in his notions, and is supposed to have been killed by his own English seamen, who afterwards boldly walked to the Senegal coast and were sent home in a Dutch ship. A third vessel sailed from London, commanded by Richard Jobson, to enquire after Thompson's fate. Jobson's first voyage, though he reached the point where Thompson had disappeared, was not very successful. On his return from Gravesend with two ships in 1620 , he sailed up the Gambia to a place called Kasson, where dwelt an influential Portuguese who had been the instigator of the destruction of his predecessor's ship. This man fled at Jobson's approach, and the latter continued on his way till he reached Tenda, where Thompson had disappeared. He then travelled in boats far above the Barrakonda Rapids ${ }^{1}$.

Then followed the journey of Jannequin de Rochefort and his companions in Senegal, and the still more important explorations of Brïe and Campagnon in the same region, journeys which have been referred to in Chapter IX. During the reign of king Charles II a Dutch or Anglicized Dutch merchant, named Vermuyden, asserted that he had ascended the Gambia and reached a country beyond, full of gold, but the truth of this story is open to considerable suspicion. In I 723 Captain Bartholomew Stibbs, and later still a man named Harrison, repeated Jobson's explorations of the Gambia. In 1720-30

1 See my Pioneers in West Africa, I9II. 
Dr Shaw, an Englishman, travelled in Egypt, Algeria ${ }^{1}$ and Tunis, and gave the first fairly accurate account of the Barbary States which had been received since they became Muhammadanized. A little later (I737-40) an English clergyman, Doctor of Laws and Fellow of the Royal Society, Richard Pococke, travelled in Egypt and explored the Nile as far as the first cataract. In about I780, Sonnini, an Italian, born in Alsace, explored Egypt, and gave a really circumstantial account of that country which did much to incite the French Revolutionary Government to invade it. In I 768-73 James Bruce, a Scotchman of good family, who had been educated at Harrow, and had spent two-and-a-half years as Consul at Algiers, travelled first in Tunis, Tripoli, and Syria. He then entered Egypt, and, becoming interested in the Nile question, he voyaged down the Red Sea to Masawa, and journeyed to Gondar, the capital of Abyssinia. Having some knowledge of medicine, he found favour with the authorities, and was given a command in the Abyssinian cavalry. After many disappointments, his ardent wish was granted; and he arrived at what he believed to be the sources of the Nile, but which really were the head-waters of the Blue Nile, to the south of Abyssinia. He journeyed back by way of Sennār and the Nubian Desert to Cairo. In I 793 William George Browne, a Londoner, and a member of Oriel College, Oxford, attracted by the accounts of Bruce's travels, entered Egypt, and crossed the Libyan Desert from Asiut to Darfur in 1793 . There he was treated extremely badly by the sultan of the country, and practically endured a captivity of three years before he succeeded in returning to Egypt.

During the 18 th century rumours had gradually been taking the shape of a belief that there was a great river in Western Africa on the banks of which stood the famous city of Timbuktu. This river was identified with Pliny's Nigris or Nigir². At

1 Where he was British Chaplain.

2 Pliny and one or two succeeding classical geographers mention the 
first it was thought that the Niger was the Gambia or Senegal, but at last it was believed that the Niger must rise southward, beyond the sources of these rivers, and flow to the eastward. Sir Joseph Banks, President of the Royal Society, who had accompanied Cook on his journey round the world, joined with other persons of distinction, and formed the African

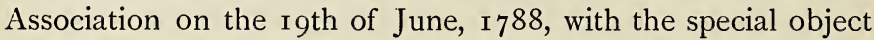
of exploring the Niger. At first they resolved to try from the North coast of Africa or from Egypt; but these expeditions proving unsuccessful, an attempt was made to march into the unknown from Sierra Leone. Major Houghton, who had been Consul in Morocco, was employed amongst other travellers, and he succeeded in passing through Bambuk on his way to Timbuktu; but he was intercepted by the Moors of the Sahara, robbed, and left to die naked in the desert. From Egypt a German traveller named Friedrich Hornemann was despatched by the same association. He reached Fezzan, set out on a journey to Bornu, and was never heard of afterwards, though it is practically certain that he reached the Niger in the country of Nupe ${ }^{1}$ about I80o. In 1795 the zealous Association accepted the services of a young Scotch surgeon named Mungo Park, and sent him out to discover the Niger from the West coast. Mungo Park started at the age of 24, having had a previous experience in scientific exploration as assistant surgeon on an East Indiaman, which had made a voyage to Sumatra. Park reached Pisania, a station high up the Gambia River, in I 795. He started at the end of that year, and after crossing the Senegal river and going through many adventures, he entered the Moorish countries of Kaarta and Ludamar to the north-east. Hence, after enduring captivity and great hardships, he escaped, and gradually found his way

Ger or Gir and the Niger as rivers of Western Africa, the former being possibly the river Draa. Both words may be derived from Berber roots.

${ }^{1}$ See my work, Pioneers in West Africa, for details of Hornemann's journey and the possible date and place of his death. 
to the Niger at Sego, and struggled along the river bank for a short distance farther east. His return journey along the Niger was attended by such hardships that one marvels at the physical strength which brought him through alive. However, at last he reached Bamaku, and thence after almost incredible difficulties regained Pisania on the Gambia, about a year and a quarter after setting out thence to discover the Niger. Owing to his return voyage taking him to the West Indies, he did not reach England till the 2 2nd of December, 1797, after performing a journey which, even if he had not subsequently become the Stanley of the Niger, would have made him lastingly famous. London received him with enthusiasm, but after the first novelty had worn off a period of forgetfulness set in. Park married, and settled down in Peebles as a medical practitioner. But in process of time the influence of the African Association filtered even into the stony heart of a Government department; and it was resolved by the Colonial Office (then a branch of the War Office) to send Mungo Park back to continue his exploration of the Niger. He was given $£ 5000$ for his expenses, and an ample outfit of stores and arms and other equipment. He held a Captain's commission, and was allowed to select soldiers from the garrison of Goree. $\mathrm{He}$ took his brother-in-law with him as second in command, a draughtsman named Scott, and several boatbuilders and carpenters. At Goree he selected one officer, 35 privates, and two seamen. The party left the Gambia in 1805 . They were soon attacked with fever, and by the time they had reached the Niger only seven out of the 38 soldiers and seamen who had left Goree were living. Descending the Niger past Sego, Mungo Park built a rough and ready kind of boat at Sansanding, which he named the Joliba. By this time his party had been reduced to five, including himself. On the r 2 th of November, I 805 , they set out from Sansanding (whence they sent back to the Gambia their letters and journals) to trace the Niger to its mouth. Mungo Park was never heard from 
any more. It was ascertained, by the information subsequently gathered from native traders and chiefs, that his party met with constant opposition from the natives in its descent of the river, with the result that he and his companions were continually fighting. After Mungo Park entered the Hausa-speaking countries of Sokoto the enmity of the natives increased, apparently because he was unable to pay his way with presents. At last, at Busa, where further navigation was obstructed by rocks, the natives closed in on him. Finding no way of escape, Park jumped into the river with Lieutenant Martyn (a Royal Artillery Officer), and was drowned. After Park's death, Major Peddie, Captain Campbell, Major Gray, and Dr Dochard all strove to follow in Park's footsteps from the direction of the Gambia, but all died untimely deaths from fever, though Dr Dochard succeeded in reaching Sego on the Niger.

The presence of the Dutch in South Africa did not lead to great explorations. Such journeys as were made were chiefly parallel to the coast. In I685 Commander Van der Stel explored Namakwaland to within a very short distance of the Orange river; but it was some 60 years later before that river was actually discovered by a Boer elephant hunter. Its discovery was made known scientifically by an expedition under Captain Hop in $176 \mathrm{I}$. This expedition obtained several giraffes, which were sent home by Governor Tulbagh, and were the first to reach Europe. In 1777 Captain Robert Jacob Gordon, a Scotchman in the service of the Dutch East India Company, discovered the Orange river at its junction with the Vaal. Subsequently Captain Gordon, with Lieutenant William Patterson, an Englishman, made a journey overland from the Namakwa country to the mouth of the Orange river, which they ascended for 30 or 40 miles. They christened what the Dutch had hitherto called the "Great (Groote) river" the "Orange river," out of compliment to the Stadhouder. There is also a rumour that two Dutch commissioners, Truster 
and Sommervill, went on a cattle-purchasing expedition in I $80 \mathrm{r}$ beyond the Orange river, and penetrated through the Bechuana country to the vicinity of Lake Ngami.

Fired by the news of African discoveries, Portugal awoke from one of her secular slumbers in 1798-as she similarly awoke in 1877-and despatched a Brazilian, Dr Francisco José Maria de Lacerda, to the Zambezi, to attempt a journey across Africa from East to West. The results of this first scientific exploration of Central Africa have been touched on in Chapter IV. It may be sufficient to mention here that Dr de Lacerda travelled up the Zambezi to Tete, and from Tete north-westwards to the vicinity of Lake Mweru, near the shores of which he died. He had been preceded along this route by two Goanese of the name of Pereira. In the beginning of the I 9 th century two half-caste Portuguese named Baptista and Amaro José crossed Africa from the Kwango river, behind Angola, to Tete on the Zambezi. In I83 I Major Monteiro and Captain Gamitto repeated Dr de Lacerda's journey from Tete to the Kazembe's country, near Lake Mweru; and in I846 a Portuguese merchant at Tete named Candido de Costa Cardoso, claimed to have sighted the southwest corner of Lake Maravi (Nyasa).

To return again to South Africa-British rule brought about a great development in exploration. Campbell, a Scotch missionary, in $18 \mathrm{I} 2$ laid down the course of the Orange river on the map and discovered the source of the Limpopo. Captain (afterwards General Sir J. E.) Alexander made an interesting journey overland from Cape Town to Walfish Bay; Dr William Burchell and Captain William Cornwallis Harris ${ }^{1}$ explored Bechuanaland and the Transvaal, and added much to our knowledge of the great African fauna. Robert Moffat and other missionaries extended our knowledge of

1 Afterwards Sir William C. Harris. He explored Shoa (South of Abyssinia) in $184^{1-2}$, and was knighted for concluding a treaty on behalf of the Government of India with the King of Shoa. 
Bechuanaland; Angas investigated Zululand; Major Vardon explored the Limpopo.

In the first decade of the igth century Henry Salt (formerly British Consul-General in Egypt) explored Abyssinia and the Zanzibar Coast. In I822 Captain (afterwards Admiral) W. F. W. Owen left England with two ships, and spent four years exploring the East and West coasts of Africa, and the island of Madagascar. He especially added to our knowledge of Delagoa Bay and its vicinity. He despatched vessels on the first voyage of discovery up the Zambezi, which unhappily ended in the death of all the British officers. The limit reached was Sena. The East and West coasts of Africa were charted by Captain Owen with the first approach to real accuracy. Although he was not an overland explorer, his voyage marks a most important epoch in African discovery, and many of his surveys are still in use.

Mungo Park and others having entertained the idea that the Niger might find its ultimate outlet to the sea in the river Congo, an expedition was sent out in 1816 to explore the lower Congo. It was a naval expedition, of course, and the command was given to Captain Tuckey. He surveyed the river to the Yelala Falls, and carried his expedition inland to above these rapids near the modern station of Isangila. Unfortunately, he and nearly all the officers of his expedition died of fever; but his journey, being conducted on scientific lines, resulted in considerable additions to our knowledge of Bantu Africa, its peoples, languages, and flora.

- Major Laing, a Scotchman, who had already, in 1823 , distinguished himself by exploring the source of the Rokel river of Sierra Leone (practically locating the source of the Niger and ascertaining its approximate altitude), determined in 1825 to strike out a new departure in the search for Timbuktu. ${ }^{\circ} \mathrm{He}$ started from Tripoli, journeyed to Ghadames and the oasis of Twat, and thence rode across the desert to the Niger over a route which may some day be followed by a French trans-Saharan 
railway. He was attacked on the way by the detestable Tawareq, who left him for dead, bleeding from twenty-four wounds. Still, he recovered, and actually entered Timbuktu on the I8th of August, r826. Being advised by the people to leave because of their dislike to the presence of a Christian, he started to return across the desert, but was killed at $\mathrm{El}$ Arwan, a few marches north of Timbuktu, at the instigation of the Fula king Ahmadu of Masina.

French names were scarce in the roll of explorers after the journeys of Brüe and Campagnon at the beginning of the I 8 th century; though Le Vaillant, as a naturalist, made small but very interesting explorations in South Africa. But in the early part of the Igth century, after the recovery of their Senegalese possessions, Frenchmen resumed the exploration of the Dark Continent. Already, in 1804 , Rubault, an official of the Senegal Company; had explored the desert country between the Senegal and the Gambia, and the upper waters of the Senegal. In 18 I 8 Gaspard Mollien discovered the source of the Gambia, and explored Portuguese Guinea. In I824 and 1825 De Beaufort visited the country of Kaarta to the north-east of the Senegal. Then came René Caillé, who reached Timbuktu and returned thence to Morocco in I827, a journey discussed for its political importance in Chapter IX.

In 1817 a British mission was sent to Ashanti, under the eventual leadership of Thomas Edward Bowdich. Bowdich, who made a treaty with the king of Ashanti, employed the opportunities of intercourse with Hausa, Mandingo, and Moorish merchants at the court of this monarch to collect a quantity of most valuable information as to the course of the Niger, the fate of Mungo Park, the geography, ethnology and languages of the heart of West Africa within the Niger bend. His book, published in 1820 , is a valuable work in African anthropology and history.

The British Government, still pegging away at the Niger problem, was roused to fresh exertions by the information 
collected. Impressed by the success with which Laing had penetrated Central Africa from Tripoli, it resolved to try that Regency ${ }^{1}$ as a basis of discovery. Mr Ritchie and Captain George Lyon started from Tripoli in 1818 , and reached the country of Fezzan. Here Ritchie died, and Lyon did not get beyond the southernmost limit of Fezzan. On his return a second expedition was organized under Dr Walter Oudney (who was actually appointed Political Agent to Bornu before that country had been discovered by Europeans!), Lieutenant Hugh Clapperton, R.N., and Lieutenant Dixon Denham. Starting from Tripoli in the spring of 1822 , they were compelled to halt there by the obstacles that were placed in their way. Denham, an impulsive, energetic man, rushed back to Tripoli to remonstrate with the Basha, and receiving nothing but empty verbal assurances, started for Marseilles with the intention of proceeding to England, but was recalled by the Basha of 'Tripoli, who henceforth placed no obstacles in his way. During his absence the expedition had visited the town of Ghat, far down in the Sahara. In 1823 this expedition reached the Sudan, and its members were the first Europeans to discover Lake Chad. They then visited Bornu and the Hausa state of Kano, where Dr Oudney died. After Oudney's death, Clapperton proceeded to Sokoto, and very nearly reached the Niger, but was prevented from doing so by the jealousy of the Fula sultan of Sokoto. Whilst Major Denham was remaining behind in Bornu, there arrived with a supply of stores a young officer named Toole, who had traversed the long route from Tripoli to Bornu almost alone, and had made the journey from London in four months. Denham and Toole explored the eastern and southern shores of Lake Chad, and discovered the Shari river, after which the unfortunate Toole died.

Denham and Clapperton then returned to Tripoli ${ }^{2}$. The

1 Then nearly independent of Turkey, and ruled by the Karamanli dynasty of Turkish pashas.

${ }^{2}$ Denham, who had really rendered great services in the cause of 
British Government sent Clapperton back to discover the outlet of the Niger. He landed at Badagri, in what is now the British colony of Lagos. He lost his companions one by one, with the exception of his invaluable servant Richard Lander. Clapperton passed through Yorubaland, and actually struck the Niger at the Busa Rapids, near where Park and his company perished. From Busa Clapperton and his party travelled through Nupe and the Hausa states of Kano and Sokoto; but he arrived at an unfortunate time, when Sokoto was at war with Bornu, and the Fula sultan was much too suspicious of Clapperton's motives to help him in the exploration of the Niger. From fever and disappointment Clapperton died at Sokoto on the $13^{\text {th }}$ of April, I827. It was a great pity that he went there at all. What he should have done on reaching Busa was to work his way down from Busa to the sea. All his companions, except his servant Lander, had predeceased him. Lander now endeavoured to trace the Niger to the sea, but the Fula sultan still opposed him, and he was stripped of nearly all the property of the expedition before he could leave Sokoto. Eventually he made his way back to Badagri by much the same route that Clapperton had followed. Lander was a Cornishman, a man of short stature, but pleasing appearance and manners. He had had a slight education as a boy, but learned a good deal more in going out to service as page, footman, and valet. In this last-named capacity he had journeyed on the continent of Europe and in South Africa before accompanying Clapperton. When he returned to England his story did not arouse much interest, as Arctic explorations had replaced Africa in the mind of the public. Moreover, the ultimate course of the Niger had by a process of exhaustion almost come to be guessed aright.

So far back as I808 Dr Reichardt of Weimar had suggested

exploration, was rewarded somewhat inadequately with the post of Secretary to the colony of Sierra. Leone and Superintendent of the slave settlement at Fernando Pô, where he soon died. 
that the Niger reached the Atlantic in the Gulf of Guinea through the Oil rivers. Later, James McQueen, who as a West Indian planter had cross-examined many slaves on the subject of the Niger, not only showed that this river obviously entered the sea in the Bight of Benin, but predicted that this great stream would some day become a highway of British commerce. Somewhat grudgingly, the Government agreed to send Lander and his brother back to Africa, poorly endowed with funds. Not discouraged, however, the Landers arrived at Badagri in March, 1830 , and reached the Niger at Busa after an overland journey of three months. Meeting with no opposition from the natives, they paddled down stream for two months in canoes. At length they reached the delta, but there unfortunately fell into the power of a large fleet of Ibo war canoes. By the Ibos they were likely to have been killed but for the remonstrances of some Muhammadan teachers, who, oddly enough, were found with this fleet. Moreover, a native trader of Brass, an Ijō settlement near the coast of the delta, happened to be visiting the Ibo chief, and agreed to ransom the Lander brothers on condition of receiving from them a 'bill' agreeing to repay to the 'king' of Brass the value of the goods which his son had furnished for their redemption. They reached the sea at the mouth of the Brass river, one of the outlets of the Niger, but not the main stream. An English merchant ship being anchored there, the Landers went delightedly on board, thinking the end of their troubles had come. They asked the captain to honour their bill, the amount of which the Government would repay him. To their amazement he refused, and altogether behaved in such a disgraceful manner that it is a pity his name has not been preserved for infamy. However, they managed on this ship to get a passage across to Fernando Pô, where they landed. The vessel by which they travelled, and the master of which treated them so badly, was afterwards captured by a pirate and never heard of again. It may be mentioned here that Richard Lander ultimately 
repaid the chief's son of Brass the whole amount of the goods which he had spent in redeeming the two explorers from the Ibo king's clutches.

No great fuss was made over the Landers when they returned in $183 \mathrm{I}$. John Lander remained at home. Richard Lander afterwards joined the MacGregor Laird expedition for opening up the Niger. This commercial undertaking met with the most awful disasters from sickness, but James MacGregor Laird nevertheless succeeded in discovering the Benue, and ascended it for some distance. In 1833 Richard Lander and Dr Oldfield ascended the Niger from the Nun mouth as far as Rabba, and explored the Benue for 140 miles above its junction with the Niger. After returning from a third trip up the Niger Lander was attacked by savages in the delta, was severely wounded, and died from his wounds at Fernando Pô on the 6 th of February, I 834 .

In $1840-4 \mathrm{I} \mathrm{Mr}$ John Beecroft, superintendent of Fernando Pô, and afterwards first consul for the Bights of Biafra and Benin, not only explored the Niger, but made known for the first time the Cross river, to the east, which he ascended from Old Calabar to the rapids. In $184 \mathrm{I}$ the British Government sent out an important surveying expedition to the Niger under four naval officers. This expedition was despatched at the instigation of Sir Thomas Fowell Buxton, the philanthropist, who had thrown himself heart and soul into the anti-slavery movement. At this period philanthropy reigned supreme in England, and a sense of humour was in abeyance, though it was beginning to bubble up in the pages of Dickens, who has so deliciously satirized this Niger expedition in "Bleak House" with its inimitable Mrs Jellyby and her industrial mission of Borriaboola-Gha. The ghastly unhealthiness of the lower Niger was ignored, and an item in the programme of the expedition was the establishment of a model farm at the junction of the Benue and the Niger. The other aims of the expedition were nicely balanced between the spreading of Christian 
civilization and the suppression of the slave trade on the one hand and the zealous pushing of Manchester goods on the other. Numerous treaties were made, but the results of the expedition were disappointment and disaster, occasioned by utter ignorance of the conditions under which some degree of health might be retained, and a muddle-headed indecision as to the practical results which were to be secured by the opening up of the Niger. The loss of life was enormous. Still, in spite of this check, British traders gradually crept into and up the Niger, with the results detailed in Chapter VIII.

In 1836 John Davidson, an Englishman of considerable attainments, started from the Atlantic coast of Morocco for Timbuktu, but was murdered at Tenduf, in the Sahara Desert.

In 1849 the British Government determined to make another effort to open up commercial relations with the Niger and Central Africa, but resolved again to try the overland route from Tripoli. After the Napoleonic wars were finished, the British Government had sent out various surveying parties to map the coasts of Africa; and a well-equipped expedition under Admiral Beechey made a thorough investigation of the coasts of Tripoli and Barka in 1821 and 1822 , and sent back the first trustworthy accounts of the Greek ruins of the Cyrenaica. Since that time several consular representatives of Great Britain in Tripoli had carried on explorations in the interior. Among these was James Richardson, who had originally accompanied Admiral Beechey, and who further made most important explorations of the Tripolitan Sahara, discovering many interesting rock paintings and inscriptions. He was appointed to be the head of this overland expedition of 1849 , and associated with him were two Germans, Barth and Overweg. Dr Heinrich Barth was born at Hamburg in the year $182 \mathrm{I}$. He had travelled extensively in Asia Minor, in Mediterranean Africa, and up the Nile.

This expedition left Tripoli in the spring of 1850 , and reached Bornu without any difficulty. Here its members 
separated. Richardson died soon afterwards and was buried near Lake Chad; Overweg died in $185^{2}$, having been the first European to navigate Lake Chad ${ }^{1}$. He was buried on the shores of that lake. For the next four years Barth carried on gigantic explorations on his own account. He journeyed from Lake Chad along the river Komadugu, and thence across northern Hausaland to the Niger at Say. From Say he cut across the bend of the Niger to Timbuktu, and descended the river back to Say, and thence to Sokoto, from which he made his way to Kukawa in Bornu, where he met Dr Eduard Vogel and two non-commissioned officers of the Royal Engineers, who had been sent by the British Government to reinforce his expedition. Barth had previously in $185^{\mathrm{I}}$ made a journey due south, and had struck the river Benue very high up in its course. Vogel started to complete the discoveries in this direction, and eventually to make his way to the Nile. He was accompanied by Corporal MacGuire, but the two quarrelled and parted, and both were murdered in the vicinity of Wadai. Dr Barth and the other non-commissioned officer made their way back across the desert to Tripoli and England. Barth's journey was productive of almost more solid information than that of any of the great African explorers, excepting Stanley, and possibly Nachtigal, Schweinfurth and Emin Pasha. Besides the geographical information given, Barth's book in five volumes and his various linguistic works on the Central Sudan languages represent an amount of information that has not been sufficiently digested yet. Heinrich Barth stands in the first rank of the very great explorers, a class which should perhaps include Mungo Park, Livingstone, Stanley, Speke and Grant, Burton, Baker, Schweinfurth, Nachtigal, Rohlfs, Grenfell, Binger and Joseph Thomson; men who have not only made great geographical discoveries but who have enriched us as well with that information which clothes the dry bones of the mere delineation of rivers, lakes, and mountains. Barth received a somewhat

${ }^{1}$ In a patent collapsible boat. 
grudging reward for his services in England. After some delay he was created a C.B., and then his existence was ignored by the Government, to whom still, and for many years to come, an African explorer, laying bare to our knowledge hundreds of thousands of square miles of valuable territory, was less worthy of remembrance than a Chargé d'Affaires at the court of the Grand Duke of Pumpernickel.

In 1846 a Portuguese trader named Graça reached the court of the Mwata Yanvo in southern Congoland, from Angola; and between 1847 and $185 \mathrm{r}$ the binterland of Angola was thoroughly explored by a Hungarian, Ladislas Magyar: In I 853 a Portuguese trader, Silva Porto, actually crossed Africa, from Benguela to the mouth of the Ruvuma, passing to the south of Lake Nyasa, but not sighting it.

In 1858 a Moroccan Jew named Mordokhai ${ }^{1}$ Abi-Serūr made a journey from the south of Morocco to Timbuktu and afterwards resided in that city till $\mathrm{I} 862$, thenceforward repeating his journeys thither until 1869 . In 1830 the Church Missionary Society had sent emissaries to Abyssinia, who included among them latterly such men as Dr Ludwig Krapf ${ }^{2}$. But these agents were expelled in I842, and Krapf settled on the east coast of Africa two years afterwards. Here he was joined by Johann Rebmann, also in the service of the Church Missionary Society. Making Mombasa their head-quarters, Krapf and Rebmann executed some remarkable journeys into the interior of what was then an utterly unknown country. Rebmann in 1848 saw for the first time Kilima-njaro, the highest mountain in Africa, nearly 20,000 feet high. In 1849 Krapf not only sighted Kilima-njaro, but pushed his way much further north, and caught a glimpse of Mt Kenya. Besides these remarkable discoveries (the truth of which was strongly

1 His name is spelt by the French "Mardochée."

${ }^{2}$ Ludwig Krapf, like his colleagues in East Africa, Rebmann and Erhardt, was a native of Württemberg, having been born near Tuibingen in that South-German kingdom. 
doubted by arm-chair geographers in England) they brought back with them such circumstantial accounts of the great Central African lakes as to lure others on to the exploration of these regions.

During the thirties Abyssinia and Shoa were explored by Dr E. Rüppel (a German traveller who added greatly to our knowledge of African natural history); during the forties and fifties by the Irish-French brothers, Antoine and Arnaud d'Abbadie (who made the most elaborate surveys), and by Sir W. Cornwallis Harris ; and subsequently by Théophile Le Fébvre, Mansfield Parkyns, H. Dufton, and the geographer, I) C. T. Beke. In $185^{6} \mathrm{Mr}$ James Hamilton made a most interesting journey of exploration in the Cyrenaica, and thence travelled overland through the oasis of Siwa to Egypt.

Meantime, in South Africa Livingstone had arisen. $\mathrm{He}$ had settled in Bechuanaland in $\mathrm{I} 84 \mathrm{I}$, and had gradually extended his journeys further and further north, until, in company with William Oswell and Murray, two English sportsmen, he discovered Lake Ngami. Mr Francis Galton had attempted to reach this lake in $185 \mathrm{I}$ by an interesting but very difficult journey through Damaraland; but he did not succeed in getting nearer to Ngami than the bed of a dried-up watercourse, the Omuramba. Andersson, a Swede, however, in i $85 \mathrm{I} \mathrm{left}$ Walfish Bay, and travelling through Ovamboland, managed to arrive at the shores of Ngami. Green explored the lower course of the Okabango-Teoge in $18_{5} 6$. In $185_{5}$ Livingstone, accompanied by his wife and family, and by $\mathrm{Mr}$ Oswell, reached the Zambezi at Sesheke. Feeling himself on the threshold of vast discoveries, Livingstone despatched his wife and family to England, with the monetary help of Mr Oswell, and placed himself under the tuition of Sir Thomas McClear, the Astronomer Royal at Cape Town. Turning his face northward in June 1852 , he reached the Zambezi again in that year, traced it along its upper course, near to its source, and then travelled across to Angola, which he reached in May 1854 . 
Returning again from Angola to the Zambezi, he followed that river more or less closely to near its mouth, and then made his way to Quelimane by the route always followed until the recent discovery of the Chinde mouth of the Zambezi. From Quelimane he was conveyed by a British gunboat to Mauritius, and arrived in London on the $\mathrm{x} 2 \mathrm{th}$ of December, 1856 .

Somaliland had been explored in 1854 by Richard Francis Burton and John Hanning Speke. Burton was an officer in the Indian army, and had previously made a remarkable journey to the holy places of the Hedjaz. In 1856 the Royal Geographical Society (which had developed from out of the African Association in $\mathrm{r} 83^{\circ}$ ) despatched an expedition under the command of Burton, who chose Speke for his lieutenant, to search for the great lakes which the Württemberg missionaries reported to exist. As the result of this epoch-making exploration Burton discovered Tanganyika (though he only mapped out the northern half), and Speke discovered the south shore of the Victoria Nyanza. Hurrying home before Burton, Speke got the ear of the Geographical Society, and was at once sent back (with Captain J. A. Grant as his companion) to discover the sources of the Nile. Burton was rather hardly treated in the matter, but he was a man too clever for his times, and one who made many enemies amongst those who directed geographical exploration in the middle of the rgth century. Speke and Grant reached the northern end of the Victoria Nyanza and the outlet of the Victoria Nile at the Ripon Falls, journeyed northwards and missed the Albert Nyanza; then, met and relieved by Sir Samuel Baker, travelled down the Nile to Egypt. It was a most remarkable journey, but in some senses a blundering one, remarkable as much for what was missed as for what was gained in exploration. Through not having made any survey of the vast lake they had undoubtedly discovered and often seen, and not being able to give much idea of its shape or area, its very existence came afterwards to be 
doubted until it was conclusively established by Stanley in I 875. Speke and Grant had left England in April I 860, and reached Khartum on the 3 oth of March, I864, and England soon afterwards. Speke died from a gun-accident in September I864. Grant, afterwards made a Colonel and a C.B., accompanied the British expedition to Abyssinia, and lived till 1892 .

Prior to the journey of Speke and Grant down the Nile, that river had been already made known up to the vicinity of the great lakes by explorers following in the footsteps of the military expeditions sent by Muhammad Ali to conquer the Sudan ${ }^{1}$. A Catholic mission had established itself on the Upper Nile in 1848 , mainly supported by the Austrian Government. Amongst the missionaries was Dr Ignatius Knoblecher, who in 1849 explored the White Nile beyond Gondokoro to Mount Logwek. Other explorations were carried out by Giovanni Beltrame, another missionary. A Maltese ivory merchant named Andrea Debono and a Venetian named Giovanni Miani had also explored the White Nile ; and the latter was the first European to visit the Nyam-nyam country. An English (or, rather, Welsh) ivory trader named John Petherick had started from Khartum in November I 853, and had ascended the Bahral-Ghazal River for some distance. He made other journeys into the unknown, more or less in the region of the Bahr-alGhazal and the Nyam-nyam country. Petherick, who became British consul at Khartum, was entrusted with the mission of meeting and relieving Speke and Grant, but by some accident

1 These in order of achievements were: Frédéric Caillaud (French) who explored the Nile as far as Khartum and the Blue Nile to Fazogl (1819-23); Adolphe Linant (Belgian) who in 1827 penetrated 150 miles above Khartum; Thibaut (French consul at Khartum, who, with one of Muhammad Ali's expeditions reached as far south as Bôr $\left(6^{\circ}, 30^{\prime} \mathrm{N}\right.$. Lat.); and Ferdinand Werne (German) who got as high up the Mountain Nile as, Gondokoro $\left(4^{\circ}, 20^{\prime}\right)$ and mapped the whole course of the river from Khartum to Gondokoro in $184 \mathrm{I}$. 
failed to do so. On one of his later journeys he was accompanied by Dr Murie, a naturalist, as far as Gondokoro. Theodor von Heuglin, Kiezelbach, Munzinger, and Dr Steudner were among the methodical German explorers who travelled in the Egyptian Sudan and in Abyssinia in $186 \mathrm{I}$ and $\mathbf{1} 862$. The greatest explorer of these regions, however, next to Speke and Grant, was Mr, afterwards Sir Samuel, Baker, who with his wife conducted an exploration of the Upper Nile on his own account with the intention of meeting and if possible succouring Speke and Grant. Baker had previously explored the Abyssinian tributaries of the Nile. After leaving Speke and Grant to continue their homeward journey, he started off for the south to fill up the blanks in their discoveries. The Nile was reached in the Bunyoro country; and after a long detention at the court of the scoundrelly Nyoro king, and enduring incredible sufferings, Baker and his wife discovered the Albert Nyanza, which from various causes he took to be much larger than it really is. The entrance and the exit of the Nile into and out from the Albert Nyanza were visited. The Bakers reached Gondokoro, and then returned homewards in March 1865. Their journey down the White Nile was blocked by the obstruction of a vegetable growth (the sudd). At last this was cut through, and Egypt was eventually reached. When Baker returned to London he was knighted for the discoveries he had made. The Albert Nyanza was afterwards circumnavigated by Gessi Pasha, a Levantine Italian in the service of the Egyptian Government, and by Colonel Mason Bey, neither of whom, curiously enough, noticed the Semliki flowing into the lake, nor did they catch sight of the snow-covered Ruwenzori.

A romantic figure in Nile and Sahara exploration was Alexandrine Tinne. "Young and beautiful (she was only 33 at the time of her death), remarkably accomplished, a daring horsewoman, a charming Diana; mistress of many tongues, including Arabic, and generous to a fault, it is little wonder that she lingered as a beautiful and gracious demi-goddess 
in the remembrance of such Arabs and Nile Negroes of the Egyptian Sudan as were not exterminated by the Mahdi's revolt ${ }^{1}$." Alexandrine Tinne, between I 858 and 1864 , devoted herself to the exploration of the Nile and the Bahr-al-Ghazal. She was accompanied on these journeys by her mother and aunt, both of whom died of blackwater fever. In 1868 Miss Tinne determined to cross the Sahara from Tripoli to Lake Chad, and then travel from Chad to the Upper Nile; but on the way to Ghat, an ancient town inhabited by very fanatical Berbers, she was killed by the orders of a treacherous Tawareq chief, as also were her Dutch attendants.

Livingstone's first great journey resulted in his being sent back with a strong expedition to pursue his discoveries in Zambezia. During these journeys between $185^{8}$ and 1864 the river Shiré was explored, and Lake Nyasa was discovered and partially mapped. Livingstone was accompanied by Dr (afterwards Sir John) Kirk, who made most valuable natural history collections, and whose subsequent long career as Political Agent at Zanzibar and many explorations along the East coast of Africa have caused his name to be imperishably connected with that part of the continent.

The French occupation of Algeria and their conquests in Senegambia had naturally produced considerable exploring work, though, as much of this was done piece by piece, it has not resulted in the handing down of notable names, with some few exceptions. Panet, a Frenchman, in I $85^{\circ}$ travelled overland along the Sahara coast from St Louis, at the mouth of the Senegal, to Morocco. Vincent, another Frenchman, in I 860 explored the country from St Louis to the Adrar district of the Sahara, up to what is nowadays the Spanish Protectorate of the Rio de Oro. Paul Soleillet described the Algerian Sahara; and Duveyrier, a really scientific traveller, made important journeys from Algeria southward and south-eastward,

${ }^{1}$ For a detailed account of Miss Tinne's work and terrible death, see my book The Nile Quest (1903). 
adding much to our knowledge of the Northern Sahara. Duveyrier visited the interior of western Tripoli, and brought back considerable information about the Tawareq and their dialects.

In 1866 Livingstone resumed his explorations of EastCentral Africa. He travelled overland south-westwards from the Ruvuma River to the south end of Lake Nyasa, then northwest and north to the south end of Tanganyika, thence from Tanganyika to Lake Mweru, to the mighty Luapula River, and to Bangweulu, which lakes and river he discovered in I868. Again reaching Tanganyika, he joined some Arabs and crossed the Manyema country eastward to Nyangwe, on the LualabaCongo. From here he returned to Ujiji, where he was met by Mr H. M. Stanley, who had been sent out by the Neze York Herald to relieve the great explorer. After travelling with Stanley half-way back to Zanzibar, Livingstone returned to Lake Bangweulu, and died there in 1873 . Various expeditions had been despatched to his relief. One under Lieutenant Grandy was sent out in 1873 to ascend the Congo, but the expedition was most unfortunate, and the explorer died near São Salvador ${ }^{1}$. After many changes and withdrawals, a great expedition, organized by the Royal Geographical Society, started from Zanzibar in 1873 to find and relieve Livingstone. It was under the leadership of Lieutenant (afterwards Commander) Verney Lovett Cameron. Cameron soon heard of Livingstone's death, but pushed on to Tanganyika, and mapped that lake for the first time accurately. He then travelled across to the Lualaba, which his altitudes practically determined to be none other than the Upper Congo; but, deterred from descending it by the tremendous difficulties that offered themselves, he struck south-westwards across a country not very difficult to traversethe slightly civilized Mwata Yanvo's empire (impregnated with

${ }_{1}$ Dr Bastian had explored the Lower Congo in $185^{8}$; and the region of Loango was examined by a German scientific expedition in $1875_{-80}$, by Bastian, Pechuel Loesche, Falkenstein, and other German explorers. 
Portuguese influence), and reached Benguela in November I 875, the first Englishman to cross Africa.

At the beginning of the sixties Dr Gerhard Rohlfs, one of the greatest of African travellers, began to explore Morocco. He had enlisted in the Foreign Legion serving in Algeria, was a doctor of medicine, a renegade, and had a great knowledge of Arabic. He subsequently travelled about the southern part of Morocco, and penetrated to the oases of Twat and Ghadames in the Sahara (1864), and in 1865 reached Fezzan and Tibesti. In I 866 he started on a journey to Bornu, and eventually penetrated across the Niger to Lagos, on the Guinea coast, thus being the first European to make a complete journey from the Mediterranean to the Gulf of Guinea. In 1873 he explored the oases of the Libyan Desert ; and in 1878 he conducted an expedition, despatched by the German Government, to Wadai, but got no further than the oasis of Kufra. Subsequently two Italians, Dr Pellegrino Matteucci and Lieutenant Alfonso Maria Massari, accompanied as far as Darfur by Prince Giovanni Borghese, travelled across Africa from east to west by way of Suakin, Kordofan, Wadai, Bornu, Kano, and Nupe to the Niger, whence they returned to England, where Matteucci unfortunately died (1882). They were the first Europeans to cross Africa from east to west north of the Equator, but their journey was not productive of much geographical knowledge. From the point of view of knowledge acquired and transmitted, one of the most remarkable journeys ever made in Africa was that of Dr Gustav Nachtigal, who, after having served as physician to the Bey of Tunis, was appointed in $\mathbf{r} 868$ by the Prussian Government to take presents to the Sultan of Bornu. Leaving Tripoli in February 1869 , Nachtigal halted at first in Fezzan, and from that country made a very interesting journey to Tibesti, a mountainous region in the very middle of the Sahara Desert. $\mathrm{He}$ was the first and only European who has really examined this remarkable mountainous region. Returning to Murzuk, he resumed his journey to Bornu, where he arrived in 1870 . 
He thoroughly explored Lake Chad and much of the Shari River, and visited Bagirmi, Wadai (where an earlier German traveller, Moritz von Beurmann, had been murdered in $186_{3}$, when searching for Vogel), Somrai, Darfur, Dar Runga, and Kordofan, thence returning home through Egypt. He brought back with him an enormous mass of geographical and linguistic information. In his journey from Tripoli to Fezzan Nachtigal was accompanied for a portion of the way by Miss Tinne.

Sir Joseph Hooker, the great botanist, already famous for his botanical exploration of the Himalayas, of Australia and New Zealand, and Palestine, in I87 r set out with Mr John Ball on a journey to the Atlas Mountains of Morocco. This resulted in a very great addition to our knowledge of the North African flora and fauna, and of that still imperfectly known and appreciated range of mountains, the highest summits of which may prove to be but little inferior in altitude to the loftiest African peaks. G. Schaudt, a German, explored the Moroccan Sahara in $1879-82$.

On the West coast of Africa the most remarkable journeys made in the fifties and sixties were those of Paul du Chaillu, who travelled in the Gaboon country, and whose natural history collections almost surpass those of any other traveller for their richness and the remarkable forms they revealed. $\mathrm{He}$ will always be remembered as the man who practically discovered the gorilla. Winwood Reade, the first modern African traveller who was at the same time a literary man, visited the West coast of Africa in the sixties, and travelled inland to the source of the Niger. His exploring journeys were of small account, but his descriptions of West Africa are the most vivid, the most truthful, and will perhaps prove to be the most enduring, of any that we possess. (Sir) Richard Burton of Tanganyika fame, who had been appointed Consul at Fernando Pô, ascended the peak of the Cameroons, and visited Dahomé and the falls of the Congo between I860 and 1864. The Marquis de Compiégne and Herr Oskar Lenz explored the Ogowé River, in French West 
Africa, in 1873 ; and later Mr George Grenfell, a member of the Baptist Mission who was afterwards to become still more famous, considerably increased our knowledge of the Cameroons.

In 1876 , Mons. M. J. Bonnat, a French trader, travelled up the Volta River and reached the Muhammadan town of Salagá in the Gold Coast hinterland; thus for the first time, since the vaguely recorded Portuguese embassies to the king of Mosi in the I $^{\text {th }}$ century, bringing Europeans into touch with the Muhammadan lands beyond the forest belt of Central Guinea.

Livingstone's death and Cameron's successful crossing of Africa did a great deal to arouse European interest in that continent. H. M. Stanley was despatched by the Nere York Herald and the Daily Telegraph to complete Livingstone's explorations of the Unknown River. In 1875 he started on that journey which in its discoveries and its results is the greatest feat to be found in the annals of African exploration. He circumnavigated the Victoria Nyanza and Tanganyika, marched across to the Lualaba, and followed its course resolutely and in the teeth of fearful obstacles until he proved it to be the Congo, and emerged on the Atlantic Ocean in 1877 .

Cameron's journeys had aroused the Portuguese from their lethargy. Three explorers, Serpa Pinto, Brito Capello, and Roberto Ivens, were despatched to Angola. Leaving São Paulo de Loanda in 1877 , Serpa Pinto journeyed in zigzags to the Zambezi, and descended that river to the Barotse country, whence he accompanied M. Coillard, the French missionary, across the Kalahari Desert to the Transvaal. Capello and Ivens explored the northern part of Angola and the River Kwango. Two or three years later they started on a journey remarkable for the importance of the geographical results obtained. They explored much of the Upper Zambezi, tracing that river to its source, travelled along the water-parting between the Zambezi and the Congo, and then turned southwards again to the Zambezi, and so out to the Indian Ocean.

In the Nile regions explorations were steadily continuing. 
One of the great African travellers, Georg August Schweinfurth, a native of German Russia (Riga), first visited the Nile valley as a botanist. In $\mathbf{I} 868$ he started on a journey of explora. tion up the White Nile and the Bahr-al-Ghazal, accompanying Nubian ivory merchants. With these he penetrated far to the southwards through the Nyam-nyam country till he reached the Mañbettu country, and there he discovered the Wele River, flowing to the west, which ultimately turned out to be one of the principal feeders of the Mubangi, the great northern confluent of the Congo. Schweinfurth returned to Egypt in I 872 , and for a long time devoted himself to the botanical exploration of Egypt, Arabia and Abyssinia. His journeys, from the enormous amount of material gathered together, were surpassed in importance by few African explorations. Sir Samuel Baker (1868-73) and later General Gordon became Governors-General of the Egyptian Sudan, a vast dependency of the half-European state of Egypt, which naturally, whether under European or Egyptian governors, employed large numbers of Europeans. Amongst those who added to our geographical knowledge were Colonel Purdy-Bey, Colonel Colston, the great General Gordon, and Marno(a Viennese); Colonel Chaillé Long (an American), who visited Uganda, discovered Lake Ibrahim, and actually proved that the Nile flowed out of the Victoria Nyanza, and then into the Albert Nyanza; and Linant de Bellefonds, a Belgian, who also visited Uganda whilst Stanley was there in 1875 , Stanley giving him a famous letter to be posted in Egypt ${ }^{1}$. There were also Colonel Mason Bey and Gessi Pasha, who circumnavigated the Albert Nyanza; poor Lupton Bey, who explored the Bahr-al-Ghazal and Nyam-nyam

${ }^{1}$ This was the letter which Stanley wrote to England appealing to missionaries to come out and settle at the court of the King of Uganda. It was taken away by Linant de Bellefonds to be posted in Egypt. After leaving Uganda, de Bellefonds was killed by the Bari on the Upper Nile. Stanley's letter was concealed in one of the boots of the corpse when it was recovered. It was handed to General Gordon, and transmitted by him to England. 
country and died after long captivity in the Mahdi's hands; and Slatin Pasha, once Governor of Darfur, who had a happier fate.

The establishment of missions in Nyasaland drew explorers thither. Captain Frederic Elton, who had been appointed Consul at Moçambique, journeyed to Lake Nyasa with several companions, explored the northern extremity of the lake, and started to return overland to Zanzibar, but died on the way. His successor as Consul, Lieutenant H. E. O'Neill, crossed backwards and forwards over utterly unknown ground between Moçambique and Nyasa, fixed many positions at the south end of the lake and in the Shiré Highlands, and explored many parts of Portuguese East Africa north of the Zambezi. Bishop Steere, Bishop Chauncey Maples, Bishop Smythies, and other missionaries of the Universities' Mission also explored the country between Lake Nyasa and the River Ruvuma and the Moçambique coast. South of the Zambezi, explorations had been carried out by Baldwin, Baines, Andersson, Eriksson, and other sportsmen-travellers. Karl Mauch and Edward Mohr (Germans) had explored Mashonaland (I866-9); and Mauch had discovered gold in the stream valleys, and the remarkable ruins of Zimbabwe. In 1875 Dr Paul Pogge made a journey from Angola to the court of the Mwata Yanvo. Two other Germans, named Reichard and Böhm, had in the later seventies crossed Tanganyika from Zanzibar, and explored the country to the north of Lake Mweru.

In 1877 , Dr Erwin von Bary, a German explorer, travelled far into the Sahara from Tripoli and Southern Tunis, discovering some remarkable recently extinct volcanoes in the country of Air. He was however killed by the fanatical people of Ghat. In 1877 also a notable journey was made into the Babr-alGhazal province of the Egyptian Sudan by a Greek doctor in the Egyptian service, P. Potagos, who thus crossed into the Congo basin and reached the Mbomu affluent of the WeleMubangi.

A remarkable journey was made in $1878-9$ by $\mathrm{Dr}$ 
R. W. Felkin, who with one or more missionary companions of the Church Missionary Society journeyed overland from Suakin up the Nile to Uganda. They came back again (with the Rev. C. T. Wilson) in I88I from Uganda via the White Nile, Bahr-al-Ghazal and Darfur to Egypt.

Between 1880 and 1887 , Professor J. Büttikofer, a Swiss (afterwards a naturalized Dutchman), conducted a very careful exploration of the coast-lands of Liberia, revealing much that was new and curious in the remarkable fauna of that still littleknown part of West Africa.

The return of Cameron and the subsequent success of Stanley had caused the King of the Belgians to become intensely interested in the exploration of Africa; at first, no doubt, from a disinterested love of knowledge, but soon afterwards with the definite idea of creating in the unoccupied parts of that continent a huge native confederation or state which should become dependent on Belgium. The king summoned to Brussels distinguished 'Africans' from most European countries, with the desire of forming an International Committee which should bring about the complete exploration of Africa. But this international enterprise soon split up into national sections; and what the King of the Belgians had intended should be entirely disinterested geographical work ultimately developed into the "Scramble for Africa." Still, it did lead considerably to the increase of geographical knowledge. The Royal Geographical Society sent out a well-equipped expedition to Zanzibar to explore the country between Tanganyika and Nyasa. It was under the orders of Keith Johnston, who died soon after starting, leaving his task to be fulfilled by Joseph Thomson. Mr Thomson was completely successful, and covered much new ground between Nyasa and Tanganyika to the west of Tanganyika, and to the south, where he discovered the north end of Lake Rukwa. ${ }^{1}$. On the West coast

1 Sir Harry Johnston and Dr Cross discovered the south end of this lake in 1889 . 
the French Section despatched De Brazza to explore what is now French Congo. His geographical discoveries led to annexation. Antonelli and other Italians directed their efforts to the exploration of Shoa, to the south of Abyssinia. But the main outcome of this action on the part of the King of the Belgians was the founding of the Congo Free State.

H. M. Stanley was sent back to the Congo at the expense of a small committee-eventually at the sole charge of the King of the Belgians. While he was by degrees reascending the Congo and making many geographical discoveries, such as the Lakes Leopold and Mantumba, a Baptist missionary already referred to, the Rev. George Grenfell, made known the Mubangi River, the great northern affluent of the Congo, which Colonel A. Vangèle and other Belgian explorers afterwards determined to be the Wele. Lieutenant Hermann Wissmann ${ }^{1}$ (afterwards Major von Wissmann) mapped out the course of the Kasai and other southern affluents of the Congo, and crossed and recrossed Africa, coming out the first time at Zanzibar and the second at the Zambezi. Dr Ludwig Wolf was the main agent in tracing the course of the great Sankuru affluent of the Kasai. Other companions of Wissmann were Major von François and Dr Hans Mueller. Together they discovered the leading southern affluents of the Congo between 1880 and 1886 ; but it must not be forgotten how much they were helped in this respect by the Rev. George Grenfell of the English Baptist mission and his mission steamer the Peace. Grenfell stands second only to Stanley as a Congo explorer. Besides his notable discovery of the Mubangi, he explored the Kwango (also mapped in the middle of its course in 1880 by the Austrian, Major von Mechow), the Kasai, Busira, Lulongo, Lomami, Aruwimi, and Ruki rivers. W. H. Stapleton, Thomas Comber, Dr Holman Bentley, and William Forfeitt, other members of the Baptist mission, and S. P. Verner, an

1 Wissmann was a lieutenant in the Prussian army, born at Frankfurton-the-Oder. He played subsequently a great part in German East Africa. 
American, also explored the Congo basin in the last quarter of the Igth century. J. R. Werner (an English engineer) contributed some surveys of the Mongalla and the Northern Congo ; and Capt. Sidney Hinde (afterwards an English official in East Africa) explored the Lualaba in $x 892-3$. The Belgian explorers who cooperated with English and Germans in the great work of laying bare the intricate mysteries of the Congo basin were, besides the estimable Vangèle, Georges le Marinel, L. van Kerckhoven, A. Hodister, Paul le Marinel, Dr Cornet, Alexandre Delcommune, Captain Baert, and Baron Dhanis.

In 1879 Dr Oskar Lenz, an Austrian who had previously explored the Ogowé, journeyed from Morocco to Timbuktu, and from Timbuktu to Senegambia. Subsequently Dr Lenz ascended the Congo, and crossed over to Tanganyika, returning to Europe by the Zambezi, on a more or less futile attempt to discover the whereabouts of Emin Pasha. In the earlier eighties another Austrian explorer, Dr Holub, travelled in South Africa and made a journey into Central Zambezia. The celebrated hunter of big game, Mr F. C. Selous, not only added much to our knowledge of South-Central Africa (the Rhodesia of to-day), but penetrated north of the Zambezi into the valley of the Kafue river, his explorations in that direction having only been "caught up with" quite recently. Mr F. S. Arnot, a missionary, made a remarkable journey from South to Central Africa, exploring the southern part of the Congo basin (Katanga) and reaching the west coast at Benguela. In I884 Lieutenant Giraud, a Frenchman, carried out an interesting exploration of the Tanganyika plateau and Lake Bangweulu, which he was the first European to map with any degree of accuracy. In 1882 the Earl of Mayo, accompanied by (Sir) Harry Johnston, explored the River Kunene, in South-West Africa. Subsequently Johnston travelled through Angola and up. the River Congo, and on his return journey to England visited that little known part of Africa, Portuguese Guinea. He was subsequently sent on an expedition to Mt Kilima-njaro, 
in East Africa. Amongst other geographical work he visited little known parts of Tunis in 1880 and 1897 ; discovered (with Dr Cross) the southern end of Lake Rukwa, in EastCentral Africa, in 1889 ; in r886-88 explored the Cameroons and the Niger Delta; made numerous journeys in "British Central Africa" (Nyasaland and Northern Rhodesia) in 188995 ; and added a little to geographical knowledge in East Africa, Uganda, and on Mt Ruwenzori in I899-I90I.

In $\mathrm{r} 883$, Joseph Thomson, already famous as an African explorer, was sent on a most important mission by the Royal Geographical Society. He was to cross the nearly unknown country separating the Mombasa littoral from the east coast of the Victoria Nyanza, between the two great snow mountains of Kenya and Kilima-njaro (Kilima-njaro since Krapf's and Rebmann's reports had been thoroughly mapped by Baron von der Decken; it had also been ascended nearly to the snow level by Mr Charles New). Joseph Thomson practically rediscovered Kenya (Krapf's account being so vague that it had become regarded as semi-mythical), and photographed this second loftiest snow mountain of Africa. After some difficulties he succeeded in penetrating the Masai country, and described the great Rift valley of Lake Naivasha (reached a year or so earlier by the German explorer, Fischer); discovered Lake Baringo and Mount Elgon, and finally reached the northeast coast of Victoria Nyanza-a most remarkable expedition, resulting in great additions to our geographical knowledge. Thomson subsequently made a journey from the mouth of the Niger to Sokoto, explored the Atlas Mountains of Morocco, mapped much fresh country in Central Zambezia, and died, still a young man and much regretted, in I895. The Hungarian, Count Samuel Teleki, who followed in Thomson's footsteps, discovered Lakes Rudolf and Stephanie. Lieutenant Höhnel, who went with him, conducted other expeditions in the same direction and accomplished admirable surveying work. 
Then came the last epoch-making journey of Stanley-the search for Emin Pasha. After the British occupation of Egypt and the loss of the Sudan, Emin Pasha had retreated to the Equatorial Province. Through Dr William Junker (a Russian traveller, who had made journeys in the western watershed of the Nile, reached the Nepoko affluent of the Aruwimi, and brought back great additions to our geographical knowledge of the Nile-Congo water-parting) he managed to communicate with Europe by way of Uganda, making known his condition, and appealing for help. Stanley was placed at the head of a great British expedition which was to go to his relief. He travelled by way of the Congo, and at the junction of the Congo and the Aruwimi entered the unknown. He crossed that always difficult barrier, the Bantu borderland-in this case an almost impenetrable forest. After overcoming innumerable obstacles, Stanley met Emin Pasha on the Albert Nyanza, and eventually escorted him to the coast at Zanzibar. In the course of this journey Stanley discovered Ruwenzori, the third highest mountain in Africa, the Edward Nyanza (one of the ultimate lake sources of the Nile), and the Semliki River, which connects the Edward with the Albert Nyanza. Stanley's explorations were much assisted in this journey by his excellent lieutenant, Captain Stairs, who was the first to attempt Ruwenzori and who subsequently explored Zambezia and Katanga.

In West Africa, which had for some time been neglected as a field for exploration, there still remained gaps to be filled up -in the great bend of the Niger and behind the Cameroons. In the last-named country German travellers-Dr Zintgraft, Lieutenants Morgen, Kund and Tappenbeck, Von Stettin, Uechtritz and Dr Passarge-explored the mountainous country between the Cameroons and the Benue watershed, or traced the course of the great and hitherto quite unknown rivers of Lom and Mbam, which unite and form the Sanagá, a river which enters the sea on the south side of the Cameroons 
estuary. Dr Oskar Baumann ${ }^{1}$ also explored the neglected island of Fernando Pô. In the bend of the Niger various French explorers and one or two Germans and Englishmen filled up the blanks. Notable among these was Captain (afterwards Colonel) L. G. Binger, who was the first to make known much of the country between the Upper Niger and the Gold Coast ; and Colonel P. Monteil, who travelled across from the Upper Niger to the Central Niger, and thence to Lake Chad and Tripoli (I890-I). Colonel Binger's journeys may be placed in the first rank of African explorations. They were undertaken between $\mathbf{I} 886$ and $\mathbf{r} 889$, and the results were published in r892 (Du Niger au Golfe de Guinée). Together with the work of Colonel Monteil, of Commandant Georges Toutée, and of the German G. A. Krause, the English Captains R. L. Lonsdale and Brandon Kirby, the Gold Coast native explorer G. E. Ferguson, and Colonel H. P. Northcott, Binger's surveys showed the comparative narrowness of the Niger basin in the great bend of the Niger. Much of the enclosed land is drained southwards into the Gulf of Guinea by the Black and the White Volta, two streams uniting after very long courses to form the main Volta. This is an important river constituting the boundary (except at its estuary) between German Togoland and the British Gold Coast. Binger did for this region what Grenfell and Wissmann did for the secondary mysteries of the Congo basin. The eastern half of the Niger course, from its mouth upward to Sokoto, had been carefully explored in I880-I by the German E. R. Flegel ; and this last most noteworthy explorer in $1882-4$ traversed the unknown southern basin of the Benue, and traced that river to its ultimate source near Ngaundéré. The gap between the basin of the Congo and Lake Chad was filled up between r89o and 1900 by the explorations of Paul Crampel, Dybowski,

1 Baumann made a careful examination of the mountainous country of Usambara in East Africa, and mapped the lands due west of the Victoria Nyanza. 
C. Maistre, E. Gentil, A. Bernard, F. J. Clozel and other French travellers.

Between r889 and 1895, Sir Alfred Sharpe (afterwards Governor of Nyasaland) gradually mapped Lake Mweru, discovered the large salt marsh between that lake and Tanganyika, explored the Luapula and the Luangwa, and made other interesting additions to the map in South-Central Africa, discoveries supplemented by the survey of Lake Bangweulu by Mr Poulett Weatherley. Captain Hore, an agent of the London Missionary Society, made a survey of Lake Tanganyika between I 878 and I889; and his discoveries in its water fauna were so remarkable that $\mathrm{Mr}$ J. E. Moore (a scientific zoologist) was sent out in 1896 to study the prawns, jelly-fish and water molluscs of Tanganyika, the remarkable character of which had first been noted by Böhm (1879) and Hore. Moore afterwards explored the snow-crowned volcanoes of Mfumbiro (Virunga) and thence proceeded to Ruwenzori (Mubuku valley) and Uganda. $\mathrm{He}$ had previously explored the water fauna of Lakes Shirwa and Nyasa. Count Goetzen explored the unknown country between Lake Edward Nyanza and Tanganyika, discovering the lofty volcanoes of Virunga and Lake Kivu; and Mr Scott Elliott journeyed from the east coast to Mt Ruwenzori, and thence to British Central Africa for botanical purposes.

The great eastern horn of Africa, Somaliland and Galaland, was long left unexplored after Burton and Speke's journey to Harrar in the fifties. At the beginning of the eighties its exploration was again attempted. Messrs F. L. and W. D. James, with three companions, penetrated Somaliland as far south as the Webbe Shebeili River. They were succeeded in exploration by Révoil (a Frenchman), by Ruspoli, BricchettiRobecchi and Bottego (Italians), and by Borelli (a Frenchman). The last-named made a most important journey south from Abyssinia, and discovered the Omo River. His account of his travels, published by the French Government, is an almost perfect exemplar of what such a work should be. Mr W. Astor 
Chanler, an American, afterwards made an important rough survey of Galaland, north of the Tana River. Dr J. W. Gregory, of the British Museum, travelled to Lake Baringo and Kenya, which mountain he ascended higher than any preceding explorer. Dr Gregory's journey was productive of much information regarding the geology of the countries traversed. Dr Donaldson Smith (an American) travelled in 1894-5 over these countries between Somaliland and Bantu East Africa, bringing back much new material for geography. Captain (now Colonel) H. G. C. Swayne explored the interior of Somaliland; Colonel Seymour Vandeleur surveyed Uganda and Unyoro; Colonel Sir J. R. L. Macdonald in $1897-9^{1}$ conducted a most important expedition, which for the first time traversed the mountainous country between Mt Elgon, Lake Rudolf and the Mountain Nile, revealing much new geography and ethnology ; and $\mathrm{Mr} \mathrm{H}$. S. H. Cavendish in 1897-8 made a remarkable journey across the eastern horn of Africa from the Gulf of Aden to Lake Rudolf and Mombasa.

In I 899, Mr H. Mackinder ascended the snow peak of Kenya to its highest summit. Nine years previously the great extinct volcano of Elgon (Equatorial East Africa) had been climbed to its highest point (I 4,000 ft.) by an expedition under Messrs F. J. Jackson and Ernest Gedge. C. W. Hobley also added a great deal of detail to our knowledge (geographical and ethnological) of inner East Africa, from Elgon to the German frontier in the south, between 1896 and 1912 .

The main features of German East Africa had already been discovered before Germany took possession politically of the region between the Zanzibar Coast and the great Lakes; but in $\mathrm{r} 889$, Dr Hans Meyer achieved the great feat of ascending the highest mountain in Africa-Kilima-njaro-to its summit

${ }^{1}$ Sir J. R. L. Macdonald (then Captain Macdonald, R.E.) had conducted with Captain Pringle, R.E. a very remarkable railway survey at the beginning of the nineties, from Mombasa to the Victoria Nyanza, a survey which was really a geographical exploration of the East Africa Protectorate. 
(I9,32 I feet). Oskar Baumann (a Viennese) examined in some detail the northern parts of German East Africa between I 888 and I 893 , visiting the ultimate sources of the Nile (the headwaters of the Kagera river) near the north-east coast of Tanganyika and discovering or describing for the first time tribes with puzzling linguistic affinities, such as the Sandawi. The journeys of Dr Franz Stuhlmann both alone and with Emin Pasha, especially in regard to the Tanganyika-CongoNile water-partings were of great interest both to geography and ethnology. Honourable mention must also be made of Captain Paul Kollmann, whose travels round the south shores of the Victoria Nyanza and its islands resulted in an admirable book on the people and languages of that district.

Between I884 and I900, much important exploring work was done in German South-west Africa by H. Schnitz, Dr von Passarge, Drs A. Schenk and Stromer von Reichenbach. Togoland in West Africa was explored during the early nineties by Dr R. Büttner (already known for his journeys in West Congoland), by L. von Bunnon and N. Seidel.

Renewed interest in Morocco was shown during the last quarter of the igth century. Besides the bold journey of Joseph Thomson to the Atlas mountains in I888, there was the really remarkable exploration of nearly the whole Moorish empire in 1883-6 by Charles de Foucauld, a Frenchman travelling in disguise. Walter B. Harris crossed the Atlas into Tafilalt in I895. In Central Africa Colonel J. B. Marchand and his companions performed a wonderful journey in r895-9. Entering French Congo from the Loango coast, Marchand travelled up the Congo and Mubangi Rivers till he paused for a further organization of his mission near the Congo-Nile waterparting. Then he transported his little steamer in sections to the Suē, a confluent of the Bahr-al-Ghazal, and thence navigated the western confluents of the Nile till he reached the main stream. Pursuing his journey east and north, he reached the old Egyptian station of Fashoda on the White Nile, where 


\section{XII] Marchand, Madagascar, Sahara}

he established himself, and where he defeated a small body of Dervishes sent against him by the Khalifa of Omdurman. The advent of the British and Egyptians under Lord Kitchener rendered the evacuation of Fashoda by Marchand necessary. The gallant French explorer therefore continued his journey eastward by following up the Sobat River as far as it was navigable, and thence struck across hitherto unknown countries, and travelled through Shoa and Somaliland to the French port of Jibuti, on the Gulf of Aden. From the point of view of distance traversed, without great loss of men or material, Marchand deserves to rank as a hero of African adventure.

The only travellers in Madagascar who achieved important resuits in geography and physical science were the English missionary, the Rev. J. Sibree (1868-85), and above all Dr Alfred Grandidier (1875-1900), E. F. Gautier (1892-9), and Dr G. Grandidier (r898-r902). To the last-named is mainly due the recent discoveries of semi-fossil extinct lemurs described in the publications of the Zoological Society of London. To Alfred Grandidier we owe the magnificent work in 28 volumes which completely describes this strange island.

At the close of the rgth century France began to take definite possession of the Sahara; and several expeditions, scientific and political, traversed this desolate region and revealed all its leading physical characteristics. Prominent among French explorers was Fernand Foureau, who concluded ten years of varied explorations by a magnificent journey in $\mathrm{r} 898-9$ from Algeria to Zinder and Lake Chad by way of Ahaggar, Air and Damerghu. G. B. M. Flamand explored the important oasis of Tuat in 1900 . Much exploring work went on in the Niger Bend and the Ivory Coast hinterland; and the expedition (r 898-r 900) of M. Hostains and Captain d'Ollone revealed great mountains and the courses of numerous rivers in north-east Liberia.

This record brings us down to the beginning of the 2 oth century. The least-explored parts of Africa that then remained 
were: (I) the interior of Liberia; (2) the region between the Benue and Cameroons watersheds; (3) Lake Chad and the country between Lake Chad, the Shari, and the Nile; (4) the Western Sahara; (5) the Libyan Desert and Tibesti; (6) Wadai; (7) the region between the Shari, the Benue, and the Mubangi; (8) that between the Cameroons, the Sanga river, and the Mubangi; (9) South-west Congoland; (10) South-east Angola; (II) the Moçambique hinterland, between Moçambique and Lake Nyasa; (12) South-west Galaland and the region between the Sobat River and Lake Rudolf.

In regard to the first-named area, a good deal has been added to our knowledge by the Dutch survey officers, Naber and Moret, by Mr John Parkinson and Messieurs A. Chevalier and Maurice Delafosse; the last-named having accomplished a remarkable language survey of West Africa. In No. (2), must be recorded the journeys of Captain E. Lenfant (who proved the connection between the Upper Benue and the Shari system by way of the Tuburi marshes); of Colonel L. Jackson; of P. Amaury Talbot (Benue, Cross River, and Ekoi country); and of the German explorers F. Hutter, F. Bauer, and O. Zimmermann. As regards No. (3)-Lake Chad-this firstdiscovered of all African lakes was never properly investigated and mapped until the beginning of the 2oth century, when this work was accomplished by the expeditions of Captain Lenfant, Colonel Destenave, Mons. A. Chevalier, and Captain Tilho. It was also examined with much minuteness by Lieutenant Boyd Alexander, whose Niger-Benue-Mubangi-Nile journey in I $9 \circ 5$ greatly added to our knowledge of the Chad region. In No. (4), the Western Sahara and Southern Morocco, we have had the important explorations of the French officers or civilians, La Perrone, Arnaud, Paul Blanchet, Edmond Doutté, Cortier, Niéger, and Gautier (this last specially studied the rock-engravings and archaeology); and the noteworthy journey of the Englishman, Captain A. H. Haywood, who travelled from Sierra Leone to Algiers. No. (5), still remains one of the 
blankest parts of Africa, though the Eastern Sahara from Tripoli to Bilma was crossed by Mr Hanns Vischer of British Nigeria in 1906. The Libyan Desert is also being explored by W. Harding King and other British explorers coming from Egypt. In Wadai, which was traversed by Lieutenant Boyd Alexander in rgro (he was killed on the Darfur border), the French military occupation will soon produce a detailed survey. In No. (7), there have been the detailed explorations of Captain E. Lenfant, and Messrs E. F. Gautier and R. Chudeau, on behalf of the French Government. The principal blanks in No. (8) have been filled up by an English traveller, Mr G. L. Bates (a remarkable field naturalist who has made very important discoveries of new vertebrates in West Equatorial Africa), by O. Zimmermann and other German explorers. In South-west Congoland a great explorer and anthropologist has come to the front, Mr Emil Torday, a Hungarian, whose admirable works on the Bushongo and the tribes of the Kwango, Kwilu, Kasai, and Sankuru rivers, have been published in English and French. Mention should also be made of the journeys through central and northern Congoland of an Austrian, Franz Thonner, which have been of great value in determining the intricate distribution of language families in that region. South-west Angola still remains very little known, though the work of the Lobito Bay-Katanga railway is gradually casting a light on the geography of this region; while in Barotseland and Northern Rhodesia there have been the firstclass surveys of Major A. St Hill Gibbons, Frank Melland, and other officials of the British South Africa Company. A good deal of accurate surveying and geological investigation is needed in No. (II). In No. (I 2 ) (Southern Galaland and the Sobat to Lake Rudolf), there have been since 1900 the remarkable explorations and surveys of Oskar Neumann (a German), Captain M. S. Wellby, Captain H. H. Austen and Captain P. Maud-English officers travelling on their own bebalf or on that of the British Government. 
Dr Richard Kandt, a German, between I90I and I906, made a thorough and careful survey of Lake Kivu, of the plateaus at the northern end of Tanganyika, and of the Kagera (the ultimate Nile source) and its tributaries. Between I900 and 1904 , Commander B. Whitehouse mapped the entire coastline of the Victoria Nyanza Lake, making many new discoveries and remedying many old errors of delineation.

The long-talked-of journey from the Cape to Cairo was accomplished first in 1900 by Mr Ewart Grogan, followed soon afterwards by Mons. Lionel Décle. Many tourists and officials subsequently have repeated this feat, rendered comparatively easy now by the development of railways and river-steamboat navigation. A noteworthy journey however was that in I9I I of Mr Frank Melland and a companion on bicycles, from Rhodesia to Egypt. German officers have motored across Africa, from German East to German South-west Africa.

Noteworthy feats in exploration, though they may not have revealed much that was new in cartography, have been the journeys and studies of Lieut. P. H. G. Powell Cotton (Abyssinia, East Africa, Congoland and Portuguese Guinea-Igoo-II); Auguste Chevalier, the French botanist (Central Sudan, Upper Niger, West Congoland and Liberia-r898-ı9ro); Alexander Whyte, a Scottish botanical collector (British Central Africa, East Africa, Uganda, and Liberia-189I-1904); Dr W. A. Cunnington (Tanganyika, I904-5); H.R.H. the Duke of the Abruzzi, who in 1906 made the first complete survey of the Ruwenzori range and ascended all the highest peaks; A. Savage Landor, who crossed Africa at its broadest, mainly on foot, from Somaliland to Senegal ( Africa and Egyptian Sudan, I909-10); and Sir David and Lady Bruce (Uganda, Nyasaland, and Northern Rhodesia-I 903-II).

The heroic stage of African exploration finished with the I 9 th century; and it is impossible to record the names of all the military and civil officials who have since been quietly, 
painstakingly, and usefully filling in the details between the broad outlines drawn (at the cost of terrible fatigue, severe illhealth, and danger from savage natives) by the great explorers of the past. There are still many high mountains to be ascended -in the Atlas, in Tibesti, on the north Liberian border, on the south-eastern limits of the Niger basin, in the Cameroons, south-west Moçambique, south-east Angola and northern Galaland; there are lakes to be plumbed, geological formations to be determined, zones of vegetation and distribution of the rapidly-disappearing fauna to be defined. Archaeology in South-east Africa, in the Sahara, in Morocco and Somaliland, still has some surprises in store for us. The palaeontological exploration of Africa is merely beginning; and already in Algeria, Egypt, East and South Africa, and Madagascar research has produced evidence of an amazing vanished fauna of giant buffaloes, giant dinosaurs, giant birds, big horses, small dinotheriums, of the remote ancestors of the elephants, whales, sirenians, hippopotami, giraffes, monkeys, and anthropoid apes. A more careful search after living types has already revealed since 1900 the okapi in the north-east Congo forests, the big black pig of Equatorial Africa, and several new antelopes and monkeys. Botanical research has, since 1900 , shown the existence in Africa of some thirty sources of good rubber, and of many valuable gums and oil-nuts. Gold has been found in the north-east Congo basin, tin in Nigeria, and diamonds in German South-west Africa, in south-west Congoland, and in Liberia. Africa will probably remain in the future, what it has seemed to the Caucasian since he began his historical colonization-the most interesting and mysterious of the continents, always producing something new. 


\section{CHAPTER XIII}

\section{BELGIAN AFRICA}

IT has been already related in the preceding chapter how the geographical ardour of the King of the Belgians resulted in the sending of Stanley with an important expedition to explore the Congo. Previous to this enterprise, however, King Leopold II had shown himself deeply interested in the fate of Central Africa. Following on the successful crossing of the continent from the Zanzibar to the Benguela coast by Commander V. L. Cameron, R.N., and his revelation of the richly endowed territories of the Southern Congo basin, King Leopold had summoned to Brussels under his own presidency a conference of geographers, which created an International Association for the Exploration and Civilization of Central Africa and for the abolition of the Slave Trade which then was really ravaging that region. This International Association soon separated into a number of National Committees; that of Belgium was founded in November, 1876, and in 1877-79 Belgian Expeditions were sent out via Zanzibar to Tanganyika. By August, r879, Capitaine Cambier (an excellent pioneer), had founded the station of Karema on the south-east Coast of Tanganyika. Captain E. Storms established himself here (together with the White Fathers' Catholic Mission) in I 880, and set to work to unite the Tanganyika tribes in self-defence against the Arab slave raiders. Storms became quite a hero after beating off the Arab forces with merely native material, hastily drilled as 
soldiers. By $\mathrm{r} 885$, he had become recognized as the great White Chief and Protector of southern Tanganyika.

In 1879 from out of the Belgian branch of the African International Association there grew the Comité d'Études du Haut Congo, which projected the idea of Stanley's concluding in its name treaties with the paramount chiefs of the Congo region, treaties by means of which these chiefs should agree to join in a sort of confederation for purposes of mutual support, while at the same time they admitted into their territories the traders who would be sent out by the Committee, which was in some sort to become the suzerain of this Congo Federation. Mr Stanley appears to have been under the impression that the final protectorate over the central Congo would be a British one; until $\mathrm{s} 884$ few people seemed to think that the King of the Belgians would make himself the sovereign of the Congo. In the early eighties a kind of Anglo-French duel had taken place on the Congo, De Brazza representing the French cause and Stanley the British. When it began to dawn on the British Government that the King of the Belgians was working for purely Belgian interests, it occurred to them that there was no reason why England and Portugal might not come to terms, at any rate about the Lower Congo. So the abortive treaty of $\mathrm{r} 884$ was drawn up, but not ratified. Believing that this was a preliminary to a British Protectorate of the Congo, France and Germany joined hands ; and a Conference on African affairs was convened at Berlin, the first of a long series of actions taken jointly by the other states of Europe to check the extension of British influence.

At the Berlin Conference of $\mathbf{1} 884-5$ the Congo Independent State $^{1}$ was recognized by all the leading powers of Europe as a

1 It was never officially styled the Congo "Free" State. The meaning of the French words was "the Independent State of the Congo"; and unhappily it was no more "free" in its subsequent history than in name. Bula Matadi was its local title in Congoland, such being Stanley's nickname (Rock-breaker). 
sovereign state with the King of the Belgians at its head. The boundaries were not definitely fixed, but the west coast of Tanganyika was made the eastern limit; and Captain Storms, to his great chagrin, was recalled. Before giving her consent, however, France reserved to herself the right of preemption over these Congo territories, besides securing by an agreement with the King of the Belgians a large portion of western Congoland. $\mathrm{Mr}$ (afterwards Sir Henry) Stanley then ceased to administer the Congo State, and was succeeded first by Sir Frederick Goldsmid, and then by Sir Francis De Winton, who governed for the King of the Belgians, but gave a distinctly English tone to the administration. Mons. Camille Janssen, however, succeeded Sir Francis De Winton in 1886 ; the international character of the state was dropped; and the British, French, Portuguese, Swedish and German officials were gradually replaced by Belgians, so that by $\mathbf{r} 891$ the entire administration was Belgian. Stanley, however, had once more intervened (in r887) in the affairs of the Free State, which had got into great difficulties owing to the attacks of the Zanzibar Arabs on the Upper Congo. Stanley temporized, seeking to gain time for the young state, and recognized Tipu Tipu ${ }^{1}$, the leading Arab, as Governor for the King of the Belgians over the Upper Congo. Tipu Tipu withdrew about $189^{\circ}$, when the Arab revolt against the Germans had caused grave tension between the Arabs and Europeans in Central Africa. After his withdrawal, the Arabs, who had now become extremely powerful on the Upper Congo, attacked the Belgians in 1892 , murdering a trader, Hodister, and the unoffending Emin Pasha, and imprisoning and eventually killing the Belgian resident and his assistant at the Arab capital (Kasongo), besides massacring the men at several outposts. The forces of the State-largely composed of Congo natives with a few Hausas from Nigeria and one or two noteworthy Liberian negroes-were ably led

${ }^{1}$ Hamed bin Muhammad bin Juma, nicknamed Tipu Tipu or "Tippootib." 
by nineteen Belgian and one English officers, and commanded by Commandant (afterwards created Baron) Dhanis. The English officer referred to was Captain (originally Surgeon) Sidney L. Hinde, afterwards a British official in East Africa.

Dhanis commenced, in July $189^{2}$, a most noteworthy campaign from a base-Lusambo-on the Sankuru river. His little army marched through forest paths to the Lomami and thus took the Arabs in flank. From the Lomami the Belgian force gained the banks of the great Lualaba-Congo, and, victory succeeding victory, they captured Nyangwe (the great Slave City of Livingstone's day) on March 4, 1893, and carried Kasongo (the Arab stronghold) by assault on April 22, 1893. The story, as told by Captain Sidney Hinde ${ }^{1}$, of the capture of Nyangwe and Kasongo reads like episodes in an impossible Rider Haggard romance. It was one of the greatest feats of arms, of endurance and splendid courage that the history of Africa can show. By the beginning of 1894 , the Belgians had achieved the conquest of the whole of the country up to the west shores of Tanganyika, and the death or expulsion from Congoland of all the Arab leaders. This brilliant episode in Belgian Congo history was however sullied by the judicial murder, in September, r893, of Gongo Lutete, the great Manyema chief who at the commencement of the struggle with the Arabs had come over to the Belgian side and whose alliance alone made victory possible to the Belgian force. The execution of this warrior chief-without respite or appeal, on no credible evidence of treachery-following a drumhead court-martial presided over by a young Belgian lieutenant, is as painful to read as the preceding campaign of Baron Dhanis against the Arab slavetraders is a source of satisfaction to all interested in the welfare of Africa. The Belgians were eventually to pay dearly for this miscarriage of justice. The remembrance of the death of Gongo Lutete smouldered amongst the negro soldiery he had

1 The Fall of the Congo Arabs, Methuen, 1897. This campaign is also described in my book George Grenfell and the Congo. 
raised for service with the Belgians; and in 1895 they broke out into open mutiny at Luluabourg and killed their Belgian commanding officer. Baron Dhanis composed this mutiny by punishment and negotiations; but in 1897 the mutiny broke out again amongst those Manyema and Batetela soldiers who had been transferred to the Lado enclave of the Nile basin. The revolt spread far and wide and was not at an end till 1900.

In I892, King Leopold II, alarmed by the progress of the British South Africa Company, sent out an expedition under Captain Stairs (Stanley's former Lieutenant-a Nova-Scotian) to occupy in his name the territory of Katanga, which was a debateable land, to some extent under British missionary influence, but claimed as lying within the boundaries of the Congo State. Its king (Msidi) was an Mnyamwezi adventurer and slave trader; nevertheless he had ruled his country with a certain degree of wisdom, and had permitted British missionaries to settle there and British travellers to explore; therefore it was learned with some regret that he had been summarily shot for refusing to hand over his territory to the Belgians. Not content with the gigantic dominion already under his control, the King of the Belgians aspired to extend it to the banks of the White Nile. In I 894 an agreement was concluded with the British Government by which, in exchange for a strip of territory which would enable the latter to connect the northern end of Tanganyika with Uganda, the King of the Belgians took over on lease the administration of territories as far north as the Bahr-al-Ghazal and the White Nile. But this settlement was practically annulled by the subsequent Belgian convention with France, which restricted the northern boundary of the Congo Independent State to the Mbomu affluent of the Wele River, while the King of the Belgians retained for a time the lease of a small patch of territory on the west bank of the White Nile, opposite Lado.

Another event in the recent history of the Congo State, 
which has caused some anger in England, was the summary execution of the unfortunate Charles Stokes by a Belgian officer named Lothaire. Mr Stokes (who was an Ulster Irishman) had once been a missionary, and used to travel backwards and forwards to Uganda. He then set up for himself as a trader, and, although a British subject, he was sufficiently international in his sympathies to work for the Germans in helping to found their East African colony. In the course of his ivory-trading expeditions he entered the Congo State. It was suspected by Lothaire that he was furnishing the Arabs with powder; he therefore sent a messenger to Stokes, summoning him to his camp. Stokes came unsuspecting. He was put through a cross-examination over-night, and in the early morning taken out of his hut and hanged. In plain language, he was murdered; for not only did he receive no trial, but at that time British consular jurisdiction was maintained in the Congo State, and no sufficient evidence was brought forward to show that Stokes had sold any powder to the Arabs, or done anything worthy of death. Major Lothaire was tried for the murder of Stokes both at Boma and again at Brussels, but was pronounced not guilty at each trial, and was regarded by a portion of the Belgian press as having been a national hero. He was, however, eventually dismissed from the service of the Congo Free State, and an indemnity of $£ 6000$ was paid to the child of Stokes.

In July i 898 , there was opened for public use (largely through the enterprise of Colonel Thys) a railway from Matadi to Stanley Pool, about 250 miles long, which had taken about $8 \frac{1}{2}$ years to construct, but which, once finished, was of enormous aid in the development of the natural resources of Congoland. Matadi is a port on the lower Congo ( $\mathrm{r}$ i 0 miles from the sea), up to which ocean-going steamers are able to ascend. From Léopoldville on Stanley Pool there are between 4000 and 5000 miles of navigable waterways along which steamers and steam-launches can penetrate into the hinterland of French Congo and the 
Cameroons, to within a few days' journey of the Central Sudan (Shari basin) and the Egyptian Sudan, German East Africa and Rhodesia.

But the effects which followed the opening of this railway were different from King Leopold's anticipations. It was discovered-slowly--by European public opinion that one of the boldest outrages on international law and equity known to history had been perpetrated by the man who had posed before Europe in 1876 as a disinterested philanthropist desirous of devoting his spare funds to the realization of Livingstone's ideals, and to the regeneration of Negro Africa. By means of Stanley he had between 1879 and $\mathrm{r} 885$ founded his Congo Independent State, basing his right to call himself "RoiSouverain" of this vast dominion on a number of treaties made by his agents in the region now known as French Congo, and also along both banks of the main Congo river from the sea upwards to the Kwa-Kasai confluence; that is to say, over only one-fortieth part of the area he claimed to govern by the assent of its native chiefs as well as of Europe.

Two of the numerous conditions imposed on his government of the Congo were freedom of trade throughout the Congo basin, and the right of missionaries to travel, to settle, and to build where they would, without hindrance. Yet no sooner was King Leopold II acknowledged internationally as KingSovereign of the Congo State than he began to set on one side all such stipulations of the Act of Berlin as fettered his intentions of self-enrichment and unquestionable autocracy. Freedom of trade, except at the mouth and along the estuarine Congo, became an impossibility. By $\mathrm{I} 890$, in the Congo basin above Stanley Pool, ivory had been constituted a State monopoly; and rubber was soon placed in much the same category. Commerce was chiefly restricted to the State, and to one Dutch and various Belgian firms, though commercial agencies on the Lower Congo wêre still maintained by merchants of other nations. 'This policy on the part of the Congo State, which on 
the strength of its philanthropic assurances had obtained permission in $189 \mathrm{I}$ to levy import duties, was much criticized, and led to some alienation of sympathy in England. Added to this were the extraordinary stories of atrocities which began to be spread by British, American, and Swedish missionaries. It was said that, to enforce the payment of tribute in ivory and rubber, the Belgian officials ordered their negro subordinates to cut off the hands of all who refused payment. It was stated that the natives were plunged into a slavery worse than anything the Arabs had introduced, that they were shot down for trifling causes, and that the negro police and soldiers of the State were allowed without hindrance to devour the bodies of the slain in battle. These charges in some cases were scarcely credible as applied to the actions of civilized human beings; King Leopold in 1896 instituted a committee of missionaries to enquire into them, and to offer suggestions for better methods of administration. But the committee was fettered in many ways and prevented from obtaining evidence. The charge of permitting cannibalism has been substantiated by the accounts of Captain S. L. Hinde, already referred to, and by other British officers in the Congo service. The fact was, that a territory nearly as large as Brazil had been handed over to be governed by a number of young Belgian officers and the employés of a few concessionaire companies. The subordinates whom they employed in their administration and warfare were savages barely reclaimed from the most barbarous practices; and just as, in a far less degree, the Matebele police of the British South Africa Company were guilty of malpractices that the Company would never knowingly have allowed to be perpetrated, so the negro soldiers of the Congo State committed appalling outrages before their officers could become cognizant of their intended actions and prevent them. But nothing can be said in excuse or mitigation of the behaviour of certain agents of privileged companies and even persons employed on the private domain of King Leopold, 
whose actions as recorded in undisputed evidence were almost those of devils.

In July I 885 the King-Sovereign of the Congo State issued a decree that all vacant land within the boundaries of the State were the "private property" (the Domaine privé) of the Government; the Government being then and for twenty-five years afterwards the despotic King-Sovereign. Little objection was raised to this measure at first, the general idea (very similar to announcements made then and later by other European Powers in their African possessions) being that King Leopold wished to protect the rights of the natives from being hurriedly and foolishly sold to private speculators in land, or concessionhunters. But in I891 a "secret decree" was sent out from the King's cabinet, reserving to the State all elephants and their ivory and all wild rubber and forest-produce on the "vacant lands" of the Domaine privé. The officers of the State were enjoined to organize the collection (as a form of taxes) of all the ivory and rubber procurable; and the natives of Congoland (except the small western strip near the Atlantic) were obliged to sell all their produce to the State only. By a later decree they were actually forbidden to leave their villages without a special permit. In short, so far as the KingSovereign's writ ran, the whole population of Belgian Congonearly a million square miles-was virtually enslaved, and this by the man who in 1876 stood up before Europe and announced that he was going to devote such of his time and money as he could spare from Belgium to the abolition of slavery in Central Africa and the raising of the Negro to a condition of freedom and enlightenment.

In 1896 another "secret decree" created the Domaine de la Couronne, and carved out for King Leopold II an area of I I 2,000 square miles in the very heart of Congoland, between the Sankuru and the Busira rivers. This region, amazingly rich in wild rubber, was to be privately administered by Leopold II without rendering any account to the State exchequer, 
and of course without laying its enormous revenues (wrung from the inhabitants by cruelties and stress scarcely surpassed by the recently-revealed horrors of the Putumayo) under any contribution towards the annual expenses of public administration in the Congo State. In addition, the whole rest of the Domaine privé (except always the exhausted strip along the Congo banks between Stanley Pool and the sea) was divided up into regions strictly reserved for a State monopoly of products, and others which were farmed out to concessionaire companies, in which either the State, or King Leopold, or both, were partners in profits. To these concessionaire companies were at first given almost unlimited powers over the natives, from which resulted the frightful abuses that shocked the conscience of Europe and Anglo-Saxon America. One foreign trading-house which might have protested was squared by being given part of the plunder; most other old-established trading houses on the Lower River were prevented from trading inland; influential Englishmen (not forgetting several connected with the press) were admitted to this profit-taking; and for some twelve years these truly iniquitous proceedings were ignored, in spite of the missionary protests which began in I898, and of Mr Fox-Bourne's trenchant attack ${ }^{1}$ on King Leopold's policy published in 1903 -ignored, that is to say, by the governments of the States which had taken part in the Berlin Conference of $\mathbf{1 8 8 4}$. Statesmen of probity found it impossible at first to believe that Leopold II, King of the Belgians, grandson of Louis Philippe, cousin of Queen Victoria, husband of an Austrian Archduchess, a devoted upholder of the Roman Church, and a very rich man, could'for a moment lend himself to a policy at once infamous, flagrantly unjust, exceedingly cruel, and incredibly mean ${ }^{2}$. The gallant actions of many a

1 Civilization in Congoland.

2 The direct trading agents of King Leopold and his concessionaire companies, and the ofttimes worthy and gallant servants of the Congo State, were miserably underpaid. 
Belgian pioneer on Tanganyika and on the Lualaba-even on the fringe of that Egyptian Sudan which Great Britain then lacked the resolution to enter-were pointed to. The great record of Storms was unearthed from missionary records, and public opinion was asked "Is it possible that the man who sent out such officers as these, who quenched the slave traffic which Livingstone abhorred but was powerless to arrest, who brought relief from Dervish tyranny to the harassed natives of the Bahr-al-Ghazal, could wish to enrich himself, and himself alone, with the produce of all Congoland, could tolerate the collection of rubber or the obtaining of ivory by methods of compulsion only to be parallelled in the worst records of Spain in the New World?" Yet it was true. Side by side with this devastation of the Congo basin-a devastation which has left Arab slave-raids far, far behind, which has reduced the native population in fifteen years (sleeping sickness aiding) from an approximate twenty millions to a bare nine millions-a work of civilization as good in its way as anything that Britain or France has done in Uganda or Nigeria was going on. Wherever Belgian officers could get a free hand, and were not the mere agents of this singularly heartless man, they built up native communities anew, and were even loved and honoured by the natives. It was not the Belgian nation, so much, that was to blame, or Belgian men who failed in those great administrative qualities which are possessed by so many other European nations; it was the system imposed on them by a being born out of due time, a personality that had stepped unaltered from the r6th century into the rgth. Yet, to be just, this conception of "African colonization" was not peculiar to Leopold II. It was the ideal of some English minds and was still more the vogue with a certain type of French Colonial administrator or minister. As we have seen, French Congo had a history very like that of the Belgian Congo.

King Leopold preserved himself long from attack and warded off many a blow from the British Parliament by 


\section{XIII] Leopoldian Conceptions of Colonization 353}

pointing to British companies and British monopolies in Africa. And we had-it seems-no statesman sufficiently adroit to indicate to him the cardinal difference. In none of her permanent arrangements and at no time even in theory did Great Britain tolerate in her African dominions or spheres of influence monopolies which limited the trade of the country to one or more privileged organizations, or which obliged the natives to confine their commerce to any particular firm or individual trader. Great Britain did acknowledge (usually where it was impossible to do otherwise) that certain pioneer companies or persons held by purchase under fair conditions large areas of land in "new" Africa; but the natives' rights to the land they occupied and used were respected, provision was always made for their expansion, and in most cases the whole of the vacant land was vested in the British Government. But not on lines parallel to those which were followed by Leopold II, not with the result of enriching the private revenues of Queen Victoria or King Edward, or of endowing Margate with a bandstand, Bournemouth with an opera house, or London with a new museum. The British Government has regarded itself as holding the vacant lands in trust for the infant state and for all its future inhabitants, without distinction of colour, except it be that a more liberal treatment is to be shown to black than white. All the revenues derived from the state lands in British Africa are accounted for annually and are applied to the service and for the benefit of the country from which they are derived. Therein lies the radical difference between the spoliations of King Leopold (or of the old Spanish Colonial Empire) and the policy of Great Britain and most other modern European powers in Asia and Africa. It may or may not be a good thing that one half of the land in Uganda or in Nigeria is the property of the State, a state mainly administered at present by Europeans. But at any rate all the revenue derived from the land can be ascertained by any native sufficiently educated to read annual reports; and 
all this revenue is spent-usually with the knowledge and advice of native counsellors-on Nigeria or Uganda, as the case may be, and not on any other land. King Leopold, it is true, while he took unto himself all the revenues, direct and indirect, derived from the Congo State, had, prior to 1890 , supported out of his privy purse the cost of creating and maintaining the Congo State (a total amount about $£_{500,000}$ in value) and probably spent in addition up till $190 \mathrm{I}$ another $£_{400,000 .}$ But even after allowing him interest at 4 per cent. (in theory) on this outlay of $£ 900,000$ and adding to that a theoretical Civil List at $£ 20,000$ a year as King-Sovereign, he was still owing the Congo State an amount understated at $£ 4,000,000$, when that State was annexed by Belgium in 1909 . That is to say, he profited by his intervention in Congo affairs at least to that amount, and probably to an extent much greater. And his great riches were obtained at a cruel cost in human lives and human misery.

I desire to present all aspects of this astounding episode in the history of the colonization of Africa. Therefore I would state that King Leopold employed a small percentage of the profits above computed-say $£$ roo, 000 -in promoting the scientific investigation of his territories and subject peoples, with the result that our knowledge of the fauna, flora, meteorology and above all ethnology of the Congo basin were immensely increased. Also, however unfair in regard to solemn treaty stipulations were his concessions and his monopolies, these did much to enrich Belgium and Antwerp in particular. It can well be imagined that, when so many of the king's subjects were raking in large and small fortunes out of Congo rubber, ivory, and palm oil, when churches were rising from Congo donations, museums were endowed, kiosques and public gardens were being presented to Belgian towns from out of the fringe of this profit-taking, Belgians (very ignorant as a rule about Africa or Colonial policy or subjects outside Belgian life) should have been enthusiastic about their monarch, 
his "slimness," and his Congo milch-cow. And notable English potentates in shipping and finance were partners with King Leopold, whose press department further stifled criticism in the journals of America, France, and Germany. Few stories therefore are at once more romantic-and will seem more incredible to posterity-than that which relates how this Goliath was overcome by a David in the person of a poor shipping clerk in the office of a Liverpool shipping firm which was amongst the partners of King Leopold.

This shipping clerk-E. D. Morel-was sent over to Antwerp, and Belgium generally, because he could speak French, and could therefore arrange all the minutiae of steamer fares and passenger accommodation, and the scales of freights for goods and produce, with the Congo State officials. In the course of his work he became acquainted with some of the grisly facts of Congo maladministration. He drew his employers' attention to these stories and their verification. The result was his dismissal.

Almost penniless, he set to work with pen and paper to enlighten the world through the British press and British publishers on the state of affairs on the Congo. From African merchants, not quite so callous as his late employers, he received support, which also came slowly and at first grudgingly from the public. He succeeded in interesting the Government of the day; for his charges were amply borne out by the British consuls sent to Congoland to report (the best-known of whom was Sir Roger Casement). Morel had to face the insults and even the personal assaults of paid opponents at his meetings, and the calumnies of King Leopold's subsidized press ; but he roused public opinion in Britain, Belgium, the United States, Switzerland, France and Germany. The first notice Goliath took of David was-very reluctantly-to appoint a Commission of enquiry consisting of a Belgian, an Italian, and a Swiss jurist of distinction and honesty. Their report, though its publication was only partial, was a virtual admission 
of the truth of the allegations made by Morel and the British consuls and missionaries. King Leopold, in fact, had no defence to offer; and although, exerting his powers as King, as the relation of Kings and Emperors, as a rich man, to the utmost, he managed to prolong discussions and negotiations as long as possible, the end was inevitable. The Congo was taken from him and was annexed by Belgium on November 14, 1908 . On December 17, 1909, King Leopold died. Stanley, "Bula Matadi," the real creator of the Congo State, had predeceased him by five years, dying in 1904, the last few years of his life saddened by the disheartening conviction that the immediate effect of his life's work had been a sordid scandal and the most monstrous piece of hypocrisy ever perpetrated by Europe in Africa ${ }^{1}$.

Leopold II found many champions in England and the United States, even among men and women travellers of good repute, incapable of being bribed or cajoled. But the explanation of this seeming anomaly, in contrast to the withering denunciations of Morel, of British, American, Swedish, and Belgian missionaries and publicists, lies in the fact that these apologists or eulogists of the King or of his Belgian officers never entered the vast Domaine de la Couronne (a territory larger in area than the United Kingdom) or penetrated far into the jealously-closed concessions of the Belgian companies; and also from the strange ignorance many of such travellers showed in the elementary ethics of native rights. They sawas the present writer did-order taking the place of disorder,

1 Sir Henry Morton Stanley (John Rowlands) was born in 1842 at Denbigh in North Wales, the son of a farmer's daughter who was very poor. He became eventually a work-house boy, but managed to acquire a passable education and to find his way twice to the United States, where he pursued many careers till at length he became a press reporter and a special correspondent. In this capacity he "found" and relieved Livingstone and prolonged Livingstone's life by two years. In 1899 Stanley, who had been in Parliament since $\mathrm{1} 895$, was made G.C.B. by the British Government. 
improved cultivation, handsome buildings, Arab slavery at an end, education spreading among and through the native soldiery, and many other beneficent signs of civilization, and they never examined into what was going on away from the stereotyped travel routes. Or if they were of the Emil Torday class of scientific explorer, they penetrated at great risk into remote parts of south-west, north, and north-east Congoland wherein the native tribes were too powerful to be enslaved and constrained to gather rubber or to confine their trade to the King's agents and concessionaires. Fortunately such districts escaped the Leopoldian ravages and are now ripe for a wellordered civilization to be imparted to their peoples through Belgian agency.

Any historian who omitted to dwell on the devoted and usually poorly paid work of many a Belgian officer and civilian in Congoland amongst quarrelsome or cruel native tribes, the achievements for the good of the natives of many a Belgian engineer, doctor, planter, road-maker, stockman, and schoolmaster, would indeed be unjust. The destruction of Arab tyranny will always remain a feat of extraordinary courage and of lasting good to Central Africa; and fortunately it was not in the regions rescued from Arab sway that the wrong-doing of the King and his concessionaires took place. The Arabconquered portions of the Congo basin have never gone back in prosperity and well-being of the natives since they became Belgian provinces ; and much the same might be said about Katanga, which under its usurping Wa-nyamwezi chiefs had been soaked in blood. But the Congo basin is still governed by Belgium under a régime which fails to conform precisely to the conditions laid down by the Act of Berlin or to satisfy those who desire justice of treatment for native races leading a settled agricultural life.

The present King of the Belgians (Albert I) visited the Congo territories in 1907 , traversed Congoland from Katanga to the mouth of the Congo, and resolved that his policy 
as King-Sovereign should be on lines radically different from those of his predecessor. Already a current of free trade is permeating the dominion and bringing with it freedom in other directions. The greater native chiefs are now encouraged to work with the Belgian Government and to look after the immediate interests of their own subjects. Railways have been rapidly pushed forward in eastern Congoland, which will some day link up Northern Rhodesia with Uganda, with the Anglo-Egyptian Sudan and the French Sudan.

There should be a great future, commercially at any rate, before the Belgian Congo, which in wealth of vegetable and mineral products and length of navigable waterways resembles Brazil and Guiana; and, theoretically, there should be no reason why Flemings and Walloons as guardians of this rich Central African state should not play as great a rôle in the Dark Continent as they have done in the industrial and artistic history of Europe. Yet little Belgium has a tremendous task before her in raising this immense territory to the condition of Brazil or Java ; and the regret naturally felt by English, German, and French writers that this wealthy territory was more or less disdained by their Governments in the days of Cameron's and Stanley's earlier journeys and advertisements of its capabilities, no doubt stimulates on their part a destructive criticism of Belgian efforts and capabilities. It is sometimes hinted that this unwieldy state will not long outlive as a political entity the monarch who founded it, and that its southern provinces will fall to England, its northern to France, and its western to Germany. But predictions in regard to the evolution of African history are very uncertain of fulfilment, and the Congo State may yet become and remain a Belgian India. 


\section{CHAPTER XIV}

THE BRITISH IN AFRICA, III

\section{(Egypt and Eastern Africa.)}

Ever since the first year of the I 9 th century, when Britain expelled the French from Egypt, she herself had longings to assume the control of that country. One reason for this desire was very clear: across Egypt lay the shortest sea route to India. Even without the Suez Canal, a day's journey on a railway or three days' journey by canal and carriage would transfer one from Alexandria on the Mediterranean to Suez on the Red Sea. Two hundred and thirty-four years ago, in the reign of Louis XIV, and one hundred and fourteen years ago, in the dawning empire of Napoleon Bonaparte, when steam was unknown as a motive power, the idea was conceived and born that Egypt controlled the back door, the garden gate of India. But when steam came into vogue on the sea, and later on the land, and people contrasted the saving of time the Egyptian route offered, compared with the weary three months' voyage round the Cape, it became apparent to British statesmen, that British influence must have full play if not exclusive control in Egypt.

Subsequent on the withdrawal of the French, a simple major of artillery from European Turkey-Muhammad Alihad suddenly risen to power by procedure which was faithfully 
copied 80 years afterwards by Arābi Pasha. He had inspired such energy and bravery into the military forces of Egypt that in $1806-7$ his soldiers defeated a British force which landed at Alexandria and Rosetta, and attempted to take possession of the country. Thus was staved off for 76 years the British occupation of Egypt, an occupation which in 1806 would have been far more rapidly converted into annexation than it could possibly be at the present day ${ }^{1}$.

Britain respected Muhammad Ali's sturdy resistance, and although she opposed his attempt to conquer the Turkish Empire, and-in opposition to the foolish encouragement he received from France-seemed at one time his enemy, she nevertheless saved him from downfall, and assisted him to establish a dynasty in Egypt which has ruled, directly or indirectly, for a century. Still, knowing British hankerings, the Tsar Nicholas I offered Egypt and Crete to Britain a short time prior to the Crimean War in return for a free hand at Constantinople. Great Britain declined, dreading to see Russia, with a new base at Constantinople and the locked Black Sea behind her, becoming the strongest Power

1 The dynasty of Muhammad Ali may be said to have begun in 1841 , in which year it was recognised and made hereditary by Turkey; but Muhammad Ali was the ruler of Egypt (as Pasha) from $18 \mathrm{r}$, after the slaughter of the Mamluk Beys. His sons and son-in-law conquered for him Syria and Western Arabia and the northern part of the Sudan. The conquests west of Sinai were given up in 1841 but in that year he became the Vali or Viceroy over Egypt and the Sudan, the succession to that post to fall to his male descendants. His immediate successor was his grandson Abbas bin Tusūn; then followed the rule of his favourite son, Said bin Muhammad. Said was succeeded in 1863 by his nephew Ismail, son of Ibrahim, the reputed eldest son of Muhammad Ali. But according to some accounts Ibrahim, the great conqueror, was only the adopted son of Muhammad Ali. The present Khedive of Egypt is the great-grandson of Ibrahim, but he is also descended from Muhammad Ali through his mother, Princess Amina, who was the great-great-granddaughter of Muhammad Ali through Tusūn. The title of Khedive (a Persian word meaning prince) was conferred on the Pasha or Viceroy of Egypt in 1867 . 
in the Eastern Mediterranean. Then came the making of the Suez Canal by Ferdinand de Lesseps, the influence of which, however, was somewhat counteracted by the fact that all the Egyptian railways were British. Nevertheless, British influence never stood so low in Egypt as at the opening of the Canal, when the heir to the British Crown was lost amid a galaxy of reigning sovereigns headed by the effulgence of the Empress of the French. But although French influence had grown so strong in Egypt, the French Government did not-overtly at any rate-strive for more than an equal voice with England in the affairs of Egypt, partly owing to a feeling of loyalty to the British alliance, which Napoleon III displayed whenever he could, and, later, to the enfeeblement of France after the German War. In I87 I something like a thousand British steamers passed through the Suez Canal, the enormous importance of which became so apparent that in 1875 the British Government purchased the Canal Shares held by the Khedive of Egypt, and thus became a controlling factor in the Canal Company.

For between 1862 and 1877 , Egypt had been ruined and reduced to bankruptcy by a reckless borrowing of money on the part of her native ruler, the Khedive Ismail. This prince at great cost purchased his country's practical freedom from Turkish control; indeed, by 1873 , he was virtually an independent sovereign. He extended Egyptian rule into Equatorial Africa, reorganized his customs' service, carried through important public works; but he also built palaces in profusion, and was guilty of needless extravagance and waste. As the result of Egyptian bankruptcy, there came into existence in 1877 the Dual Control of Britain and France over Egyptian finances. Ismail instigated a rebellion against this interference with his government and was deposed in 1879 by the Sultan of Turkey. The Dual Control was re-established (Lord Cromer, then Major Evelyn Baring, being one of the controllers) under the new Khedive Taufik; but in $\mathbf{1} 88 \mathbf{I}$ 
occurred the revolt of the army headed by Colonel Ahmed Arābi. France under the influence of Gambetta pursued the same policy as Britain, namely, the delivering of verbal warnings at intervals without the display of force. At last, in June $\mathrm{r} 882$, there was a riot and a massacre of Christians at Alexandria. When the British fleet prepared to take action the French withdrew, a hostile vote of the Chamber having dissolved the Dual Control. Britain then intervened in Egypt against Arābi's revolt, bombarded the port of Alexandria (July Ix, I882), and seized the Suez Canal. Lord Wolseley, of Ashanti fame, fought the battle of Tel-el-Kebir, occupied Cairo (September I 5), and reconquered the country for the Khedive. When this had been done, the British Government was in a dilemma. Had it, say some, on the capture of Cairo, declared Egypt to be a British protectorate outright, it would have only done what all the Powers of Europe expected. On the other hand, this bold step would have meant the tearing up of treaties and the partitioning of the Turkish Empire. Perhaps this might have been got over by direct negotiation with the Sultan and assurances of the continuance or composition of the tribute.

From about 1853 an interest was taken in the development of the Sudan by the British Government. A Glamorganshire mining engineer, John Petherick, after his contract of service with the Egyptian Government was over, established himself at Khartum as an ivory trader and was made British Consular Agent. In the sixties the journeys and explorations of Speke and Grant, and of Sir Samuel and Lady Baker, brought the Egyptian Sudan prominently into notice. In I 869 Sir Samuel Baker was made Egyptian Governor of the Equatorial Province (Gondokoro to the Albert Nyanza). In I 874 he was succeeded by Colonel Charles George Gordon, who became GovernorGeneral over the entire Egyptian Sudan in 1877. Between I 877 and 1879 Gordon devoted himself, with the Italian Romolo Gessi as lieutenant, to the defeat and suppression of the 
"Nubian" or "Bazinger" slave-traders and raiders on the Bahral-Ghazal and Darfur. Unsuccessful wars of conquest against Abyssinia took place during the seventies, and equally unsuccessful attempts to secure the Mombasa coast and the kingdom of Uganda-attempts opposed by the British Government. Gordon was replaced by a Turk as Governor-General in r880; and civilized rule over the Egyptian Sudan began to decline, though Emin Pasha (Eduard Schnitzer, a German of Silesia) ruled well and wisely over the Equatorial Provinces till about $\mathbf{1} 886$.

In the autumn of $\mathbf{I 8 8 2}$, the British Government was probably sincere in declaring its intention presently to evacuate Egypt; but it seemed as though fate had ordained that the British garrison should remain in that country. In I 88I the Mahdi's revolt had broken out in the Sudan ${ }^{1}$. In November I 883 Hicks Pasha's force was cut to pieces in the wilds of Kordofan. General C. G. Gordon was sent to relieve and remove the garrisons, instead of doing which he remained

1 This was a revolt against Egyptian rule, taxation, and interference with the slave trade, started by an Arab fanatic born in the Dongola district who was named Muhammad Ahmad, but called himself the Mahdi or Messiah. His first successes were amongst the ignorant Muhammadans of Kordofan who had grown to loathe the exactions of Turkish (i.e. Egyptian) rule. Muhammad Ahmad died in 1885 and was succeeded by his Lieutenant, the Khalifa Abdallah-al-Taaisha. His fanatical followers were usually called the "Dervishes." Muhammad Ahmad's forces captured Al-Obeid the capital of Kordofan in January $188_{3}$, and overwhelmed nine months later a force of 10,000 men under Hicks Pasha sent by the Egyptian Government to recover the Western Sudan from anarchy. Hicks Pasha (Colonel William Hicks) was an officer of the Indian Army who had served with distinction in the Mutiny and had fought in the Abyssinian campaign of 1867-8. In 1882 he entered the Khedive's service as Chief of the Staff in the Sudan, recaptured the Sennar country from the Mahdists, and might have suppressed the whole rebellion and obviated Gordon's mission and all subsequent disasters if he had been allowed a free hand by the Egyptian ministry at Khartum. Out of his force of 8000 fighting men and 2000 camp followers, all but 300 were slain at Kashgil on the fatal day of November 5,1883 . 
at Khartum in the vain hope of restoring before he left it some kind of order to the country that he loved. An army under Viscount Wolseley was sent to rescue him. It arrived a few days too late, yet might even then have retaken Khartum and put down the revolt; but Russia was threatening to impinge on the borders of India, and Great Britain could not afford to lock up many soldiers in Central Africa. Not being able, therefore, to settle the Sudan question, the British were forced to remain in Egypt to prevent that country from being overrun by the Mahdists. An attempt was made in $1885-6$ to negotiate terms of withdrawal with the Sultan, but the proposed convention was not ratified, owing to the opposition of France and Russia. Gradually, owing to the ability and truly British calm of the British Agent and Consul-General, Sir Evelyn Baring (who became Lord Cromer in 1892), the situation grew into a possible one. A moderate British garrison was retained. The Exchequer was placed under British control, as were public works, the administration of justice, the organization of the army, posts and telegraphs, and other departments where an infusion of order, honesty, and economy was necessary. The Khedive of Egypt continued to reign with British support and under British advice. In 1890 the conclusion of the Anglo-German agreement for delimiting the British and German spheres of influence in East, West, and Central Africa had secured from one European Power, at least, recognition of an eventual British control over the former Equatorial provinces of Egypt. From this event and from the contemplation of maps arose the idea of "the Cape to Cairo" ; and British ministries began slowly to contemplate the reconquest of the Sudan. The Mahdists aided the growth of this resolve by their fatuous hostility and constant attacks on Suakin and on the Wadi

1 This phrase first made its appearance in a pamphlet issued by the late Sir Edwin Arnold in 1876 and was revived by the author of this book in an article in the Times of August ro, 1888. 
Halfa boundary to the south of Egypt proper, behind which the Egyptian forces withdrew in $\mathrm{r} 885$. In $\mathrm{r} 886$ the Mahdists attempted to invade Egypt by following the Nile, but sustained a crushing defeat at the battle of Sarras. Three years later, again led by Wad-an-Nejumi the conqueror of Hicks Pasha and of Khartum, they were completely routed at Toski by Lord Grenfell, and Wad-an-Nejumi was killed. In I 894-5 the vicinity of Suakin was freed from these marauders and the eastern Sudan reconquered, Italy greatly aiding by her gallant capture of Kasalá ${ }^{1}$. The terrible disaster which befell the Italian arms in Abyssinia in 1896 caused the British Government to press forward the conquest of the Sudan in order to distract the Dervishes from attacking the Italians. The Egyptian commander-in-chief-Sir Herbert Kitchener, now Lord Kitchener of Khartum-had thoroughly reorganized the native Egyptian army under British officers; and with this material and a small contingent of British troops he reconquered the province of Dongola during the summer of 1896 . In 1897 (Battle of the Atbara) and the early part of 1898 the advance up the Nile valley was continued; and on the 2 nd of September, 1898 , occurred the decisive battle of Omdurman, in which a mixed army of British and Egyptian regiments, under Sir Herbert Kitchener, finally shattered the Khalifa's power and avenged Gordon's death. Anglo-Egyptian control was rapidly extended eastward to the Abyssinian frontier and southward to the Sobat river, but a half-expected obstacle came to light which imposed a temporary check on the southward advance towards Uganda. Major Marchand had reached Fashoda, near the confluence of the White Nile and the Bahr-al-Ghazal, and had hoisted the French flag over that abandoned Egyptian post. Before the determined attitude of Great Britain, France, after two months' delay, withdrew Major Marchand, and later on in I 899 concluded with Great Britain a supplement to the Niger

1 Taken by the Italians from the Dervishes in 1894 and restored to Anglo-Egyptian control in $\mathbf{1 8 9 7}$. 
Convention (p. 222), by which, broadly speaking, the whole western Nile basin and Darfur were admitted to be an exclusively British "sphere of influence." Although France had not yet specifically recognized the peculiar position of Great Britain in Egypt, she had prepared the way for the Convention of 1904 , in which this recognition was given in return for a similar acknowledgement of French interest in Morocco. This I 904 Convention definitely closed the long era of Anglo-French rivalry and diplomatic conflict in Egypt; and thenceforth the British met with no obstacle from any outside nation but Turkey in their task of reforming and rehabilitating the country of the Pharaohs. Turkey in 1906 attempted to withdraw the greater part of the Sinai peninsula from Egyptian rule, to bring Turkish posts down to the vicinity of the east bank of the Suez Canal, and to hold both shores of the Gulf of Akaba. It required a virtual ultimatum from Great Britain before Turkey would give way; and this crisis (which ended by the definite inclusion of all the Sinai Peninsula within the Egyptian dominions, while the Turks as definitely regained those former Egyptian posts in the land of Midian held by Egypt since 1832) gave occasion to the British Government to assign to the British occupation of Egypt a more definite and permanent character than it had hitherto been accorded in diplomatic documents.

But from this period (1906) onwards there was much "national" unrest in the towns of the Nile Delta, chiefly Cairo and Alexandria. The prosperity which Egypt was enjoying, the spread of a modern, European type of education, the downfall of Sultan Abd-al-Hamid in 1908, and the promise of a constitutionally governed, modernized Turkey, were conditions which caused the Muhammadan Egyptian townsfolkmostly the professional classes--to think the time had come for the establishment of a completely constitutional régime in Egypt, coupled with a removal of British control and militaryoccupancy. This movement had begun in 1892 with the accession of the 
young Khedive, Abbas Hilmi; but of late years the Khedive has dissociated himself from attacks on, or even coldness towards, the British occupation. His approximation to the British point of view was more apparent after the Earl of Cromer's retirement in I907. Sir John Gorst, Lord Cromer's successor, sympathized to some extent with "nationalist" ideals, but he regarded the Christian Copt as being just as much an Egyptian as the Muhammadan Arab, Egyptian or Turk. Copts were enabled to rise high in the public service of Egypt. In r9o8 a Copt -Boutros Pasha-became Prime Minister of the Khedive's Government. Christian ministers of state-Armenians, Copts, Levantines-were no novelty in Egypt; but the idea was most repellent to the aggressive "Pan-Islamism" of the Muhammadan "nationalists," and the excitations of the Nationalist Press excited a student, Al Wardani, to murder Boutros Pasha in February 19ıo-an event which so deeply affected Sir John Gorst (a sincere friend towards real "nationalism" in Egypt) that he contracted an illness which caused his death a year later. Viscount Kitchener of Khartum succeeded him as British representative in Egypt. In I9I I-I 2 the "nationalist" agitation was resumed, and a plot was arranged for the nearly simultaneous assassination of the Khedive, Lord Kitchener, and the Egyptian Premier. It must be remembered by all who are disposed to sympathize with the growth and achievement of nationalism that Egypt contains, in addition to some 10,500,000 Muhammadans (only about 5 per cent. of whom are literates), a million Christians of Egyptian and of European race, who represent-for the most part-the brains and wealth of the country. Until this important minority is regarded by the Nationalist party as equally entitled to full Egyptian citizenship, until the $\mathrm{Mu}$ hammadanism of Egypt sheds its intense fanaticism and its contempt for science, sanitation, for ancient history and modern learning, the British Government in its capacity of guardian over the land of the Pharaohs, the land of deathless history 
which the Arab, Turk, and Circassian have done so much to destroy and deface, is right in withstanding a movement which is not strictly national, in the Egyptian sense, but a revival of Islamic intolerance and civic dishonesty.

The Anglo-French Convention of 1904 having accorded a limited but distinct recognition on the part of France to the British control over the Egyptian Khediviate, various important reforms in finance and administration followed, and the way was paved for the abolition of the capitulations, of the last vestiges of mistrust felt by Europe for the tribunals of a Muhammadan nation. Since I876, the separate consular courts in Egypt had been done-away with in favour of the mixed tribunals on which were conferred the powers formerly attributed to the consular courts and which now try all civil and criminal cases in which foreigners are concerned. These foreign tribunals may be succeeded in time by national Egyptian courts. At any rate, the Anglo-French agreement of 1904 tends in that direction. Owing to this agreement Egypt is now allowed to apply her surplus, after the service of the Funded Debt has been provided for, to any purposes she may deem advisable in the interests of the country, either for the extension of public works or the diminution of taxation. Prior to the facilities accorded by this agreement, however, the Earl of Cromer (the creator of modern Egypt) had, with the financial assistance of Sir Ernest Cassel and the engineering skill of Sir William Willcocks and others, commenced those great irrigation works above Assuan which will triple the productive capabilities of Lower Egypt and proportionately increase the prosperity of the Khedive's country. Under the British control (since I882) the Funded Debt has been diminished by I 2 millions sterling; taxation has been greatly reduced, yet the revenue has increased by 4 millions of pounds; the total trade of Egypt has more than doubled; and the population has risen from $6,832,000$ in I 882 to nearly I $2,000,000$ in I91 2 . Forced labour has been abolished; the position of the peasantry has 


\section{xIV] Wingate completes Conquest of Sudan 369}

been enormously improved; twice the former area of land is cultivated and under cultivation; and the boundaries of the country have been definitely extended to the frontier of Syria and to the Cyrenaica.

In the Sudan great changes followed the victories of Lord Kitchener in 1 898. A convention with Egypt in January 1899 determined the constitution of the, henceforth, Anglo-EgyptianSudan south of Wadi Halfa. This was to be a joint dominion of Britain and Egypt. The Governor-General was to be selected by the British Government and appointed by the Khedive. By a stroke of the pen the cumbersome system of Consular or Mixed Tribunal Courts which had formerly existed in the Egyptian Sudan was abolished and the direct jurisdiction of the Anglo-Egyptian Government substituted. By I900, the reconquest of the Egyptian Sudan, begun in 1896 , had been effectually completed. In November 1899, after Lord Kitchener had been despatched to South Africa, his successor in the Sudan, Sir Reginald Wingate, pursued the fugitive Khalifa into the recesses of Kordofan; and this successor of the Mahdi lost his life on the field of battle of Om Dubreikat, on November 25, r899. Osman Digna, the other great Dervish leader, was taken prisoner in the Tokar hills near Suakin on January I9, I900. Gradually in the succeeding years the boundaries of the Anglo-Egyptian Sudan were adjusted with Abyssinia. Darfur remains a semi-independent kingdom, accepting somewhat grudgingly an Anglo-Egyptian suzerainty. The region of the Bahr-al-Ghazal was occupied by the Sudan Government in pursuance of the claims of Egypt over this region and in opposition to the aspirations of the King-Sovereign of the Congo State, who at one period (1894) had received permission from the British, without prejudice to the dormant claims of Egypt, to exercise control over this region. The King did not take immediate advantage of this opportunity; and in the interval Egypt had revived her claims to the original dominions of the Egyptian Sudan after 
the shattering of the Khalifa's forces at Omdurman. But, although the Congo State was not allowed to exercise authority over the Bahr-al-Ghazal, it maintained its sway in the smaller Lado enclave between the Congo frontier and the western bank of the White or Mountain Nile by a lease which terminated at the death of Leopold II in 1909 , when the Lado enclave passed under the control of the Anglo-Egyptian Sudan Government in 1910 .

Apart from the Arabs, the British have had but little trouble in imposing their supervising rule over the natives of the Sudan, the government of which is directed from Khartum. The only tribe that adopted a hostile attitude towards the British, prior to 1904 , was a section of the Dinka people between the Mountain or White Nile on the west and the affluents of the Sobat on the east. But in the autumn of I 904 a strong expedition had to be directed against the powerful Nyamnyam tribes of the Western Bahr-al-Ghazal. This people, armed with about 20,000 modern rifles obtained by purchase or pillage from the Belgian stations, was disposed to question the "Pax Sudanica" and to resume its former slave raids. In $190^{\circ}$, another Mahdi-a Tunisian Arab-arose in Kordofan, but he was promptly captured and executed. In I 908, yet another fanatic, an Arab of the Halawi tribe in Sennar, declared himself to be Jesus Christ, returning to earth to expel the European from the Sudan. He murdered a British official but was caught soon afterwards and hanged for his crimes. In $19 I I-I 2$ two expeditions were rendered necessary against the Annaks, a Nilotic negro tribe on the Sobat river. The Annaks had armed themselves with thousands of French rifles sold by French merchants on the frontiers of Abyssinia and passed on to the Annaks in trade by the Abyssinians. From this direction much more trouble may occur eventually.

A good deal of commercial development has taken place in the northern regions of the Egyptian Sudan and in Southern Egypt owing to the resumption of gold-mining operations 
which had been dormant since ancient Egyptian days, or at any rate since the Muhammadan conquest, and the great increase in cotton planting. The advance of the Sudan towards prosperity is only hampered by the present dearth of indigenous population. It has been computed that the Mahdi's revolt and the Khalifa's massacres must have cost the Sudan something like three millions of lives, this loss being entailed by direct massacre (at some places on the Nile 70,000 people-men, women, and children-were killed in the course of two or three days), by the unchecked spread of disease, by starvation owing to the destruction of crops and the neglect of agriculture, and by loss in battle against the Anglo-Egyptian forces. Efforts are being made by the enlightened administration which rules from Khartum to encourage agriculture and to educate the people. The Gordon College was founded at Khartum in 1899 with the special purpose of giving a practical and secular education to the Arabs and negroes of that dominion. One splendid feat, among others, due to British courage and tenacity of purpose was the cutting through the Sadd (as it is pronounced, or Sudd as it is ordinarily written), the dense growth of floating water vegetation which from time immemorial has blocked the courses of the Mountain Nile and its tributaries between $\mathrm{Boz}$ and the 6th degree of latitude, and the confluence of the Sobat. At intervals between $187 \mathrm{I}$ and I 882 this sadd had completely barred the way to steamer or boat journeys between Khartum and the Equatorial provinces. The great work of cutting through the sadd was finally achieved under the direction of Sir William Garstin between I899 and 1904 by Major Malcom Peake, Lieut. Drury, R.N., and Major G. E. Matthews. Since that time the Anglo-Egyptian Sudan has been completely linked up by a steamer mail service with the British Protectorate of Uganda.

The area of this vast dominion, between Wadi Halfa on the north, Gondokoro and the 5 th degree of latitude and the Nile-Congo-Shari waterparting on the south, is 984,520 
square miles; yet the population is still only estimated at $2,600,000$, though it is capable of supporting $50,000,000$ black or brown men and is healthy in a few parts for Europeans.

Aden, at the south-west extremity of Arabia, was occupied by the Indian Government in 1839 in view of the opening up to steam-ships of the Egyptian route to India. To Aden were added in 1840 , by treaties of purchase or exclusive influence, Zeila and Musha Island on the Somali coast, the island of Perim in $185^{8}$, and the island of Sokotra in $1876^{1}$. Egypt in $\mathbf{1} 875$ had annexed the coast of Somaliland opposite Aden, with the exception of the French post of Obok. When the Egyptian dominion of the Sudan collapsed, it was necessary to our interests that the Somali coast opposite Aden should not come under the influence of another European power; so a British protectorate was established there $(\mathbf{1} 884-89)$ by accord with France and Italy, France extending her Obok territory to meet the British Somali Protectorate, while the town of Harrar in the interior, which was likely to be a bone of contention, was transferred to Abyssinia together with a small adjoining piece of territory in 1897 .

In 1898 , a considerable slice off the south-west portion of British Somaliland was surrendered to the Empire of Ethiopia (Abyssinia) by the Rennell Rodd agreement made in 1897 . The Italians between 1889 and 1892 had acquired rights over all the sea-board east and south of British Somaliland, but, as time went on, the interior-never well disposed towards Europeans-became disturbed. The eastern and southern parts of this Protectorate were ravaged between 1899 and 1904, and again between 1908 and 1910 , by a Somali leader, Muhammad bin Abdallah, called most inappropriately the Mad Mullah. This man-a native of southern Ogadein Somaliland-appears at first to have been the exponent of legitimate grievances on the part of some of the coast Somalis. The British administration

1 Placed under British protection in $\mathbf{r} 88_{4}$. 
of Somaliland during the close of the 19 th century was not fortunate in its dealings with a turbulent and fickle people. Some of the earlier officials seemed to be more interested in the hunting of big game than in acquiring knowledge as to the predilections, traditions, and general affairs of the Somali tribes under their government. Gradually Somali opinion grew restless under restrictions which were seemingly not backed by adequate force, and leant towards the side of their national leader, the Mullah. The latter attacked successfully those tribes on the coast which remained faithful to the British rule. A succession of expeditions against the Mullah culminated in an elaborate and expensive campaign conducted by the British War Office in 1903-4. The Mullah was repeatedly driven into Italian territory, and the permission of Italy was obtained to use the coast of Italian Somaliland as a fresh base of operations against the Somalis. Somewhat dubious and half-hearted assistance was also supposed to be rendered by Abyssinia. As the result of these operations, the Mullah and his forces were repeatedly defeated (after more than one disaster had happened to the British troops), and he was driven out of British territory into the no-man's-land in dispute between Italy and Ethiopia. Between 1905 and 1908, there was peace, the Mullah being content to settle down under Italian supervision. Then he broke out again and finally attacked the tribes under British protection. Previous Somali wars (1900-4) having cost the British government the lives of many British officers and negro and Indian soldiers, besides over two million sterling expended in maintaining armies of 7000 men, it was decided to leave the interior of British Somaliland --a barren and sparsely inhabited region-alone, and confine the British occupation to the coast towns. This decision was carried into effect in 1910. The Mullah Muhammad bin Abdallah is still at large, but the interior tribes are gradually asserting themselves against him. The area of the Protectorate is about 68,000 square miles. Prior to 1902 , this territory, 
alone amongst the British Protectorates in Africa (excepting Zanzibar), paid its own way without a subsidy, the revenue being derived from the considerable receipts at the Customs Houses. Unfortunately, the war destroyed so much in the way of live-stock as to make it difficult for years to come for Somaliland to recover the partial prosperity it enjoyed in earlier days. But nevertheless considerable towns are springing up on the coast-line, where they can be easily defended by garrisons of Indian troops and Somali police.

After the Portuguese had been expelled by the Arabs from Zanzibar and Mombasa, all the East coast of Africa from Somaliland to the Ruvuma river came under the control of the Imam of Maskat, who usually deputed a brother or some other relation to be his viceroy at Zanzibar. Owing to internecine quarrels which arose in the princely family of Maskat, the British Government intervened in $186 \mathrm{I}$, and definitely separated the Sultanate of Zanzibar from the Imamate of 'Oman or Maskat. As the French were beginning to take a keen interest in the affairs of Zanzibar and Maskat, the British Government at that time (1863) concluded a treaty with the French Empire by which both powers bound themselves to respect the independence of Zanzibar and Maskat. Many years previously, in 1824 , a Lieutenant Reitz, by the orders of Captain W. F. W. Owen, had hoisted the British flag at Mombasa, and had endeavoured to occupy that town for the East India Company, but his action was disallowed. Nevertheless, British influence at Zanzibar grew very strong through the Political Agent whom we established at the court of the Sayyid or representative of the Imam of Maskat (known later as the Sultan of Zanzibar) ${ }^{1}$, and the powerful squadron of cruisers which were maintained in Zanzibar waters to put down the slave trade. In I 866 Dr, afterwards Sir John, Kirk,

1 The first British Agent (for the East India Company) and Consul General at Zanzibar was appointed in $\mathbf{1} 8_{4} \mathbf{r}$. 
who had been Livingstone's second in command on the Zambezi, was appointed Vice-Consul and gradually rose to be Consul and then Political Agent and Consul-General. $\mathrm{He}$ threw himself zealously into the task of suppressing the Zanzibar slave trade, which had become an outrage on humanity. The British Government supported him; and in 1873 Sir Bartle Frere was sent to Zanzibar to negotiate a treaty with the Sultan.

The Sultan (Barghash) was recalcitrant, and even went to the length of offering his territory to France. Finally, however, before a threatened British bombardment could take place or the French squadron arrive, Sir John Kirk had persuaded the Sultan to sign the treaty, after which Sayyid Barghash bin Said resolved to visit England, which he did in 1874 . It is said that even at that date he had some idea of invoking German protection, provided he were allowed to tear up the slave-trade treaty. However, the wisdom and tact of Sir John Kirk did wonders for British influence at Zanzibar; and in 1876 the Sultan offered the lease of nearly all his continental territories to Mr, afterwards Sir William, Mackinnon, the chairman of the British India Steam Navigation Company. But $\mathrm{Mr}$ Mackinnon was an over-cautious man. Instead of accepting, and then forcing the hand of the British Government, he refused to take the Sultan's concession unless he could first obtain a British guarantee, an action to which the Government was naturally unwilling to commit itself. In I 88 I Sir John Kirk thought of another plan, that of inducing the Sultan to employ capable Britons, who would develop his territories as governors or commissioners. $\mathrm{He}$ secured the services of $\mathrm{Mr}$ Joseph Thomson to develop the resources of the Ruvuma Province, an appointment which might have effectually prevented any future German intervention; but $\mathrm{Mr}$ Joseph Thomson was too pessimistic and perhaps shortsighted. The country seemed to him poor in resources, though it has long since been shown to be more productive than he thought. He bluntly told the 
Sultan so and therefore was relieved of his appointment. In I883 Sir John Kirk returned from England, having induced the Government to appoint a number of salaried vice-consuls at various points in the Sultan's territories. It must be noted that at this period a very large proportion of the Zanzibar trade was in the hands of British subjects, natives of British India.

In 1882-4 took place the remarkable exploring journey of $\mathrm{Mr}$ Joseph Thomson under the auspices of the Royal Geographical Society. Thomson travelled from Mombasa to the verge of Busoga, on the north coast of the Victoria Nyanza, and revealed all the most striking features of British East Africa. Sir John Kirk had also about the same time entered into friendly relations with Mandara, a chief on Mt Kilima-njaro, and had urged the sending out of a scientific expedition, to the leadership of which Mr H. H. Johnston was appointed in 1884, in order to explore that mountain. After some months' stay on Kilima-njaro Mr Johnston reported the great advantages this region possessed as a sanatorium, and, while waiting for instructions from Sir John Kirk, concluded treaties with several chiefs. The response of the British government was favourable to the establishment of British interests in this direction; but various obstacles arose which required consideration, amongst others the remembrance of the 1862 agreement with France. Another European power, however, was bound by no such agreement, and had no such scruples, as will be related in Chapter XIV. Although Mr Johnston's treaties with Chaga (South Kilima-njaro) and Taveita (the eastern slopes) proved the basis on which the British East Africa Company was eventually founded, the actual mountain district of Kilimanjaro finally fell to Germany. By 1885 , the British Government had more or less indicated to Germany that portion of the Zanzibar dominions which must come under British influence if there was to be a division of those territories; and after several years of diplomatic conflict, the whole question was settled with fairness to both parties by the $\mathrm{r} 890$ Convention 
between Great Britain and Germany, and by a secondary agreement with France, which definitely allotted to Great Britain the northern half of the Sultan of Zanzibar's dominions, the islands of Zanzibar and Pemba, and a sphere of influence in the interior which included Uganda and Lake Albert Nyanza.

The British East Africa Company, organized in 1886 , was chartered in $\mathrm{I} 888$, and undertook the government of the vast territories lying between the Mombasa coast and the Victoria Nyanza. For the first two years things went smoothly. The company possessed a capable administrator, $\mathrm{Mr}$ (afterwards Sir) George Mackenzie, who solved the slavery difficulty by redeeming the slaves of the Arab gentry and then setting them free. This no doubt prevented the coast Arabs from attacking the British régime at a time when they had nearly destroyed that of Germany in the regions farther south.

But the Imperial British East Africa company had undertaken a task far too great for its resources in capital. It was expected by the people and government of Great Britain to maintain and defend British interests over a vast hinterland. The country of Uganda ${ }^{1}$, on the north-west of this greatest of African lakes, had been allotted to the British sphere by the German Convention; but unfortunately for British interests the country had been entered by French Roman Catholic missionaries of Cardinal Lavigerie's White Fathers' mission (cf. pp. 245-6), who were such ardent Frenchmen that they rather forgot the religious purpose for which they had come, and fomented serious quarrels between the king and the Protestant missionaries who had preceded them. The great King Mtesa died in I884, peevish and disgusted with the missionary disputes and religious recriminations that buzzed in his ears,

${ }^{1}$ Uganda will probably continue to be the general name for this protectorate; but the correct form of the word is Buganda. This rendering is now reserved for the native kingdom or province of Buganda, while the Swahili version of the term-Uganda--is applied to the whole protectorate of five provinces. 
and longing for the old, easy, pagan life he had led before pressing Stanley (p. 326) to send him Christian teachers. After his death, the Arab party prejudiced his son Mwanga against the Christian foreigners and native converts. Bishop Hannington, of the Church Missionary Society, newly appointed to East Equatorial Africa, persisted in entering Uganda along Mr Thomson's route by what the king called the "back way." Frightened lest the bishop might be coming to take the country by the methods which the Germans had employed farther south, the king ordered him to be murdered in Busoga, not far from the Victoria Nile. Soon after this, the missionaries, Protestants and Catholics, were expelled from Uganda. Then later on there was a Muhammadan revolt, which drove Mwanga flying. $\mathrm{He}$ took refuge with the Catholic missionaries at the south end of the lake, and became a Christian. He was restored to his throne by the aid of Mr Stokes, who was afterwards hanged by Major Lothaire (p. 347). Then the French missionaries got control over the king, and attempted to prevent the country from becoming a British protectorate-if it could not be French, at any rate let it be German ; and Dr Peters arriving on the scene strove to make it German; but his efforts were annulled by the 1890 Convention. After this, to prevent the country from falling under the sway of the Muhammadans, who might have joined the Mahdists or become French, the British East Africa Company was obliged by public opinion to intervene, although it did not possess sufficient funds to administer such an expensive empire. Captain, now General Sir Frederick, Lugard not long returned from the Arab war in Nyasaland, was sent there as their agent in I890-I, and in an exceedingly able and courageous manner restored order, obtaining from the king a treaty with the Company, and putting down revolts of the Roman Catholic Christians and of the Muhammadans. But the East Africa Company was obliged to appeal to the British Government to come to its assistance lest Uganda should swallow up all its resources. The late Sir Gerald Portal, 
Agent and Consul-General at Zanzibar, was sent to Uganda to report on the advisability and the means of retaining this country under British influence. Unhappily, he died soon after his return to England in I894, but his report led to the establishment of a British protectorate. Through the intervention of the Pope, some appeasement of bitterness was obtained in regard to the White Fathers' mission, whose field of work was bounded on the east by the Victoria Nile. A new Roman Catholic mission under Bishop Hanlon, an Irishman, supported by English, Irish and Dutch priests, has since carried on the conversion and teaching of the natives in the eastern half of the protectorate on harmonious terms with the British administration; though indeed since 1900 all bitterness of feeling between the White Fathers' mission and the British officials or the native chiefs is completely at an end. The French missionaries were compensated in 1895 for the destruction of some of their stations in the civil war by a payment of $£$ io, 000.

After the withdrawal of Emin Pasha from his Equatorial province a number of his former Sudanese soldiers volunteered for employment in Uganda, and were eagerly recruited as a capable fighting force. But they were Muhammadans, and always inclined to intrigue against a Christian power. Added to this, Mwanga, the Kabaka or King of Buganda, was the most unstable of men, and an exceedingly bad character to boot. His vices and his cruelty had made him so hateful in the eyes of his subjects, that without British support he would probably have been deposed or killed. As it was, the presence of the British prevented this, but did not arrest his intrigues with that section of the populace which disliked European intervention. After an undecided behaviour which lasted several years he finally attempted to massacre a few of the British officers and missionaries, but was defeated, and fled across the German border. Then the Sudanese troops revolted, seized a fortress and some guns, and for nearly a year set the 
British and the loyal Baganda at defiance. Finally, a detachment of $45^{\circ}$ Sikhs reached the country (a handful of these splendid soldiers had already enabled the European officers to face the Muhammadan mutineers), order was to some extent restored, and a determined effort was made to capture the truant king Mwanga and that aged scoundrel Kabarega, the King of Bunyoro, who has been justly hated by Europeans since Speke and Baker's time ${ }^{1}$. This capture was achieved by Colonel John Evatt in June, 1899. The British Government having decided that the military and civil organization of Uganda should now be settled definitely, decided in the same year to dispatch Sir Harry Johnston as a Special Commissioner to frame and inaugurate a suitable scheme of administration in these countries round the Nyanzas and the Upper Nile?

Prior to these troubles, continual warfare was carried on for some years with the Bunyoro kingdom to the north, which was finally conquered and eventually annexed to the Protectorate. In these wars with Bunyoro (commencing with unprovoked hostilities on the part of Kabarega) Major A. B. Thurston greatly distinguished himself. This gallant officer and able linguist was afterwards killed by the mutineer Sudanese soldiers (I897). Major 'Roddy' Owen had hoisted the British flag at Wadelai, on the White Nile (in I894), but this action was not confirmed by the British Government. Nevertheless, with the movement towards Khartum in prospect, and the eventual reconquest of the Sudan, it was decided to send

1 Kabarega was the son and successor of the Kamasi who had so persecuted the Bakers, Emin, Casati and other travellers.

${ }^{2}$ The work of this Special Commission was additional to and confirmatory of the efforts of Sir Henry Colvile, Mr Ernest Berkeley, Mr F. G. Jackson (since Governor of Uganda), Mr George Wilson and Colonel Trevor Ternan (Commissioners or Acting Commissioners) to found a stable confederation of warlike and peaceful negro peoples, to combat famine and disease caused by intertribal wars, and to extend the boundaries of this protectorate northwards to the navigable Nile. 
out a well-equipped surveying expedition under Colonel (Sir) J. R. L. Macdonald which should explore thoroughly the lands between the Victoria Nyanza and the Mountain Nile. It was partly the demand that this expedition should be escorted by a Sudanese battalion which precipitated the mutiny of these discontented soldiers. Sir James Macdonald cooperated in breaking the chief resistance of these mutineers and then proceeded on an epoch-making survey which revealed new mountains, new lakes, new peoples and new languages, and laid the foundations of British influence on the northern part of the Uganda Protectorate.

The Special Commission of Sir Harry Johnston arrived in Uganda at the close of I899, when the Sudanese mutiny and other troubles were nearly over. As the results of this Special Commission the boundaries of the Uganda Protectorate were carried northward to Gondokoro on the Mountain Nile, to the $5^{\text {th }}$ degree of $\mathrm{N}$. latitude and to Lake Rudolf; the state of Ankole on the south-west was also included up to the German frontier. A definite constitution was given to the kingdom of Buganda. The native ruler of Buganda received the title of His Highness the $\mathrm{Kabaka}^{1}$; the native Parliament or Lukiko was recognized; and the kingdom was divided into a number of administrative counties. A land settlement was arrived at, by which at least half of the land of the kingdom of Buganda was secured to native owners. Settlements somewhat similar to that effected in the province or kingdom of Buganda have been carried out in the adjoining provinces of Ankole, Toro, and Bunyoro. In 1903, the Eastern (Masai) province was transferred to the administration of the adjoining East African Protectorate, thus reducing the total area of the Uganda

1 The Kabaka of Buganda has been, down to 1912 , a minor under a native regency. He is descended from a dynasty which has apparently ruled in Buganda since a period contemporary with the reign of Henry IV in England. This dynasty, like most others in Equatorial East Africa, appears to have been founded by a man of Gala descent. 
Protectorate at the present day to I I 7,68I square miles, with a population-almost entirely negroes-of about 2,900,000 (650 Europeans).

In the summer of I90 I a new portent appeared in Uganda - the terrible disease known as sleeping sickness. This is a malady caused by the injection into the human system through the proboscis of a Tsetse fly of trypanosome animalcules which after swarming in the blood reach the spinal marrow and then kill the patient-negro or European. This terrible disease, which has existed for centuries in West Africa, penetrated from the Congo forest into Uganda in I90I-2 and killed many thousands of the natives year after year along the shores and islands of the Victoria Nyanza. It is being carefully studied with a view to its extirpation.

After the Zanzibar Sultanate had been placed under British protection it was necessary to reorganize its administration. The islands of Zanzibar and Pemba remained under the more or less direct rule of the Sultan, who, however, appointed English ministers to control the various departments of state, and was at the same time subject to the advice and financial control of the British Agent and Consul-General. Several Sultans succeeded one another and died in a few years; and on the occasion of the death of Sultan Hamid bin Thwain (1896) a palace revolt occurred, occasioned by a disappointed claimant to the throne. This revolt, however, was really a premature outbreak on the part of the Arab party, who frankly disliked British interference which entailed the abolition of the slave trade and even the disappearance of slavery, and were sufficiently foolish to imagine that they were strong enough to resist a European nation. A few hours' bombardment of the Sultan's head-quarters quelled this rebellion. Since that time, by degrees, and with a wise system of gradation, slavery is being abolished, and will soon cease to exist as a recognized status. In I9 I I the young Sultan of Zanzibar (Ali bin Hamūd) abdicated for reasons of health; and his son, Sü'id bin Ali, was 
proclaimed under a regency, the Regent-and-First Minister being a British official. Between 1903-5 there was considerable local dissatisfaction with the methods of government employed in Zanzibar, and a deputation of Zanzibaris came to London to make representations on the subject; but since reforms were instituted in 1906 the people of Zanzibar and Pemba have been quiet and prosperous. The total area of these two islands is 1020 square miles and the population $(200,000)$ mainly negro, with about 10,000 Arabs, I0,000 Indians, and 300 Europeans. Zanzibar Island is a great rendezvous for shipping and is the head-quarters of a great ocean cable company; apart from this, it produces cloves and other tropical vegetable products, and Pemba is rich in cattle.

On the mainland between the Umba river and Mombasa on the south and the Juba river and Somaliland on the north, the Imperial British East Africa Company continued to rule until 1894. But as soon as the British Government had undertaken to govern Uganda as a Protectorate (1894) it was evident that the company's rule over the intervening district from Kikuyu to the coast could not continue. Accordingly in I894 the company's charter was annulled and they were compensated with $£ 450,000$. On July 1, 1895, Sir Arthur Hardinge took over the administration of the British East Africa Protectorate.

The new administration had scarcely been installed on the Mombasa coast than it found itself obliged to deal with the question of the Mazrui Arabs. It has been mentioned elsewhere in this work that early in the I8th century the Arab power on the coast between the Rufu River on the south and Malindi on the north was exercised nominally on behalf of the Imam of Maskat by an Arab family known as the Mazrui. Various explanations are given of this name and of the origin of this clan, some deriving them from an old colony of Egyptian Arabs (Masr is the Arab name for Egypt); but more probably 
they came from Southern Arabia, or even from Oman, prior to the arrival of the Portuguese, who dispossessed them for a time. In the 17 th century they had made common cause with the Arabs of Oman in attacking and expelling the Portuguese, but, when it came to their accepting the Imam of Maskat as their sovereign lord, they usually evaded the direct issue by partial compliance. In the early part of the igth century they had defied the representative of the Imam at Zanzibar and had attempted to place Mombasa under British protection. During the latter part of the r 9 th century the Sultan of Zanzibar, backed by Sir John Kirk, had asserted Zanzibar rule over the coast strip as far north as Somaliland. He held, indeed, all the principal ports of what is now Italian Somaliland, as well as Lamu, Malindi, and Mombasa. In the hinterland of Lamu was another semi-independent Arab Sultanate, that of Vitu, on the Ozi River; while the Mazrui clan between Mombasa and the German frontier was represented by a line of Sultans usually called Sidi Mubarak or Mbaruk (Sidi means lord, the rest of the name is a varying form of the Arab word for blessing). The Germans in their dealings with East Africa had early appreciated the dissidence between the Sultan of Zanzibar and the independent Arab powers on the mainland; and, when Germany and Britain were striving in the eighties for an East African dominion, Germany had recognized the independence of the Sultanate of Vitu. By the I 890 agreement Vitu was transferred to the protectorate of Great Britain, much against its will. It was a country rendered inaccessible by an extravagant growth of forest nourished by the delta of the Rivers Ozi and Tana, but was nevertheless captured in the late autumn of $\mathrm{I} 890$ by a naval expedition under Admiral Sir E. Fremantle, to punish the Sultan for resuming the trade in slaves and ordering a party of German timber-cutters to be massacred. A little further action on behalf of British officials resulted in the tranquillity of this small state being re-established with a reasonable degree of self-government. 
Sir Arthur Hardinge, on assuming the control of British East Africa, found that he had first of all to fight a long war of skirmishes, ambushes, and repelled raids, against the Sultan Mubarak, whose strongholds were a series of small Arab towns in the hinterland regions, south-west of Mombasa. This difficulty was not finally disposed of till the following year, 1896, when Mubarak after several defeats inflicted on him by the negro and Indian troops of the British, took refuge on German territory. Since that time there has been no further difficulty with the Arabs in this part of East Africa.

The Masai of the East African hinterland, who, it was thought, would give the most serious trouble to any overruling power, very soon acquiesced in the idea of a British protectorate and have really been the allies of the British in many of their difficulties with recalcitrant tribes. In the Kikuyu forest country, which was once the western borderland of the East African Protectorate, a few police operations had to be carried out, as the industrious Kikuyu people, suspicious after many years of raiding by the Masai, at first looked upon the white man as another enemy, and attacked British settlers or big-game hunters in the neighbourhood of their country.

In I902-3, as already mentioned, the Protectorate of East Africa was extended over the eastern province of Uganda up to the shores of the Victoria Nyanza, the slopes of Mount Elgon, and the south-west coast of Lake Rudolf. On the south it was of course bounded by the Anglo-German frontier, which last was accurately defined between I903-5. On the north, after long negotiations with Abyssinia, its boundaries were so drawn as to admit the Abyssinian Empire to the northeast corner of Lake Rudolf. From this point the East African boundary is drawn along the Goro escarpment to the Juba River, which it then follows down to the sea. The total area of the Protectorate is about 200,000 square miles, and the total 
population at the present day is guessed at $4,040,000^{1}$. It consists mainly of negroes and negroids, the negroids being the result of ancient or modern intermixture between the Hamitic tribes of Ethiopia and Somaliland and the negroes of Equatorial Africa. The Gala, a handsome and interesting Hamitic people, displaying their kinship with the white man by their use of the plough, by their possession of a sex-denoting language, and by many other features, inhabit a portion of the northern parts of the Protectorate, coming as far south as the Tana River. In the north-east, on either side of the Jub or Juba River, are the Somali clans chiefly belonging to the group known as Ogadein. These southern Somalis are much mixed with negro blood, and are not such a handsome or Caucasian people as those of Northern Somaliland. Alike to the Italians and to the British -and perhaps even more markedly towards the British-they have shown themselves inimical from the very first. It will be remembered how cruelly they treated in older times the Portuguese Catholic missionaries who attempted to travel through their country into Abyssinia. Since 1896 they have murdered several British officials stationed at Kismayu, or other places in their territory; and punitory expeditions have been directed against them in 1898 and in I90I. This last expedition ended somewhat disastrously for the British arms, but was wisely not followed up by an expensive avenging campaign, as the country is not at present worth conquering, and is only inhabited by semi-nomad, warlike Somalis, who are, however, by the lure of commerce gradually settling down into a peaceable condition. In the Borān Gala country in the northernmost parts of the Protectorate, raids of Abyssinian soldiers take place from time to time and are particularly exasperating by the reckless damage

1 The Protectorate now contains seven provinces and a northern tract of territory not yet organized. The narrow coast-belt from Lamu to the Umba River is leased from the Sultan of Zanzibar for a payment of $£ 17,000$ per annum. 
which is done to the big game of the country. In this portion of East Africa the big game is being rapidly exterminated by the Abyssinians.

Big game, indeed, has been found to be one of the assets of this East African Protectorate. The writings of Joseph Thomson, H. H. Johnston, F. G. Jackson, Count Teleki, and Lieutenant Höhnel--explorers of this region between 1882 and I888-revealed to the world the amazing wealth of mammalian life in this region, formerly so abundant as to rival in this respect the South Africa of the early r 9 th century. Not long after the definite establishment of a British administration, measures were taken to preserve this wonderful fauna from a too rapid extinction at the hands both of European and of native hunters; and game reserves were established.

But perhaps the most important feat performed by the British Government, and one which has irradiated good as an exemplar and as a transport agency over all East and Central Africa, was the building of the Uganda railway between 1897 and 1903 . The railway commences at Mombasa, with another station at the great harbour of Kilindini on the south side of Mombasa Island, and pursues a course of 585 miles till it reaches the head of Kavirondo Gulf on the northeast of the Victoria Nyanza. Before long it will no doubt be extended through Kavirondo and Busoga till it attains the Victoria Nile and links up with railways which are being made from the birthplace of that river to the Albert Nyanza and Gondokoro. The Uganda railway, so early as the commencement of the 2oth century, enabled European tourists and settlers to penetrate far into Eastern Africa, and thus brought to public notice what had for some time past been realised by a few individuals - the fact that a good deal of the interior of British East Africa is a high and healthy plateau, possessing a very good climate, a kind of mild, perpetual summer, but invigorating, genial, and sufficiently rainy to support an abundant vegetation, In British East Africa there are, in 
fact, scattered areas of relatively-uninhabited, healthy upland amounting in all to about 30,000 square miles, uninhabited at the beginning of the 2 oth century because the native population had either been dispersed or exterminated by intertribal wars and famines, or found the climate too cold and preferred the lower-lying lands. At one time there was a project of offering a region about the size of Wales, carved out of these plateaus, to the distressed Russian, Rumanian, and Galician Jews through the Jewish Territorial Organization Committee. But the offer was foolishly declined by that body, and it is most unlikely it will ever be renewed, for, no sooner was the South African War over, than Boer settlers to the number of 600 or 700 with their wives and families proceeded to this interior part of East Africa and began to take up land from the British Government. Before and subsequent to their arrival there came not a few British for the same purpose, and at the present day there is a settled white population in British East Africa numbering at least 2000 . Without injustice to the indigenous peoples, there is no reason why some 30,000 square miles of East Africa should not be set aside for white settlement and nourish in course of time a sturdy population of three or four millions, which might prove to be a very potent factor in the politics of Equatorial Africa. It is not to be supposed that this region is without disease, but the disease arises not from the climate, but from the co-existence of black men with germs in their blood, and mosquitoes, ticks, and tsetse flies, whose odious purpose in life is to transfer these germs from the blood of one man to that of another. But the mosquito is often absent from both the high and the dry parts of East Africa, and in that case germ-diseases cannot be spread, or it is possible by cultivating the land to get rid of this and other pests. No doubt also in the plans which will be adopted for the eventual settlement of the whole country, some policy of segregation will be adopted, separating to a certain extent the colonies of the white man and of the British Indian. For, 


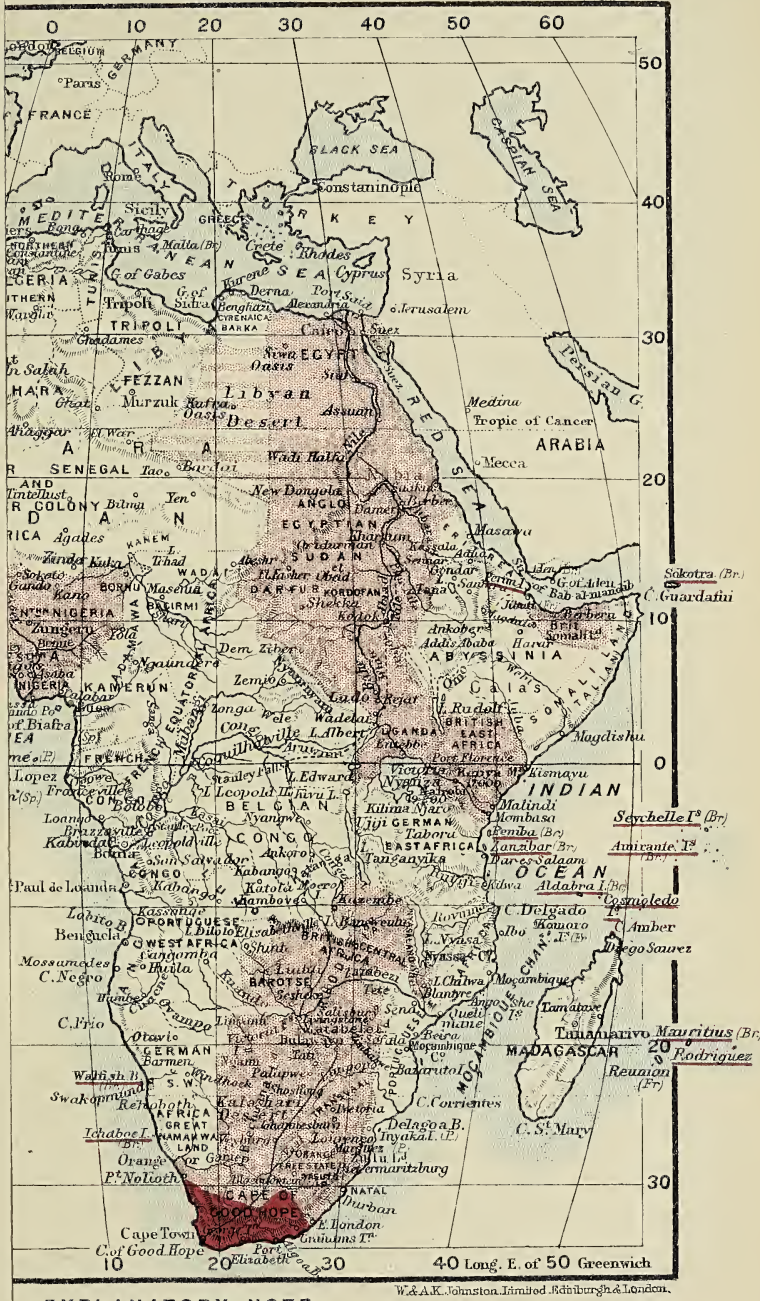

EXPLANATORY NOTE

rotectorates, Spheres of Influence or Control

rker colour in Cape Colony represents the extreme extent

tch South Africa when taken over by the Britisih)

rs imply uncertainty of possession) 

BRITISH AFRICA

Plate $\mathrm{Y}$.

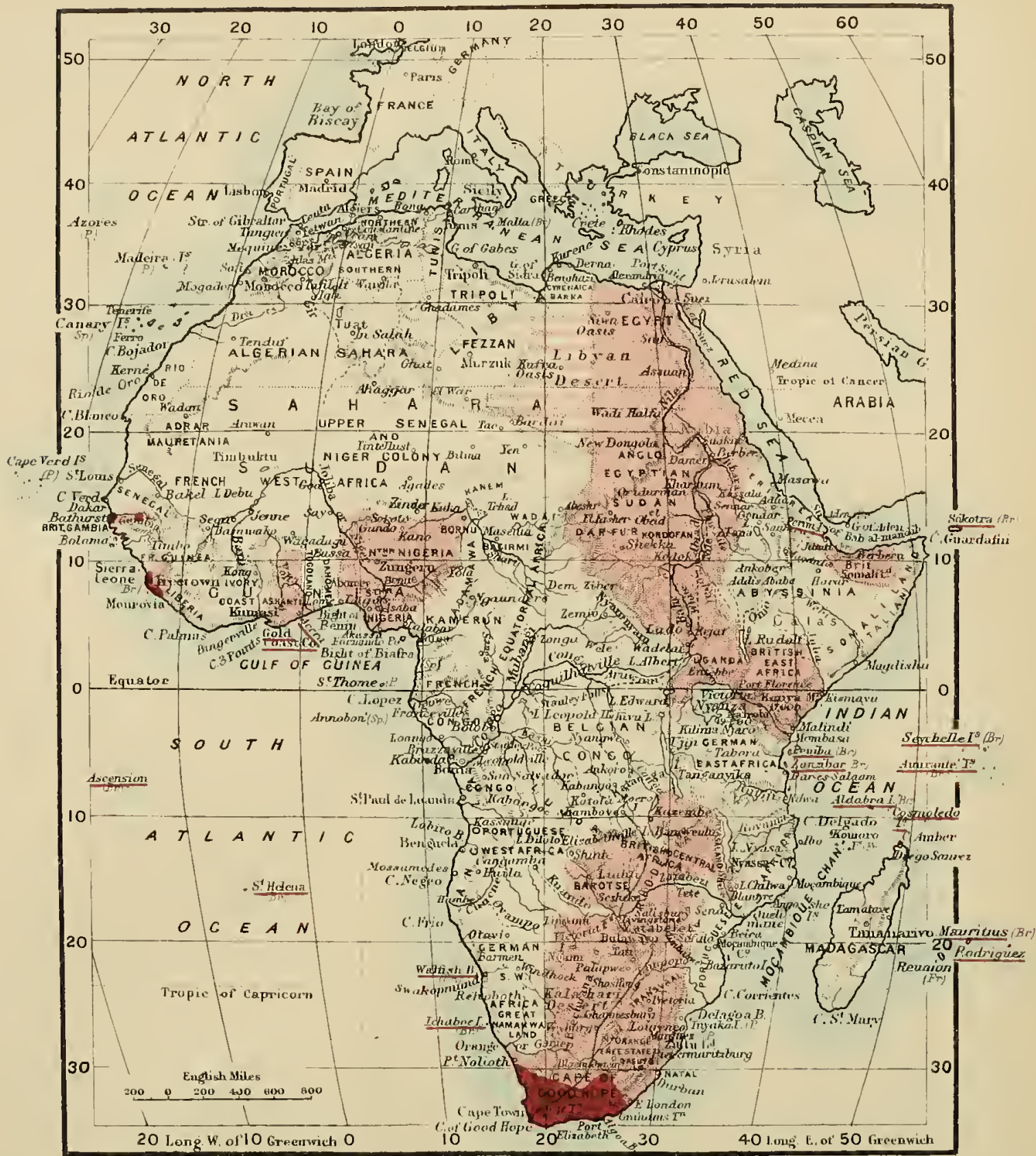

EXPLANATORY NOTE

Colonies, Protectorates, Sphieres of Influence or Control

In 1815 (This darker colour in Cape Colony represents the extrene cxtent of Dutch South. Africa when taken over (yy the british)

In Igra (Pink bars imply uncertainty of possession) 

amongst other things which are happening as the result of the British development of East Africa, is the in-pouring of a number of British Indian colonists, and even of Persians; and this Asiatic population shows every sign of prospering. It would be more reasonable, however, to reserve for Asiatic colonization the vacant lands near the coast and in the more northern parts of the Protectorate, which are hot and lowlying, and therefore unsuited to European settlement, but which would be well adapted for the cultivation of cotton and grain crops and the rearing of cattle by agricultural colonies of Asiatics. 


\section{CHAPTER XV}

\section{THE ITALIANS IN AFRICA}

The part played by Italy in the colonization of Africa after the submergence of Roman civilization in that continent under the Arab invasion was remarkable; it was not, however, a part attributable to Italy as a whole, but to some of her component states. The little principality of Amalfi had early dealings with the Saracens, and imported from them some knowledge of the new navigation, and of that newly-introduced group of fruit trees - the orange family - which was to find a second home in Italy. Pisa, Genoa, and Venice alternately warred and traded with the north of Africa. Naples obtained from Egypt the domestic Indian buffalo so early as the $13^{\text {th }}$ century. Sicily was finally conquered by the Saracens in 832 A.c.; and Sardinia from 7 I 2 became intermittently a Saracen possession for more than three centuries until it was definitely rescued by the Pisans after Ior 5 A.C. Consequently Sicilian and Sardinian renegades figure in the early Muhammadan history of Tunis, Tripoli, and Algeria. But the two states which before the Portuguese era shared most prominently in the commerce of North Africa were Genoa and Venice. Genoa had most to do with the 'Tunis littoral; she had intermittent establishments at Tabarka and Bona, besides occasionally holding Mehdia on the coast of Tunis. Genoa sent several noteworthy seamen to explore the Atlantic, the north-west coast of Africa, the Azores and Canary 
Islands; and it is believed that Genoese ships may even have found their way along the west coast of Africa to the Gulf of Guinea as early as the $14^{\text {th }}$ century; for in a volume of eight maps - the famous Laurentian Portulano, executed by a Genoese about I35I (and subsequently acquired for the Laurentian Library at Florence), Africa for the first time in history is delineated as a continent with a great western projection, a tapering southern extremity and its bold eastern horn of Somaliland. (This information, however, may have been derived from Arabs during the Crusades.) Venice cultivated a friendship with Egypt during and after the Crusades, and in this way obtained control over the Indian trade, until the Portuguese discovered and utilized the Cape route. Even then the interest of Italy in Africa did not slacken. It was displayed chiefly in Rome during the $\mathrm{r} 6$ th and $\mathrm{I} 7$ th centuries, when the Roman pontiffs took up geographical research into the problems and possibilities of Africa with some eagerness, especially with regard to the Congo, Abyssinia, and the northern Sudan. Noteworthy amongst the Popes who promoted African studies were Leo X, who encouraged the Italianized Moor, Johannes Leo ("Leo Africanus"), to write in Italian a description of his travels through the Nigeria and Northern Sudan"; Sixtus V, who caused his chamberlain Filippo Pigafetta to publish much valuable information from Portuguese travellers and missionaries concerning the Congo and Abyssinia; Paul V,

1 Leo Africanus, who wrote the most important work on Africa in the 16th century, was born at Granada in southern Spain in 1494 , just after the capture of that place by the Spaniards. His family migrated to Morocco, and "Hassan ibn Muhammad al Wizaz," surnamed "Al-Fasi," was educated mainly at Fas or Fez: whence his nickname. He travelled throughout North Africa and crossed the Desert to the Niger; visited Guinea, Mandingoland, the Niger Bend, Agades, Hausaland and Lake Chad, Egypt, and the Nile. Captured by Italian pirates he was sold as a slave and presented to Pope Leo X, who converted him, christened him, pensioned him, and encouraged him to give to the world his valuable geographical and historical information. 
who sent a mission to the King of Kongo in $162 \mathrm{I}$ to report on that West African kingdom; and Urban VIII, who in 1640 erected the Kongo Kingdom into an Apostolic prefecture dependent on the Roman See and despatched many Italian missionaries thither. His efforts were revived in $165^{2}$ by his successor, Innocent X.

During the 15 th, 16 th, 17 th and 18 th centuries, Abyssinian Christian students frequently journeyed to Rome and lived in Italy more or less as pensioners of the Popes. Similarly, during the 17 th and 18 th centuries so many Italian craftsmen, surgeons, physicians, naturalists, and botanists, travelled in and through Tunisia and Egypt, and stayed there permanently, that (besides the innumerable Italian slaves captured by the pirates and absorbed into the Muhammadan community) there grew up the great Levantine communities in the principal towns of Egypt and Barbary. In I600, an Italian surgeon named Federigo Zeringhi killed two hippopotamuses at Damietta, at the eastern mouth of the Nile; and in ${ }^{6} 5_{5} 8$ other Italian travellers noted the extinction of the hippopotamus in the Nile Delta. Italian influence sank to its lowest ebb in the late I8th century, but after Napoleon's invasion of Egypt many Italians were employed in the service of that country, under Muhammad Ali. Thousands of Italians (many of them Jews) also emigrated to Eastern Algeria and Tunis in the first half of the rgth century and financed the sponge fisheries off Tripoli. United Italy; in 1862 , began to assert herself at first in Tunis. During the sixties of the 19 th century the affairs of Tunis, instead of being debated only between France and Britain, were submitted to the consideration of a third power, the Kingdom of Italy ; and in 1869 a triple control of these three powers had been established over its finances. Then Britain ceased to claim a consultative voice in the control of this tottering Turkish regency, and France and Italy were left face to face. Italy had to give way in $\mathrm{r} 88 \mathrm{r}$. She had, however, for some time been cultivating 
an interest in Tripoli, where she had established, as in Tunis and Egypt, "Royal schools" for the gratuitous teaching of Italian; but a too vivid display of her interest in the affairs of Tripoli after the French occupation of Tunis caused the Sultan of Turkey to reinforce his garrison there by 10,000 soldiers, and Italy decided that the time was not then. Italian influence of a more or less Levantine, denationalized stamp had become well established in Egypt before the British occupation, and had to a great extent replaced that of France, the Italian language being employed as a kind of Lingua Franca. The present writer can remember, when first visiting Egypt in $\mathbf{1 8 8 4}$, that most of the letter-boxes at the post-offices had on them "Buca per le lettere," while Italian was much better understood in the towns than French, English of course not being understood at all at that time. So that, if it be true that $\mathrm{Mr}$ Gladstone in $\mathbf{1} 882$ invited Italy to take the place of France in a dual control with England over Egypt, the proposal was not, at the time when it was made, such a preposterous one as it might now appear.

So far back as 1873 Italy had cast an eye over Abyssinia; and one of her great steamship companies had purchased a small site on Assab Bay as a coaling station. Assab Bay, in the Red Sea, was on the inhospitable, ownerless Danákil coast, not far from the Straits of Bab-al-Mandib. In 1875 the suspicious movements of Italian ships about Sokotra obliged England to take that island under her protection. From 1870 onwards Italian missionaries and Italian travellers had begun to move about this coast, and to explore the south of Abyssinia. In 1880 the Italian Government revived the Italian claim to Assab Bay, but did not take actual possession of it until July 1882 , when the bombardment of Alexandria had awakened Europe to the apprehension of a great change in Egyptian affairs. An acrimonious correspondence took place between Italy, Egypt, and Turkey regarding this claim to Assab Bay; but Italy received the tacit support of England, and when the 
Egyptian hold over the Sudan crumbled, the Italians rapidly extended their occupation north and south, until Italian influence was conterminous on the south with the French Somaliland territory of Obok (and consequently opposite the Straits of Bab-al-Mandib), and on the north reached to Ras Kasar, I ro miles south-east of Suakin. In this manner Italy acquired about 670 miles of Red Sea coast, including the ancient and important port of Masawa. This coast in its partial condition of sterility and its terribly hot climate would be of little value did it not possess a cool, mountainous hinterland, considerable areas of gum forest, and fertile river-valleys, besides having much grazing ground for camels and other livestock, and commanding the easiest and nearest approaches to Abyssinia. In one part of the coast the natives are practically of Abyssinian stock, and Abyssinia has constantly striven through centuries to maintain her hold on the seaboard, but has always been driven back to her mountains by maritime races, such as the Greeks, Romans, Arabs, and Turks. Seeing Italy step in, after the downfall of Egypt, to replace that power in Masawa and elsewhere, King John of Abyssinia soon fell out with the Italians. The Italians had occupied an inland town called Sahati, formerly an Egyptian stronghold. Ras Alula, an Abyssinian general, with I0,000 men attacked $45^{\circ}$ Italian troops on their way to Sahati, and, as may be imagined, massacred nearly all of them. Italy felt her honour at stake, and in spite of the expense, would have been obliged to commence an Abyssinian war but for the good offices of the British Government. Lord Salisbury sent Mr, afterwards Sir Gerald, Portal on a mission to Abyssinia, which had the effect of arranging a temporary peace between the Italians and King John. Shortly afterwards King John of Abyssinia advanced against the Mahdists, and was killed in battle. Italy then occupied the posts of Keren and Asmara, which gave her control over the mountain passes leading, on the north-east, into Abyssinia. She had previously maintained a great 
friendliness with Menelik, the vassal king of Shoa in the south. (Abyssinia proper may be said to be divided into three principal districts, which sometimes become semi-independent satrapies or kingdoms-Tigre on the north, Amhara in the centre, and Shoa to the south.) When King John of Abyssinia died, Menelik, as the strongest of his vassals, seized somewhat illegally the Abyssinian Empire. Although now viewing the Italians in a more suspicious manner, he nevertheless concluded a treaty with them, which enabled him to negotiate a loan and to obtain a large quantity of war material, but contained a clause dealing vaguely with the "mutual protection" of the contracting parties. The Italian protectorate over Abyssinia was recognized by England and by Germany, but not by France or Russia. In order to annoy Italy as a member of the Triple Alliance, France and Russia commenced encouraging Menelik to a repudiation of the Italian protectorate, and supplied him with quantities of arms and ammunition. Russia, indeed, for years past had shown a disposition to concern herself about Abyssinia on the pretext that the Greek Christianity of that country linked it specially to Russia. She sent numerous "scientific" expeditions thither, and also a party of Cossack-monks to stimulate Abyssinian Christianity. On one occasion these Cossack-monks even went to the length of seizing a port on the French coast, near Obok. This was too much, even for the French; and force was used to expel these truculent missionaries.

In March I89 I, with a view to regulating future action on the part of Italy, England had entered into an agreement delimiting the respective spheres of British and Italian interests in East Africa; and by this agreement Italy was permitted, if she found it necessary for military purposes, to occupy the abandoned post of Kasala (then in the hands of the Dervishes), on the frontiers of the Egyptian Sudan. Accordingly this post was occupied by Italy in I 894. In the beginning of 1895 , the Italian forces being again attacked by the Abyssinians, the 
war was carried into the enemy's country, and after several sanguinary defeats had been inflicted on the Abyssinians, the greater part of the Tigre Province was occupied. Menelik, whose administrative capital still remained at Adis Ababa in Shoa, organized a vast army, and prepared to defend his kingdom. In the early spring of 1896 General Baratieri (in fear lest he might be superseded, and without waiting for sufficient reinforcements) assumed the offensive against the Abyssinians in the vicinity of Adua, with the result that he sustained a terrible reverse. Nearly half the Italian army (1 3,000 men-7,000 only Italians, the rest natives of the coast -against 90,000 Abyssinians), was killed, and of the remainder many prisoners were taken. This was a terrible blow to Italy, and its effects on European politics were far-reaching. General Baldissera somewhat retrieved the position; but all thought of an Italian protectorate over Abyssinia was at an end, a position frankly recognized by Italy in her subsequent treaty of peace with Menelik. She lost but little of her original colony of "Eritrea," but Eritrea seemed then of small value except as the stepping-stone to Abyssinia. The French and Russians were triumphant; and French adulation of the Emperor Menelik was scarcely worthy of a nation in the high position of France.

A British mission was sent in 1897 to open up friendly relations with Abyssinia, and to establish a political agency at the king's court. The treaty concluded seemed at first sight not wholly satisfactory to British interests, as it yielded a portion of Somaliland to Abyssinia, and did not provide for any delimitation of Abyssinian boundaries on the west ; but apparently there were other clauses not made public which subsequently ensured the friendly neutrality of Menelik during the Khartum campaign.

Since 1897 , or rather since the institution of civil government in 1900, the colony of Eritrea has made a quiet progress towards well-being and commercial prosperity insufficiently 
appreciated by historians of Africa. "Colony" remains an inaccurate designation, since the excessive heat of the lowlands makes Italian settlement in large numbers impossible (there are only 3000 settlers in the whole colony), while the uplands are either barren or sufficiently well populated by a sturdy race of negroids - a mixture of Hamites, Semites, and Nilotic negroes. But this native population $(275,000)$ has prospered and increased under Italian rule. A considerable trade is being developed in the nuts of the hyphæne palms, exported to the approximate annual value of $£ 50,000$. Hides and cattle, wax, gum, coffee, ivory, and salt are also exported; and the annual trade-imports and exports-now (1912) averages $f \mathrm{r}, 000,000$ in value. The area of Eritrea, which extends southward to Cape Dameirah on the Straits of Bab-al-Mandib, is 45,800 square miles.

Finding that Germany did not intend to push claims, halfdeveloped, to the Somali coast, Italy in $\mathbf{1} 889$ began to make treaties in that direction, and by the end of that year had established a protectorate over the whole Somali coast from the west side of Cape Guardafui to the mouth of the river Jub, a claim subsequently confirmed by agreements with Britain and with the Sultan of Zanzibar. Italian enterprise has led to a great deal of geographical discovery near the Jub River and the Webi Shebeili, an eccentric stream, which after arriving within a few miles of the sea and meandering along parallel with the coast, loses itself in a sandy desert near the mouth of the Jub River. Several Italian expeditions came to grief in these Somali and Gala countries, but Italy held on, and deserves to succeed in the long run. An Italian commercial company was founded to deal with the exploitation of the Benadir coastonce in the hands of the Sultan of Zanzibar-where there was still some lucrative trade to be done in products of the interior. But complaints were made as to mistreatment of the natives by the Chartered Company; and in I9oo the Italian Government bought from the Sultan of Zanzibar, for $£_{144,000 \text {, the ports }}$ 
(Benadir: plural of Bandar, a sea port) of Magdishu, Brawa, Marka, and Warsheikh which had long been appanages of the Sultan of Zanzibar. The name of the "colony" is now "Somalía Italiana," Italian Somaliland, and the capital is at Magdishu-the "Mogadoxo" of the I6th century Portuguese. Inland, Italian rule stretches along the Jub or Juba river as far as the Gala towns of Bardera and Lugh. Farther north, along the coast, there is the native Somali sultanate of Obbia and then the Somali tribal territory of Nogal. The total area of Italian Somaliland is about 140,000 square miles, and the population (Gala, Somali, Swahili negroes, Arabs, and helot tribes) is 400,000 .

About the year 1904 a rapprochement took place between France and Italy relative to a settlement of colonial "aspirations," coincidently with agreements, secret or avowed, entered into between France and Britain. It was then laid down that, should Italy at any time establish herself in place of Turkey in the Tripolitaine, the boundaries of her sphere of influence there should practically be conterminous with those then recognized by France as being the Turkish limits, comprising Tripoli (as far west as Ghadamés and Ghat), Fezzan, and Cyrenaica. It is probable also that a similar understanding was come to with Great Britain in the early part of the 2 oth century. In fact it was openly stated in the literature of the period that Italy had "ear-marked" the Tripolitaine as her share of the Turkish Empire should any further curtailment of the Turkish dominions take place. No official repudiation of such an idea emanated from Germany or Austria. Nevertheless, when Italy did move in this direction in $19 \mathrm{I}$, it was from Germany and Austria that she received the bitterest reproaches. The explanation of this changed attitude was no doubt that between 1909 and I9I I an idea had grown up both in Germany and Austria that Tripoli was now considered by Italy as practically worthless from the point of view of a future field for Italian colonization; and that it might be possible, through 
some scheme of concessions and chartered companies, for the Teutonic allies to effect a settlement and control over the Tripolitaine (under the Turkish flag, possibly). Thence they might build a trans-Saharan railway which would connect this German foothold on the south Mediterranean coast with the future Congolese Empire which Germany was resolving to shape in course of time out of French, Belgian, and Portuguese possessions, by purchase, exchange, and it may be some pressure. This idea bore fruit in an attenuated form in the concessions made to Germany by France in north-west Congoland in rg I I (see p. 234).

Italy had nearly gone to war with Turkey in I910 over a dispute regarding the Italian Post Offices in the Turkish Empire, and, as her principal means of punishing Turkey, was preparing an expedition to land in Tripoli. But the Turks gave way before a practical ultimatum, and Italy was left without an excuse. Then followed the announcement that a well-equipped Austrian "scientific" mission would start for the thorough exploration of the Tripolitaine in the winter of r9ro-rgri. Italy appealed to Turkey to grant similar facilities for an Italian expedition, but received an evasive reply. In July I9r I came the startling incident of Agadir, with all that it implied, both as to North African and as to Central African aims on the part of Germany. It was felt soon afterwards that Germany, being baulked of a foothold in Morocco, would be more than ever anxious to establish herself on the Tripoli coast. A quarrel was therefore picked with Turkey on somewhat vague grievances; and a declaration of war was followed by the immediate landing of an Italian army at the town of Tripoli on September 20, I9I I. Soon afterwards, in the autumn and winter of I9II, all the other towns on the coast of Tripoli and Cyrenaica were occupied by the Italians, whose Senate, on February 2.3, I912, ratified a decree annexing these provinces to Italy, as far to the west, south, and east as the spheres of France, Britain, and Egypt. The whole of the 
port of Solum and its vicinity was given over to Egypt-a solatium accepted without hesitation by the Anglo-Egyptian government.

The European conscience of course was outraged, and much sympathy was expressed with Turkey, but no assistance furnished. No doubt the action of Italy in theory was a political crime. In a time of perfect peace, she delivered an ultimatum to a neighbouring European power based on ostensible grievances of a trifling kind; and before that power could discuss any rectification of the said grievance, two large provinces of its territory were forcibly annexed. In theory the action of Italy was indefensible; in practice it was probably a matter of stern necessity. The coast of Tripoli is immediately opposite Italy, and it is far away from Turkey. A little hesitancy, and this littoral might have first been assigned commercially to German and Austrian subjects and subsequently have passed for ever beyond the scope of Italian sea-power. Italy would then have had the ironical punishment which Fate so often allots to those who let "I dare not wait upon I would." As to any regret being felt for Turkey, let us consider for a moment what were her moral claims to these two provinces. Their coast ports were seized by Turkish pirates in the middle of the i6th century. Eventually there grew up a Turco-Arab dynasty of the Karamanli Pashas to whom was delegated by Turkey in the early 18 th century the government of Tripoli and Barka (Cyrenaica). The Karamanli Pashas, though they sent out piratical fleets into the Mediterranean to attack the ships of powers not in treaty relations with them, nevertheless did much to open up Fezzan and the northern Sudan to European commerce; and their friendship with Britain made it possible for the British expeditions to Lake Chad and Bornu to take place in $182 \mathrm{I}-3$. In 1835 the Turkish Government at Constantinople, alarmed by the spreading power of Muhammad Ali and the French seizure of Algiers, intervened in the affairs of Tripoli and 
annexed it; a guerilla warfare continued for ten years afterwards. From $185^{\circ}$ onwards, a great revival of the Sudan slave-trade took place through the Tripolitan ports; and this was still more marked after Egypt, governed by the Khedive Ismail, ceased to export slaves. Under direct Turkish rule, the Tripolitaine became almost impenetrable by European travellers, several of whom were assassinated within its limits. Nothing was done for the improvement of Fezzan, of the oases, or even of the Tripolitan coast towns. Locusts ravaged the crops unchecked; and the desert sands steadily advanced on the cultivable regions. No public works worth mentioning exist to testify to any benefits derived from Turkish rule. Turkey has been tried in the balances of Tripolitan history and found to be utterly wanting.

By the summer of r9r2, the Italians had fought many battles and skirmishes with the Turks and Arabs of the Tripolitaine. They had been accused of the usual inhumanities of war by the usual Anglo-Saxon journalist, but they were in possession of all the coast towns, and in several of their lavish public works began to reconcile the much-tried Moorish population to the dominance of the "Rumi" - in this case a singularly truthful term, for it really was the "Roman" come back to rule a land which fourteen hundred years before (prior to the Vandal descent) he had raised to a position of considerable fertility and prosperity. In July, r9r 2 the chief of the great Senussi brotherhood (see page 236) made terms of peace and amity with the Italians ; and, as this edition goes to press, peace has been concluded (Oct. I5, 1912) between Italy and Turkey on the basis of the retrocession to the eldest daughter of Rome of two among the North African provinces torn from her Mother State, first by the Vandals and next by the Arab invasion of the 7 th century A.c.

When Italy is enabled to take complete possession of this area of 400,000 square miles, she will find that barely one-third is cultivable, and that the remainder consists of naked plateaus, 
mountains of sun-baked rock, and vast "seas" of drifting sand. The sand is a less hopeless proposition than the rock, for under it often lie layers of imprisoned water, releasable by artesian wells. But when the claims and requirements of the natives of "Libya" (as the Italians call their scarcely-won possession) are duly provided for, there will not remain much agricultural land for Italian settlement. Yet there may arise many promising industries which will provide employment for Italians in the towns on the coast. Moreover, with time, patience, sympathy and understanding, the Italians will find the million of Arabs, Jews, Berbers, Tibus, negroids and negroes who make up the Tripolitan and Cyrenaic population a people possessing many fine qualities of physique and endurance, who under a wise and fraternal government may cooperate with the European in making the desert blossom as the rose.

Whether Italy will be required to halt on the verge of the Sahara and Libyan Deserts, or whether France and Britain, declining to play the dog-in-the-manger, will withdraw on either side the skirts of their spheres of influence so as to admit the Italian to direct access to the Northern Sudan, on the borders of Darfur and Kanem, is an eventuality on the knees of the gods, and likely to remain for long among unborn events until the sands of the Libyan Desert prove to be valuable enough to be worth claiming and crossing. 


\section{CHAPTER XVI}

\section{GERMAN AFRICA}

German settlement in Africa is not altogether the outcome of the scramble for Africa in I884; German settlements on the West coast of Africa date back to $\mathrm{I}_{68}$, and Prussian or German protectorates in Africa were discussed during the sixties of the 19 th century. Ships from Emden ${ }^{1}$ and Gretsyl, belonging to the Friesland possessions of the Electorate of Brandenburg (the mother of the Prussian monarchy), stole out of the North Sea and took a part in the West African trade in slaves and gold. These ships were much harassed by the French, Portuguese, and Dutch, but the Brandenburgers, together with the Prussian Company of Emden, managed to establish a foothold at the close of the $I 7$ th century on the Gold Coast, where they held for a time Grossfriedrichsburg and Takrana. The little island of Arguin near Cape Blanco, off the Senegal coast, was bought by Frederic William (the Great Elector of Brandenburg) from the Dutch, and was held for some years. The Brandenburg Africa Company was definitely founded in $168 \mathrm{I}$, but by 1720 these North Germans, distracted by quarrels at home, had abandoned their West African enterprise.

During the forties of the I 9 th century some consideration was given in Germany to the question of colonization, but attention was directed to unoccupied territories in America, and nothing was said about Africa. About I850 German steamships (under the Hamburg flag) began to trade along

1 East Friesland.

$$
26-2
$$


the West Coast of Africa; and in that year the celebrated House of Woermann opened its first agencies at Monrovia (Liberia) and elsewhere on the West Coast.

Many German missionaries and colonists between 1845 and r 865 went out to South Africa to settle chiefly in Cape Colony, Namakwaland and Natal. Between 1860 and 1865 , a Hanoverian Baron, von der Decken, was exploring Kilimanjaro and the East coast of Africa. It began to dawn on him that Zanzibar and the Zanzibar coast would form a legitimate field for German enterprise, settlement, and colonization, "especially after the opening of the Suez Canal." Although von der Decken was killed on the Jub River in 1865 , he transmitted his opinions to Otto Kersten, who wrote an article in 1867 , stating that von der Decken had had ideas of buying Mombasa from the Sultan of Zanzibar in order to found a German settlement. By this time Hamburg merchants had established a flourishing trade at Zanzibar, and until 1885 the German representative at that place was almost invariably a Hamburg man; indeed before the unification of the German Empire there was a Hamburg (Hanseatic) consul at Zanzibar, rather than a German representative. Until the deliberate intervention of Germany on the East coast of Africa, these Hanseatic merchants practically placed themselves under British protection.

In 1878 the German African Society of Berlin was founded as a branch of the International African Association. It absorbed two similar societies dealing with Africa, more from a geographical than political point of view. German "international" stations were founded between Zanzibar and Tanganyika, and German explorers made a careful examination of the country round Lake Mweru and of the river Lualaba. Other German explorers (Wissmann amongst their number) traversed and mapped the southern half of the Congo basin; and, when the present writer visited the Congo in $\mathrm{I}^{882-3}$, the German explorers, nominally in the service of the King of the Belgians, 


\section{XvI] German Missionaries in Damaraland 405}

made no secret of the desire of Germany to acquire control over the Western Congo. This, no doubt, was one reason why Bismarck opposed the Anglo-Portuguese treaty of I883-4 (pp. 89-343). But, when the conference he had negotiated was brought about, he felt that French and Belgian opposition, united, and the absence of German treaty claims, made a German Congo State impossible. The energies of Germany were then directed towards the Niger, but here they were thwarted by the National African, afterwards the Royal Niger Company.

Several emissaries were, however, sent out to Nigeria by the German Colonial Society. This institution was founded at Frankfort-on-the-Main in $\mathrm{I} 882$, and at once met with enthusiastic support.

In the fifties, sixties, and seventies, German Protestant missionaries had established themselves in Damaraland and Namakwaland, in South-West Africa. In I864 some of these missionaries bought the estates of the Walfish Bay Copper Company, to the north-east of Walfish Bay, and here they hoisted the German flag. So early as 1877 Sir Bartle Frere began to regard the proceedings of the German missionaries with suspicion, and, to combat their action, proposed adding Damaraland to the South African Empire. But the British Government would only permit the annexation of Walfish Bay. About $\mathbf{I} 880$ the German missionaries renewed their complaints as to the treatment they suffered at the hands of the natives and the lack of protection they received from the British authorities. Prince Bismarck took up these claims, and asked the British Government whether it was prepared to protect Europeans in Damaraland and the Namakwa country. Lord Granville repudiated any responsibility outside Walfish Bay, and informed the Governor of the Cape that the Orange River was the north-western boundary of Cape Colony. In I 88 I the German missionaries asked for a gunboat to protect their interests on the Namakwa coast. The Foreign Office 
was consulted, and again repudiated any British claims to this territory outside Walfish Bay. At the beginning of $188_{3}$ Herr Lüderitz of Bremen, acting possibly under the inspiration of the German Colonial Society, asked the German Government whether he would receive German protection if he acquired territories in South-West Africa. He received a guarded consent (after the German Foreign Office had again consulted the British Government and received a vague reply). In April r 883 the agents of Herr Lüderitz went with a German ship to the Bay of Angra Pequena, I50 miles north of the Orange River. The Germans landed there, and marched inland I 00 miles to the German mission station of Bethany. The Hottentot chief of that district sold to these agents of Herr Lüderitz a piece of land 24 miles long and ro miles broad, with that breadth of frontage on the Bay of Angra Pequena, including all sovereign rights. On the 2nd of May, I883, the German flag was hoisted on the shore of Angra Pequena Bay over the first German colony. When the news reached the Cape, an English gunboat, the Boadicea, went to Angra Pequena, and was met at that place by a German gunboat, whose commander informed the captain of the Boadicea that he was in German waters, and could exercise no authority there. Nearly five months had apparently elapsed between the hoisting of the German flag at Angra Pequena and this visit of the British warship, and during that period no action had been taken in England. Nor, indeed, could any action have been taken after the explicit manner in which both Lord Beaconsfield's and Mr Gladstone's Administrations had disavowed any British claims to the coast of South-West Africa. Too late, Lord Granville informed Prince Bismarck that "any claim of sovereignty or jurisdiction on the part of a foreign power over any part of the coast between the Portuguese boundary and the Orange River would be regarded as an encroachment on the legitimate rights of Cape Colony." Even then Germany did not proceed to immediate action, but 


\section{xvI] British inactive regarding S.W. Africa 407}

repeatedly pressed the question whether England did or did not intend to take upon herself the administration of this Damara coast. The British Government sought to evade a direct reply by consulting the Cape Government. No answer was returned by the latter till May $\mathbf{1 8 8 4}$, when the Cape offered to take over the control of the whole coast up to Walfish Bay. But in April Germany had made a statement that she would not recognize British protection over this coast, and on the 2 Ist of June she secured from England a recog. nition of a German protectorate. If the action of the British authorities was blameworthy (from a national point of view) in refusing to take Germany seriously, and in puzzling her by declining to proclaim a British protectorate between the Orange River and the Portuguese possessions, the blame falls equally upon the Cape Parliament. It was the parsimony of Cape Colony which feared to be led into expense, coupled with the shortsightedness of the English Ministry of the day which refused to believe in the possibility of Germany desiring colonies, that permitted Germany to establish herself as a South African power. As to the German Government, it behaved throughout with perfect "correctness." It gave the British Government ample time and opportunity to make good any preceding rights.

Germany did not act here as she did in the Cameroons, where she merely informed the British Government that Dr Nachtigal had been commissioned by the German Government to visit the West coast of Africa in order to report on the state of German commerce, and asked that he might be furnished with recommendations to the British authorities in West Africa. Her ambassador did, it is true, mention that Dr Nachtigal would conduct negotiations connected with certain questions, but the context implied that these questions were commercial matters. Therefore the British Government, which had already made arrangements for establishing a protectorate over the whole coast between Lagos and the Cameroons, did not cause Consul 
E. H. Hewett to return to his post with any undue hurry. Dr Nachtigal arrived at the Isles de Los, on the Sierra Leone coast of Africa, on the rst of June, r 884, with the intention of taking under German protection the River Dubreka, situated in the district which the French call Rivières du Sud; but, as there was some doubt as to French claims, nothing further was done at the time; and, when afterwards the German flag was hoisted, it was at once removed on the receipt of a French protest. On the $5^{\text {th }}$ of July Nachtigal reached a district on the east of the English Gold Coast colony, now known as Togoland. Here arrangements were made with the native chiefs and the country was declared a German protectorate. Then Dr Nachtigal steamed right across to the Cameroons. Here he was just in time. The principal chief, King Bell, had been won over by the gift of $£$ rooo to sign a treaty with Germany. The other chiefs refused to do so, and Bell himself waited for a week to see if Consul Hewett would arrive. However, when the Consul did come on the I 9 th of July, King Bell had signed the treaty, and the German flag had been hoisted over the Cameroons River. Consul Hewett was in time to carry out the rest of his programme, and, so far as actual treaty-signing went, the British had only lost a small piece of the coast-line they had determined to secure ; but, in order that a grudging spirit might not be shown to Germany, she was finally allowed to take over all the Cameroons district ${ }^{1}$.

In East Africa Germany's procedure may be summarized thus. Count Pfeil, Dr Carl Peters, and Dr Jühlke arrived at Zanzibar on the $4^{\text {th }}$ of November, I884, as deck passengers, dressed like mechanics. Officially discountenanced by the German Consul, they nevertheless left at once for the interior; and on the 19 th of November the first treaty was signed with

1 Perfunctory regret for such concessions may be spared when it is borne in mind that the United States of Europe (as they would have become in an Anti-British League) would hardly have allowed even Free-trade England to acquire all the coast-line of the Dark Continent. 
a native chief, and the German flag was hoisted in Uzeguha. Eventually other treaties were concluded in Nguru, Usagara, Ukami, and other adjoining countries, which resulted in a solid block of 60,000 square miles being ostensibly secured on paper. Dr Peters hastened back to Berlin, and on the I 2 th of February, I 885, he had already founded a German East African Company, to whom he transferred his treaty rights. On the $27_{\text {th }}$ of February following, the German Emperor issued an official notice of the extension of his protection to the territories acquired, or which might be further acquired. In vain the Sultan of Zanzibar protested. The British representative was instructed to support German claims, and eventually it was decided that the Sultan of Zanzibar's authority was to be limited to a strip ten miles broad along the coast between Cape Delgado and Somaliland.

In May I 885 the Foreign Office informed Germany that a British company desired to develop the country between the Mombasa coast and the Victoria Nyanza. The foundation for this scheme was the treaties which the present writer had concluded on or near Kilima-njaro in the preceding year, and which at the suggestion of the Foreign Office had been transferred to the late Mr James Hutton of Manchester. The Sultan of Zanzibar, however, refused to give in, even to British representations, and made strenuous efforts to support his claims to the hinterland of the East African coast. On the 7 th of August, I885, a German squadron hove to in front of Zanzibar and delivered an ultimatum. The Sultan bowed to the inevitable, and recognized the German territorial claims, including a protectorate over Vitu ${ }^{1}$, a little patch of territory near the Tana River. Gradually, however, matters settled down. An agreement was come to in 1885 between the British and German Governments for a recognition with France

1 The concession of Witu, or Vitu, had been obtained by the Denhardt brothers on the 8th of April, 1885 , and a German protectorate was declared on the 27 th of May. For subsequent history see page $3^{8}$. 
of the independence of the Sultan of Zanzibar, and the definition of his exact dominions by a joint commission. Eventually, in I886, the respective British and German spheres in East Africa were defined. In the same forceful manner the Germans had taken Kilima-njaro. Except for the bulge of Kilima-njaro, a line drawn from Wanga on the coast (near the river Umba) straight to the north-east shore of Lake Victoria Nyanza is the Anglo-German frontier in East Africa. The limit of the British sphere on the north was the Tana River, Germany maintaining her hold on Vitu. The German Government then came to terms with Portugal, and agreed that the territories of the two powers in East Africa should march together as far as the east coast of Lake Nyasa. Germany also concluded treaties along the Somali coast.

The German Colonization Society and the German Colonial Society subsequently united under the latter title, while the German East African Association had been incorporated by Imperial charter. Further subsidiary companies were organized; and by 1888 numerous plantations had been established in the north of German East Africa, near the coast. In 1888 the German East Africa Company obtained from the Sultan of Zanzibar the lease for 50 years of the whole of the Sultan's coast territory from the Ruvuma River to the Umba. A great development then took place in the Company's operations, which were more and more identified with the German Government. A staff of over 60 officials was sent out to carry on the new administration. Sir Charles Euan Smith, who had succeeded Sir John Kirk as British Agent at Zanzibar, warned the German administration in a friendly manner that, unless greater care for Arab susceptibilities was shown in replacing the Sultan of Zanzibar's government on the coast, troubles with the Arabs might ensue. His warning was only too well founded. Five days after taking over the administration of the country-on the 2 Ist of August, r 888-disturbances fomented by the Arab and Swahili population broke out, 
and in another month the Germans held very few posts on the coast or in the interior. An animosity also began to be directed not only against the Germans, but against all Europeans, and the situation became very serious. In I889, the resources of the Company having broken down, Captain Hermann Wissmann (afterwards Major von Wissmann) was appointed Imperial Commissioner for East Africa. With Iooo native troops, mainly Sudanese recruited with the help of the British Government, 200 German sailors, and 6o German officers and non-commissioned officers, von Wissmann carried on a vigorous campaign against the Arabs and Swahili, and by the end of 1889 he had put down the revolt and captured and executed the leader of it, Bushiri. It took six months longer, however, to quiet some of the interior districts and those near the River Ruvuma.

In the middle of 1890 Germany concluded a very wise arrangement with England, by which, as has already been described in another chapter, all German possessions to the north of the British boundary at the Umba River were given up, and a British protectorate over Zanzibar was recognized, while the German boundaries were carried inland to the frontier of the Congo State. On the south, Great Britain was admitted to the south end of Tanganyika, and secured all the west coast of Lake Nyasa. From I 890 to the present time German settlement and the development of German East Africa have gone on without any disagreeable check so far as the Arabs or the European powers are concerned. In 1893 a large and well-appointed steamer, the Hermann von Wissmann, was placed on Lake Nyasa; and the British authorities round that lake were amply rewarded for any help they might have contributed towards its conveyance thither by the services which the German steamer afterwards rendered in acting as a transport for a portion of the British forces in the last war against the Lake Nyasa Arabs. At the beginning of the 2 oth century the Germans had placed a fine war-steamer on Lake Tanganyika. 
On the Zanzibar coast new quarters in the old Arab towns sprang up like magic, the streets being widened, kept clean, and well lit. Flourishing plantations covered many acres of what was formerly waste land. There was fair security for life and property, even in the distant interior. The Arabs became reconciled to German rule, while on the other hand the German officials slowly learnt the art of dealing tactfully with subject races. Since 1890 , when the coast strip leased from the Sultan of Zanzibar was finally purchased from him, the whole of German East Africa has been under direct Imperial administration. This German possession has now an area of about 384,000 square miles, with a populationmainly Bantu negroes-estimated at ro, settlers are stated at only 7000, and the Europeans (mainly Germans) at 3800 . It is likely to turn out in course of time a flourishing tropical settlement ; not a country which Germans could colonize in the sense that Australia or Canada are colonizable, but a Ceylon, a Java, a Southern India, where the German planter may make a competence, where the goods of Germany may find unrestricted markets, and where the Teuton may educate and raise into a higher state of civilization a vigorous negro people-some tribes of which, like the Wanyamwezi and the Waswahili, possess fine qualities. The plateau region to the north and north-east of Tanganyika may support here and there small but flourishing colonies of white men. British Indians are already settling somewhat thickly in the coast towns and are exchanging their nationality for that of German subjects.

In $\mathrm{r} 89 \mathrm{I}$, scarcely two years after Wissmann had broken the power of the Arabs, the Germans found themselves fighting a more difficult, brave and unaccountable enemy, the Wa-hehe of the plateau region south of the Rufiji river. These people seem to have some distant affinity with the Zulu in appearance, character, and mode of warfare. This may be due to their having been influenced by the Wa-ngoni further south (partly 
in Portuguese, partly in German East Africa), the Wa-ngoni (under various tribal names) being derived from Zulu clans which left South-east Africa early in the Igth century and crossed the Zambezi, reaching northwards nearly to the Victoria Nyanza. The German war with the Wa-hehe lasted till about I 893. Then ensued a period of comparative peace till the year I905, when a most serious native rising took place in the southern districts of the colony, between North Nyasa and the Kilwa coast. Nearly all the tribes, Muhammadan and Pagan, joined in attempting to oust the Germans. Officials, Catholic missionaries (male and female), planters, and traders were murdered. It took nearly a year and a half to subdue this rebellion completely, and something like $\mathrm{I} 20,000$ natives (adults and children) died during this struggle, or from its immediate results; they were killed in battle, by famine resulting from the destruction of crops or neglect of agriculture, or by disease. The effects of this depopulation are still to be seen in the coast belt of Kilwa and in the Ruvuma watershed. The Wa-ngoni (or Magwangwara as they are sometimes called) were almost exterminated-an achievement by no means to be greatly mourned, since they had kept East Africa (Lake Nyasa to the Indian Ocean) unsettled by their raids, sparsely populated, and scarcely cultivated for some fifty years previously. The Germans subdued this native rising with a small army of German officers and non-commissioned officers, and Masai and Sudanese soldiers, and even brought the Oceanic negro of New Guinea face to face with his African brother for the first time for something like three hundred thousand years! But these Papuan and Melanesian soldiers were not altogether a success.

It was alleged that this great rising was caused by misgovernment, and by imposing on the people labour taxes which were most unpopular, especially when this forced labour was leased out to conscienceless European planters. Herr Dernburg -then German Colonial minister-came out to investigate the 
cause of this revolt in 1907. Since his recommendations were adopted the whole of German East Africa has been peaceful.

In 1890 railway construction began, firstly in a line from Tanga (a northern port) to Usambara and eventually Kilimanjaro. This at present (I9I2) has a length of Io8 miles. In the early years of the 2 oth century a Dar-es-Salaam ${ }^{1}$ Tanganyika line was begun which already reaches Kilimatinde, 240 miles inland. Another line, starting from Kilwa on the southern coast, aims at the northern end of Lake Nyasa.

The later history of the Cameroons has been much like that of German East Africa-revolts, "sharp lessons," then attacks by hostile tribes inland, which are quelled by expeditions and the building of forts, followed by other revolts still further in the interior, to be succeeded by still further victories and advances; but on the whole increasing peace and order throughout the country, and a great development of trade. Unfortunately, as amongst some officials of the East Africa Company and Administration, so among a few of the Government servants in the Cameroons, there were instances of great cruelties committed between 1887 and 1896 , cruelties which led to a serious revolt among the negro soldiery (1895). Germany wisely did not hush up these affairs, but investigated them in an open court and punished the guilty. It will be seen, I fancy, when history takes a review of the foundation of these African states, that the unmixed Teuton-Dutchman or German -is on first contact with subject races apt to be harsh and even brutal, but that he is no fool and wins the respect of the negro or the Asiatic, who admire rude strength; while his own good nature in time induces a softening of manners when the native has ceased to rebel and begun to submit. There is this that is hopeful and wholesome about the Germans. They are quick to realise their own defects, and equally quick to

1 Dar-es-Salaam is the capital of German East Africa. 
amend them. As in commerce so in government, they observe, learn and master the best principles. The politician would be very shortsighted who underrated the greatness of the German character, or reckoned on the evanescence of German dominion in strange lands.

In $1904-5$ there were risings of the Bantu negroes against German authority in the western part of the Cameroons ${ }^{1}$ colony. These were suppressed after much bush fighting, but the cause of them being oppressive legislation, the Governor of the Cameroons was changed in I906, since which time the whole country has been peaceful. In the far interior German influence was established over the banks of the Shari and of Lake Chad by I902; and about the same time Germans began to open up relations with the "Fang" country in the western part of the Congo watershed. Railways were begun in the first decade of the 2 oth century. One from Victoria (Ambas Bay-the original settlement of the Baptist mission-see p. 244) runs round the southern flanks of Cameroons Mountain to Buëa, the German capital (3000 ft. above sea-level); another from the Cameroons river (Duala) to the Manenguba mountains and Bayoñ (this will eventually link up with the VictoriaBuëa line and be built northwards towards the Shari river); and a third from Duala south-eastward to the Nyanza river.

In I9II-I 2, Germany obtained from France additional territory on the south and west of the Cameroons Colony to the extent of 100,000 square miles, bringing this African dominion eastwards into the Central Sudan, to the Mubangi river, main Congo, and north coast of the Gaboon. Germany thus secures the whole basin of the Sanga river (a valuable waterway into the Fang country) and now possesses in the Cameroons-or as it is spelt in the German fashion, Kamerun -an. Empire in Western Equatorial Africa of some 292,000

${ }_{1}$ Kamerun is the official spelling of the old Portuguese name for this region (Camarões) which we render "Cameroons." 
square miles, with a population of negroes and negroids numbering about $4,000,000$. The country is rich in valuable products, and already the annual trade amounts to about $f_{2,200,000}$ in value.

In South-west Africa Germany, by arrangement with Portugal and eventually with England, secured a protectorate or sphere of influence over a very large stretch of country322,450 square miles-bounded on the north by Portuguese West Africa, on the south by the Orange River, and on the east by British Bechuanaland, with, in addition, a long, narrow strip, which reached the Zambezi at its confluence with the Chobe. This country along the coast-line is very barren; it is, in fact, a hopeless desert, most hopeless of all between the Orange River and Walfish Bay. But the interior is mountainous, and in these mountains there are stretches of well-watered country where cattle are kept in enormous herds. Moreover, this mountainous country is very healthy. With the Bantu Herero, who inhabit the northern part of German South-west Africa, the Germans at first got on very well, thanks to the influence exerted by the German missionaries; but with the pure-blood and half-caste Hottentots, who inhabit the southern section of the colony and almost all the coast-belt, the Germans have been constantly at war. These Hottentots, many of whom have some slight infusion of Dutch blood which renders them more warlike than their relations in Cape Colony, are Christians of a kind, wear clothes, and bear Dutch names. They at first found a leader in a certain Hendrik Witbooi, who again and again inflicted defeats on small parties of German soldiers, made treaties and broke them, and from first to last gave the Germans a great deal of trouble. Although he could boast of but a paltry number of followers, he fought in a waterless, mountainous country, where concealment was easy and pursuit difficult. In 1894 he made peace with the Germans and remained more or less their ally till i904. As he spoke Cape Dutch fluently he soon mastered German, and for a time seemed really 
reconciled to the Germanization of his people-already Calvinist or Lutheran Christians.

But in 1903 , the Hottentots living on the north of the Orange River and largely mixed with Boer blood-the Bondelzwarts-rose against the Germans; and, although they only numbered some five thousand fighting men at most, they occupied the German forces for four years before they were conquered, mainly by extermination. The deserts in which they lived (yet from which they were being dispossessed) were remote and inaccessible except from the British possessions. Whilst the German forces were attacking the Bondelzwarts, the Bantu Damara or Ova-herero in the far north broke out into rebellion, attacked the German settlers and traders without warning, and murdered some of them, destroying all the homesteads they could find. The excuse they gave for this furious outburst was that, when they signed the original treaties of friendship and acceptance of protection, they had no idea they were signing away their native land; and that subsequently much vacant land in the Damara country had been given or sold by the German Chartered Company ${ }^{1}$ or government to white settlers, some of whom also on unfair pretexts had taken away native cattle. Reinforcements came out from Germany under General von Trotha, and the mass of the Herero army was attacked in its stronghold, the Waterberg range of mountains in about Lat. S. $2 \mathbf{1}^{\circ}$. The Herero warriors were slaughtered in numbers; nevertheless, the larger proportion of the fighting men succeeded in evading the encircling movement of the Germans and escaped under the leadership of a chief, Samuel Maherero, and fought against the Germans for months

1 In the early days of the colony, when Germany rather despaired about the unprofitable region she had annexed on the map, she brought into existence the German South-west Africa Company in order to introduce capital into the country. To this company were given extensive land and mineral concessions without any regard whatever for native rights or sentiment. Hence, when these rights were exercised, arose much trouble with the settled regro population. 
after their great defeat in the Waterberg mountains in August I $904^{1}$.

In the early autumn of that year the Hottentots broke out again with renewed vigour, first under the leadership of a Herero half-caste, Morenga, and a few days later under the renowned Hendrik Witbooi. The Nama Hottentots, as a signal of their defiance of the German power, assassinated about sixty German settlers in the south-east part of the Colony, scrupulously distinguishing between them and the Boers or British residing in or travelling through the country. These (as the Herero had done, far to the north) they left uninjured in any way. General von Trotha was baffled by the double enemy-Hottentots and Bastards in the south, Herero in the north. He issued proclamations of a somewhat savage tone in his exasperation, and these being annulled by the Imperial Government he resigned and returned to Germany in 1905 . In the autumn of that year a new governor-von Lindequistarrived, and by reasonable measures of conciliation and by the allotment of definite native reserves made peace with the Ovaherero. Samuel Maherero however preferred to remain on British territory, where he had taken refuge. Since the close of 1906, however, there has been no more trouble between the Germans and the Herero, who are slowly recovering from the awful loss of life and diminution of their notable nation during this terrible war of fierce hatred on either side ${ }^{1}$. The Ovambo farther north have given signs of unrest, but are believed now to have become reconciled to German rule.

Hendrik Witbooi died in 1905 ; and Morenga was finally

1 There are said to be only about 20,000 Herero people now living in Damaraland. It would be a great pity if this intelligent, strong race of Bantu negroes disappeared. They must have an interesting history behind them, which is being slowly pieced out by tradition and by the etymology of their remarkable language, by some regarded as the "Sanskrit of the Bantu." They seem to have emigrated almost direct to South-West Africa from East Equatorial Africa some fifteen or sixteen hundred years ago, bringing their long-horned cattle with them. 
killed by a British police patrol, in August 1907, in the Kalahari desert. He had fled to British territory in I906, but had not been surrendered to the Germans. On the contrary, he was treated as a political refugee and given every chance of settling down peacefully. He only abused this kindness, however, in order to organize attacks on the Germans from the secure basis of the British frontier. Therefore his death in a skirmish with British mounted police was entirely his own fault.

By 1908 all these troubles were at an end, and German South-west Africa was free from native foes. But the long war in these deserts and bare, rocky mountains had cost the Germans the lives of over five thousand soldiers and settlers, and an expenditure of 15 millions sterling! So that it would have been cheaper at the commencement of this colony's history to have carried out a fair land-settlement which would have contented the natives and still have left more than half the area of South-west Africa at the disposal of the white man.

In I908 diamonds were discovered in the sandy desert country at the back of Luderitz Bay. Their quality was that of the Brazilian or Liberian diamond, rather than of the type of Cape Colony or Transvaal stone. Though as yet not large in size they were of good "water," and in r 909 the total value of the diamonds exported was $£ 771,776$ in value. In succeeding years the supply fell off somewhat. In the northern part of the Colony, at Otavi and Tsumeb, copper mining is carried on ; and the output of copper is sufficient to warrant the construction of railways of considerable length. Cotton cultivation has been begun, and the keeping of cattle, sheep, and Angora goats has revived once more with the cessation of warfare. The amount of sheep indeed is beginning to approach a total of half a million. Cattle thrive well in the interior, especially in the northern half. So also do horses, camels, asses and pigs. Camels have proved most useful for the desert regions of the coast-belt and the south. 
The guano islands along the coast all belong to British subjects and are part of Cape Colony. So also is the only really good harbour on the coast-Walfish Bay. This little enclave of 430 square miles belongs to Cape Colony and is British territory. It would be an act of not wasted generosity some day to transfer this little patch to Germany for the benefit of German South-west Africa. Its retention by the British Empire is of the dog-in-the-manger type of policy. It is no longer of any use to us, nor does the want of it cripple German South-west Africa; yet its possession by Germany would relieve her of the continued heavy expenditure needed to maintain the adjoining Swakopmund as a landing-place for passengers and goods.

A railway of over two hundred miles now connects the southern port, Luderitzhafen (Angra Pequena) with the inland settlement of Keetmanshoop, and will be extended some day to the Orange River and the Cape railway system. Another and longer railway (359 miles) goes from Swakopmund to the Tsumeb copper mines. A third railway (237 miles) of small gauge--the first constructed-connects Swakopmund with the administrative capital, Windhoek. There is also a short line between the Otavi copper mines and Groot Fontein. So that, between 1900 and I912, Germany has constructed over rooo miles of railway in her colony of South-west Africa.

This indeed comes nearer to being a real colony than any other possession of Germany in Africa. Out of a total population of not quite 100,000 , nearly $\mathrm{I} 1,000$ are Germans, the rest of the twelve to thirteen thousand whites being Boers and British. (The negro population-Bantu, Hottentot, Bushman, and half-castes-only numbers about 85,000 since the wars of 1903-7.) The climate is nearly everywhere healthy for the white man, and the tsetse fly is almost completely absent from the entire colony of $3 \mathbf{2 2 , 4 5 0}$ square miles. Only in the extreme north, near the Kunene River, the Kubango, and Kwando is there malarial fever. In the interior, more or less parallel 
with the coast, are mountain ranges rising to considerable altitudes -8972 feet is the highest point. They enclose fertile valleys, and their mists and rains nourish perennial streams, which however do not send their waters to the sea except in flood time. Indeed over much of this central and northern mountain region the average yearly rainfall, between October and April, is only 20 inches.

Germany has made far from a bad bargain with Fate in investing in what was thought at the time by ignorant statesmen in England and Cape Colony to be a derelict portion of South Africa. Like parts of the French Sahara, German Southwest Africa may turn out to be a singularly healthy and wealthy tract of land. But can it remain long a German Colony? Will not the attraction of the South African Union be more powerful than the fiat of governments five thousand miles away in London and Berlin? The parallel instances of 'Texas, Florida, and the United States may be quoted some day, very appositely. But such a movement, if it ever does come about, will be a peaceful one because it will be irresistible; and it may be coeval with a very close alliance in Europe, Asia, and Tropical Africa between Germany and her oldest Colony-Britain.

Togoland, between the Gold Coast and Dahomé, became a German protectorate in I884. It has an area of 33,700 square miles and a negro population of about $1,000,000$. Its boundaries were finally settled with France and Britain in I 899, and the neutral sphere, which contained the towns of Yendi and Salagá, was divided between Germany and Britain. Togoland stretches northward to the I Ith degree of $N$. Lat. (its boundary with France) and includes the important Muhammadan towns of Yendi and Sansanne Mangu, in which the trading population is mainly Hausa. The administrative capital is Lome on the very narrow coast-belt. High and less unhealthy land for European settlement has been discovered in the interior; there have been no disturbances with the natives, and German trade has prospered. The annual 
total of imports and exports is now (I9I2) about $£ 900,000$. There is a railway, in all of about $\mathbf{I} 30$ miles, which links up Lome with other coast stations and with the hill stations in the interior. Togoland is the only German colonial possession which is self-supporting and does not require an annual subsidy towards its upkeep. The land has not been taken from the natives, and the native "Kings" and chiefs not only remain in power but are much consulted by the German government. Consequently there has never been any native rising or discontent with the white man's over-rule.

Germany now possesses an African Empire of $\mathrm{r}, 032,000$ square miles with a population of about $\mathrm{I} 4,500,000$ negroes and 30,700 whites--mainly Germans. 


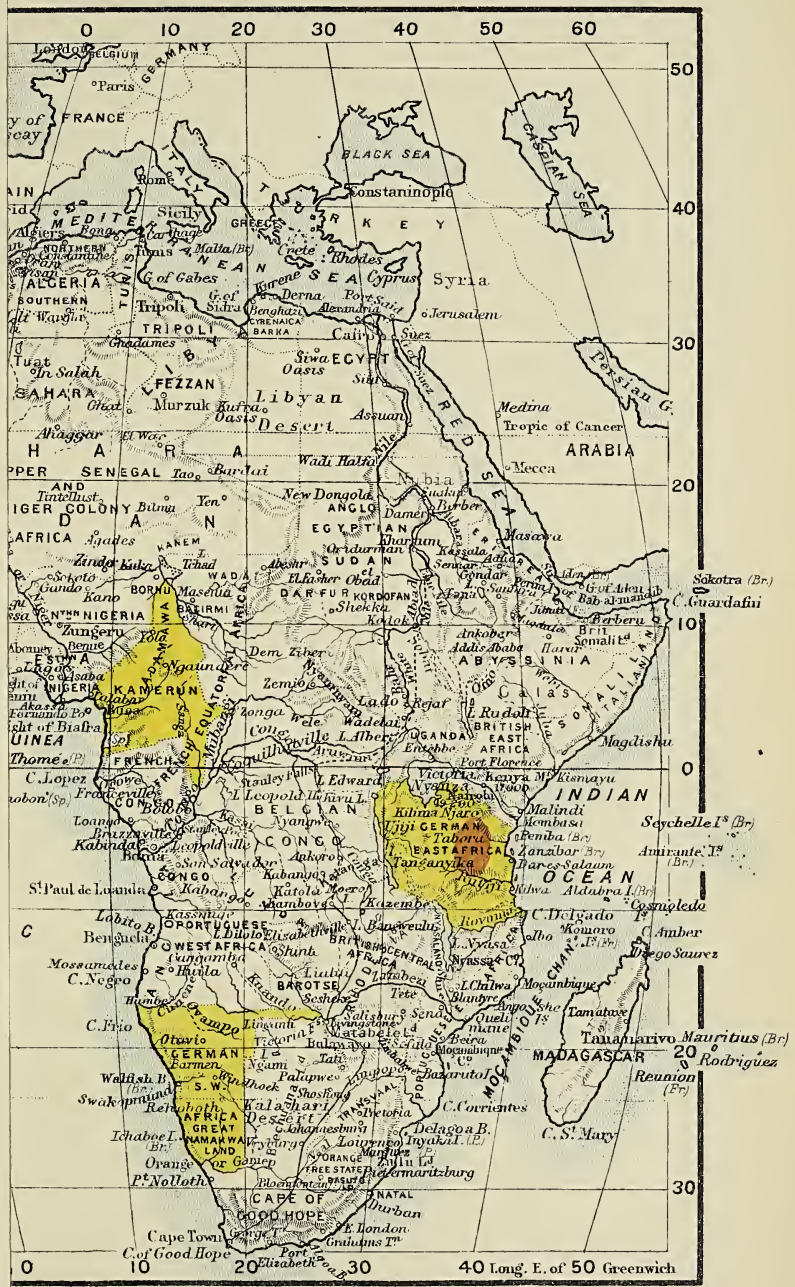

EXPLANATORY NOTE

Area of German Possessions in 1885

$$
\text { , , . }
$$



GERMAN AFRICA

Plate VI.

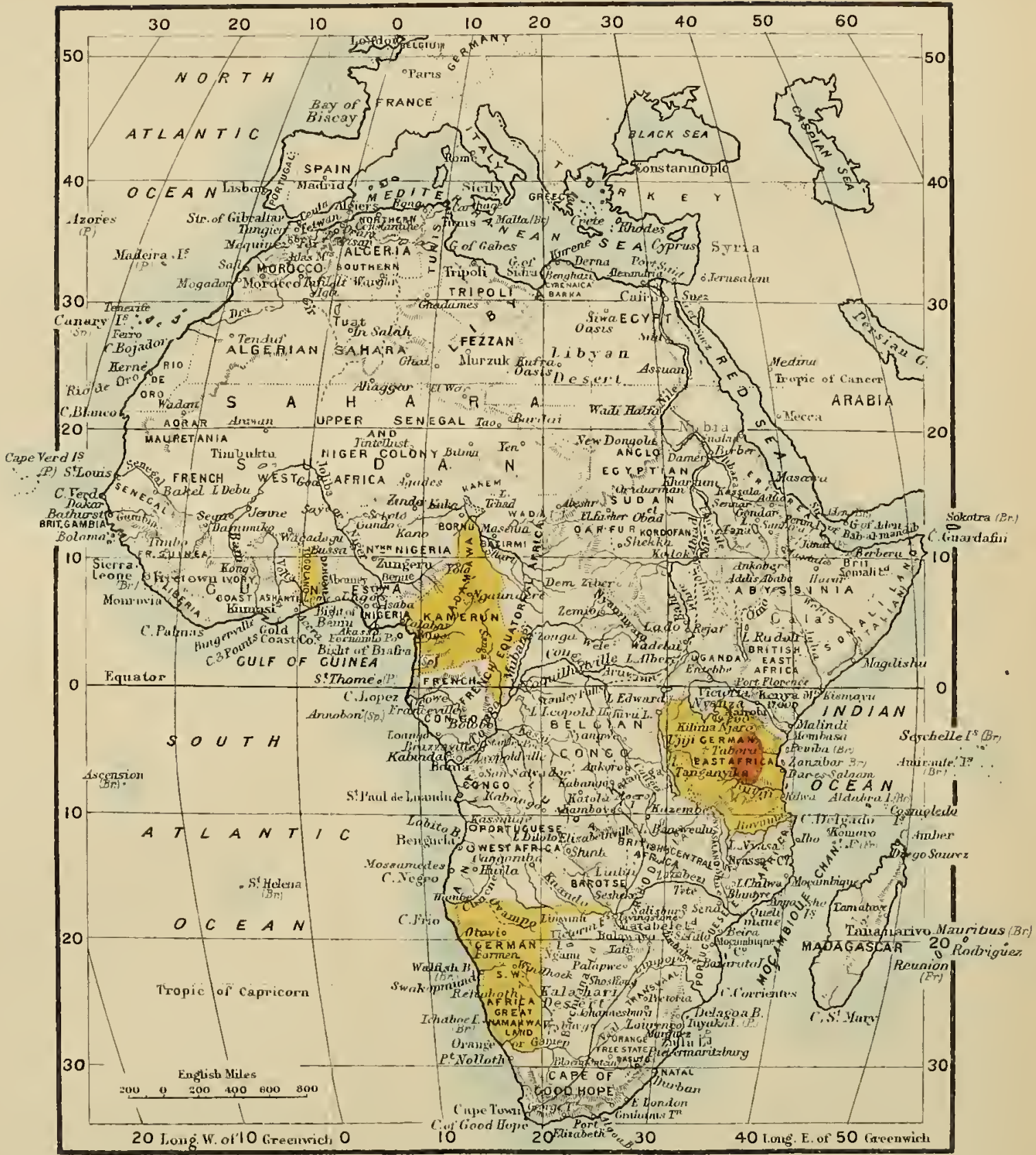





\section{CHAPTER XVII}

\section{THE FRENCH IN MADAGASCAR}

THE Island of Madagascar is possibly alluded to by the Alexandrian Greek geographer, Ptolemy, who wrote during the 2nd century after the birth of Christ, as "Menouthias ${ }^{1}$," and by other classical geographers as Monouthis or Menoutheseas; though it is more probable that at most Pemba, Zanzibar or one of the Komoros was meant both by Ptolemy's informants and the unknown authors of the Periplus of the Erythræan Sea who first used the term "Menouthias" a century earlier (about 50 A.C.). Then comes a break, and when the study of geography is resumed in Europe the allusions to this island are more obvious, and evidently come through post-Islamic Arabs; a large island in the Indian Ocean is alluded to as "Albargoa," and "Manutia-Alphil." Older Arab names were rendered in medieval European geography as Serandab, Phenbalon, Quambalon. Later an allusion is made to it in Arab writings as "Jazirat-al-Komr"- "Island of the Full Moon"; but this name more probably applies to what are still called the Komoro Islands, an adjoining archipelago. On the maps of the Venetian geographers Fra Mauro and Andrea

1 There is stronger evidence to show that Menouthias was a little island-Zanzibar, probably-close to the African coast. Menouthias is repeated in the Arab name Manutia, and Al-phil means "ivory"-the ivory island or market. 
Bianco, between I 457 and I459, wherein use has been made of Arab information, the Cape of Good Hope is indicated (forty years before the discovery of Diaz) as Cavo di Diab(olo), and Madagascar is given as a triangular island to the north-east, and has on it the names of Sofala and Xengibar. From Arab sources we learn that an Indian dau in 1420 rounded the southernmost point of Africa- "Cape Diab"-and, turning again eastward, sailed back past Madagascar, on the shore of which island they discovered a rukh's egg ${ }^{2}$. Madagascar was mentioned and described in much fuller detail and with allusions to the gigantic bird (whose fossil remains were discovered in the I 9 th century) by Marco Polo the Venetian explorer at the beginning of the r $4^{\text {th }}$ century. Polo obtained his information from Arab sea-captains of the Persian Gulf. More authentic news of Madagascar was sent to Portugal near the end of the 15 th century by Pedro de Covilham, whose journeys overland to India have been alluded to in Chapter IV. On the Ist of February, I 506, a Portuguese fleet sent out by King Manoel, under Francisco de Almeida, discovered the east coast of Madagascar; but the island had already been sighted by a Portuguese sea-captain on the Ioth August, I 500, and named "São Lourenço," because the discovery was made on St Laurence's Day. In $\mathrm{I}_{5 \circ}^{\circ} 7$ its west coast was visited and its shape more clearly defined by Gomez d'Abreu. The name "Madagascar," like the adjective "Malagasy," is probably of native origin, the former having been introduced in its present form by Marco Polo and the Portuguese, and the latter by the French.

It was not until 1540 that any Portuguese actually settled on the island, and those who made this venture at its south-east

1 Almost certainly this was an egg of the gigantic Appyornis. The Æpyornis, a ratite bird as large as, or larger than, an ostrich and distantly allied to both ostriches and cassowaries, lived on in Madagascar to the human period-say two thousand years ago or even later. It was quite possibly seen alive by the earliest Arab visitors to the island. 
extremity were nearly all massacred in 1548 . At the end of the 16 th century the Dutch visited Madagascar, and about the same time Dominican, Ignatian, and Lazarist monk-missionaries made an unsuccessful attempt to obtain a hearing for Christianity. Between 1618 and 1640 English and Dutch adventurers nibbled at Madagascar, but the hostile and treacherous attitude of the natives and the unhealthy climate of the island coasts caused these attempts to end invariably in disaster. In I642, however, the French "Company of the East" was formed under the patronage of Cardinal Richelieu with the main object of colonizing Madagascar. Pronis, a French Protestant of dissolute habits, was sent out as Governor. Two years later a rival project for the same purpose was started in England under the presidency of Prince Rupert, and a small station was founded at St Augustine's Bay; but this was soon after abandoned, and the Company broken up on account of the Civil War in England.

The name of the first French settlement at the south-east extremity of Madagascar was "Fort Dauphin." Pronis, whose immoral life shocked the French settlers, was replaced as Governor by Flacourt, but the fortunes of the settlement were chequered. The parent Company got into trouble, and its charter was abolished. The royal concession of Madagascar was then bandied about from nobleman to nobleman, and was finally sold to Louis XIV, who, having reassumed these rights on behalf of the crown, sent out the Duc de la Meilleraye. One of the officers of the staff of the Duc de la Meilleraye was Vacher de Rochelle, who explored the country, and acquired the rare advantage of winning the friendship of the Malagasy. Vacher de Rochelle, for some unknown reason nicknamed and ordinarily known as La Case', was admired by the natives for his courage, and was invited to marry the heiress of a powerful native chief. He did so, and becoming dissatisfied with the mismanagement of the French settlement retired into the

1 But by the natives as Andrian Potsy, i.e. "White King." 
interior, and became King-Consort of the state of Ambole at the death of his father-in-law. Nevertheless, when the French got into difficulties with the natives and were hard pressed, Vacher de la Rochelle came to their assistance with great bravery. This remarkable person, whose life should be written by some framer of romances, died about $\mathrm{I}_{7} 7 \mathrm{I}$, assassinated by a native.

In 1664 the French East India Company was founded, and took over Madagascar amongst other concessions under the pretentious title of Gallia Orientalis. As if to punish them for this overweening assumption, a great massacre occurred eight years afterwards, leading to the almost entire extinction of the French settlers round Fort Dauphin. The few survivors fled to the Island of Bourbon, which the French had taken in I638-43. Nevertheless, in spite of this disaster, the French Government calmly annexed Madagascar by an Order in Council of r686, which was confirmed in 1719,1720 , and I 725 .

At the end of the $I 7$ th and the beginning of the 18 th century, European pirates-English, French, and Dutch-who had begun to infest the eastern seas, and to trade in defiance of the commercial monopolies given to various Chartered East Indian companies, gradually made Madagascar their headquarters, and formed several strongly fortified settlements hidden away up creeks or inlets or the mouths of rivers. Some of these pirates founded a cosmopolitan city of freedom which they called "Libertatia," on the island of St Marie, off the east coast of Madagascar. They were swept away by British and French war vessels in 1722-23. Numerous half-caste offspring-known as Malata by the Malagasies-arose from these unions with the native women; and men of this hybrid type sometimes became powerful chiefs.

In $175^{\circ}$ the French East India Company created a settlement on the island of St Marie de Madagascar, which underwent violent vicissitudes of fortune for the first few years of its life. 
In I 768 Fort Dauphin was for a short time reoccupied. In that year a man of superior scientific attainments, M. Poivre, was appointed Governor of Mauritius and initiated a scientific investigation of Madagascar by sending thither a French naturalist, Philibert Commerson, who, as the result of his brief examination of the flora and fauna, pointed out the isolated character of Madagascar. In I774 the French naturalist Sonnerat ${ }^{1}$ visited Madagascar, and discovered the Ravenala or "Traveller's Tree," and that extraordinary aberrant lemur, the Ayeaye (Chiromys).

In 1772 Madagascar was visited by a type of adventurer then very uncommon, an Austrian Pole, called Benyowski, who alternately offered his allegiance to France and England, and ultimately tried to carve out for himself a native Malagasy principality, as the result of which he was killed by the French in $\mathrm{r} 786$.

Allusions were made in the first two chapters of this book to the Malay invasion of Madagascar. This great island seems to have at first been peopled by negro or negroid races from East Africa, while Arabs had from very early days settled for trading purposes in the adjoining Komoro Islands ${ }^{2}$ and in the north of Madagascar. But at a period of time probably antecedent to the Christian era Madagascar was invaded by a people of Malay stock, coming thither from the Malay Archipelago. Despite the vast distance which separates Java and Madagascar, there is a current always streaming from the Sunda Islands towards the east coast of Madagascar and the

1 Already famous for his discoveries in India; a beautiful jungle fowl is named after him.

2 The Malay immigration into the Komoro Islands was relatively slight. The bulk of the population here is composed of East Coast negroes, speaking a Bantu dialect allied to the tongues spoken on the Zanzibar coast. There was a large influx of Arabs, however; and this mingling with the negroes produced the present race of the Komoro Islanders, a very fine type of the successful results that attend the mixture of the Semite and the negro. 
Komoro Islands; another flows more towards Ceylon, the Maldivs, and the Seychelles. Aided by the east Trade Winds, Malay outrigger canoes with sails might conceivably be driven across the Indian Ocean to Madagascar in a few weeks. Even of recent years cases have been known of Javanese junks being stranded on the Komoro Islands, in one case with a Javanese crew on board. However, numbers of Malays or rather Polynesians must have invaded Madagascar simultaneously in order to be able to overcome and absorb the previous negro inhabitants. It would almost seem as though we had here an instance of deliberate over-sea colonization on the part of this interesting race, which at the same time was pushing eastward, almost further from its base, to the Hawaii Islands. When the term "Malay" is used to describe these Asiatic invaders of Madagascar it does not necessarily imply the direct descendants of the Malays of the Malay Archipelago, but those of an older race, from which Malays, Polynesians, and other non-Papuan peoples of the Pacific are descended-a divergent branch of the Mongol stock intermixed with an Indonesian (Caucasian) element, perhaps also tinged with the Melanesian?

About the middle of the $\mathbf{r} 8$ th century there was a tribe dwelling on the high plateau of East-central Madagascar, known as the Hovas but really bearing the name of Merina (Imerina) or even calling themselves "Malagasy." They were more recent colonizers of Madagascar from across the sea, who, having landed on the coast of the great island, some hundreds or even a thousand years ago, left as quickly as possible the malarial coast region and forced their way through the forests to the cool and open plateaus of Imerina. Here they were much harried by the more mixed races around

1 The Hovas, or Merina, as they are properly called, of Central Madagascar bear a strong physical resemblance to the Javanese. They seem to have reached east Madagascar much later than the ancestors of the Sakalava and Betsi-misáraka, and subsequently to the Arabs. The Merina ruling caste is very "Malay" or Mongoloid in appearance. 
them, who were of stronger physique. At last, driven into a corner, they turned at bay, and from being the persecuted became the persecutors; by means of much better military organization they pursued and conquered the tribes which had harassed them; and their conquests, spreading to the east coast and the south, brought them into contact with European traders and settlers.

In 1792 the National Assembly of France sent M. Lescallier to visit Madagascar. In I80 I Bory de St Vincent went thither and announced that the colonization of Madagascar would atone to France for the loss of San Domingo. In the following year Mr Inverarity, of the Honourable East India Company's service, made a survey of Bembatoka Bay, a harbour on the west coast, since better known by the name of its principal town, Mojanga. Lord Keith, a British admiral cruising in these waters, visited the place in $\mathrm{I} 79 \mathrm{I}$, and directed the attention of the Indian Government to the worth of Madagascar. In 1807 the French, in spite of British hostilities, made a determined attempt to settle at Foule Point ${ }^{1}$. In the following year, Impoina, the most powerful Hova chief on the Imerina plateau, died, leaving the supreme Hova chieftainship to his second son, Radama.

When the British had seized Mauritius, Bourbon, and the Seychelles Islands, it was determined to finish the work of clearing the French out of the Indian Ocean by taking the trading stations which still remained in their possession on the east coast of Madagascar, namely, Tamatave and Foule Point. In I8I I this was effected, and Tamatave was occupied by British soldiers. This capture was ratified by the definite treaty signed at Paris on May 30, I8I4, which ceded the settlements in Madagascar as "one of the dependencies of Mauritius.". The Island of Bourbon was, however, restored to France by this treaty. (In I848 it was

1 A post a little to the north of Tamatave on the east coast.

2 Further confirmed by the treaty of the $I_{3}$ th of November, ${ }^{2} 8 r_{5}$. 
re-christened Réunion.) Sir Robert Farquhar, a very enterprising governor of Mauritius, obtained soon afterwards a large concession from the native chiefs of the north-east of Madagascar, which included Diego Suarez Bay. Various proclamations were issued in the Mauritius Gazette claiming Madagascar as a British possession. On the other hand, it had been agreed that all French possessions in Madagascar which were in existence in 1792 were to be restored to France by England; but as a matter of fact, in 1792 France held no post in Madagascar, all places having been abandoned. Tamatave was not founded till r 804. All this confusion was due to the ignorance of local geography, then most characteristic of both British and French Government offices. Nevertheless, it is clear that France imagined that she still had rights over Madagascar, because in I8I 7 the French Governor of Bourbon protested against the British proclamation declaring Madagascar an appendage of Mauritius, and the French protest was further supported by the reoccupation of the island of St Marie de Madagascar. While Sir Robert Farquhar was in England on leave of absence, the ActingCommissioner, a military officer named Hall, deliberately undid much of Sir Robert Farquhar's work, and thereby prejudiced any further insistence on British claims over Madagascar. Subsequently, when Sir Robert Farquhar returned, he deemed it the better policy to back up the efforts of the Hova king Radama to conquer the whole of the island, and proclaim himself king of all Madagascar, in spite of a protest from the French, which was absolutely disregarded.

In 1818 the first missionaries of the London Missionary Society arrived, and established themselves on the Hova Plateau. Radama was murch helped in his conquests by the loan of several English soldiers and non-commissioned officers, amongst whom one made himself specially prominent, a Mr Hastie. By degrees Radama took possession of Tamatave (held for some years by a French mulatto, Jean René), and 
of all other French posts on the mainland of Madagascar, including Fort Dauphin. Here he cut down the French flag and deported the small French garrison to the island of $\mathrm{St}$ Marie de Madagascar. Radama died in 1828 , and was succeeded in a very irregular, Catherine-the-Great manner by his senior wife, Ranaválona. But her policy was not that of her great prototype in Russia, for it was a reactionary return to barbarism. She persecuted the native Christians and the missionaries, showed the greatest enmity to any foreign influence, and so flouted the French that the latter were compelled to take some notice of her hostility. In I829 the Government of Charles $\mathrm{X}$ decided to send a small expedition against Madagascar, which was to be largely composed of Yolof soldiers from Senegambia - a new departure in European warfare in Africa to be afterwards largely followed. The French bombarded Tamatave successfully, but were repulsed at Foule Point, though they made a successful attack on another Hova post. Still, the results of the expedition were ineffective, though the Prince de Polignac wrote to the Queen of Madagascar proposing a French protectorate, with French stations at Diego Suarez, St Augustine's Bay, and other places on the coast. But the Government of July reversed this policy, and evacuated all French posts on the mainland of Madagascar, after which there was not for years a Frenchman on Madagascar soil, with the exception of a remarkable personage named Laborde, originally a French shipwrecked sailor, who had been sent up to the Queen of Madagascar for her to decide on his fate. From his comely appearance he found great favour in her eyes, and was the only European tolerated at her court, where he attained a very influential position. In $\mathrm{r} 833$ a French surveying party had pronounced Diego Suarez Bay to be a very suitable place for a settlement.

During the thirties of the last century Queen Ranaválona had made herself infamous by her persecution of the native Christians and by forcing all European missionaries to leave 
the island; in addition to which her soldiers, in exacting tribute and in emphasizing their conquests over the Sakalavas, committed the most atrocious cruelties and wholesale slaughters. The Queen of Madagascar, feeling at last even in her remoteness that she was banned by Europe, sent an embassy in $183_{3} 6$ to William IV of England, but the envoys effected nothing in the way of renewing friendly relations.

In 1840 the Sakalavas ${ }^{1}$, driven to desperation by the Hova attacks, placed themselves under French protection, with the result that France, to enforce her protectorate, occupied the islands of Nosi Mitsiu, Nosi Bé, and Nosi Komba, as well as the island of Mayotta, in the Komoro Archipelago. In 1845 the Hova Government intensified its unfriendliness to Europeans by expelling all foreign traders from Tamatave. This action roused the French and English Governments, who replied by a joint bombardment of Tamatave. Unhappily, the bombardment was followed by a landing party, which met with a most disastrous repulse, which neither France nor England thought fit to revenge otherwise than by breaking off all political and commercial relations with Madagascar. Between 1847 and 1849 the French had abolished slavery in Réunion and in their Madagascar possessions; but this philanthropic action subsequently caused outbreaks among the Sakalavas, who were angry at having their slave-trading operations interfered with by the French.

Between 1847 and $\mathrm{I}_{5} 5^{2}$ the queen's son, Rakoto, heirapparent to the throne, applied at intervals for French protection, in order that he might depose his mother and put an end to her ferocious policy. No very definite answer was made to these appeals (which possibly were not genuine, but fabricated for their own purposes by the Frenchman Laborde, who still lived at the Malagasy capital, and by a

1 The tribes of the western half of Madagascar, a finer race physically than the Hovas owing to their greater intermixture with negroes. They now number about i 56,000 . 
M. Lambert, who visited Madagascar as a slave-trader); nor were they followed up by any action on the part of the French Government. In 1853 the merchants of Mauritius, finding that the Madagascar Government continued to refuse to pay the indemnity demanded by the British Government for the disaster of Tamatave (in consequence of which refusal trade with Tamatave was forbidden), subscribed amongst themselves and paid up the indemnity to the extent of $£ 3125$. Trade was then reopened. In 1855 the French adventurer and ex-slave-trader, Lambert, visited Tanánarivo, the Hova capital, and after an interview with Prince Rakoto, conveyed from him to the French Government fresh proposals for a French protectorate ; but these were rejected by the Emperor Napoleon III, because he was loyal to the British alliance and would do nothing in Madagascar which might seem unfriendly to Great Britain.

In $1856 \mathrm{Mr}$ Ellis, one of the pioneers of the London Missionary Society's agents, who, after many years of work had left Madagascar in despair in 1836 , was invited to return thither to confer with the Queen, and went out as an informal messenger of the British Government. His mission resulted in nothing, however. Lambert, the French adventurer, returned to Madagascar in that year, and escorted to the capital Mme Ida Pfeiffer (one of the earliest of women travellers, the Mrs Isabella Bird of her day). Lambert plotted a coup d'état which should place Rakoto on the throne under French influence, with Lambert himself as Prime Minister. But Rakoto was frightened, and kept his mother informed of the conspiracy. It was therefore nipped in the bud, and Lambert and Laborde were promptly expelled from the country, the latter after many years' residence losing in one day all his property in lands and slaves. But in r 86r this ferocious old Queen, who had ruled Madagascar with a rod of iron for 33 years, and had successfully set Europe at defiance, died, and was succeeded by her son Rakoto, who took the title of Radama II. 
If Ranaválona, his mother, was like Catherine of Russia, Radama II resembled in his brief career Catherine's predecessor, the unhappy Peter III. He reversed the Queen's anti-Christian policy, abolished customs' duties, and was such an enthusiastic reformer as almost to suggest flightiness. $\mathrm{He}$ invited and received an English envoy in I86r. Laborde and Lambert returned, and were received by him with almost extravagant affection. The foolish King signed without hesitating a deed presented to him by M. Lambert which gave the latter the most extravagant concessions in Madagascar. He is also supposed to have created Lambert "Duc d'Emirne," a title, however, which the ex-slave-trader soon found it wiser to drop owing to the ridicule it entailed. At this time also Roman Catholic missionaries ${ }^{1}$ came out to settle in the Hova country. Mr Ellis also returned, and brought letters of congratulation from the British Government. The English missionaries reestablished themselves, and in 1862 British and French Consuls were established at Tanánarivo. The French Consul was Laborde, who had resided for so many years in Madagascar. But the Hovas were profoundly dissatisfied with their King's reforms and extraordinary generosity to Europeans. A palace revolution took place in $\mathbf{I} 862$, and the unhappy Radama was strangled. A female cousin, Rabodo (Rasohérina), was proclaimed Queen, but was dominated by the Prime Minister, as have been subsequently all the remaining queens of Madagascar. The French treaty was denounced on account of Lambert's claims. These last were compounded for finally by the payment of $£ 36,247$. 7s. in silver. The concession was returned to the Malagasy envoys, and solemnly burned at Tamatave.

The whole procedure of the French Government in supporting Lambert's unfair claim profoundly affected the Hova people, and caused them to be suspicious in future of all European enterprise. Queen Rasohérina died in 1868 , and

1 In 1840 Jesuit priests had again endeavoured to establish themselves in Madagascar, on the north-west coast, but they all died from fever. 
was succeeded by her cousin, Ranaválona II, who established Christianity as the state religion. In her reign arose a very powerful Prime Minister, afterwards to be famous as the opponent of the French, Rainilaiarivóny. In 1872 the French Government again allowed its influence in Madagascar to wane, and withdrew its subsidy from the Jesuit missionaries; but with returning energy, and in the dawn of the new phase of colonial activity, it resumed a more active policy at the beginning of the eighties. Laborde, the French Consul, died in 1878 , but the Malagasy Government opposed his landed property passing to his heir on the plea that he was only a life tenant, and that no land could be alienated in Madagascar. The French Government supported the claims of Laborde's heirs, and disputed the matter between 1880 and 1882 , at the same time reviving the idea of a French protectorate over the Sakalava of North-west Madagascar. The situation becoming strained, the Madagascar Government sent a mission to Europe, but it was unsuccessful in obtaining assurances of support. The Malagasy argued with some justice that the French treaty of 1868 recognized the Queen's rule over the whole mainland of Madagascar, and made no mention of any French protectorate over the Sakalavas. But we know in the fable that the lamb's arguments availed but little with the wolf. The French had endeavoured in $\mathrm{I} 88 \mathrm{I}$ to find cause for a quarrel in the murder by the Sakalavas of four French subjects on the west coast of Madagascar, and claimed an indemnity from the Hova Government ; which, logically, they could not have done if the country had been under a French protectorate. The Malagasy Government promptly paid the indemnity demanded; but, when later on they endeavoured to strengthen their authority over the Sakalavas, they were forbidden to do so by the French. In the following year, 1882, a French protectorate over the northern coast was distinctly asserted, and the demand was made that the Hova flag should be withdrawn from those 
territories. The demand was refused, and the French Commissioner left Tanánarivo. Lord Granville in 1882 protested against the assertion of French claims to the Northwest coast of Madagascar, but received no immediate reply, nor was the opposition of the British Government deemed an obstacle worth taking into account, seeing that we had already tied our hands with the occupation of Egypt. It was, however, asserted by the French with some degree of truth that a certain Sakalava chief opposite Nosi Bé had concluded protectorate treaties with France in 1840 and 1843 .

Another cause of complaint which France urged against Madagascar was the passing of a law in $188 \mathrm{I}$ forbidding the Malagasy to sell their land to foreigners; but in 1883 this complaint was somewhat obviated by other edicts facilitating the transfer of land on perpetual leases ${ }^{1}$. Nevertheless in May I 883 war broke out between France and Madagascar, and the French fleet under Admiral Pierre captured Mojanga. Subsequently Admiral Pierre steamed round the island, and anchored in the roadstead of Tamatave, where he found H.M.S. Dryad, Commander Johnstone, already watching events. The French admiral, after delivering an ultimatum, which was rejected, bombarded and occupied Tamatave, and destroyed other Hova establishments on the East coast. Mr Shaw, an English medical missionary, was established at Tamatave, and, beyond rendering medical assistance to the wounded natives, took no part in the struggle. Nevertheless, his dispensary was broken into, and he was arrested, accused of poisoning French soldiers ${ }^{2}$, and closely confined as a prisoner on the French flag-ship. The British Consul, Pakenham, who had gone down to Tamatave and was very ill, was ordered to quit the town in 24 hours, but died before this

1 This law was completely abrogated by the French in 1896 , and foreigners can now acquire land as easily as natives.

2 Who had made themselves ill by appropriating and drinking his claret -that was all. 
time elapsed. Anglo-French relations were severely strained by the attempt of the French to intercept Captain Johnstone's mails. When the news of French action reached England $\mathrm{Mr}$ Gladstone made a very serious speech in the House of Commons regarding Mr Shaw's arrest. The French Government, feeling its agents had gone too far, made a conciliatory reply. Mr Shaw was released, and given an indemnity of $E_{1}$ ooo. In the meantime the Queen of Madagascar died, and was succeeded by another Queen, Ranaválona III. Admiral Pierre also fell ill, and died just as he reached Marseilles. His successor, Admiral Galiber, did much to restore cordial relations between the British and French officials by his courteous manner. In I 884 an Englishman named Digby Willoughby, who had been a volunteer in the Zulu war, succeeded in running a cargo of arms and ammunition across to the south coast of Madagascar, and in reward for his energy was taken into the service of the Malagasy Government, made an officer in their army, and finally rose to be their Commander-in-Chief. The war dragged on through I 885, causing some dissatisfaction and lassitude in France. It is probable that the French Government would not have insisted on the protectorate but for German action on the adjoining coast of Africa, which caused the French to feel that in the African scramble they should be fairly represented. At last a treaty of peace was negotiated, and finally concluded in January, I886. General Willoughby represented the Malagasy Government at Tamatave, and concluded a treaty in their name. This agreement gave France a virtual protectorate over Madagascar-at any rate, a control over her foreign relations-an establishment at Diego Suarez Bay, and an indemnity of $£ 400$, 000 .

A few months later, in June I886, France declared her protectorate over all the Komoro Islands, of which she had already annexed Mayotta in 1840 .

In $189^{\circ}$, England, in return for the waiving of French 
opposition to a British protectorate over Zanzibar, recognized a French protectorate over Madagascar. But the Malagasy themselves had been sullenly refusing their recognition of any such protectorate and endeavouring to shake themselves free of the trammels of the 1886 treaty. It was believed in England and in France that the conquest of Madagascar would be an extremely difficult undertaking, that the opposition of the Hovas would be a determined one, and that their warlike energy combined with the terribly unhealthy climate would make success doubtful or dearly purchased. For some nine years, therefore, the French Government put up with many a rebuff from the powerful Prime Minister of Madagascar. But at last the French were obliged either to let their protectorate become a dead letter or enforce their right to a predominant influence at the Malagasy court. Their ultimatum in I 895 was rejected. A powerful French expedition was sent -over 10,000 French soldiers, and an equal number of Senegalese. The idea of landing at Tamatave and forcing a way up to the capital through dense forests and across steep mountain terraces was wisely abandoned, and in preference the forces entered Bembatoka Bay (Mojanga), on the west coast, and were transported up the Ikopa river. From the point where its navigability came to an end they started overland for Tanánarivo, which was captured after the feeblest resistance on the part of the Hovas ${ }^{1}$.

At first an attempt was made to continue the government of the Queen of Madagascar under French protection, but this only led to treachery and intrigue on the part of the Hovas.

1 Whether the Hovas had overlooked the Mojanga route and had decided to concentrate all their resistance on the approach from Tamatave is not known; but after their repeated boasts as to the determined resistance they would make to an invader, the collapse of their defence and the feebleness of the resistance they offered to the French are matters of considerable astonishment. It must have been mainly due to the fact that the Hova rule over the bulk of the island was hated, and that the other tribes were not inclined to fight for its maintenance. 
The Prime Minister was exiled, the Queen was deposed, and exiled first to Réunion and subsequently to Algiers. In 1896 the island was annexed to France, and became a French colony. At the same time, and by this act of annexation, the commercial treaties of other nations with Madagascar were annulled; the coasting trade was confined to vessels flying the French flag; and the fiscal policy adopted was that of the severest Protectionist type, the commerce and enterprise of other nations being practically excluded from Madagascar. These actions gradually came to be apprehended and resented in England, where in the previous recognition of the French protectorate no intention whatever had existed of abandoning British commercial rights.

The Hova rule was bloody and barbarous, and more recent by quite a hundred years than the first establishment of European influence. But it at least established freedom of religion $^{1}$, and complete freedom of commerce and enterprise for all civilized nations. By pursuing this retrograde policy in commerce and religion France has somewhat alienated the sympathy and interest with which one might otherwise have watched her resolute intention to civilize Madagascar. But from all accounts-British and French-the persistent efforts of the first great administrator of Madagascar (General Galliéni) to restore law and order and to open up this island of 228,000 square miles to cultivation and civilization produced favourable results between 1897 and $1905^{2}$. The slaves have been emancipated (in I896); Tanánarivo (the French, as it was the Hova capital) has been transformed into a fine town of

1 Since the annexation to France, and the consequent dominating influence of the Roman Catholic missionaries, many natives have been constrained to exchange their Protestant faith for Roman Catholic Christianity.

2 Particulars as to General Galliéni's reforms and the resulting condition of Madagascar are given in an article "French Policy in Madagascar," in the October Tournal of the African Society, London, I904. 
European aspect. Roads are being rapidly made, canals have been dug to connect the coast lagoons with the sea and the mouths of rivers, and railways into the interior are in course of construction ${ }^{1}$. Already the connection of Tamatave, the principal port on the East coast, by railway with Tanánarivo the capital is nearly complete. Gold, iron, copper, lead, silver, zinc, and many other metals and minerals are being worked. Agriculture has not been neglected, and of late Madagascar has begun to export rice. Rubber, wild and cultivated, is entering into the list of exported products, of which the principal are gold, cattle, hides, coffee, vanilla, cloves, and silks. The land has not been taken from the natives, and the native population, said to have at first decreased under French rule, has of late shown a distinct increase. In I9I it was found by census to number $3,054,65^{8}$; of whom only 13,539 were of European race ( 7606 being French). Forced labour in the public service was abolished in I $90 \mathrm{I}$. The natives are a good deal governed by their own elected chiefs and notables, and of late years very little local legislation has been enacted without taking the leading native authorities into consultation.

The mass of the Malagasy people are growing in contentment and well-being under the paternal rule of a French governor-general, but the volume of trade has not markedly increased and remains at about an annual value of $£ 3,000,000$. And nearly the entirety $(£ 2,300,000)$ of this is done with France or French possessions, differential duties and other forms of protection having greatly hampered foreign trade with Madagascar since 1896 .

As already mentioned, France had annexed the Mascarene Islands of Mauritius (Ile de France) in 1715 and Réunion (called Bourbon from I649 to 1848 ) in I643. Both were taken

1 The French occupation of Madagascar has resulted in great gains to science. Noteworthy are the investigations in palæontology of the two Grandidiers and of M. A. Jully, which have revealed a marvellous extinct fauna of lemurs, hippopotami, carnivores, birds, and giant reptiles. 
from her by Britain in the Napoleonic wars; but, though Mauritius was kept by the British, Réunion was restored to France in 1815 . (Both islands had been held by the French East India Company till I 767 , when they became appanages of the Crown.) Réunion has an area of 965 square miles and a population-nearly all white-of about 174,000 .

The Komoro Islands to the north-west of Madagascar (area, about 760 square miles, population of Muhammadan negroids about 100,000 ) were finally annexed to France in I 910 and are now under the Madagascar government. 


\section{CHAPTER XVIII}

\section{CONCLUSIONS AND FORECASTS}

WE have now seen the result of these race movements during three or four thousand years, which have caused nations superior in physical or mental development to the Negro, the Negroid, and the Hamite to move down on Africa as a field for their colonization, cultivation, and commerce. The great rush, however, has only been made since $\mathrm{r} 88 \mathrm{I}$, and may be said to have begun with the French invasion of Tunis. Now there remain but two small portions of the map of Africa which are uncoloured, that is, attributed to the independent possession of a native state. These tracts, theoretically independent, or the overlordship of which is international, are the Negro Republic of Liberia on the West coast and the Ethiopian Empire in North-east Africa. The whole remainder of the continent is now allotted to the dominion, overlordship or exclusive political direction of some one European, Christian power : Britain, France, Germany, Portugal, Belgium, Italy, or Spain. Morocco, on the extreme north-west of the continent, the bulk of whose trade was formerly with England, and whose principal seaport was once in English hands, has now France for a protector, educator and disciplinarian, and Spain for recolonizer. There is Egypt, in the occupation and under the control of Britain, though still nominally a tributary state of the Turkish Empire. Since this book was first published in 
I898, the truculent Muhammadan state of Wadai has been annexed and conquered by France, together with Baghirmi and Kanem, Air and the Saharan oases. Darfur is under Anglo-Egyptian suzerainty; Tripoli, Cyrenaica, and Fezzan are annexed to Italy as the future "Colony" of Libya ; and British rule has been made very real over the eastern Fula States of Nigeria and Bornu. The South African Republic and Orange Free State are part of the Union of South Africa. Even Liberia has recently entrusted its finances to the indirect control of its original parent, the United States. Only Abyssinia-now the Empire of Ethiopia in very fact, since I 900--remains theoretically independent; and even Abyssinia is aware that three European powers-Britain, France, and Italy - while guaranteeing her independence, have in a sense agreed to take joint action if she should abuse that independence to the commercial or political injury of their interests. Abyssinia, for many reasons connected with her history, her religion, and her sturdy assertion of independence deserves more than any other state of Africa to preserve her national self-respect and her sovereign status, provided she will abstain from offence, and recognize her geographical and racial limitations. But if through ambition she should attempt to arm and to lead the peoples of the Sudan against the new order of things which is being patiently introduced by Great Britain, she will find herself restricted once more to the African Switzerland which has been the nucleus and the last refuge of this Semitico-Hamitic people. Liberia by studiously following American advice and educating herself on the right lines to be an African Negro State and not an African parody on a tiny scale of the vast United States of North America, may play an important part some day in the political development of West Africa.

What is Europe going to do with Africa? It seems as though there were three courses to be pursued, corresponding with the three classes of territory into which Africa falls when 
considered geographically. There is, to begin with, that much restricted healthy area lying outside the tropics (or in rare instances, at great altitudes inside the tropics), where the climate is salubrious and Europeans can support existence under much the same conditions as in their native lands. Here they can freely rear children to form in time a native European race; and in these regions (except in parts of South Africa) there is no dense native population to dispute by force or by an appeal to common fairness the possession of the soil. These lands of the first category are of relatively small extent compared to the mass of Africa. They are confined to the districts south of the Zambezi and the Kunene (with the exception of the neighbourhood of the Zambezi and the eastern coast-belt); to the fifty thousand square miles on the mountain plateaus of Northern Rhodesia, and about a hundred and thirty thousand on the highlands of Nyasaland, Katanga, South and Central Angola, Uganda and British East Africa; to the northern half of Tunisia, a few districts of north-east and north-west Algeria and the Cyrenaica (northern projection of Barka); and to parts of the northern projection of Morocco. The second category consists of countries like much of Morocco, Algeria, southern Tunis, and Tripoli; Barka, Egypt, Abyssinia and parts of Somaliland; where climatic conditions and soil are not wholly opposed ${ }^{1}$ to the healthful settlement of Europeans, but where the competition or numerical strength or martial spirit of the natives already in possession are factors opposed to the substitution of a large European population for the present owners of the soil. The third category consists of the remainder of Africa, mainly tropical, where the climatic conditions make it impossible for Europeans to cultivate the soil with their own hands, to settle for

1 Although in the Sahara desert and the coast region of German S.-W. Africa the great summer heat and the waterless nature of the soil are obstacles sufficient, at any rate at the present time, to render these countries uncolonizable, such difficulties are being fast overcome by the resources of science. 


\section{XVIII] The three categories of African lands 445}

many years, or to bring up healthy families. Countries lying under the first category I should characterize as being suitable for European colonies, a conclusion somewhat belated, since they have nearly all become such. The second description of territory I should qualify as "tributary states," countries where good and settled government cannot be maintained by the natives without the control of a European power, the European power retaining in return for the expense and trouble of such control the gratification of performing a good and interesting work, and a field of employment and profitable enterprise for a few of her choicer sons and daughters. The third category consists of "plantation colonies"-vast territories to be governed as India is governed, autocratically but wisely and as far as possible through native chiefs and councils, with the first aim of securing good government and a reasonable degree of civilization to a large population of races at present inferior in culture and mentality to the European. Here, however, the European may come, in small numbers, with his capital, his energy, and his knowledge to develop a most lucrative commerce, and obtain products necessary to the use of his advanced civilization.

It is possible that these distinctions may be rudely set aside by the pressure of natural laws one hundred, two hundred years hence, if the other healthy quarters of the globe become over-populated, and science is able to annul the unhealthy effects of a tropical climate. A rush may then be made by Europeans for settlement on the lands of tropical Africa, which in its violence may sweep away contemptuously the pre-existing rights of inferior races. But until such a contingency comes about, and whilst there is so much healthy land still unoccupied in America and temperate Africa, it is safer to direct our efforts along the lines laid down in these three categories I have quoted. Until Frenchmen have peopled the north of Tunis and the Aures Mountains of Algeria, it would be foolish for their Government to lure French emigrants to make their homes in Senegambia or 
on the Congo; until Cape Colony, Natal, the Orange Free State, the Transvaal, and Rhodesia south and north of the Zambezi are as thickly populated with whites as the resources of the country permit, it would be most unwise to force on the peopling by Europeans of Sokoto or the coast lands of British East Africa. On the other hand, however healthy the climate of Egypt may be, it is a country for the Egyptians, and not for Englishmen, except as administrators, instructors, capitalists, or winter tourists. Since we have begun to control the political affairs of parts of West Africa and the Niger basin our annual trade with those countries, rendered secure, has risen from a few hundred thousand pounds a year to about $£ \mathrm{I} 0,000,000$. This is sufficient justification for our continued government of these regions and their occasional cost to us in men and money.

In the north of Africa the white Berber race will tend in course of time to weaken in its Muhammadan fanaticism, and to mingle with the European immigrants as it mingled with them in ancient times and in the middle ages, when it invaded Spain and southern Europe. The Arab will gradually draw aloof, and side with those darker Berbers, who will long range the Sahara wastes unenvied ; or else he will betake himself to the Sudan, and lead a life there freer from European restrictions, even though it be under a loose form of European rule. The Egyptians will probably continue to remain the Egyptians they have been for untold centuries, no matter what waves of Syrian, Libyan, Hittite, Persian, Greek, Roman, Arab, Turkish, French or English invaders swept over the land; but they will probably come within that circle of confederated nations which will form the future British Empire-nations of every origin, colour, race, religion, united only by one supreme ruler, and the one supreme bond of peace, mutual defence, and unfettered interchanging commerce. The Negro or Negroid races of all Africa between the Sahara Desert, the Red Sea, and the Zambezi will remain negro or negroid, even though here and 
there they are slightly lightened with European blood, and on the east are raised to a finer human type by the immigration of the Hamites, the interbreeding of Arabs, and the settlement of Indians. It is possible that there may be a considerable overflow of India into those insufficiently inhabited, uncultivated parts of East Africa now ruled by Britain and Germany. Indians will make their way as traders into British Central Africa, but these territories north of the Zambezi will be governed also in the interests of an abundant and powerful negro population, which before many years have elapsed will be as civilized and educated as are at least a million of the negro inhabitants south of the Zambezi at the present day. South of the Zambezi great changes will take place. The black man may continue to increase and multiply and live at peace with the white man, content to perform for the latter many services which his bodily strength and indifference to health permit him to render advantageously. But as the white population increases from one to twenty millions it will tend to reserve to itself all the healthy country in the south of Africa, and inland on that great central plateau which stretches up to and beyond the Zambezi ; and the black man will be pushed by degrees into the low-lying, tropical coast regions of the south-east and of the Zambezi valley-regions which with much of Bechuanaland and Nyasaland must for an indefinite period be regarded as a Black Man's Reserve.

The European nations or national types which will predominate in the New Africa are the British (with whom perhaps Dutch will fuse), the French and the French-speaking Belgian, the German, the Italian, the Greek, and the Portuguese. The Spaniard may be met with on the North-west coast and in Morocco and Western Algeria; the Portuguese may have in Angola a second Brazil, but this dream will dissolve disenchantingly unless this nation can soon recover national energy and divert her thousands of emigrants annually to Portuguese Africa rather than to Portuguese- or English-speaking America. 
Portugal itself requires colonists and ought to be able to support not a discontented six but a prosperous fifteen millions of people. Italy's share of colonizable territory may be comparatively small under her own flag, and Greece may have none at all, but the north, the north-east, and north-central parts of Africa will teem with busy, thrifty, enterprising Italian and Greek settlers, colonists, merchants and employés ${ }^{1}$.

The great languages of New Africa will be English, French, Italian, Portuguese, Arabic, Hausa, Swahili, and Zulu. It is doubtful whether German will ever become implanted as an African language any more than Dutch has taken root in the Malay Archipelago. It is true that Dutch in a corrupted jargon has become a second language to the Hottentots and a few Bantu tribes. But Dutch is simpler in construction, and easier of pronunciation to a negro than German. I have observed that in the Cameroons the Germans make use of the "pigeon" English of the coast as a means of communication with the people when they do not speak in the easily acquired Duala tongue. In East Africa, on the other hand, they use Swahili universally, just as the Dutch use Malay throughout their Asiatic possessions. English may not become the dominant language in all countries under British influence in Africa. It will certainly become the universal tongue of Africa south of the Zambezi, and possibly, but not so certainly, in British Central Africa, where, however, it will have the influence of Swahili to contend with. In British East Africa, in Zanzibar, and in Uganda the prevailing speech will be the easy, simple, expressive, harmonious Swahili language, a happy compromise between Arabic and Bantu. In Somaliland, Egypt, the Sahara, and the Sudan Arabic will be the dominating language; but Italian, French, and English will be much used in Lower Egypt. Italian, Arabic, and French will remain coequal in use in Barka, Tripoli, Tunis, and Eastern

1 It is interesting to observe how under the British ægis Maltese are prospering in Egypt and on the northern and eastern coasts of Africa. 


\section{XVIII] Muhammadanism and Christianity 449}

Algeria; French and Arabic (French perhaps prevailing) in Algeria; and French will make its influence felt in Morocco (though it will contend there with Arabic and Spanish), and right across the Western Sahara to Senegambia and the upper Niger. English will be, as it is now-either in jargon or correctly spoken - the language of intercommunication on the West coast of Africa from the Gambia to the Gaboon. French, Swahili and Portuguese will prevail in the Congo basin; Portuguese in Angola; and Hausa in Nigeria and around Lake Chad. In Madagascar French will predominate, mingling in the Komoro Islands with Swahili.

Paganism will disappear. The continent will soon be divided between nominal Christians and nominal Muhammadans, with a strong tendency on the part of the Muhammadans towards an easy-going rationalism, such as is fast making way in Algeria, where the townspeople and the cultivators in the more settled districts, constantly coming into contact with Europeans, are becoming indifferent to the more inconvenient among their Muhammadan observances, and are content to live with little more religion than an observance of the laws, and a desire to get on well with their neighbours. Yet before Muhammadanism loses its savour, there will probably be many uprisings against Christian rule among Muhammadan peoples who have been newly subjected to control. The Arab and the Hamite for religious reasons may strive again and again to shake off the Christian yoke, but I strongly doubt whether there will be any universal mutiny of the black man against the white. The negro has no idea of racial affinity. He will equally ally himself to the white or to the yellow races in order to subdue his fellow black, or to regain his freedom from the domination of another negro tribe. There may be, here and there, a revolt against the white rule in such and such a state; but the diverse civilizations under which the African will be trained, and the different languages he will be taught to talk, will be sufficient to make him as 
dissimilar in each national development as the white man has become in Europe. And just as it would need some amazing and stupendous event to cause all Asia to rise as one man against the invasion of Europe, so it is difficult to conceive that the black man will eventually form one united negro people demanding autonomy, and putting an end to the control of the white man, and to the immigration, settlement, and intercourse of superior races from Europe and Asia. Difficult, this conception may be, in the light of past history, and because language counts for so much, but not impossible. Any repetition of Leopoldian tactics on a large scale, any gross oppression of the negro in South, East, West or Central Africa might fuse all culture differences, blend black and yellow men of diverse religious beliefs and superstitions in one blazing rebellion against the white race which might avail to wreck the new and the growing European civilization now spreading so fast over Africa. But otherwise the indigenous races of Africa will grow up into being black or brown British subjects (unless we deny them all suffrage), Frenchmen, Portuguese or Germans. Great white nations will populate in course of time South Africa, North Africa, and Egypt; and rills of Caucasian blood will continue, as in the recent and the remote past, to circulate through Negro Africa, leavening the many millions of black men with that element of the white-skinned sub-species which alone has evolved beauty of facial features and originality of invention in thought and deed. But the black-or, as it will be in the future, the brownrace will, through bowing to many an influence and submerged by many an invasion, in the long run hold its own within limits, and secure for itself a large proportion of the soil of Africa. All predictions as to the future of the Dark Continent seem futile in face of the unexpected, the strange, the unlookedfor which arises in Africa itself. A new disease may break out which destroys the negro and leaves the white man standing; or unconquerable maladies may be evolved which sweep the 


\section{XVIII] The Negro of the future}

white man away or make it too dangerous and unprofitable for him to settle on the soil of tropical Africa. On the other hand, remedies for all African diseases may be found, and it may be no more dangerous to the white man's health to reside at Sierra Leone or on the Upper Congo than it is for the indigenous black man. No doubt, as in Asia and South America, the eventual outcome of the colonization of Africa by alien peoples will be a compromise-a dark-skinned race with a white man's features and a white man's brain. 


\section{APPENDIX I}

\section{NOTABLE EVENTS AND DATES IN THE MODERN HISTORY OF AFRICAN COLONIZATION}

B.C.

Foundation of the colony of Utica (Atiqa) on the N. African

(Tunisian) coast by the Phœnicians . . . about I Ioo Foundation of the colony of Carthage by the Phœnicians about 822 Expedition of Dorians founds first Greek colony in Cyren-

aica (modern Barka) . . . . . . about 63I

Pharaoh Niku II of Egypt (son of Psammetik) sends out

Phœnician Expedition from Red Sea which is said to

have circumnavigated Africa in three years . . about 600 Conquest of Egypt by the Persians under Cambyses . about 525 Hanno the Carthaginian explores the West Coast of Africa

as far south as Sierra Leone and brings back chim-

panzees. . . . . . . . . about 520

Alexander of Macedon conquers Egypt from the Persians;

and founds the city of Alexandria . . . . 332

The Romans take Egypt under their protection . . . 168

The Romans definitely conquer and destroy Carthage and

found the Roman province of Africa (consisting event-

ually of modern Tunis and part of Tripoli) . . . I46-5

Numidia (Algeria) annexed to the Roman Empire . . 46

Egypt annexed to the Roman Empire. . . . . 30

Romans invade Fezzan (Phazania) . $\quad . \quad$. $\quad . \quad$. 19

Mauretania (Morocco) annexed to the Roman Empire $\quad 42$

$\begin{array}{ll}\text { Jewish massacre of Greek inhabitants of Cyrenaica . . } & \text { I I7 }\end{array}$

North Africa torn from the Roman Empire by the Vandals 429

Recovered partially by the Byzantines : . . . 53I-4

Persian armies occupy Egypt . . . . . . 616 
Herodius recovers Egypt from the Persians

The Muhammadan Invasion of Africa:

Amr-bin-al Asi conquers Egypt .

The Arabs invade Tripoli and Tunis, defeat the patrician Gregory and partially destroy Byzantine rule

Oqba-bin-Nafa is appointed by the Khalif "governor of Ifrikiyah" (669), overruns Fezzan and South Tunis, and founds there the Muhammadan capital of Kairwan . . . . . . . . $640-2$ $647-8$

Oqba traverses $\mathrm{N}$. Africa till he reaches the Atlantic Ocean . . . . . . . . .

Carthage taken by the Arabs (698); Tunisia finally conquered from the Berbers (705); Morocco and Algeria conquered about 708; Spain invaded by Arabs and Berbers . . . . . .

First Islamic settlements founded on E. African coast about 720; Kilwa Sultanate founded . . . Aghlabite (Berber) dynasty begins in Tunis in 800 (Morocco contemporaneously ruled by the Idrisites) and comes to an end . . . . . . . Rise of the Fatimite dynasty over Tunis, Tripoli, and Egypt (909), by whom Cairo (Al Kahira) is founded Great Arab invasion of North Africa (especially Tunis). . $\quad . \quad . \quad . \quad . \quad . \quad$. about 1045

About ro5o commences the invasion of $\mathrm{N}$. Africa from the Niger and the Moroccan Sahara by the Berber sect of the Murabitin (Al-moravides), who have conquered all N. Africa and Spain by . . . 1087 Timbuktu founded by the Tawareq . . . about I IoO The Third Great Berber dynasty of the Muahadim (Al-Mohade) arises in W. Algeria about I I5O, conquers Morocco, Spain and Algeria, and finally Tunis (from which the Normans are driven away) French and German Crusaders occupy eastern part of Nile Delta and garrison Cairo before they are driven out by "Saladin" . . . . . $1163-70$ Hafs dynasty founded in Tunis . . . . . 1236 
A.C.

King Louis IX of France ("Saint Louis") invades Egypt in 1248 ; is disastrously repulsed, captured and ransomed. Twenty-two years later he invades Tunis, where he dies of fever . . . . . . . .

Roman Carthage finally destroyed by the Moors, and Tunis made the capital of "Ifriqiyah" . . . . about I27I

The Portuguese take Ceuta from the Moors . . . I4I5

The river Senegal reached by Portuguese exploring vessels

sent out by Prince Henry . . . . . . 1446

Diego Gomez reaches and names Sierra Leone . . . 1460

The Canary Islands, discovered by a Norman adventurer and ultimately sold to Portugal, are transferred by that power to Spain

Gold Coast, Niger Delta, Fernando Pô, Cameroons and

Gaboon discovered by the Portuguese. . . I 47 I-80

River Congo discovered by the Portuguese . . . I482-5

Bartolomeu Diaz rounds the Cape of Good Hope . . $\quad$ I488

Melilla (N. Morocco) captured by the Spaniards . . 1490

Christianity introduced into the kingdom of Congo by the

Portuguese ·. . · $\cdot$.

Vasco da Gama passing round the Cape of Good Hope I49I

discovers and names Natal (Christmas, I497), reaches

Sofala and Malindi (East Africa) . • • • . 1498

Sofala occupied and Portuguese East African Empire begun I5O5

Madagascar discovered by the Portuguese . . . . 1500-6

The Emperor Charles $\mathrm{V}$ grants a charter to a Flemish

merchant for the exclusive importation of negro slaves into Spanish America; Slave Trade thus definitely founded .

The Turks conquer Egypt .

Charles $\mathrm{V}$ intervenes in the affairs of Tunis (to restore 1517

Arab Hafside Sultan and drive out the Turkish corsair Khaïreddin Barbarossa)

Charles V sustains disastrous repulse at Algiers (from which dates gradual decay of Spanish power over North Africa)

Delagoa Bay.first explored and temporarily settled by the

Portuguese. 
First British trading ships leave London for the West African coast

Sir John Hawkins conveys the first cargo of negro slaves to America under the British flag. . . . .

The Turks (having through corsairs founded the Regency of Algiers in 15 I9, that of Tripoli in 1551) once more take Tunis and make it a Turkish Pashalik.

Portugal founds the colony of Angola . $\quad$. $\quad$. $\quad$. 1574

Dom Sebastião, King of Portugal, defeated and slain at the battle of Kasr-al-Kabir; and the Portuguese Empire over Morocco thenceforth crumbles . . . .

Turkey attempts to wrest from Portugal the Zanzibar Coast, but is utterly defeated by the Portuguese Admiral Thomé de Sousa Coutinho . . . . . .

Abu al Abbas al Mansur, the first "Sharifian" Emperor of Morocco, who was the victor over Dom Sebastião, sends an army across the Sahara and annexes Timbuktu and the Upper Niger to the Moorish dominions

The first Dutch trading ships appear on the West African Coast . . . . . . • · · .

The Dutch replace the Portuguese at Arguin (N. W. Coast of Africa) and Goree (Dakar) in I62I ; and at Elmina (Gold Coast) .

French traders from Dieppe found the Fort of St Louis at the mouth of the Senegal . . . . . .

Foundation of the French Compagnie de L'Orient for the purpose of colonizing Madagascar .

The British East India Company takes the Island of St Helena from the Dutch

The Dutch take possession of the Cape of Good Hope .

The dynasty of the Filali Sharifs acquires the possession of the whole Empire of Morocco and Upper Nigeria .

A British African Company chartered by Charles II builds a fort at James Island, at the mouth of the Gambia . 1578 1584

I 590

I642 1651 1652

1662

This same Company (afterwards the Royal African Company), taking advantage of the war declared against Holland, seizes and retains several Dutch forts on the Gold Coast 
Denmark establishes forts on the Gold Coast . . about 1672 Brandenburg (Prussia) builds the Fort of Grossfriedrichsburg on the Gold Coast . . . . . . England, to whom Tangier had been ceded by Portugal in 1662 , abandons it to the Sharifian Empire of Morocco

The rising Arab power of 'Oman had driven Portugal out of all her possessions north of Moçambique by . . The present Husseinite dynasty of Beys (from I706 to I 88 I practically independent sovereigns) is founded in Tunis by a Turkish Agha-Hussein bin Ali Bey . . . Sieur André de Brüe, who went out to St Louis in I697 as the Governor of the French Senegal Company, founds during the next 18 years the French colony of Senegal and returns to France . . . . . . .

1706

The French occupy the Island of Mauritius (Bourbon or "Réunion" not being occupied until 1764). . .

The Portuguese (having finally lost Mombasa in I730) recognize the Maskat Imamate on the Zanzibar coast and decree the Bay of Lourenço Marquez on the south and Cape Delgado on the north to be the limits of their East African possessions . . . . .

The Portuguese lose Mazagão, their last foothold in Morocco Spain acquires Fernando Pô in the Gulf of Guinea . . Sierra Leone ceded to the British by the natives . . Spain loses Oran by a terrible earthquake, and with it her last hold over Algeria . . . . . . . I79I

Denmark forbids the Slave Trade to her subjects . . 1792 Britain first seizes the Cape of Good Hope . . . . 1795 Mungo Park discovers the river Niger at Segu . . • 1796

The London Missionary Society's Agents land in Cape

Colony and commence work amongst the Kafirs and Bushmen

Napoleon Buonaparte conquers Egypt, I798; Nelson destroys French fleet at Abukir Bay same year; French evacuate Egypt . . . . . . . . Britain finally occupies the Cape of Good Hope . . . 1806 Sierra Leone and Gambia organized as Crown Colonies . 1807 


\section{A.C.}

An Act of Parliament is passed abolishing the Slave Trade in the British dominions . . . . . . .

British capture from the French Seychelles (I794), Mauritius and Réunion in I8Io, and Tamatave and Island of St Marie (Madagascar) in . . . . . . I8II Muhammad Ali destroys the Mamluks in Egypt . . I8II First Kafir war in South Africa . . . . . I8II-I2 Cape Colony definitely ceded by Holland to Great Britain . I8I4 Island of Réunion (Bourbon) restored to France . . I814 Holland abolishes the Slave Trade in her dominions . . I8I4 France and Sweden abolish the Slave Trade . . . 1815

France reoccupies Island of St Marie de Madagascar (first taken in 1750) . $. \quad . \quad . \quad . \quad . \quad . \quad$. I8I7

Invasion of the Egyptian Sudan by Muhammad Ali's forces (1820-22) and foundation of Khartūm as its capital . 1823

A British Government Expedition under Oudney, Clapperton, and Denham discovers Lake Chad . . . 1823

Vice-Admiral W. F. W. Owen completes his great coast survey of Africa, in which for the first time in history the outline of the African Continent was correctly delineated

Governor Sir Charles Macarthy defeated and killed by the

Ashanti in 1824 ; consequent first British war with Ashanti terminates victoriously . . . . . 1827

The Brothers Lander sent out by British Government trace the Niger from Busa to the sea and establish its outlet in the Gulf of Guinea . . . . . . . A French Expedition conquers Algiers . . . . Portugal abolishes the Slave Trade . . . . . First British steamers (Macgregor Laird's Expedition) navigate the Lower Niger $(1832)$ and discover the Benué River . . . . . . . . . Slavery abolished in all British African possessions, including Cape Colony, by . . . . . . 1834 Third Kafir War in South Africa $\quad$. $\quad$. $\quad$. $\quad . \quad$. 1834 Turkey sends expedition to Tripoli to restore her direct authority

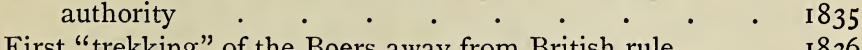
1830 1830 1830 1834 First "trekking" of the Boers away from British rule . . $\quad$ I836 
Boer emigrants treacherously massacred by Dingane, King of the Zulus .

The Sakalava of N.-West Madagascar place themselves under French protection, and France occupies the islands of Nossi Bé and Mayotta

Second Niger Expedition despatched from England .

Muhammad Ali the Macedonian (once a Turkish officer of Bashi-bazuks) confirmed in the hereditary sovereignty of Egypt as Pasha and Wali

The last of the quasi-independent Karamanli Pashas of

Tripoli seizes and garrisons the important Saharan towns of Ghadames and Ghat in $1840-4 \mathrm{I}$; but is himself removed by the Turks, who annex definitely to the Turkish Empire Tripoli and Barka . . . Natal becomes a British Colony . . . . . . Gold Coast finally organized as a Crown Colony . . French war with Morocco . . . . . . . Waghorn's Overland Route finally established across Egypt Independence of the Freed-slave State of Liberia recognized Abd-al-Kader surrenders; Constantine (East Algeria) taken

by the French , . , . , . .

Foundation of the French Freed-slave settlement of Libre-

ville in the Gaboon . . . . . .

Krapf and Rebmann discover the snowy Mountains of

Kenya and Kilima-njaro . . . . . .

Slavery had been abolished throughout all the French possessions in Africa by . . . . . . 1849

Denmark cedes her Gold Coast forts to England . . 1850 Livingstone and Oswell discover the Central Zambezi . $185 \mathrm{I}$ Independence of the Transvaal Republic recognized by Great Britain

Representative Government established in Cape Colony . General Faidherbe appointed Governor of Senegal in 1854 ; he breaks the Fula power in Senegal and greatly extends the French possessions by . . . . . A British Expedition is sent out in 1849 under Richardson, Oberweg, Vogel and Barth to explore North Central Africa: Oberweg navigates Lake Chad, ascends the 
A.C.

river Shari and is killed in Wadai; Barth visits the Upper Benué, Timbuktu, etc., and returns to England Livingstone makes his famous journey from Cape Colony to Angola and from Angola to the Indian Ocean, exploring the Zambezi from source to mouth, and returns to England . . . . . . . Burton and Speke discover Lake Tanganyika, and Speke reaches south end of the Victoria Nyanza . . . Livingstone and Kirk discover Lake Nyasa Spanish War with Morocco. . . . . . I859-60 Zanzibar separated as an independent State from the Imamate of 'Oman . . . . . . . I 86 I Lagos becomes a British Crown Colony . . . . $\quad$ I863 Speke and Grant establish the Victoria Nyanza Lake as the main source of the Nile, visit Uganda, and follow the Nile down to Cairo (Sir) Samuel Baker discovers Lake Albert Nyanza . Second Government Expedition under Dr Baikie sent out to explore rivers Niger and Benué (1854); Dr Baikie made Consul for the Niger, founds Lokoja at NigerBenué confluence and explores Benué (1857) and greatly extends British influence; but dies in 1863 ; Consulate abolished $\div$. . . . . .

Discovery of a diamond near the Orange River in Cape Colony .. . . . , . . . . .

Lakes Mweru and Bangweulu and the Upper Luapula

(Congo) R. discovered by Livingstone in $\mathrm{I} 867$ and . Basutoland placed under British protection . . . British Army enters Abyssinia to release captives of King Theodore and wins victory of Magdala . . . Establishment of Triple Control gver Tunisian finances . Opening of Suez Canal

Sir Samuel Baker. appointed Governor of the Equatorial province, Egyptian Sudan . . . . . . $1860-4$ I 864

I 866 I 867 I 868 I 868 1868 I 869 I 869 1869

Dr Schweinfurth discovers the R. Wele-Mubangi, the great northern affluent of the Congo . . . . . Livingstone discovers the Lualaba or Upper Congo at Nyangwe ; is met at Ujiji and relieved by Stanley . 1870 I 87 I 
Insurrection against French in Eastern Algeria suppressed A.C. Responsible Government introduced into Cape Colony . Sultan of Zanzibar signs treaty forced on him by England for abolition of the Slave Trade . . . . . .

Second Ashanti War: Sir Garnet Wolseley takes and burns

Kumasi .

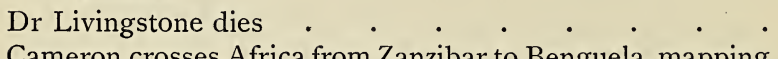

Cameron crosses Africa from Zanzibar to Benguela, mapping

Tanganyika correctly for the first time . . . $1873-5$

Stanley circuinnavigates the Victoria Nyanza and traces

the river Congo from Nyangwe to the Atlantic Ocean-

the greatest journey in African Exploration . . .

Transvaal annexed by Great Britain . . . . . 1877

The Dual Control of France and England imposed on

Egyptian Government (1876); Ismail Pasha deposed . War between Great Britain and the Zulus . . . . The International Association founded by the King of the 1879 I 879

Belgians, having developed a special branch, the "Comité d'Études du Haut Congo," sends out H. M. Stanley to found what becomes six years later the "Congo Independent State" . . . . . 1879 De Brazza secures part of the Upper Congo for France . 1880

The Transvaal revolts against Great Britain and obtains recognition of its independence under British suzerainty French force enters Tunis and imposes French protection on that country . . . . . . . .

French conquests reach the Upper Niger . . . . I88I-2 Arabi's revolt in Egypt (I88I), abolition of Dual Control, bombardment of Alexandria and defeat of Arabi at Tel-el-Kebir by Lord Wolseley; British occupation of Egypt begins

Italy occupies Assab Bay on Red Sea coast and commences creation of colony of Eritrea $\quad . \quad$. $\quad . \quad$. . 1882

Occupation of Obok by France . $\quad . \quad$. $\quad . \quad$. $\quad$. 1883

The commencement of the African Scramble: Germany establishes her protectorate over South-West Africa, and over Togoland and the Cameroons in West Africa, France occupies Grand Bassam and Porto Novo (Ivory 
A.C.

and Slave Coasts); Gordon is despatched to the Sudan (which revolted from Egypt in I883); and the Berlin Conference on African questions is summoned . Death of General Gordon at Khartūm and temporary loss of Egyptian Sudan

Recognition by all the powers of Congo Independent State Bechuanaland taken under British protection . . . Germany founds her East African possessions in the interior of the Zanzibar Sultanate . . . . .

Great Britain declares protectorate over Niger Coast and river Niger and grants Charter to Royal Niger Company: Joseph Thomson makes a Treaty for latter Company with the Sultan of Sokoto . . . . Portugal extends her territory to the south bank of the Congo and to Kabinda . . $1884-5$

France concludes treaty with Madagascar which gives her predominant influence over that island (declares protectorate over Komoro Islands I886) . . . .

The Anglo-Egyptian forces sustain severe defeats near Suakin at the hands of the Sudanese under Osman Digna: Suakin is retained, but Egyptian rule in the Nile valley is restricted to Wady Halfa. Italy occupies Maşawa

Great discoveries of reef gold in the Transvaal ; founding of Johannesburg . . . . . . .

War breaks out in N. Nyasaland between British settlers and Arab slave traders .

In Oil rivers (Niger Delta) Jaja, King of Opobo, is arrested and banished; access to interior markets is then obtained . . . . . . . . .

French Senegambian possessions definitely extended to the

Upper Niger .

Imperial British East Africa Company receives Charter . Serious rebellion against the Germans breaks out in East Africa (is not finally subdued by von Wissmann till $\mathrm{I} 890$ ) British protectorate over N. Somaliland first organized . Italian protectorate established over East Somaliland: and treaty concluded with Menelik of Ethiopia by 
A.C.

which Italy claimed to control foreign relations of Abyssinia

Charter given to British South African Company . British Central Africa declared to be under British protection: British flag hoisted on Lakes Tanganyika and Nyasa

In 1887 Stanley conducts an expedition by way of the Congo to relieve Emin Pasha. He discovers the Edward Lake and Ruwenzori Mountains and reaches Zanzibar

Anglo-German Agreement concluded relative to East

Africa : Zanzibar taken under British protection; Great

Britain recognizes French protectorate over Madagascar and French Sphere of Influence between Algeria, the .Niger, and Lake Chad; and France recognizes the British Control over Sokoto and the Lower Niger

Cecil Rhodes, managing director of the British South

Africa Company, becomes premier of Cape Colony . French expeditions reach the river Shari from the Congo

Basin and secure that river to French influence . I890-I Captain (afterwards Colonel Sir Frederick) Lugard establishes British predominance over Uganda \& ... . A German force annihilated by Wa-hehe in south central part of German East Africa . . . . . Paul Crampel, the first explorer crossing from the Congo basin to the Shari river, is . killed by a subordinate chief under Rabah Zobeir on the borders of Dar Banda Belgians establish posts in Schweinfurth's Wele . Natal receives responsible government . . . France conquers and annexes Dahomé . . . . 1893 Rabah Zobeir becomes Sultan of Bornu by conquest . . 1893 First Matebele war; death of Lobengula; Buluwayo becomes the capital of Rhodesia $\quad$. $\quad . \quad$. $\quad . \quad$ I893 French occupy Jenne and Timbuktu on the Upper Niger . 1893-4 The Belgian forces under Baron Dhanis capture all the Arab towns on the Lualaba (Upper Congo) and destroy the Arab power in Congoland . . . . . . . . . . . . I892-4 
A.C.

Witboo Hottentot outbreak against Germans in Southwest Africa. . . . . . .

Uganda declared a British protectorate; Charter of British I 894

East Africa Company withdrawn and British East Africa henceforth administered under British Commissioner

Arabs finally defeated and expelled from Nyasaland ProI $894-5$ tectorate

Major Mouzinho de Albuquerque captures the Zulu king Gungunyana and firmly establishes Portuguese dominion in South-east Africa . . . . .

Captain Bottego establishes Italian post at Lugh on the Jub river

France conquers and annexes Madagascar . . . . I894-6

Jameson raid into.Transvaal; Matebele revolt and second Matebele war

Italy sustains terrible defeat in North Abyssinia. Her pro-

tectorate over Abyssinia withdrawn and that country's independence recoonized

Anglo-Egyptian army reconquers Dongola . . . 1896

Conquest of Nupe by the Royal Niger Company . . 1897

Zululand incorporated with Natal . . . . . 1897

Railway completed to Buluwayo . . . . . . 1897

Emile Gentil reaches Shari river and Lake Chad from Congo, and establishes French protectorate over Bagirmi

Benin city and kingdom conquered by a British Naval Expedition (after a massacre of a pacific expedition under J. R. Phillips) . . . . . . .

German .East Africa declared a German colony . . . Revolt of Sudanese soldiers ternporarily imperils British position in Uganda. Col. Sir J. R. L. Macdonald's expedition reveals geography of region between Lake Rudolf and Nile; Sir Harry Johnston reorganizes the administration of Uganda protectorate and concludes a new treaty with kingdom of Buganda . I 897-98-I900 Anglo-French agreement signed with regard to Niger . $\quad 1898$ Anglo-German agreement relative to Delagoa Bay and other Portuguese possessions in Africa signed in . . $\quad 1898$ 
Samori, the last great warrior chief of Senegal-Niger, defeated and captured by the French . . . . $\quad 1898$ Serious rising against the British Sierra Leone protectorate $\quad 1898$ Railway opened from Lower Congo to Stanley pool . . Khartum captured by Sir H. (since Viscount) Kitchener and Anglo-Egyptian influence established over the Sudan; Wadi Halfa-Dongola railway continued towards Khartum

Major Marchand, who is sent to Fashoda by French Government, is withdrawn thence on British protests . The British and French Governments conclude an appendix to the Niger Convention of 1898 which determines approximately the boundaries of British and French influence in the Eastern Sudan . . Ashanti rising and final conquest of Ashanti . . . 1900

Northern Nigeria taken over for administration by the British Government . . . . . .

The Khalifa and nearly all his remaining generals perish in the battle of Omdubreikat (Kordofan) in November, 1899 , and Osman Digna is captured near Suakin in January. Sir Reginald Wingate becomes GovernorGeneral of Sudan . . . . . . . . .

Rabah Zobeir, the Sudanese conqueror of Bornu, etc., dies in battle with the French . . . . . .

The Sadd or obstructive water vegetation of Mountain Nile is cut through by Major Malcolm Peake and navigation opened up between Khartum and Gondokoro (Uganda)

Railway from Wadi Halfa reaches Khartum . . Sleeping sickness begins in Uganda in the autumn of War breaks out in South Africa between Boer Republics and Great Britain (October 1899); Bloemfontein and Pretoria taken, 1900; Orange Free State and Transvaal annexed to British Empire, 1900; peace concluded

Fadl-Allah, son and successor of Rabah, dies after his defeat by the French on the frontiers of Bornu . .

Right Hon. Cecil Rhodes dies at Muizenburg near Cape 1900

I900

I900

I900-I

I90I

I90I

1902

1902

Town, March $\quad$ • . . . . . . . 1902 
The final conquest of Northern Nigeria begins I902. (Yola, Bauchi, Bornu) and finishes (Kano and Sokoto) ..... . Uganda railway from Mombasa to Victoria Nyanza open for through service in . . . . . . .

Mr E. D. Morel commences his public denunciations of King Leopold's misgovernment of the Congo State in I902; (Sir) Roger Casement sent out to investigate and report

British-Somali War

Anglo-French Agreement, allotting Morocco to a French and Egypt to a British Sphere of Influence .

King Leopold sends an international commission to the Congo basin to investigate truth of charges brought against his administration.(I904); the commission reports . • • . . . . . . . .

Mauretania (land between Senegal and Moroccan Sahara) taken under French administration

1903

1903

$1903-4$

$1902-4$

1904

1905

I $904-5$

Lagos and Niger coast united as "Southern Nigeria" . I904

Rhodesian "Cape to Cairo" railway reaches and bridges

Zambezi at Victoria Falls . . . . . . . .

1905

French conquest of Wadai, the great slave-raiding state of the Central Sudan, begins . . . . . .

Italian government takes on direct management of Italian

Somaliland . . . . . . . . . . . . .

German Emperor decides to pay state visit to Morocco at

Tangiers and thereby calls in question the allotment

of Morocco to France as a sphere of influence. .

The Congress of Algeciras meets in southern Spain to discuss the future of Morocco . . . . .

Railway from Khartum-Berber to Port Sudan (Red Sea) opened . . . . . . . . . . . . 1906

Grant of responsible government to the Transvaal . . 1906 In 1903 the Hottentots rebel against. German authority in

South-west Africa. In Igo4 the Ova-herero (Damaras)

join the rebellion, which is not finally crushed until : I906-7

Responsible.government granted to Orange River Colony

(Orange Free State)

I907 
Diamonds found in German South-west Africa . . . 1908

Belgium annexes the Congo Independent State . . . . I908-9

In 1908 serious troubles break out in Western Morocco (Shawia country) obliging France to land a large force and occupy Casa Blanca and the neighbourhood; Mulai Hafid defeats his brother (Abd-el-Aziz) and becomes Sultan in his place; France and Germany come to a temporary arrangement which recognizes France's "political interests" in Morocco . • .

Union of South Africa (Cape Colony, Natal, Transvaal, and Orange State) proclaimed . . . . . Spaniards send an army of 50,000 men to conquer and occupy Rif country (North-east Morocco) .

France conquers the Arab and Berber nomad tribes of Adrar (Mauretania)

France finally conquers Wadai . . . . . . 1910 Rhodesian "Cape to Cairo" railway opened as far as Congolese frontier in Katanga Viscount Kitchener becomes British Agent in Egypt . . I9I I "Cape to Cairo" railway extended from Khartum to El

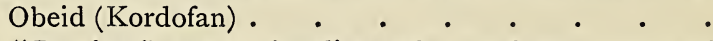
I9I I

The "Panther," sent to Agadir on the south-west coast of Morocco by Germany, reopens the Morocco question; but the incident ends in a German recognition of a French protectorate over Morocco . . . .

Italy lands 80,000 men at Tripoli and eventually annexes

all Tripoli and Barka

France cedes to Germany important territories which connect the Kamerun colony with the Mubangi river and the main Congo, making Germany a "Congo" power I9II-I 2 Railway from Lagos to Kano (Hausaland) finished . . 1912 Liberian Republic entrusts the management of its finances and interior police to officials appointed by United States President . • . • . . . I9II-I2 France and Spain definitely settle their partition of Morocco ; and France occupies all important Moroccan towns except Tangier 


\section{APPENDIX II}

BIBLIOGRAPHY OF THE HISTORY OF COLONIZATION OF AFRICA. BOOKS SPECIALLY USEFUL

All Blue BOOKS published by Foreign Office and Colonial Office DEAling with AFrica and the Slave Trade from I830 to the present day-especially for the years between 1876 and I 898, and I903-II.

A History of Ancient Geography; by (Sir) E. H. Bunbury. 2 vols. 2nd edition.

The Gold OF OPHIR; by Professor A. H. Keane.

John Murray. I883.

Edward Stanford. I90I.

Les Civilisations DE L'Afrique DU NORD (Berbères, Arabes, Turcs); par Victor Piquet. Paris: Armand Colin. I909. Histoire de L'Afrique SePtentrionale (Berbérie); par Ernest Mercier. 3 vols. Paris: Ernest Leroux. I89I. (An excellent and trustworthy compilation.) HistoIre DE L'ÉtABLISSEMENT DES ARABES DANS L'AfRIQUE SePtentrionale selon les auteurs Arabes. By the same author. I vol. Paris: Challamel. I875.

The Dawn of Modern Geography. Vols. II. and III.; by C. Raymond Beazley. Oxford. 1906. Prince Henry the Navigator; by Professor C. Raymond Beazley.

Also by same author:

Putnam. 1895.

PRINCE HENRY OF PORTUgal, ETC. (Gives much interesting detail as to early Portuguese colonizing work.) American Historical Review. Vol. XVII. I9I2. 
The Chronicle of The Discovery and Conquest of Guinea. G. de Azurara. Translated from the Portuguese by C. R.

Beazley and E. Prestage. Hakluyt Society. 2 vols. 1899. History OF THE Kingdom of Congo; by Duarte Lopesrendered into Italian by Filippo Pigafetta.

English translation: John Murray. I88I. Historia da AFrica Oriental PORTUGueza; por José Joaquim Lopes de Lima.

Travels of the Jesuits in Ethiopia; by B. Tellez. Lisbon. $\quad$ I862.

London. I710.

The Barbary Corsairs (Story of the Nations); by Stanley Lane Poole. T. Fisher Unwin. I890. DoCUMENTS SUR L'HistoIRe, ETC., DE L'AFRIQUE ORIENTALE; par le Capitaine M. Guillain. 3 vols.

Paris. 1856.

The Early Chartered Companies; by George Cawston and

A. H. Keane.

Edward Arnold. 1896.

MUngo PARK AND THE Niger; by Joseph Thomson.

George Phillips. I890.

Pioneers in WeSt AFriCA; by Sir Harry Johnston.

Blackie. I9I I.

The Lands of Cazembe (Lacerda's journey to Cazembe in 1798);

a compilation by Captain R. F. Burton.

Royal Geographical Society. 1873.

ZANZIBAR; by the same author.

London. $187 \mathrm{I}$.

The Maps of Africa BY TREaty; by Sir Edward Hertslet, K.C.B. 2 vols. Harrison \& Sons. I 894-5. Egypt in the Nineteenth Century; by D. A. Cameron.

Smith, Elder \& Co. $\quad$ I898.

ENGLAND In Egypt; by Viscount Milner, G.C.B.

London: Arnold. I892-1910.

UGANDA AND THE EgYPTIAN SUdAN; by Dr R. W. Felkin and C. T. Wilson. 2 vols. Sampson Low. 1882 . MARTYRDOM OF MAN; by Winwood Reade.

Kegan Paul. (Ed. of I910.)

SAVAGE AFRICA; same author.

Smith, Elder \& Co. $\quad$ I 864 .

THE HEART OF AFRICA; by Dr Georg Schweinfurth.

Sampson Low. 1873 .

OUR SUDAN ; its pyramids and progress ; by John Ward. 
A History and Description of the British Empire in AFRICA ; by Sir Harry Johnston. National Society. I9I I. Historical GEOGRAPHY OF THE BRITISH Colonies. Vol. IV.

Parts I \& 2 (dealing with South and East Africa); by Sir C. P. Lucas, B.A.

Do. Do. Vol. III. WeST AFrica.

Clarendon Press. 1897. History of South Africa; by G. McCall Theal. 5 vols.

Juta \& Co., Cape Town. I888-93.

ANGola AND the River Congo; by J. J. Monteiro. 2 vols.

AfricA. 2 vols. By Professor A. H. Keane.

Macmillan \& Co. $\quad 1875$.

Edward Stanford. I902.

Travels and Discoveries in North and Central Africa;

by Dr Henry Barth. 5 vols. Longman, Brown, Green. I857.

The STORY OF AFrica; by Dr Robert Brown. 4 vols.

Cassell and Company. 1894-5. (A most valuable book of reference.)

The Partition of Africa; by (Dr) J. Scott Keltie. 2nd Edition.

Edward Stanford. I895.

How I found Livingstone. Through the Dark Continent.

2 vols. THE CONGO: AND THE FOUNDING OF ITS FREE State. 2 vols. IN DARKeSt Africa. 2 vols. By H. M. Stanley.

Sampson Low.

Du Niger au Golfe de GuinéE; par le Capitaine Binger.

Paris 1892.

The Fall of the Congo Arabs; by Captain S. L. Hinde.

Methuen. 1897.

British Central Africa; by Sir H. H. Johnston. 2nd Edition.

Methuen. I899.

Fighting the Slave Hunters in Central Africa; by Alfred J. Swann.

Seeley \& Co. I910.

AdVENTURES IN NyASALAND; by Low Monteith Fotheringham.

Timbuctoo the Mysterious; by Félix Dubois.

Sampson Low. I891.

William Heinemann. 1897.

The Rise of our East African Empire; by Captain F. D.

Lugard, D.S.O. 2 vols. Blackwood, Edinburgh. $\quad$ 1893. BRITISH EAST AFRICA; by P. McDermott.

Chapman \& Hall. 1895. 
Fire ANd SWORd in THE Sudan; by Sir Rudolf Slatin Pasha.

Edward Arnold. I896.

L'Omo: Viaggio di Esplorazione nell' Africa ORientale; da Vannutelli e Citerni. Milan. I899.

(Deals with Italian Somaliland, Galaland, etc.)

À travers l'Afrique Centrale: DU Congo AU Niger; by C. Maistre.

Paris. I 895 .

The UGanda Protectorate; by Sir H. H. Johnston. 2 vols. 2nd Edition.

MADAGASCAR; by Captain S. Pasfield Oliver. 2 vols.

Macmillan. I886.

The Rise of our West African Empire (Sierra Leone); by Captain C. Braithwaite Wallis.

The History of Sierra LeONe; by Major J. J. Crooks.

Simpkin Marshall. 1903.

Times History of the South African WaR. 5 vols.

Times Office. I903-5.

Civilization in Congoland; by H. R. Fox-Bourne.

London. 1903.

King LeOPolD'S Rule in AfricA; by E. D. Morel.

Heinemann. I904.

BRitish Nigeria; by Lieut.-Colonel A. F. Mockler-Ferryman.

London. . 1902.

LiBERIA. 2 vols. By Sir H. H. Johnston. Hutchinson. I 906. MADAGASCAR : Essai de Géographie Physique (gives much history, also); par E. F. Gautier.

Paris. 1902.

THE NEGRO IN THE NEW WORLD (gives history of Slave

Trade); by Sir H. H. Johnston.

Methuen. I9IO.

Nyasaland under the Foreign Office; by H. L. Duff.

A Tropical Dependency; by Lady Lugard.

George Bell. I903.

Uganda ANd its Peoples; by J. F. Cunningham.

London. I904.

Hutchinson. I904:

Seventeen Trips through Somaliland, etc.; by Colonel H. G. C. Swayne, R.E. 3rd Edition.

The Nile QuesT; by Sir H. H. Johnston.

Rowland Ward. I903.

Lawrence \& Butler. I904. 
George Grenfell and the Congo; by Sir H. H. Johnston. 2 vols.

Hutchinson. I908.

The Garden Colony: the Story of Natal and its neighbours; by Robert Russell.

J. M. Dent. I903.

The Great Plateau of Northern Rhodesia; by C. Gouldsbury and $H$. Streane.

Edward Arnold. I9II.

A History of Geographical Discovery in the Seventeenth AND EighteEnTh CENTURies (treats of early history of South Africa); by Edward Heawood, M.A.

Cambridge University Press, I9I2.

DAWN IN DARKeST AFRICA ; by John H. Harris.

Smith, Elder \& Co., I9I2.

Morocco in Diplomacy; by E. D. Morel.

Smith, Elder \& Co., I9I2.

The Statesman's Year-Book; by Dr J. Scott Keltie.

(Annual publication.) Macmillan.

Colonial Office List; by W. H. Mercer and A. E. Collins.

Harrison \& Sons. 1898-1912.

Also the works of Livingstone, W. Flinders Petrie, Sir Richard Burton, Capt. J. H. Speke, Sir Samuel Baker; Journals of Charles GeORge Gordon, and I th Edition, ENCYCLOPAEDIA BRITANNICA. 


\section{INDEX}

Abatetwa clan, 28 I

Abbadie, Antoine and Arnaud, 226, 317

Abbas bin Tusūn, 360

Abbas Hilmi, 367

Abbasid Khalifs, 67, 69, 71, 72

Abd-al-aziz, 223

Abd-al-Hamid, 366

Abd-al-Kader, 2 I4, 2 I 8

Abd-al-Mumin, 64

Abd-al-Wadite kings of Tlemsan, 64

Abdallah-al-Taaisha, 363

Abdallah-bin-Abu-Sarh, 56

Abdallah-bin-Zubeir, 56

Abd-ar-rahman bin Mūawiya, 59

Abo, 192

Abraham of Beja, 81, 82

Abreu, Gomez d', 424

Abruzzi, Duke of the, 340

Abu Muhammad Hafsi, 64

Abu-AbdAllah, 6o

Abukir Bay, 2 I 2

Abu'l Abbas Ahmad-al-Mansur, 66 et seq.

Abyssinia, 7, 10, 16, 17, 19, 21, 22, $43,5 \mathrm{I}, 52,62,82$ et seq., I $52,2 \mathrm{I} 2$, $226,227,241,242,245,253,300$, 3०1, 303, 308, 3 г6, 3 I 7, 319, 320, $326,363,393$ et seq., 443

Abyssinian explorers, 45, 3 I 7

Accra, 1 24, I 77, 178, 196

A $\chi$ dar mountains, 42

Acila, 66

Açores Islands, 92, 116, 390

Acre, 2 I 2

Acunha, Tristan d' (Conquistador), 83
Adamawa, 194

Aden, 18, 19, 73, 83, 226, 22 7, 235, $335,337,372$

Adis Ababa, 227, 396

Adonis, 39

Adrar, 12, 12 I, 32 I

Adrar Temmur, 209

Adua, 396

Adulis, 43

Aelius Gallus, 298

Aepyornis, 424

Afar-Danakil - Somali language group, 2 I

Afarik, 37

Affonso (of Kongo), 86

Africa, prehistoric race movements in, I et seq.; negroes of modern Africa, 5, 6; indebted to Egypt for domestic animals and cultivated plants, I9, 20; Mediterranean colonization of, 32 et seq. ; derivation of name, 37; Arab conquest of, 52 et seq.

"Africa" (the Roman province of), 47, 49 et seq., 59, 2 I9

African Association, 304, 305, 318

- Lakes Company, 248, 277,284

"Afrikander Bond," 276

Afrikanders, I29, I40, 276

Agades, I3, I9, 49, 209

Agadir, 224, 225, 399

Agau-Bilin, 2 I

Aghlab, Aghlabite dynasty, 59, 60

Agisymba, ${ }_{4} 8$

Agulhas, Cape, 8 I

Ahaggar, 337

Ahmad bin Tulūn, 70

Ahmadu Abdulei, 203 
Ahmadu Ahmadu, 202

Ahmadu bin Tidiani, 202, $2 \mathrm{O}_{4}$

Ahmadu Lobo, 202

Ahmadu, the Fula King, 309

Air, country of, $327,337,443$

Air and Asben, oasis, 209

Akaba, Gulf of, 366

Akko, 32

Al-Araish, 77

Al-'Askar, 60

Albanians, r9, 70

Albany, 256, 258

Albargoa, 423

Albert Nyanza, see Nyanza

Albreda, I 7 I

Albu, Sir G., I46, 2.74

Albuquerque, Major Mouzinho de, I 14

Aldabra, 29, 295

Aleppo, 7 I

Alexander, Lieut. Boyd, 338, 339

Alexander, Sir J. E., 307

Alexander the Great, 43

Alexandria, 44, 45, 52, 7 I, 2 I2, 2 I $4,238,298,359,360,362$, 366,393

Al-Fasi, 39 I

Alfonso I, 76

Alfonso III, 77

Alfonso V, 76

Alfonso VI, 76

Al Fostat, 60

Alfred, county of, 270

Algarve, 77

Algeciras Conference, 223, 225

Algeria, 5, 8, 1 2, 22, 35, 38, 47, $49,50,5.3,56,59$ et seq., 1 16, I I9, I 20, I60, 207, 2 I3 et seq., $245,252,253,301,32 \mathrm{I}, 337$, 444,445

Algiers, I I 7, I I 8, I95, 2 I 3, 2 I 4 , 230, 235, 400

Algoa Bay, 8I, I26, 259

Alhucemas, Is., I I 9

Ali, 56, 59, 6o, 66, 69

Ali bin Hamūd, 382

Al Jof, 237

Al Kahirah, 6o

Al-Kaïm bi Amr Allah, 60

Al Kasr-al-Kabir, 77
Al-Katai, 60

Allah, 55

Allat, 55

Al-Mahdi Senussi II, 236

Al-Mansur, 67, 69

Al-Masr, 6o

Almeida, Francisco de, 424

Almirante Islands, 28, 29, 295

Almoravide, Almohade, see Marabut and Muāhadim

Al Mu'izz, 6o

Al-Obeid, 363

Alsace-Lorraine settlers in Algeria, 216

Alula, Ras, 394

Alvares, Dom, 86 et seq.

Alvarez, 83

Al Wardani, 367

Amalfi, 390

Amamfengu, 267

Amaro José, 307

Amatola Mountains, 263

Amatongaland, 28r, 283

Ama-zulu, 28I

Ambas Bay, 184, 244, 4I 5

Ambriz, 94

America, 88, 92, I 24, I 54

American Colonization Society, ${ }_{58} 8$, I 64

American Missionaries, $36,96,175$, 228, 252, 26 I

American slave-trade, 153, I 54 , I 56

American War of Independence, I 73

Amerindian type, 4

Amhara, 395

Amiens, Peace of, 254

Amina, Princess, 360

Amir-al-Mumenin, 63

Amorites, 22

Amr-bin-al-Aș, 55

Amsterdam, I 27

Anamabu, 176

Andalucia, 50, I 20, 202

Andaman Islands, 3

Anderson, Benjamin, I66

Andersson, C. J., 317, 327

Angas, G. F., 308

Angles, 50

Anglo-French Conventions, 2 ro, $225,230,366,368$ 
Anglo-German Convention of 1890 , $364,4 \mathrm{II}$

Angola, 87, 89 et seq., 96, 97, 104, 106, 108, 124, 1 $28,154,184,245$, 250, 25 I, 258, 29 I, 30 I, 3 I 6 et seq., $325,338,444$

Angoni-Zulus, 24, 103, 160, 279

Angora goats, $265,274,419$

Angoshe, 103, го9, I 10

Angra Pequena, 99, 406, 420

Anhaya, Pedro de, 83

Ankobra, I 24

Ankole, 38 I

Annesley Bay, 43

Anno Bom Island, I 2 I

Anti-Atlas Mountains, I20, 224

Antilles, II 7

Antonelli, 329

Anuaks, 370

Apollonia, 42, 124

Arābi, Ahmed, 360, 362

Arabia, I, 4, 17, 21, 22, 24, 26, 29, $33,39,43,5 \mathrm{I}, 52,54$ et seq., $62,84,103,152,156,159,160$, 326

Arabic language, 40, 6r, 70, 75, $217,253,448,449$

Arabs, I3, 14, 19, 22 et seq., 29, 30, $42,44,45,52$ et seq., 70 et seq., I34, I46, I52, 160, I6r, 2 I3, 2 I 5 , 2 I 7,24 I $, 279,285,291,294,344$ et seq., 446 etc.

Aragon, II 6

Aramaic, 2I, 40

Archinard, Col., 204, 206

Argonauts, 4I

Arguin, 79, 1 23, 198, 403

Arizona, 153

Armenia, 20

Armenians, 19, 21, 22

Arnaud (explorer), 338

Arnold, Sir Edwin, $36_{4}$

Arnot, F. S., 330

Arõ tribe, 187

Aruwimi, R., 329, 332

Arvad, 32

Aryan tongues, 2 I

Aryan type, 22

Arzila, 66

Ascension Island, 99, 268
Ashanti, I0, I 2, I4, 48, I 24, I46, 154, I6I, I76 et seq., 204, 309

Ashmun, 39

Ashmun, Rev. Jehudi, I64

Asia, probable birth-place of the negro, 4 ; modern negroes of, 5 elc.

Asia Minor, 69

Asiatics in S. Africa, 291, 294

Asil, 237

Asiut, 303

Asjer, 37

Asmara, 393

Ass, the, 75

Assab Bay, 393

As-Sanusi, 236

Assini, 205

Assuan, 368

Assyria, Assyrians, 19, 21, 33, 37

Astarte, 39

Atbara, 46, 365

Atiqa, 32, 33

Atlantic Ocean reached by Arabs, 57

Atlas Mountains, 2, 47, 49, 64, 223, $224,324,331,336$

"Atrocities," 349

Augustus Caesar, 298

Aures Mountains, 445

Aurigha, 53

Austen, Capt. H. H., 339

Australia, 264, 293

Australoids, 2

Austria, 59, 245

Austrian attempt on Delagoa Bay, I I I

Austrian Catholic Mission on Nile, 319

Austrian missionaries, 245

Author. His experience of slave traffic, I 55, I 56 ; administers Ambas Bay, 184 ; removes Jaja, 185; explores the Benin river, I86; administers British Central Africa, 278, 284; with Dr Cross discovers south end of Lake Rukwa, 328; other African explorations, 330, 33I ; and Kilima-njaro, 376, 409; appointed Special Commissioner, $380,38 \mathrm{r}$; 
on the East African Protectorate, 387

Avis, House of, 66,88

Awarigha, 37

Awuraghen, 37

Axim, 124

Axum, 43, 300

Ayeaye, the, 427

Ayubite kings of Egypt, 7 I

Baal-hammana, 38

Baal Milkkart, 39

Bab-al-Mandib, Straits of, 4, 393, 397

Babel or Babylon, 6o

Baboons, 43

Badagri, 3 I I , 3 I 2

Baert, Capt., 330

Baetica, 50

Baganda, 380

Baghdad, 58, 59, 67, 69 et seq.

Bagirmi, I3, I4, I94, 230, 235 et seq., 324, 443

Bagradas, 38

Bahr-al-Ghazal, I2, 16, I9, 43, 46, $319,32 \mathrm{r}, 326,327,336,3^{6} 3,369$

Baikie, Dr W. B., I 88

Bailundo, 96

Baines, Thomas, 283

- William, 327

Ba-jok, 87, 30I

Baker, Sir Samuel and Lady, 3도, 3 18, 326, 362

Bakhunu, 204

Ba-kioko, 87

Bakka, 54

Ba-kongo, 240

Balboa, I 53

Baldissera, General, 396

Baldwin, 327

Ball, Mr John, 324

Bamaku, 202, 203, 305

Bambotus, 49

Bambuk, r99, 304

Banana (tree), 27, 75, 92, 93

Bandiagara, 202

Bangweulu, Lake, 322, 330, 334

Bani, I 4

Banks, Sir Joseph, 304

Bantu Africa, 26, 308, 335
Bantu border-line, 230, 332

- language, го, г г, г6, I34

- negroes, 26, 30, 45, 5 I, 97, I22, I 26, I $34,232,4$ I 5,4 r 8

- - migrations of, $134, \mathrm{r} 35,255$

Baptist Mission (Cameroons and Congo), I $84,244,325,329,4$ I 5

Baptista (explorer), 307

Baratieri, General, 396

Barbarossas, the, i 8

Barbary, 54, 59, 61, 62, 66, 298, 302

Barbary States, г 18, г69, г95, 303 ; see also Algeria, Tunis, Tripoli

Barclay, Hon. Arthur, ${ }^{6} 67$

Bardera, 398

Bardo Museum, 35

Barghash, Sultan, 375

Bari people, 245, 326

Baring, Sir E., see Cromer

Baringo, Lake, 3.3 I, 335

Barka, 4r, 57, 6r, 69, 3I 4, 444

Barke, 42

Barotse, 249, 278, 325, 339

Barrakonda Rapids, 302

Barreto, Francisco, ror, IO2, 300

Barth, Dr Heinrich, 195, 314, 3 I 5

Bary, Dr E. von, 327

Basel Mission, 248

"Bastards," the, I39, r42, 418

Bastian, Dr, 322

"Bastion de France," 2 I I

Basuto, Basutoland, r 34 , r 40 et seq., $249,250,26_{3}, 26_{4}, 270$,

$273,275,28 \mathrm{I}, 29 \mathrm{I}$ et seq.

Batavia, 1 26, 1 27, 1 35,136

Bateke country, 90

Batenstein, Fort, 124

Bates, G. L., 339

Batetela, 346

Bathurst, r 70 , I $7 \mathrm{r}$

Batoka country, 240, 247

Battel, Andrew, 30I

Bauchi, r 94

Bauer, F., $33^{8}$

Baumann, Dr, 333, $33^{6}$

Baya country, 234

Ba-yaka, 87

Bayoñ, 4I 5

Beaconsfield, Lord, 406 
Beaufort, de, 200, $3 \mathbf{1} 9$

Bechuana, Bechuanaland, 134,140 , I 43, I 45, 249, 255, 269 et seq., 29I, 292, 307, 308, 31 7

Beechey, Admiral, $3{ }^{1} 4$

Beecroft, Capt. John, r83, r88, 313

Behanzin, 206

Beira, 82, 100, I I3 et seq. , 279, 285, 286

Beirūt, 32

Beit, Alfred, $\mathrm{I}_{4} 6,274$

Beja, 2 I, 8I

Beke, Dr C. T., 3i 7

Belgian Africa, 342 et seq.

Belgian Congo, $87,96,233,235$, 272, 291

Belgians, King of the, 229 et seq., $328,329,342$ et seq.

Belgium, Belgians, I6 [, 328, 329, 342 et seq.

Bell, King, 408

Beltrame, Giovanni, 3 9

Belzoni, Giovanni, r 86

Bembatoka Bay, 429, $43^{8}$

Bena-mutapa, 23

Benarir, 397, 398

Bengal, Bay of, 28

Benghazi, 42

Benguela, 90, 94, 96, I 59, 25 I, $301,316,323$

Beni-Hilal, $6 \mathbf{r}$

Beni-Merin, 54, 64

Beni-Midrār, 59

Benin, I54, I69, I8 r et seq.

Beni-Rustam, 59

Beni-Soleim, 6r

Bentley, Reverend Dr H., 244, 329

Benue, R., I 2, I 3,48, I 85, I 88 , I9o et seq., 313, 332, 333, 338

Benyowski, 427

Benzert, $3^{8}$

Berber states and dynasties, 194

Berbers, 12 et seq., I8, 21, 36 et seq., 50, 51, 53, 54, 57 et seq., I I $7,2 I_{4}, 2$ I 5,2 I $7,253,446$

Berenike, $\mathrm{I} 8$

Berg River, I3 I

Berg-Damara negroes, 7

Berkeley, E., 380
Berlin Conference, I89, I92, 2 I9, 229, 23I, 343

Berlin Convention of $\mathrm{I}_{884}$, I I 2

Bermuda, $26_{4}$

Bermudez, 84

Bernard, A., 334

Beshar, 222

Best, Rev. Mr, $25 \mathrm{I}$

Betancourt (Béthencourt), Jean de, 85 , í 6

Bethany, 406

Betsi-misáraka, 428

Beurmann, M. v., 324

Bey of Constantine, 2 I 4,2 I 8

Bey of Tunis, $219,220,323$

Bezuidenhout brothers, 258

Biafra, I 83

Bianco, Andrea, 424

Bibars, 7 I

Bights of Biafra and Benin, $x 83$, 205, 312, 3 I3

Bihé, 25 I

Bilma, 209, 339

Binger, Colonel Louis G., 203, 205, 3I 5,333

Bird, Mrs Isabella, 433

Biruna, 32

Biruta, 32

Bisandugu, 204

Bisharin, I7, I8, 21, 52

Bishops (Christian), see Christian; Negro do., 86, 243

Biskra, 57

Bismarck, Prince, 405, 406

Bismarck archipelago, 3

Bitter Lakes, 33

Bizerta (Hippo-Zaryt), $3^{8}$

"Black Africa," 449, 450

"Black, White, and Yellow," 272

Blanchet, Paul, 338

Blanco, Cape, 78, 79, г 2 I, 17 I, I 98,403

Blantyre, Io8, $25 \mathrm{I}$

Blemmyes, 52

Bloemfontein, I49, 288; Convention, I 42

Blyden, Dr E. W., ${ }^{1} 6_{7}$

Bocarro, Jasper, 300

Boer victories, I 49

Boers, the, 7, 95, 129, 136, 138 
et seq., 257, 258, 260 et seq., $28 \mathrm{I}$ et seq., 292, 293, 388

Böhm, 327, 334

Boiteux, Lieut., 206, 207

Bojador, Cape, 78, I 2 I

Bolts (adventurer), . I I I

Boma, 8o, 87, 347

Bombay Presidency, I 52

Bona, Bône, 38, 66, I I 7, 2 16, 390

Bondelzwarts, 4 I 7

Bondu, 20I, 202

Bonnat, Mons. M. J., 325

Bonnier, Col., 204, 207

Bonny, R., I85, I89

Boomerang, I 5

Bôr, 3 I9

Borān Gala country, 386

Borckenhager, Mr, 276

Borelli, H., 226, 334

Borghese, Prince Giovanni, 323

Borgnis-Desbordes, General, 202

Borgu, I 2, 5I, I 82, I 92 et seq.

Bornu, I 2, I 5, I9, 48, 5 I, 68, 70, I60, I9I, 193, 204, 235, 236 , 304,3 I0, 3 I4, 3 I 5, 323, 443

Boroma, 247

Botha, General Louis, I 50

Bottego, 334

Bourbon, Island of, $127,296,426$, 429

Boutros Pasha, $3^{6} 7$

Bowdich, Thomas Edward, I76, 309

Bragança, House of, 67,93

Brandenburg in Africa, 403

- Great Elector of, 403

Brass, R., I89, 312

Brass settlement, 3I2, 3I3

Brass work, I87

Bratières, Serg., 205

Brava (Barawa), Ioo

Brawa, 398

Brazil, Brazilians, 91, 92, 94, 96, 98, I04, I 58, I 59, 226, 30 I

Brazza, Savorgnan de, 228, 229, 234, 329, 343

Brest, 20I

Bricchetti-Robecchi, 334

Bristol, I 57, 205

Britain. British, 72, 77, 104, I 10,
I 26, I32, I 33, I 54, I6 I, I63, I65 et seq., I 7 I, I 77, I78, I 80 , I82, I83, I89, I9I et seq., I98, 219, 227, 239, 254 et seq., 359 et seq.

Britain and the Slave Trade, 239

- Missionary efforts, 239

British Element in Cape Colony, 257

- Empire in India, I33

- Empire of the Future, 446

- Central Africa, 107, ro8, I79, 278, 279, 284, 33I, 334

- East Africa, ro, I 56, 250,444

- - Company, 376, 378, $3^{8} 3$

- Government, the, 73, I07, II2,

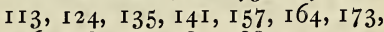
г 76, 178, г83, 187, 188, 192, г94, 206, 257 , etc.

- Nigeria, I88, I90 et seq.

- occupation of Egypt, I9, I59

- South Africa, 95, I I5, I44, I 49, 254 et seq., 29 I

- South Africa Chartered Co., I I 3, I I 4, I 47, I60, 23 I , 278,284 , $285,287,339,346$

Bronze work, I86, I87

Brown, Dr Robert, I 54, 199

Browne, William G., $3 \circ 3$

Bruce, James, 303

- Sir David and Lady, 340

Briie, André de, I98, I99, 302, 309

Bu Amama, 2 I 7

Bube, the, I 22

Buchanan, John, 278

Buëa, 4I5

Buffalo, Indian, 75,390

- River, 255

Buganda, 377, 379, 38I

Bugeaud, Marshal, 2 I 4

Bugia, 66, I 17

"Bula Matadi," 87, 343, $35^{6}$

Bullom, I 74

Buluwayo, 272, 285

Bunbury, Sir E. H., 4 I, 298

Bunnon, L. von, $33^{6}$

Bunyoro, 320, 380, 38I

Burchell, Dr William, 307

Burmese, 3

Burton, Sir Richard F., I83, I86, 3 I5, 3I8, 324, 334 
Buru, 3

Busa, 188, 190, 191, 208, 306, 31 I, 3 I 2

Bushiri, 4I I

Bushmen, 2, 5 et seq., 18, 26, 29, I26, I34, 232, 255

Bushongo, 16, 26, 339

Busira, R., 329

Busoga, 376, 378, 387

Buittikofer, Prof. J., 328

Buittner, Dr R., 336

Buxton, Sir Thomas Fowell, $3^{\mathbf{I}} 3$

Byzacene, 58

Byzantium, Byzantine Greeks, I9, 39, 4I, 43, 50, 52, 53, 55 et seq., $74, \quad$ I 52

Cabo Tormentoso, 8I

Cacao tree, 92, 96, 97, 122 , I 80

Ca' da Mosto, 79

Cadiz, $3^{2}$

Caillaud, F., 3 I9

Caillié, René, 200, 309

Cairo, 60, 67, 69, 71, 72, 82, 212 , $245,279,303,362,366$

Caius Plinius Secundus, 45, 298

Calabar, see Old

California, 293

Cam, Diogo, 8o, 85

Cambier, Capitaine, $34^{2}$

Cambon, M. Jules, 220

Cambyses, 43, 298

Camel, the, $48,54,75,419$

Cameron, Capt. V. L., 322,325 , $328,34^{2}$

Cameroons (Kamerun), 5, 6, 12 , I $3,20,36,49,79,99$, I 22, I 82 et seq., 228, 229, 234, 244, 25 I, $324,325,331,33^{2}, 33^{8}, 407$, $408,414,415$

Campagnon, Sieur, 199, 302, 309

Campbell, Capt., 306

- (Scotch missionary explorer), 307

Canaanite settlements in Berberland, 37

Canada, $143,173,216$

Canary Islands, 32,85 , I I 6, I I 7 , I $20,196,225,226,390$
Candido de Costa Cardoso, 307

Cannibalism, 349

Cantin, Cape, 35

Cape Bon peninsula, $4 \mathrm{I}$

- Coast, 99, г 24, г 76, I 77

- of Good Hope, 8I et seq., 99, 100, 104, I 25 et seq., 242,254

- Colony, гzo et seq., 176, 240, 254 et seq., 404

- Dutch, I47, I49

- Town, 106, I25, I 28, 129 , I32, I33, I 35 et seq., 254, 255 , 269, 272, 273, 279

- Verde, 36, 79, 99, г97, 20 г

- - Islands, 79, 92, 98, г33

"Cape Boys," 267

"Cape to Cairo," 279, 340, 364

Cape-Jubi-Bojador region, 225

Capello, Brito, 325

Capuchins, 94, 228

Carnarvon, Lord, 143, 269, 280

Caron, Lieut., 203

Carthage, 24, 32, 35, 37, 38, 46, $47,57,65,1_{52}, 235$

Carthaginians, 33, 35 et seq., 79, I 2 I

Casablanca, 223

Casamanse, River, 201

Casati, 380

Casement, Sir R., 355

Cassel, Sir E., 368

Castile, 85 , I 6

Castile-Aragon, 66

Cat, the domestic, 92

Catalans, 78

Cathcart, General, 263

Cattle, 39, 180, 255, 274, 419

Caucasia, 20

Caucasian race, $4,5,7,9,13,16$, $2 \mathrm{I}, 75$

Cavendish, Capt., 267

Cavendish, Mr H. S., 335

Cerne, see Kerne

Cetewayo (Ćechwayo), 282

Ceuta, 57, 58, 65, 67, 77, 78, I 19

Ceylon, 4, 28, 29, I 29, I33, 428

Chad, Lake, 8, I4, I 5, 20, 46, 48, 54,62 , I 59, I90 et seq., 230 , $235,300,310,315,324,337,33^{8}$

Chafarinas Islands, I 9 
Chaga, 376

Chagos group, 28

Chaillé-Liong, Col., 326

Chaillu, Paul du, 228, 324

Chaka, I40, I4I, 261, 267, 28 I

Chaldaea, 37

Chali, 259

Chama, 124

Chamberlain, Mr Joseph, 287

Chanler, W. Astor, 335

Chanoine, Capt., 221, 222, 236

Charlemagne, 59

Charles of Anjou, 65

Charles II of England, I 76, 302

- V of Spain, I I8, I53

- $\mathrm{X}$ of France, 213, 43I

Chartered companies, I09, 1 I 4 , I 24 , 192, 278

Chatelain, Rev. Héli, 25I

Chekhs, 72

Chelmsford, Lord, 282

Cherim, го6

Chevalier, A., $33^{8}, 34^{\circ}$

Chillies, 9I, 92

Chimpanzee, the, I 7, 36

China, Chinese, 29, 83, 9I, 290, 29I, 294

Chinde, R., I I 4, I I5, 318

Chiromys, 427

Chobe, R., 4 I 6

Christian Bishops in Tunisia, 65 ; in Central Africa, 86, 327, 378; Madagascar, 248

Christian Missions in Africa, list of : American Presbyterian Mission, 250, $25 \mathrm{I}$

Austrian Catholic Mission (Sudan), 245

Baptist (American) Gaboon Mission, $25 \mathrm{I}$

- (British) Cameroons and Congo Mission, 184, 244 - (Scotch) Nyasaland Mission, 252

Basel Mission, 248

Bavarian (Roman Catholic) Mission, 249

Berlin Missionary Society, 249

British Roman Catholic Mission, 246
Christian Missions (cont.):

Church Missionary Society, I 59, $242,243,248,25$ I $, 316,328$, 378

Dutch Reformed Church Mission, 250

Edinburgh Missionary Society, 242, 250

Episcopal Methodist (American) Mission, $25 \mathrm{I}$

Established Church of Scotland Mission, 250

Free Church Mission (Scotch), 250

French Evangelical Missionary Society, 249

French Roman Catholic Missionary Society, 245

Glasgow Missionary Society, 242, 250

Jesuit missions (Zambezi), 246; (Madagascar), 247

London Missionary Society, 242, $247,248,284,334,430,433$

Moravian Protestant Mission, $242,248,249$

North African Mission, 252

North German (Bremen) Mission, 249

Norwegian Mission, 25I

Plymouth Brethren, 252

Primitive Methodist Society, 243

Rhenish Missionary Society, 249

Society for the Propagation of the Gospel, 243

Society of Friends' (Quaker) Mission, 247

Swedish Protestant Mission, 249

Swiss Calvinist Mission, 249

Swiss Protestant Mission, 248

United Presbyterian Mission, 250

Universities' Mission, 25 I, 277 , 327

Wesleyan Methodist Missionary Society, 242, 243

White Fathers of the Sudan Mission, 245; (in Uganda), 377,379

Zambezi Industrial Mission, 252 
Christianity, establishment of, $5 \circ$

Christianity (in Kongo Kingdom), $86,87,239,240$; among negro races in general, 240,449

Christians in North Africa, 62; Madagascar, Uganda, 378,379

Chudeau, R. (explorer), 339

Chumi River, ${ }_{25} 6$

Cinchona tree (Quinine), 96

Circassians, 19, 70, $7 \mathrm{I}$

Cis-Saharan Africa, I

Clapperton, Hugh, 193, 194, 310, 3 I I

Clarke, General, I 36

Clarke, John (missionary), 244

Clarke, Sir Marshall, 282

Clarkson, I 55

Claudius Ptolemaeus, 45, 299

Clozel, F. J., 334

Coco-nut palm, 92, 93, I Iо

Coelo-Syria, 55

Coffee and coffee cultivation, 75, 96, I 10, 270, 279

Coillard, Rev. Mr, 249, 325

Colonial Office, I87, 26I

Colonies, three classes of, in Africa, 443 et seq.

"Colony of the West African "Settlements," I 75

"Colony of Upper Senegal and Niger," . 209

Colorado, 293

Colston, Col., 326

Colvile, Sir H., 380

Comber, Rev. Thos., 244, 329

"Comité d'Etudes du Haut Congo," 343

Commerson, Philibert, 427

Comoro Islands, see Komoro

Compiègne, Marquis de, 324

Conference, Berlin, 189, 192, 219, 229, 231, 232

- Brussels, 232

Congo Christianity, 85 et seq., 239 ,

240

- Free State, I6I, I92, 23I, 278, 329,343 et seq.

- river and basin, 5, 6, 9, I I, I 5 , $16,20,25,74,78,80,85,87$ et seq., 160, 193, 228 et seq., 244,
$245,25 \mathrm{I}, 30 \mathrm{I}, 308,322,324$, $325,329,330,332,336,342$ et seq.

Congo Treaty of $1884,277,278$

- French, see French Congo

Congoland, 5, 10, 12, 15, 16, 26, $85,88,94$, I 24, I6I, I9I, 227 , 238 et seq., 316, $33^{8}$ et seq.

"Conquistadores," Portuguese, 77 , 90, 9 I

Constantine, 214, 216, 218

Constantinople, 5I, 69, 72, 21 2, 360

Constitution granted to Cape Colony, $25^{8}$

Conventions, see under title of nationality or place

Convicts sent to Cape, $26_{4}$

Cook, Captain, 304

Coomassie, see Kumasi

Copper, 96, I10, 273, 419.

Coppolani, French Commissioner, 209

Copra, I Io

Coptic Church, 253

- language, 70

Copts, 52, 53, 70, 367

Corisco Bay, 99, I 2 I, 234

Cornet, Dr, 330

Coromanti, I 24

Corsairs, see Pirates

Cortes, 153

Cortier, 338

Cosmoledo, 295

Cossack "Monks," 395

Costa Cardoso, Candido de, 307

Cotton, 270, 279, 4I9

Cotton, Lieut. P. H. G. Powell, 340

Covilhão, Pero de, 82 et seq., 300 , 424

Craig, General, I35, I36

Crampel, Paul, 230, 235, 333

Crimean War, 159, 219, 265, 266

Croats, 72

Cro-Magnon race, 4

Cromer, Lord, $36 \mathrm{r}, 364,368$

Cromwell, I 40

Cross, Dr, 328, 33I

- River, I83, 184, I87, 250, 313, 338 
Crowther, Samuel (Bishop), I88, 243

Cuanhama, see Kuanyama

Cuba, I 17, I 20, I 58 , I 59

Cunnington, Dr W. A., 340

Cybele, 39

Cyclades, 4 I

Cydames, 49

Cyprus, 33

Cyrene, Cyrenaïca, I6, 33, 40 et seq., 47, 53, 6 $\mathrm{I}, \mathrm{I} 6 \mathrm{I}, 236$ et Cyrus, 43

Dagomba-Moshi, I 80

Dahia-al-Kahina, Queen, 57, $5^{8}$

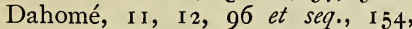
г6r, I76, г81, 182, 190, 205, 206, 208 et seq., 324

Daily Telegraph, the, 325

Dakar, 1 23, 198, 209, 2 10, 230, 234

Damara, 97, 4I7

Damaraland, $9,249,255,274,275$, $3 \mathrm{I} 7,405,4 \mathrm{I} 8$

Damascus, 60, 2 I 4

Dameirah, Cape, 397

Damerghu, 337

Damietta, 392

Danákil Coast, I 7, I 8, 84, 300, 393

Danes, see Denmark

Dar-al-Baida, 223

Dar-es-Salaam, 44, 4I 4

Darfur, I9, 54, 62, 70, 194, 3०3, $323,324,327,339,363,369$, 402,443

Dar Runga, 237, 324

Dar Sila, 237

Date-palms, 38, 4I

Dauphin, Fort, 425 et seq.

Davidson, John, 3 I $_{4}$

De Beaufort, 200, 309

De Beers Diamond-mining Company, 284

Debono, Andrea, 319

Decken, Baron von der, 331, 404

Décle, Lionel, 340

Delafosse, Maurice, 338

Delagoa Bay, 93, 105, I 10 et seq., I 32, I 34, I 49, 274, 28 I, 308

Delcommune, Alexandre, $33^{\circ}$
Delgado, Cape, I04, I10, II3, 409

Demerara, I37

De Mist, Commissioner-General, I $37,254,255$

Denham, Major D., I93, I95, 3 10

Denhardt brothers, 409

"Denis," King, 228

Denmark abolishes slave-trade, I 54, I 57; withdraws from Gold Coast, I 77

De Pass family, the, 146,273

Dernah, 42

Dernburg, Herr, 4 33

Dervishes, 22 7, 337, 36 3,395

De Séchelles, 295

Destenave, Col., 338

Dë tribe, $16_{4}$

Devonshire merchants, 169

Dey of Algiers, 2 I3

Dhanis, Baron, 330, 345, 346

Diamonds, Diamond Fields, I 42 , I 46, I66, 268, 269, 272 et seq., 34 I, 4I 9

Diaz de Novaes, Bartolomeu, 80, 8 I, 89, I 25

- Diniz, 79

- Diogo, 85

- Paulo, 89, 90

Dickens and "Mrs Jellyby," 3 I 3

Diego, Dom, 86

- Garcia, 295

- Suarez Bay, 429, 43I, 437

Dieppe adventurers, $78,80,196$ et seq.

Dikjeschop, I 24

Dinar Bu'l-Muhajr, 57

Dingane, 28r, 282

Dingiswayo, I 40, I 4I, 28 I

Dinizulu, 282

Dinka people, 370

Diogenes, 44, 45

Dixcove, I 24

Djur, R., 227

Dochard, Dr, 306

Dodds, General, 206

Dodo, the, I 23

Dog, the, 39, $9^{2}$

Domestic animals and plants of Africa, 92

Donaldson Smith, Dr, 335 
Dongola, 5, I $5,70,72,83,365$

Doornkop, 147

Doria, I 9

Dorians, 41

Doutté, Edmond, $33^{8}$

"Downing Street" doubts, drifts, and dallies, I 4 I, 275

Draa, River, 32, 36, 37;66, 299, 304

Dragut, I 8

Dravidian races, $27 \mathrm{I}$

"Drifts" question, 287

Drury, Lieut., 37 I

Dual Control, the, 361, 362

Duala, I $84,244,415$

Dubreka, R., 408

Duck, the domestic, 92

Duckworth, W. L. H., 5, 7

Dufton, H., 3I 7

Durban, I4I, 26I, 262, 272

D'Urban, Sir Benjamin, 259 et seq.

Dutch, the, 28, 77, 85, 93 et seq., I 23 et seq., I57, I58, I77, I78, $197,254,257$ et seq., 267 etc.

- half-castes, I 24

- language, 139, 258, 276, 448

Duveyrier, 321,322

Dwarf races, 43

Dybowski, M., 230, 333

Eannes, Gil, 78

Eannes, Gonçalvez, 300

East Africa, see British, German, etc.

East Africa, State of, II 5

East India Company, British, 85, I I I, 268, 374

- - Austrian, II I

- Dutch, I 25 et seq., 254, 306

- French, 426, 44I

East Indies, 9I, I I I

Eastern Province of Cape Colony, $265,267,273$

Ediya, I22

Edward VI, I69

Edward VII, 292

Egypt, I, 5, 7, 13 et seq., 18, 19, $21,22,24,33,37,42,43,45$, $47,49,5$ I et seq., $84,102,5_{2}$, $187,212,235,252,326,44^{2}$

Egyptian Government, 320
Egyptians, Ancient, I3, 16 et seq., $22,32,33,52,53$

- Modern, 446

Ekoi country, $33^{8}$

Elamites, 3

El Arwan, 309

Elephant, African, 35, 39, I10, 270

Elgon, Mt, 19, 331, 335, 385

Elise Carthage, Fort, I 24

Elizabeth, Queen, 169, I70

Elliott, Mr Scott, 334

Ellis, Mr (of Madagascar), 433, 434

Elmina, 80, I23, I24, I78, 196

Elphinstone, Admiral, 136

Elton, Captain Fred., 327

Embo, 270

Emden, 403

Emin Pasha, 315, 330, 332, 336, 344,363

England, English, see Britain, British

- and Portugal, 98, 108, II3, I 15,168

English language, I22, I65, I67, $244,258,448,449$

Eratosthenes 45, 298

Erhardt, 316

Eriksson, 327

Eritrea (Italy's Red Sea Colony), 227, 396, 397

Errik, 76

Ethiopia, Ethiopians, 2 I, 43, 46, 52,82 et seq., 226, 298, 372, 442

Euan-Smith, Sir Charles, 4 IO

Euesperides, 42

Eunuchs, Negro, I52, I 56, I 59

Euphrates, 32, 60

Eurasians, 294

European population of Cape Colony in 1770,132 ; in 1791 , 135 ; in 1806,255 ; in 1850,264 ; in 1891,291 ; in 1904,291

Eusebius, $4 \mathrm{I}$

Evatt, Col. J., 380

Evora, Pero d', 300

Exeter Hall, I 40

Explorers, Great, 297 et seq.

- fourteen greatest, list of, 3 I5

Fadl-Allah, 193 
Faidherbe, General, 200, 201, 221

Faleme, R., 209

Falkenstẹin, 322

False Bay, I 26, 135

Fang negroes, 122, 415

Fanti, I 24, I 76, I 78

Farewell and King, Lieuts., 26r

Farquhar, Sir Robert, 294, 429

Fas $(\mathrm{Fez}),{ }_{5}$

Fashoda, 204, 227, 336, 337, 365

Fatima, 60, 66, 69

Fatimites, 56, 60, 6r, 7 I

Fazogl, 3 I 9

Federation of South Africa, 142, I $43,147,280$

Felkin, Dr R. W., 328

Ferdinand I, 76

Ferdinand and Isabella, I 16

Ferguson, G. E., 333

Fernandez, João, 79, 300

Fernando Pô, Island, I I I, 122, I $83,184,243,244,324,333$

Fez, 59, 65, 67, 224

Fezzan (Phazania), I2, 15, 47, 56, $69,70,304,3$ го, $323,398,4$ ㅇ, 443

Figig, 47, 222

Fiji, 3

Filali dynasty, 66 et seq.

Fingo Kafirs, 267

Finland, 293

Fischer (explorer), 33I

Flacourt, Governor of Madagascar, 425

Flamand, G. B. M., 337

Flanders in Africa, I I I

Flatters, Col., 22 I

Flegel, Herr, 190, 333

Flemish Colonists, 90

- missionaries, $88,24^{\circ}$

Flinders, Matthew, 295

Florida, I 53

Fodi Kabba, I 72

Fodio, Othman Dan, I94, 201

Fodi Silah, I 72

Foreign Office, 405, 409

Forfeitt, Rev. W., 329

Fort Dauphin, 425 et seq.

Fort James, 170

Fort Salisbury, 285
Foucauld, Charles de, 336

Foule Point, 429, 43I

Foureau, Mons. F., 221, 222, 236 , 337

Fox-Bourne, Mr, 35 I

France, 4, 8, 50, 97, 106, 1 2 I, I32,

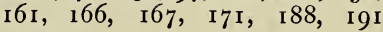
et seq.

- and Abyssinia, 395

Francis I, 2 I I

Franco-German war, 202, 215

François, Major von, 329

Frederic William I, 403

Freetown, 176

Fremantle, Admiral Sir E., 384

Fremona, 300

French, 28, 7I, 72, 104, 105, 109, I 8 , I 26, I 33, I 57, I $_{58}$, I96 et seq., 294, 423 et seq.

- Congo, 172, 192, 221,227 , 228, 23I, 233 et seq., 329, 336

- East India Company, 426

- Guinea, I0, 209

- language, 448,449

- missionaries, 88, 94, 207, 228, $240,278,377$ et seq.

- Nigeria, 20I

- Revolution and its effects on Dutch settlers in Cape Colony, I35

- - and Egypt, 212

- rule of Egypt, 19

- settlers in Dutch South Africa, I 29

- settlers in Algeria, 2 I6

- Somaliland, 227

- West Africa, total area of, 2 I I

- West India Company, 198

Frere, Sir Bartle, I 43, 280 et seq., 375,405

Frey, Col., 203

Frio, Cape, 99

Froude, Mr J. A., 280

Fūl people, I 2

Fula race and Empire, I3, I6, 49, $53,68,151,161,170,172,190$ et seq.

- speech, II, I 2

Fulde speech, I2

Funj Empire, 62, 72

Further India, 3 
Futa Toro, Futa Jallon, 20I et seq. "Fuzzie-wuzzies," I $7,5^{2}$

Gaboon, 36, 99, 1 72, 184, 205, 228 et seq., $25 \mathrm{I}, 324$

Gades, 32

Gafsa, 5०, 53

Gaghu, Gao, 68

Gaika clan, 266, 267

Galas, Galaland, 13, 16 et seq., 19, $2 \mathrm{I}, 22,45,5 \mathrm{I}, 15 \mathrm{I}, 16 \mathrm{I}, 245$, $249,334,335,338,339,386$

Galeka clan, 260, 266, 267

Galiber, Admiral, 437

Galicia, 76

Galley-Hill man, 2 et seq., I 7

Galliéni, Col., 202, 439

Gallwey, Sir H. L., 186

Galton, Mr Francis, 317

Gama, Christoforo da, 84

Gambetta, 189,362

Gambia, R., 12, 36, 79, 98, I 54, 169 et seq., 200, 201, 206, 229, $302,304,305,309$

Gamitto, Capt., 307

Gamtoos River, I3 I

Gao, 202

Garama, 47,48

Garamantes, 47, 54

Gardiner, Capt. Allen, 26r

Garstin, Sir W., 37 I

Gautier, E. F., 35, 337 et seq.

Gaza, I I 4

Gedge, Ernest, 335

Genoa, Genoese, 62, 78, 85, I53, 2 II, 390

Gentil, M. Emil., 230, 235, 334

Ger, R., 47

German Colonial Society, 405, 406, 410

- East Africa, 9, 10, 21, 44, 245, $249,252,291,335,336$

- East African Association, 410

- South Africa, 95

- South-West Africa, 7, 273, 276,336

- South-West Africa Company, 4I 7

- missionaries, 242, 275, 404, 405
Germany, Germans, 59, 71, 72, 77,

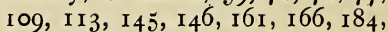
190 et seq., 2 I 6,223 et seq., $26_{5}$, $266,275,276,278,399,403$ et seq.

Gessi Pasha, 302, 326, 362

Getulians, 53

Ghadames, 49, 308, 323, 398

Ghana, I 4

Ghat, 37, 310, 32 I, 327, 398

Gibbons, Major A. St H., 339

Gibraltar, 2, 32, 33, 58, I46, I95

Ginger, 92

Gir, R., 47,49

Giraffe, the, I30, 306

Giraud, Lieut., 330

Gladstone, Mr, 282, 286, 393, 406, 437

Glenelg, Lord, 260, 261, 263

Glover, Sir John, I 78

Goa, 103, 104, 109, 27 I ; Goanese, 307

Goats, 75

Goetzen, Count, 334

Gold, I4, 24, 26, 79, 96, гоo, гог, I03, I 32, I45, I66, I80, I99, $283,34 \mathrm{I}$

- Coast, I I, I4, 79, 80, 98, I 24 , I 25, I 28, I 54, I69, I 75 et seq., I96, 205, 248, 325, 333, 403

Goldie, Sir George Taubman, 189, I 92, 208

Goldsmid, Sir Frederick, 344

Golea, 22 I

Goletta, 66, I 18, I I9, 2 I9

Gomba, 208

Gomez, Diego, 79

Gonçalo de Silveira, Ior, 24 $\mathbf{r}$

Gondar, 303

Gondokoro, 319, 320, 37 I

Gongo Lutete, 345

Gonsalvez, Antonio, 78

Gordon College, 370

- General, 326, 362, 363

- Capt. R. J., I 3 I, 306

Goree, 123 , I 98, 200, 305

Gorilla, the, 5, 6, I 7, 36 , I 21,228 , 324

Goro, 385

Gorst, Sir J., 367 
Gouraud, Col., 209

Gova, Francisco de, 87

Graaf Reinet, I3 I

- Van de, I3I

Graça, 3 I 6

Grahamstown, 256

Grain Coast, I64, I6 5,169

Granada, 65, 66, г г6

Grand Basa, 164

- Bassam, I 72, 205

- Canary, II 7

Grandidier, Dr A., 337, $44^{\circ}$

Grandy, Lieut., 322

Grant, Col. J. A., 315, 31 8 et seq. - Sir C., 260

Granville, Lord, 277, 405, 406, 436

"Granvilles," I 74

Gray, Major, 306

Great Britain, see Britain, England

- Fish River, 8I, I3I, I32, I34, I35, 255 et seq.

- Lakes region, I2

Greece, $4 \mathrm{I}$

Greek Church, 253

- language, 70

Greeks, I9, 4I, 42, 44, 46, 53, 57, 70 et seq.

Green (explorer), 3I 7

Greenville, ${ }^{1} 6_{4}$

Gregory, Dr J. W., 335

- the Patrician, ${ }_{5} 6$

Grenfell, Lord, 365

Grenfell, Rev. George, 229, 244, 3 I $5,325,329,333$

Grenna, $4^{2}$

Gretsyl, 403

Grey, Sir George, I4I, 142, 265, $267,280,293$

Grikwaland East, 263

- West, 269

Grikwas, Grikwaland, I42, I46, 269

Grogan, E., 340

Groot Fontein, 420

Grossfriedrichsburg, 403

Ground-nuts (Arachis), rog, г го, I 7 I

Guadalquivir, R., 32

Guanches, I I 7
Guano, 146, 273, 275, 420

Guardafui, Cape, 397

Guavas, 92

Guiana, I 24

Guinea, 79, 80, 86, 92, 94, 123, I24, I53, I97, 199

- Gulf of, $78,8 \mathrm{I}, 194$ et seq., 323,391

Gungunyama, I I 4

Gurara, 222

Gurley, Rev. Robert, I64

Habesh, 84

Hadhramaut, 73

Hafs dynasty of Tunis, 64 , I 18

Haiderān, 6r

Hajji 'Omaru, Al, 200 et seq.

Halawi tribe, 370

Halikarnassos, 42

Hall (Acting-Commissioner), $43^{\circ}$

Hamadi dynasty of Tunis, 64

Hamed bin Muhammad bin Juma, 344

Hamid bin Thwain, 382

Hamilton, Mr James, 3 I 7

Hamite race, 7 et seq., 18, 19, 21, $22,48,52,72,194,230,386$, 447

Hamitic languages, 10, $14,17,18$, 20, $21,46,70$

Hampden, Mt, 23

Hanlon, Bishop, 379

Hannibal, $3^{8}$

Haunington, Bishop, 378

Hanno's voyage, 35,36, I 73,298

Hanse towns (Hansburg), 314, 404

Haqsu, 22

Hardinge, Sir A., 383, 385

Haricot beans, 92

Harrar, 22, 227, 334, 372

Harris, Sir D., I 46,274

- Sir W. C., 307,3 I 7, 336

Harrison (explorer), 302

Hartzell, Bishop, $25_{2}$

Harun-al-Rashid, 59

Hassan-bin-Kassim, 67

Hassan-bin-Numan, 57, 58

Hastie, Mr, $43^{\circ}$

Hausa, the, Io, I3 et seq., I 78 , I79, I9I et seq., $42 \mathrm{I}$; land, 48 , 
70, 160, 193 et seq., 222, 306, 3 I 5 ; language, 448,449

Hawai, 3, 428

Hawkins, Sir John, I 53, I69, I73

Haywood, Capt. A. H., $33^{8}$

Hebrew language, 40

Hedjaz, the, 3 I 8

Hekataios, 43

Helena, St, Id. of, $85,92,99$, I 25 et seq., 267, 268, 282

Heliopolis, 60

Henderson, Lieut., 204

Henric of Besançon, 76, 77

Henrique, Cardinal, 88, 93

- Dom, 86

Henry the Navigator, Prince, $6_{5}$, 78,79, I 68

Heraclius, 53

Hercules, 39

- Straits of, 35

Herero, Ova-, the, 97, I 34,255 , $274,4 \mathrm{r} 6$ et seq.

Hernandez, I 53

Herodotos, 33, 34, 42, 49, 297, 298

Heuglin, Theodor von, 320

Hewett, Mr E. H., I84, 408

Hicks Pasha, $36_{3}, 36_{5}$

Hides, 146

High Commissioner of South Africa, I $48,269,280,284,288$

Hikushahu (Hyksos), 22

Hima, I 2, I6

Himyarites, 22, 73

Hinde, Capt. S. L., 330, 345, 349

Hintsa, Chief, 260

Hippo, 38

Hippo-Diarrhytos, 38

Hippon-Zaryt, $3^{8}$

Hippopotamus, 30, 49, го , I66, $39^{2}, 440$

Hispaniola, I 53

Hlubi, 273

Hobley, C. W., 335

Hodgson, Sir F. and Lady, I79

Hodister, 344

Hodister, A., 330

Hofmeyr, Mr J. H., 276

Höhnel, Lieut., 331, $3^{87}$

Holland, see Dutch; also 262
Holub, Dr, 330

Homo primigenius, 2

- sapiens, 2

Hooker, Sir Joseph, 324

Hop, Capt., 306

Hore, Capt., 334

Hornemann, Friedrich, $30_{4}$

Horse, the, 39, 48, 75, 92

"Horseshoe arch," 74

Hostains, M., 337

Hottentots, 7 et seq., 95, 126, 128, г30, I31, I34, I36, I39, I42, 232 , 24I, 242, 249, 255, 257 et seq., 29I, 4 I6 et seq.

Houghton, Major, 304

Hourst, Lieut., 208

Hovas, the, 27, 31, 247, 248, 428 et seq.

Huara, 53

Huguenots, I 29, 24I

Humt Suk, Ir9

Hunein, 66, I I 7

Hussein bin 'Ali, 2 I 8

Husseinite Beys of Tunis, 218

Hutter, F.. $33^{8}$

Hutton, Mr James, 409

Ibadite sect, 73

Iberia, 37,65

Iberian race, 76

Ibn Batuta, 299

Ibn Errik, 76

Ibn Haukal, 299

Ibn Tumert, 64

Ibn Yașin, 63

Ibo, Iо9, I I 0, I 85, I 87

Ibos, the, $3 \mathbf{I}_{2}$

Ibrahim, 360

Ibrahim-bin-Aghlab, 59

Ibrahim, Lake, 326

Idda, $\mathbf{1} 87$

Idris, 58

Idris II, 59

Idris or Edrisi (geographer), 299

Ifni, 120

Ifriqiah, 56,59

Ijō, 3I 2

Ikopa, R. (Madagascar), $43^{8}$

Ikshids, 7 I

Île de France, 294, 440 
Ilhas dos Idolos, 2 Io

Illórin, I 93

Ilo, 208

Imam of Maskat, 73, Iо4, 374, $3^{8}, 3,3^{8} 4$

Imbangola, 87

Imérina, 3I, 428, 429

Impoina, 429

India, 3, 4, 22, 24: 26, 28, 29, 44, $75,82,91$ et seq., I00, 101, I03, I $52,1_{56}, 1_{58}, 300$

Indian architecture, 74

- fig, 93

- Ocean, 12, 19, 28, 31, 102, I 26

Indians in Africa, 29, 105, 109, 447 ; in Natal, 27I, 272 ; Mauritius, 294

India-rubber, г го, 166, 279,348 , 350

Indo-China, 28

Indonesians, 28

Inhambane, 34, I I 4, I I 5

Innocent X, Pope, 392

Insalah, 222

Insuma, I 24

International Association for the Exploration and Civilization of Central Africa, 342, 343, 404

Inverarity, $\mathrm{Mr}, 429$

Ionian Islands, 4 I

Ireland, 4, 25

Irish, 72

Irish settlers, 257

Isandhlwana, 282

Isangila, 308

Ishak-bin-Sokya, 67, 68

Islam (Muhammadanism), 4, I 4, 25 , 30, 39, 56, 58, 63, 70 et seq., I I 7 , I $52,202,237,238,240,24$ I

Islands in Indian Ocean belonging to British, 295

Isle of Man, 293

Isleños, I I 7

Isles de Los, 408

Ismail, 2 I9, 36o, 36r, 4 or

Italian language, 216, 393, 448

- missionaries, 88, 94, 240, 24r, $39^{2}, 393$

Italians, Italy, $4,38,42,49,50,62$,
7 I, $72,74,78$, г 16, г6 г, I96, $216,219,238,245,390$ et seq.

Ivens, Roberto, 325

Ivory, 79, 110, 187, $270,274,279$, $34^{8}, 35^{\circ}$

- Coast, 203 et seq., 337

Jackfruit, 92

Jackson, Col. I.., $33^{8}$

- F. G., 380, $3^{8} 7$

- F. J. (Sir), 335

Jacobite Church, 52

Jacobs, Hon. Simeon, $1_{4} 6,274$

Jacquin, Capt., 205

Jafarabad, I 53

Jaga, Jagga, the, 87,88 , 30

Jaghbub, 236

Jaja, King, 185

Jamaica, I 54, I $_{5} 8$, I $_{74}$

James bros. (explorers), 334

Jameson, Dr (Sir Starr), I 47, I48, $285,286,289$

Janjira, I 53

Jannequin de Rochefort, I97, 198, 302

Janssen, Camille, 344

Janssens, Governor, I37, 254, 255

Japanese, 29I

Jauhar-al-Kaid, 6o, 7 r

Java, 27, 28, 31, 126, 427

Jazirat-al-Komr, 423

Jean René, $43^{\circ}$

Jenné, I 4, 202, 204, 206, 300

Jentinck's duiker, I 66

Jerba, Is. of, $39,41,56,66$, I 19 Jerma, 47

Jesuits, $\mathrm{S}_{4}, 88$, гог, 105, го6, 239,

$240,246,247,300,301,434,435$

Jewish Territorial Organization Committee, $3^{88}$

Jews, the, $3^{2}, 40,42,50,53,58,59$, $72,81,145,146,2 I_{5}, 217,218$, 273,274

Jibl-al-Tarik, 58

Jibuti, 227, 337

Jilolo, 3

Jinga, 87

Jinga Bandi, 93

Joal, 198

João I, Dom, 78 
João II, 81, 82

João, King of Portugal, 86

Jobson, Capt. Richard, I 70, 302

Johannesburg, 145, I 47, I 48, 294

John of Abyssinia, King, 394, 395

John of Gaunt, 78, 168

Johnson, Elijah, I64

Johnston, H. H., see Author

- Keith, 328

Johnstone, Commodore, I33

- Commander, 436, 437

Jok, 87

Jolofs, I 2

Jorāwa, 57

José, Amaro, 307

Joseph of Lamego, 81, 82

Jouffre, Col., 207

Jub, or Juba, River, 2 I , 383, 385 , $386,397,398$

Jubi, Cape, I 20, I 2 I

Judaism amongst Berbers, 58

Juder Basha, 68

Jühlke, Dr, 408

Julian, Count, 5 7 , 58

Julius Maternus, 48

Jully, M. A., 440

Junker, Dr William, 332

Kaarta, 200, 203, 204, 304, 309

Kabail, 2 I 5

Kabaka, the, of Buganda, 379, 38I

Kabara, 203, 206, 207

Kabarega, 380

Kabinda, 89, 97

Kafa, 2 I

Kaffa, 226

Kaffraria, 243, 260, 266, 267

Kafir Wars, I35, I36, 256,259 , $260,263,267$

Kafirs, I0, I30, I34, I35, 140, I4I, 255 et seq., $28 \mathrm{I}, 294$

Kafue, R., I 06,330

Kagera, R., 336, $34^{\circ}$

Kahina, Queen Dahia-al-, 57, 58

Kairwan, 57, 6o, 61, 65

Kalahari desert, $276,325,419$

Kamasi, $3^{80}$

Kambujiya, 43

Kamerun, see Cameroons

Kandt, Ir R., 340
Kanem, 48, 54, 194, 237, 238, 402, 443

Kanemi Sheikhs, I93, I94

Kankan, 2 Io

Kano, I87, 193, 194, 310, 31 I, 323

Kanuri people and language (Bornu), I5, I9I

Karamania, I 8

Karamanli dynasty, 310, 400

Karanga, I 34

Kareli, 260

Karema, 342

Karoo, 272

Kart-hadshat, 32

Kasai, R., 95, 97, 301, 329, 339

Kasalá, 365, 395

Kashgil, 363

Kasongo, 344, 345

Kasr-al-Kabīr (Morocco), 66 et seq., $77,78, \mathbf{1} 20$

Kasr-es-Said, treaty of, 220

Kasson, 302

Katanga, 96, 97, 272, 330, 332, 339, $346,357: 444$

Kathiawar, I 53

Kavala, 248

Kavirondo, I9, 387

Kayès, 2 Io

Kazembe, 105, 307

Keetmanshoop, 420

Kei, R., I34, I 35, 259, 260, 263, 267

Keiskamma, R., 256, 257, 259

Keith, Dr A., 5

- Lord, 429

Kenya, Mt, 316, 33I, 335

Kerckhoven, L. van, 330

Keren, 394

Kerne, 36, 37, 79

Kersten, Otto, 404

Ketama, 60

Khaireddin Barbarossa, I 18

Khalifs of Baghdad, 58, 59, 67 , 69 et seq.

Khariji, sect of Islam, 56, 59, 73

Khartum, 46, 319, 363, 364

Khedives of Egypt, 72, 360

Khmirs, 220

Khojas (Indians), 27 I

Kiezelbach, 320 
Kikuyu, $3^{8} 3,3^{85}$

Kilima-njaro, 44, 3 I6, 330, 33 I, 3.35, $376,404,409,4 \mathrm{ro}, 4^{\mathrm{I}} 4$

Kilimatinde, 4 I 4

Kilindini, 387

Kilwa (East Africa), 73, 83, 100, IO3, $4 \mathrm{I} 3$

Kimberley, 146, 268, 272, 273, 283

Kimberley, Lord, 275

Kimo, 29

King, W. Harding, 339

Kiokwe, Ba-, 87

Kipling, Rudyard, I7

Kir, 46

Kirby, Capt. Brandon, 333

Kirk, Sir John, 32 I, 374 et seq., 4 ro

Kisches, the, 274

Kisi, I 75

Kismayu, 386

Kitchener, Lord, 227, 288, 289, $337,3^{6} 5,3^{67}, 3^{6} 9$

Kivu, Lake, 334,340

Kleber, 2 I 2

Klobb, Lieut.-Col., 222

Knoblecher, Dr, 319

Koelle, Rev. Dr S. W., I 59, 243

Kollmann, Capt. Paul, 336

Komadugu, R., 3 I5

Komatipoort, I 49

Komoro Islands, 22, 27, 29, 30, 73, $4^{2} 3,427,428,437,44$ I

Konakri, 209,2 10

Kong, $2 \mathrm{O}_{4}$

Kongo, Kingdom of, 85 et seq., 228 , $39^{2}$

Konkan, I 53

Koran, the, 74

Kordofan, Io, II, I9, 54, 70, 237 $245,323,324$

Kormantyn, I 24 , I 76 , I 96

Kosoko, I8 I

Kosseir, 18

Kotonu, 2 ro

Krapf, Dr Ludwig, 242, 243, 316, $33 \mathrm{I}$

Krause, G. A., 333

Kroumirs, the, 220

$\mathrm{Kru},{ }^{6} 6_{5}$

Kruboys, I 51, I 74, 205

Kruger, President, 149, 286 et seq
Kuanyama, 97

Kubango, R., 420

Kufra, 237, 323

Kukawa, $3 \mathbf{5} 5$

Kulikoro, 210

Kulis, 27 I, 294

Kumasi, г76, г78, г 79

Kund, Lieut., $33^{2}$

Kunene, R., 95, 97, 330, 420, 444

Kurds, 7 I , 72

Kurene, 41, 42, 46, 298

Kuros, 53

Kuseila, the Berber prince, 57

Kushite type, 20, 2 I

Kwa, 348

Kwando, R., 420

Kwango, R., 87, 95, 301, 307, 325 , 329,339

Kwanza, R., 89 et seq.

Kwilu, 339

Kwo-ibo, 182

Laborde, M., 43I et seq.

La Calle, 2 I I

"La Case," 425

Lacerda e Almeida, Dr F. J. M. de, $105,106,307$

Lado, 346,370

Ladysmith, 288

Lagos, 99, I75, I 80 et seq., 205, $242,311,323,407$

Laing, Major, 308, 3 Iо

Laird, MacGregor, I88

Laka country, 234

La Mar Chica, 224

Lambert, Capt., 197

- M., 433, 434

Lamego, 8I

La Mine d'Or, 8o, I96

Lamta, Lemtuna, 63,68

Lamu, 26, 73, 83, 100, го г, 384

Lamy, Commandant, $221,222,236$

Lander, Richard and John, I88, 3II et seq.

Landor, A. Savage, 340

Langalibalele, 273

Lang's Nek, I 43

La Perrone, $33^{8}$

Last, J. T., 243

Latin, $5 \circ, 76$ 
Lavigerie, Cardinal, $245,246,377$

Lebanon, 33

Lebda, 37

Le Fébvre, Théophile, 3I 7

Leibnitz, 2 I 2

Lemon, the, 9I

Lemur, the, 427,440

Lemuria, 4, footnote

Lenfant, Capt. E., 338, 339

Lentils, 92

Lenz, Dr Oskar, 324, $33^{\circ}$

Leo Africanus, 299, 39I

Leo X, Pope, 39I

Leo XIII, Pope, 245

Leon, 76

Leon, Pedro, 84

Leonora, Queen of Portugal, 86

Leopold II, King, 192, 23 I, 233 , 342,346 et seq.

Leopold, Lake, 329

Léopoldville, 347

Leptis, 37, 53

Lescallier, Mons., 429

Lesseps, F. de, 36r

Le Vaillant, 309

Levant, 65

Levantine Italians, 392, 393

Libenge, 234

Liberia, 10, 36, 79, 93, 99, I 22, I 58, 163 et seq., 1 96,203 et seq., 250,25 I, 262, 298, 328, 337, 338, $44^{2}, 443$

Libreville, 228

Libyan Desert, 48, 54, 70, 75, 237, $303,323,338,339,402$

Libyan tongue, $2 \mathrm{I}, 53,54$

Libyans, I2, I3, I6, I8, 21, 22, 42, $48,49,53,54$

Likoma, Bishop of, 252

Lilienfelds, 146,274

Lime, the, $75,9 \mathrm{r}$

Limpopo, K., 7, 283, 307, 308

Linant, Adolphe, 3I9

Linant de Bellefonds, 326

Lingam, the, 24

Lipperts, I $_{4} 6$

Lisbon, $77,83,84,86,90$, Іог, 109, 168

Lithgow, William, 30I

Little Dieppe, 196
Little Paris, I 96

Liverpool, I 57, 23I

"Liverpool of West Africa," I 8 I

Livingstone, Dr, 95, 106 et seg., 160, 246, 250, 25 I, 276 et seq., $315,317,321,322,325$

Lixus, R. (the R. Draa), 32, 36

Loanda, São Paulo de, 90,93

Loango, 94, 228, 230 et seq., 30 , 322,336

Lobengula, 283 et seq.

Lobito Bay, 96, 97, 339

Lobo, Jeronimo, 84, 300, $30 \mathrm{r}$

Loesche, Pechuel, 322

Loge, R., 89

Logone, 14

Logwek, Mount, 3 I9

Lokoja, s 88

Lom, R., 332

Lomami, R., 97, 329, 345

Lome, 421,422

London Convention, I44, I45

- Company of Adventurers, I69, 301,302

"Long juju," I 87

Lonsdale, Capt. R. L., 333

Lopes, Duarte, 88, 92, 93

Lorraine frontier, 235

Los, Isles de, 210

Lothaire, Major, 347,378

Lotos, Lotos Eaters, 38, 4I, 56

Louis Napoleon, see Napoleon

- IX (Saint) of France, 65

- XIV of France, I29, 211,226 , 359,425

- Philippe, 205, 228

Louisiana, 216

Lourenço Marquez, I05, I 10 et seq., I 49

Lovedale, 250

"Lower Guinea," 228

Luabo, I02

Lualaba, 322, 325, 330, 345

Luangwa, R., I08, 334

Luapula, R., 105, 322, 334

Luata, 53

Lucas, Sir Charles, I25

Ludamar, 304

Luderitz Bay, 4I9

Luderitzhafen, 420 
Liuderitz, Herr, 406

Lugard, General Sir Frederick, I $93,208,285,378$

Lugh, $39^{8}$

Lukkus, R., 77

Lukolela, 234

Luluabourg, 346

Lulongo, R., 329

Lunda, 87,94 , 105

Lupton Bey, 326

Lurio, R., ro9, 1 10

Lusambo, 345

Lusitania, 77

Lydzaamheid, $\mathbf{1} 32$

Lyon, Capt. G., 310

Lyons Missionaries, 244, 245

Maba, 16r, 237

Macarthy, Sir Charles, 177

Macdonald, Col. Sir J. R. L., 335, $38 \mathrm{I}$

Macdonald, Sir Claude, 186

Macedonia, Macedonians, s9, 37, 43

Macgregor Laird, James, 3i 3

Macguire, Corporal, 3I5

Mackenzie, Bishop, 25 I

- Sir G., 377

Mackinder, H., 335

Mackinnon, Sir Wm., 375

Maclean, Charles, I 77

Macmahon, Marshal: his Delagoa Bay award, III, II2, 274

Madagascar, 4, 22, 24, 26 et seq., $44,5 \mathrm{I}, 73,74,82,84,85,93$, I00, 104, I09, I26, I 28, 225 , 235, 247, 248, 25 I, 294 el seq., $308,337,423$ et seq.

Madan, Mr, 252

Madeira, 85, 9I, I 16

Mad Mullah, the, 372, 373

Mafeking, 286

Magdishu, 83, 100, 398

Mage, Lieut. E., 20I

Magwangwara, 4I3

Magyar, Ladislas, 3 I 6

Mahdi (Sudan), 237, 245, 327, 363 et seq.; Mahdis frequently arising in Islam, $60,63,64$

Mahdia, 60

Mahé, 295
Maherero, Samuel, $4 \mathrm{I} 7,4 \mathrm{r} 8$

Mahmud Basha, 68

Mahrab (Sacred Shrine), 39, 55, 74

Maistre, Lieut. C., 230, 334

Maize, 91, 92, 279

Majerda, R., 32, 33, 38

Majorca, Majorcans, 62, 78

Majuba Hill, I 43

Makana, 256

Makhzen, 224

Makka, 54

Makololo, the, 108

Makoma, 259

Makua, the, I03, I05, II4, I32

Malacca, 9r

Malachite, 1 ro

Malagasy people, 27, 29, 30, 294, $295,425,428$ et seq.

Malata, 426

Malay Peninsula, 3

- races, 27 et seq., 255, 258, 259, $291,427,428$

Malaysia, $3,28,128,428$

Maldiv archipelago, 28, 29, 428

"Malik," 7I

Malindi, 26, 82, 83, 100, 300, 383, $3^{8} 4$

Malta, 40,62

- Knights of, 66, 69

Maltese, 40, I I 9,2 I6, 319, 448

Mamluks, 59, 71, 72, 212, 360

Mañanja, Io6

Mañbettu， I 2， I6, 326

Mandara, 194, 195,376

Mandingoes, Io, I3, I4, 5I, I5I, 161, 170, 172, 203 et seq.

Manenguba, 4I 5

Manika, I00, I0I, I05

Manioc, 91, 92

Mannesmann, firm of, 224

Manoel, King, 424

Manputo, 92

Mantumba, Lake, 329

Manutia-Alphil, 423

Manyema, 160, 322, 345, 346

Maples (Archdeacon, then Bishop), Chauncey, 252, 327

Marabut, Marabitin (Almoravides), $62,63,68$

Maravi, Lake, 276, 307 
Marchand, Capt. J. B., 204, 227 , $336,337,365$

Mare, Uso di, 79

Maria Theresa, I I I

Marie of Madagascar, St, 426, 430, $43 \mathrm{I}$

Marinel, Georges le, $33^{\circ}$

- Paul le, $33^{\circ}$

Marinus of Tyre, 45, 47, 299

Marka, 398

Marks, Senator S., I 46

Marno, 326

Maroons, I 74

Marrakesh, 67

Marseilles, 4I, I Io, I 72

Martin V, Pope, 79

Martyn, Lieut., 306

Maryland, I64, I65

Mary, Queen, I69

Masai, 2 I, 33 I, 381, $3^{8} 5$

Masawa, 83, 84, 226, зот, 3о3, 394

Mascarene archipelago, 28, 84, I23, $27 \mathrm{I}, 296,44^{\circ}$

Mascarenhas, 84 , I 23

Mashonaland, 26, I г3, 247, 285, 327

Masina, 202, 203, 309

Maskara, $2 \mathrm{I}_{4}$

Maskat, 73,83 , 104, I6o, 374,383 , 384

- Arabs, 73

Masmuda, 64

Mason Bey, 320, 326

Massaia, Monsignor, 245

Massalit Arabs, 237

Massari, Lieut. A. M., 323

Massowah, see Masawa

Masudi, 299

Matadi, 347

Matebele, -land, 26, г13, 160, 267, 276,285

Matmata country, 38

Matopo hills, 285

Matteucci, Dr, 323

Matthews, Major G. E., $37 \mathrm{I}$

Mauch, Karl, 283, 327

Maud, Capt. P., 339

Mauretania, 5, 16, 32, 35, 39, 43, $46,57,6 \mathrm{r}, 72,209$

Mauritius, 28, 3I, 85, I23, I26,
I27, I32, 27I, 294 et seq., 318, $429,440,44 \mathrm{I}$

Mauro, Fra, 423

Mayo, Earl of, $33^{\circ}$

Mayotta, 432, 437

Mazagan, 78

Mazrui Arabs, $3^{8} 3,3^{84}$

Mbam, R., 332

Mbomu, 230, 235, 327, 346

McClear, Sir Thomas, 317

McMurdo, Col. E., I 49

McQueen, James, and the Niger, 3 I 2

Mecca, 54, 55, 63, 67, 82, 202, 236

Mechow, Major von, 329

Medina, 54, 67, 82, I 72, 201, 202

Medina-Coeli, Duke de, I I 9

Mediterranean colonization of Africa, 32 et seq.

- man, 22

- Sea, 79, 9г г г 8, г46, г95, 299

Mehdia, 6o, 390

Mehedia, I I 8

Meilleraye, Duc de la, 425

Melanesians, 3 $\mathrm{I}$

Melilla, 66, 67, I 17, I I9, I20, 224

Melland, Frank, 339, 34०

Mello, Duarte de, 83 , roo

Memphis, 60

Mendelssohns, I46, 274

Mendi, I 74, I 75

Menelik, Emperor, 395, 396

Meninx (Jerba), 38,56

Menoutheseas, 423

Menouthias, 44,423

Merina, ${ }_{428}$

Meroe (Merawi), 46, $5 \mathrm{I}$

Mesopotamia, 17, 69, 70, 74

Mesurado, Cape, $16_{4}$

Mexico, ז39, I 53

Meyer, Dr Hans, 335

Mfumbiro, 334

Miani, Giovanni, $3 \mathbf{1 9}$

Middle men of W. African trade, 185

Mikindani, 300

Milk (Moloch), 38

Millet, M. René, 220

Milner, Sir Alfred (Viscount), 288, 289

Minaean kingdom, 22

Missionaries, Christian, 5r, 88, 
I08; (attitude towards Cape Dutch), I 39, r 40, 257 ; summingup of their characteristics, 253

Missions, Christian, 239 et seq.; see Christian

Mizon, Lieut., I90, I9I

Mnyamwezi, 346

Moçambique, 8, 26, 29, 73, 82, 83, 94, 99, 100, I02 et seq., I23, I 28 , I $32,258,327,338$

- Co., I I 4

Moffat, Rev. R., 307

Mogods, 2

Mohade, Al-, see Muāhadim

Mohair, I 46

"Mohocks," the, 198

Mohr, Edward, 327

Moir, John and Frederick, 284

Mojanga, 429, 436, 438

Mokha, 44

Mollien, Gaspard, 200, 309

Mombasa, 24, 26, 73, 83, 100, 102, $10_{4}, 242,300,316,33 \mathrm{I}, 335$, $3^{6} 3,374,3^{84}, 3^{87}$

Monastir, I I 7 , I I 9

Monclaros (the Jesuit priest), Ior, IO2

Mongalla, 330

Mongase, IO2

Mongoloids, 4, I7

Mongols, 7 I

Monomotapa, 23, roo et seq., 24 I

Monophysite Church, $5 \mathbf{2}$

Monouthis, 423

Monrovia, 164,404

Monteil, Col. P. L., 204, 333

Monteiro, Joachim Monteiro, Major, 307

Moore, J. E., 334

Moorish conquests in Nigeria, I 4

Moors, geographical enterprise of the, 300

Moravians, 242

Moravide, see Marabut

Mordokhai Abi-Serūr, 35, 3 I 6

Morel, E. D., 234, 355, 356

Morenga, 4 I 8

Moret, 338

Morgen (explorer), Lieut., 332

Morland, Colonel T. L. N., I93
Morocco (Mauretania), 5, I 2, 16, 32 et seq., 47, 49, 50, 53, 56 et seq., 77, I 6 , I I9 et seq., I.52, I 59, 169, I76, 195, 197, 200, 208, $214,216,217,223$ et seq., 252, $253,299,323,336,442,444$

- Spanish possessions in, I 2 I, I 22,442

Moselekatse, see Umsilikazi

Mosely, Prof. A., ${ }_{14} 6$

Moselys, 274

Mosenthals, the, 146,274

Mosi, Io, 325

Mosi-Gurunsi speech, I 2

Moslems, 59, 202

Mossamedes, 9, 94, 95

Mossel Bay, 8I

Mostaganem, 236

Mosto, Ca' da, 79

Motawakkil, 69

Mount, Cape, $\mathrm{I} 64$

Mountains of the Moon, 45

Mouzinho de Albuquerque, I I 4

Mpongwe, 228

Mpozo, R., 80

Msambiji, I00

Msidi, $34^{6}$

Msilikazi, I 43

Mtesa, King, 377

Muāhadim (Almohade), 64

Mubangi, 6, I0, I 5, 229, 230, 234 et seq., 244, 326, 329, 336, 338, 4 I 5

Mubarak, $3^{8} 4,3^{8} 5$

Mubuku, 334

Mueller, Dr Hans, 329

Muhammad Ahmad, $3^{6} 3$

Muhammad - al - Amin - al - Kanemi, I93, 194

Muhammad Ali, 72, I95, 245, 319, $359,360,392,400$

Muhammad-al-Mahdi, 66

Muhammadan colonization, 74

Muhammadanism, see Islam

Muhammadans, $55,56,6_{3}, 65,67$, 240,252

Muhammad bin Abdallah, 372, 373

Muhammad-bin-Ali, 236

Muhammad Granye, 84

Muhammad ibn Abd-al-Wahhab, 73

Muhammad Sharif, 236 
Muhammad (the Praiser), 54 et seq., $59,60,66$

Muhibidi, Ioo

Mu'izz-li-din-Allah, 6o, 7I

Mulai Abd-al-Malek, 66

Mulai Hafid, 223, 224

Mulai Ismail of Morocco, 68

Mulattoes, I63 et seq.

Muluba, Io

Muluya, R., I19, I20, 223

Muni, R., I 2 I

Munyamwezi, 10

Munzinger, 320

Murie, Dr, 320

Murray, Mungo, 317

Murzuk, 49, 323

Musa, 93

Musa-bin-Nusseir, 58

Musambiki, ı००

Musgu speech, I 4

Musha Island, 372

Musk duck, 92

Muza, 44

Mwanga, King, 378 et seq.

Mwata Yanvo, 94, 316, 322, 327

Mwene-mutapa, 10r

Mweru, Lake, 105, 278, 307, 322, 327,334

Mzab Berbers, 53,56

Nabataean kingdom, 52

Naber, Capt., 338

Nachtigal, Dr, 184, 315, 323, 324, 407,408

Naivasha, Lake, 33I

Namakwaland, I 28, 243, 255, 275, $276,306,404,405$

Namuli, 1 Iо

Nana, I 86

Nantes, Edict of, I 29

Napata, 46

Napier, General, 262

Naples, Neapolitans, 62, 65, 2 13, 214,390

Napoleon the Great, 99, I57, 2 I2, 268,349

- III, 205, 214, 215, 217, 218, $36 \mathrm{I}, 433$

Napoleonic wars, I37, I63, I 7 I, $200,228,3 \mathrm{I} 4,44 \mathrm{I}$
Nassau, Fort, 124

Natal, 82, 1 40 et seg., 261, 262, 269, 270, 273, 281 et seq., 404

- Bay of, 128

National African Company, I89

"Native Question," the, 293

Nature, her pranks, 256

Naukratis, 42

Navarre, I 6

Neanderthal species, 2

Necho, Pharaoh, 33

Nefusa, 53, 56

Negrito tribes, 3

Negro, the, characteristics of, I $_{5}$, I52, 27I; warning to, I62; Christian, 239, 240; Muhammadan, 240 ; future of, $446 \mathrm{et} \mathrm{seq.}$

Negroes, 2 et seq., 18, 29, 45, 48, $5 \mathrm{I}, 68,74,80$, I 22, I 24, I 51 et seq., 230, 255, 258, 259, 29I

Negroid races (Nubians, Fulas, Mandingoes, etc.), I3 et seq., 22, $48,5 \mathrm{I}, 54,230,446$

Nejd, 73

Nelson, I I 7,2 I 2

Nepoko, R., 332

Nero, 46, 298

Netherlands Railway, 287

Neumann, O., 339

Neumann, Sir S., 146

Neumanns, 274

New, Mr Chas., 33I

New Caledonia, 3, 205

- Guinea, 3, 75

- Mexico, I53

- Zealand, 3, 205, 293

New York Herald, 322, 325

Ngami, Lake, 274, 307, 3I 7

Ngaundéré, 333

Nguru, 409

Nicholas I, Tsar, 360

Niéger, $33^{8}$

Niger, Convention with France, 182 , 190

- Coast Protectorate, I86, I87, 189

- Company, Royal, I87, I89 et seq., 208, 23I, 232

- R., 8, 1 I et seq., I9, 20, 43, 47 et seq., 62, 63, 67, 68, 70 , 
74,79, I 59, I 72, I 82, I 84, I 87 et seq., 299, 304, 305, 308, 3 I I et seq.

Niger Delta, 79, 99, I 54, I 82, I 83 , I 85, I $87,242,33$ I

Nigeria, Iо, I 2 et seq., 43, 63, 67, 75, I 52, I 6 ,, I 7 , I79, I84, I 85 , I $94,227,250,339,443$

Nikki, 208

Niku II, Pharaoh, 33, 34, 42, 297

Nile, the, 5, I I, I 7 et seq., 2 I, 22, 33,42 et seq., 60 et seq., 84 , $227,230,245,298$ et seq., 318 et seq.

Nilotic speech-group, ro, 2 I

Nogal, 398

Normans, 62, 78, 8o, 85, I96 et seq.

North African Mission, 252

Northcott, Col. H. P., 333

" Northern Nigeria," I92, I93

Northern Rhodesia, 278, 279, 29I, 292, 33I

Norway, 293

Nosi Komba, 432

- Mitsiu, 432

Nosi-bé, 432 , $43^{6}$

Nova Scotia, I74

Nubia, Nubians, 5, I5, I7 et seq., $5^{2}, 70,72,74,298,303,326$

Numidia, 46,47

Nun, Cape, I 20

Nunez, R., 200

Nupe, Io, I 2, I6 I, I9 I et seq., 304, $3 \mathrm{I}, 323$

Nyam-nyam, I 2, I6, 319, 326, 370

Nyangwe, 322, 345

Nyanza, Albert, 45, 318, 320, 326, 332

- Edward, 332, 334

- Victoria, 9, ro, I2, 19, 20, 44, $45,281,318,325,326,331,335$, $336,340,377$

Nyasa, Lake, 9, го9, г6o, I6 I, $248,249,25 \mathrm{I}, 252,276$ et seq., $300,307,321,322,327,328$, $334,33^{8}$

Nyasaland, 8, 26, 89, го7, I Iо, I I 4, I I 5, I 59, 247, 250 et seq., 279, 29I, 292, 327, 33I, 444

- German, 249
"Nyassa," Chartered Company of, I09, 110

Nyoro, 320

Nzadi, 86

Oak tree in Cape Colony, I29

Obbia, 398

Obeid-Allah, 60

Obok, 226, 372, 394

Oceania, 3, 27

Ochiali, I 9

Oea, 53

Ogadein Somaliland, 372, 386

Ogowé, R., 79, 8o, 228, 233, 324, $33^{\circ}$

Ohrwalder, Father, 245

Oil Islands, 295

"Oil Rivers," I82 et seq., 312

Okabango.Teoge, R., 3 I 7

Okapi, the, $34 \mathrm{I}$

Old Calabar, 99, I82 et seq., 2 50, 3 I 3

Oldfield, Dr, $3 \mathbf{I} 3$

Olifants River, I 31

Olive oil, I Io

Ollone, Capt. d', 337

Omaiyad dynasties, 56,59

'Oman, 73, 74, 83, 160, 374, 384

Omar, 59

'Omaru bin Saidi, 202

Om Dubreikat, 369

Omdurman, 193, 337; victory of, $227,3^{6} 5$

Omo, R., 334

Omuramba, 3 I 7

On, 6o

Ondonga, 97

O'Neill, Lieut. H. E., 327

Onions, 92

Opobo, R., I85, I89

Oqba-bin-Nafa (the Prophet's barber), 56,57

Oran, 66, I I 7 et seq., 2 I4, 2 I 6 et seq., 230

Orange Free State, I 40 et seq., $25^{8}$, $264,268,269,271,280,281$, 286, 288, 29 I, 292, 443

- Prince of, I35, I37, 254

- River, 9, I3I, I32, I40, I42, I 45, 206, 256,26 I et seq., 268 , $274,306,307$ 
Orange tree, $75,85,91,92,390$

Orangia, I 46

Ormuz, Is., 83

Osheba country, 234

Osman Digna, 360

Ostrich, Ostrich farming, 43, 255, $265,268,274$

Oswell, Mr W., 317

Otavi, $4 \mathrm{I} 9,420$

Oudjda, 223

Oudney, Dr, 3 Io

"Outlanders" (Uitlanders), I 47 , I 48,288

Ovambo," Ovamboland, 97, 274, 317,418

Overweg, Dr, 314, 3I 5

Owen, Admiral W. F. W., זо6, III, I I 2, 308, 374

- Major Roddy, 380

Ozi, R., $3^{84}$

Paarl, 272

Pacific Ocean, I 53

Padrone, Cape, 8I

Paez, Pedro, 84, 300, 30 I

Paiva, Alfonso de, 82

Pakenham, Mr, 436

Palestine, $7 \mathrm{I}$

Palgrave, Mr W. C., 275

Pallier, Lient., 222

Palm, see Coco-nut, Date-palms

- oil, I82, I83

Palmas, Cape, 79, 99, I64

Palmerston, Lord, I65

Panama, I 53

Panda, 282

Panet, M., $32 \mathrm{I}$

Pangani, 44

Papaws, 9I, 92

"Paradise, grains of," I69

Park, Mungo, I $72,188,203,304$ et seq.

Parkinson, J., 338

Parkyns, Mansfield, $3 \mathbf{I} 7$

Passarge, Herr, 332, $33^{6}$

Patex, 39

Paterson, Lieut. W., 306

Paul V, Pope, 94, 39I

Peacock, the, in N. Africa, 39

Peake, Major M., $37 \mathrm{I}$
Peddie, Major, 306

Peebles and Mungo Park, 305

Pemba, Is., $44,100,377,3^{82}, 3^{8} 3$, 423

Peñon, I 7 , I 18

Pepper, 169

Pereira, 307

Perim, Is., 226, 372

Péringuey, Dr, 7

Periplus of the Red Sea, 44, 45

Persia, -n Empire, I, 3, 4, 22, 29, $37,4 \mathrm{I}, 43,45,52,53,55,72$, I 52, I 59

Persian influence on Zanzibar coast, 73,74

- Gulf, 32, 73, 81, 83, 100, 103, 104, I 58

Persians, 19, 22, 35

Peru, I53

Peters, Dr, 378, 408, 409

Petherick, John, 319, 362

Petrie, Prof. W. Flinders, I 7, 34, 296, 297

Pfeiffer, Mme Ida, 433

Pfeil, Count, 408

Phallic worship, 24, 39, 74

Phazania, 49, 54

Phenbalon, 423

Philae, 298

Philip, Dr, 260

- II of Spain and Portugal, 88, 93

Philippa, 78

Philippine archipelago, 3

Phillips, J. R., massacre of, I 86 - Sir L., I46, 274

Phoenicia, Phoenicians, 22, 24, 25, 30, 32 et seq., 55, 83, I46, 297

Pierre, Admiral, 436,437

Pietermaritzburg, 272

Pig (domestic), 39, 92

Pigafetta, Filippo, 88, 39 I

Pine-apple, 9I, 92

Piquet, Victor, 37

Pirates (Dutch), I०3

- (Madagascar), 426

- (Moorish), 77, II9, 2 I I

- (Turkish), 69, гг8, гा9

Pisa, Pisans, 62, 390

Pisania, 304,305 
Pitt, organises second expedition to take Cape Colony, r 37

Pius IX, Pope, 245

Plantain, the, 93

Plettenberg's Beacon, 255

Pliny, 45, 298, 209, 303

Pococke, Dr Richard, $3 \circ 3$

Pogge, Dr, 327

Poivre, Mons., 427

Pokquesoe, I 24

Poles, 72

Polignac, Prince de, 43 I

Polo, Marco, 424

Polybius, 49, 298

Polynesians, 28, 3 I

Pombal, Marquez de, 247

Pomel, Prof. A., 35

Pompeii, $4^{8}$

Pondoland, 263,267

Port Elizabeth, 273

- Herald, ir 5

- Natal, 261

- Nolloth, 273

Portal, Sir Gerald, 378, 394

Portendik, I7I, I98, 200

Porto Novo, I 72, I 82, 205, 206

- Praya, I 33

- Rico, гі $7,{ }^{8} 8$

- Silva, 316

Portudal, I 98

Portugal, $65,67,76$ et seq., 106, I I 5, I $_{57}$, I $_{5} 8$, I 69 et seq.

— and Dahomé, 96

- and England, I68

- and Germany, 410

Portuguese, $23,26,28,65$ et seq., 73,75 et seq., I16, 168 et seq., I8I, 182, 196 et seq., 239 et seq., $274,277,278,300$ et seq.

- East Africa, 100, 105 et seq., $241,277,327$

- Guinea, 98, 201, 209, 309, 330

- language, $76,448,449$

- missionaries, 90, 94, 240, $24 \mathrm{I}$, 300,301

- West Africa, 95, ro8

Portulano, the Laurentian, 39I

Potagos, P., 327

Potato, the, 91 , 92

Potsy, Andrian, 425
Poultry, 75

Praça de São Sebastião, 100

Prehistoric race movements, I et seq.

Presbyterian missionaries, 242

Prester John, $8_{3}, 24 \mathrm{I}$

Preston, Rev. Mr, $25 \mathrm{I}$

Pretoria, I48, I49, 288, 292

Prime Minister of Madagascar, 438 , 439

Primitive Methodist missionaries, I 22, 243

Prince Henry of Portugal, see Henry

Prince Imperial of France, 282

Prince's Fort, I 24

- Is. (Principe), 86, 91, 92, 96

Pringle, Capt., 335

Pronis, first French Governor of Madagascar, 425

Prostitutes sent to Sierra Leone, I 74

Protectionist policy in French Colonies, 23I, 439.

Protestant Missions in Africa, 24I, $247,248,252,253$

Proto-Semitic speech, I7

Prussian Company of Emden, 403

Psammetik I, Pharaoh, 42, 297

Ptolemaios Soter, 43

Ptolemies, 19, 42, 43, 298

Ptolemy the Geographer, 45, 47, 299, 423

Pungwe, R., I I 3

Punic, 5o, see Phoenicians

Purdy-Bey (Col.), 326

Putumayo, 35I

Pygmies of the Congo, 7, 9, 232

Quambalon, 423

Queens of Madagascar, 43I et seq.

Quelimane, 73, 82, 83, I00, IOI, I06 et seq., 318

Quraish tribe, 54

Rabah Zobeir, 193, 235, 236

Rabai, 242

Rabba, 3I3

Rabbat Amma, 39

Rabinowitz family, 146, 274 
Rabodo (Rasohérina), Queen, 434

Radama I, King, 429 et seq.

- II, King, 433, 434

Railways, 96, 97, II 2, II4, II 5 , I 49, I 75, I 79, I 80, I 87, I 94,203 , $210,217,2$ 19, 22 1, 227, 238, 272 , $279,286,387,4 \mathrm{I} 4,415,420,422$

- in Cape Colony, 272

- in Congo Free State, 347,358

- Cape to Cairo, 340

Rainilaiarivóny, Prime Minister, 435

Rakoto, Prince, 432, 433

Ranavalona, Queen, 247, 43I, 434

- II, Queen, 435

-. III, Queen, 437

Rand, the, 290

Rapaports, the, $\mathrm{r}_{4} 6,274$

Ras Alula, 394

Ras Benās, 18

Ras Kasar, 394

Rashüf, 39

Ravenala, the, 427

Ravenstein, Mr E. G., 80

Rawson, Admiral Sir H., 186

Reade, Winwood, see Winwood Reade

Rebmann, Rev. Johann, 242, 243, $316,33 \mathrm{I}$

Recollets friars, 94

Red Sea, the, 4, I6 et seq., 21, 22, $43,44,52,70,82$ et seq., 100, 102, 226, 227, 299, 394

Reichardt, Dr (explorer), 3II, 3I 7

- (missionary), 243

Reichenbach, Dr S. von, 336

Reitz, Lieut., 374

Reitz, Mr, 276

René, Jean, $43^{\circ}$

Rennell Rodd agreement, 372

Réunion (Bourbon), 28, 31, 84, $\mathrm{I}_{2} 3$, I $27,295,296,43 \circ, 440,44 \mathrm{I}$

Révoil, M., 334

Rhapta, 44

Rhaptum, 44

Rhinoceroses, $4^{8}$

Rhodes, Right Hon. Cecil J., I47, I $48,279,283$ et seq.

Rhodesia, 23 et seq., I00, 107, II4, I $46,23 \mathrm{I}, 270,27 \mathrm{I}, 278,279,285$, 29r, 33०, 339
Ribat (on the Niger), $6_{3}$

Rice, 75, 92

Richardson, James, 195; 3I4, 3I 5

Richelieu, Cardinal, 425

Riebeek, Jan van, 125

Riff country (N. Morocco), I 20 , $223,224,226$

Rio de Janeiro, 3or

Rio d'Ouro (Rio de Oro), 36, 78 , $79,121,196,209,300,321$

Rio del Rey, 184, 191

Rio Muni, 234

Rio Pedro, 205

Ripon Falls, 3 I 8

Ritchie, Mr, 3 ro

"Rivières du Sud," 201

Robert of Sicily, Count, 299

Roberts, Joseph Jenkins, I65

- Lord, 288

Robertsport, I $6_{4}$

Robinson, Sir H., 284, 288

Rochefort, Claude Jannequin de, I97, 198, 302

Rochelle, Vacher de, 425,426

Rodriguez, 28, 1 23, 295

Rohlfs, Gerhard, 315, 323

Rokel, R., I 73, 308

Roman Catholic Missions, 94, 228, $240,24 \mathrm{I}, 244,247,253,319,377$, $378,434,439$

Roman Empire, 40, 43, 45, 47, 62, 299

Romans, the, I9, 37, 40, 45 et seq., 57, 298, 391

Rome, 42, 43, 50, I52, 39I

Ronga, I34

Roosevelt, Theodore, $34^{\circ}$

Rosetta, 42, 360

Rosmead, Lord, 288

Roumas, the, 202

Rowlands, John, see Stanley

Royal African Company, 176

- Geographical Society, 244, 318, $322,328,331,376$

- Senegal Company, 198

- Umbrella, 60

Ruad, 32

Rubault, M., 309

Rudolf, Lake, ro, 2I, 5I, 33 I, 335, $338,339,385$ 
Rufiji, R., 4 I 2

Rufisque, I98

Rufu, R., 44, 383

Ruki, R., 329

Rukwa, Lake, 328, 33 I

Rūm, 72

Ruma, Rumi, 68

Rupert, Prince of Madagascar, 425

Rüppell, Dr E., 3 I 7

Ruspoli (Explorer), 334

Russia, I 32, 364

- German, 326

Russia's action in Abyssinia, 253, 395,396

Ruvuma, R., I00, I09, I I3, 300, 3 I6, 322, $327,375,4$ ro, 4 I I, $4 \mathrm{I} 3$

Ruwenzori, Mt, 45, 320, 331, 332, 334,340

Saadian dynasty, 66, 67

Sabaeans, 22, 83, I 34, I $_{4} 6$

Sabi, R., 23, I I4, I1 5

Sacred Shrine, 39, 55

Saffi, 78

Sagres, 78

Sahara desert, 8, I3 et seq., 20, 25, $33,36,37,47$ et seq., $62,63,68$, $70,74,75,78, \mathbf{1} 21$, 160, 192, 1 94, 2 I 7, 22 I, 222, $238,299,300$, 3I 4,320 et seq.

Sahati, 394

Saho, 2 I

Said bin Muhammad, 360

Saida, 32, 37

Saint Augustine (Florida), $\mathrm{r}_{53}$

Saint George's Bay Company, 173

Saint Helena, Is., see Helena, St

Saint Laurence, Is., 85

Saint Louis, 196 et seq., 32 I

Saint Mary, Is., I 70

Sakalava, the, 3 I, 428, 432, 435

Saker, Rev. Edward, 244

Salagá, 325, 42 I

Salah-ad-din Yusaf bin Ayub (Saladin), 7 I

Saldanha Bay, г26, г 36

Salisbury, 23

Salisbury, Lord, 394

Salt, I4
Salt, Henry, 308

Samori, I6I, 203 et seq.

Sanagá, R., 332

Sand River Convention, I41, I42, 263

Sandawi, 9, 336

Sandile war, 263

Sanga, R., I9I, 234, 338, 4 I 5

Sanhaga (Sanhaja), 53, 54, 60

Sankuru, R., 329, 339, 345

San Pedro, R., $16_{5}$

Sansanding, 305

Sansanne Mangu, 42 I

Santo Domingo, 167

Santorin, 4 I

São João d'Ajudá, 97

São Jorge da Mina, 8o

São Lourenço, 424

São Miguel, 90, 94

São Paulo de Loanda, 90,93 el seq. , I 23, 325

São Salvador, $86,89,94,322$

São Thomé, 81, 86, 91, 92, 96, 97

São Vicente, 99

Saracenic architecture, 74

Saracens, 390

Sardinia, 25, 50, 62, 390

Sarepta, 32

Sarras, 365

Savage, Dr, 228

Saxons, 50

Say (on the Niger), I90, 208, 3 I 5

Sayyid Sa'id, 242

Schaudt, G., 324

Schenk, Dr A., 336

Schnitz, H., 336

Schnitzer, E., 363

Schön, Rev. J. F., 243

Schweinfürth, Dr, 230, 31 5, 326

Scotch, Scotsmen, г38, г 39, 257 ; similarity with Dutch, 138 ; in

Nyasaland, 279

Scott (draughtsman), 305

Scott-Elliott, Mr, 334

Sealskin industry, 146

Sebastião, Dom (King of Portugal), $66,68,77,87$ et seq.

- São, Fort of, at Moçambique, 100

Sebu, 35 
Secondee, $\mathbf{I}_{2} 4$

Sego (Niger), 20 I et seq., 305, 306

Seidel, N., 336

Sekondi, I 79, 180

Selim, Sultan, I 8

Selous, Mr F. C., 330

Semitic colonization, 16, I9, 20

- languages, 20 et seq.

- race, 22, I 34, 230

Semliki, R., 320, $33^{2}$

Sena (Zambezi), 73,83, Iо1, 102, I04, 106, 107, I I 5,308

Senegal, R., Iо, I 2, $36,49,54,62$, 75, 79, 99, г 59, I 7 г, 196 et seq., 304

- Colony, r 2, г 7o, г88, г98, 206, 209, $210,221,227,235,302$

Senegalese, 10, 207, 227, 237

Senegambia, io et seq. $63,68,70$, 83,98, 169, г70, 172, 190, г94, $200,20 \mathrm{I}, 245,300,32 \mathrm{I}, 445$

Sennār, 62, 70, 72, 2 1 2, 245, 303

Senussi or Sanusi, 236,401

- II, 236, 237

- III, 237

Septa, 57, 77

Septimus Flaccus, 47,48

Serandab, 423

Serbs, 72

Serpa Pinto, Colonel, I08, 325

Sesamum, I Io

Sesheke, 317

Seychelles Islands, 28, 29, 295, 428, 429

Sfax, I I 8, I I 9

Sharifian dynasty of Morocco, 66 et seq., 77

Shari, R., I I et seq., I9I, 230, 234, 235, 237, 310, 324, 338

Sharp, Granville, I 54, I 74

Sharpe, Sir Alfred, 278, 285, 334

"Shatts," the, 38

Shaw, Dr, 303

- Mr (Madagascar), 436, 437

Shawia, the, 223, 224

Shea-butter, r8o

Sheep, 39, 75, 255, 274, 419

Shela Mountains, 95

Shepherd kings, 22

Shepstone, Sir T., I 43, 28I
Sherboro, R., 36

Sherbro, $\mathbf{I}_{5}$

Shia faith, $56,59,60,7$ I

Shiré Highlands, I08, I I4, $25 \mathrm{I}$, 277 et seq., 327

- River, Іо6, І08, I Iо, I I4, 277 et seq., 300, $32 \mathrm{I}$

Shirwa, Lake, 334

Shoa, 242, 245, 307, 317, 329, 337, 395

Sibree, Rev. J., 337

Sicily, Sicilians, $38,4 \mathrm{I}, 60,62,65$, $74,299,390$

Sidi Ferruj, 2г3, 230

Sidi Mubarak, 384

Sidon, 32, 33, 37

Sierra Leone, I I, 36, 79, 93, 98, 99 , І 22 , I 54, I 58, I $_{59}, 1_{6}$, I $_{4}$, 167 , 172 et seq., 200, 201, 203, 242, 304, 308

Sierra Leone Company, I 73

Sigilmessa, Sijilmassa, 59, 67

Sikhs, I6r, 279, 380

Silva Americano, 96

Silveira, Gonçalo de, IoI, 2+. I

Simon's Bay, 263, 264

- Town, I 36

Sims, Dr, 25 I

Sinai Peninsula, 366

Sinô, I $\hat{6}_{4}$

Sintra, Pedro de, 79

Siwah, 18, 53, 70, 236, 317

Sixtus V, Pope, 39I

Slagter's Nek, 258, 26r

Slatin Pasha, 327

Slave Trade, 4, 80, 94, 96, 97, 103, I04, 107, I 2 I, I 22, I 24, I 5 I et seq.

- Abolition of, I07, I55, I57 et seq., 238, 258, 259, 432

Slavery, 80, 95, I6 I

Slaves (Christian), 24 I

- (Negro), I 28, I 53, I 73, 228, 259

Slavs, 59, 70 et seq.

Sleeping sickness, 382

Smeathman, Dr Henry, I 73

Smith, Sir Harry, 259, 263

Smythies, Bishop, 327

Sneeubergen, I $3^{2}$ 
Sobat, R., 227, 298, 337 et seq.

Sofala, 23, 26, 34, 73, 82, 83, 99 et seq., I 34, 299, 300, 424

"Sofas," 204

Sokoto, r9o et seq., 222, 306, 3 10, 3 II, 3 I 5

Sokotra, Is., 44, 83, 372, 393

Sokya (Askia) dynasty in Sudan, 67,68

Soleillet, Paul, 32 I

Solomon Islands, 3

Solomons, 274

Solum, 400

Somalía Italiana, 398

Somaliland, Somalis, 4, 7, I5, I7, I $8,22,44,70,72,73,75,82,84$, 99, I 5 I, 226, 227, 300, 318, 334, 335,337 et seq.

Somerset, Lord Charles, 256, $25^{8}$, 26I

- East, 259

Sommervill (Dutch Commissioner), 307

Somrai, 324

Songhai, I3, I4, 49, 5I, 79, I9I, 209

Sonnerat, 427

Sonnini, 303

Sonyo, 85

Sor, 32

Sousa Coutinho, Thomé de, ro3

"South African Republic," I44, I 48, I 49, 283, 288, 443

South African War (1899-1902), 286, 288, 29I, 388

South American states abolish slave-trade, I 57

Southern Nigeria, Protectorate of, I $85 \mathrm{et}$ seq.

Southern Rhodesia, 285, 286, 292

Spain, Spaniards, 4, 8, 32, 34, 38, $39,4 \mathrm{I}, 57$ et seq., $65,72,74,76$, 93 , 1 1 6 et seq., 146, I 52, I 53, I69, I 83,2 I 6,225

- in Africa, I I6 et seq., 241

Spanish, I 22, 2 I6, 449

- Guinea, I 2 I

- missionaries, I22, 24 I

Speke, Capt. J. H., 3I5, 3I 8 et seq., 334
Spice Islands, 75 :

Spices, West African, I68

St Augustine's Bay, 425, 43 I

St Marie de Madagascar, 426, 430, $43 \mathrm{I}$

St Vincent, Bory de, 429

Stadhouder (also see Prince of Orange), г 30, г 36,306

Stairs, Capt., 332,346

Stanley, H. M., 87, 9r, 229, 248, 3 г 5,3 19, 322, 325, 326, 328, 329, 332,342 et seq.

Stanley Pool, 85, 9 r, 229, 23 I, 347

Stapleton, Rev. W. H., 244, 329

Steere, Bishop, 25I, 252, 327

Stephanie, Lake, 33 I

Stettin, von, 332

Steudner, Dr, 320

Stevenson, Mr Jas., 284

Stewart, Rev. Dr James, 250

Stibbs, Capt. Bartholomew, I 7 r, 302

Stockenstrom, Sir Andries, 260

Stokes, Chas., 347, 378

Storms, Capt. E., 342, 344, $35^{2}$

Stover, Rev. W. M., 25 I

Strabo, 298

"Strandlooper" skulls, 3, 7

Stuhlmann, Dr Franz, 336

Suakin, $21,82,323,328,364,365$

Sudan, 20, 37, 48, $51,54,67,68$, 74, I 52, I6I, I87, 190, I93, 194, $226,230,235,237,238,245,320$, 326,362 et seq.

Sudanese language-families, ro

Sudd, 46, 298, 320, 37 I

Suē, R., 336

Suetonius Paulinus, 47, 49

Suevi, 76

Suez, r6

- Canal, 268, 36г, $3^{62}$

- Gulf of, I8, 33

Suffetula (Sbeitla), 56

Suffren, Admiral, I 33

Sufis, 204

Sugar, Sugar-cane, the, 75, 91, 92, I I o, I 46, 270,27 I

Sü'id bin Ali, 382

Sumatra, 3, 27, 28, 3 r, I 24, 1 78 , 295, 304 
Sunda Islands, 427

Sunday River, 256

Sunni faith, 56, 59, $7 \mathrm{I}$

Sūs country (South of Morocco), 35, $57,224,225$

Susa (Tunis), II 7 , I I9

Susu, I 74, 242

Swahili (people and language), Io, 3o, IOI, 4IO, 4II, 448, 449

Swakopmund, 420

Swann, Alfred, 16I

Swayne, Col., 335

Swazi dialect, I34

Swazis, Swaziland, 143, I45, I49, 270,292

Sweden, Swedes, I57, I77

Sweet potato, the, 91, 92

Swiss missionaries, 96

- settlers in Algeria, 2 I6

Syria, Syrians, I, 4, 22, 24, 32, 37, $39,40,52,55,69$ et seq., 2 I 2 , 29I

Syrian Desert, 32

Tabarka, 390

Table Bay, I25, I26, I37

Tafilalt, $59,67,336$

Tagus, R., 76

Tahiti, 205

Tajurra, 227

Takorari, I 24

Takrana, 403

Takrur, 202

Talbot, P. A., 338

Tamatave, 296, 429 et seq.

Tammuz, 39

Tamul race, $27 \mathrm{I}$

Tana, R., 2I, 335, 384, 386, 409, 4 IO

Tanánarivo, 433, 434, 438, 439

Tanga, 4I 4

Tanganyika, Lake, 9, I34, 160, 245 , $248,278,279,28 \mathrm{I}, 284,29 \mathrm{I}, 3 \mathrm{I} 8$, $322,324,325,327,328,33 \circ, 334$, $336,340,344,404,4$ I I

Tangier, $5 \mathrm{I}, 53,66,67,7 \mathrm{I}, 75,78$, I $20,195,223,226,238$

Tangiers, 58

Tangis, 53

Tanit, 38
Tapioca, 92

Tappenbeck, Lieut., $33^{2}$

Tarifa, $5^{8}$

Tarik, 58

Tasmania, 3

Tasmanian aborigines, 2 et seq.

Taufik, Khedive, $36 \mathrm{I}$

Taveita, I 56, 376

Tawareq (Tamasheq), ז5, 54, 63, $67,68,205,207,221,222,232$, $309,32 \mathrm{I}, 322$

Tea, 270

Tebessa, 50, 53, 216

Teda, I3, I5, 54

Teleki, Count Samuel, 331, 387

Tel-el-Kebir, 362

Tembe, I I I

Tenda, I 70,302

Tenduf, $3{ }^{\mathrm{I}} 4$

Tenerife, I I 7

Teniahir, Lagoon of, $3^{6}$

Ternan, Col. T., 380

Ternate, 75

Tete, IOI, IO3, II 5, 24I, 247, 307

Tetwan, 66, 119

Teutonic type, 22, 76, 77

Teuxeira, 42

Thala, 53

Thames, R., 48

Theion Oxema, I 73

Thera, $4 \mathrm{I}$

Thibaut, 3 I9

Thira, $4 \mathrm{I}$

Thomé, São ('Thomas, St), (Is.), see São Thomé

Thompson, Capt. George, I 70, 302

Thomson, Joseph, I9o, 315,328 , $33 \mathrm{I}, 336,375,376,387$

Thonner, Franz, 339

Three-points, Cape, I 24

Thurston, Major A. B., 380

Thys, Col., 347

Tiaret, 59

Tibesti, I5, 19, 323, 338

Tibu country, Tibus, I3, I5, 47, $54,209,222,232,237$

Tidiani, $20 \mathrm{I}$

Tidikelt, 222

Tieba, $20_{4}$

Tigré, $245,395,396$ 


\section{Index}

Tilho, Capt., $33^{8}$

Timbo, 203

Timbuktu, ${ }_{3}, 67,68,78,79, \mathbf{1} 6$, 186, 200, 202 et seq., 300, 303 , $304,308,309,315$

Timgad, 53

Timne, II, I74, I75

Timor, 3

Tingis, $5 \mathrm{I}$

Tinne, Alexandrine, 320, 321, 324

"Tippoo-Tib," Tipu-Tipu, 344

Tlemsan, $57,64,65$, I 18,236

Tobacco, 27, 91 , 92, I 54, 279

Togoland, I 2, 248, 333, 336, 408 , $42 \mathrm{I}, 422$

Tokar hills, 369

Tomato, the, 92

Tonga, I 34

Toole, Mr, 3 Io

Torday, Emil, 339

Toro, $38 \mathrm{I}$

Torobe, 202

Toski, 365

Totem, 10 I

Toucouleurs, 202

Toutée, Commandant Georges, 333

Tozer, Bishop, $25 \mathrm{I}$

Transcontinental Telegraph, 279

Transkei, 267

Transsaharan Railway, 194, 22 I

Transvaal, 95, II 2, I 40, I42 et seq., $263,269,27 \mathrm{r}, 274,276$, 280 et seq., 307

Trinkomali, 133

Tripoli, 5, I 2, 33, 37 et seq., 47, 49 et seq., 61, 62, 64, 66, 69, г60, I6r, 187, 194, 195, 204, 2 16, 218, 238, 252, 308, 310, 314, $322,393,443$

Tripolis, 53

Tripolitaine, 15, 53, 54, $39^{8}$ et seq.

Tristam, Nuno, 78

Tristan d'Acunha Is., 99, 268; see Acunha, Tristan d'

Troglodytes, 36

Trotha, General von, 4I 7, 4I8

Truster (Dutch Commissioner), 306

Tsetse fly, 26, 102, 382

Tsumeb, 419, 420
Tsur, 32

Tuaregs, 13, 14 37,37

Tuāt, 222,337

Tuburi, 338

Tuckey, Capt., 308

Tugela, R., 263

Tulbagh, Governor, I30, 306

Tulunid dynasty, $7 \mathrm{r}$

Tungi Bay, Ir3

Tunis, Tunisia, 2, 24, 32, 33, 35, $37,39,46,47,49$ et seq., 6 г, 62 , 64 et seq., I 18, I19, 160, 2 I 6 et seq., 245, 252, 301, 390, 392, 393,444

Turkana, Io

Turkey, Turks, 19, 65, 69 et seq., 84 , I02, Іо3, I 8 , I 19, I 52 , เ 59 , I6o, I95, 2 I2, 2I $8,238,300$, 30 I, 366,398 et seq.

Tusūn, 360

Twat, $41,68,308,323$

Tyre, Tyrians, 32,33

Ubbo, 38

Uda, 44

Uechtritz, Herr, $33^{2}$

Uganda, 20, 235, 245, 246, 248 $326,328,33 \mathrm{I}, 334,335,363$, $377,387,444$

Ujda, 223

Ujiji, 322

Ukami, 409

Ulysses, 4 I

Umba, $383,386,4$ IO, 4II

Umhlakazi, 266

Umsilikazi, 283

Union of S. Africa, 292, 293, 443

United States of America, 96, I 24 , I54, I 57 et seq., $16_{3}, 167,240$, 262,443

Unknown River, the, 325

Unyamwezi, 9

Unyoro, 335

Urban VIII, Pope, 392

Uruj, I I 8

Usagara, 409

Usambara, 333, 4I4

Uso di Mare, 79

Utica, 32, 33

Uzeguha, 409 
Vaal River, I4I, I42, 26I, 306

Vacher de Rochelle, 425, 426

Vai language, 93

Va-kioko, 3 이

Vandals, 50, 5I, 40 I

Vandalusia, 50

Vandeleur, Col., 335

Van der Stel, Commander, 306

Van Diemen's Land, 264

Vangèle, Capt., 329, $33^{\circ}$

Vardon, Major, 308

Vasco da Gama, 82, 99, 100

Velez de la Gomera, II 9

Venice, Venetians, 62, 102, I68, 319, 390, 391

Verde, Cape, 36, 79, 99, 197, 201

- Islands, 79, 92

Vereeniging, 149, $29 \mathrm{I}$

Vermuyden, 302

Verneaux, Dr, 4

Verner, S. P., 329

Victoria (Ambas Bay), 4 I 5

- Falls, 247, 279; - Nyanza, see Nyanza

- Queen, r65, 280

- (territory), 262

Vienna, Congress of, I 57

Vincent, M., the explorer, $32 \mathrm{r}$

Vine, the, 39, 127

Virginia, I 54

Virunga, Mt (Volcano), 334

Vischer, Hanns, 339

Vitu, 384, 409, 4IO

Vogel, Dr, 315, 324

Volta, R., 70, 177, 179, 204, 325, 333

Volubilis, 59

Von Lindequist, 4I 8

Voulet, Capt., 22 1, 222, 236

Vredenburg, I 24

"Vryheid" (New Republic), 282, 283

Wadai, 62, 70, 159, 161, 236 et seq., $315,323,324,33^{8}, 339$, 420,443

Wad-al-Makhazen, 66

Wad-an-Nejumi, 365

Wadelai, 380

Wadi Halfa boundary, 364,369 , 37 I
Wahehe, 4I2, 4I3

Wahhabis, 73

Waima, 203

Wales, 4

Walfish Bay, 275, 291, 292, 307,

317,405

Wanga, 4 10

Wa-ngoni, 412, 413

Wa-nyamwezi, 160, 357, 412

Wargla, 22 I

Wargli, the, 54

Warren, Sir Charles, 145,283

Warsheikh, 398

Waswahili, 412

Waterberg mountains, 4I 7,418

Waterboer, 269

Wax, I Io

Wa-yao, I6o

Weatherley, Mr Poulett, 334

Webi Shebeili River, 334, 397

Wele, R., 230, 235, 244, 326, 327 , 329,346

Wele-Mubangi, $\mathbf{2} 2$

Wellby, Capt. M. S., 339

Welsh, 257, 319

Wends, 72

Werne, Ferdinand, 319

Werner, J. R., $33^{\circ}$

West African Settlements, 175, r 80 - India Company, Dutch, I24, 125

- Indies, I 24, I 53, I 54, I 58, I69, I $73,227,240$

Whale oil industry, 146

Wheat, $75,92,127,132$

"White Fathers," the, 207, 245, $246,342,377,379$

Whitehouse, Commander B., $34^{\circ}$

White peoples, 162

White, Sir Geo., 288

Whyda (Dahomé), I 76

Whyte, A., 340

Wibsen, Fort, I 24

Wilberforce, Wm., I $55,{ }_{74}$

Wilhelm II, Emperor, 225

Willcocks, Col. (Sir) James, I 79

- Sir W., 368

William IV of England, 432

Willoughby, Digby, 437

"Willyfoss Niggers," I 74 
Wilson, G., $3^{80}$

- Rev. C. T., 328

- Rev. J. L., $25 \mathrm{I}$

Windhoek, 420

Wingate Sir R., 369

Winton, Sir Francis de, I 75, 344

Winwood Reade, 324

Wissmann, Major H. von, I6 I, 329, $333,404,4$ I I

Witbooi, Hendrik, 416, 4 I 8

Witu, see Vitu

Witwatersrand, 145

Woelfel, Lieutenant, 205

Woermann, House of, 404

Wolf, Dr Ludwig, 329

Wolofs, I 2, I3, I5I

Wolseley (Sir Garnet, afterwards Viscount), $178,273,362,364$

Wood, Sir Richard, 2 I 9

Wool, I46, 255, 265, 268

Wuli, I72, 201

Wyoming, 293

Xengibar, 424

Ximenez, Cardinal, ı 18

Xosa-Kafirs, I 34, 257, 259, 26o, $263,266,267$

Yakub bin Killis, $7 \mathbf{I}$

Yaman, 43, 44, 73, 74

Yanbu, 67

Yao, Wa-, the, 247,252

Yathrib, 54

Yellala Falls, 8o, 308

Yellow peoples, 162

Yendi, 42 I

Yolofs, 43I

Yonnis, the, 175

Yoruba, Yoruba-land, I3, I 79, 3 I I

Young, Lieut. Edward, 277

Yussuf-bin-Tashfin, $6_{3}$
Zaire, 86

Zambezi, R., 5, 8, 23, 73, 74, 82, 83,91 , 100 et seq., I32, I34, I43 et seq., I $54,1_{59}, 240,24 \mathrm{I}, 246$, $247,249,250,252,272,274$, $276,278,279,300,307,308$, $3^{\mathrm{I}} 7,3 \mathrm{I} 8,325,444$

Zambezia, 9, г 2, I 7, 26, 92, гог, I05, 109, 24I, $276,279,300$, $32 \mathrm{I}, 33 \mathrm{I}$

Zanzibar, 22, 29, 30, 44, 73, 83, Ioo, I03, I04, II3, I 52, I 59, I6o, 242, 25I, 252, 279, 299, 308, 322, 327, 328, 374 et seq., 404,410 et seq., 423

Zebra antelope, 166

Zeila, 82, 300, 372

Zenaga, 54

Zeneta, 53, 54

Zeringhi, Federigo, 392

Zeyanite kings of Tlemsan, 64

Zimba, Ba- or $\mathrm{Va-}, 23,24,29,103$

Zimbabwe, 23 et seq., 29, 39, $5 \mathrm{r}$, $134,146,327$

Zimmermann, O., 338, 339

Zinder, 222, 337

Zintgraft, Dr, $33^{2}$

Ziri dynasty (N. Africa), 64

Zizyphus, $4 \mathrm{I}$

Zobeir Pasha, r93

Zoroastrian faiths, $\mathbf{5 5}$

Zulu dialect, I 34, 448

Zulus, Zululand, Zulu-Kafir race, Iо, 24, 97, 103, I I 4, I 28, I 34 , I40, 14 I, I 43, I 45, I49, I 5 I, $25 \mathrm{I}, 256,26 \mathrm{I}, 263,270,279$, 28 r et seq., 308

Zumbo, 105, I08, I I 5, 240, 247

Zuurveld, 256

Zwartebergen Mountains, I 3 r 



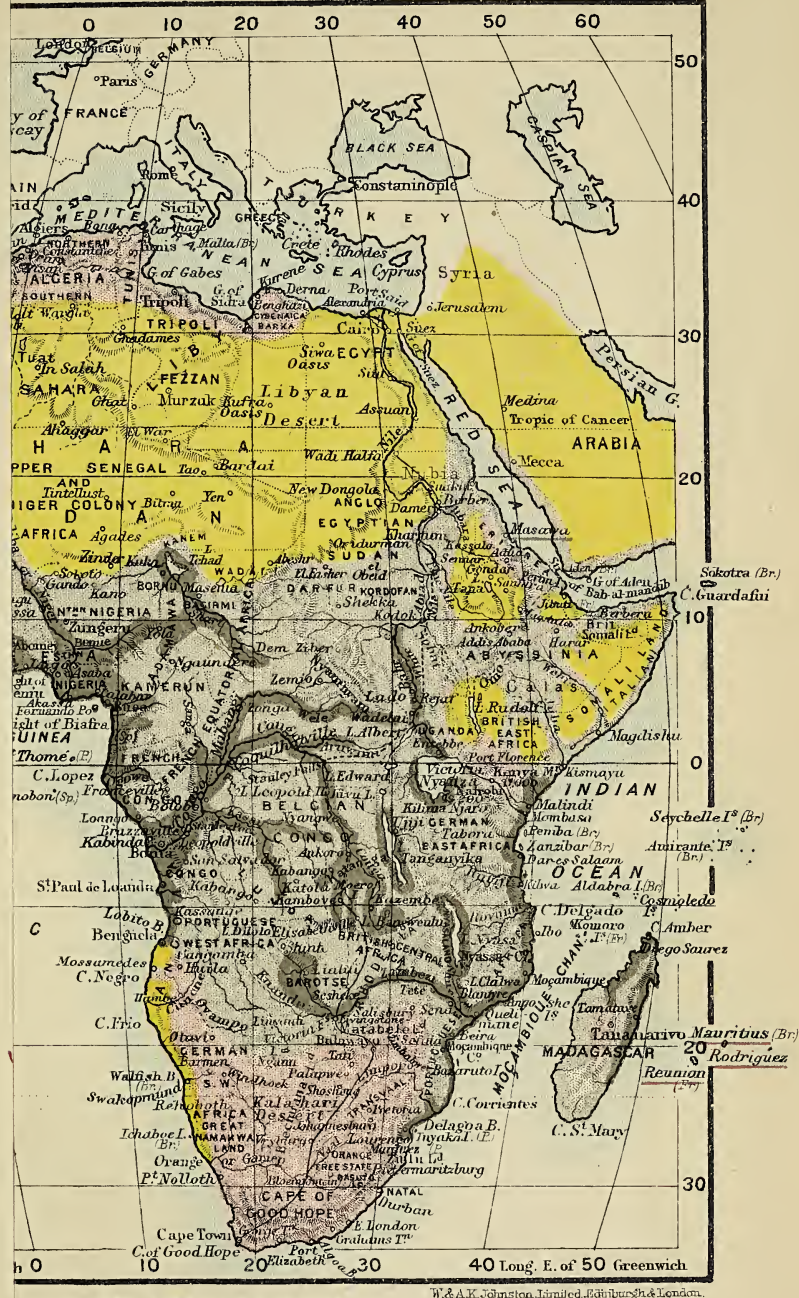

EXPLANATORY NOTE

a, where European races may be expected to become in time the prevailing. y European states may be formed but where unfavourable conditions of soil or water supply, or the prior like or enlightened native races or other causes, may effectually prevent $n$

'e Africa; impossible for European colonization, but for the most part of lue and inhabited by fairly docile, governable races; the Africa of the zd of European control and supervision 

COLONIZABLE AFRICA

Plate VII.

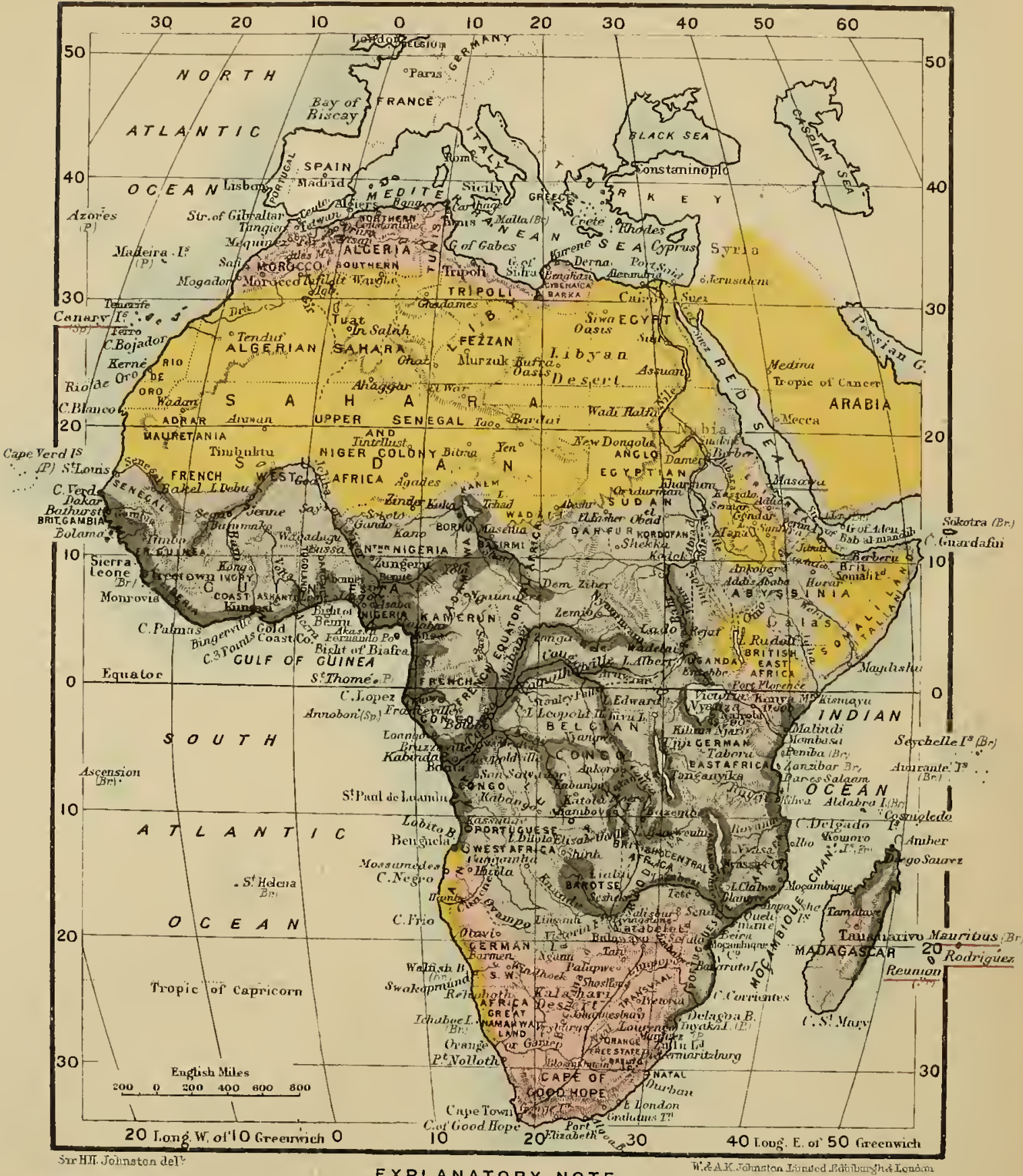

EXPLANATORY NOTE

Healthy colonizable Africa, where European races may be expected to become in time the prevailing type, where essentially European states may be formed

Fairly healthy Africa; but where unfavourable conditions of soil or water supply, or the prior establishment of warlike or enlightened native races or other causes, may effictually prevent

Unhealthy but exploitable Africa; impossible for European colonization, lut for the most part of great commercial value and inhabited by fairly docile, governable races; the Africa of the trader and planter and of Europian control and supervision

Very unhealthy Africa 



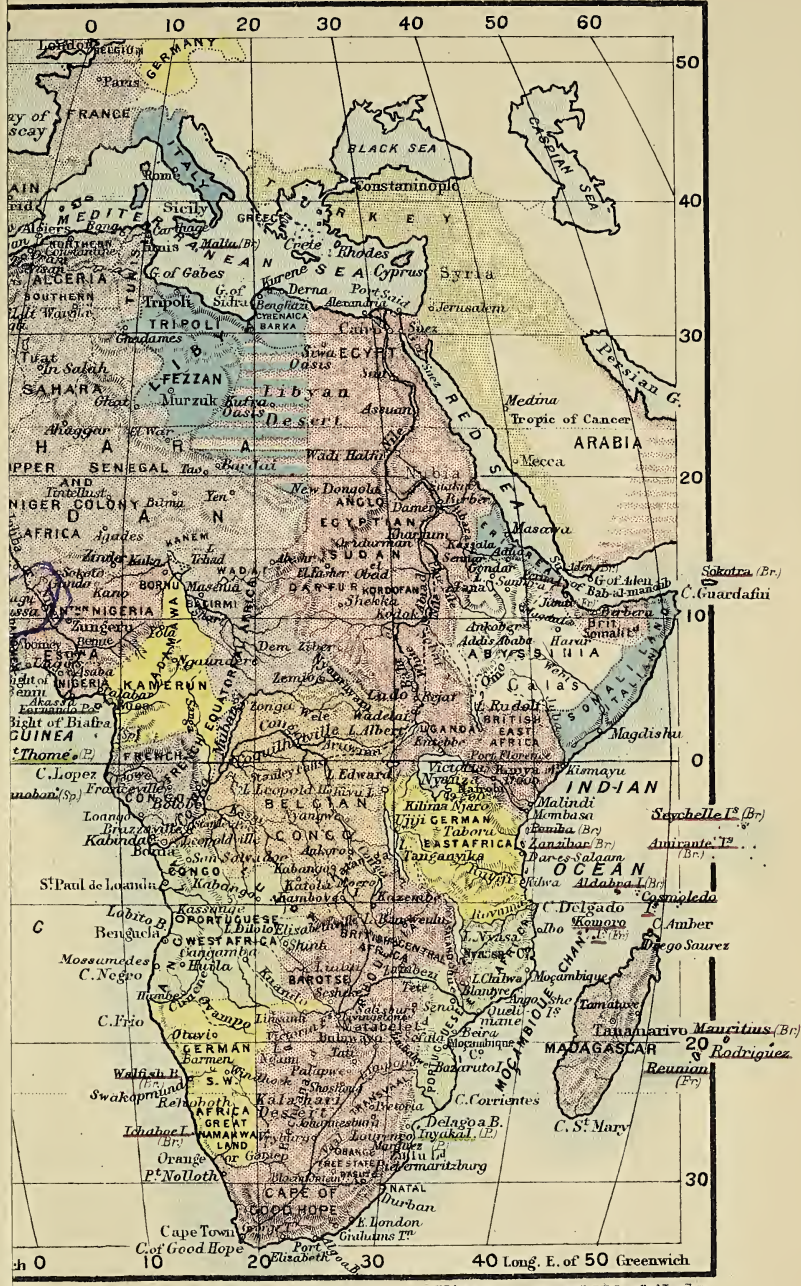

EXPLANATORY NOTE

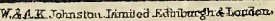

ectorates, Spheres of Influence or occupation of countries

$\begin{array}{ll}\text { British } & \square \text { Portuguese } \\ \text { French } & \text { Purkish } \\ \text { Italian } & \text { Belgian Congo } \\ \text { German } & \text { Spanish }\end{array}$

ependent or unoccupied States are uncoloured $k$ bars on blue imply uncertainty of possession 

POLITICAL AFRICA-1912

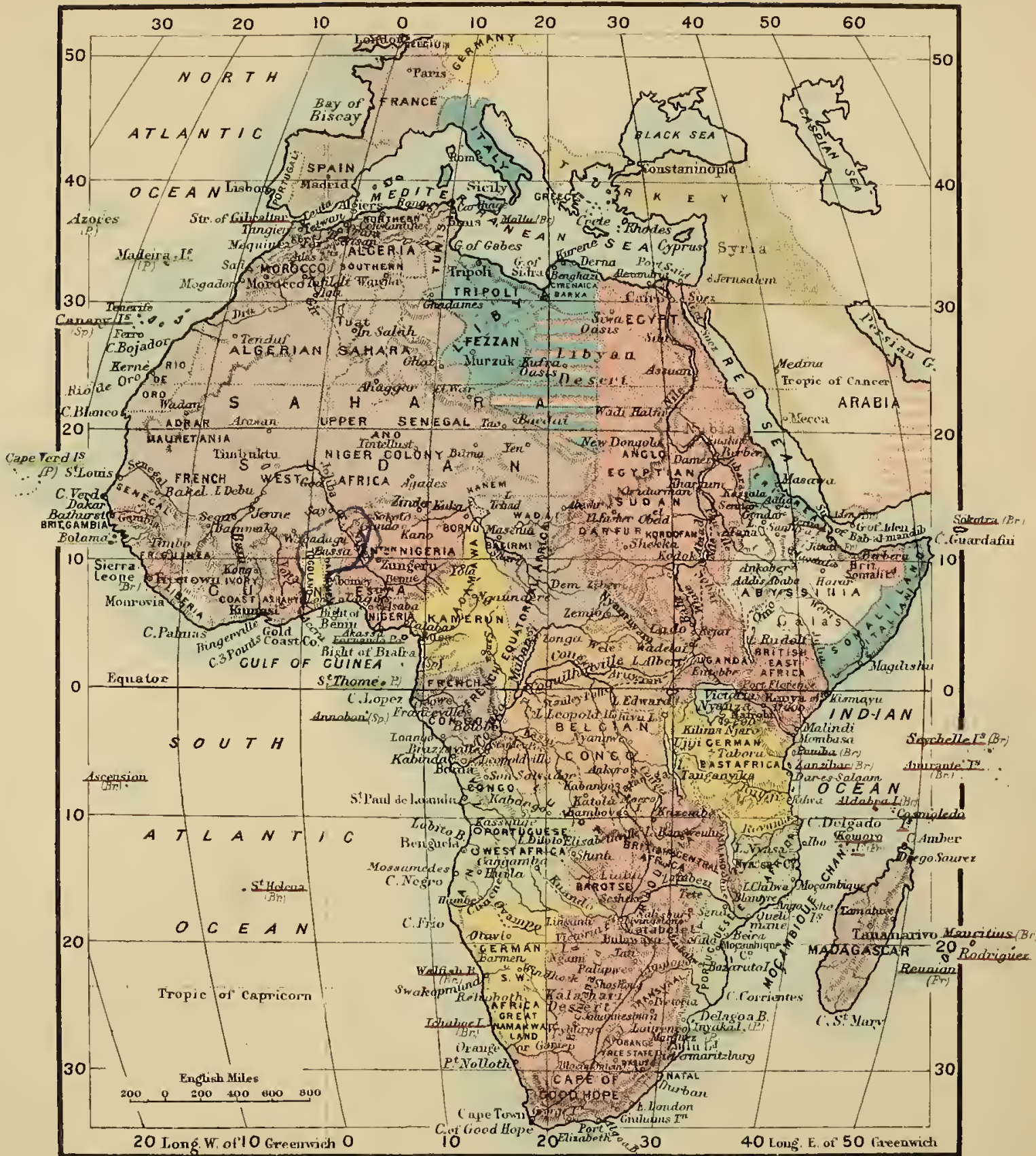

EXPLANATORY NOTE

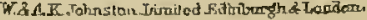

Possessions, Protectorates, Spheres of Influence or occupation of countries
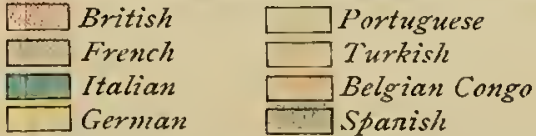

Independent or unocupied States are uncolourud

Pink bars on blue imply zuncertainty of possession 





\section{Stanford University Library Stanford, California}

In order that others may use this book, please return it as soon as possible, but not later than the date due. 
d on

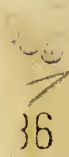



